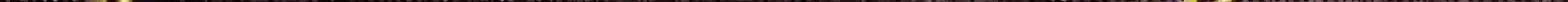


RB261315

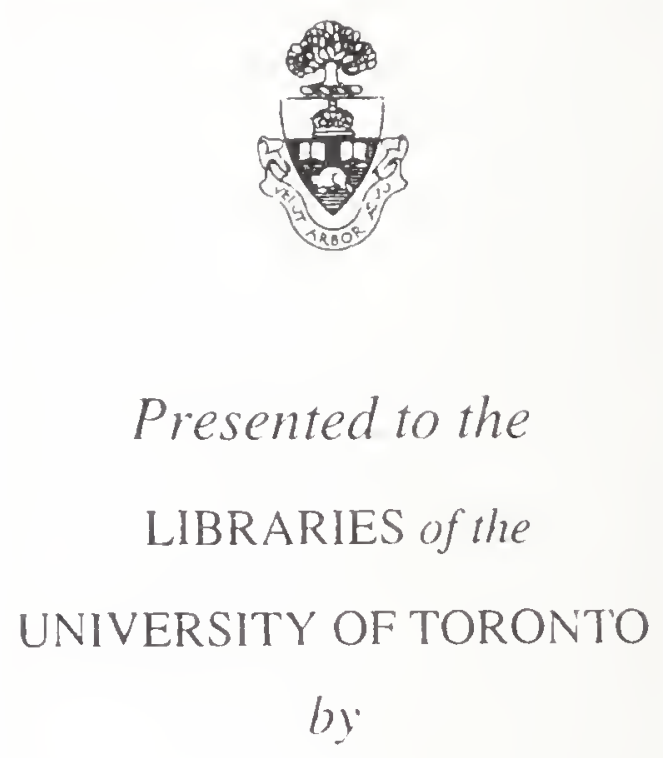

Larry Pfaff 

Digitized by the Internet Archive in 2018 with funding from University of Toronto 


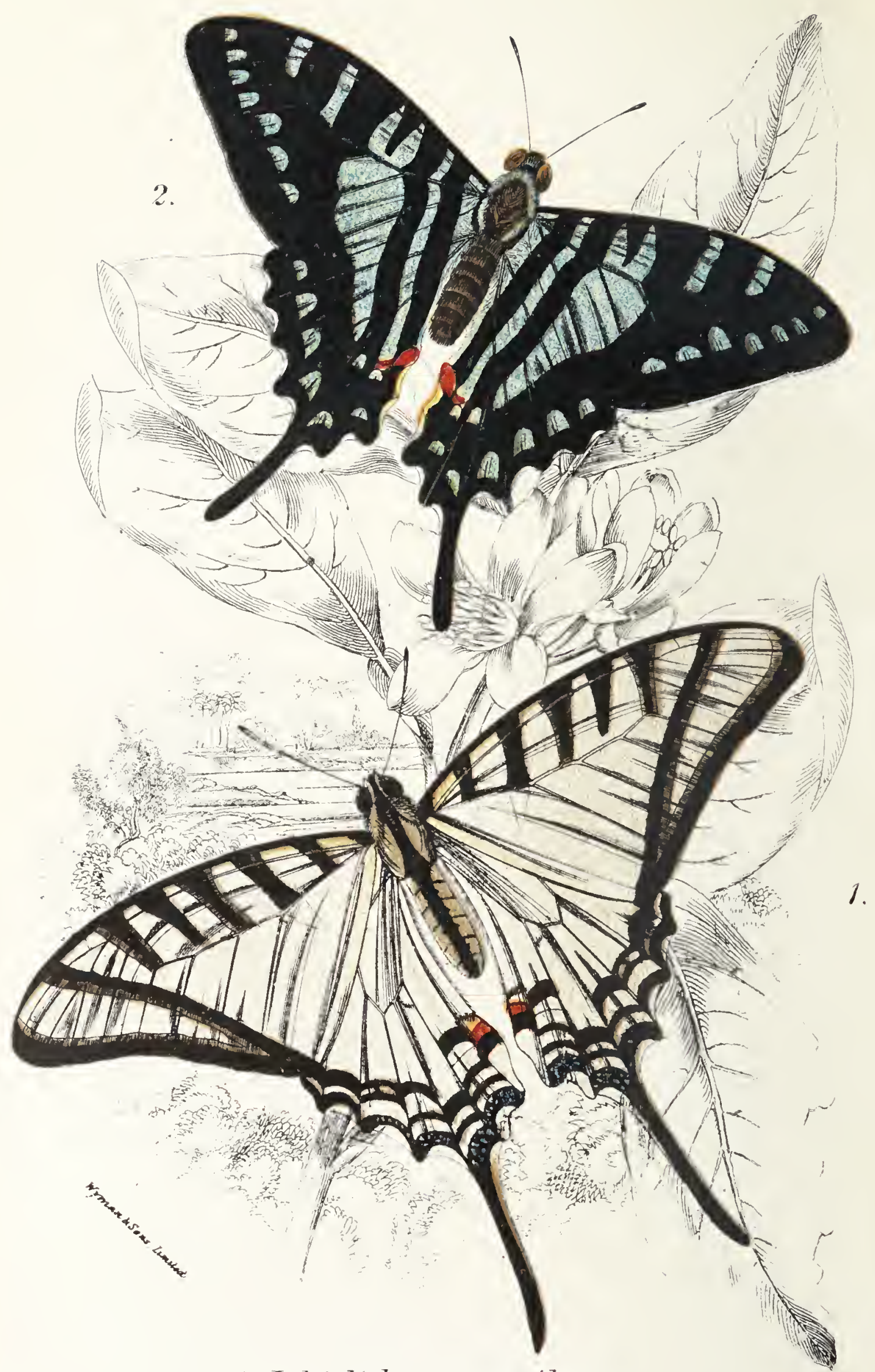

1. Iphiclides protesilaus. 
LLOYD'S NATURAL HISTORY.

Edited by R. Bowdler Sharpe, LL.D., F.I.s., \&c.

\section{$\Lambda$ HAND-BOOK}

TO THE

\section{ORDER}

\section{LEPIDOPTERA}

$\mathrm{BY}$

W. F. KIRBY, F.L.S., F.Ent.S.,

DEPARTMENT OF ZOOLOGY, PRITISH MUSEUM,

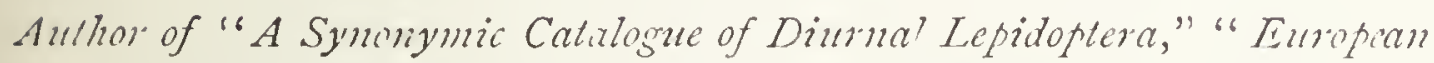

Buttorfics and MToths," "A Text-book of Entomology", slc., elc.

PART I.

BUTTERFLIES. - VOL. Ií.

LONDON :

EDWARD LLOYD, LIMITED,

I2, SATISBURY SQUARE, FLEET STREFT. 
PRINTED BY
AND SONS, LIMITED. 


\section{PREFACE.}

Writ the present volume Mr. Kirby completes his survey of the Butterflies, with the exception of the Hesperiide, which will be published in the third volume, where the author will commence his review of the Moths.

Mr. Kirby is especially well-known as an authority on entomological bibliography, and it is not surprising to find that his recent researches into the nomenclature of Butterfies have led him to arrive at conclusions concerning the proper names of our British species somewhat different from those adopted in most modern works. The confusion of nomenclature in the Lepidoptera seems to be even greater than that which recently existed among the Birds; but even as Ornithologists are gradually progressing towards an uniform system of nomenclature, so it may be ho?ed that Lepidopterists also will speedily arrive at definite conclusions as to the names which the British species of Butterflies should bear. From this point of view, I hope that Mr. Kirby's volume will be found to contain some useful conclusions.

R. BOWDLER SHARPE. 



\section{AUTHOR'S PREFACE.}

In the Preface to the first volume of Lepidopiera I announced my intention of completing the Butterflies in two volumes; but the amount of matter which I found it necessary to include proved more considerable than I had expected, and the present volume includes only Families II. to VI. of the Butterflies, viz., Liby'theide, Lemoniida, Lycenida, Pieride, and Equitida; the Hesperiidce being left over till the third volume.

As at present arranged, it is proposed to devote three volumes to the remainder of the Lepidoptera, making five in all, divided as follows :-

Vol. I. Butterflies: Nymphalidæ.

II. $\quad$ III. $\quad$ Libytheidre to Equitidx.
" III.

Moths: Pages, Burnets, Tiger-Moths, \&c.

" IV. " Hawk-Moths, Emperors, \&c.

" V. " Owl-Moths, Loopers, Clothes-Moths, \&c.

The Family Equitide (usually called Papilionide), containing the true Swallow-Tailed Butterflies, is in a most chaotic state, never having been sub-divided into genera like the other Families. A thorough revision would have been beyond the scope of the present work; but I have carefully examined all the generic names which have been proposed for any portions of this extensive Family, collated them with 
Felder's groups, and endeavoured as far as possible to fix their types and limits, thereby bringing together a considerable amount of very scattered information.

Many interesting observations on habits, \& c., will be found scattered through the present volume, including those of Trogonoptera brookeana, with which Sir Hugh Low has kindly favoured me.

The uncertainty of nomenclature is much to be regretted. Detailed explanations of the principles which have guided me will be found in the Prefaces to my Synonymic Catalogues of Odonata, and of Rhopalocera Heterocera, and need not here be repeated. I may, however, say that I have long been of opinion that 1758 , the date of the tenth edition of Linnæus' "Systema Naturæe," should be regarded as the logical startingpoint of our nomenclature, and that I attach more importance to the assignation of a type to a genus, than even to a definition. As regards specific names, it is a pity that so oldestablished a name as edusa has no claim to be retained for the Clouded Yellow (see pp 2 I 4, 2 I 5). But it is interesting to find that in some cases the Entomologists of the last generation had correctly applied Linnæus' names (e.g., camilla to the White Admiral, and fuciformis to the broad-bordered Bee Hawk-Moth), whereas contemporary writers have preferred to follow erroneous determinations of Continental Entomologists. The first step towards arriving at correct conclusions, is to eliminate obvious and palpable errors.

Now that the present work is so far advanced, I hope to make arrangements for the speedy issue of the second edition of my Catalogue of "Lepidoptera Rhopalocera." 


\section{SYSTEMATIC INDEX.}

ORDER LEPIDOPTERA (continued).

PACE

A. LEPIDOPTERA RHOPALOCERA(continued)... $\quad \ldots \quad$... I

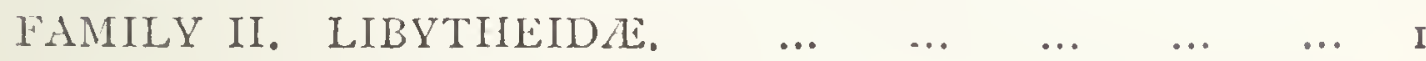

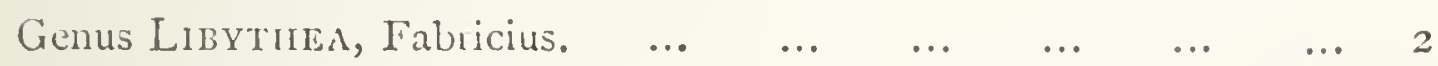

$\begin{array}{llllllll}\text { L. celtis (Fuessly). } & \ldots & \ldots & \ldots & \ldots & \ldots & \ldots & 4\end{array}$

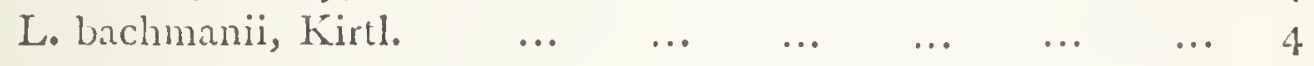

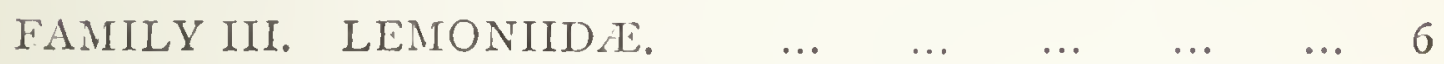

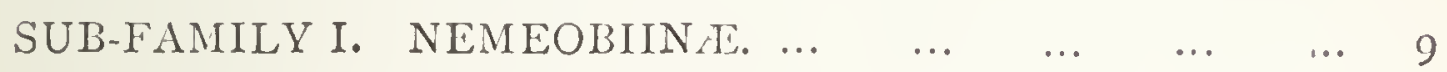

Genus Nemeolim

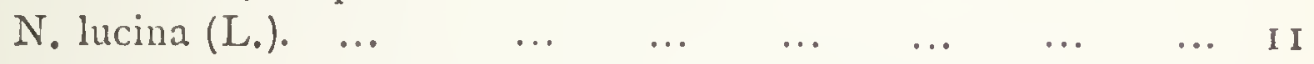

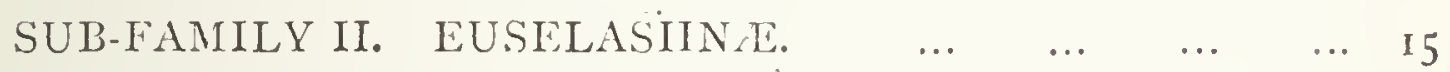

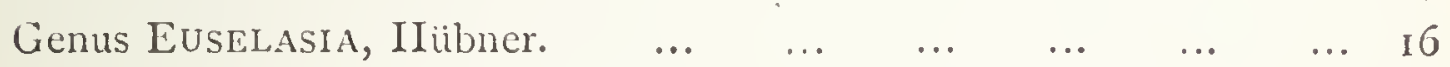

$\begin{array}{lllllllll}\text { E. gelon (Stoll). } & \ldots & \ldots & \ldots & \ldots & \ldots & \ldots & \ldots & \text { I } 7\end{array}$

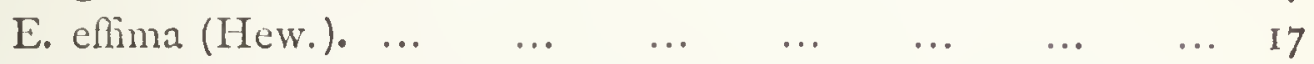

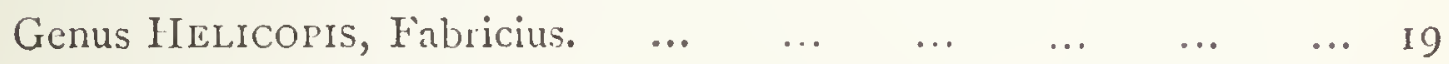

$\begin{array}{lllllllll}\text { II. acis (Fabr.). } & \ldots & \ldots & \ldots & \ldots & \ldots & \ldots & \ldots & =0\end{array}$

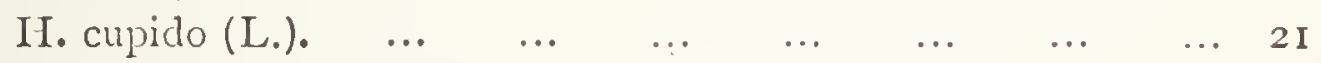

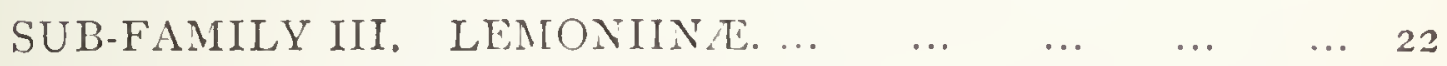

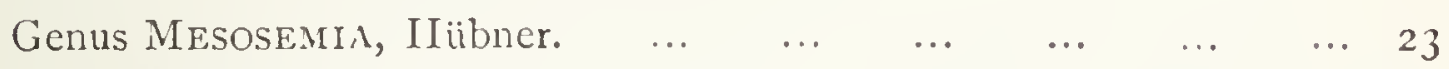

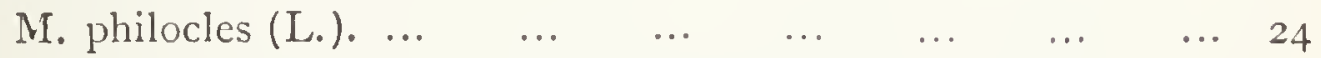

$\begin{array}{llllllll}\text { M. bifasciata (Hew.). } & \ldots & \ldots & \ldots & \ldots & \ldots & \ldots & 24\end{array}$

$\begin{array}{llllllll}\text { Genus Eurybia, IIübner, } & \ldots & \ldots & \ldots & \ldots & \ldots & \ldots & 25\end{array}$

E. salome $\left(\begin{array}{llllllll}(\text { Cram. }) . . . & \ldots & \ldots & \ldots & \ldots & \ldots & \ldots & 25\end{array}\right.$

$\begin{array}{llllllllll}\text { Genus Zeonia, Swains. } & \ldots & \ldots & \ldots & \ldots & \ldots & \ldots & \ldots & 27\end{array}$

$\begin{array}{lllllllll}Z \text { Z. faunus (Fabr.). } & \ldots & \ldots & \ldots & \ldots & \ldots & \ldots & \ldots & 27\end{array}$

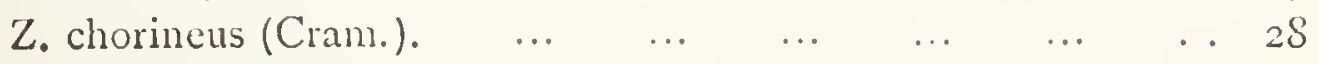


Genus Diorhina, Morisse.

PAGE

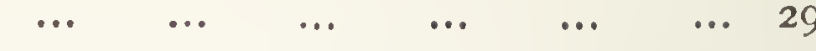

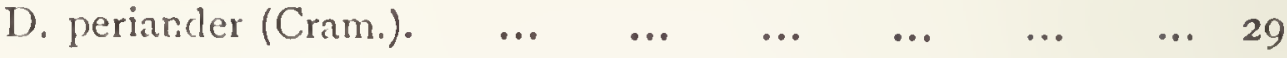

Genus AnCri.uris, Hiibner.

A. meliboeus (Fabr.).

Genus Antreros, Hiibner.

A. formosus (Cram.).

A. achreus (Stoll).

Genus Lemonias, Huibner.

L. emylius (Cram.).

Genus Nymphidium, Fabr.

N. carica (L.).

N. ethelinda, Ifew.

Genus Catagrammina, Bates.

C. tapaja (Saunders).

C. hewitsoni, Kirby.

Genus Isapis, Vestw.

I. agyrtus (Cram.). ...

SUB-FAMILY IV. STALACHTINA.

Genus Stalachtis, Hübner.

S. phlegia (Cram.)....

FAMILY IV. LYCANID

... 30

... 3 I

... 35

‥ 35

... 36

... 38

... 39

... 40

‥ 40

... $4 \mathrm{I}$

‥ 42

$\therefore 42$

‥ 43

43

- 43

SUB-FAMILY I. LYCANIN.E.

Genus Thecla, Fabr.

T. spini (Den. \& Schifferm.)

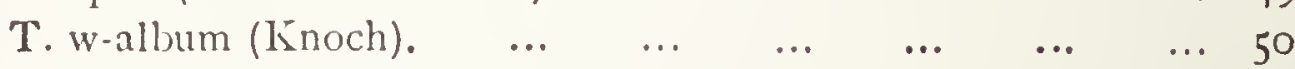

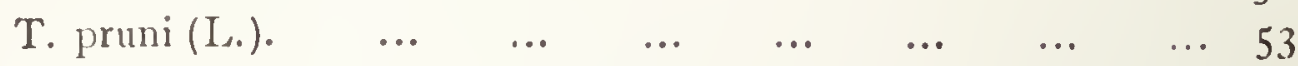

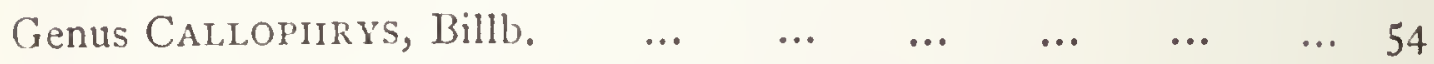

$\begin{array}{lllllllll}\text { C. } r \text { rubi (L.). } & \ldots & \ldots & \ldots & \ldots & \ldots & \ldots & \ldots & 54\end{array}$

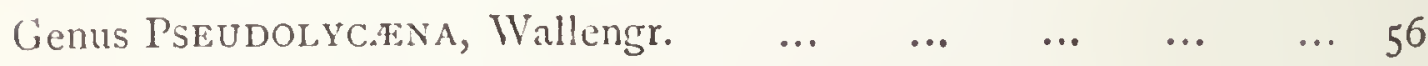

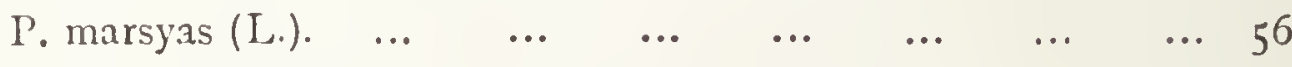

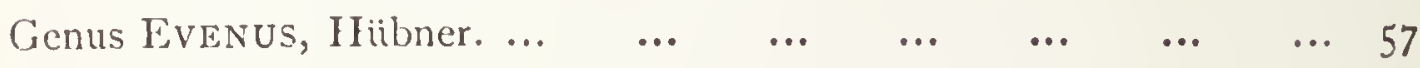

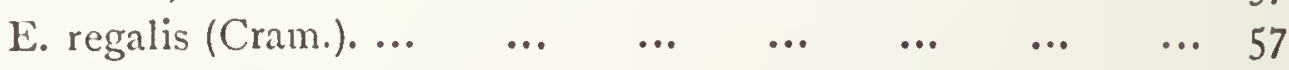

Genus ArCas, Swains.

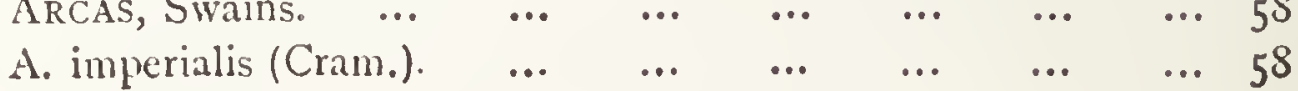


Genus Micandra, Schatz.

$\begin{array}{llllllll}\text { M. platyptera (Felder). } & \ldots & \ldots & \ldots & \ldots & \ldots & \ldots & 59\end{array}$

$\begin{array}{llllllll}\text { Genus Eumæus Hïbner. ... } & \ldots & \ldots & \ldots & \ldots & \ldots & \ldots & 60\end{array}$

$\begin{array}{llllllll}\text { E. minyas, Hübner. } & \ldots & \ldots & \ldots & \ldots & \ldots & \ldots & 60\end{array}$

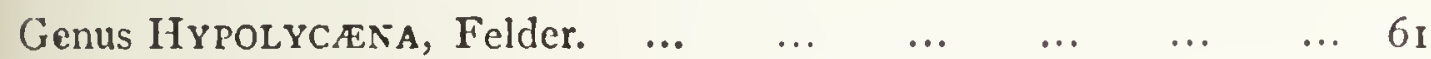

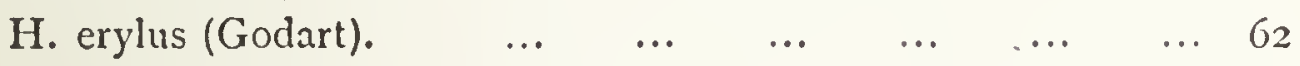

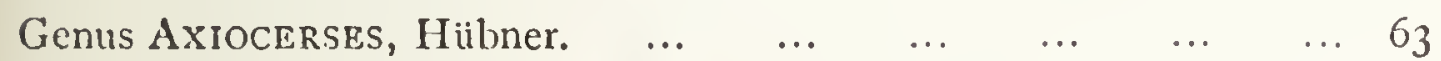

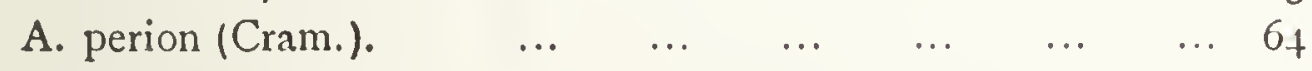

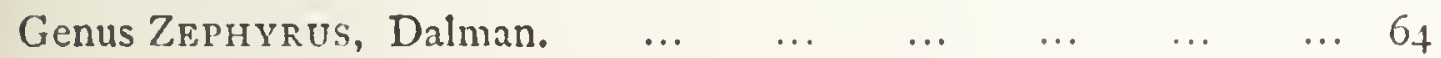

$\begin{array}{lllllllll}\text { Z. betuliee (L.). } & \ldots & \ldots & \ldots & \ldots & \ldots & \ldots & \ldots & 6_{5}\end{array}$

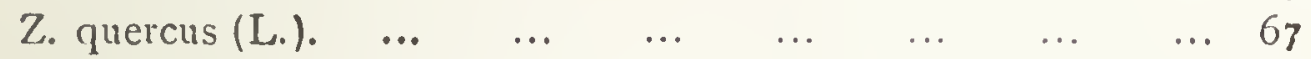

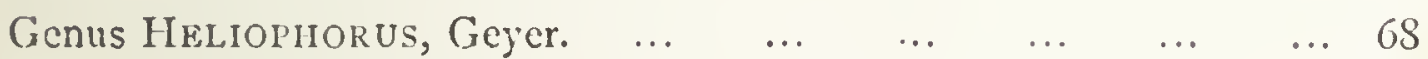

$\begin{array}{llllllll}\text { H. epicles (Godart). } & \ldots & \ldots & \ldots & \ldots & \ldots & \ldots & 69\end{array}$

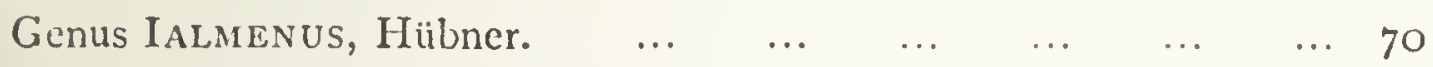

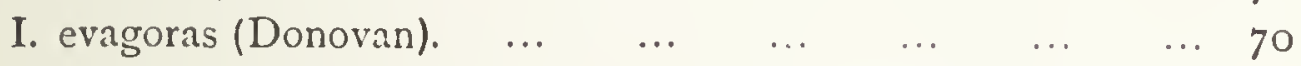

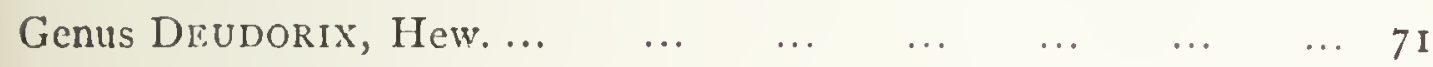

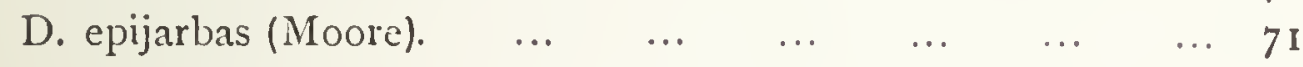

$\begin{array}{lllllllll}\text { Genus Iola us, Huibner. } & \ldots & \ldots & \ldots & \ldots & \ldots & \ldots & \ldots & 73\end{array}$

$\begin{array}{lllllllll}\text { I. helius (Fabr.). } & \ldots & \ldots & \ldots & \ldots & \ldots & \ldots & \ldots & 73\end{array}$

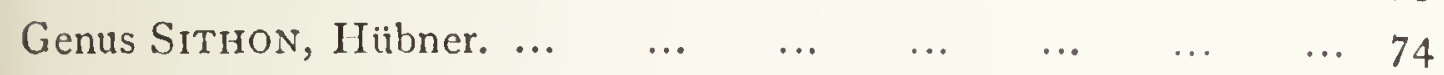

S. nedymonda $\left(\begin{array}{llllllll}\mathrm{Cram} .) & \ldots & \ldots & \ldots & \ldots & \ldots & \ldots & 74\end{array}\right.$

Genus Mrrina, Fabr.

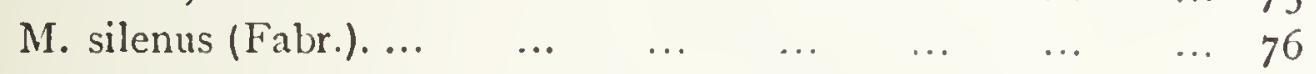

$\begin{array}{llllllllll}\text { (ienus Loxura, Horsf. } & \ldots & \ldots & \ldots & \ldots & \ldots & \ldots & \ldots & 77\end{array}$

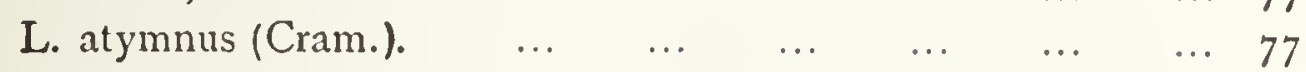

$\begin{array}{llllllllll}\text { Genus Phasis, Huibner. } & \ldots & \ldots & \ldots & \ldots & \ldots & \ldots & \ldots & 77\end{array}$

$\begin{array}{llllllllll}\text { P. thero (L.). } & \ldots & \ldots & \ldots & \ldots & \ldots & \ldots & \ldots & 78\end{array}$

$\begin{array}{llllllll}\text { Genus Aphneus, Hübner. } & \ldots & \ldots & \ldots & \ldots & \ldots & \ldots & 79\end{array}$

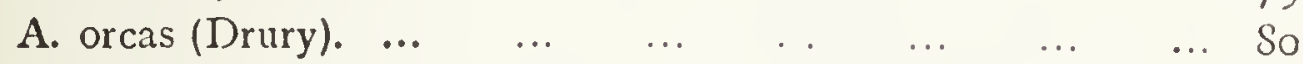

$\begin{array}{llllllll}\text { Genus Miletus, Huibner. } & \ldots & \ldots & \ldots & \ldots & \ldots & \ldots & S_{\text {I }}\end{array}$

$\begin{array}{llllllll}\text { M. polycletus (L.). } & \ldots & \ldots & \ldots & \ldots & \ldots & \ldots & 8 \mathrm{I}\end{array}$

$\begin{array}{llllllll}\text { Genus Lampides, Hübner. } & \ldots & \ldots & \ldots & \ldots & \ldots & \ldots & S 2\end{array}$

$\begin{array}{lllllllll}\text { L. breticus (L.). } & \ldots & \ldots & \ldots & \ldots & \ldots & \ldots & \ldots & \mathrm{S}_{2}\end{array}$

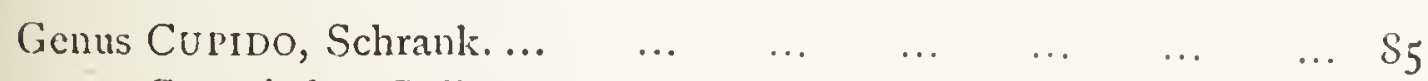

$\begin{array}{llllllll}\text { C. } \operatorname{argiadles}(\text { Pall. }) . & \ldots & \ldots & \ldots & \ldots & \ldots & \ldots & \$ 55\end{array}$ 
Gcrus Plebeius, L.

P. argus (L.).

Genus Polyommatus, Latr.

P. corydon (Poda).

P. thetis (Von Rotteml.)....

P. icarus (Von Rotteml).).

P. alexis (Scop.).

P. salmacis, Steph.

I'. artaxerxes (Fabr.).

Genus Craniris, Dalman.

C. $\operatorname{argiolus}(\mathrm{L}$.$) .$

Genus Zizera, Moore.

Z. minima (Fuessly).

Genus Nomiades, Hübner.

N. semiargus (Von Rottemb.).

N. arion (L.).

N. alcon (Den. \& Schifferm.).

Genus Scolitantines, Iübner. ..

S. orion (Pall.)

Genus Castalius, II iibner.

C. rosimon (Fabr.).

Genus Pitilecops, Horsf.

P. hylax (Fabr.).

Genus Lycienesthes, Moore.

L. bengalensis, Moore.

Genus Lycexid, Fabr.

L. virgaure:e (L.). ...

L. dispar, IIawort?.

L. rutila (Werneb.).

L. hippothoe (L.). ...

L. phlæeas (L.).

Cenus Tomares, Rambur.

T. ballus (Fabr.). 
Genus AMblyonia, IIorsf.

... 130

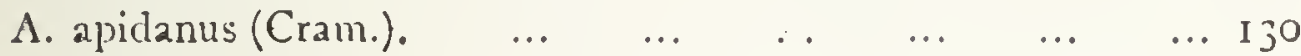

Genus Ogyris, Westw.

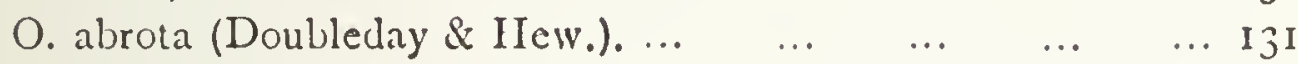

Genus Curetis, Ilübner. ...

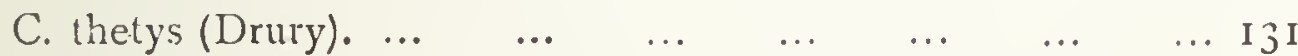

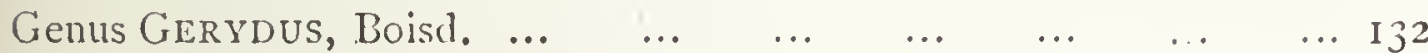

$\begin{array}{llllllll}\text { G. symethus (Cram.). } & \ldots & \ldots & \ldots & \ldots & \ldots & \ldots & 132\end{array}$

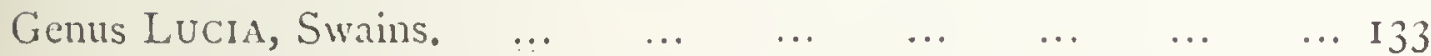

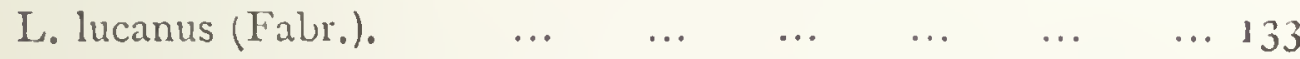

SUB-FAMILY II. LIPTENIN $\pi$.

Genus Liphyra, Westw. ...

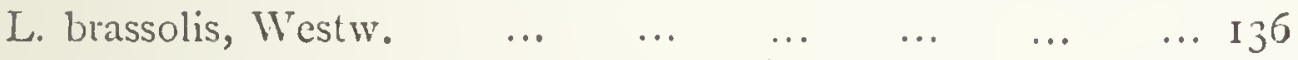

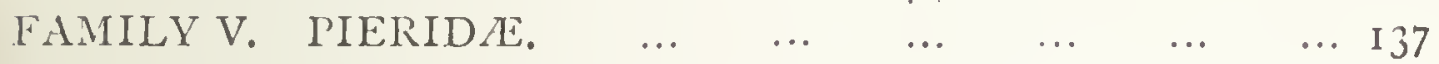

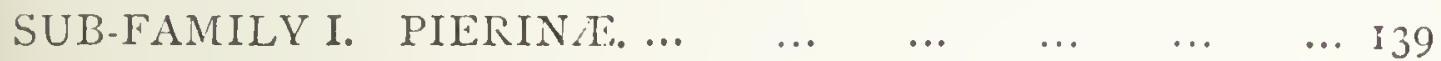

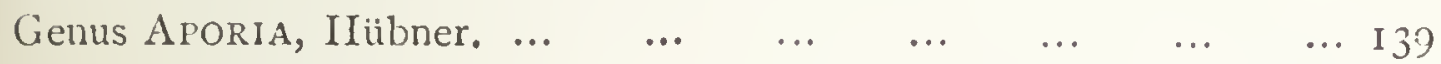

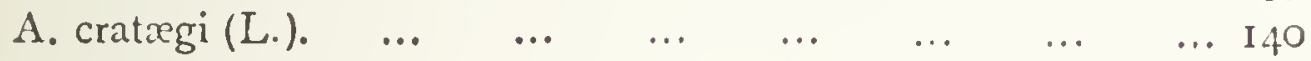

$\begin{array}{lllllllll}\text { Genus Pifris, Schrank. } & \ldots & \ldots & \ldots & \ldots & \ldots & \ldots & \ldots & \text { I } 42\end{array}$

$\begin{array}{lllllllll}\text { P. brassicæ (L.). } & \ldots & \ldots & \ldots & \ldots & \ldots & \ldots & \ldots & \mathrm{I}_{44}\end{array}$

$\begin{array}{llllllll}\text { P. chariclea }(\text { Steph.). } & \ldots & \ldots & \ldots & \ldots & \ldots & \ldots & \text { I } 45\end{array}$

$\begin{array}{lllllllll}\text { P. rapre (L.). } & \ldots & \ldots & \ldots & \ldots & \ldots & \ldots & \ldots & \text { I } 45\end{array}$

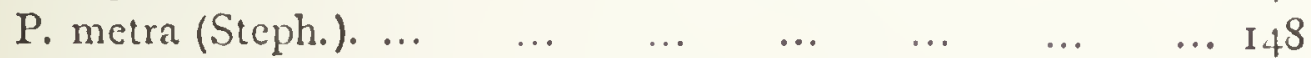

$\begin{array}{lllllllll}\text { P. napi, Linn. } & \ldots & \ldots & \ldots & \ldots & \ldots & \ldots & \ldots & \text { I } 48\end{array}$

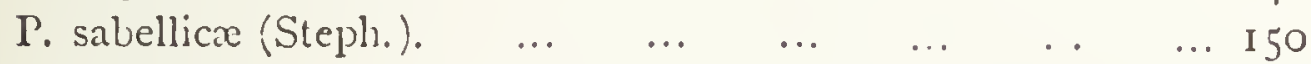

Genus Pontia, Fabr.

$\begin{array}{lllllllll}\text { P. daplidice (L.). } & \ldots & \ldots & \ldots & \ldots & \ldots & \ldots & \ldots & 152\end{array}$

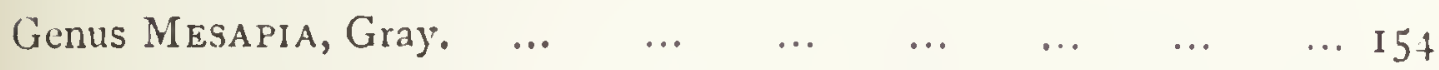

$\begin{array}{llllllll}\text { M. } \text { peloria }(\mathrm{Hew} .) . & \ldots & \ldots & \ldots & \ldots & \ldots & \ldots & \text { I } 55\end{array}$

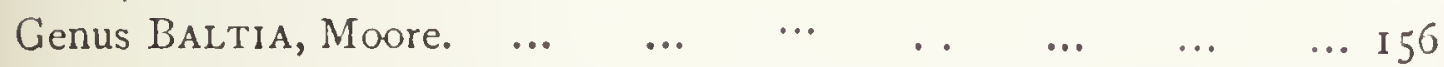

$\begin{array}{lllllllll}\text { B. shawii (Bates). } \ldots & . & \ldots & \ldots & \ldots & \ldots & \ldots & \ldots & 156\end{array}$

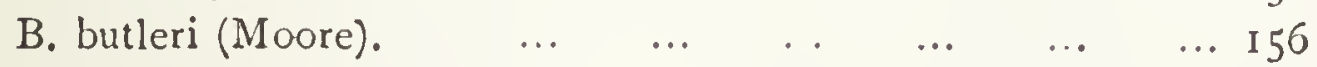

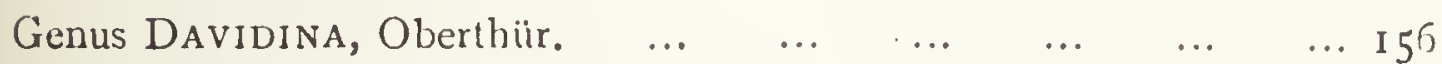

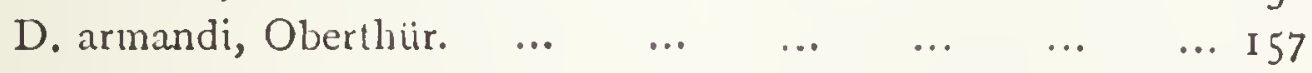

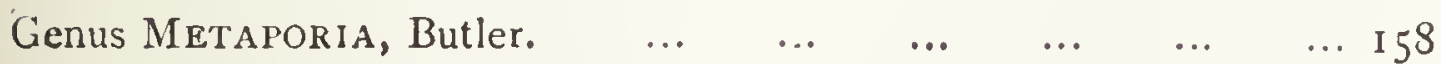

$\begin{array}{llllllll}\text { M. agathon }(\text { Gray). } & \ldots & \ldots & \ldots & \ldots & \ldots & \ldots & \text { I } 58\end{array}$ 
Genus Perruybris, Hübuer.

P. pyrrha (Fabr.). ..

Genus Mylothris, Hübner.

M. rhodope (Fabr.).

Genus Belenors, Hübner.

B. calypso (Drury).

Genus Scinatzin, Kirby. ...

S. socialis (Westw.).

Genus Archorias, Hübner.

A. tereas (Godart).

Genus I'Ereute, Ierr.-Schaff.

P. leucodrosime (Kollar). . .

Genus Delias, Ilübner. ...

D. belisama (Cram.).

D. eucharis (Drury).

D. cæneus (L).

D. egialea (Cram.).

Genus Prioneris, Wall. ...

P. thestylis (Doubleday).

Genus Appias, Hiibner. ...

A. zelmira (Cram.).

Genus Melete, Swains. ...

M. flippantha (Fabr.).

Genus Elodina, Felder. ...

E. egnatia (Godart).

Genus Leptosia, Hübner.

L. xiphia (Fabr.). ...

Genus Levcidia, Doubleday.

L. elvina (Godart).

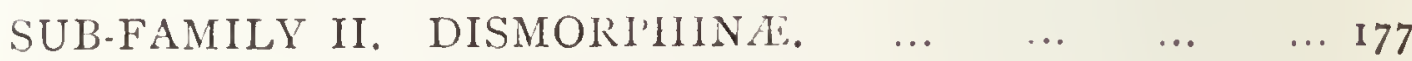

$\begin{array}{lllllllll}\text { Genus Leptidia, Billb. } & \ldots & \ldots & \ldots & \ldots & \ldots & \ldots & \ldots & 178\end{array}$

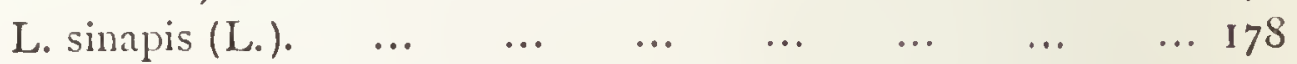

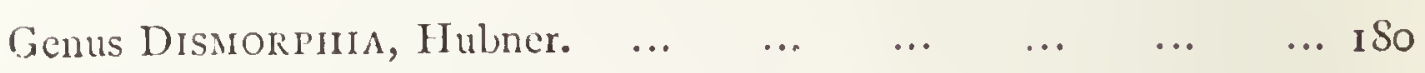

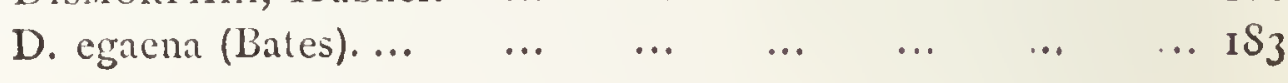


PAGE

Genus Acmetopteron, Godm. \& Salv.

... 183

A. nemesis (Latr.).

... 183

Genus Enantia, Hübner.

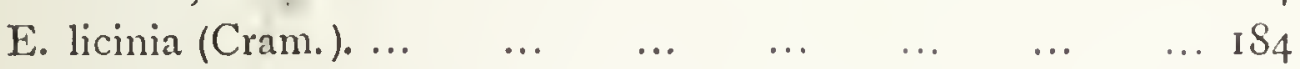

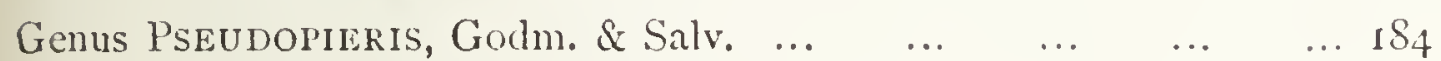

$\begin{array}{llllllll}\text { P. nehemia (Boisd.). } & \ldots & \ldots & \ldots & \ldots & \ldots & \ldots & \text { I } 84\end{array}$

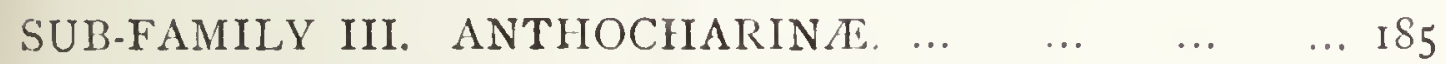

Genus Euchlos, Hübner.

E. cardamines (L.). $\quad \begin{array}{llllllll} & \ldots & \ldots & \ldots & \ldots & \ldots & \ldots & \text { I } 86\end{array}$

$\begin{array}{llllllll}\text { E. turritis }(\text { Ochsenh. ). } & \ldots & \ldots & \ldots & \ldots & \ldots & \ldots & \text { I } S 8\end{array}$

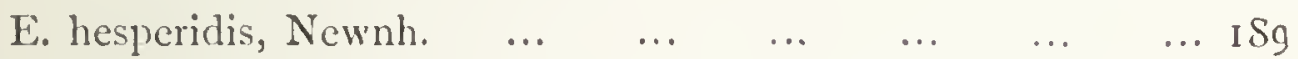

$\begin{array}{llllllll}\text { Genus Phyllocharis, Schatz. } & \ldots & \ldots & \ldots & \ldots & \ldots & \ldots & \text { I } 90\end{array}$

$\begin{array}{llllllll}\text { P. tagis (Huibner). ... } & \ldots & \ldots & \ldots & \ldots & \ldots & \ldots & \text { I } 9 \text { I }\end{array}$

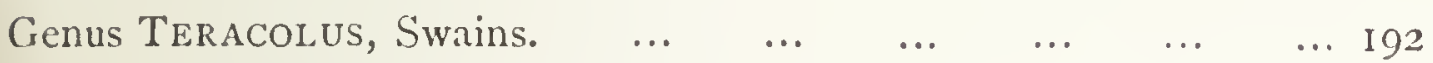

$\begin{array}{llllllll}\text { T. subfasciatus, Swains. } & \ldots & \ldots & \ldots & \ldots & \ldots & \ldots & 193\end{array}$

Genus Callosune, Doubleday. ...

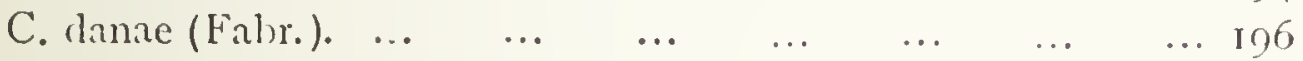

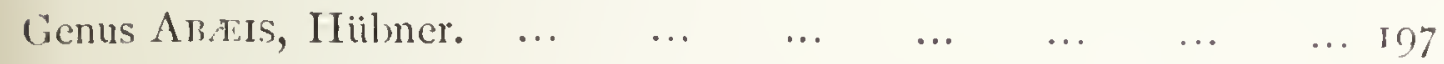

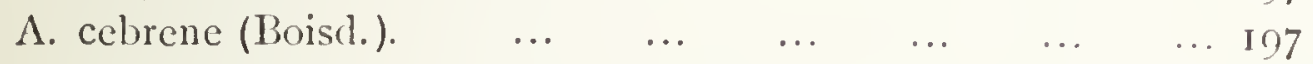

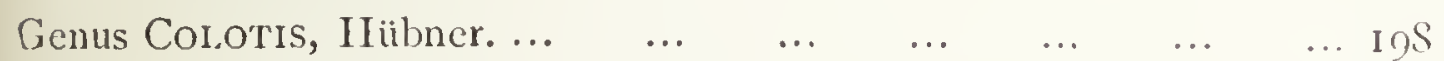

$\begin{array}{lllllllll}\text { C. } \operatorname{amata}(\text { Fabr.). } & \ldots & \ldots & \ldots & \ldots & \ldots & \ldots & \ldots & \text { I } 9 S\end{array}$

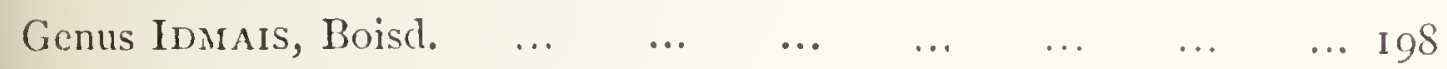

$\begin{array}{llllllll}\text { I. chrysonome }(\text { Klug). } & \ldots & \ldots & \ldots & \ldots & \ldots & \ldots & \text { I } 99\end{array}$

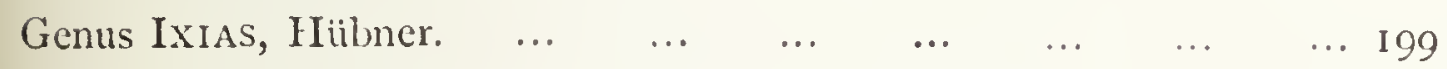

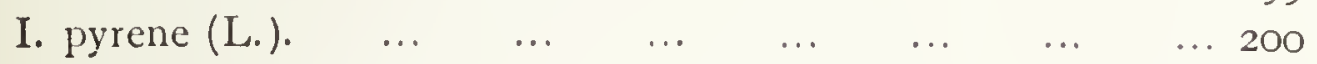

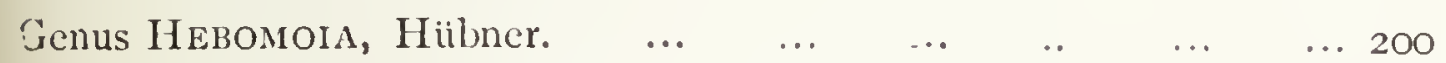

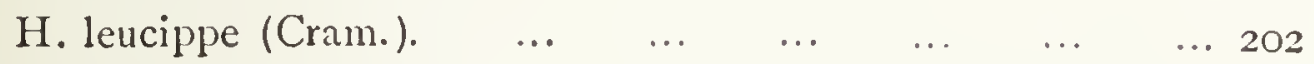

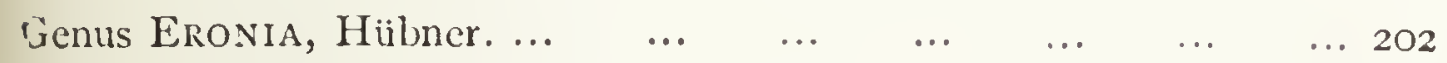

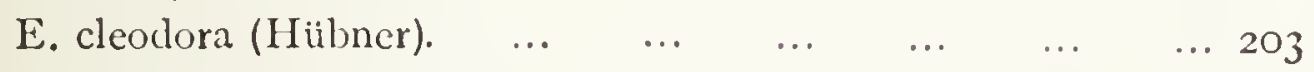

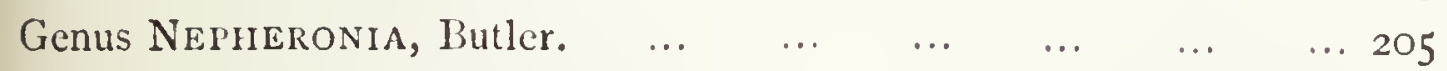

$\begin{array}{llllllll}\text { N. idotiea (Boisd.). } & \ldots & \ldots & \ldots & \ldots & \ldots & \ldots & 205\end{array}$

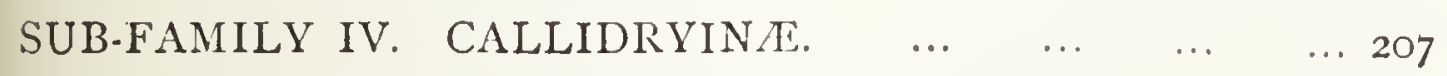

$\begin{array}{llllllll}\text { zenus Nathalis, Boisd. ... } & \ldots & \ldots & \ldots & \ldots & \ldots & \ldots & 207\end{array}$

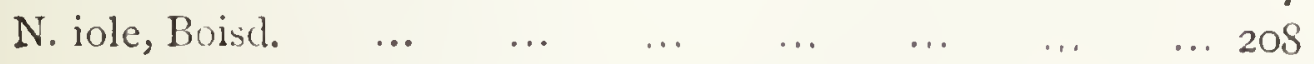


Genus Eurymus, Swains.

E. hyale (L.).

E. kirbyi (Lewis). ...

E. philodice (Godart).

Genus Meganostoma, Reakirt. ...

M. cesonia (Stoll). ...

Genus Colias, Fabr.

C. rhamni (L.).

... 208

... 2 II

... 215

... 217

... 219

... 220

... 220

22 I

Genus Catopsilia, Huiłner.

225

C. crocale (Cram.).... 226

Genus Callinryas, Boisd. \& Leconte. 226

C. eubule (L.).

Genus Sphenogona, Butler. 230

S. mexicana (Boisd.).

Genus Terias, Swains.

T. hecabe (L.).

$\begin{array}{llllllll}\text { FAMILY VI. EQUITID } A . & \ldots & \ldots & \ldots & \ldots & \ldots & \ldots & 234\end{array}$

SUB-FAMILY I. PARNASSIINA… $\quad \ldots \quad \ldots \quad \ldots \quad \ldots \quad \ldots 236$

Genus Parnassius, Latr.

P. apollo (L.)

SUB-FAMILY I'T THAIDINTS.

Cenus Thais, Fabr.

$\mathrm{T}$ medesicaste (Fabr.).

.. 242

... 243

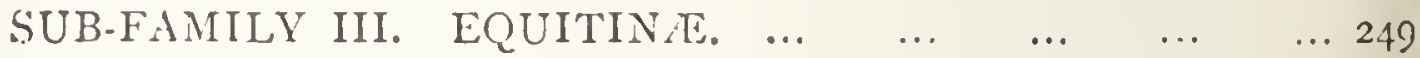

(ienus Drurya, Auriv.

D. antimachus (Drury).

Genus Troldes, Hiibner.

T. priamus (L.).

... 251

... 252

Genus Atreoptera, Rippon. ... ...

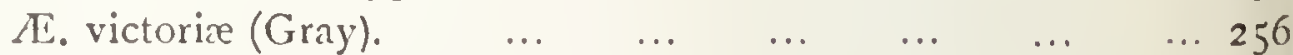

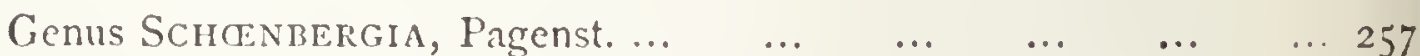

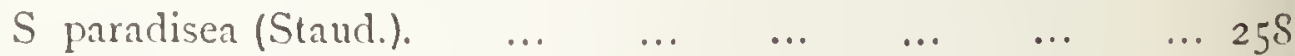

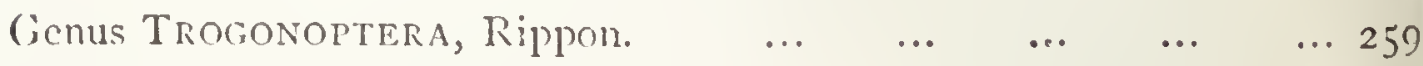

T. brookeana (Wall.). 
Genus Ornithoptera, Boisd. ..

O. hippolytus (Cram.).

... 263

... 266

Genus Papilio, Latr.

267,269

Sect. IV. Ascanides, Geyer.

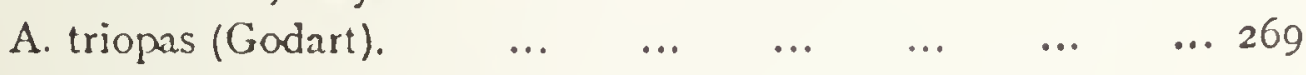

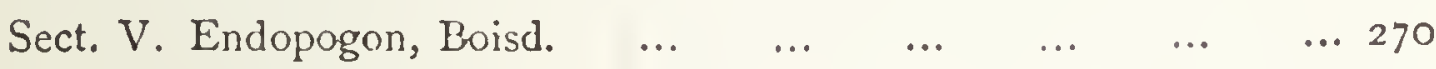

$\begin{array}{llllllll}\text { E. sesostris }(\text { Cram. }) . & \ldots & \ldots & \ldots & \ldots & \ldots & \ldots & 270\end{array}$

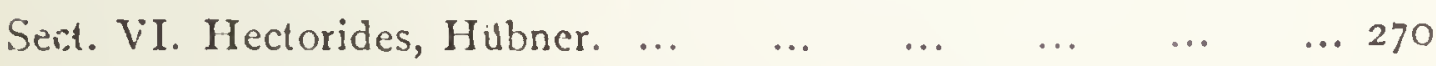

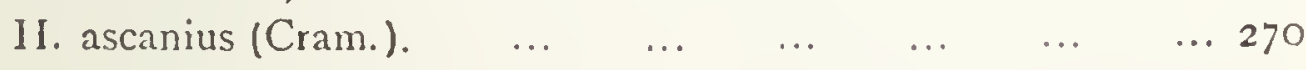

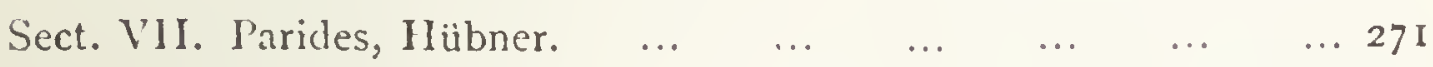

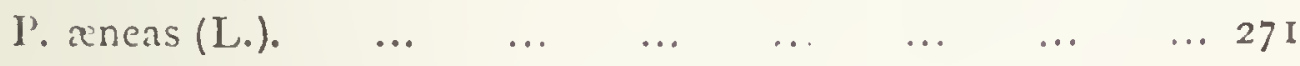

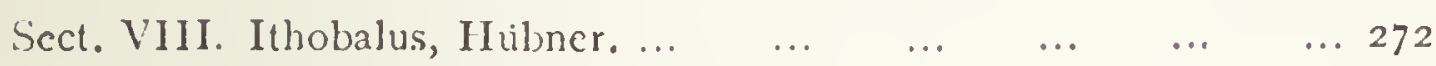

$\begin{array}{llllllll}\text { I. polydamas (L.). } & \ldots & \ldots & \ldots & \ldots & \ldots & \ldots & 272\end{array}$

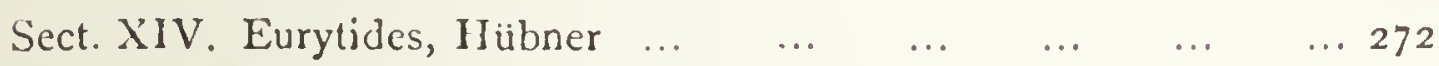

$\begin{array}{llllllll}\text { E. dolicaon }(\text { Cram.). } & \ldots & \ldots & \ldots & \ldots & \ldots & \ldots & 272\end{array}$

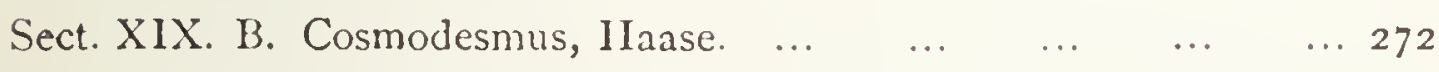

$\begin{array}{llllllll}\text { C. protesilaus (L.) } & \ldots & \ldots & \ldots & \ldots & \ldots & \ldots & 273\end{array}$

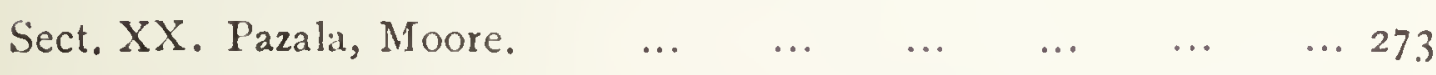

$\begin{array}{llllllll}\text { P. glycerion (Gray). } & \ldots & \ldots & \ldots & \ldots & \ldots & \ldots & 273\end{array}$

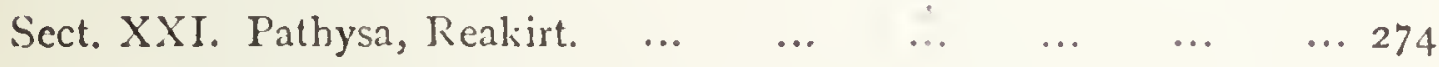

$\begin{array}{llllllll}\text { P. antiphates (Cram.). } & \ldots & \ldots & \ldots & \ldots & \ldots & \ldots & 274\end{array}$

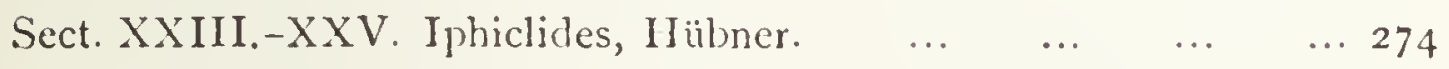

$\begin{array}{llllllll}\text { I. celadon (Lucas). } & \ldots & \ldots & \ldots & \ldots & \ldots & \ldots & 274\end{array}$

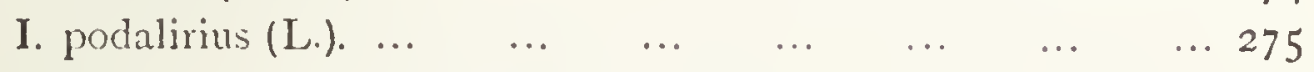

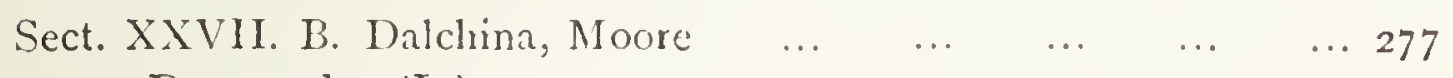

$\begin{array}{lllllllll}\text { D. } \operatorname{sarpedon}(\mathrm{L} .) & \ldots & \ldots & \ldots & \ldots & \ldots & \ldots & \ldots & 277\end{array}$

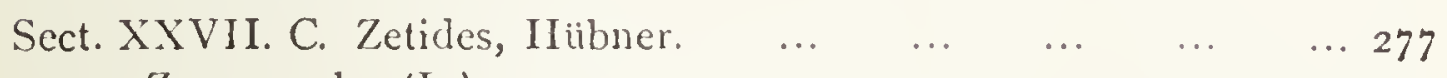

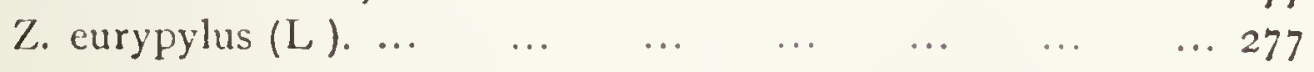

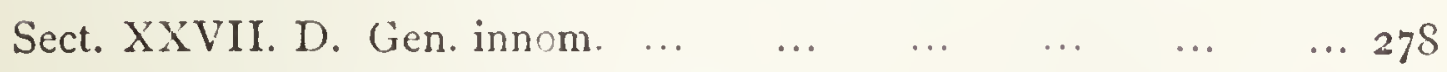

$\begin{array}{llllllll}\text { P. agamemnon, } \mathrm{L} . & \ldots & \ldots & \ldots & \ldots & \ldots & \ldots & 878\end{array}$

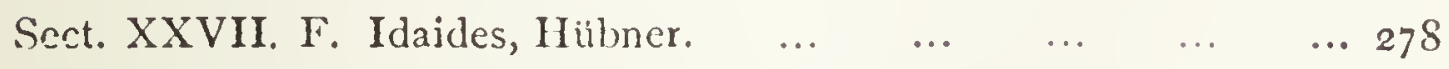

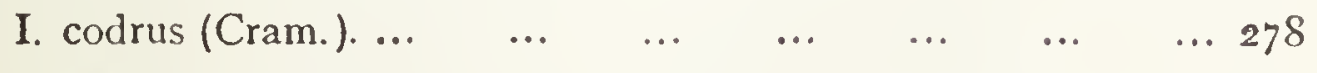

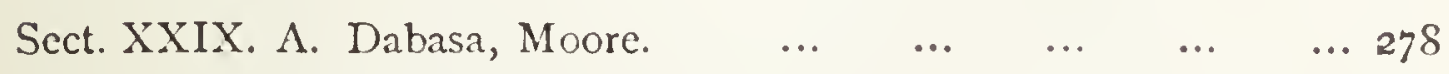

$\begin{array}{llllllll}\text { D. gyas (Westw.). } & \ldots & \ldots & \ldots & \ldots & \ldots & \ldots & 278\end{array}$ 
Sect. XXIX, B. Magr

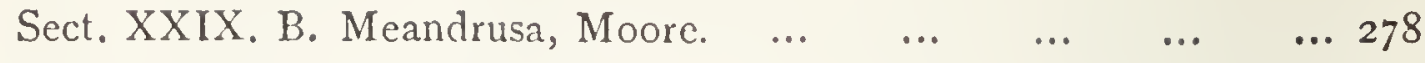

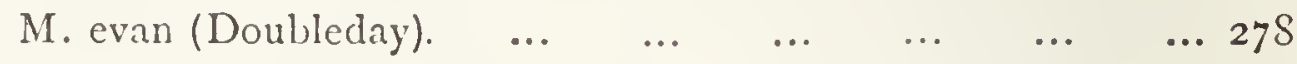

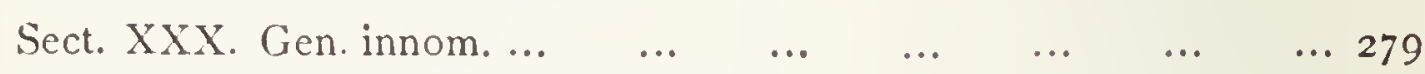

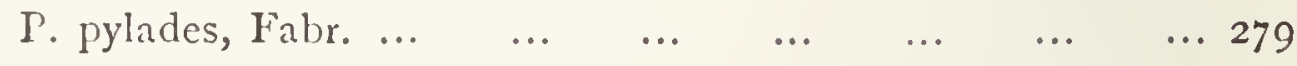

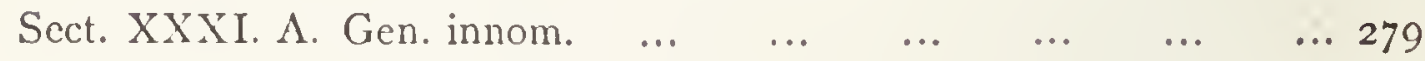

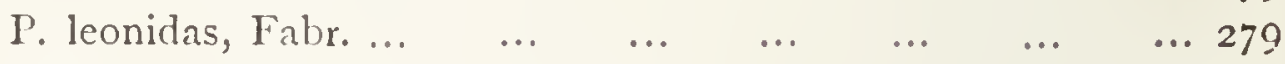

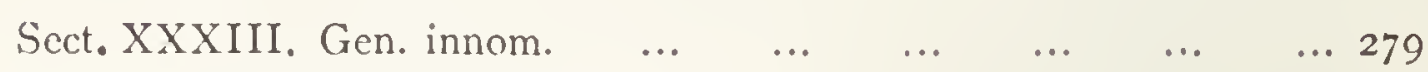

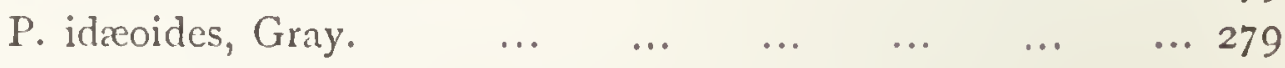

Sect. XXXVI. Paranticopsis, W'ood-Mason and De Nicév. ... _.. 279

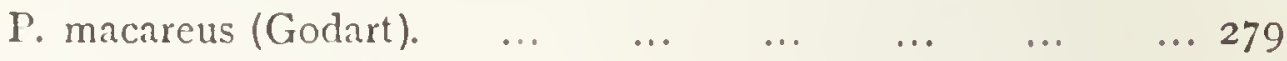

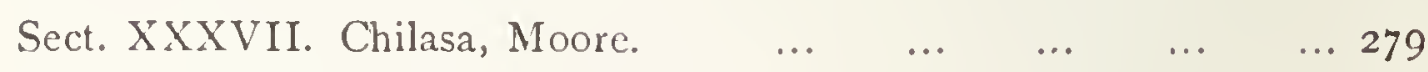

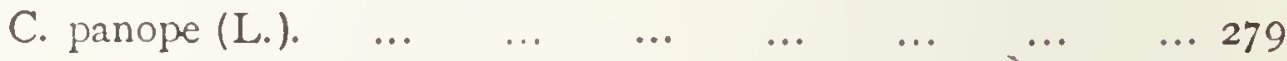

Sect. XXXVII. pt. Euplœopsis, De Nicév. $\ldots$. . $\quad \ldots \quad$.. 280

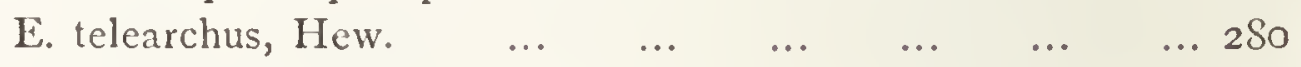

Sect. XXXVII. pt. Menamopsis, De Nicév. $\quad . . \quad$.. $\quad \ldots \quad$... 2 So

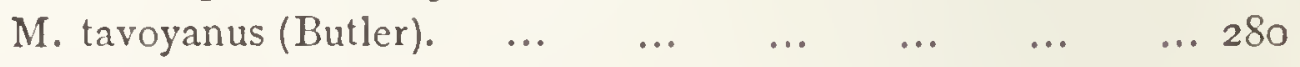

Sect. XXXVIII. Cadugoides, Moore. $\quad \ldots \quad \ldots . \quad \ldots \quad \ldots \quad \ldots \quad$... 2 So

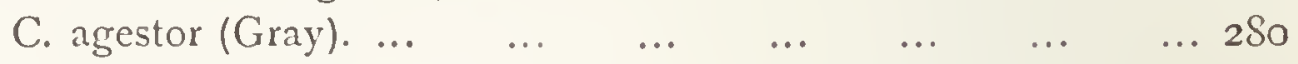

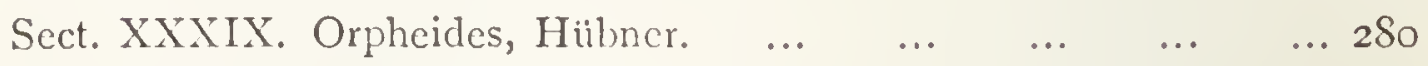

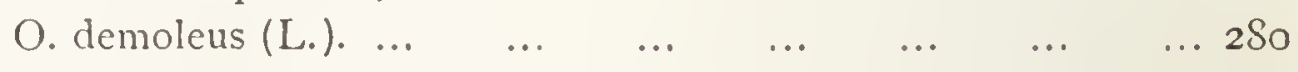

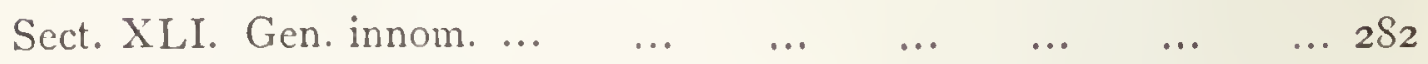

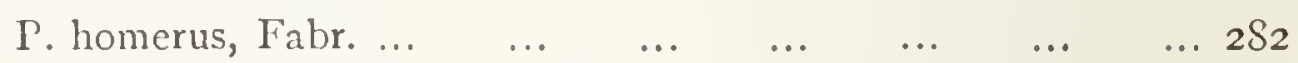

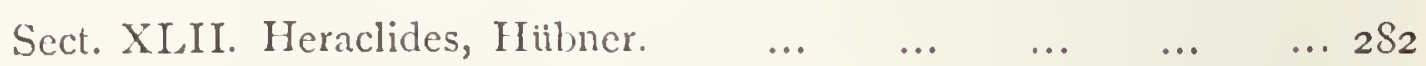

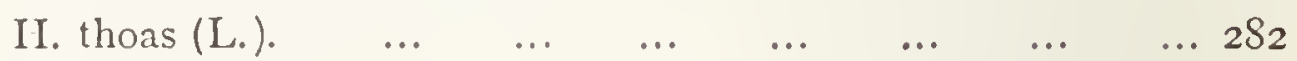

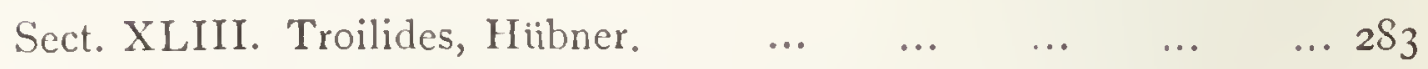

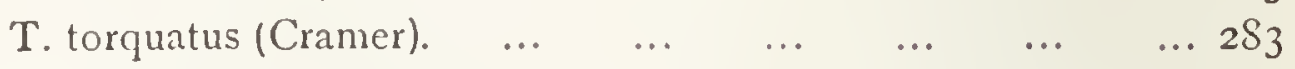

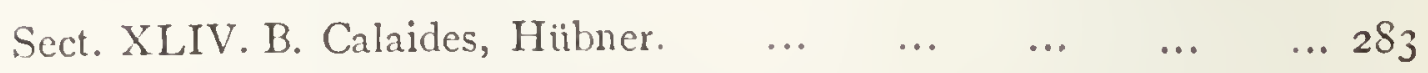

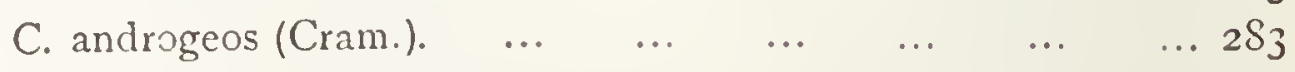

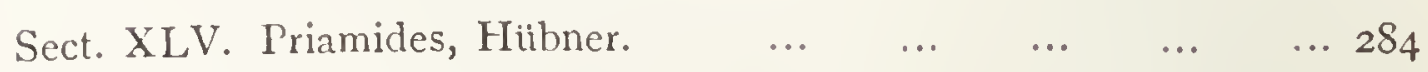

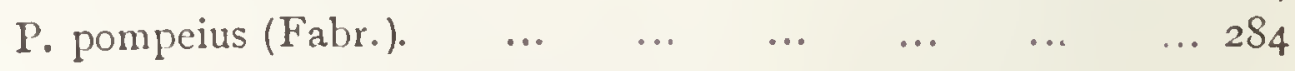

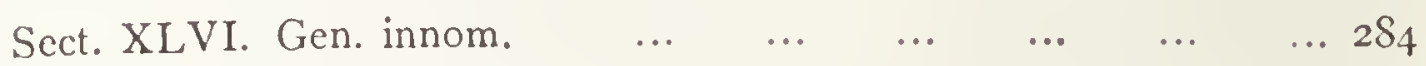

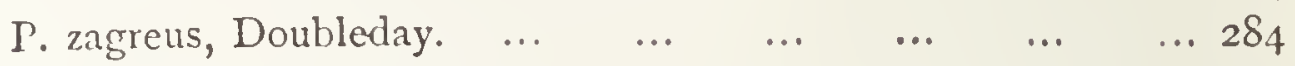

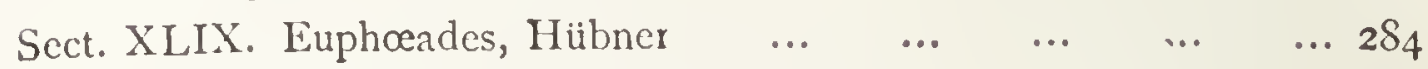

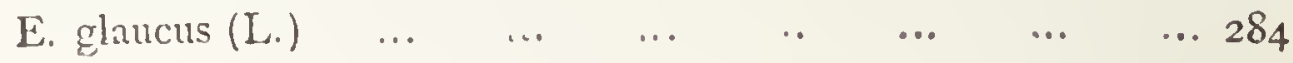


Sect. LI. A. 'Jašonia dés, Huibnér.'

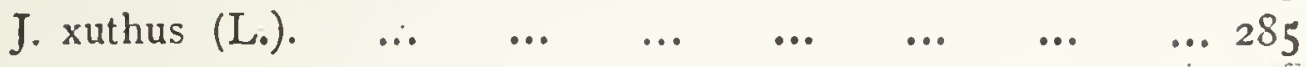

Sect. LI. B. C. Achivus, Barbut. $\quad \ldots \quad \ldots \quad \ldots \quad \ldots \quad \ldots \quad \ldots 286$

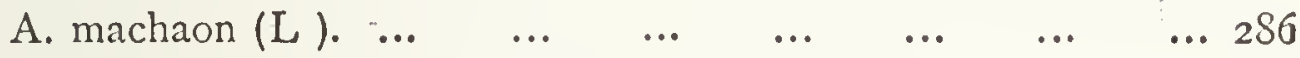

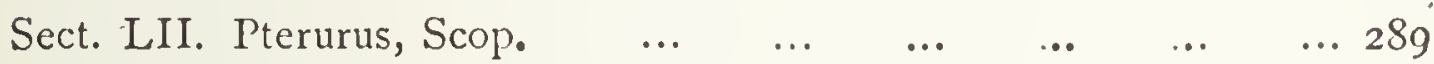

$\begin{array}{lllllllll}\text { P. } \text { troilus (L.). } & \ldots & \ldots & \ldots & \ldots & \ldots & \ldots & \ldots & 289\end{array}$

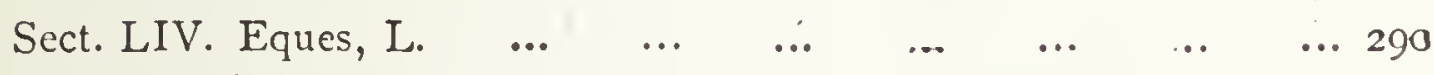

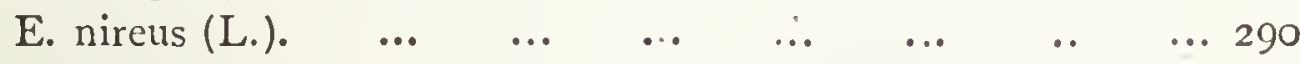

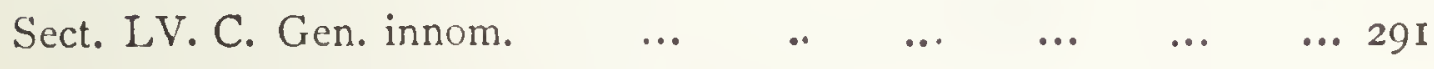

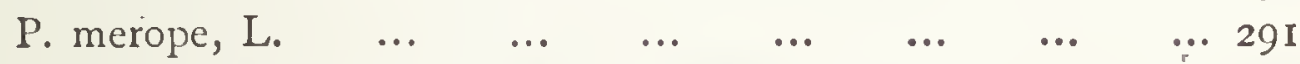

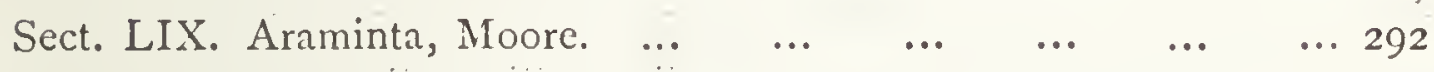

A. demolion $\left(\begin{array}{llllllll}\text { Cram.). } & \ldots & \ldots & \ldots & \ldots & \ldots & \ldots & 292\end{array}\right.$

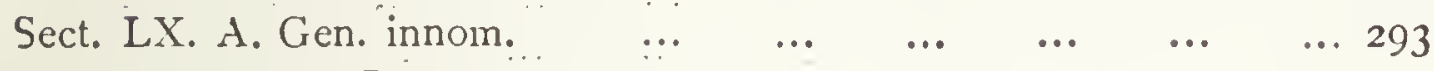

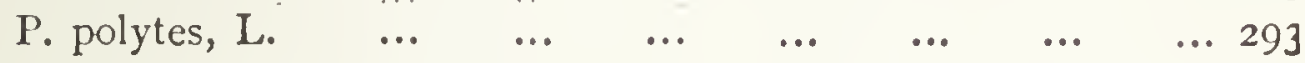

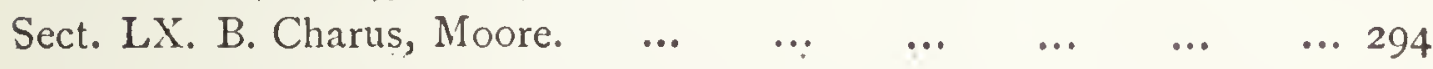

$\begin{array}{lllllllll}\text { C. helenus, L. } & \ldots & \ldots & \ldots & \ldots & \ldots & \ldots & \ldots & 294\end{array}$

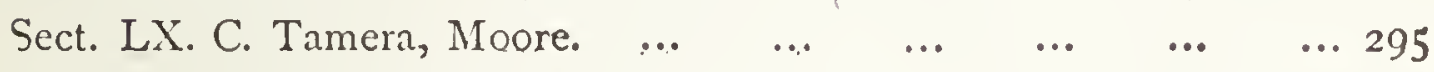

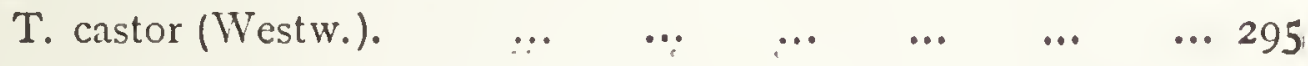

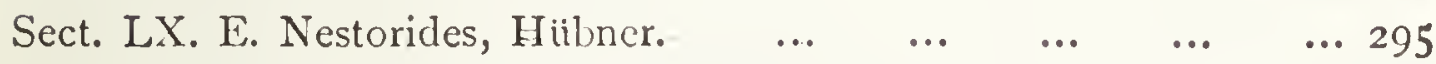

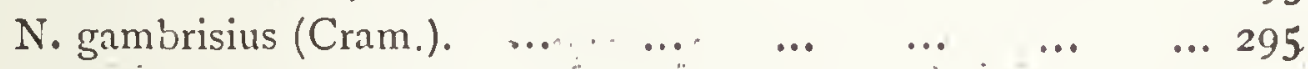

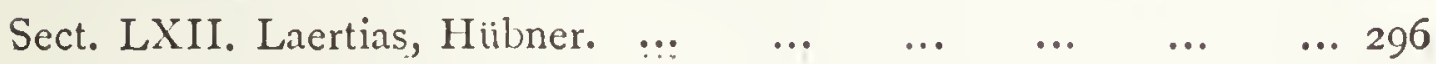

$\begin{array}{lllllllll}\text { L. ulysses }(\mathrm{L} .) & \ldots & \ldots & \ldots & \ldots & \ldots & \ldots & \ldots & 296\end{array}$

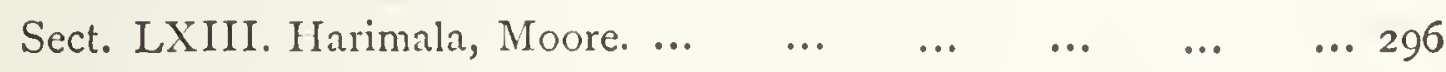

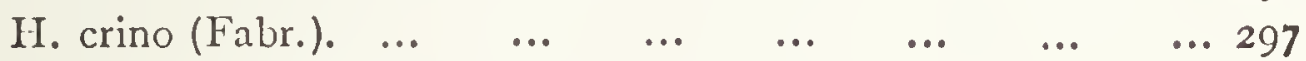

Sect. LXIV. A. pt. Achillides, Hübner. $\quad \ldots \quad \ldots \quad \ldots \quad \ldots \quad \ldots 297$

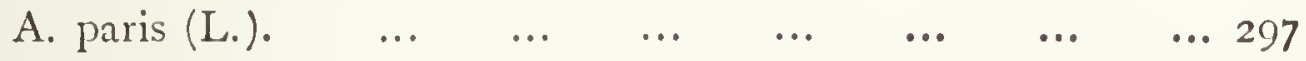

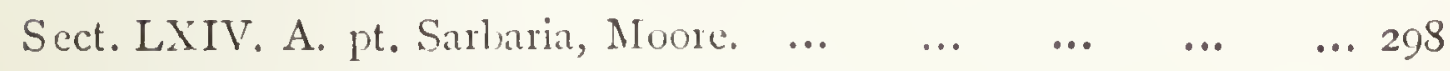

$\begin{array}{llllllll}\text { S. polyctor (Loisl.). } & \ldots & \ldots & \ldots & \ldots & \ldots & \ldots & 29 S\end{array}$

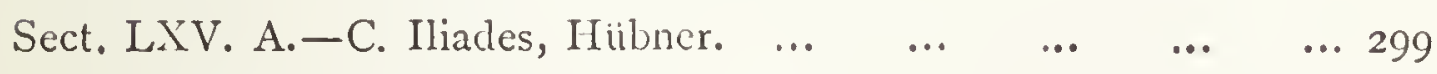

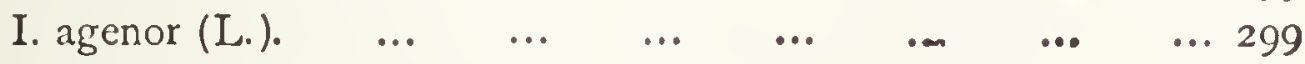

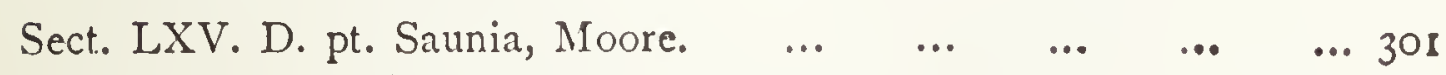

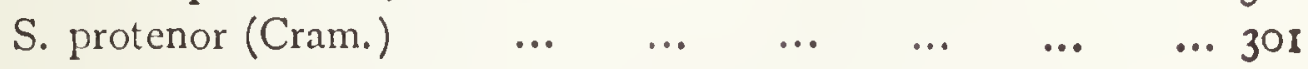

Sect. LXV. D. pt. Panosmiopsis, Wood-Mason and De Nicév. ... 30 I

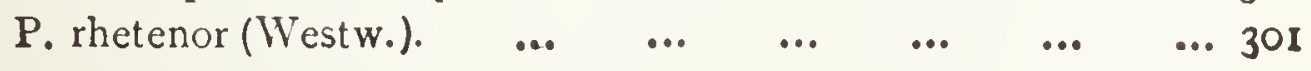


Sect. LXV D. Pangeranopsis, Wood-Mason and De Nicév PAGB

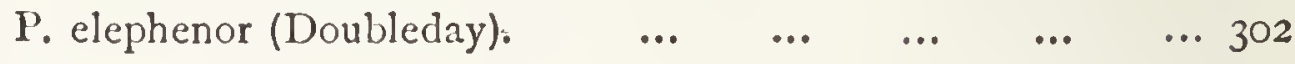

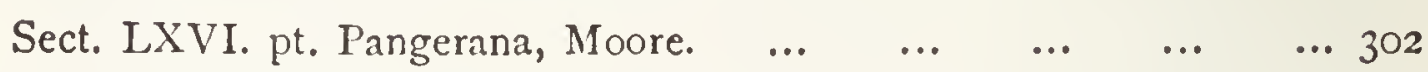

$\begin{array}{llllllll}\text { P. varuna (White). } & \ldots & \ldots & \ldots & \ldots & \ldots & \ldots & 302\end{array}$

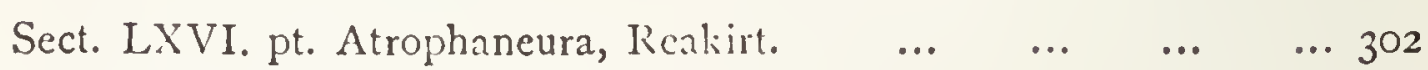

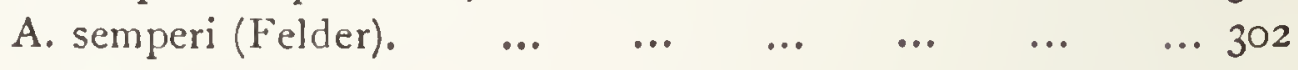

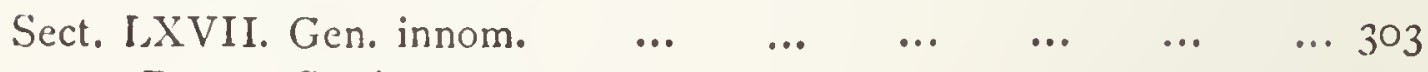

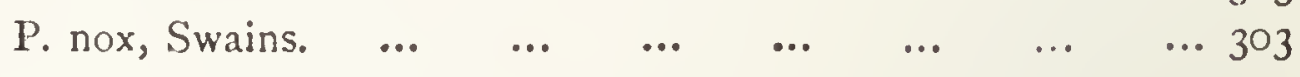

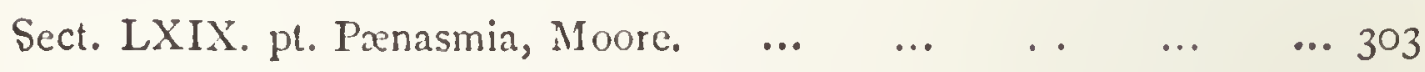

$\begin{array}{llllllll}\text { P. dasarada, Moore. } & \ldots & \ldots & \ldots & \ldots & \ldots & \ldots & 303\end{array}$

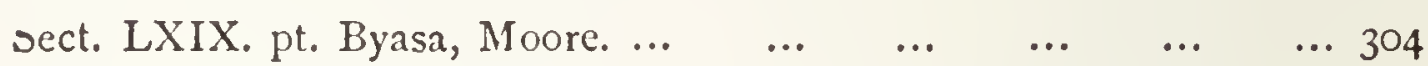

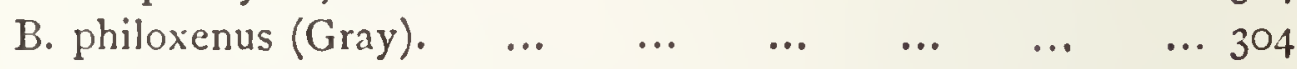

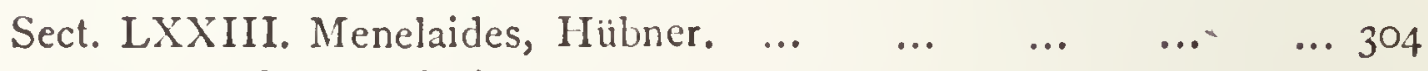

$\begin{array}{llllllll}\text { M. polydorus (L.). } & \ldots & \ldots & \ldots & \ldots & \ldots & \ldots & 304\end{array}$

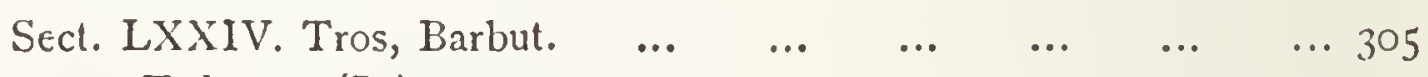

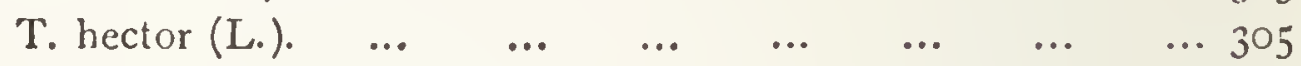

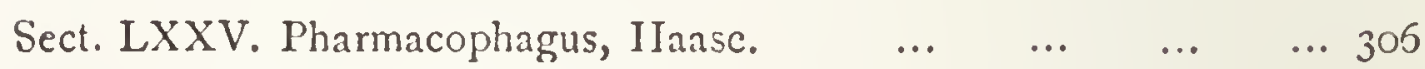

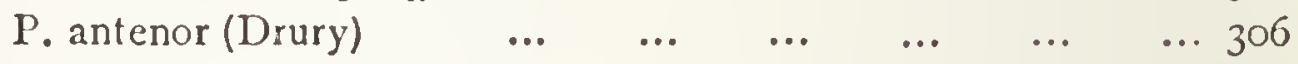

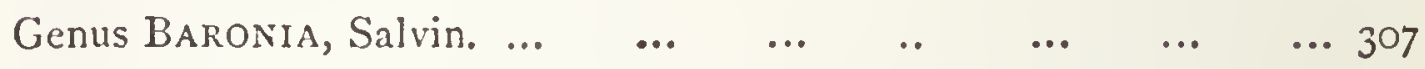

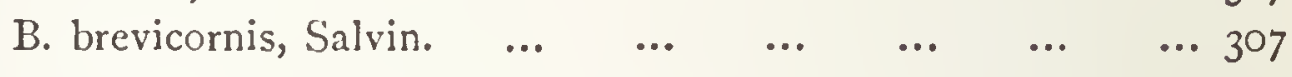

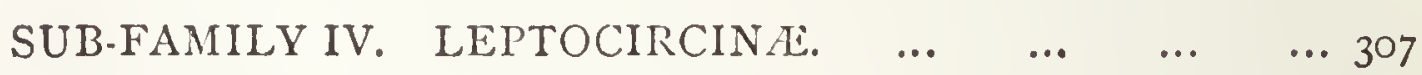

Genus Leptocircus, Swains. $\quad \ldots \quad$...

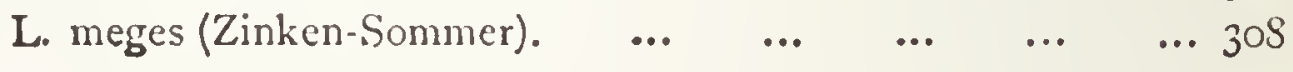




\section{LIST OF PLATES.}

XXXVIII.-Fig. I.

Fig. 2.

Figs. 3, 4 .

Figs. 5, 6 .

Fig. 7 .

Figs. 8, 9. XXXIX.-Figs. I, 2.

Fig. 3 .

XL. - Figs. I, 2.

Fig. 3 .

XLI, -Figs. I, 2.

Figs. 3, 4 .

Figs. 5, 6 .

XLII.-Figs. I, 2.

Figs. 3. 4 .

XLIII. -Figs. I, 2.

Figs. 3, 4 .

XLIV. -Figs. I-3.

Figs. 4-6.

XLV.-Figs. I-3.

Figs. $4-6$.

Figs. 7-9. Polyommatus icarus (p. 96).

XLVI.-Figs. I-3. Polyommatus thetis (p. 93).

Figs. 4, 5. Plebeius argus (p. 88).

XLVII.-Figs, I, 2. Nomiades arion (p. I08).

Figs. 3, 4. Nomiades alcon (p I Io).

Figs. 5, 6. Polyommatus corydon (p. 9I).

XLVIII.-Figs. I, 2. Polyommatus alexis (p. 99).

Figs. 3-5. Polyommatus salmacis (p. 100).

Figs. 6, 7. Polyommatus artaxerxes (p. 102).

XLIX. - Figs. I-3. Cyaniris argiolus (p. I03).

Figs. 4, 5. Zizera minima (p. 105).

Figs. 6, 7. Nomiades semiargus (p. 106).

L. -Figs. I-3. Lycæna dispar (p. I I 7).

Figs. 4, 5. Lycæna virgaureæ (p. I I 5). 
LI. - Figs. 1, 2. Lycæena hippothoe (p. I22). Figs. 3, 4. Lycæna rutila (p. I2I).

Figs. 5, 6. Lycæna phlæas (p. I 25).

LII.-Figs. I, 2. Pieris brassice (p I44).

Fig. 3. Pieris rapæ (p. I46).

LIII. -Fig. I. Pie: is chariclea (p. I45).

Figs. 2, 3. Pieris metra (p. 148).

Figs. 4, 5. Pieris sabellicæ (p. I 50).

LIV.-Figs. I, 2. Pieris napi (p. I48).

Figs. 3-5. Pontia daplidice (p. 152).

LV. - Fig. I. Pereute leucodrosime (p, 164).

Fig. 2. Schatzia socialis (p. I 62$)$.

Fig. 3. Dismorphia ega nsis (p. 183).

Figs. 4, 5. Perrhybris pyrrha (p. I 59).

LVI. -Figs. I, 2. Delias eucharis (p. I67).

Fig. 3. Delias philyra (p. I68).

LVII. - Fig. I. Delias belis $₫$ ma (p. I66).

Fig. 2. Callosune danae (p. 196).

Fig. 3. Hebomoia leucippe (p. 202).

LVIII.-Figs. I-4. Euchloe cardamines (p. I 86).

Fig. 5. Leptidia sinapis (p. I;8).

LIX.—Fig. I. Sphænogona mexicana (p. 230).

Figs. 2-4. Callidryas eubule (p. 227).

LX.-Fig. I. Colias rhamni (p. 22I).

Figs. 2, 3. Eurymus hyale (p, $2 \mathrm{I} \mathrm{I}$ ).

LXI.-Figs. I, 2. Eurymus kirbyi (p. 215).

Fig. 3. Eurymus philodice (p. 217).

LXII.-Fig. 1. Parnassius apollo (p. 236).

Fig. 2. A poria cratægi (p. I 40).

LXIII.-Fig. I. Thais medesicaste (p. 243).

Fig. 2. Leptocircus meges (p. 308).

LAIV.-Fig. I. Troides priamus (p. 252).

Fig. 2. Ornithoptera remus (p. 2f,6).

LIV. - Fig. I. Hectorides ascanius (p. 270).

Fig. 2. Achillides paris (p. 297).

LXVI.-Fig. I. Iliades agenor (p. 299),

Fig. 2. Parides æneas (p. 27).

LXVII.-Fig. I. Achivus machaon (p. 2S6).

Fig. 2. Iphiclides potalirius (p. 275).

LXVIII.-(Frontispiece). Fig. I. Cosmodesmus protesilaus (p. 273).*

Fig. 2. Iphiclides celadon (p. 274).

* Iphiclides on plate. 


\section{THE BUTTERFLIES AND MOTHS-ORDER LEPIDOPTERA.}

\section{THE BUTTERFLIES-LEPIDOPTERA RHOPALOCERA.}

In our first volume, we dealt with the extensive Family $N y m$ phalide, in which the front legs are always more or less imperfect in both sexes. We have now to consider the remaining Families of Butterflies, in all of which the front pair of legs are fully developed in the females, and sometimes also in the males, though in those which approach nearest to the $N_{y} m$ phalida, the front legs are more or less imperfect in the males, and are shorter than the other pairs of legs in the females.

\section{FAMILY II. IIBYTHEIIAE.}

Egg.-Ampulliform, ridged, twice as high as broad (Doherty).* Regularly elliptic, with sharply-round, prominent longitudinai ribs (Sadder).

Larva.-Cylindrical, slightly pubescent, segments with four transverse divisions; head small, rounded.

Pupa.-Rather stout, ridged, suspended by the tail only.

Imago.-Of moderate size, with angulated and dentated wings,

* Dr. Scudder thinks that this description was taken from distorted specimens; but there is no reason why the eggs of the Indian and American species should not differ in shape. 
at least in the female; colour, except in the Austro-Malayan species, brown, with markings varying from reddish fulvous to pale buff; or blue in some of the Eastern species just mentioned. Palpi very long, about four times as long as the head. Front legs in male very small, the tarsi reduced to a single joint, without claws; front legs of the female almost perfectly developed, but considerably smaller than the others.

Range.- "The twelve or fourteen species of this Sub-family, which it hardly appears necessary to divide into genera, are singularly scattered over all the warmer parts of the globe; except, I believe, the continent of Australia, and Polynesia. The type of the genus, L. celtis (Fuessly), inhabits Southem Europe and Asia Minor; the Fthiopian region "has three species; India and the Indo-Malayan Islands, three; the Austro-Malayan and Australasian Islands, two or three; two are natives oc the United States and the IVest Indies, and one is found in Surinam and Brazil. It does not seem improbable that these few and widely-scattered congeners are but the surviving members of what was at some former period a numerous and generally prevalent group" (Trimen). The same opinion is expressed by Dr. Scudder, who mentions the discovery of two fossil species in Colorado.

Habits.--The species frequent open places; road-sides, vineyards, forest glades, hedge-sides, \&c., especially near water, and they have a rather rapid flight.

We shall notice representatives of three different sections of this small family.

\section{GENUS LIBYTHEA.}

Libythea, Fabricius, in Illiger's Mag. Insekt. vi. p. 2S4 (1Soz); Latreille, Enc. Méth. ix. pp. Io, I70 (ISI9); Westwood, Gen. Diurn. Lepid. p. 4I2 (185I); Schatz \& Röber, Exo.. Schmett. ii. p. 226 (1892).

Type, Papilio celtis, Fuessly. 
Hypatus, Hübner, Catal. Franck, p. 85 (1825); Scudder, Butterflies of Eastern United States, p. 753 (1889).

\section{Type, Papilio carineuta, Cramer.}

Dr. Scudder considers the American species of this Subfamily to be entitled to generic rank, and retains for them Hübner's name Hypatus, observing: "I have not been able to study the Asiatic species, but the European and African are certainly distinct from the American forms. I would call attention to the abruptly lobate front margin of the hind-wing in the European species (Libythea proper), and the close approximation of the third and fourth superior sub-costal nervules of the fore-wings at their origin, to the gradually incrassating antennæ, in which the club can scarcely be separately distinguished, but may be said to occupy half the length of the antennæ, to the coarser, and owing to the comparative brevity of the apical joint, the somewhat shorter palpi, and finally to the deeply bifid termination of the eighth abdominal segment in the male, with the irregular and thorny clasps, which are in striking contrast to those of Hypatus. It may also be pointed out that the larve of Libythea are not thickened on the thoracic segments, have no thoracic tubercle, and that the chrysalis terminates at the anterior extremity in a single and not a double protuberance; in other words, there is no apical notch" (Scudder, op. cit. pp. 155, I56).

But having regard to the very small number of species known, and the much greater divergence of the species of the AustroMalayan group, which has not yet been separated as a distinct genus, we have preferred to leave Libythea undivided in the present work. The characters are therefore those of the Family; but the large Austro-Malayan species differ much in shape and appearance from the species of other parts of the world, and will probably have to be separated from them as belonging to a different genus. 
The type is

THE NETTLE-TREE BUTTERFLY. LIBYTHEA CELTIS.

Papilio celtis, Fuessly, Arch. Ins. pl. 8, figs. I-3, and pl. I 4 ( I $782-$ I783); Esper, Schmett. i. (2) p. I68, pl. 87, figs. 2, 3 ( 783 ); p. 109, figs. 2-8 (เ800: transf.); Hübner, Eur. Schmett. i. l'p. 447-449 (I799?).

Libythea celtis, Godart, Enc. Méth. Ins. ix. p. I70, no. I (1819); Kirby, Eur. Butterflies and Moths, p. 43, pl. I3, fig. 9 (I879) ; Lang, Butterflies Eur. p. 152, pl. 32, fig. 2 (I882: with transf.).

This Butterfly measures an inch and a half, or an inch and three-quarters across the wings, which are brown, with fulvous markings, and are strongly angulated ; towards the tips of the fore-wings is a white spot on the costa, and a square blotch obliquely below it, beyond the more extended tawny colouring of the wing. The Butterfly has much of the appearance of a small Vanessa, but its very long palpi are amply sufficient to prevent it from being mistaken for any other European species. It inhabits Southern Europe and Asia Minor. The larva and pupa are both green, and the larva feeds on the nettle-tree, Celtis australis, but will also eat cherry. It is double-brooded, the Butterfly appearing in March and June, and it is not uncommon where its food-plant grows.

THE SNOUT BUTTERFLY. LIBYTHEA BACHMANII. (Plate XXXVIII. Fig. I.)

Libythea bachmanii, Kirtland, Amer. Journ. Science (2), xiii. p. 336, cum fig. (1852); Edwards, Butt. N. Amer. ii. Lib. pl. i. (I874); Maynard, Butt. N. Eng'and, p. 3 I, pl. 8, figs. 36, 36a ( I 886).

Hypatus bachmanii, Scudder, Butterflies of Eastern United States, p. 760 (is89). 
1.

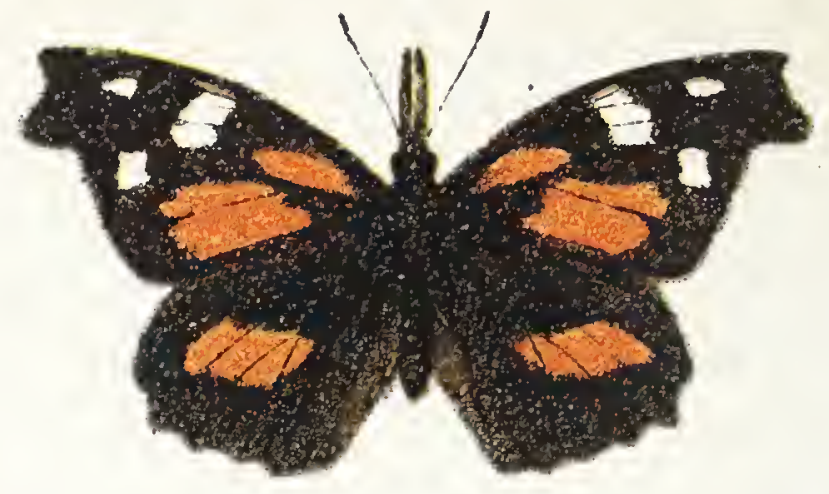

PLATE XXXVI
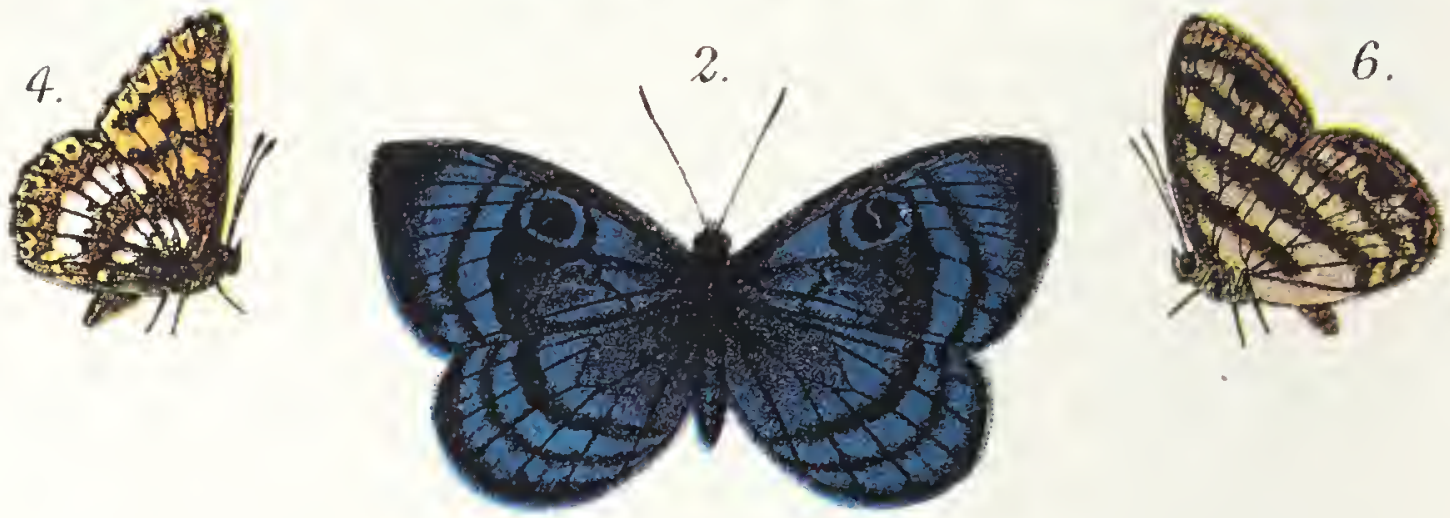

3.
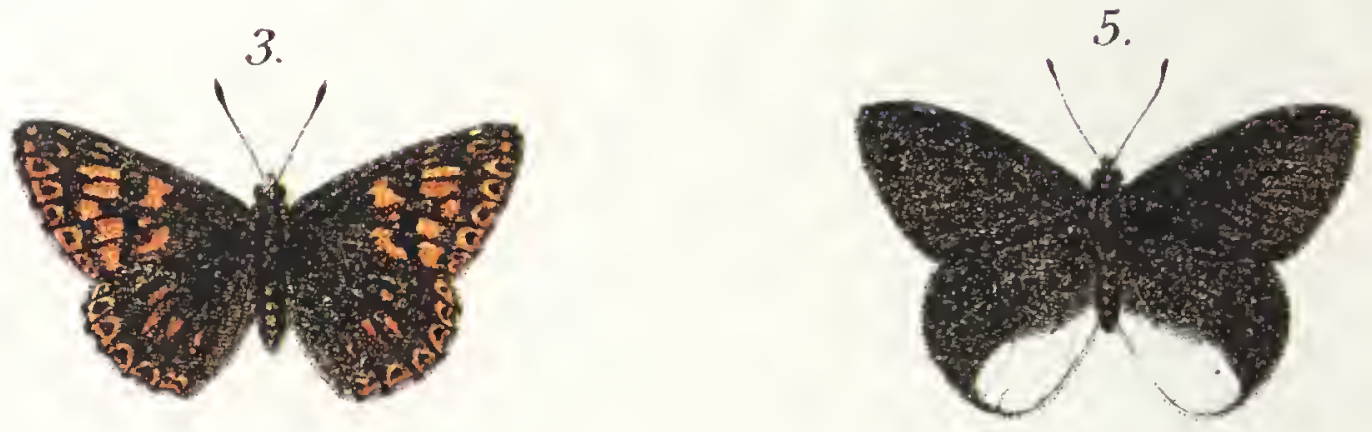

7.

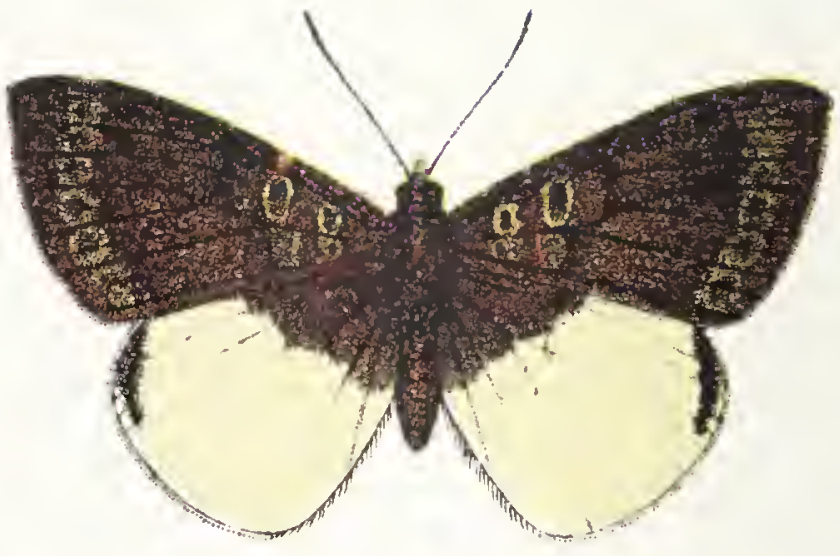

9
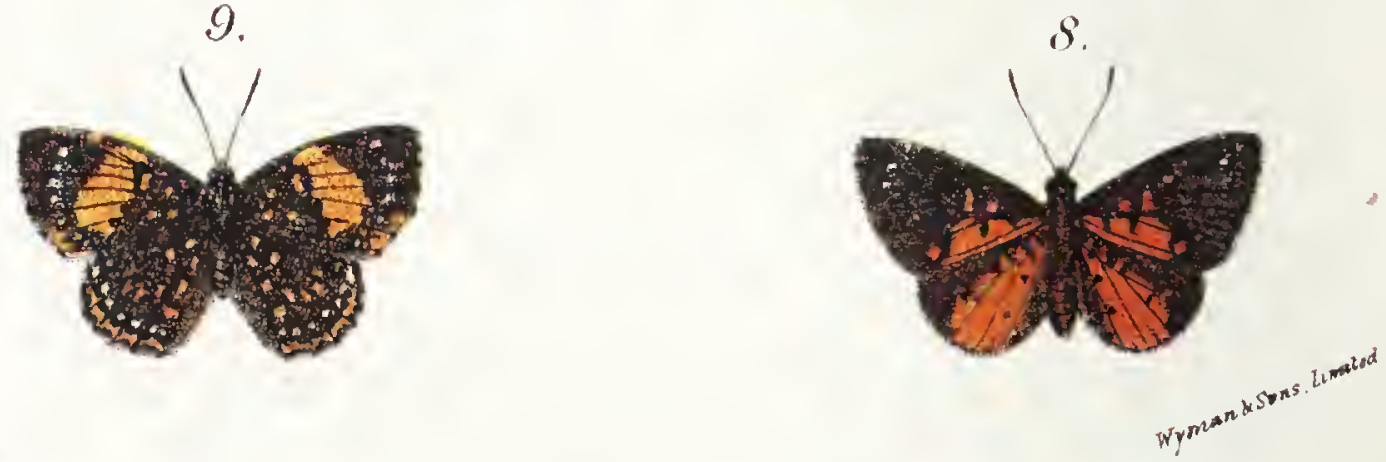

1. Libythea bachmani 5.6. Euselasia effima.

2. Mesosemia bifasciata. 7. Nymphidium ethelinda

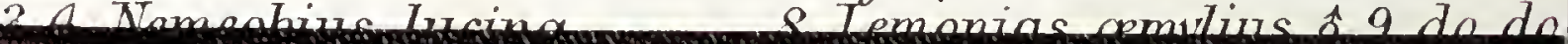


Libythea motya, pt. Boisduval \& Leconte, Lépid. Amér. Sept. pl. 64, figs. 3, 4 (nec figs. I, 2) (I 833 ).

This species is about the size of L. celtis, but the fore-wings are longer, the apex projecting in a more produced lobe, with a concavity between the two angles, the upper angle being nearly as long as the lower one. The hind-wings are less denticulated than in L. celtis, and project in a small rectangle in the middle of the hind-margin. The colour is brown, with rather brighter tawny markings than in L. celtis. On the forewings the cell, and the greater part of the space between this and the inner-margin is filled up with bright tawny colour, the costa, apical region, and hind-margin remaining brown; on the apical region are three large white, or yellowish-white, spots. Beneath the fore-wings are coloured as above, but paler. The hind-wings are brown, with a curved tawny band a little below the costa, and beneath they are of a purplish-grey, with a yellowish-grey band running from the base, a little below the centre, to the hind-margin.

The larva is cylindrical, green, with yellow lines and dots; the pupa is also green, sometimes tinged with blue or yellow, and sprinkled with yellow dots, especially on the abdomen.

The larva feeds on sugar-berry or hack-berry (Celtis ocidentalis, L.), and probably on other plants; and there is a succession of broods throughout the summer. It is common in many parts of the Southern United States; in the Northern States it becomes rare and local, but touches Canada, having been met with as far north as Southern Ontario. It frequents gardens, meadows, road-sides, and other open places, and is particularly fond of flying about raspberry blossoms.

The South American L. carinenta (Cramer), the type of the genus or sub-genus Hypatus, is a species very similar to $L_{n}$ 
bachmanii, but with the tawny portion of the fore-wings broken up, more or less distinctly, into three spots.

The various species of the Austro-Malayan group inhabit several of the Moluccan and Papuan islands, and extend to the Philippines, though probably not to any other part of the Indo-Malayan region, the Indian species of Libythea more resembling the group of $L$. celtis. The Austro-Malayan species are much larger than the others, expanding upwards of two inches. In the male the apex of the fore-wings is obtusely rounded, hardly lobate, the hind-margin being slightly oblique, and nearly straight, or slightly concave, between the apex and the anal angle. In the female there is a slight apical lobe, truncated, but not concave; the hind-margin beneath is more strongly concave than in the male. The hind-wings are rounded, but hardly dentated or angulated, except that they are somewhat produced at the anal angle in the female. The palpi are much shorter and more hairy than in the more typical species of the genus. The colour, too, differs considerably; the males are brown above, with more or less of the base and centre of the wings filled up with violet-blue, more or less cut by the nervures. Sometimes there are some whitish spots on the fore-wings, and a reddish stripe on the hind-wings. The females are brown with fulvous markings, and sometimes with white spots on the fore-wings and a fulvous bar on the hind-wings; but these markings are all at or beyond the end of the cell, the basal portion of the fore-wings being always brown.

\section{FAMILY III. LEMONIIDÆ.}

Egg.- "Broader than high, tiarate or oblately spheroidal, more or less deeply and densely reticulate, with converging septa 
extending from the walls of the cells towards their centre" (Scudder).

Larva (newly emerged).- " Body with chitinous dorsal and substigmatal shields on every segment, to which the haired papillie are confined, and only sub-dorsal annuli" (Scudder).

Larva (full grown).-Short and stout, somewhat onisciform, without spines or long hairs; head at least half as broad as the middle of the body.

Pupa.-Short and stout, sometimes pilose, and with a few long bristly hairs, attached by the tail, and sometimes freely suspended, as in the Nymphatida, but more frequently recumbent, heing secured by an additional thread across the middle.

Imago.-Of small or moderate size, the largest species rarely exceeding two inches in expanse, and of delicate structure; hind-wings with a pre-costal nervure; very rarely with ocellated spots. Front legs perfectly developed in the female, but smaller than the others; imperfectly developed in the male, with the tarsi reduced to one or two joints, without spines or claws.

The present group is generally regarded as of the rank of a Family, though Dr. Scudder considers that it is not sufficiently distinct from the Lycenida to be considered as more than a Sub-family. There are, however, many differences, and even in pattern and general appearance the two groups are so dissim.lar that there are very few species belonging to either of them which would be likely to be mistaken for the other, even at the first glance, by anyone who was fairly well acquainted with the general appearance of the Butterflies. There are, however, a few Lemoniida which superficially resemble some of the smaller Nymphalide. Again, the Lemoniide and Lycanide may be taken as in some measure representative of separate Faunas, 
for the Lemoniida, with the exception of a few somewhat aberrant Old World genera, are almost entirely confinc d to tropical America, whereas the Lycrenide are almost entirely an Old World group, if we except the tropical American species allied to Thecla. These, though numerous, are closely allied, and cannot be considered as a set-off against the very numerous and varied genera of the Old World.

To return to the Lemoniide (or Erycinida, as the Family is often called).* The first attempt at a natural division of the genera was made by Bates, in a catalogue of Erycinide, commuricated to the Linnean Society of London on June 20, I 867 ("Journ. Linn. Soc. Zoology," ix. pp. 367-459). In this paper he divided the group into three Sub-families, which have been generally accepted by entomologists, with some modifications.

In 1885 Messrs. Godman and Salvin, in their "Biologia Centrali-Americana "Lepidoptera Rhopalocera, i. pp. 36r, 362, removed from Bates' first Sub-family, the Nemeotiine, all the New World genera which Bates had placed in it, transferring them to Bates' third Sub-family, the Erycinince (Lemoniince of Kirby), but combining with it Bates' second Sub-family, the Eurygonine (Euselasiune of Kirby), thus bringing together all the genera in which the basal nervure is absent or rudimentary. They remark: "We have not yet discovered satisfactory. characters whereby to separate the Old from the New World genera of this Sub-family."

It is, however, clearly desirable to separate groups of species geographically when this can be done; and, in I892, Schatz and Röber proposed to restrict the Nemeobiince to the Old World genera, and to reinstate Bates' Sub-family Eury'gonine or Euselasiince. But neither in the Lemoniida, Lycanidre,

* The alteration of the Family name was rendered necessary by the rejection of the genus Erycina, Fabr., on account of this name being pre-occupied in Mollusia: 
nor Hesperiula, do the Sub-families rest on such important differences as those which separate the Sub-families of the Nymphalide, nor are they nearly so well marked.

Most of the species prefer to settle on leaves rather than on flowers, and the position of the wings in repose varies a good deal.

"The Family is remarkable for the wonderful diversity of form and colouring which it presents, and the habits of the species are almost equally varied. Some are of very slow, lazy flight, whilst others are excessively rapid in their movements. It may be stated, however, as an universal rule, that their fight is short, never exhibiting the sustained motion which is characteristic of the Nymphalide, Salyrida, and other superior Families of Butterflies. A large number of genera have the habit of settling on the under side of leaves near the ground, extending their wings flat on the leaf. In many genera, on the contrary, the position of the wings in repose is vertical; and a few species settle on the upper surface of leaves with the wings half elevated"(Bates).

\section{SUB-FAMILY I. NEMEOBIIN $A$.}

Egg.--More or less rounded, smooth, and slightly reticulated or granular.

Larva.-Short, somewhat wood-louse-shaped, though longer than in the Lycenide, and set with small hairy warts.

Pupa.-Short, obtuse, rounded, slightly hairy, attached by the tail, and a girth round the middle.

Imago.-Wings broad, rather short. The hind-wings sometimes with an angular projection; brown, with tawny, white, or red markings; fore-wings with the sub-costal nervure five-branched (except in Polycena, Staud. (4), and Simiskina, Dist. (3); cells 
closed; hind-wings with no basal nervure,* and with the sub-costal nervure and upper discoidal nervule rising from a common stalk (except in Simiskina).

Range.-About a dozen genera are at present admitted as belonging to this Sub-family, but they are not numerous in species, nor have they a very wide range. Of these, Nemeobius, Steph., contains the only European species of the Family, the well-known "Duke of Burgundy Fritillary"; another genus, the few species of which likewise have a superficial resemblance to small species of Melitea, Fabr., is Polycana, Staud., which is confined to Thibet and IVestern China; and all the other genera are restricted to the Indo-Malayan and Austro-Malayan regions, except that some of the former probably cross the southern frontier of the Palaarctic region, and that the genera allied to Abisara, Feld., have one or two representatives in Africa and Madagascar, as well as in the East Indies.

Habits.-Woodland insects, of low flight, preferring to settle on bushes rather than on flowers. Some of the Indian and Chinese species are met with at an elevation of at least 10,000 feet in the mountains.

\section{GENUS NEMEOBIUS.}

Nemeobius, Stephens, Ill. Brit. Ent. Haust. i. p. 28 ( 1827 ); Westwood, Gen. D. Lepid. p. 4 I9 (185I); Schatz \& Röber, Exot. Schmett. ii. p. 230 (IS92).

Antennæe distinctly clubbed; eyes with short hairs; palpi slender, pointed; fore-wings with the costa nearly straight, hardly longer than the hind-wings; hind-margins gradually curved and denticulated.

There is only one species, which is common in Central and Southern Europe, and is also found in England. 
THE DUKE OF BURGUNDY FRITILLARY. NEMEOBIUS

\section{LUCINA.}

\section{(Plate XXXVIII. Figs. 3, 4.)}

Papilio lucina, Linn. Syst. Nat. (ed. x.) i. p. 4So, no. I 35 ( 75 S);

id. Faun. Suec. p. 2 So, no. Io6 I (I76I); Esper, Schmett.

i. pt. I, p. 206, pl. i6, fig. I ( 1777 ).

Nemeobius lucina, Stephens, Ill. Brit. Ent. Haust. i. p. 29 ( 1827 ); Kirby, Eur. Butterfies and Moths, p. 44, pl. I 3 , fig. Io (1879); Newman, Brit. Butt. p. Io3 (ISS I); Lang, Eur. Butterflies, p. I 50, pl. 33, fig. I (ISS2); Barrett, Lepid. Brit. Isl. i. p. I०2, pl. I 5, figs. I, I $a-\mathrm{I} e$ (1S92); Buckler, Larvæ Brit. Lepid. i. p. 85, pl. i 2, fig. 3 (1 \$\$6). Hamearis lucina, Curtis, Brit. Ent. vii. pl. 3 I6 (1 830$)$.

The Duke of Burgundy Frittillary measures about an inch and a quarter across the wings, which are brown, with three rows of tawny spots across the fore-wings, the outermost containing a row of black dots. On the hind-wings there are only two rows, that nearest to the base on the fore-wings being absent. The fringes are white, chequered with brown. There are two rows of white spots on the under side of the hindwings.

The eggs are laid on either the upper or under side of the leaves of the primrose or cowslip. The larva is blackish when young, but, when full grown, it is of a dull green, with a dark, somewhat macular, dorsal line. The hairs are black above and paler beneath; the head is brown.

The pupa is rather short, and is of a pale yellow colour, with numerous black spots, more or less arranged in rows; and the insect passes the winter in this stage, the Butterfly appearing in May and June; and on the Continent there is a second brood, which appears in August.

The Butterfly is found in sunny places in woods, and is also 
found among bushes in hilly districts throughout Southern and Central Europe. Its flight is weak, and it is usually seen in open places, such as a sunny drive or a glade, never flying far, and apparently restricted to a narrow area, probably in the vicinity of the food-plant.

\section{Exotic genera of Nemeobiince.}

Most of the Asiatic and African species of Nemeobiince, except those belonging to the two following genera, are considerably larger than our European species. The Central Asian genus Polycand most resembles Nemeobius in general appearance, and the species are likewise very similar to small species of Melitea. They are brown Butterflies, with more or tess confluent tawny or reddish markings on the fore-wings ; the hindwings have a double row of spots, the sub-marginal row tawny, or reddish, and the inner more yellowish. The under side is dark brown, with a sub-marginal reddish line, and with more or less extensive fulvous or pale yellow markings on the fore-wings, and pale yellow or whitish markings on the hindwings. They are not much larger than Nemeobius; nor is Stiboges nymphidia, Butler, a Butterfly very dissimilar to the Fritillaries in co'our, which is found in Western China, Bhutan, Penang, \&c., and which is remarkable for its superficial resemblance to some of the South American Lemoniida. It is dark brown, with a very broad white band covering the hindwings, except at the extreme base, to beyond the middle, and extending over the fore-wings nearly to the costa, except at the base, and across and beyond the lower part and end of the cell.

We may mention most of the principal tropical forms of this Sub-family, as they are not very numerous. The genus Zemeros, Boisduval, contains two or three species, common in the East Indies, generally measuring rather less than two inches across the wings, which are more or leșs dẹtated, and sometimes 
slightly produced at the outer angle of the hind-wings. Zemeros flegyas (Cramer), from India, is brown, with many pale yellowish spots, adjoining black ones, and arranged in more or less irregular transverse rows, on both sides of the wings. In Zemeros albipunctata, Butler, from the Malay Peninsula and the adjacent islands, pale spots are present only towards the tips of the fore-wings, and towards the hind-margins of the wings beneath. Another species, which inhabits the same localities (Zemeros emesioides, Felder), has the wings hardly dentated, and is marked with parallel alternate stripes of black and fulvous, the latter being broader and paler on the under surface.

The genus Dodona, Hewitson, includes several North Indian species, measuring from an inch and a half to two inches in expanse. The fore-sings are broad and rather short, with the hind-margin not very oblique, and the hind-wings are very long, being gradually produced into a large lobe at the anal angle. They are brown above, with transverse tawny bands in the male, much resembling very large Butterflies of the Lycænid genus Aphnaus in colour; the females are reddish-brown, with a white oblique band on the fore-wings, beyond which the tip is black.

Dicallaneura, Butler, is another small but very pretty genus containing a few species which are confined to the Papuan islands. They are rather smaller than the species of Dodonc, with the costa of the fore-wings more rounded, and the hincwings shorter, with a broad rounded lobe before the anal angle: In one species, D. pulchra (Guér.), from Waigiou, the male is black above, with a pale blue transverse band on the forewings, and the female is reddish-tawny on the hind-wings and at the base of the fore-wings; outwardly, the fore-wings shade into yellowish tawny, and more than the apical third of the fore-wings is black. On the hind-wings is a sub-marginal row of black spots and streaks. 
In D. decorata (Hewitson), found in the Aru Islands, the male is reddish-tawny, with a tawny oblique band on the fore-wings, beyond which the apex is black, and the female is uniform yellowish-tawny, except the broad black tip of the fore-wings: and the sub-marginal black spots of the hind-wings. Both species are elegantly marked beneath with pale lines and spots on a tawny or reddish-brown ground.

The genus Tarila, Westwood, has the hind.wings rounded or slightly dentated, but hardly lobate. The species inhabit India and the Indo-Malayan region generally, and measure about an inch and a half across the wings. They are brown, red or banded, with unicolorous hind-wings, and many of them are of a beautiful purplish-red colour, with spots and streaks on the under-surface of a dull metallic blue. In some of the species there is a large and conspicuous white or pale blue spot on the inner-margin of the fore-wings above.

Abisara, Felder, contains rather large brown species, often with broad white or pale bands on the fore-wings at least. On the hind-wings some of these have a long tail, and are not unlike species of the Satyrid genus Lethe, Hübner. They are found in the East Indies and Africa. Allied to these is a rather isolated species, Saribia tepahi (Boisduval), the only Butterfly belonging to the I.cmonliake, which is found in Madagascar, while it is remarkable for being the only Old W'orld species with thee tails, or rather, two, in addition to the lobe at the anal angle. It 15 a brown Butterfly, expanding from $1 / 2$ to $\mathrm{I} 3 / 4$ inches, and its diverging tails, though not its colour, give it something of the appearance of the Tropical American genus, Helicopis.

The Erycinide of the Old World are a small but interesting group, and are one of the sections of Butterflies that require a thorough revision of the genera and species. The various existing genera, most of which we have noticed, are not-in all 
cases sufficiently well-defined, and there are some iso.ated forms, such as Abisara gerontes (Fabricius), from West Africa (a brown white-banded Butterfly, with tails, and with one or two ocellated spots, a very unusual character in this Farnily), for which new generic names are certainly required. But the domain of entomology is very extensive, and it would be a great mistakc to imagine that it is anything like worked-out at present, even in the case of insects so much studied and sought after as Iutterflies. The number of new and beautiful forms which are discovered every year in almost all parts of the world would alone dispel any such an idea.

The genus Simiskina, Distant, which is distinguished from all the other Nemeobince by the three-branched sub-costal nervure, is placed by Schatz and Röber in the Erycinidce with considerable hesitation. It includes only two brown and tawny species from Malacca, measuring about an inch and a half across the wings. 'The hind-margin of the hind-wings projects at an angle considerably further from the anal angle than in Abisara, \&c. ; the under side of all the wings is brown with darker lines, or yellowish-tawny with reddish lines. One of the species was referred by Hewitson to the Lycrenid genus Poritia, Moore, and the o'her was regarded by Distant as the type of a new genus of Erycinidie.

\section{SUB-FAMILY II. EUSELASIINAE.}

Egg.-Undescribed.

Larva.- Onisciform or cylindrical, clothed with a dense pilc, as well as with longer hairs.

Pupa.-Iong or short, pilose or hairy.

Imago--Wings broad, rather short; fore-wings with thr: 
hind-margin entire, nearly straight, only slightly curved; hind wings generally rather long, sometimes dentated, or with several tails, or with the anal angle produced. Prevailing colours brown, with blue, tawny, or pale markings. Forewings with the sub-costal nervure three, four, or five-branched (within the limits of the genus Euselasia itself); cells closed, hind-wings with no basal nervure and with the upper radial nervule rising from the upper disco-cellular. On the forewings the upper disco-cellular nervule is absent, except in Perophthalma, Westwood.

Range.-The few genera of this restricted group are confined to South and Central America. With the exception of the typical genus Euselasia, the species are not numerous, though some of the other genera are interesting.

\section{GENUS EUSELASIA.}

Euselasia, Hübner, Verz. bek. Schmett. p. 24 (1816); Schatz \& Röber, Exot. Schmett. ii. p. 234 (1892). Eurygona, Boisduval, Spec. Gen. Lépid. i. pl. 2 I, fig. 3 ( $\left.8_{3} 6\right)$; Westiv. Gen. Diurn. Iepid. p. 437 ( $185 \mathrm{I}$ ).

An extensive genus of small Butterflies, usually measuring from an inch to an inch and a half across the wings. The fore-wings are short and broad, and the hind-wings frequently show a tendency to assume a somewhat oblong form; but in a few species the hind-wings are considerably drawn out almost to a point at the anal angle, though they are never actually tailed. In other species the hind-wings are slightly dentated.

IVe have already indicated the general coloration of the species in our remarks on the Family. Several are striped and occasionally imperfectly ocellated on the under surface in such a manner as to give them a strong superficial resemblance, in some cascs, to Satyrince of the genus Euptychia, and, in other 
cases, to some of the numerous South American species of Iyceniace allied to Thecla. The most remarkable of all, however, are one or two tawny species, such as E. opalescens and O. preclara, of Hewitson, which are shot with a most splendid and delicate mother-of-pearl iridescence, for which we may seek in vain elsewhere in Butterflies, except in Ornithoptera magellanus, Felder, Morpho sulkowskyi, Kollar, and in the crimson spots of some of the South American Equiticles.

According to Messrs. Godman and Salvin, "all the species of this genus have the habit of resting on the under surface of leaves within a few fect of the ground."

The type is indicated by Dr. Scudder as-

EUSELASIA GELON.

Papiliogelon, Stoll, Pap. Exot. Suppl. pl. 5, figs. 2, 26 (i $7 S_{7}$ ). Eryina gelon, Godart, Enc. Méthod. ix. p. 568, no. I 9 (1823).

A rather inconspicuous brown Butterfly, with rounded wings, expanding about an inch. There is a fulvous blotch towards the anal angle of the hind-wings, both above and below. The under surface is pale yellow, with three parallel brown lines. It is found in Surinam. Dr. Scudder remarks that the larva "is said by Bar to be nocturnal in habits, and processional, the caterpillars following one another in a single rank; it is covered with pile (velvet), and 'wholly resembles the caterpillar of a small Bombyx.' 'The chrysalis somewhat resembles that $\alpha^{\prime}$. Thecla." This processionary habit has previously only been observed in the case of certain Moths (Bombiges).

As an illustration of this genus we have selccted

\section{EUSELASIA EFFIMA. \\ (Plate YXYTVIIT. Figs. 5, 6.)}

Eurysona effina, IIewitson, Equatorial Lepidoplera, p. 46, no. $\$_{3}(1869)$ 
The mate is dark brown on the upper side, with the anal angle of the hind-wings broadly white.

The under side is pale brown, darker towards the margins. All the wings are crossed by three brown bands. The forewings have also a sub-marginal brown band, marked with a black spot in the middle. The hind-wings have a sub-marginal row of black spots marked with white, of which the third spot from the tip is the largest.

The insect measures rather less than an inch and a quarter across the wings. It was brought from Ecuador by the late Mr. Buckley, some years ago, but has not been figured before. Mr. Hewitson compared it with a species which he had previously described from the Amazons, under the name of $E$. euryone, but which has no white on the upper side of the wings, and with $E$. phadica (Boisduval), from Cayenne and the Amazons, which, however, has black sub-marginal semi-ocellated spots on the under side, almost like a Euptychica.

The smaller genera of this Sub-family are very easy to recognise.

Perophthalma tenera, Westwood, is an inconspicuous little Butterfly, which measures about an inch across the wings, and is common throughout South and Central Amer.ca. It much resembles a small Mesosemia, to which genus both Westwood and Hewitson referred it. It is of a light reddish-brown colour, with a large black eye in the middle of the fore-wings in a yellowish ring, and bi-pupillated with white. The northern specimens have a white band across the fore-wings, which is nearly obsolete in Brazilian specimens; and the hind-wings are more or less ochraceous, or banded with ochraceous, above. It is a gregarious insect, congregating in sunny openings in the forest, and resting on the upper side of the leaves.

Hades noctula, Westwood, is common in cocoa plantations in Central America and Venezuela, settling on the under side 
of the leaves. It is a black Butterny, measuring about two inches in expanse across the rounded wings; and Messrs. Godman and Salvin remark on its resemblance to Morpheis ehrenbergii, Hübner, a species belonging to the Nymphaline, which inhabits similar localities. On the under surface, $H$. noctuin has a red patch at the base of the wings, and there are traces of grey radiating lines at and between the extremities of the nervures on the hind-margins of all the wings.

The genus Methonella includes one or two broad-ringed species, measuring two inches, or rather less, across the wings, which are black, with the centre more or less filled up with fulvous. The hind-wings are rounded, and strongly dentated.

\section{GENUS HELICOPIS.}

Helicopis, Fabricius in Illiger, Mag. Insekt. vi. p. $2 S_{5}$ (ISO7); Westwood, Gen. Diurn. Lepid. p. 423 (I85 I).

The present genus is regarded by Schatz and Röber as somewhat intermediate in its characters between the Euselasiince and the Lemoniine, though with preponderating affinities towards the former. The antennæ are long and slender, ringed with black and white, and terminating in an oval club, pointed at the end, and the front legs are much shorter than the others, and clothed with short hair in the male, and with sca!es in the female. The fore-wings are short and broad, and the hind-wings are as long as the fore-wings, and throw out long tails at the ends of all the nervules, that in the middle median nervule being the longest, and curved outwards. The colours are black, fulvous, and creamy-white, and the under side of the hind-wings is ornamented with metallic spots. The larva is thickly clothed with soft hairs, and the pupa is attached by the tail, and a belt of silk round the miadle of the body.

These were among the first Butterflies which attracted the 
notice of Messrs. Bates and Wallace in the immediate neighbourhood of Parà. The former writes of them as follows, in the first chapter of his "Naturalist on the Amazons :- "One day we made our first acquaintance with two of the most beautiful productions of Nature in this department, namely, the IFticotis cupido and H. cudymion. A little beyond our house one of the narrow green lanes which I have already mentioned diverged from the Monguba avenue, and led, between enclosures overrun with a profusion of creeping plants and glorious flowers, down to a moist hollow, where there was a public well in a picturesque nook, buried in a grove of Mukajá palm-trees. On the tree-trunks, walls, and palings, grew a great quantity of climbing Pothos plants, with large, glossy, heart-shaped leaves. These plants were the resort of these two exquisite species, and we captured a great number of specimens. They are of extremely delicate texture. The wings are cream-coloured; the hind pair have several tail-like appendages, and are spangled beneath as if with silver. Their flight is very slow and feeble; they seck the protected under surface of the leaves, and in repose close their wings over the back so as to expose the brilliantly spotted under surface."

THE SILVER-SPOT BUTTERFLy. HELICOPIS ACIS.

$$
\text { (Plate XXXIX. Figs. I, 2.) }
$$

Papilio acis, Fabricius, Spec. Ins. ii. app. p. 504 ( I $7 S_{\text {I }}$ ). Papilio gnidus, Fabricius, Mant. Ins. ii. p. 64, no. 607 ( 17S7). Rusticus armatus gnialus, Hübner, Samml. Exot. Schmett. i. pl. I O I ( 8 I 6 ?).

Papilio endymion, Cramer, Pap. Exot. iii. pl. 244, figs. C, F ( 779 ); Stoll, Suppl. Cramer, pl. iv. figs. 5a, b ( I 7 S7). This is the largest and darkest species of the genus, and is 
widely distributed in Tropical America. It measures about two inches across the wings. The fore-wings are of a creamy-white, with the base slightly tinged with yellow in the male, and more broadly and deeply in the female (which is larger and darker than the male); and the hind-margin and the outer half of the costa are bordered with black. The hind-wings are similar, but with a very broad black border, marked with a row of pale sub-marginal lunules; the tails are black, the largest being tipped with white; the under surface is pale, with silvery metallic spots on the hind-wings.

The larva is white, clothed with long hairs of the same colour, the head yellow, surmounted by a tuft of red hairs. It feeds on the leaves of the Passion-flower, and changes into a brown pupa, with a tuft of red hairs at the head and tail.

The type of the genus is

THE GOLDEN-SPOT BUTTERFLY. HELICOPIS CUPIDO.

Pupilio cupido, Linnæus, Syst. Nat. (ed. ro.), i. p. $4 S_{2}$, no. I 45 ( 758 ) ; id. Mus. Lud. Ulr. p. 3 I 3 (I754); Cramer, Pap. Exot. ii. pl. I64, figs. D-G (1777); Stoll, Suppl. Cramer, pl. iv. figs. A-C ( I787).

Rusticus armatus cupido, Hübner, Samml. Exot. Schmett. i. pl. I02 (I 8 I6 ?).

It is a much smaller insect than $H$. acis, and much paler. It is of a creamy-white, with narrow black borders, and the base of the fore-wings is yellowish, and the hind-margin of the hindwings is broadly pale yellow. The metallic spots of the under side of the hind-wings are of a deep golden-brown. The head of the larva is red, but otherwise it is very similar to that of H. acis.

It is a common species in many parts of Tiopical $\Lambda$ merica. 


\section{SUB-FAMILY III. LEMONIINA.}

Egg.-Deeply reticulated and filamentosed.

Larva.-More or less cylndrical, fasciculate.

Pupa.-Attached by the tail, and sometimes also by a girth round the middle of the body.

Imago. - Wings generally short and rounded; occasionally the fore-wings are rather long or pointed, and the hind.wings are sometimes dentated, or, if long, are frequently tailed. Wings very various in colour (rarely vitreous), and with no characteristic patterns except within generic limits. Fore-wings with the subcostal nervure four-branched, except in a few genera, most of which used to be classed with the Nemeobiince (Eurybia, Mesosemia, \&c.), and in Isapsis, in which it is three-branched. (This character, however, is not constant, for Mesosemia has the sub-costal nervure four-branched in some species.) Discocellular nervules generally more or less imperfectly developed. Hind-wings with the basal nervure well developed.

Range.-This extensive group is entirely confined to Tropical America, with the exception of a very few species which are met with in the United States, or which extend beyord the Tropical portions of South America.

Note.-The species of this Sub-family have been divided in'o subordinate groups by Schatz and Röber, according to the number and posi . tion of the branches of the sub-costal nervure and other characters of minor importance. But with the exception of Stalachtis, which seems te be sufficiently distinct to be reinstated as a Sub-family, into which it was originally formed by Bates, we are not inclined to regard these distinctions as of special importance. Even the number of sub-costal branches is not always constant in the larger genera.

The Lemonime are very numerous and dissimilar, and we cannot attempt to do more than discuss a limited number of the most important and characteristic genera. Some of the 
species are brown or black, but many are adorned with very bright colours.

In the following genera the sub-costal nervure is usually fivebranched.

\section{GENUS MESOSEMIA.}

Mesosemia, Hübner, Verz. bek. Schmett. p. 20 (ISI6); Westwood, Gen. Diurn. Lepid. p. 453 (IS5I); Godman and Salvin, Biol. Centıali-Amer. Lepid. Rhop. i. p. 378 (1885); Schatz, and Röber, Exot. Schmett. ii. p. 237 (IS92).

This is the largest genus of the whole Family, numbering considerably over roo species. They are of small or moderate size, generally measuring from an inch to an inch and a half in expanse. They are very numerous in South America, but only sixteen are recorded from Central America. 'The fore-wings are hardly longer than the hind-wings. The wings are rounded and entire in most of the species, being very rarely pointed or angulated, and never tailed. They are generally brown or blue, brown banded with white or buff, or white banded with brown, and most of the species have a round black eye just before the middle of the fore-wings, with two or three white pupils. By this character they can generally be recognised at a glance; but many of the white brown-banded species, which have no eye spots, or else have a series towards the margins of the wings, have much resemblance to various similarlycoloured species of Euptychia, or even Thecla. Some species have brown fore wings, and white, blue, or tawny hind-wings. The sub-costal nervure is five-branched in most of the species, but only four-branched in some, showing (as in the case of Euselasia) either that this character is not of absolute generic importance in the Lemoniida, or that these genera require further sub-division. The palpi, and also the front legs of the male, are extremely short in this genus.

Dr. Scudder has shown that the type is 
MESOSEMIA PHILOCIF.S.

Papilio philocies, Linnæus, Syst. Nat. ed. x. i. p. 483 , no. I 55 (I 758) ; id. Mus. Lud. Ulr. p. 35 I ( I764); Clerck, Icones, pl. 45, fig. 3 ( ( 764 ); Cramer, Pap. Exot. ii. pl. I 84 , figs. D, E ( I 779).

Erycina philocles, Godart, Encycl. Méth. ix. p. j3i, no. So ( 1823 ).

Mesosemia philocles, Bates, Journ. Linn. Soc. Lond. Zool. ix. p. 373 (I868).

This and several closely-allied local forms or representative species, found in different parts of South America, have longer and more pointed fore-wings than is usual in the genus; this character is most conspicuous in the males, in "which the fore-wings are black, with a short bluish-white band between the central ocellus and the hind-margin, and the hind-wings are also more or less broadly bordered with bluish-white (the breadth varying in the different forms), but the base is always brown. The female is slaty-grey, with blackish transverse lines. There is a testaceous ring round the central eye of the fore-wings, and the hind-margin of the hind-wings is more or less broadly bordered with white.

As a representative of this genus we have figured

\section{MESOSEMIA BIFASCIATA. \\ (Plate XXXVIII. Fig. 2.)}

Mesosemia bifasciata, Hewitson, Equatorial Lepidoptera, p. 94 (1877).

Upper side, IIale.-Blue-black; both wings crossed beyond the middle by two broad parallel bands of indigo-blue. Anterior wing with the usual black discal spot bordered with blue, and marked by three minute white spots.

Under side.-Dark brown. Anterior wing indigo-blue in middle; the discal spot as above, with a short black band 
between it and the base, two black spots below it, and a longer band outside of it, also black, crossed by a sub-marginal band of white. Posterior wing irrorate with white, a discal black spot marked by two minute white spots, crossed obliquely in the middle, from margin to margin, by a band of black; a very indistinct sub-marginal brown band.

Exp.- $-\frac{7}{10}$ inch.

Must nearly allied to M. meeda, Hew., in the colouring of the upper side.

This is a rare and little-known species from Ecuador, which has not been figured before, and as the pamphlet in which it is described is very scarce, we have thought it well to reprint the original notice of the insect as it stands. M. meeda, with which Hewitson compares it, is a Brazilian species.

\section{GENUS EURYBIA.}

Hübner, Verz. bek. Schmett. p. I 7 (I\$16); Latreille, Enc. Méth. ix. P. 45 S ( S $23_{3}$ ); Westwood, Gen. Diurn. Lepid. p. 416 (I85 I); Godman and Salvin, Biol. Centr.-Amer. Lepid. Rhop. i. p. 374 (ISS5) ; Schatz and Röber, Exot. Schmett. ii. p. 237 (1 892 ).

The species belonging to this genus are among the largest of the Lemoniince, measuring two or two and a half inches across the wings, which are brown, more or less spotted with white, on the fore-wings at least, and with more or less reddish submarginal markings on the hind-wings, enclosing one or two rows of black spots. In other species the fore-wings have a large black eye in the middle, with a blue pupil, and a reddish outer ring, and the hind-wings are more or less of a rich blue. The wings are broad, the fure-wings not much longer than the hind-wings, and the latter are rounded. The Brazilian $E$. carolina, Godart, differs in shape from the others, the forc- 
wings being hooked, and the hind-margin of the hind-wings almost rectangular. It is brown, with scattered red spots, hardly arranged in rows, chiefly towards the base and middle of all the wings; at about two-thirds of the length of the fore-wings there is an interrupted row of white spots, partly interspersed with the outermost red ones.

The type of Eurybia is

\section{EURYBIA SALOME.}

Papilio salome, Cramer, Pap. Exot. i. pl. I 2, ligs. G II ( 1775 ).

Eurybia salome, Godman and Salvin, Biol. Centrali-Amer Lepid. Rhop. i. p. 376 (I885).

Papilio nicaus, Fabricius, Systema Entomologix, p. 482, no. I 75 ( 1775 ).

Eurybia nicaus, Godart, Enc. Méth. ix. p. 459, no. 2 (1823); Lucas, Lepid. Exot. p. I44, pl. 79, fig. I ( 1835 ).

This is one of the smaller species, measuring about two inches across the wings. It is brown, with an eye on the forewings, and two white spots beyond the end of the cell; the hind-wings have a reddish marginal band spotted with black. It is found from Nicaragua southwards to Ecuador and the Amazons. Farther south it is replaced by a very similar, but larger species, $E$. donna, Felder.

Among other genera with the costal nervure five-Uranched, is Ithomiola, Felder (Comfsoteria, Hew.), the species of which are transparent, with dark nervures, and resemble small species of the genus Ithomia. They have also much resemblance to Dioptis, a genus of Moths which likewise resemble Ithomia. They are found in Ecuador and other parts of Tropical America. Nearly all the remaining genera of Lemoniince have the subcostal nervure of the fore-wings four-branched, and these have 
been divided by subordinate characters of neuration and structure. Thus, the following genus differs from the others in having all the branches of the sub-costal nervure emitted from the end of the cell.

\section{GENUS ZEONIA.}

Zeonia, Swainson, Zoological Illustrations, Ins. ser. ii. vol. 3, pl. I I I (1833); Westw. Gen. Diurn. Lepid. p. 43 I (I85 I); Godman and Salvin, Biol. Centrali-Amer. Lepid. Rhop. i. p. 388 (I885); Schatz and Röber, Exot. Schmett. ii. p. 239 ( 1892 ).

The species of this genus may be recognised at once by the transparent wings with black borders and the transverse stripe, which, on the hind-wings, occasionally coalesces with the border, and is sometimes separated from it. The long hindwings, of which the lower part is black, striped in the middle, or bordered below with bright red or orange, and throwing off a long narrow black tail from the outer angle, are characacteristic. There is generally a shorter tail also (sometimes reduced to a mere projection) nearer the anal angle. The species, which inhabit various parts of South America, are not numerous, and one only ( $Z$. bogota, Saunders) is known to extend to Central America, where it was found by Mr. Champion frequenting sunny openings in the forest.

On account of the shape and general colour of this genus, the late $\mathrm{Mr}$. IVilson Saunders has not inaptly compared it to the East Indian genus Leptocircus, which belongs to the Equitide.

The type is

ZEONIA FAUNUS.

Papilio faumus, Fabricius, Systema Entomologiæ, p. 532, no. 380 ( I 775 ).

Papilio octavius, Fabr. Mant. Ins. ii. p. 9, no. 72 ( 1787 ). 
Zeonia heliconides, Swains. Zool. Ill. Ins. (ii.), 3, pl. I I I ( I 833 ); Saunders, Trans. Ent. Soc. Lond. (2), v. p. 99, pl. ro, fig. 5 ( ( 859 ).

This species, which is found in North Brazil, is the largest of the genus, expanding nearly two inches. The black transverse band is broad, and continued, apart from the border, on the hind-wings; the broad red band on the latter is transverse, not extending to the anal angle, and is more orange than usual; and the inner tail is very short and slender.

We have figured the following species :-

\section{ZEONIA CHORINEUS. \\ (Plate XXXIX. Fig. 3.)}

Papilio chorineus, Cramer, Pap. Exot. i. pl. 59, fig. A. (1 775). Papilio octavins, Herbat (nec Fabr.), Naturs. Schmett. iv. pl. 6o, fig. 2 ( 1790 ).

Erycina octavius, Godart, Enc. Méth. ix. p. 564, no. 6 (1823); Duncan, Nat. Libr. Foreign Butterflies, p. 185, pl. xxiv. fig. 3 ( 1840$)$.

Zeonia octavius, Morisse, Ann. Soc. Ent. France, vi. p. 426 ( I 837 ).

This is one of the smaller species of Zeonia, expanding only an inch and a half. It agrees with $Z$. faumus in the transverse band, being continued on the hind-wings, but differs from it by the very long and slender tail, and the much longer and narrower hind-wings, with a very large red patch occupying the whole of the inner marsinal region within the tail. It inhabits Surinam and the Amazon region.

The next section includes the genera in which one branch of the sub-costal nervure of the fore-wings is thrown off before the end of the cell; and this is again divided into two subsections, in the first of which the middle disco-cellular nervure 


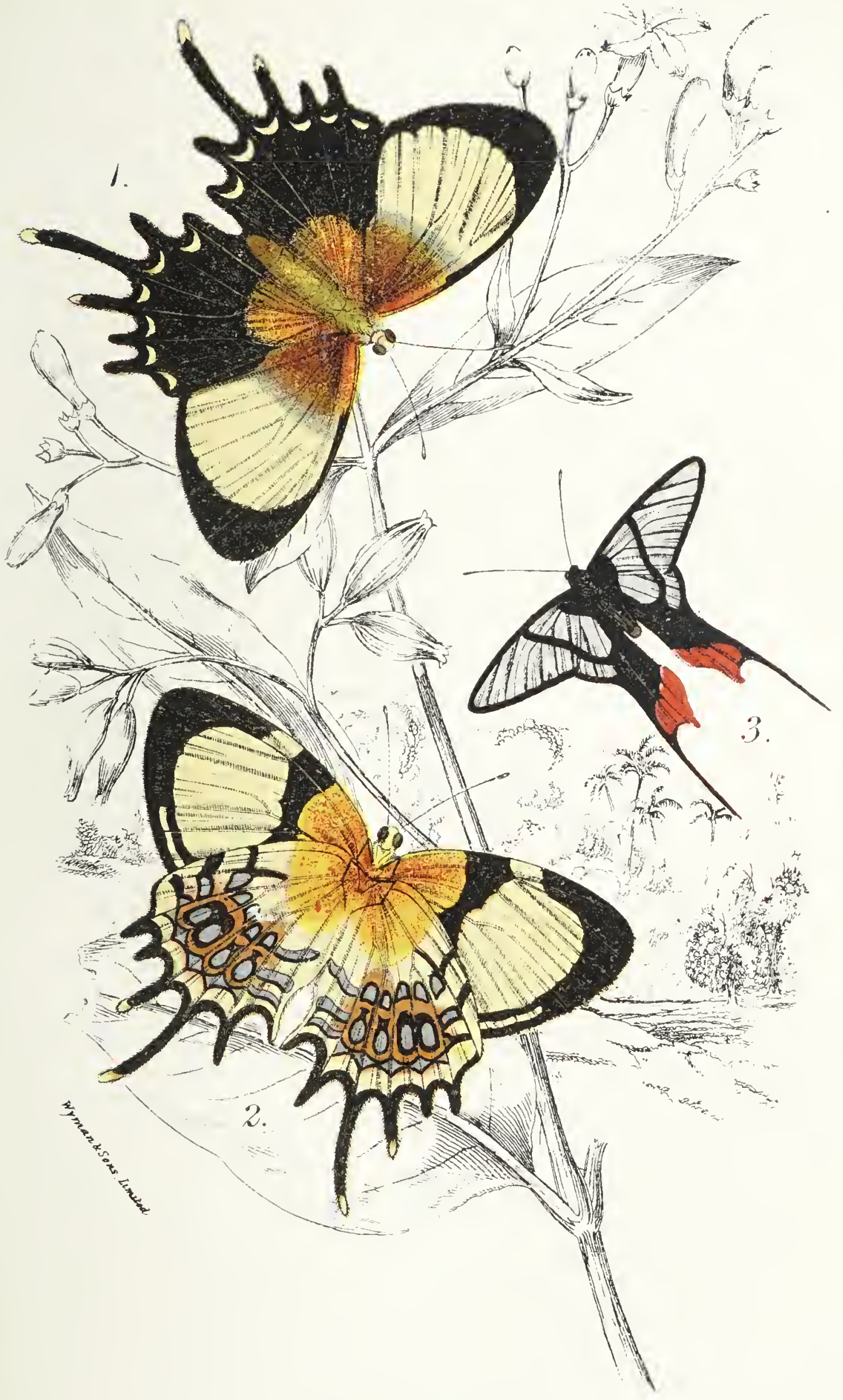

1. 2. Helicopis acis 

of the fore-wings is perfect. This sub-section includes some of the largest and handsomest species of Lemoniina. Most of them are tailed species, and some of these are very like Zeonia in shape, though generally with narrow white bands, instead of broad transparent ones. These include the types of the old genus Erycina, and therefore some of the most typical forms belonging to the Family. The fore-wings are usually short and broad, scarcely extending beyond the hind-wings, which are long, and often more or less tailed.

\section{GENUS DIORHINA.}

Diorfina, Morisse, Ann. Soc. Ent. France, vi. p. 422 (IS37); Godman and Salvin, Biol. Centrali-Amer. Lepid. Rhop. i. p. 390 (IS85); Schatz and Röber, Exot. Schmett. ii. p. 239 (IS92).

This genus is clossly allied to the next, and is chiefly distinguished from it by the longer palpi, the usually longer tails, which are less curved outwards, and the absence of metallic colour on the under side, notwithstanding that the males are usually more or less blue above.

The type is

DIORHINA PERIANDER.

Papilio periander, Cramer, Pap. Exot. ii. pl. I S8, fig. C (1777). Erycina iphinoe, Godart, Enc. Méth. ix. p. 565, no. 7 ( 1823 ).

Ancyluris iphinoe, Geyer; Hübner, Samml. Exot. Schmett. iii. pl. 46 (I 824$)$.

Diorkina laonome, Morisse, Ann. Soc. Ent. France, vi. p. 4z2, pl. I 4, figs. 5, 6 (1 837$)$.

Diorhina periander, Staud. Exot. Schmett. i. p. $2 \nmid 8,131.89$ (isS8).

This species, which measures rather less than two inches in 
expanse, and has short obtuse tails, longer in the female than in the male, appears to be common throughout the northern part of South America, and it extends as far north as British Honduras. The wings are dark brown or blackish, and in the male the greater part is filled up with rich blue, bounding which, on the fore-wings, is a more or less distinct whitish line. Towards the extremity of the inner-margm of the hindwings, and across the base of the tail are some red bands. The female is similar, but instead of the blue colour of the male, it has two transverse white bands, that nearest the base being the broadest.

\section{GENUS ANCYLURIS.}

Ancyluris, Hübner, Verz. bek. Schmett. p. 23 (I $\$$ I6); Schatz and Röber, Exot. Schmett. ii. p. 239 (x885).

Erycina, Fabricius, in Illiger, Mag. Insekt. vi. p. 266 (1S07);

Latreille, Enc. Méth. ix. p. Ix $\left(\mathrm{x}_{23}\right)$; Westwood, Gen.

Diurn. Lepid. p. $42 S$ (I $8_{5}$ I) ; Godman and Salvin, Biol.

Centrali-Amer. Lepid. Rhop. i. p. 392 (r885).

The name Erycina, having been used l'y Lamarck for a genus of shells in $\mathrm{x} 805$, cannot be retained in Lepidoptera.

As mentioned under the heading of the genus Diorhina, Ancyluris differs by comparatively slight characters. The wings are black above, banded with red, orange, or, more rarely, white, and are sometimes adorned with blue markings; while the under surface is usually richly banded and suffused with various metallic tints of blue and green. The species measure somewhat less than two inches in expanse, and the hind-wings are produced into a lobe or tail, turned outwards, and usually much longer in the female than in the male. The species are most numerous in the northern parts of South America. 



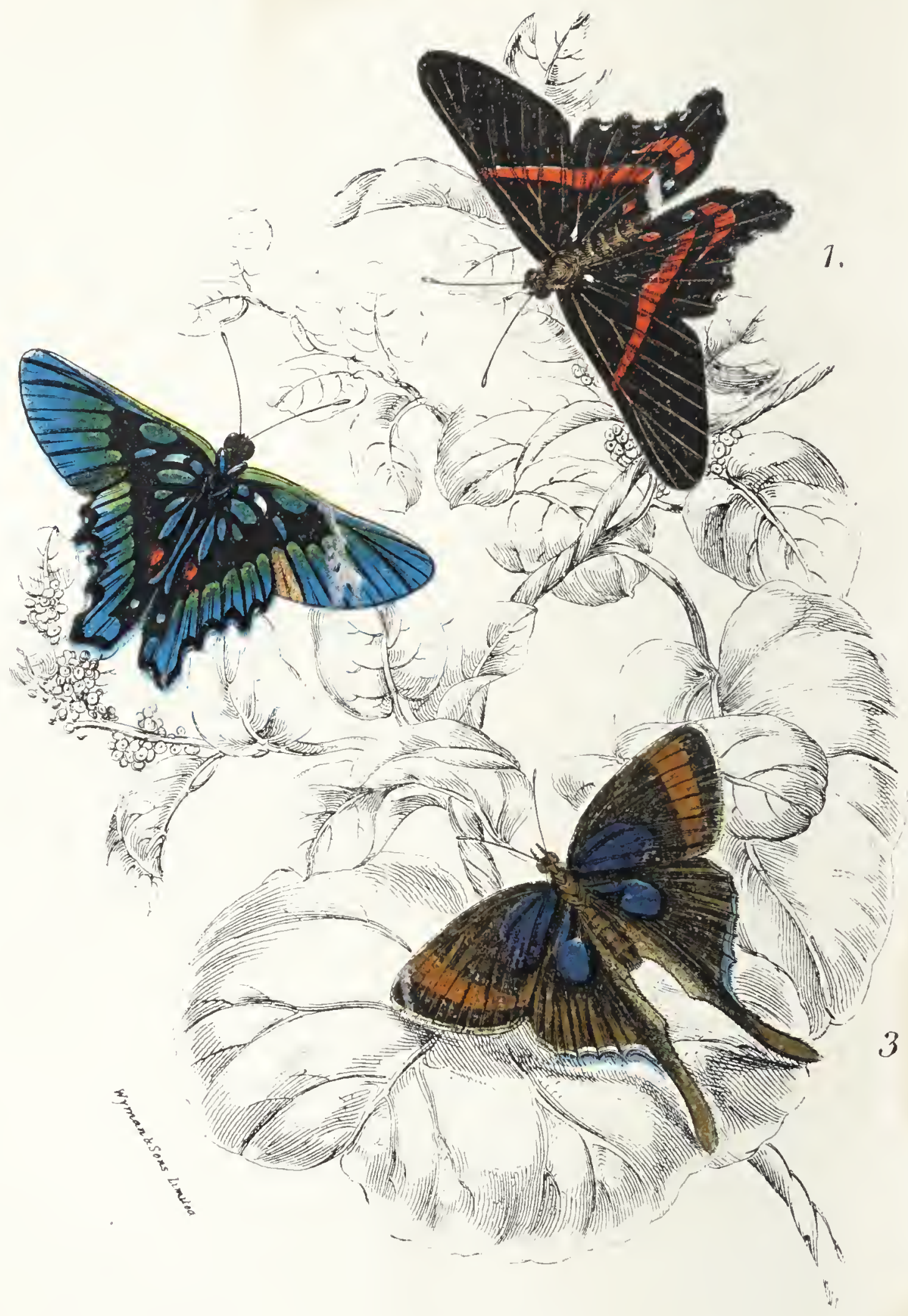


iVe have figured the typical species

ANCYLURIS MELIBEUS.

(Plate XL. Figs. I, 2.)

Papilio melibaus, Fabricius, Genera Ins. p. 277 (1877).

Erycina melibcus, Godart, Enc. Méthod. ix. p. 505, no. 9 ( 1823 ).

Papilio pyretus, Cramer, Pap. Exot. ii. pl. 144, figs. A, B (I 777 ).

This species measures about two inches across the wngs, which are blackish, crossed by an oblique red band, curving inwards to the inner margin of the hind-wings. On the latter is a large curved red stripe near the base of the short obtuse tail, forming the commencement of a second outer band. The under side is dark brown, with brilliant broad metallic-blue bands, varied with greenish-coppery, especially where the markings radiate towards the upper part of the hind-wings. There is a red spot about the middle of the inner-margin of the hindwings, and a yellowish-white one lower down towards the anal angle. The incisions, at least on the hind-wings, are spotted with yellowish-white, both above and below.

There are several closely-allied species in various parts of South America. The females of this group have longer tails, more strongly curved inwards than in the males. In some of the allied species the bands are broader than in $A$. melibeus, and are replaced with orange. A. melibcus inhabits Surinan and the Amazon district.

There are several other beautiful and interesting genera of this sub-section, to some of which we must give a passing notice. Necyria, Westwood, includes species greatly resembling Ancyluris in colour and markings, but with broad wings, the hind-wings being rounded and denticulated. The species 
of Lyroptery.x, Westwood, have more rounded wings still, with whitish or greenish radiating markings or else a broad red band, cut into stripes by the nervures and folds, on the hind-margins of all the wings. There are also numerous red spots towards the base, at least on the under surface of all the wings, and, more rarely, above as well. The genus Cartea, Kirby, includes one or two Amazonian species, with longer and narrower wings, and represents a different class of colouring, which is not unlike that found in various South American Bombyces, belonging to the Lithosizae, \&c. The species of Cartea are black, with a broad fulvous band running from the base, and covering a considerable portion of each wing. The margins and the apical half of the fore-wings are free, and the apex of the fore-wings is crossed by an oblique yellow stripe. Felder originally called this genus Orestias in 1862 , but as that name had been used by Valenciennes for a genus of fishes in I 839, it became necessary to change it, and I therefore called it after my kind old chicf, the late Dr. Alexander Carte, the Curator of the Museum of the Royal Dublin Soc.ety. But Dr. Staudinger goes out of his way to inform his readers that the name is derived from Carteia, the classical name of an ancient town in Spain!

To this sub-section also belongs the curious little genus Syrmatir, Hübner. The fore-wings do not expand much more than an inch, and extend much beyond the hind-wings, which are very much produced, and terminate in a long tail. The wings are entirely black, except a large white spot, cut by the nervures, in the middle of the fore-wings; and sometimes there is also a white stripe nearer the base, extending to both wings.

In the next sub-section, the first branch of the sub-costal nervure of the fure-wings is emitted before the end of the cell, 
but the miadile disco cellular nervule is obsolete. The Butterflies which belong to it are generally smaller, and much less brightly coloured than the majority of the preceding genera, and many of them are black, with radiating white or bluishwhite markings, not unlike those which we meet with in many South American Moths, and also in certain genera of Hesperiida found in the same countries. One genus, Chamelimnas, Felder, exhibits a still more remarkable resemblance to the South American Moths of the genus Cyllopoda, Dalman, having long fore-wings, which are black, with a bright yellow transverse band, and often a yellow basal stripe also, and bright yellow hind-wings, with broad black borders.

The genus Ithomeis, Bates (Ithomiopsis, Felder), includes larger species, measuring about two inches across the wings, which have derived their name from their resemblance to various species of the genus Ithomia, Hübner (see vol. i. p. 30). They are black, with orange-tawny and whitish subhyaline markings, and some of the species much resemble those of Stalachtis, Hübner, (postea, p. 44), which itself much resembles the Ithomiince.

The next section includes the great bulk of tropical American Lemoniida, and is characterised by having two branches of the sub-costal nervure of the fore-wings thrown off before the end of the cell, and the middle disco-cellular nervule of the hind-wings not emitted before the upper radial.

In the first sub-section, the palpi do not extend beyond the head, and the antennæ are not ringed or spotted with white. Here again we meet with some tailed species, the handsomest being Euerycina calphurnia (Saunders) which expands two inches and upwards, and is not unlike some of the species of the genus Timetes, Boisd., among the Nymphalince, in general appearance. It is brown, with a white band, edged with light blue in the male, running from the costa of the fore-wings to the 
middle of the hind-wings. Thence the band turns outwards, becoming light blue, and coalesces with a narrow light blue border which runs down from the middle of the hind-margin of the fore-wings, and borders the lower part of the hind-wings, which is gradually produced into a long, but not very pointed tail, which is likewise blue, except at the tip, where it is white. Within this blue stripe and the brown inner margin is a chocolate-coloured stripe, running up to the base of the hind-wings. In the female the white band is broader and longer, and is separated on its lower end by a red line from a white line which runs from the base of the hind-wings to the inner edge of the tail; the latter, as well as the hind-margin of the hind-wings, being bordered by a white line. The under side of this handsome Butterfly is bluish-white at the base, separated by a dusky band from a whiter space, the outer part of the wings being tawny, except for the narrow white edging of the hind-wings.

The present classification of the Lemoniince is very unsatisfactory, and the sub-sections are certainly only tentative and provisional. This may be seen from the dissimilarity of the various genera which are included with Euerycina in this group. One of these is Barbicomis, Latreille, which differs from Euerycina nearly as much as Syrmatia differs from Ancyluris. Barbicomis basalis, Godart, is a Brazilian Butterfly with such slender antennæ that some authors have regarded it as a Moth. It expands about an inch and a half; the fore-wings extend far beyond the hind-wings, and are adorned with two fulvous or orange bands, one running from the base along the lower part of the cell, and then running outwards, nearly parallel to the inner-margin; and the other oblique, and sub-apical. The hind-wings throw out a straight narrow tail, as long as the hindwings themselves, from the middle of the hind-margin. Several genera of this sub-section, like sume of those of the last, are black, with sub-hyaline stripes; but the largest and most impor- 
tant is Lymnas, Blanchard, which includes about thirty species of moderate-sized Butterflies, not generally expanding more than an inch and a half across the wings, which are brown, generally with large red spots on the under side, and with an orange or yellow border to the hind-wings, and an oblique bar across the fore-wings. Sometimes the oblique bar is replaced by an orange tip to the fore-wings; or there are no yellow markings, but only large red spots towards the base, or perhaps a red bar on the costa of the hind-wings.

The next sub-section only differs from the last in having the antennæ ringed or spotted with white. It includes a variety of small and moderate-sized Butterfies. As an illustration of this group we have figured a representative of the following genus.

\section{GENUS ANTEROS.}

Anteros, Hübner, Verz. bek. Schmett. p. 77 (I \& I6); IVestwood, Gen. Diurn. Lepid. p. 427 (IS5I); Schatz \& Röber, Exot. Schmett. ii. p. 349 (I 892 ).

In this genus there is a conspicuous tuft of hair on the first joint of the tarsi of the four hinder legs, more strongly developed in the male than in the female. The hind-wings are generally produced into a short obtuse tooth, and have also a short broad tuft of hair at the anal angle. In some species the hind-wings are produced into several tails, somewhat as in Ilelicopis (with which genus they were formerly classed by some authors), but shorter. The hind-wings are frequently adorned with metallic silvery or golden spots and stripes.

The type is

ANTEROS FORMOSUS.

Papilio formosus, Cramer, Pap. Exot. ii.pl. is 8, fig. G (г 777). Papilio cressis, Fabricius, Spec. Ins. ii. p. I I 7, no. I 22 (I 78 I). 
Patílio valens, Fabricius, Mant. Ins. ii. p. 67 , no. 644 (1787). Polyommatiss valens, Godart, Enc. Méth. ix. p. 644, no. 100 (1823); Perty, Delectus Anim. Artic. p. I53, pl. 30, figs. 3,36 ( 1834 ?).

This is a small South American Butterfly, which was first described from Surinam; it measures about an inch across the wings, which are brown above, and yellowish, spotted with red and golden-green beneath. There is a white spot in the middle of the fore-wings above in the male.

\section{ANTEROS ACHÆUS. \\ (Plate XLIII. Figs. 3, 4.)}

Papilio achaus, Stoll, in Cramer, Pap. Exot. iv. pl. 352, figs. G, $\mathrm{H}$ ( I $7 \mathrm{SI}$ ) ; Donovan, Ins. Ind. pl. 4I, fig. 4 (I800).

Polyommatus achaeus, Godart, Enc. Méth. ix. p. 644, no. 99 (I 823 ).

This Butterfly, which expands an inch and a half across the wings, is found in Surinam and the Amazon district. 'The upper side is brown, with two yellow oval spots on the forewings, and two transverse curved streaks of the same colour on the hind-wings, and at the anal angle a ferruginous spot. The under side is yellow, with numerous ferruginous patches, each of which is ornamented with several small spots of golden-yellow; the hind-margin has a continuous ferruginous band bearing a series of golden-yellow elongated spots. The body is brown above and yellowish beneath.

It will be noticed that both the above species were classed by Godart with the Lycenide.

The genus Emesis, Fabricius, includes dull-coloured species, with more or less pointed brown, or reddish-brown wings, with 
blackish markings, and lighter beneath, with much more distinct blackish lines and spots, the lines often zig-zag or broken. The pupa of Emesis is suspended by the tail. Among the other genera which belong here are many containing small species, not much exceeding an inch in expanse, such as Symmachia, Hübn., Charis, Hübn., Mesene, Vestwood, \&c. Many of these are dark-colourcd Butterflics, some with large white spots, and others spotted all over with small ones. Others are brown, banded with red, or brown with numerous darker spots. But we have not space to notice these Butterflies in detail, and must pass on to the next subsection, which includes several of the most interesting and typical genera of the Lemoniina, which are distinguished from those which we have just been considering by the palpi being longer than the head, especially in the females. We may mention one or two of the more important genera in addition to Lemonias and $N y m p h i d i u m$, of which we have figured examples. One of these is Theope, Westwood, which is remarkable for its curious superficial resemblance to Thecla, except that the fore-wings are rather broader and more obtuse, and the hind-wings are rounded and not tailed. The upper side is black, with the hind-wings, except the border, and more or less of the fore-wings towards the base and the inner-margin of some shade of blue or purple. The under side is buffy-brown, or ycllowish, most frequently without any markings. In some cases the upper side is varied with orange-tawny instead of blue.

Pandemus pasiphaë, Cramer, is a species resembling Theope in shape, but very much larger, expanding about two inches. The male is pale blue, with the apical region brown, bordered within by two white spots. The female is white, with a yellowish tinge, and the apex of the fore-wings brown; the border of the hind-wings is also brownish. 


\section{GENUS LEMONIAS.}

Lemonias, Hübner, Sammlung Exot. Schmett. i. pls. 35-38 (1805 ?); Doubl. List Lepid. Brit. Mus. ii. p. I6 (1847); Westwood, Genera of Diurnal I.epidoptera, p. 457 (I851) ; Butler, Journ. Linn. Soc. London, Zoology, ix. p. 213 (I867); Godman and Salvin, Biologria CentraliAmericana, Lepid. Rhop. i. p. 457 (I886); Schatz \& Röber, Exot. Schmett. ii. p. 253 (1892).

This is the typical genus of a large number of closely-allied forms, many of which have a general resemblance to Lycrenidce. They are small and rather delicately-formed Butterflies, generally brown above, more or less varied with red, blue, tawny, or yellow, and the under surface is of some paler colour spotted with black. The fore-wings are triangular, broad, not much longer than the hind-wings, and rarely pointed at the tips; the hind-wings are rounded and entire.

Hübner used the name Lemonias for at least three totally different genera in successive works, and the dates are doubtful. It is true that, as Dr. Scudder points out, he indicated Melitea matuma, Linn., as the type in his "Tentamen," with a binomial nomenclature; but the date of this very rare tract is doubtful, and is almost certainly later than 1807 . But in his "Sammlung exotischer Schmetterlinge," vol. i., which was commenced in 1805 , he figures four species of the present group as "Lemonias maculata," viz., L. m. zygia, L. m. luciana, L. m. alphea, and $L$. m.epulus. The generic names of the first volume of the "Sammlung" (apart from the objection that they are not characterised) are often rejected because of their trinomial form, "Lemonias maculata," \&c. But this objection, if valid, would also apply to many, if not most, of the Linnæan genera, and would thus shake the very foundations of our nomenclature. In 
the present instance Lemonias has been applied by Doubleday and all recent authors to a more or less restricted group, into which the second of Hübner's species will fall, even allowing for his having figured two closely allied species as sexes. We have figured the sexes of a species very closely allied to the types.

LEMONIAS EMYLIUS.

$$
\text { (Plate XYXVIII. Fig. 807,99.) }
$$

Papilio emylius, Cramer, Pap. Exot. i. pl. 66, figs. G, II (I 775 ).

Erycina emylius, Godart, Enc. Méth. ix. p. 577 , no. 64 (I8 19).

Lemonias emylius, Staudinger, Exot. Schmett. i. p. 258, pl. 92 ( 1888).

Papilio crispus, Cramer, l.c. pl. iा 8, figs. D, E (1777).

This Butterfly measures about an inch or a little more across the wings, which are black in the male, with a large red space on the inner-margin of the fore-wings, and two small white spots towards the tip; the hind-wings are red, except broadly along the costa, and more narrowly along the hind-margin. The under side of the fore-wings is pale yellow, and speckled with black, except along the costa, and more broadly on the hind-margin, where there is an irregular row of white spots. The hind-wings are whitish, spotted and flecked with black, especially towards the hind-margin. The female resembles the male on the under side, except that the fore-wings are pale yellow on the costa to the middle. On the upper side it is black, with a sub-marginal row of white spots, within which are numerous yellowish spots, and on the fore-wings is a broad curved transverse yellowish bar just within the spots, extending from the costa nearly across the wing. It is a common Butterfly in South America. 


\section{GENUS NYMPHIDIUM.}

Nymptridium, Fabricius, in Illiger, Mag. Insekt. vi. p. 286 r8o7); Westwood, Gen. Diurn. Lepid. p. 447 (185I); Godman and Salvin, Biol. Centrali-Americana, Lepid. Rhop. i. p. 470 (1886); Schatz \& Röber, Lepid. Exot. ii. p. $254(\mathrm{I} S 92)$.

This is a very large genus, comprising nearly roo species, which will, no doubt, be sub divided sooner or later. They are stouter insects than Lemonias, with longer and more pointed fore-wings, and the hind-wings sometimes produced, and occasionally even lobate, at the anal angle. The colour, howcver, is very different and characteristic, usually consisting of a broad white or yellow band, commencing on the inner-margin of the hind-wings, and occupying more or less of the centre of the wings, till, towards the middle or apex of the fore-wings it tapers and ceases. The borders are brown, often spotted with white and orange-tawny. Of course there are variations in the arrangement of the colours, but this is a fair sketch of the most characteristic pattern. One or two of the larger species are remarkably like some species of the genus Adelpha in the Nymplatince, the size, markings, and pattern being almost identical. In other cases, chiefly among the smaller species, the pale colour occupies almost the whole of the wings, except a narrow border.

The type of the genus is

NYMPHIDIUM CARICE.

Papilio carica, Linneus, Syst. Nat. (ed. x.), i. p. 484 , no. 158 (1758), id. Mus. Ludov. Ulr. p. 324 (1764); Clerck, Icones, pl. 2o, fig. 2 (I $76_{4}$ ); Cramer, Pap. Exot. ii. pl. I 7o, fig. E (I777); Sepp, Pap. Surinam, iii. p. I45, pl I I I (1852).

Limnas subtilis caricre, Hübner, Sammlung Exot. Schmett. i. pl. $3 \circ$ ( 1 S० 5 ?). 
Erycina carice, Godart, Enc. Méth. ix. p. 575, no. 53 ( 1823$)$.

A common South American Butterfly, measuring from I $1 / 4$ to $\mathrm{I} / 2$ inches in expanse. The wings are blackish, with a white band covering the hind-wings from the base to beyond the middle, and forming a large triangle, resting on the innermargin nearly to its base, and extending upwards to the middle of the fore-wing. The broad dark borders are traversed first by an orange-lawny band, and then by a sub-marginal row of large black spots, darker than the ground-colour; on the dark costal border above the white portion of the fore-wings, are four large reddish-tawny spots. The sexes differ little, except that the female is rather $\mathrm{pa}^{\prime} \mathrm{er}$, with the white portion of the hindwings extending to the base, and the fore-wings less acute at the tips than in the male.

The larva is green, with black dots, a yellow lateral line, and a tuft at the head and tail. The pupa is attached to a leaf by the tail, and a girth around the body.

The larva feed; on a species of Inga, and like that of a Butterfly allied to Thecla, which feeds on the same plant, is always attended by small llack ants. The larva and pupa figured by Madame Merian as those of $N$. carice cannot belong to Nymphidium.

I have figured one of the largest and handsomest species of this genus.

\section{NYMPHIDIUN ETHELINDA.}

$$
\text { (Plate XXXVIII. Fig. 7). }
$$

Nymphidium ethelinda, Hewitson, Entomologist's Monthly Magazine, vii. p. 6 (I870); id. Exotic Butterlies, iv. Nymphidium, pl. 6, figs. 25, 26 (187 r).

This species, which was brought from the province of Minas Geraes in Brazil, measures somewhat less than two inches across the wings in the male, and rather more in the female. 
The male has dark brown fore-wings obscurely spotted with black. The hind-wings are creamy-white, brown at the base, and with a short black band at the apex. The female is white, with the base of the wings brown. The costa and hind-margin of the fore-wings are rather broadly brown, and the hind-wings have a black sub-marginal line, surmounted with seven connected lunules.

The following genus belonging to this section is sufficiently remarkable to demand a detailed notice.

\section{GENUS CATAGRAMMINA.}

Catagrammina, Bates, Journ. Linn. Soc. Zool. ix. p. 4II (I868); Schatz \& Röber, Exot. Schmett. ii. p. 255 (I892).

Catagrammina tapaja.

Necyria tapaja, Saunders, Trans. Ent. Soc. Lond. (2), v. p. Io8, pl. I I, fig. I7 (I859).

Catagrammina tapaja, pt. Bates, l.c. (i868).

This species derives its generic name from the resemblance of the female to the genus Catagramma, Boisd.; it expands rather less than two inches in the male, and rather more in the female. The male is black, with a bright red transverse band, varying in width, on the fore-wings, and sometimes also on the hindwings. The female, however, has the basal two-thirds of the fore-wings red or orange, more narrowly towards the costa. There is a black stripe on the sub-median nervure, and in the dark apical region of the wing is an oblique red or orange-yellow stripe followed by a sub-marginal row of white spots, which are continued across the hind-wings. In fact, the female much resembles Catagramma sinamara, Hewitson, to which we have alluded (vol. i. p. II7) as the probable female of $C$. astarte, Cramer. The resemblance of the male to a Catagramma is much less striking. Very little is known of this rare and curicus mimicking Butterfly, but it is not unlikely that there may be more than one species confounded under the name of $C$. 
tapaja; in which case the type of the species will be the insect procured by Saunders from the Tapajos, with a red patch on the hind-wings; and the specimen without this patch, which he calls a variety, must be regarded as distinct. Bates gives the additional locality of Ega ; and Dr. Staudinger has figured a female from 'Teffe, which is the name of the river on which Ega stands. From its larger size I suspect that it will prove to be the female of a distinct species, corresponding to Saunder's variety, in which case it may stand as follows:

CATAGRAMMINA HEWITSONI, $n$. $s p$.

Necyria tapaja, var., Saunders, Trans. Ent. Soc. Lond. (2), v. p. ro8, pl. r i, fig. i \& (1 859).

Catagrammina tapaja, pt. Bates, l.c. (I868); Staudinger, Exot. Schmett. i. p. 262 , pl. 92 (i 888 ).

The male differs from that of $C$. tapaja, as explained above, by the absence of a red blotch or band on the hind-wings; and the female by the black stripe on the sub-median nervure of the fore-wings being replaced by a black stripe below the nervure, and a corresponding blotch above.

The next section contains the species in which the sub-costal nervure has only three branches. It only includes one genus.

GENUS ISAPIS.

Isapis, Westwood, Gen. Diurn. Lepid. p. 465 (I85 I) ; Schatz S Röber, Exot. Schmett. ii. p. 258 ( ${ }_{1} S_{92}$ ).

The type is

\section{IS $A$ PIS AGYRTUS.}

Papilio agyrtus, Cramer, Pap. Exot. ii.pl.I23, figs. B, C ( 1777$)$. Erycina agyrtus, Godart, Enc. Méth. ix. p. 590, no. I26 (IS23). Isapis agyrtus, Doubleday and Hewitson, Gen. Diurn. Lepid. pl. 72 , fig. 5 (I85I); Staud. Exot. Schmett. i. p. 246, pl. 89 (ISSS). 
This is an inconspicuous little South American Butterfly, measuring about an inch across the wings, which are brown, with a broad fulvous bar running obliquely from the middle of the costa of the fore-wings to the hind-margin, a little above the hinder angle. On the under side of the wings a yellow band runs just beyond the base, from the costa of the fore-wings to the rounded-off anal angle of the hind-wings.

I. hera, Godman and Salvin, from Guatemala, is purplishblack above, with longer wings; and the basal band on the under surface is fulvous instead of yellow.

\section{SUB-FAMILY IV. STALACHTINÆ.}

The upper radial of the hind-wings branches beyond the middle disco-cellular nervule, thus rising from a common stalk with the sub-costal. The lower disco-cellular nervule runs into the upper median nervule. The palpi project beyond the head, and the antennæ are not ringed with white. The larva is cylindrical, and the pupa is suspended by the tail, but otherwise much resembles that of Nemeolius. There is but one genus, containing less than twenty species, all Tropical American.

\section{GENUS STALACHTIS.}

Stalachtis, Hübner, Verz. bek. Schmett. pp. 26, 27 (ISI6); Westwood, Gen. Diurn. Lepid. p. 466 ( $18 j \mathrm{r}$ ); Schatz \&

Röber, Exot. Schmett. ii. p. $25^{S}$ (IS92).

The species of this genus are rather large Butterflies for Lemoniida, expanding from two to three inches. They have long rounded wings, and are redlish-tawny or orange, with black markings and white spots, or are black, sometimes flushed with purple, and streaked or spotted with hyaline-white or bluish-white, and with orange sub-marginal markings. Some of the species resemble Ithomiince among the Butterflies, but 
are rather stouter and broader-winged insects, while others resemble large Dioptida, among the Moths. The type is S. phlegia (Cramer), a black Butterfly, with numerous white spots; it is broadly reddish towards the base, and there is also a reddish and incomplete sub-marginal band. The body is dotted with white. The wings are shorter in this species than in others of the genus.

\section{FAMILY IV, LYCANID E.}

Egg.-Thick-shelled, echinoid or semi-echinoid, studded with connected elevations, or punctuated, occasionally almost smooth.

Larvæ.-Onisciform, thickest in the middle, sometimes downy, or with short fascicles of hairs; head small, retractile; legs also small; habits sluggish; sometimes carnivorous or cannibal.

Pupa.-Short, thick, rounded, very rarely slightly angulated, the head and usually the terminal segment on the under surface of the body. Usually attached by the tail, and by a belt round the body; rarely free, and found on or under the surface of the ground.

Imago.-Of small or moderate size, and often of delicate structure; wings densely scaled, always opaque; fore-wings nearly always short and broad, sub-triangular, with three, four, or five sub-costal branches; hind-wings rounded, frequently produced into a long tail, or with one or more slender filiform tails, but very rarely dentated; frequently with pale lines or with ocellated spots beneath, those nearest the anal angle often more or less metallic. Prevailing colours, red, blue, brown, or white, very rarely green or yellow. Front legs in both sexes usually smaller than the others, but of equal length in both sexes, the front tarsi of the males usually unjointed, 
and ending in a single claw, always with a row of short spines beneath. Occasionally, however, the front legs are fully developed, even in the males.

Range.-This Family has numerous representatives in all parts of the world, and several genera are both very numerous in closely-allied species, and have a very wide range, though there are also an unusual number of well-marked smaller genera, including only one or two species, and of very limited range. In Europe and North America the Family is numerously represented by the three well-marked and almost cosmopolitan genera, Thecla, Lycrena, and Polyommatus, and one or two smaller, but allied, genera. In the tropics of the Old World the Family reaches its greatest developmernt, both in size and in the number of well-marked generic forms, including nearly all those in which the hind-wing is produced into a very long tail. Africa is very rich in Lycenide, producing many species of genera common to other parts of the world, while others, including almost the whole of the Sub-family Liptenince, are peculiar to the Ethiopian Region. In Tropical America we find an immense number of species (in fact, several hundreds) closely allied to Thecla, and usually placed under that genus, as they have not yet been satisfactorily sub-divided. There are also a few very distinct and wellmarked genera, peculiar to Tropical America, of which the most notable is Eumaus, Hübner.

Habits. - The smaller species, the larvæ of which feed on low plants, flutter about flowers in meadows, and are frequently very pugnacious, attacking and driving away Butterflies much larger than themselves. Some of the larger species, however, are capable of very strong and sustained flight. Those which feed on trees fly about their food-plants, and settle on the leaves in the manner of the Lemonizde. Different species fly at different times of the day, and some, probably, 
even by night. On dull days, or in the evening, some species, e.g., Plebeius argus, may often be found asleep on the stalks of grass or rushes.

Note. - Attempts have been made to sub-divide this Family, but this cannot be satisfactorily accomplished without a much more extensive acquaintance with the exotic forms than we at present possess. For the same reason it is somewhat premature to sub-divide sucl genera as Thecla and Polyommatus to any great extent. In the present work we shall follow Schatz and Röber in dividing the Ly'cenzidce into two Sub-families only, Lyconine and Liftenine.

\section{SUB-FAMILY I. LYCÆNIN Æ.}

Transformations.-See those of the Family.

Imago.-See generally those of the Family. Sub-costal nervure of the fore-wings three-branched, rarely four-branched, very rarely five-branched in the male. Upper radial of the hind-wings rising from the disco-cellular nervule. Hindwings often tailed, and usually striated or ocellated beneath.

Note.-As this section contains the typical Lyccenine, and the other Subfamily, the Liftenina, is aberrant, most of our preceding observations may be taken as applicable rather to the former group than to the latter. Of the numerous genera we have only space to notice those which are most important and interesting. Very little has been recorded respecting the habits and transformations of the Liftenince.

Mr. Distant, in his "Rhopalocera Malayana," p. I96, proposes the following sub-divisions for the Malayan species :-

A. Posterior wings without filamentous tail-like appendages near the anal angle: Curetaria.

$B$. Posterior wings with filamentous or prominent tail-like appendages near the anal angle. Posterior wings convex, about as broad as long: CASTALARIA.

C. Posterior wings more or less elongate, distinctly longer than broad: APHNARIA. 
We may mention some of the characteristic genera of each division :

Curfitaria : Poritia, Curetis, Zephymu, Gerydus, Neopithe. cops; also Eumcus and Trichonis in Tropical America, Ogyris in Australia, and the Liptenince in Africa.

Castalaria: Castalius, Catochrysops, Lampides, Lycanesthes.

Apunaria: Spindasis, Sithon, Hypolycana, Amblypodia, Deudorix, Loxura.

But this division is only provisional, being founded on the Butterflies of a small area, and it brings together forms more unlike in some cases than those which it separates.

I shall now proceed to enumerate the more interesting genera of Lycenine in some detail.

A. Costal nervure three-branched.*

\section{GENUS THECLA.}

Thecla, Fabricius in Illiger, Mag. Insekt. vi. p. 286 (I807); Ieach, Edinburgh Encycl. ix. p. I29 (I8I5); Westwood, Gen. Diurn. Lepid. p. 48r (1852); Schatz \& Röber, Exot. Schmett. ii. p. 264 (r892).

The original types of Thecla were $T$. betulce, $T$. spini, and T. quercus; and Dr. Scudder and other recent authors have agreed with me in accipting Papilio spini, Denis and Schiffermüller, as the type.

This genus includes our smaller tailed Hair-streaks, of which there are three species in Britain, and several others on the Continent, and in Northern Asia. Most of these are

* As this character, besides being subject to exceptions, would separato closely-allied genera, I do not regard it as of Sub-family importance. 
brown, with one or more orange spots torrards the anal angle of the hind-wings beneath, and with white lines on the under side, which has given rise to the name, "Hair-streaks," by which they are popularly known. They have also a filiform tail on the hind-wings. They are small Butterflies, measuring from an inch to nearly an inch and a quarter across the wings. The genus obtains its maximum of development in Tropical America, but is not represented in the tropics of the Old IVorld.

The antenne are more or less distinctly clubbed, the eyes are naked and finely bairy, and the palpi are rather long. The fore-wings are short, broad, and triangular, with the sabcostal nervure three-branched, the first two branches rising. before the end of the cell, and the third ruming to the rather fointed tip of the wing. The hind-wings are rounded and generally tailed. The larve generally feed on trees and shrubs; and the Butterflies are usually to be found fying about their food-plants, or frequenting brambles and other flowers growing in bushy places.

\section{THE PALE RROWN HAIR-STREAK. THECLA SPINI.}

Papilio spini, Denis \& Schiffermüiler, Syst. Verz. Schmeıt

Wien, p. IS6, no. 6 ( 1776$)$; Fabricius, Mant. Ins. ii. p. 68, no. 65 I (1787) ; Hübner, Eur. Schmett. i. fig. 376, 377 ( $\mathrm{ISO}_{3}$ ?).

Polyommatus spini, Godart, Enc. Méth. ix. p. 650, no. i i6 (1823).

Thecla spini, Stephens, Ill. Brit. Ent. Haust, i. p. 78 ( 1828 ); Kirby, Eur. Butterflies and Moths, p. 6o (I879) ; Lang, Butterflies Eur. p. 76, pl. xvii. fig. 2 (ISSI).

Papilio quercus, var. Esper, Schmett. i. (r), pl. 39, fig. 3 ( 1777$)$. 
Papilio lynceus, Esper, l.c. p. 356 (I 777); Hübner, ı.c. firg $674,675,602,693$ (iso3 ?).

This species, which is the type of the genus, masurcs rather less than an inch and a quarter across the wings, which are brown, generally with one or two orange spots near the anal angle of the hind-wings in the male, and more in the female; the hind-wings have a slender fillform tail, tipped with white. On the under side a white line runs across all the wings, considerably beyond the middle, which is strongly Wshaped towards the inner-margin of the hind-wings There is also a white sub-marginal line on the hind-wings, on which rests a row of orange spots, marked outside with black, and towards the anal angle is a large blue spot, which is the most charactcristic marking in this species.

The larva is green, with two ycllow lateral lines, and a dark dorsal streak, spotted with pink. It is found in June, and fceds on biack-thorn, from which it derives its name, and also on white-thorn.

The Butterfly is found in June and July in bushy places. It is common in many parts of Central and Southern Europe, and Northern Asia, but is somewhat local. It has been erroneously reputed British.

II. THE WHITE LETTER HAIR-STREAK. THECLA W-ALBUM.

$$
\text { (Plate XLI. Figr. 3, 4.) }
$$

Papilio prmi, (nec L.), Lewin, Ins. Brit. i. pl. 44, figss. I, 2

(1 795); Haworth, Lepid. Brit. p. 38, no. $4 \mathrm{~S}$ (1803).

Papilio zel-album, Knoch, Beitr. Ins. ii. p. S7, pl. 6, figs. I, 2 (I 782$)$; Hübner, Eur. Schmett. i. figs. $3^{\text {So, }} 3^{\text {SI }}$ $(\mathrm{I} S \circ 3$ ?).

Polyommatus a album, Godart, Enc. Méth. ix. p. 648, no. I 12 ( I 823$)$.

Thecla primi (nec Linn.), Stephens, Ill. Brit. Ent. Haust. i.p. 77 $\left({ }_{1} S_{2} 8\right)$. 
Thecla ce-album, Kirby, Eur. Butterflies and Moths, p. 59 (1879); Lang, Butterflies Eur.p. 77, pl. xvii. fig. 3 (I88I); Buckler, Larvæ of Brit. Butterflies and Moths, i, pl. I3, fig. I ( 1 886).

This is a smaller insect than the last, rarely expanding more than an inch and a quarter. The upper side is dark brown with a silky gloss, the fore-wings having a greyish patch near the middle. Hind-wings with an orange spot at the anal angle, and a slender tail tipped with white. The under side is light brown, with a narrow transverse, slightly interrupted, white line, placed towards the hindmargin of the fore-wings, but starting rather beyond the middle, on the hind-wings, and forming two acute angles

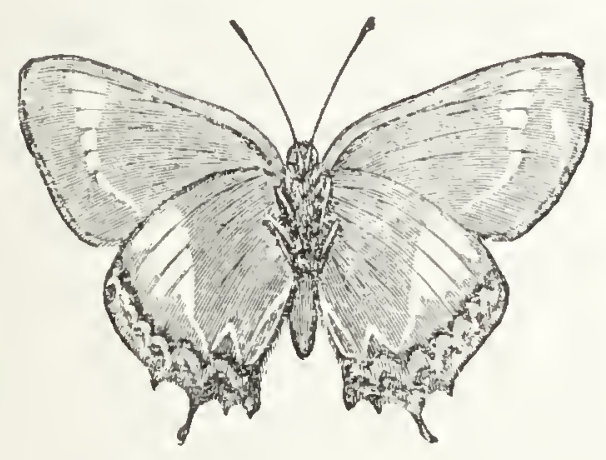

Whi te-Letter IIair-streak (Thecla w-alunin) variety.

posteriorly, in such a manner as to resemble the letter $W$. Behind this is an irregular band of orange-red, widest towards the anal angle, and bounded on the inner side by a black line, which is sometimes edged internally with white. The hindmargin itself is black. The Butterfly appears in July. A variety is figured in the above woodcut.

The larva is green, with oblique yellowish-iwhite lines; the head is black, and the body is clothed with fine hairs. It feeds on elm in May and June. The pupa is brown, with a white head. 
This Butterfy is widely distributed both in England, and on the contincuts of Europe and Northern Asia, frequenting elm trees and open bushy plaees. But it is loeal, and uncertain in appearance, and is rarely common, though it occasionally appears in amazing abundance, without any apparent reason. Stephens' observations on this subject have often been quoted, but are suffieiently interesting to be repeated here in full.

"This speeies is us dally esteemed a scarce inseet in the neighbourhood of London, and previously to the last season I never saw it alive; but the boundless profusion with which the hedges, for miles, in the vicinity of Ripley, were enlivened by the myriads that hovered over every flower and brambleblossom last July $\left[1 \delta_{27}\right]$, exeeeded anything of the kind I have ever witnessed; some notion of their numbers may be formed when I mention that I eaptured, without moving from the spot, nearly 200 specimens in less than half-an-hour, as they sueeessively approached the bramble-bush where I had taken up my position. How to account for their prodigious numbers I am perfeetly unable, as the same ficlds and hedges had been carefully explored by we at the same, and different periods of the year, for several preeeding seasons, without the oceurrence of a single speeimen in either of its stages; and it is worthy of remark, that the hedges to the north and north-cast of the village were perfectly free, although the brambles, $\mathcal{E}$., were in plenty. A few speeimens were also taken near Windsor, and in Cambridgeshire, and I believe ncar Ipswich, during the past season. The entomologists of this last town, Mr. Kirby informs me, do not esteem it a scarce insect; its usual time of appearanee is the end of June, and sometimes till the middle of July."

This species was mistaken by the older British entomologists for the next, which had not then been taken in Britain. 
4.
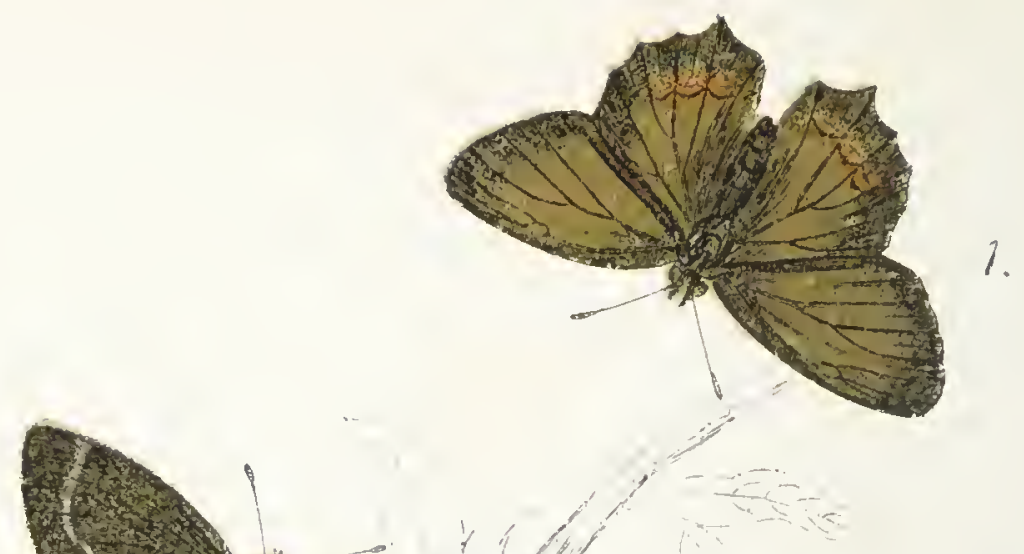

5.

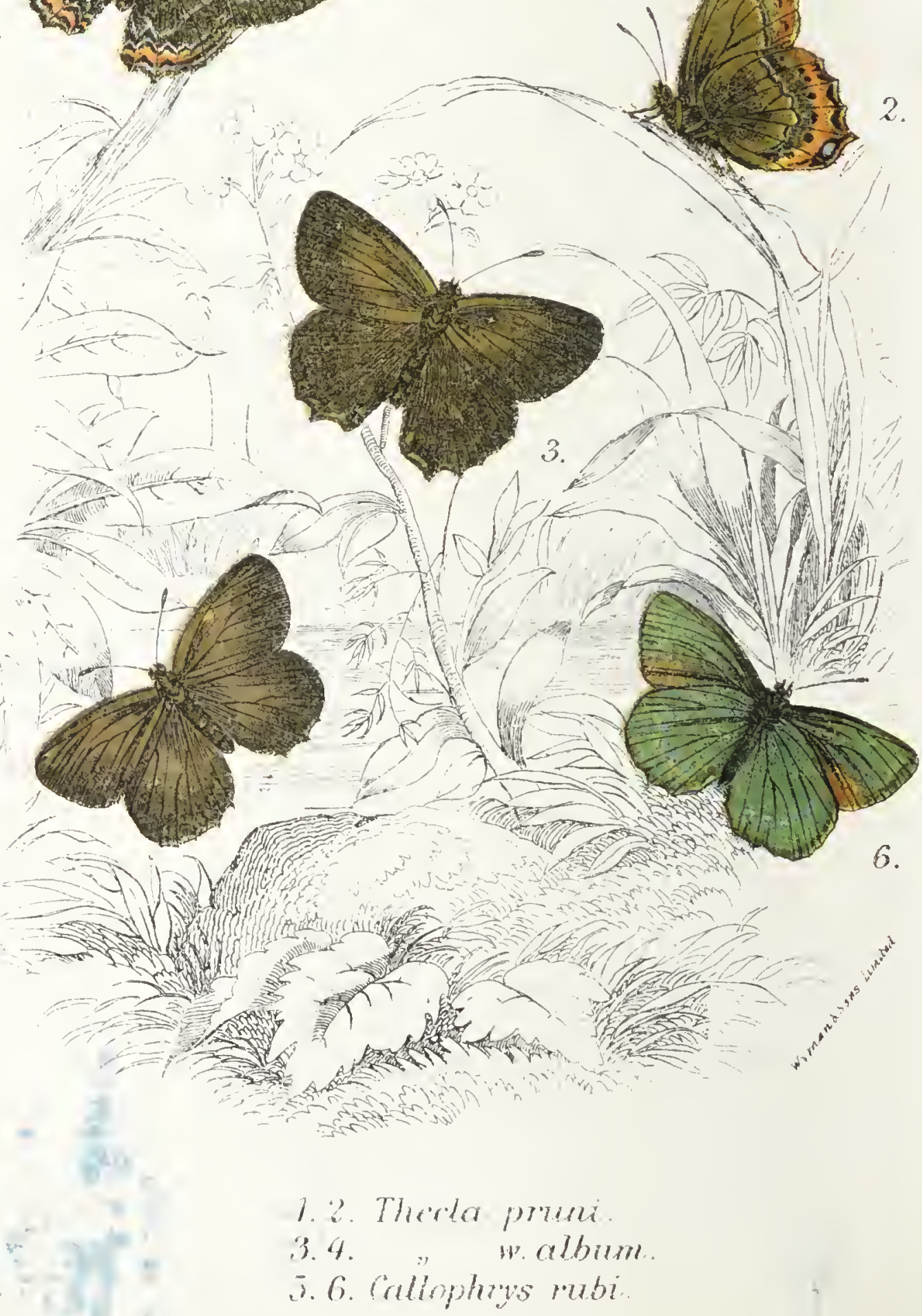


III. TIIE BLACK HAIR-STREAK. TIECLA PRUNI.

$$
\text { (Plate ALI. Figs. I, 2.) }
$$

Pafilio proni, Linnæus, Syst. Nat. (ed. x.) i. p. 432, no. 147 (1758) ; id. Faun. Suec.p. 283 (176r) ; Esper, Schmett. i. (I), p. 259, pl. I9, fig. 3 ; p. 353, pl. 39; fig. I a (1777); Hübner, Eur. Schmett. i. figs. 386,387 (I 803 ?).

Polyommatus prumi, Godart, Enc. Méth. i. p. 647, no. II I $(1823)$.

Thecla proni, Curtis, Brit. Ent. vi. pl. 264 (1829); Steph. Ill. Brit. Ent. Haust. iv. P. $3 S_{2}$ ( $\left.S_{35}\right)$; Kirby, Eur. Butterflies and Moths, p. 59, pl. 15, figs. $4 a-c$ (I879); Lang, Butterflies Eur. p. So, pl. I 8 , fig. I (I88I); Buckler, Larvæ Brit. Butterfies and Moths, i. pl. I 2, fig. 5 (1886).

This is another dark brown species, of about the same size as the last, which it somewhat resembles; but there is a submarginal orange band on the hind-wings, and sometimes also towards the hinder angle of the fore-wings, especially in the female. The under side is lighter brown, with a bluish-white, slightly irregular line beyond the middle, which does not form a W-mark on the hind-wings. There is a sub-marginal orange band on all the wings, bordered with bluish-white, and accompanied on the hind-wings, on the inner side, with a very distinct row of round black dots between the nervures. The hind-wings have a slender tail, as in the allied species. The Butterfly is found in June.

The larva (vol. i. pl. 3, fig. 8) is green, with yellow spots and stripes; the head is small, and yellow. It feeds on black-thorn, and perliaps on other trees, in May.

This species is found in Central Europe and the Altai Mountains, but is an extremely local insect in the midland counties of England, the principal locality being Monks' Wood, in Huntingdonshire. Newman ("British Butterflies," pp. I Io, 
I I ) states that specimens of this Butterfly, obtained from a collector named Seaman, were distributed at a meeting of the Entomological Club in September, i $\delta_{2} S$, under the impression that they were $T$. w-album, then called $T$. pami. Neman noticed the difference, and succeeded in identifying the insect, upon which Seaman gare out that the specimens were from Yorkshire, which locality is given by Curtis, Stephens, and even Duncan, although Stephens had corrected the error before Duncan wrote.

I have taken this species in Germany, flying round detached sloe-bushes, but not frequently, or in great abundance. By far the commonest Thecla in that country is T: ilicis, Esper, which abounds in every oak-wood. This specics has generally an orange blotch towards the hinder angle of the fore-wings, and an orange spot towards the anal angle of the hind-wings. It resembles $T$.prumi, in the white hair-streak of the under side not forming a $W$, but differs from it in wanting the round black spots within the sub-marginal orange band on the under side of the hind-wings. It has bein reputed British, but doubtless in error.

\section{GENUS CALLOPIRYS.}

Callophry's, Billberg, Enum. Ins. p. So (i $S 20$ ).

This genus differs from the other European Thecle by the absence of a tail, though there is a slight notch before the anal angle of the hind-wings. It is also distinguished at once by the greer colour of the under side of the wings.

I. THE GREEN HAIR-STREAK. CALLOPHRYS RUti.

(Plate XLT. Figs. 5, 6.)

Papilio mbt, I.innæus, Syst. Nat. (ed. x.) i. p. $4 \delta_{3}$, no I 54 ( $75 S)$; id. Faun. Suec. I). $2 S_{4}$ (r76r) ; Esper, Schmett. i. (I), p. 279 , pl. 2 r, fig. 2 (I 777 ); Hübner, Eur. Schmett. i. figs. 364,365 (ISo3?), fig. 786 ( I $\mathrm{I}$ IS?). 
Polyommatus rubi, Godart, Enc. Méch. ix. p. 673, no. I75 $\left(\mathrm{I} \mathrm{S}_{23}\right)$.

Thecla mbi, Stcphens, Ill Brit. Ent. Haust. i. p. $7 \delta(1 S 2 S)$; Kirby, Eur. Buttcrflics and Moths, p. 59, pl. I5, fig 3 (IS79); Lang, Butterflies Eur. p. SI, pl. xviii. fig. 3 (ISSr); Buckler, Larva Brit. Butterfics and Moths, i. p 89, pl. i3, fig. 3 (ISS6).

This Butterfly is the smallest British Hair-Streak, rarely measuring much more than an inch across the wings. It is of a rather light uniform brown abore; the hind-wings are not tailed, but slightly notched towards the anal angle. The under surface is of a beautiful green; and instead of a white line, we find a more or less distinct and continuous series of white dots, especially on the hind-wings.

The larva is pubescent, light green, or greenish-yellow, with a row of triangular yellow spots on each side, and a white line above the legs. It feeds on bramble, broom, and many other plants in July. The pupa is dark brown, and hairy, and is attached by the tail and by a belt round the middle.

The Green Hair-Streak is common throughout Europe and Northern and Wcstern Asia, and a closely-allied Californian form (C. dumetorum, Boisduval) may not be truly distinct. Our species is found in April and May, flying about the brimbles which grow in sunny places, on banks, road-sides, heaths, \&c., with the bright green opening leares of which its green under side harmonises well. In the south it is doublebrooded, a second brood appearing in August.

I have figured three of the largest and most beautiful of the multifarious South American species placed provisionally under Thecla* It will be see.s at a glance that they belong to

* Some of the more ordinary-looking South American species exhilit 
genera far removed from our European species; and the genera under which they will probably be classed are here indicated, but without characters being given.

\section{GENUS PSEUDOLICENA.}

Pseudolycena, Wallengren, Kongl. Vetensk. Akad. Fïrhandl. Stockh. xv. p. \&g (18.58).

\section{PSEUDOLYCANA MARSYAS.}

(Plate XLII. Firss. I, 2.)

Papilio marsyas, Limnaus, Syst. Nat. (ed. x.) i. p. $4 S z$, no. I 49 (I758); id. Mus. Ludov. Ulrice, p. 315 (I764); Clerck, Icones, pl. 4I, fig. I (I764); Cramer, Pap. Exot. iv. pl. 332, fig. A, B (1780).

Polyommatus marsyas, Godart, Enc. Méth. ix. p. 6zo, no. II (1823).

Thecla marsyas, Staudinger, Exot. Schmett. i. p. 2S5, pl. 97 ( $18 S S$ ).

The present species, which is very common in Tropical America, is one of the largest species of Lycenidie found in the New World, expanding about two inches and a half, or cven more. It is grcenish-blue on the upper side, changing in certain lights into violct, with the costa of the fore-wings narrowly, and the apical region broadly, black. Beneath, the colour is glossy lilac, with seven or eight black spots in white rings above and beyond the discoidal cell in each wing; the hind-wings have two black lines cdged with white beyond the spots, the innermost incomplete above; towards the anal

curious aberrations of structure and habits; in one species the front legs are perfectly developed in both sexes, while another species has been taken at light. 


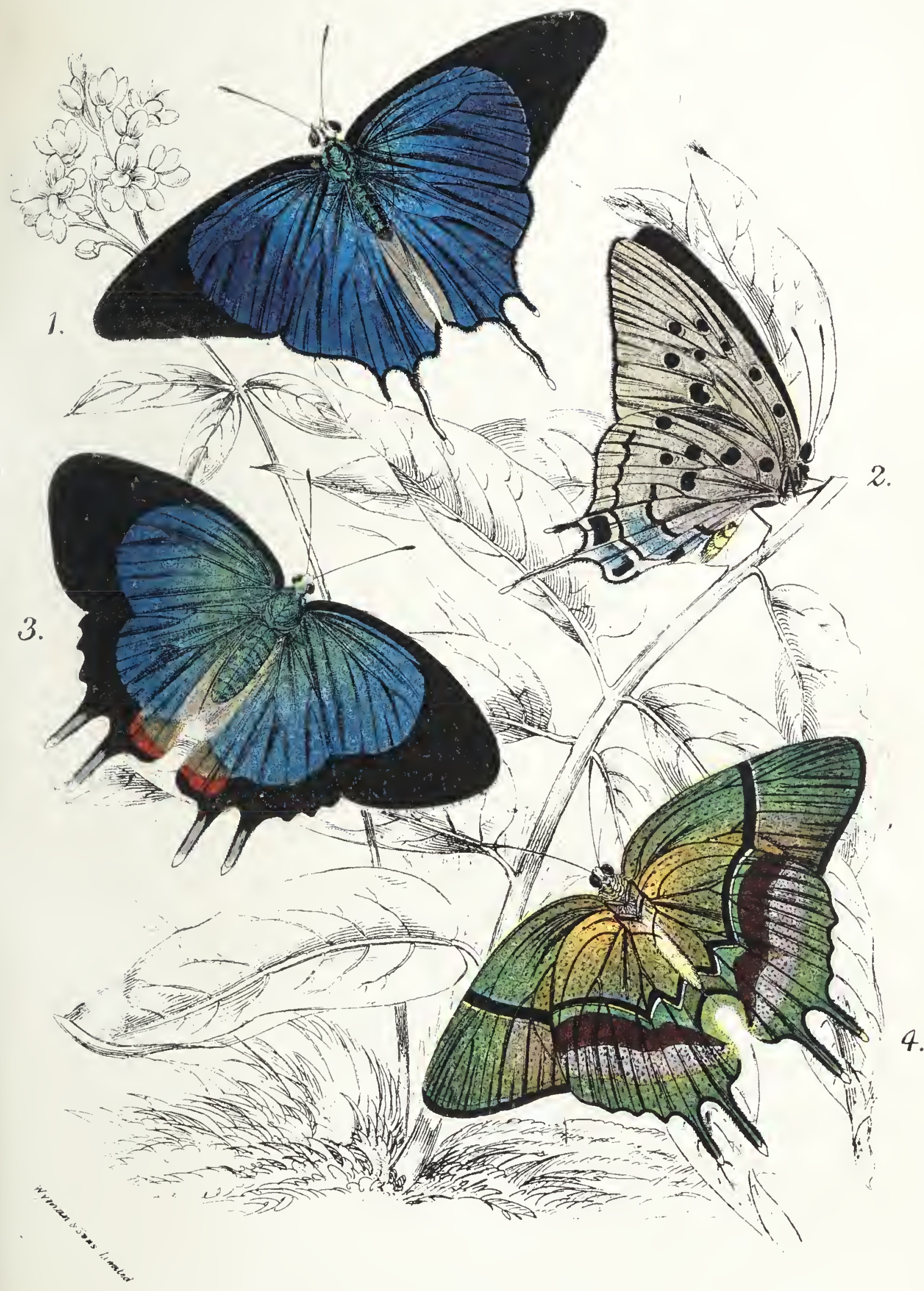

1.2. Pseudolycaena marsyas.

3. 4. Evenus regatis. 

angle are two rather large black spots, which are sometimes also visible on the upper side.

The fore-wings are very long and rather pointed, and the hind-margin is very oblique. Towards the anal angle are two tails, the mnermost much longer than the other. The body is blue above, and white beneath, and the antennæ are black, with pale rings.

In the female the ground-colour is more greenish, and the black border is continued round all the wings, though it is narrower towards the apex of the fore-wings.

\section{GENUS EVENUS.}

Eicnus, Hübner, Verz. bek. Schmett. p. 78 (ISI6).

1. EVENUS REGALIS.

(Plate XLII. Figs. 3, 4.)

Papilio regalis, Cramer, Pap. Exot. i. p!. 72, flgs. E, F (1775). Papilio endymina, Fabricius, Spec. Ins. p. I15, no. 506 $(\mathrm{I} 7 \delta \mathrm{I})$.

Polyommatus cridymion, Godart, Enc. Méth. ix. p. 622, no. i 7 $(1823)$.

Eadymion regalis, Swainson, Zool. Illustr. Ins. ii. pl. $S_{5}$ (1833).

Thech regalis, Staudinger, Exot. Schmett. i. p. $2 S_{4}$, pl. 97 (is8S).

This beautiful Butterfly is found in various parts of South America. The male measures rather less than two inches across the wings, and the female rather more. It belongs to one of the most gorgeous groups of Tropical American Lycrenide. The wings are of a very brilliant lulue, with a tinge of greer. and are bordered with black, rather narrowly in the male, but yery broadly in the female, which we have figured, and which 
has more rounded wings than her mate. There is a large blood-red spot at the anal angle of the hind-wings, which have two moderately long tails of nearly aqual length, which are black, tipped with white. On the under side the green hue predominates, and the whole is thickly powdered over with gold-dust, giving it a very rich appearance. All the wings are traversed near the middle by a broad black line, bordered outside with pale blue, and forming a $W$-shaped pattern on the hind-wings. Beyond this, on the hind-wings, is a broad deepred, or ferruginous band, paler towards the hinder edge, and sprinkled with blue atoms. Towards the hind-margins the wings are darker than elsewhere.

\section{GENUS ARCAS.}

Arcas, Swainson, Zool. Illustr. Ins. ii. pl. 88 ( $\left.\delta_{33}\right)$.

ARCAS IMPERIALIS.

(Piate XLIII. Figs. I, 2.)

Papilio imperialis, Cramer, Pap. Exot. i. pl. 76, figss. E, F ( 775 ).

Papilio vemus, Fabricius, Spec. Ins. ii. p. I I 5, no. 507 (I $7 S_{1}$ ). Polyommatus venus, Godart, Enc. Méth. ix. p. 623, no. 20 $\left.\left(\mathrm{x} \mathrm{S}_{2}\right)\right)$.

Arcas imperialis, Swainson, l. c. ( $\mathrm{IS}_{33}$ ).

Thecla imperialis, Staudinger, Exot. Schmett. i. p. $2 S_{4}$, pl. 97 (1SS8).

This species resembles Pseudoljcena marsy'as in having two tails on the hind-wings, of which the innermost is much longer than the other, but it differs from it in its much smaller size (measuring scarcely an inch and a half across the forewings), and the wings are much shorter, with the hind-margins regularly curved. The upper surface is brilliant blue, with the 


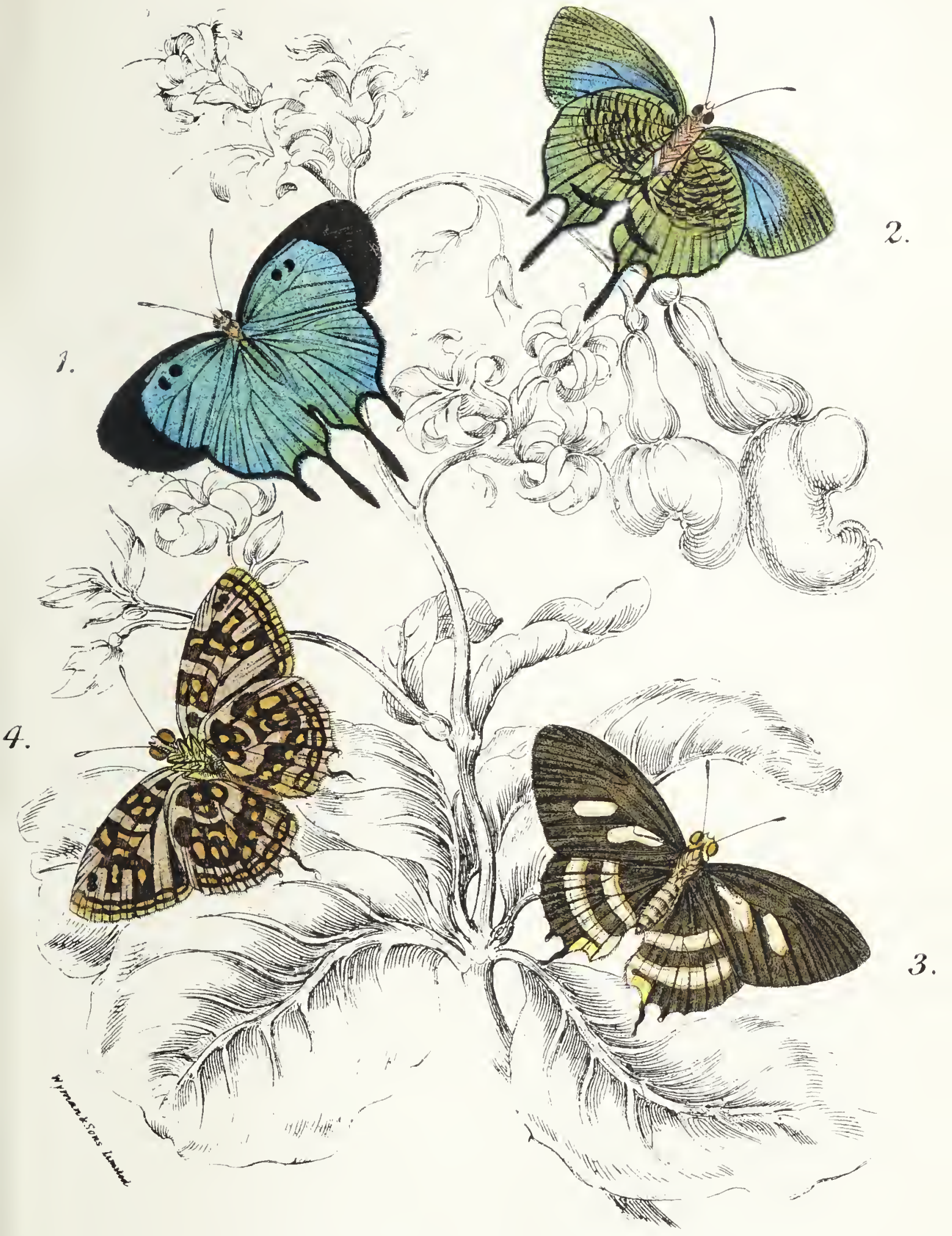

1.2. Arcas imperiatis.

3.4. Anteros achaeus. 

costa and hind-margin of the fore-wings black, and with two black spots in the cell in the male. On the under surface the colour is green, richly glossed with golden-yellow, and the anterior portion of the hind-wings transversely streaked with narrow black marks. The tails are wholly black.

It is found in Surinam, and in other parts of South and Central America.

There are several other well-marked Tropical American genera more distantly allied to Thecla, of which I shall only mention two.

\section{GENUS MICANDRA.}

Micandra, Schatz, Exot. Schmett. ii. p. $26_{5}$ (ISc,2).

An insect of very remarkable form, with the fore-wings very short and broad, the costa strongly arched, and the hindmargin rounded outwards, so that the hinder angle is actually further from the base than the apex. The hind-wings are tailless, much rounded, and considerably broader than the fore-wings, though about equally long.

\section{MICANDRA PLATYPTERA.}

Pseudolycana platyptera, Felder, Reise d. Novara, Lepid. ii. p. 246 , no 285 , pl. 28 , figs. 6,7 (I 865 ). Micandra platyptera, Staudinger, Exot Schmett. i. p. 288, pl. 97 ( I S86).

The fore-wings are shining greenish-blue in the male, with a black border, narrowing to the hinder angle. In the middle is a very large conical patch of dull greyish-blue scales, with the pointed end directed towards the base. The hind-wings are of the same blue, with the costa, and more narrowly, the hindmargin, except towards the anal angle, black. On the under side the fore-wings are blue, with the costa and hind-margin bordered with black; the hind-wings are blackish, covered with slender white interrupted serpentine lines. 
This curious species has been found in Venczucla, Colombia, and Peru.

The following genus diverges still more from Thecla, and at one time it was proposed to separate it as a distinct Family.

\section{GENUS EUMAUS.}

Eumaus, Hübner, Verz. bek. Schmett. p. $67(1816)$; Westwood, Gen. I)iurn. I,epid. p. 469 (1852): Scha'z \& Röber, Exot. Schmett. ii. p. 266 (1S92).

Eumenia, Lateille, Enc. Méth. ix. p. 826 (1823).

These are rather large Butterflies, generally expanding two inches or more. 'They are more robustly formed than in Thecla, with broad rounded wings, not tailed or dentated. The pattern is quite dissimilar from that of Thecla, being black, or blue-black, with blue or green markings, consisting of a broad band on the fore-wings, and at least one row of large sub-marginal spots on the hind-wings; beneath, the wings are ornamented with at least three sub-marginal rows of spots on the hindwings; and sometimes the whole surface of all the wings is spotted. The species inhabit Central America and the IVest Indies.

The young larva is cylindrical and tuberculate; the fullgrown larra is much flattened, but longer than usual in larre of this Family; the pupa is stout, arched, and rounded.

The type is

\section{EUMEUS MINYAS.}

Rusticus adolescens minjas, Hübner, Samml. Exot. Schmett. i. pl. 97 ( 1805 ?)

Eumenia toxea, Godart, Enc. Méth. ix. p. 826 (i 823 ); Lucas, Lép. Exot. p. 1 43, pl. 79, fig. 2 ( I $_{35}$ ).

This species is blue-black above, more or less broadly greenishblue at the base (the hind-margins being always black, and 
is black beneath. It has three sub-marginai rows of goldengreen spots on the hind-wings, both above and below, and there is an orange blotch on the middle of the hind-margin of the hind-wings beneath, the abdomen is also orange beneath, exccpt at the base.

It expands two inches or more, and is found in Mexico and Honduras.

Only four Old-IVorld genera, besides Theila, are included by Schatz and Röber as belonging to the section with the sub-costal nervure three-branched. They are rather small and delicate Butterfies, generally with two or three long slender tails on the hind-wings; and the wings have sometimes metallic markings on the under side. We may notice the two most important genera.

\section{GENUS HYPOLYCANA.}

Typolyccena, Felder, Wiener Ent Monatschrift, vi. p. 293 (IS62) ; Hewitson, Illustr. Diurn. I.epid. p. 48 (1 865); Schatz \& Röber, Exot. Schmett. ii. p. 265 (is92).

A rather extensive and wide-ranging genus, inhabiting the Indo- and Austro-Malayan Regions and Africa. It consists of blue or brown insects, not unlike the typical European species of Thecla in shape and appearance, and generally measuring about an inch and a quarter across the wings, and having two tails on the hind-wings, either of considerable length, in which case one (usually the innermost) is longest; or equal, and of more moderate length. There are generally two or more black spots, frequently ocellated, at the base of the tails. The fore-wings are sub-triangular.

H. lara (Linn.), is a small and somewhat aberrant species found in East Africa, from Abyssinia to the Cape, measuring 
about an inch across the wings, which are glistening pale ferruginous, with a row of large black sub-marginal eyes in black rings in the lower part of all the wings. The anal angle of the hind-wings is slightly produced, but not tailed. The larva is described by Mr. Trimen as very broad and thick, slightly narrower and thinner posteriorly; head very small. It is green, with a lake-red head and dorsal line, and feeds on Cotyledon cuncatum. The pupa is robust, rounded, and rather tapering behind; it is rather darker green than the larva, with a faint red line on the hinder half of the back of the abdomen; it is attached to the under side of a leaf, head downwards. "Mrs. Barber gave me the name of the larva's food-plant; and it is interesting to observe in her drawing how clearly the green red-edged colouring of the insect accords with that of the Cotyledon" (Trimen).

Dr. Scudder appears to have mistaken the type of this species (a very unusual error in such a careful and painstaking compilation as his "Historical Sketch of the Generic Names Proposed for Butterflies"), and quotes only the three species described by Felder, without any reference to the preceding remarks, commencing: "Diversitatem M. [Myrinc] eryli, Godt. et affinium (sipyli, Feld., atoli, Fabr.)" \&c. Felder also refers to a preceding note relative to his Myrina thecloides, which commences, "Species haec et ejus affines, $M$. erylus, Godt. et sipylzis, Feld., a My'rinis palporum articulo secundo capite breviore, tertio longo aciculari arcuato antennisque graciliter dentatis recedunt." I infer from this that Felder regarded the following species as the type of his genus.

IIYPOLYCAENA ERYLUS.

Polyommatus erylus, Godart, Enc. Méth. ix.p.633, no.60 (IS23). Amblypodia erylus, Horsf. Cat. Lep. E. Ind. Co's. Mus. p. I I , no. 43 (I 829 ). 
İypolycciza erylus, Hewitson, Illustr. Diurn. 1.epid. p. 49, no. I, pl, 2 I, figs. I, 2, 4 (1S66); Distant, Rhop. Malay. p. 285, pl 20, figs. 5, 6 (i 885 ); Staudinger, Exot. Schmett. i. p. 282 , pl. 96 (1 $8 S 6$ ).

This species, which expands from $1 \mathrm{I} / 4$ to $\mathrm{I} / 2$ inches, is common throughout the Indo-Malayan Region, from India to Celebes. The male is of a deep blue, with rather narrow black borders, and a black patch of scalcs at the end of the cell; the fringes of the hind-wings are white; towards the anal angle is a black spot bordered with white. Under side greenish-grey, with a double dark line at the end of each cell, followed by a common brown stripe, edged on both sides with paler brown, and angulated towards the anal angle of the hindwings, where there are two rather long slender tails, on each side of the base of which are two black spots, more or less surrounded with white and orange. The female is brown above, with a sub-marginal row of black spots partly surrounded with orange, white, and black towards the anal angle of the hind-wings. The under surface is nearly similar to the male.

\section{GENUS AXIOCERSES.}

Axiocerses, Hübner, Verz. bek. Schmett. p. 72 (1816). Chrysorychia, Wallengren, Lepid. Rhop. Caffr. p. 44 (1857); Trimen, South African Butterflies, ii. p. I6 I (ISS7).

This genus includes a few African Butterflies of small size, measuring from an inch to an inch and a quarter a ross the wings. They are rather stout, hairy insects, of a brown or black colour, with more or less of the surface of the wings red or orange. The fore-wings are sub-triangular, and the anal angle of the hind-wings is produced into a lobe. The under" surface of the wings is more or less varied with small metallic golden or silvery spots. 
The type of the genus is

AXIOCERSES PERION.

Pafilio perion, Cramer, Pap. Exot. iv. pl. 379, figs. B, C ( I $\left.7 S_{I}\right)$.

This is a red Butterfy, expanding an inch and a quarter across the fore-wings, and with a rather long slender tail on the hind-wings. In the fore-wings the costa and hind-margin are broadly black, and there are two black bands across the red part of the wing. The hind-wings are narrowly lordered with black, and have a third short black band nearer the base than the others. The under side is brown, with a sub-m.arginal row of small golden spots, and a similar sub-costal row on the fore-wings. There are also three or four irregular rows of larger transverse golden spots on ail the wings.

The locality given by Cramer is Surinam; but the Butterfly is probably a native of West Africa.

\section{B. Sub-costal nervure usually four-liranched.}

This section includes most of the typical Old-World Lycrenide. Most of the genera are tailed, and marked with ocellated spots beneath. The section is sparingly represented in North America by a few species bslonging to, or allied to, European genera; and in Tropical America we meet with only a very few species allied to Pldbeins; the Lycenida (except so far as regards species allied to Theche being almost entircly replaced in Tropical America by the allied Famiiy Lemoniidie.

\section{GENUS ZEPIIYRUS.}

Ruralis, Barbut, Gen. Ins. p. I79 (I73r).

Zepleyrus, Dalman, K. Vet. Acad. Handl. Stockh. xxxvii. pp. 62, 90 ( I S I 6); Wallengren, Lepid. Skand. Rhop.p. I 7 I I I 57 ); De Nicéville, Butterfics, Ind. iii. p. 299 (1890); Schatz \& Röber, Exot. Sclmmett. ii. p. 267 (I 892 ).

* Vide sutrit, p. 48 . 


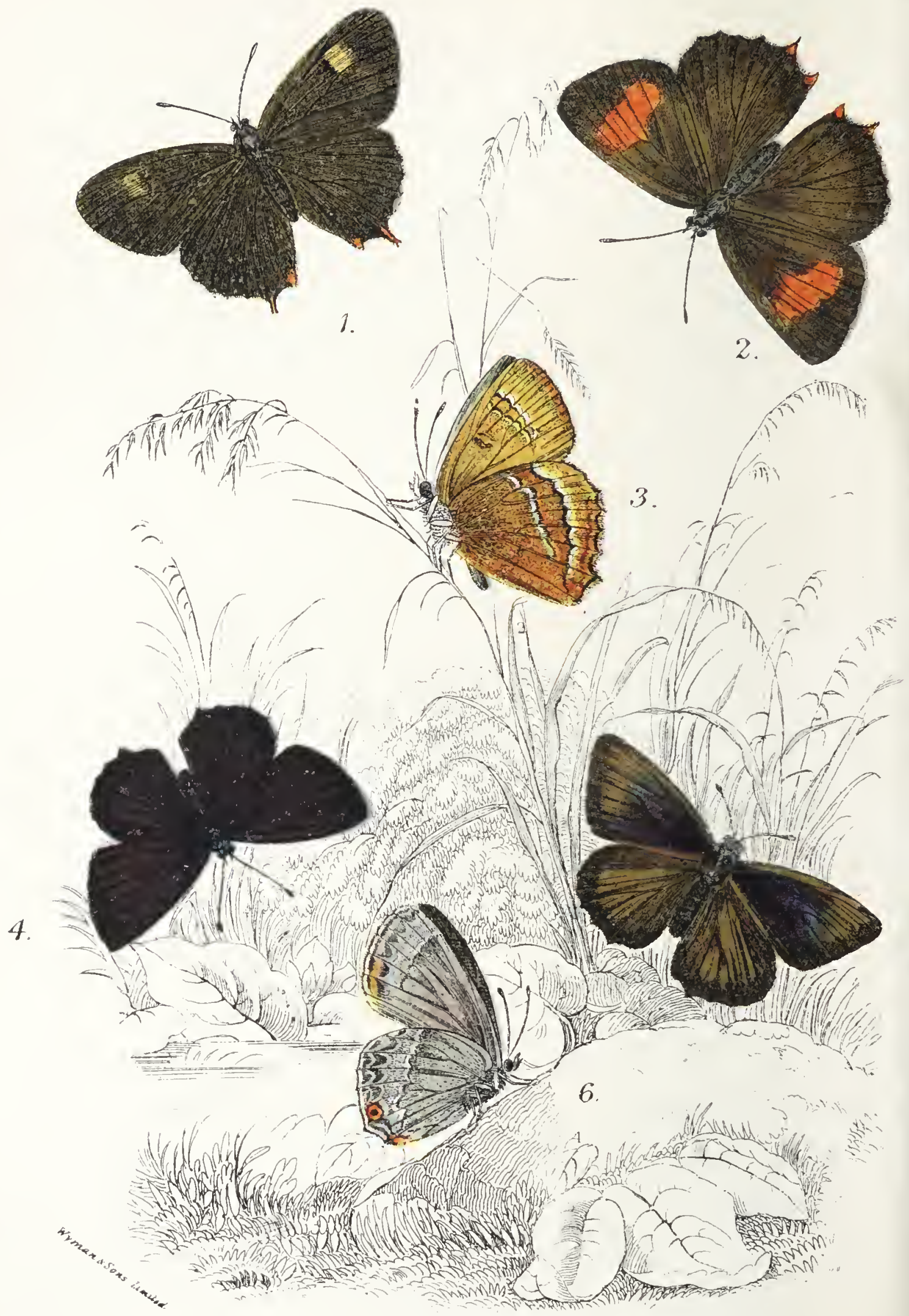


Dipsas, Westwood, Gen. Diurn. Lepid. p. 479 (I852);

Hewitson, Ill. Diurn. Lepid. p. 64 (IS6S). Aurotis, Dalm. l. c. pp. 63, 90 (ISI6).

The type of Zephyms is Z. betule, and that of Aurotis is Z. quercus. Ruralis, used by Barbut for Z. betule, is hardly admissible as a generic name.

Antennæ with a long, gradually-formed club; palpi short and slender, hairy and scaly; eyes hairy. Fore-wings with the sub-costal nervure four-branched, the two first branches thrown off before the end of the cell, the two last forming a small fork at the apex; upper radial nervule branching from the subcostal nervure a little beyond the cell; fore-wings often with a patch of raised scales in the male.

This is a Palaarctic genus of limited extent, ranging as far as Northern India and California. There are only two European species, which are considerably larger and more robust than the species of Thecla. The genus attains its maximum of development in Northern India, China, and Japan. The colours are blue, green, orange, or brown, and the sexes generally differ considerably, which is not the case in Thecla.

The pupa of this genus is smooth, and appears not to be attached, but to be piaced on or under the surface of the ground, among leaves.

The type is

I. TIIE DROWN HAIR-STREAK. ZEPHYRUS BETUL, (Plate XLIV. Figrs. I ठ̋,2马, 3 under-side.)

Papitio betulce, Linnæus, Syst. Nat. (ed. x.) i. p. $4 S_{2}$, no. ${ }_{4} 6$ (175S) ; id. Faun. Suec. p. 282 (176r); Esper, Schmett. i. ( I) p. 256 , pl. I 9, fig. I ( 777 ); Hübner, Eur. Schmett. i. figs. $3 s_{3}-3 S_{5}$ ( $1 S_{3}$ ?). 
Polyommatus betulee, Godart, Enc. Méth. ix. p. 647 , no. iro ( 1823 ).

Thecla betule, Stephens, Ill. Brit. Ent. Haust. i. p. 75 (1828); Lang, Butterflies Eur. p. 75, pl xvii. fig. I (r88 r); Barrett, Lepid. Brit. Isl. i. p. 43, pl. 7, fig. 2, 2a-d (1892); Buckler, Larvæ Brit. Butterflies and Moths, i. P. I84, pl. I 2, fig. 4 (I886).

Zephyrus betulce, Kirby, Eur. Butterflies and Moths, p. 58, pl. $\mathrm{I}_{5}$, figs. $5 a, b$ (1879).

The Brown Hair-streak measures an inch and a half across the wings, which are of a dark silky brown above, with a blackish discoidal patch in the male, usually with a faint yellowish band beyond it; in the female the latter is replaced by a broad curved orange band. The hind-wings in both sexes are clothed with fine silky hairs towards the inner-margin, and the tail and the slightly projecting anal angle are marked with orange-yellow. The under side is dull orange, with a deeper coloured marginal line, most distinctly marked on the hind-wings; and with two narrow transverse undulating white lines edged with black, the anterior one abbreviated, and forming only a dusky streak on the fore-wings, edged with white. The antennæ are ringed with white, and the club of the antennæ is tipped with ferruginous. The Butterfly appears about the end of July, or the beginning of August.

The larva is green, with longitudinal white lines and oblique yello.vish ones between them. It feeds on birch, blackthorn, plum, and other trees, in spring; the pupa is brown.

The Brown Mair-streak is a very common Butterfly throughout Europe and Northern and Western Asia; it is widely distributed in England and the south of Ireland, but is rarely abundant, except in certain localities in the south. It is found along hedgerows and about bushes, and is liable to be overlooked on the wing amongst a crowd of Epinephele janira and 
Hipparchia hyperanthus, which often fly in the same localities, and which are still plentiful when it appea:s.

II. THE PURPLE HAIR-STREAK. ZEPIIYRUS QUERCUS. (Plate XLIV. Fir. 4c, 5 ?, 6 under-side.)

Papilio queraus, Linneus, Syst. Nat. (ed. x.) i. p. 48z, no. I 48 ( 7758$)$; id. Faun. Suec. p. $28_{3}$ (I76I); id. Mus. Lud. Ulr. p. 3 I 4 ( 1764$)$; Esper, Schmett. i. (I) p. 262, pl. I9, fig. 2 (1777); Hübner, Eur. Schmett. i. figs. 368-370 ( $\mathrm{ISOj}_{3}$ ?).

Polyommatus quercus, Godart, Enc. Métin. ix. p. 65 I, no. i I 7 $\left(\mathrm{I}_{23}\right)$.

Thecla betulce, Stephens, Ill. Brit. Ent. Haust. i. p. 76 (i 828 );

Lang. Butterflies Eur. p. 8I, pl. I 8 , fig. 2 (I $\$$ I) ;

Buckler, Larve of Brit. Butterflies and Moths, i. p. I 85 ,

pl. I3, fig. 2 (1886); Barrett, Lepid. Brit. Isl. i. p. 5 I, pl. 8, figs. 3, $3 a^{a-c}(1892)$.

Zaphyrus querius, Kirby, Eur. Butterflies and Moths, p. 58, pl. I 5, fig. 6 (1879).

The Purple Hair-streak is rather smaller than the last species, rarely expanding more than an inch and a half across the wings.

The male is purplish-blue above, with a narrow black border. The female is brown, with a rich purple blotch reaching half across the front part of the fore-wings, and beneath nearly to the hinder angle. On the under side the wings are of a light silky grey, traversed by a continuous undulating white streak, edged with brown anteriorly; beyond this there is a double row of faint whitish crescents, with a few dusky dots on the fore-wirgs, and the hind-wings are ornamented with two fulvous spots, one at the anal angle, ard the other forming an ocellus with a yellow iris and a black pupil. The Butterfly appears in July and August. 
The larva is brownish-green, with a dark brown head, and pinkish dots on the back; it is sometimes tinged with reddish. It feeds on oak, and is full-grown in June.

The Purple Hair-streak is common throughout Europe and Western Asia, and is the only Hair-streak except Callophrys rubi which is considered common in the British Islands; it appears, however, to be rare in most parts of Scotland. It is always met with flying round oak trees, and sitting on the leaves.

Several other allied species are found on the continent feeding on oak, besides Zephy'rus quercus. One of these is Thecla ilicis (Esper), to which we have already alluded (antea, p. 54), and another is a much rarer and more local insect, found only in Southern Europe, Leeosopis roboris (Esper), which is about the same size as $Z$. quercus and much rosembles it, being purplish-brown above in the male, but the hind-wings are tailless, and instead of "hair-streaks" beneath, we find rows of sub-marginal orange and white spots, separated by a row of black dots.

We will now consider a series of beautiful and interesting genera allied to Thecla and Zephyrus, and mostly including tailed species, which inhabit the tropical regions of the Old World.

\section{GENUS HELIOPHORUS.}

Heliopnionus, Geyer, in Hübner, Zutr. Exot. Schmett. iv. p. 40 (i 832 .

Ilerda, Doubleday, List Lepid. Ins. Brit. Mus. ii. p. 25 (1847); Hewitson, Illustr. Diurn. Lepid. p. 57 (1865); Schatz \& Röber, Exot. Schmett. ii. p. 267 (I892); De Nicéville, Butt. Ind. iii. P. 322 ( I $\left.S_{90}\right)$.

A genus of small extent, confined to the Indo-Malayan Region, and mo t numerous in North India. They are tailed 
species, resembling Zephyrus, but recognisable at once by the very characteristic colouring of the under side. The males are generally blue, green, or coppery above (at least at the base), with black borders, and often with a sub-marginal orange-red band (or rather a row of connected lunules above black spots) on the hind-wings; and the females are brown, with a short transverse orange bar on the fore-wings, and a sub-marginal orange band, as in the males; the fringes are spotted with black and white. The under side is of a peculiar greenishyellow, with obsolete (if any) markings, except towards the margins. Towards the hinder angle of the fore wings are one or two black spots surrounded with white, and sometimes edged within with a white line; the hind-wings have a sub-marginal orange-red band bordered within with white, of which there is sometimes a trace on the fore-wings also. The species are most easily distinguished by the different colours of the upper side in the male.

The type is

HELIOPHORUS EPICLES.

Polyommatus epicles, Godart, Enc. Méth. ix. p. 666, no. 109 (1823).

Thecla epicles, Horsfield, Cat. Lep. Mus. E. I. C. p. 92, no. 25, pl. I, fig. 3 ( 1829 ).

Ilerda epicles, Hewitson, Illustr. Diurn. Lepid. p. 58, no. 4 (I 865); De Nicéville, Butterflies, Ind. iii. p. 225 (IS90); Leech, Butterflies of China, Japan, and Corea, p. $4 \mathrm{x} S$, pl. 30 , fig. 6 (1893).

Heliophorus belenus, Geyer, in Hübner, Zutr. Exot. Schmett. iv. p. 40 , figs. $785,786\left(18_{32}\right)$.

This is one of the commonest species of the genus throughout Northern India, Burma, Java, and parts of China. It measures rather less than an inch and a half across the wings, 
which are brown, richly shot with violet in the male, which is sometimes marked with an orange spot in the middle of the fore-wings. The female is brown, with an orange spot, varying considerably in size and shape, on the fore-wings, and a reddish-orange border on the hind-wings, also visible in the male towards the anal angle. The orange-red border on the under side of the hind-rings is variable in breadth.

\section{GENUS IALMENUS.}

Ialmemus, Hübner, Verz. bek. Schmett. p. 75 ( I S I6); Hewitson, Illustr. Diurn. Lepid. p. 53 (I865); Schatz \& Röber, Exot. Schmett. ii. p. 268 (1892).

The types of this genus are Australian species, somewhat resembling Heliophorus, but much larger, and with spots at the ends of the cells. The colours are also different.

The type is

\section{IAIMENUS EVAGORAS.}

Papilio evasuras, Donovan, Ins. New Holl. pl. 30, fig. I ( I So 5).

Ialmems evagoras, Hübner, Zutr. Ex. Schmett. i. figs. I75, r 76 (18rS); Staudinger, Exot. Schmett. i. p. 274, pl. 95 ( $\mathrm{i} S 86)$.

Ialmemus coagoras, Anderson and Spry, Victorian Butterflies, 1). 97 ( ( 894$)$.

Myrina eargoras, Godart, Enc. Méth. ix. p. 593, no. 3 ( 1823$)$.

This species, which is not uncommon in Australia, measures about an inch and a half across the wings, which are of a silvery-green above in the male (paler in the female), with broad black borders, and a black spot at the end of the cell of the fore-wings, and a black streak at the end of that of the hind-wings. 'Towards the anal angle of the hind-wings, ncar 
the base of the slender tail, which is longer than in Zepluyms or Heliophorus, are two orange spots, separated by a cluster of blue atoms. The under side is yellowish-ashy, with some blackish spots in and near the cell, and a dusky line beyond, forming a $W$ above the two orange spots at the anal angle, which are well-marked both above and below. The hindmargins are black, preceded ly a double reddish line, and the tails are black, tipped with white. The antennæe are black, ringed with grey, and the body is ashy above, and yellowish beneath.

"The larvie feed gregariously on various species of wattle, and are invariably attended by ants; they seem to prefer young or stunted trees. The chrysalides are placed side by side on a common web" (Anderson and Spry). According to the figure, the larva appears to be furnished with four rows of short fleshy spines.

\section{GENUS DEUDORIX.}

Dadorix, Hewitson, Illustr. Diurn. Lepid. p. I6 (г86.3); Distant, Rlop. Malayana, p. 277 (I885); Schatz \& Röber, Exot. Schmett. ii. p. 268 (1892).

A considerable number of species, inhabiting various parts of the tropics of the Old World, are referred to this genus, which includes moderately-sized species with triangular forewings, as in Thecla, and a conspicuous lobe at the anal angle cf the hind-wings, and a short tail near it. The species are of various colours : brown, blue, red, or partly white above, and brown, green, yellow, \&c., below, with no specially characteristic markings, except that the lobe at the anal angle of the hind-wings is generally marked with a black spot beneath.

The following species may be regarded as the type:-

DEUDORIX EPIJARBAS.

Dipsas epijarbas, Moore, Cat. Lepid. Ins. Mus. E. I. C. i. p. 32, no. $40(1857)$. 
Deudorix epijarbas, Hewitson, Illustr. Diurn. Lepid. p. 20, pl. 7, figs. I6-IS (IS63); Staudinger, Exot. Schmett. i. p. 278 , pl. $9 S$ (isSS).

This species, which is common in India, and is also said to occur as far as Celebes, expands from an inch and a half to nearly two inches. The male has dark brown fore-wings, with a large triangular coppery-red patch extending from the base nearly to the hind-margin, and occupying rather more than half of the lower part of the wing. 'The hind-wings are of a duller red, with a large brown patch at the base of the costa, and covering the cell; the female is of a fulvous brown, and has more rounded wings. The under side is of a rather dark brown, with two whitish undulating lines, and also two short black lines at the end of the cell of the fore-wings. There are two black spots towards the anal angle of the hind-wings, one on the lobe, surmounted by a crescent-shaped spot of metallic green, and the second above it, enclosed by a yellow ring.

Another Indian species, Deudsrix isocrates, Fabricius, is brown above, blue towards the base in the male, and with two black spots at the anal angle of the hind wings, corresponding to those below, on a pale ground. 'The under surface is grey, with two short black lines at the ends of the cel's, two median lines enclosing a darker space, and one or two more sub-marginal lines. It is remarkable for the unusual habit of the larva, which live gregariously in the interior of the pomegranate. When they are full-fed, they cut a ho!e in the shell of the fruit, and spin a web attaching it to the tree to prevent it falling off, and then return to the interior, where they assume the pupa state. (See Westwood, Trans. Ent. Soc. London, ii. p. I, pl. I ( I 37.$)_{37}$ 
Other larve of this genus are known, but do not appear to exhibit anything unusual in their habits.

\section{GENUS IOLAUS.}

Lolaus, Hübner, Verz. bek. Schmett. p. SI $(18,6)$; Westwood, Gen. I)iurn. Lepid. p. $480\left({ }_{1} S_{52}\right)$; Ifewitson, Ill. Diurn. Lepid. p. 40 (1565); Schatz \& Röber, Exot. Schmett. ii. p. 269 (ז892).

This is a genus common to Africa and the East Indies, much resembling Deudorix, but with rather long palpi, and two slender tails on the hind-wings. The males have frequently a tuft of bristles on the inner-margin of the fore-wings beneath, and a corresponding round patch of scales on the upper side of the hind-wings. The prevailing colours above are blue and black; beneath they are brown or white, more or less banded towards the hind-margins, and with two black spots, often marked with orange, towards the anal angle.

The type is

IOIAUS HELIUS.

Papilio helius, Fabricius, Spec. Ins. ii. p. 112, no. $4 S_{9}\left(17 S_{1}\right)$. Polyommatus helius, Godart, Enc. Méth. ix. p. 618, no. 3 (1823).

Papilio eurisus, Cramer, Pap. Exot. iii. pl. 22 I, fig. D (1779). Iolaus eurisus, Hewitson, Illustr. Diurn. Lepid. Suppl. p. 40, pl. 4, figs. 31, 32 (1 869).

This Butterfy, which is common in West Africa, measures about an inch and a half across the wings, which are of a bright blue above, with the apex of the fore-wings broadly black. The hind-wings have three slender tails, tipped with white. The under side is ashy-grey, with three brown transverse lines; the spots at the anal angle stand in red rings, and the lower eye is bordered behind by a cluster of blue atoms.

A South $\Lambda$ frican species, I. silas, Westwood, is blue and black 
above, with red spots at the anal angle of the hind-wings; beneath, it is white, with a slender incomplete red line. The thick rounded pupa is remarkable for being "attached with silk, by the tail only, horizontally on the under side of a leaf", (Trimen).

\section{GENUS SITHON.}

Sithon, Hübner, Verz. bek. Schmett. p. 77 (ISI6); Distant, Rhopalocera Malayana, p. 253 (ISS5); Schatz \& Röber, Exot. Schmett. ii. p. 269 (1892).

Myrina, Latr. (nec Fabr.) Enc. Méth. ix. pp. I I, 592 ( I S I9I 823 ) ; Horsf. Cat. Lepid. E. I. C. p. г г6 (г 829 ); Westwood, Cat. Diurn. Lepid. p. 475 (IS52); Hewitson, Illustr. Dium. Lepid. p. 27 (1863).

The types of this genus are confined to the Indo-Malayan Region, and may be known from their allies by the sub-costal neivure of the fore-wings having only three branches, the first impinging on the costal nervure. The wings are rather short and broad, and the hind-wings have a slender tail, and the anal angle produced into a long lobe.

With these insects are frequently associated a number of East Indian and African Butterflies, sometimes called Sithon or Myrina, varying in the number of branches of the sub-costal nervure; most of them are remarkable for having a very long tail on the hind-wings, and frequently a much shorter and more slender one on each side. The Eastern species of this section have been divided into a variety of genera (Biduanda, Cheritra, \&c.) by Distant, Moore, and others. Most of these genera will doubtless be retained; but we have not space to discuss them in detail here.

The true type of the genus Sithon is

SITHON NEDYMONDA.

Papilio nedymond, Cramer, Pap. Exot. iv. pl 299, figs. E, F ( $17 \mathrm{SO})$. 
Thecla nedymond, Horsf. Cat. Lepid. E. I. C. p. 96, no. 28 (I 829).

Sithon nedymond, Distant, Rhopalocera Malayana, p. 253, pl. 22, fig. I (1885); Staudinger, Exot. Schmett. i. p. 277 , pl. 95 (1 888).

q (?) Thecla chitra, Horsf. l. c. p. 97, no. 29, pl. 1, fig. 5 (1829).

Sithon chitra, Distant, l.c. p. 454, pl. 23, fig. 15 (1885).

This species has been found in Java and Sumatra, as well as in the Malay Peninsular, but is considered very rare everywhere. The wings are rather short and broad, and expand about an inch and a quarter. They are black, with a rich purplish-blue band covering the whole of the fore-wings, except the costa, hind-margin, and the base of the inner-margin ; and on the hind-wings the outer third is of the same blue as far as the tail and lobe, which remain black. 'The under surface is white, with the borders broadly dusky; towards the anal angle of the hind-wings is a large fulvous blotch, spotted with metallic blue; above this a short dusky stripe runs from the band to the inner-margin. The supposed female, S. chitra (Horsf.) is brown above, with a white space at the anal angle of the hindwings, containing two black spots, the outer one marked with blue. The fore-wings, and the upper part of the hind-wings are orange, reddish towards the base, and the greater portion of the rest of the hind-wings is white, with the spots towards the anal angle black, bordered with blue and white.

\section{GEVUS MYRINA.}

Myrina, Fabricius in Illiger, Mag. Insekt. vi. p. 286 (1807); Trimen, S. African Butterflies, ii. p. I40 (I887); Schatz \& Röber, Exot. Schmett. ii. p. $2 C_{9}$ (1S92).

Myrina, sect. C. Latreille, Enc. Méth. ix. pp. J J, 592 (ISI9I $\left.S_{23}\right)$. 
A genus, the name of which was formerly used to include the series of genera and species which we have discussed under Sithon, the true types of Myrina being included with those of Loxura. Myrina, as now understood, includes only a few African species with very long palpi, gradually thickened antennx, not distinctly clubbed, and a long spatulate tail. The colours are black and blue above.

The type is

\section{MYRINA SILENUS.}

\section{(Plate XL. Fig. 3.)}

Papilio silenus, Fabricius, Syst. Ent. p. 53 1, no. 37 S (1775). Papilio alcides, Cramer, Pap. Exot. i. pl. 96, figs. D, E (1776). Myrina alcides, Godart, Enc. Méth. ix. p. 594, ro. 4 (IS23).

The present species, which expands about an inch and three quarters, is dark brown above, with the basal area of the wings shining violet-blue, which colour also extends to the borders of the hind-wings, and to the tail. Beneath, the colour is brown as far as the middle of the wings, where there is a narrow yellow line, which is incomplete on the fore-wings.

This species is closely allied to the South African Myrina ficedula, Trimen, in which the blue colouring of the fore-wings is much more extended than in $M$. silenus, and there is a distinct ferruginous bar on the hind-margin of the fore-wings. This species has been described and figured by many authors as identical with the West African M. silenus. The yellowishgreen, white-spotted larva of $M$. ficedula feeds on figs, and the short broad pupa is "attached by the tail only, but in a horizontal position, to leaves of the food-plant-usually on the under side, or to its twigs" (Trimen). Mr. Trimen ad is, respecting the larve: "There is no doubt that their pecular colouring is highly protective, agreeing very thoroughly wh that of the terminal green shoots, the hract and oceasi : 1 
withered portions of which are ferruginous; while the conspicuous white spots most completely resemble the drops of milk-like sap that exude from the stems and leaves on the slightest wound. Moreover, both the larva (when in a slightly contracted position) and the pupa bear a very strong resemblance to the small, rough, ashy-varied fruits of their foodplant. I found that those pupæ which were disclosed at large on the plants were much greener and more like the little figs than those which resulted from larvæ kept captive in a dimlylighted breeding-cage."

GENUS LOYURA.

Loxura, Horsfield, Cat. Lepid. E. I. C. p. I I9 (I829); Westwood, Gen. Diurn. Lepid. p. 474 (1852) ; Distant, Rhopalocera Malayana, p. 280 (1885); Schatz \& Röber, Exot. Schmett. ii. p. 270 (1888).

The species of this genus were formerly placed with those of Myrina, which they rescmble in general appearance; but they are more slender Butterflies, with much longer and slenderer palpi, and the long tail is pointed and not spatulate at the extremity. They, moreover, inhabit India and the adjacent islands, not Africa. The wings are fulvous, or ochraceous, with brown or black borders, and the type is Loxura atymmus (Cramer), which is found almost throughout the southern part of the Indo-Malayan region, except, perhaps, in Sumatra.

\section{GENUS PIIASIS.}

Phasis, Hübner, Verz. bek. Schmett. p. 73 (ISI6). Aloeides, Hübner, l. c. p. 73 (1816).

Zeritis, Boisduval, Spec. Gén. Lépid. i. pl. 22, fig. 6 ( (836) $_{3}$; Westwood, Gen. Diurn. Lepid. p. 500 (1852); Trimen,

S. African Butterflies, ii. p. I67 (I887).

Cisaritis, Donzel, Ann. Soc. Ent. France, (2) v. p. 528 (1847); Lucas, Expl. Algér. Zool. iii. p. 362 ( ( 849 ). 
Axiocerses, pt. Kirby, Cat. Diurn. Lepid. p. 337 (IS7r); Schatz \& Röber, Exot. Schmett. ii. p. 27 I (1892).

There are a considerable number of $A$ frican species, usually classed under the names Axiocerses or Zcritis, which we may notice here. They are stout-bodied insects, and differ from true Axiocerses in the sub-costal nervure bemg four or fivebranched. Ultimately they will be divided into several genera (for although many genera have already been separated, the remainder are far from homogeneous), for some of which the names quoted above will be available, as their types mostly represent different groups.

In general terms we may say that the species are of rather small size, and of a coppery-red, or orange, with broad brown borders. There is no tail in this group, but the hind-wings are frequently more or less produced at the anal angle. They are sometimes flushed with blue towards the base ; and many of the species are marked with metallic spots beneath.

The type of Phasis is P. thero (Linnæus), the largest species of the group, sometimes expanding two inches. It is dark brown above, with eight red spots on each of the fore-wings, one in the cell, one beyond, a row of five on the disc, and a larger one nearer the base towards the inner-margin ; the hindwings are dentated and sub-caudate (somewhat as in Lycana phleas (Linn.)), and the fore-wings are strongly emarginate on the hind-margin below the middle. In fact, the general appearance of the Butterfly is somewhat between a Lycena and a Libythea. The under side of the fore-wings is fulvous, with black borders and markings; the three black spots in the cell are centred with silver. The hind-wings are brown, with silvery-white spots, one of which (a large curved spot in the middle) is very conspicuous. The orange spots of the upper side vary in size and number, and some of them are confluent in the female. It is a common South African Butterny. 
The type of Aloeides is A. pierus (Cramer), another South African Butterfly, dotted with grey or yellowisli.grey at the base of the wings, and with a red patch near the anal angle of the hind-wings, and in the female, also on the fore-wings. The under side is brown, with slightly metallic spots, and the fore-wings are fulvous in the centre, spotted with black and sil. very. The Butterfly has rounded wings, and expands rather less than an inch and a half.

The type of Zeritis is Z. neriene (Boisduval), a Gaboun Butterfly, cxpanding about an inch and a half across the wings. The upper side is unfigured; the under side is tessellated with square yellow and red spots, forming irregular alternate bands, and partly separated by black lines, much in the fashion of a Melitea. A black zig-zag line runs near the hind-margins, enclosing white spots on the fore-wings. The hind-wings are rounded, not dentated or tailed.

The type of Cigaritis is C. zohra, Donzel, a North African species very like Lycena phlceas. It expands an inch and a quarter across the wings; the hind wings are sub-caudate in the male, and have longer tails in the female. The fore-wings are bright coppery-red, with a black hind-marg.n, two short black bands in the cell, and a sub-marginal black band beyond. The hind wings are black, with two or three coppery bands, imperfectly separated, towards the hind-margin. The under side of the hind-wings is dull yellowish-green, with irregular white markings. These are not all the well-marked forms of this heterogeneous African group, but will sufficiently serve to illustrate it.

\section{GENUS APHNAUS.}

Aphnceus, Huibner, Verz. bek. Schmett, p. 8I (1816); Hewitson, Illustr. Diurn. Lepid. p. 60 (I865); Trimen, S. African Butterflies, ii. p. I46 (I887); Schatz \& Röber, Exot. Schme!t. ii. p. I 7 I (I 892 ). 
Stindasis, Wallengr. Lepid. Rhop. Caffr. p. 45 (I 857 ).

This is a genus including several East Indian and African species, with triangular fore-wings, and somewhat produced and lobate hind-wings, furnished with two slender tails. The upper side is more or less extensively marked with blue or orange on a dark ground, and the under side is marked with transverse bands, more or less silvery in the middle, or with parallel lines arranged in pairs, and filled up with silver. Many of the species are extremely similar. The larva and pupa are more elongate than is usual in the Lyccenida.

The type is

\section{APHNEUS ORCAS.}

Papilio orcas, I)rury, Illustr. Exot. Ent. iii. pl. 34, figs. 2, 3 $\left(\mathrm{I} 7 S_{2}\right)$.

Hesperia pindarus, Fabricius, Ent. Syst. iii. (1) p. 262, no. I 5 (I 793).

Papilio pindarus, Donovan, Ins. India, pl. $3^{8}$, fig. 2 (ISoo). Polyommatus orcas, Godart, Enc. Méth. ix. p. 645, no. Io2 (I 823 ).

Aphneus orcas, Hewitson, Illustr. Diurn. Lepid. p. 60, no. I $\left(\mathrm{i} 86_{5}\right)$.

This Butterfly, which measures an inch and a quarter in expanse, is a native of West Africa.

In the male the centre of all the wings is of a shining greenish-blue, with the costa and hind-margin black. There are three black spots in the cell of the fore-wings, and two red spots at the anal angle of the hind-wings. The under side is of a yellowish-grey, with broad silvery blotches and bands bordered with chocolate-brown. On the lobe at the anal angle of the hind-wings is a large black spot, bordered above with orange. The female is uniform dark brown; the fore-wings with a pale spot at the end of the cell. The under side is 
rufous-yellow, and the spots are silvery-white, bordered with pale brown.

\section{GENUS MILETUS.}

Miletus, Hübner, Verz. bek. Schmett. p. 7 I (18 I6).

Thecla, sect. Hypochrysops, Felder, Wien. Ent. Mon. iv. p. 243 ( 1860$)$.

Hypochrysops, Felder, Reise Novara, Lepid. ii. p. 25 I (1865);

Schatz \& Röber, Exot. Schmett. ii. p. 272 (IS92);

H. H. Druce, Trans. Ent. Soc. Lond. I89 I, p. I 79.

This is one of the most characteristic genera of the AustroMalayan Region, and one of the most richly ormamented. On the upper side it is generally blue, or blue and black, or brown, frequently with a white blotch on the fore-wings, and occasionally orange-tawny; but beneath it is decorated with red spots and bands bordered with silver, on a brown ground, or with metallic blue lines and rows of spots bordered with black or tawny, and set off by large masses of white on the fore-wings.

The type is $M$. polycletus (Linnæus), from Ceram and Amboina, which expands about an inch and a half. The male is of a rich blue above, with black borders, and the female is black, with more or less of the base greenish-blue. The under surface is dark brown, with numerous red bands bordered with black, and then with golden-green.

We now come to the immense group of small blue Butter. flies, which have latterly been divided into numerous genera, at least as regards the Indo-Malayan species. These genera will be bricfly noticed, with reference to those which contain European (and especially British) species, and to one or two of the more remarkable of the exotic forms. It must be remembered that such names as Plebeius, Cupido, Lycana, and 
Cyaniris were originally intended to include all the Blues, and sometimes all the Lycrenide, or even the Hesperiida as well.

The European species belonging to this group of Butterflies are always of a blue or brown colour, generally with numerous dark spots beneath, surrounded with paler colour. They are distinguished from the Butterflies allied to Thecla by the subcostal nervure of the fore-wings being four-branched, and from the genera allied to Lycrena, by the presence of the upper disco-cellular nervule in the fore-wings.

\section{GENUS LAMPIDES.}

Lampides, Hübner, Verz. bek. Schmett. p 70 (I8I6). Polyommatus, pt. Latrenlle, Hist. Nat Crust. Ins. xiv p. I I6 (1805).

The comparatively large size, tailed hind-wings, and streaked under side of the only British species of this genus, will prevent its being mistaken for any other "Blue."

The name Lampides has been sufficiently often applied to L. beticus to warrant this species being regarded as the type. Several recent authors have treated $L$. breticus as the type of Polymmatus Latr., but I consider that Latreille indicated $P$ corydon as the type of Polyommatus by figuring it ; and moreover the name Polyommatus is wholly inap licable to L. baticus.

THE LARGE TAILED BLUE. LAMPIDES BETICUS.

$$
\text { (Plate XLV. Figs, I-3.) }
$$

Prpilio baticus, Linnwus, Syst Nat. i. (2) p. $7 S_{9}$, no. 226 (1767); Esper, Schmett. i. (1) p. 319, pl. 27. figs, $3 a, b$ ( 777 ) ; i. (2) p. I $S$ r, pl. 9 I, fig. 3 (I 784$)$; Hübner, Eur. Schmett. i. figs. 373-375 (1So3).

Polommatus betica, Godart, Enc. Méth ix. p. 653, no, I 22 ( $S_{2} 3$ ).

Lampides boticus, Newman, Brit. Butterflies, p. I I $($ ISSI). 


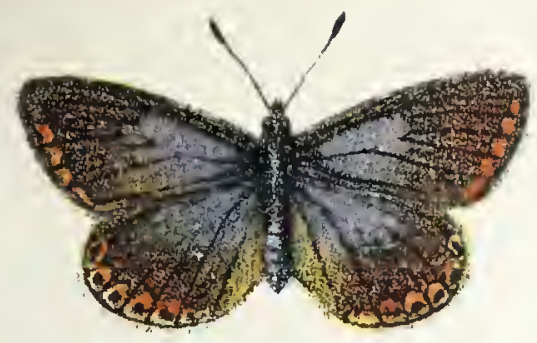

8.

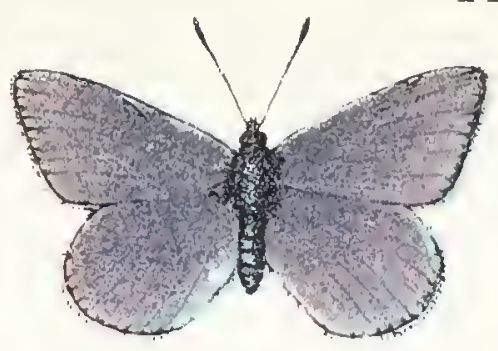

7.

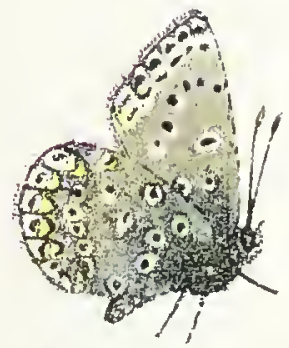

9.

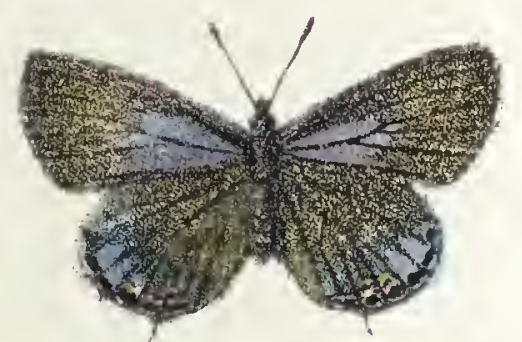

5.
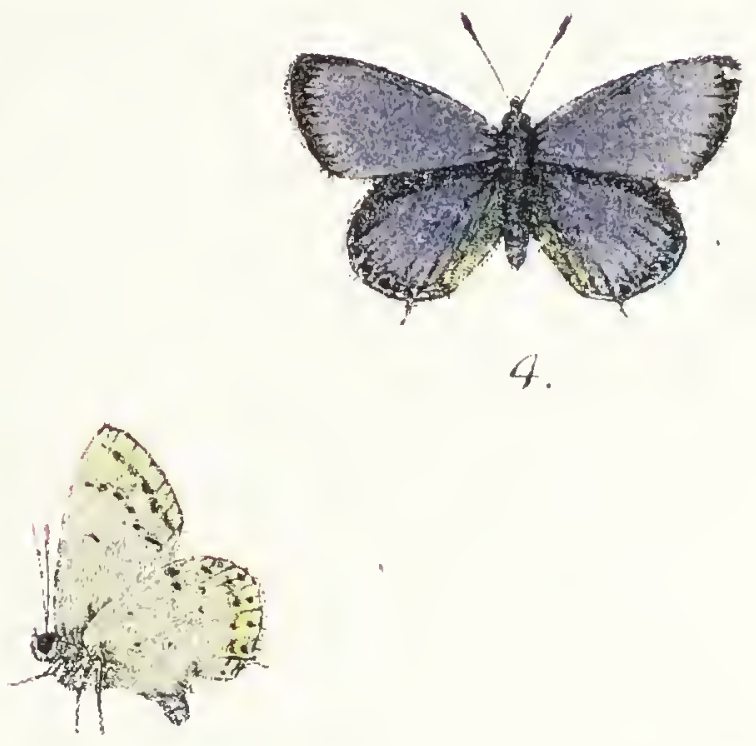

6.
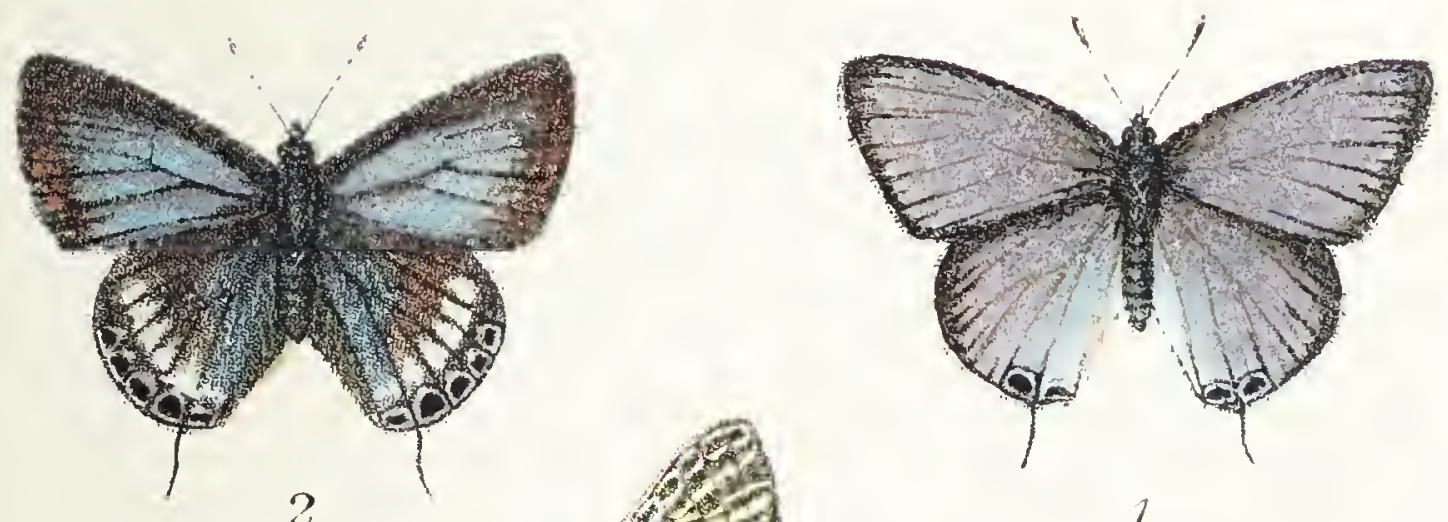

1.

1. 3. Lampides boeticus.

4.6. Gupido argiades.

7. 9. Polyommatis icarus. 

Poljommatus baticus, Kirby, Eur. Butterflies and Moths, p. 53 (1879).

Lycana batica, Millière, Icones, i. p. 245, pl. 4, figs. I-6 (I86I), Lang, Butterflies Eur. p. 99, pl. 22, fig. 2 ; pl. 28, fig. 5 (larva) ( I 88 I).

Lycana bretica, Barrett, Lepid. Brit. Isl. i. p. 65, pl. Io, figs. I, I $a(\mathrm{I} 892)$.

This Butterfly expands about an inch and a quarter across the fore-wings, which are violet-blue in the male, with narrow brown borders, and grey fringes. There are generally two black spots at the anal angle of the hind-wings, near which is a slender tail. The female is brown, more or less blue at the base of the fore-wings, and towards the inner-margin of the hind-wings, and often has some zig-zag whitish markings within the black sub-marginal spots, which are more numerous than in the male, and are edged with white on the inside. The under side is pale brown, with numerous white streaks; most of these are straight, and converge more or less towards the inner-margin of the wings; the dark sub-marginal spots are edged within with white crescents, and beyond the middle of the hind-wings is a broad, nearly straight, and slightly irregular white band. The spots towards the anal angle of the hind-wings are black, edged below with metallic green, and broadly surrounded with orange.

The larva is green or reddish-brown, with a dark dorsal line, and a white lateral line below the yellow spiracles; the head is black. The eggs are laid on the stems of the bladder-senna (Colutea arborescens), and on other leguminous plants. The young larvæ hatch in the following summer, when they pierce the pods, and feed on the seeds. On reaching their full growth they abandon the pods, and the pupa is usually attached to a stem, or formed among the dried leaves of the food-plant. The pupa is reddish or yellowish, with brown 
dots, and obtuse at both ends, and is attached by a belt round the middle.

The food of the larva varies in different parts of its range; it will feed on the common pea, the field pea, and lupine.

This species is common throughout Southern Europe, the whole of Africa, and southern and eastern Asia, as far as China and Japan; and also throughout the eastern islands to Australia and the Sandwich Islands. But in Europe it is one of those Mediterranean species which have not crossed the Alps, but are gradually extending their range northwards along the west coast of Europe. In Germany the only recorded locality (and that somewhat doubtful) is Aix-la-Chapelle; but the

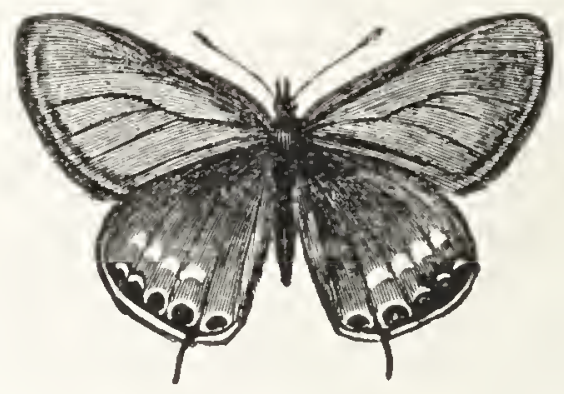

Lampides bretica. Upper side of female.

Butterfly has long been known as at least an occasional v:sitant to the Channel Islands. In 1859 , the last of a series of unusually fine and hot summers, to which many entomologists doubtless still look back with regret, this Butterfly reappeared in the Channel Islands, where it had not been seen for twenty years; and one day Mr. Henry Cooke, of Brighton, where I was then living, told me that Mr. McArthur had captured "a new Thecla" on the Downs. I knew that there were tailed Blues, and that it was not a likely locality for a Thecla, and was not surprised when the insect was identified. The few specimens known to have occurred in England have all been met with in the southern counties during August. There is also a May brood on the continent. Many species, 
much resembling this in shape and markings, are found in the East Indies. Some of these, such as L. clianus, Fabrici is (which some authors treat as the type of Lampides, considering $L$. bceticus as generically distmct), are of a very pale blue, almost white.

\section{GENUS CUPIDO.}

Cupido, Schrank, Fauna Boica, ii. (I) pp. I 53, 209 (ISor). Everes, Hiibner, Verz. bek. Schmett. p. 69 (I $\mathrm{SI}_{5}$ ); Moore, Lepid. Ceylon, i. p. 85 (I 88 I).

The type of this genus is a small blue Butterfly, with a slender tail on the hind-wings, and spotted, not streaked, on the under surface. 'The only species which Schrank described at unusual length under Cupido was $C$. puer, which subsequently proved to include two species, $C$. argiades and $C$. alsus, placed together as male and female. The large space given to $C$. puer, in conjunction with the name, is sufficient to establish the male ( $C$. argiades) as the indubitable type of Cupido.

THE SMALl tailed BlUE. CUPIDO ARGIADES.

$$
\text { (Plate XLV. Figs. 4-6.) }
$$

Pupilio argiades, Pallas, Reise, i. p. г72, no. 66 (I77 I). Papilio tiresias, Von Rottemburg, Naturforscher, vi. p. 23 , no. ro (1775); Esper, Schmett, i. (r) p. 337, pl. 34, figs. I, 2 ( 1777 )

Cupido puer, ơ. Schrank, Fauna Boica, ii. (I) p. 2 I 5, no. I 374 ( $\mathrm{I} 80 \mathrm{r}$ ).

Var. Papilıo polysperchon, Bergsträsscr, Nomenclator, ii. pl. 44, figs. 3-5 ( 779 ); Ochsenheimer, Schmett. Eur. i. (2) p. 6 I ( $\mathrm{s} 8 \mathrm{~S})$.

Papilio tiresias, var. Esper, l. c. i. (I) p. 384 , pl. 49, fig. 2 (1777); Hübner, l.c. figs. 319-321 (1803?) 
Var. Papilio coretas, Ochsenheimer, Schmett. Eur. i (2) p 60 (1808).

Polyommatus argiades, Kirby, Eur. Butterfies and Moths, p. 53, pl. I 4, fig. I I ( I 879).

Lyccena argiades, Lang, Butterflies Europe, p IоI, pl. 22, fig. 5 (I882), Barrett, Lepid. Brit. Isl i. p. 68, pl. Iо, figs 2, $2 a, b(\mathrm{I} 892)$.

Papilio amyntas, Fabricius, Syst. Ent. p 533, no. $3 S_{4}$ (1 775$)$;

Huibner, Eur. Schmett. i. figs. 322-324 (1803).

Polyommatus amyntas, Godart, Enc Méth ix. p. 659, no. I40 ( 1823 )

This Butterfly measures from four-fifths of an inch to rather more than an inch. The male is violet-blue above, with a narrow brown border; and the female is brown. more or less blue at the base; the fringes are white. There are some brown spots towards the anal angle of the hind-wings, marked with orange in the female. The under side is of a pale blue or bluish-grey, with a sub-marginal row of black spots, edged within by a more or less distinct orange band (obsolete in var. coretas), and a row of black spots across the disc of the wing; there is a black lunule at the end of the discoidal cell of the fore-wings.

The larva is pale green, with darker stripes, and brown and white spots. It feeds on various species of Lotus, Trifolium, \&c., in June, and also from autumn to spring.

This species is widely distributed throughout Southern and Central Europe, and the greater part of Asia, and is also said to cccur in North America and Australia. It frequents open flowery places in hilly districts, often in company with Zizerc minima, of which Schrank supposed it to be the male. But it has only recently been discovered to be a British species, the first British specimens having been taken by the sons of 
the Rev. O. Pickard Cambridge, on August i8th and 2oth, I855, flying over a grassy place on Bloxworth Heath, Dorset.** Two or three other captures of the Butterfly at Bournemouth, Blackpool, \&c.., have also been recorded.

Mr. Pickard Cambridge has kindiy permitted me to publish an extract from a letter received from him, dated June 3, i $\$ 95$ "We have never again met with $L$. argiades. I hardly nov think it can be indigenous. Those we found were probably from a brood produced by an accidental early-summer immıgration of a few of the first Continental brood. If you remember, it was also taken at Bournemouth, fourteen miles distant, within two days of our takin r it here. Very likely it might have been found at many other places along the south coast that year if collectors had had their eyes open for it; and probably it will turn up again at some future season in the same way" In which case, I may add, it may succeed, sooner or later, in establishing itself.

This species varies much in size, the first brood (var. polysperchon) being much smaller than the others. The tails are very slender, and are sometimes obsolete in small specimens. The larger specimens might easily be passed over on the wing as Plebeius argus, or Polyommatus icarus, and the smaller ones as Zizera minima.

\section{GENUS PLEBEIUS.}

Plebcius, Linnæus, Syst. Nat. ed x p. $48_{3}$ ( 1758 ); Cuvier: Tabl. Elém. d'Hist. Nat. p. 59 I (I 799).

Rusticus, Hubner, Tentamen, p. I ( I810?). Lyccides, Hübner, Verz. bek. Schmett. p. 69 (ISI6).

The type of this genus, the oldest of the Lycienide genera, was fixed by Cuvier (though he used only the plural form) as

* See "Entomologist," xviii., pp. 249-252 (October, 1885), and "Pro. ceedings of the Dorset Natural History and Antiquarian Field Club," viị. pp $79-8_{3}$, pl. 5 (ioloured). 
the Silver-Studded Blue. Thus restricted, it includes various Butterflies, blue in the male, and brown in the female, with rounded hind-wings, not tailed, on the under surface of which the sub-marginal spots bear distinctly metallic markings.

IHE SILVFR-STUDDED BLUE. PLEBEIUS ARGUS.

(Plate XLIT. Figrs. 4, 5.)

Papilio argus, Linnæus, Syst. Nat. (ed. x.) i. p. 483 , no. I 52 ( 758$)$; id. Faun. Suec. p. 283 (176r) ; Lewin, Ins. Brit. i. p. 82, pl. 39, figs. 5-7 (I 795).

Polyommatus agon, Godart, Enc. Méth. ix. p. 685, no. 2 I 3 (I823); Kirby, Eur. Butterflies and Moths, p. 32 (I879); Barrett, Lepid. Brit. Isl. i. p 89, pl. I $\boldsymbol{\Gamma}$, figs. I, I $a-c$ (IS92) ; Buck'er, Larvæe of Brit. Butterflies and Moths, i. p. I I 2, pl. I 5, fig. 3 ( ISS6).

Papilio agon, Den:s \& Schiffermüller, Syst. Verz. Schmett

Wien. p. I 85 , no. I5 (I775); Hübner, Europ. Schmett.

i. figs. 3 I 3-3 I 5 ( I 803 ?).

Polyommatus argus, Stephens, Ill. Brit. Ent. Haust. i. p. 93 ( 1828$)$.

Lycana arsus, Wallengren, Lepid. Scand. Rhop. p. 206, no. 2 ( I $\left.S_{53}\right)$.

Lycrena regon, Newman, Brit. Butterflies, p. Irg (i88 I), Lang, Butterflies Eur. p. Iо3, pl. 23, fig. I ( IS\&2).

The Silver-Studded Blue is common throughout the greater part of Europe and the Mediterranean Region, as well as in Northern and Western Asia; and alled species are met with in various parts of Asia and North America. It is common and widely distributed in England, but appears to be scarce and local in Scotland and in the north of Ireland. It frequents heaths and meadows, and I have often seen it asleep in the evening, clinging to heath, rushes, or grass-stems. 


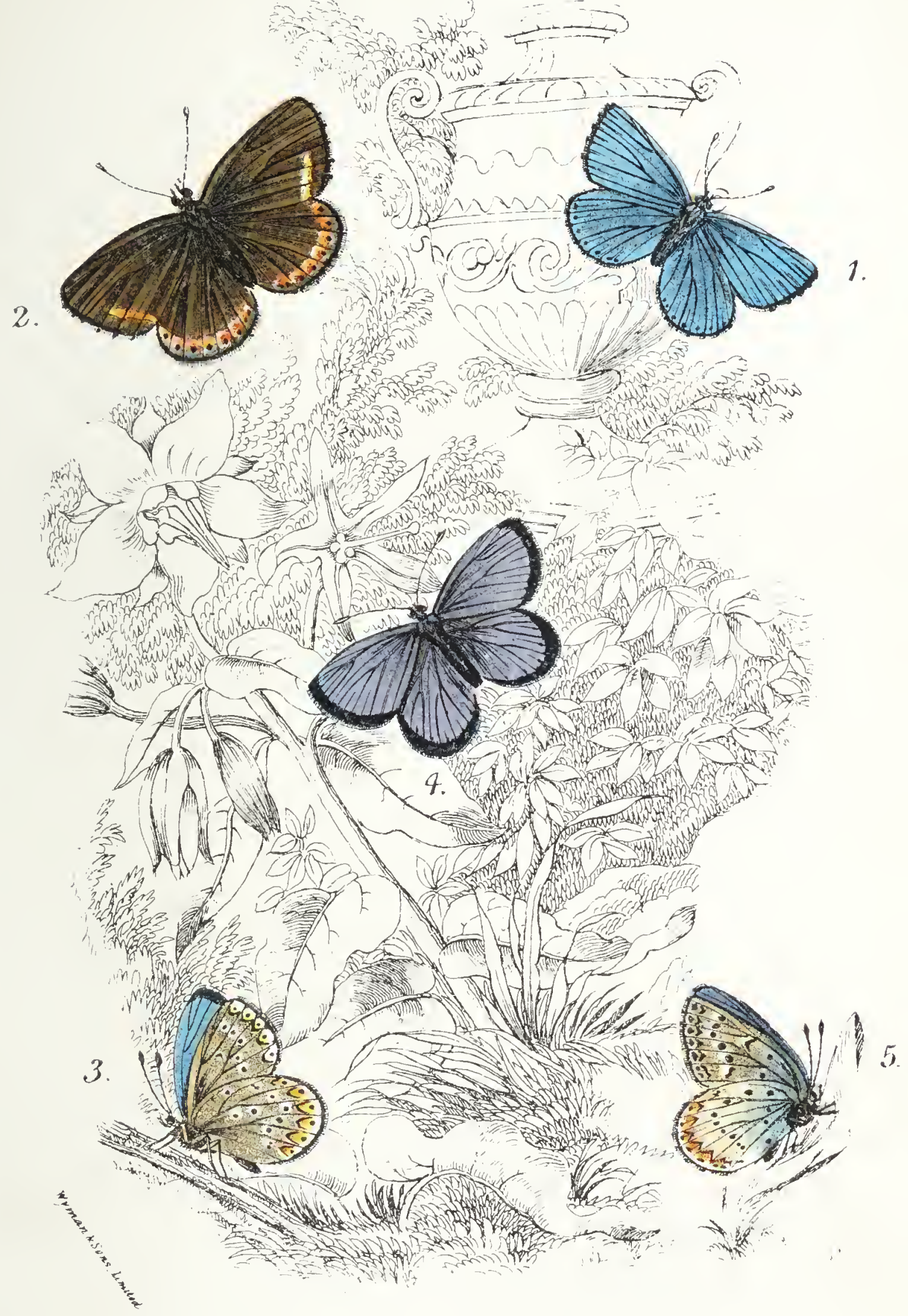

1_3. Polyommatus thetis.

4. 5. Plebeins argus. 

The male is of a deep violet-blue, with rather broad brown borders, and white fringes. The female is brown, more or less blue at the base, and with a row of sub-marginal black spots, surmounted with orange, on the hind-wings. The under side is grey in the female, but tinged with blue, especially at the base, in the male. They are marked with numerous ocellated spots, and on the hind-margin of the hind-wings is an interrupted orange-tawny band, containing six bright silveryblue spots, crowned with a series of black crescents.

The larva is dull green, with the head and legs blackish, a ferruginous line along the back, and oblique ones of the same colour, bordered with white, on the sides. It feeds on broom,

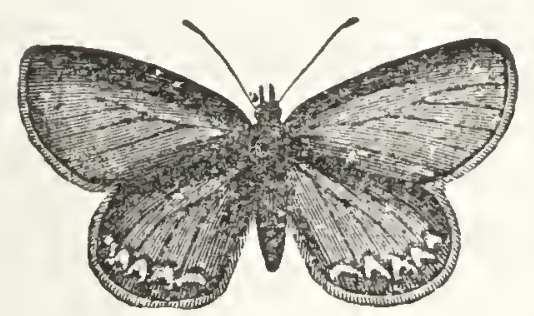

Upper side of female.

sainfoin, and various kinds of trefoil and vetch. There are two broods in the year, as in most of the small "Blues," the Butterflies appearing from May to August. The pupa is dull green.

There is a closely-allied species, $P$. argyrognomon (Bergsträsser), to which the Linnean name of argus is applied by many authors. It is common on the Continent, but of doubtful occurrence in England, and may be distinguished from our Silver-Studded Blue by having only a very narrow black border in the male. Both species are very variable on the Continent, or else there are several closely-allied and ill-differentiated species. The British form of $P$. argus does not appear to vary. 


\section{GENUS POLYOMMATUS.}

Polyommatus, Latreille, Hist. Nat Crust. Ins. xiv. p. in6 (1805); id. Enc. Méth. ix. pp. II, 618 (1819-23); Stephens, Ill. Brit. Ent. Haust. i. p. 83 (1828). Lyccena, p. Fabricius, Illiger's Mag. Insekt. vi. p. 285 (I 807 );

Leach, Edinb. Encycl. ix. p. I29 (I8I5); Westwood

Gen. Diurn. Lepid. p. 488 (1852).

When Latreille established the genus Polyommatus he figured $P$. corydon, and thus, in my opinion, permanently fixed the type. Dr. Scudder disallows this, and selects P. beticus as the type of Polyommatus, but this, being a streaked, and not primarily a spotted species, cannot possibly be regarded as typical of a genus deriving its name from its "many eyes."

As regards Lycena, Dr. Scudder considers that as Oken restricted it to the "Blues" in a work published in I8I $5, L$. phlieas is not admissible as the type, but Oken's action, I take it, is forestalled by Leach, who published an article in the same year (I8 I 5) in which he divided the genus Lycena (with Polyommatus as a synonym) into two sections, the first including the Coppers and the second the Blues, commencing zeith P. corydon, the type of Polyommatus, and thus restricting Lycena (true) to the Coppers. Subsequently Curtis indicated L. phleas as the type of the genus Lycena. The species which Dr. Scudder selects as the type of Lycena is Papilio endymion, Den. and Schiff, a light blue species, with a brown female, with submarginal spots bordered with white, which is found in many parts of Southern and South-Central Europe, and which is remarkable for having the hind-wings dentated in the female, and slightly so towards the anal angle in the male.

In the present genus we may include all the British species which are tail-less, and destitute of metallic markings beneath, and which have well-marked orange sub-marginal spots on the under side of the hind-wings. Most of the species belonging 


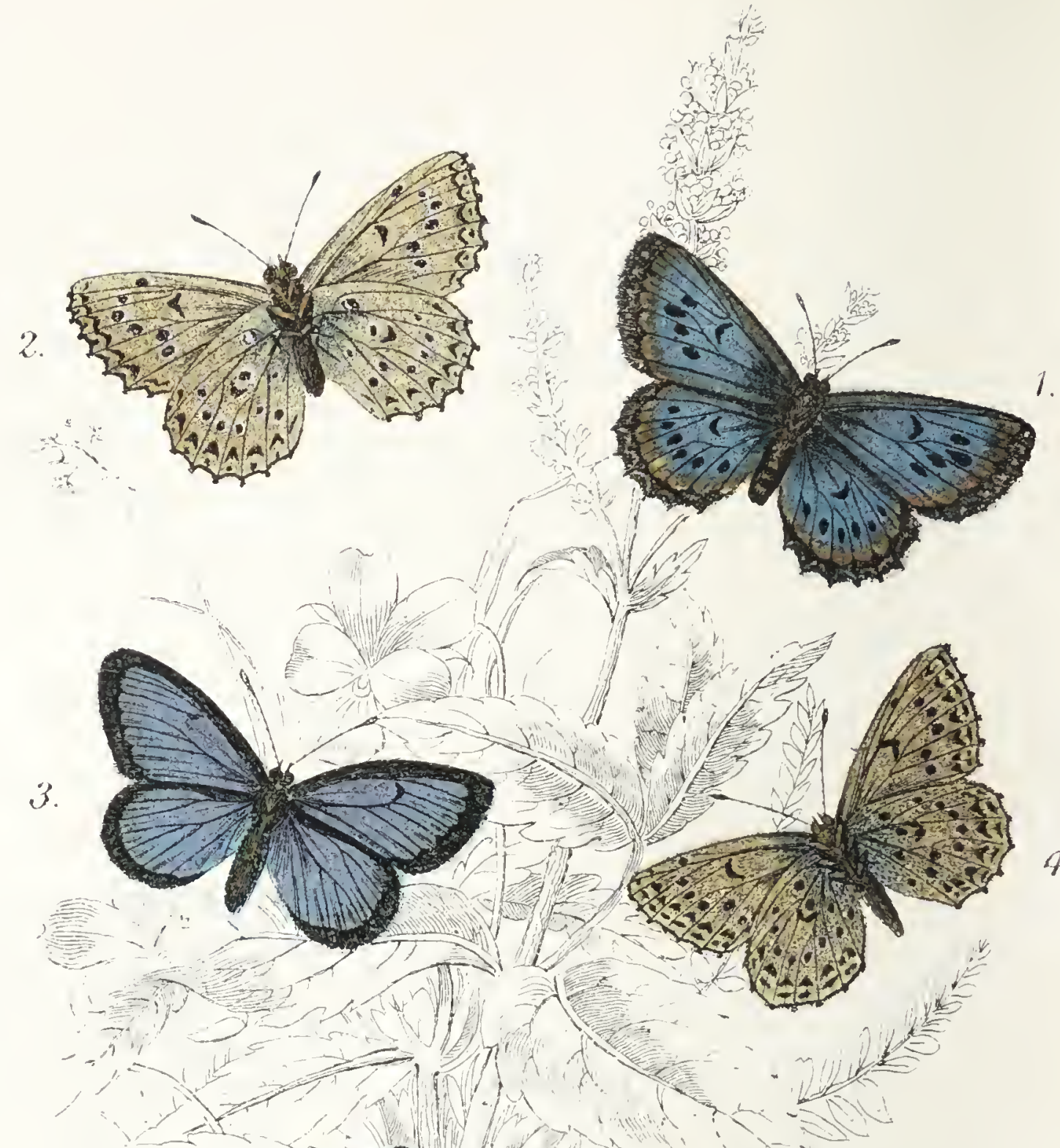

5

3
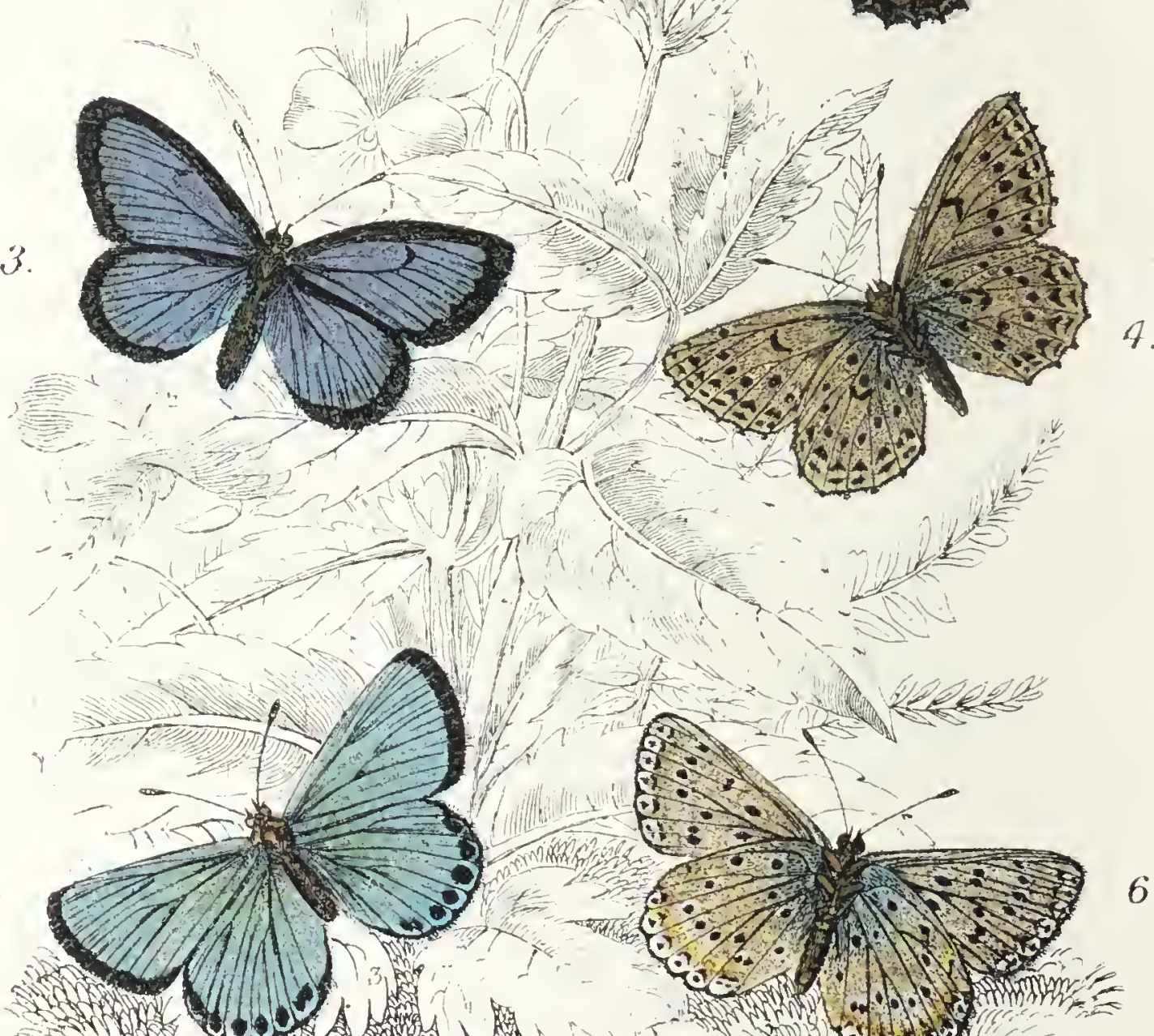

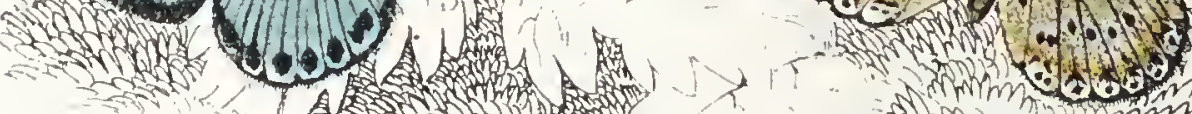
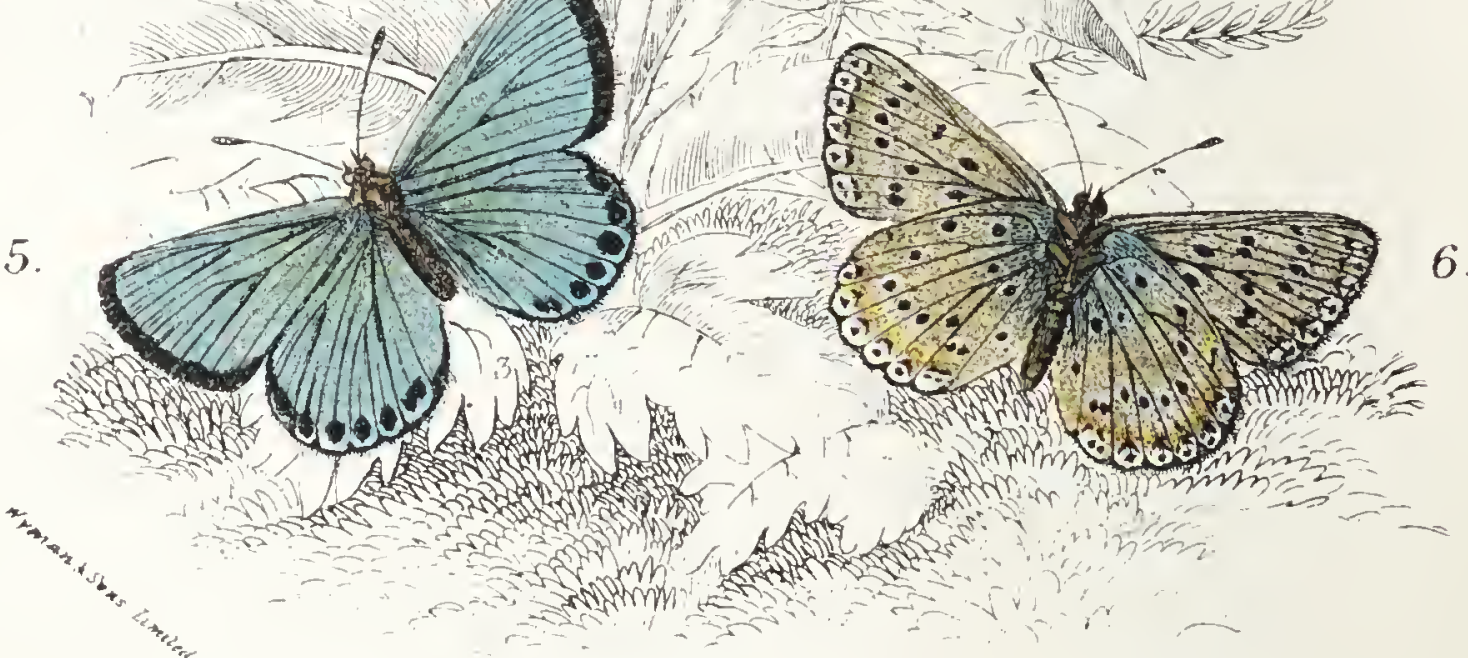

1.2. Nomiades arion.

3.7 alcon.

5.6. Polyommatus corydon. 
to it are peculiarly attached to the chalk or lime-stone in England, though of more general distribution on the Continent. They may often be all found flying together in favourable localities on the South Downs.

I. THE CHALK-HILL BLUE. POLYOMMATUS CORYDON.

$$
\text { (Plate XLVII. Figs. 5, 6.) }
$$

Papilio coridon, Poda, Mus. Græec. p. 77 (1761); Scopoli, Eint. Carn. p. I 79 ( $\left.17 \sigma_{3}\right)$.

Papilio corydon, Esper, Schmett. i. (I) p. 335, pl. 33, fig. 4 ( 777 ); i. (2) p. I 34, pl. 79, fig. I ( 1782$)$; Hübner, Europ. Schmett. i. figs. 286-288 (I803?).

Papilio tiphys, Esper, Schmett. i. (2) p. 6, pl. 5I, fig. 4 (I780). Polyommatus corydon, Godart, Enc. Méth. ix. p. 693, no. 227 (1823); Stephens, Ill. Brit. Ent. Haust. i. p. 8S (I 828 ); Kirby, Eur. Butterflies and Moths, p. 48, pl. r4, figs. $8 a-c$ ( 1879$)$; Barrett, Lep. of Brit. Isl. i. p. 85 , pl. I 2 (1892); Buckler, Larvæ of Brit. Lepid. i. p. I9I, pl. I4, fig 3 (I 886).

Lycena corydon, Newman, Brit. Butterflies, p. I 3 I (I88I) ; Lang, Butterflies Eur. p I 2 I, pl. 26, fig. 6 (I882).

Var. Lyccena corydon, var. albicans, Boisduval, Gen. et Ind. Méth. p. I2, no. 96 (I840); Herrich-Schäffer, Schınett. Eu:. i. App. p. 27 , figs. 494, 495 (185 I); Lang, Butterflies Eur p. I22, pl. 26, fig. 8 (I882).

The Chalk-Hill Blue is common throughout Southern and Central Europe and Western Asia Minor. In England it is common in many places, but local, and is most frequently met with in the chalky districts of the south, whence it derives its name. On the Continent it is double-brooded, like most of the allied species; but it appears to be single-brooded in England, appearing about the middle of July, at the same time that the second brood of the other species is beginning to appear. 
The Butterfy is slightly larger than its allies, on the average, expanding from an inch and a quarter to an inch and a half across the wings. The male is of a light silvery-blue with a fine silky lustre, with a moderately broad dark border, bordered on the inside with a row of black spots. The female is brown, with a black discoidal spot and a sub-marginal orange band on the hind-wings within the black spots. The under side is grey, with discoidal lunules, a basal eye on the fore-wings, and a sub-marginal row of orange spots. On the hind-wings there are three basal spots, separated from the central row, so as not to form a regular curve round the discoidal spot. The fringes are broadly spotted with black and white, except on the under side of the hind-wings, in which the fringes are white.

This species varies very much in Southern Europe and Asia Minor, and to a less extent with us. One of its varieties ( $P$. albicans) is nearly white above in the male.

The female is admittedly very difficult to distinguish from that of the following species, with the second brood of which it is usually found in company. The black spaces of the fringes are, however, a little broader, and the orange sub-marginal spots are rather larger in $P$. corydon. Stainton gives the differences as follows: "P.corydon $q$. Under side of hind-wings with a distinct black spot in a white blotch near the middle, faintly visible on the upper side. Besides, in $P$. corydon we find the dark dashes in the white fringes broader and more conspicuous than in $P$. adonis. A further point of distinction is that the black spots of the under side are more conspicuous in $P$ corydon than in P. adonis."

The larva is green, with yellow dorsal and lateral lines; it feeds on various papilionaceous plants. "Pupa brownish-green, unattached, on or under the ground" (Barrett).

Concerning the colours of the males of this and the follow- 
ing species, Stainton writes: " $P$. adonis wcll deserves its name, and is the most splendid Blue we have. $P$. corydon, however, has a peculiar beauty of its own; it reminds one of the soft, silvery appearance of moonlight, whilst $P$. adonis recalls the intense blue of the sky on a hot summer day." Mr. Barrett also remarks respecting $P$. corydon: "A very beautiful insect, of a colour very difficult to depict or describe, and rarely to be seen in nature. I have seen the same colour in the sky in the late twilight of a stormy day, on the patches of pale blue visible between heavy clouds; but no flower, and hardly any other insect, seems to possess it. No doubt the peculiarity arises largely from the presence of the white hairs, already mentioned, on the upper-side of the fore-wings, which this species possesses in greater abundance than any other, except the very singular $P$. dolus, a South European species."

$P$. dolus, Hübner, above referred to, is a species found in Southern France, which belongs to a different group to $P$. corydon, and has central rows of spots on the under side of the wings, but no sub-marginal spots, and a straight white stripe running across the hind-wings beneath, from the base, towards the middle of the hind-margin.

II. The Clifden BlUE BUtTerfly. polyomatimes THETIS.

(Plate XLVI. Figss. I, 38,2 우.)

Papilio thetis, Von Rottemburg, Naturforscher, vi. p. 24, no. I I (I775).

Papitio bellargus, Von Rottemburg, l. c. p. 25, no. I 2 (1775);

Esper, Schmett. i. (I) p. 333, pl. 32, fig. 3 ( I 778 ); i. (2)

p 29, pl. 55, figs. 2, 6 ( I 780 ).

Polyommatus bellargus, Kirby, Eur. Butterflies and Moths, p. 48, pl. i 4, fig. 7 ( I $\left.S_{79}\right)$. 
Lycana bellargus, Lang, Butterflies Eur. p. I20, pl. 26, fig. 4 (I 882 ).

Papilio adonis, Denis \& Schiffermüller, Syst. Verz. Schmett. Wien. p. I84, no. iा (I 776$)$; Hübner, Europ. Schmett. i. figs. $298-300$ ( 1803 ?).

Polyommatus adonis, Godart, Enc. Méth. ix. p. 69r, no 223 (I 823 ), Stephens, Ill. Brit. Ent. Haust. i. p. 99 ( ${ }_{2} S_{2}$ ) ; Barrett, Lepid. of Brit. Isl. i. p. 8 I, pl. I3, figs. I, I $a-f$ (г885); Buckler, Larvæ of Brit. Lepid. i. p. ıо6, pl. I5, fig. I (i 886 ).

Lycana adonis, Newman, Brit. Butterflies, p. I 29 (I88I).

Papilio hyacinthus, Lewin, Ins. Brit. i. pl. 37, figs. 4-6 (I 795). Var. Pap. ceronns, Esper, l. c i. (2) p i 78 , pl. 9o, fig 2 (1784); p. 50, pl. 102, fig. I (1791 ?) Hübner, l. c. figs. 295, 297 (1 803 ?).

Lycena bellargus, var. ceronus, Lang, l. c. p. I2 I, pl. 26, fig. 5 ( 1882 ).

Var. Pap. cinnus, Hübner, l. c. figs. $8_{30}$, $8_{31}$ ( 1827 ?).

Var. Polyommatus dorylas, Stephens, l. c. p. 83 (1828).

This species is common in many places throughout Southern and Central Europe, and the Mediterranean Region; and in the southern parts of its range it is much more widely distributed, and much more variable than in the north. It is found, frequently with $P$.corydon, chiefly on a chalk or limestone soil, and as a British insect, appears to be confined to the south of England. It is, I believe, still to be taken abundantly in certain localities close to Brighton, where five species of this group, Polyommatus corydon, P. thetis, P. icarus, P. alexis, and Zizera minima, may all be found flying together. Wherever I have been collecting on the Rhine, at the right season, I have found $P$. thetis fairly common in the flowery meadows on the banks, where $P$. corydon, when it occurs at all, is scarcer; but I never saw $P$. thetis far from the banks of the 
river. It is a double-brooded Butterfy, both in England and on the Continent, and is met with from May to September.

The Clifden Blue is a little smaller than $P$. corydon, the largest specimens rarely measuring an inch and a half across the wings. The male is of a brilliant sky-bluc above, with narrow black borders, and the fringes white, spotted with black. There is o.ten a sub-marginal row of small black dots on the hind-wings. The female is brown above, more or less blue at the base, and with a row of sub-marginal orange spots, which border the black ones on the hind-wings; the fringes are black and white, as in the male. There is a black discoidal mark on the fore-wings only. The under side is grey, with discoidal lunules, a row of spots beyond, and a marginal row of orange spots, bordered with black ones. The hind-wings have three basal spots, forming, with the central row of eyes, nearly a circle round the discoidal spot. For the differences between the female and that of P.corydon, see that species (p. 92).

In the varlety $P$ cinnus, the spots of the under side are not ocellated, and in var $P$. ceronis, the female is blue above, instead of brown. The true $P$. dorylas, of Denis and Schiffermuiller, with which Stephens confounded a variety of $P$. thetis, is a European species which does not occur in the north-west; it resembles $P$. thetis in the shade of blue in the male, but the fringes are white, and unspotted. Stephens' description of his $P$. dorylas, which is supposed to apply to a variety of $P$ thetis, is as follows: "The male is of a bright blue above, and has a slender black marginal line as in $P$. adonis, but the cilia are immaculate; beneath, the anterior wings are pale cinereous, and have a central transverse black streak on the disc, followed by a waved row of black dots faintly cinctured with whitish; there is then a delicate interrupted band of fulvous, terminated with a whitish margin; the posterior-wings resemble these of $P$. adonis, but they are 
without the black streak in the centre of the triangular discoidal spot; the ocelli are fewer in number, and the margin has a few fulvous spots, and is banded with whitish; the cilia are immaculate. The female is brown above; in other respects she resembles the male"

The larva is green, with black bristles and numerous yellow streaks. It feeds on various low plants (Lotus, Trifolium, Sc.).

III. THE COMMON BLUE. POLYOMMATUS ICARUS

$$
\text { (Plate XLV. Firss. 7, } 9 \text { J, 8q.) }
$$

Papilio icarus, Von Rottemburg, Naturforscher, vi. p. 2 I, no. 8 (I775) : Esper, Schmett. i. (1) p. 333, pl. 32, fig. 4 ( 778 ?) ; i. (2) p. I 35, pl. 79, fig. 2 (I 782 ?).

Papilio thetis, Esper, l. c. p. 332, pl. 32, fig. 2 ( I $77^{S}$ ?). Lycana icarus, Newman, Brit. Butterflies, p. I 28 (I88I); Lang, Butterflies Eur. p. I 7 7, pl. 25, fig. 4 (I882).

Polyommatus icarus, Kirby, Eur. Butterflies and Moths, p. 48 ( 1879 ).

Papilio alexis, var. 2, Scopoli, Ent. Carn. p. I 79 ( I 763 ). Papilio alexis, Denis \& Schiff. Syst. Verz. Schmett. WVien. p. I 4 $_{4}$ no. I 2 (I776); Hübner, Eur. Schmett. i. figs. 292-294 ( 1803 ?).

Polyommatus alexis, Godart, Enc. Méth. ix. p. 690, no 222 (I823); Stephens, Ill. Brit. Ent. Haust. i. p. 9I (IS27); Barrett, Lepid. of Brit. Isl. i. p. 77, pl. I I, figs. 2, $2 a-j$, (IS92); Buckler, Larvæ of Brit. Lepid. i. pp. III, I9I, pl. I 5, fig. 2 (i 886 ).

Papilio polyphemus, Esper, Schmett. i. (I), p. $3 S_{7}$, pl. 50, figs 2, 3 ( 1778 ?).

Var. Papilio icarinus, Scriba, Journ. Ent. iii. p. 2 I6 (1791); Meigen, Eur. Schmett. ii. p. 25, pl. 48 , figs. $2 a, b$ (I $S_{30}$ ). Papilio icarus, var. Esper, l. c. i. (2) p. 29, pl. 55, fig. 5 (I 780 ). Lycena alexis, Herrich-Schäffer, Schmett. Eur. i. p. I 20, fig. 246 $(18+4)$. 
Lycana icarus v. icarimus, Lang, l. c. p. II 7, pl. 25, fig. 5 ( $188_{2}$ ).

Var. Polyommatus latienus, Jermyn, Butterfly-Collector's Vade-Mecum, p. 5 S ( $S_{25}$ ).

Var. Polyonmatils thestylis, Jermyn, l.c. (IS25).

Var. Polyommatus la on, Jermyn, l.c. ( 1825$)$.

Var. Polyommatus eros, Stephens, l.c. p. 9 I (i 827 ).

Var. Polyommatus icarius, Stephens, l. c. p. 93 (I 827 ).

The Common Blue is the most widely-distributed and abundant of all the species of this group throughout Europe and Northern and Western Asia, and varies greatly. 'There are two or more broods in the year, so that it may be found throughout the fine season.

It generally expands rather less than an inch and a half, but varies very much in size. The smallest specimen which I have ever seen I took on the beach between Hove and Shoreham Harbour on July i 8, I 865. It was recorded in the "Entomologist's Monthly Magazine" (vol. ii., p. 92), and was a male in excellent condition, measuring only $\$ 1 / 2$ lines across the wings. Some years afterwards I lent it to a friend who wished to draw it; but on pressing him for its retum, he informed me that he had put the box aside and forgotten it, and on opening it, found that the specimen had been destroyed by mites.

The male is of a lilac-blue, with a narrow black border, and white unspotted fringes. The hairs on the body and at the base of the wings are likewise whitish. The female is brown, more or less blue at the base (sometimes, however, the surface is entirely purplish-blue), and ornamented with a row of fulvous marginll spots, those on the hind-wings bordered below with a row of black spots. On the under side the wings are of a brownish-ash colour, with the base more or less 
bluish or greenish, the fore-wings usually having (wo ocelli towards the base (which are absent in the variety $P$. icarinus) within the discoidal lunule, and a curved row of ocelli near the middle, succeeded by a continuous row of dusky crescents, edged with reddish-yellow externally, and beyond this there is a row of small dusky spots on a whitish ground; a black line at the base of the fringes. The hind-wings have generally four ocelli near the base; an angular white spot near the middle, frequently having a black streak in its centre; a curved band of eight or nine ocelli, succeeded by a series of markings similar to those on the fore-wings, but the crescents and fulvous spots are larger and more conspicuous. A white blotch near the middle unites the band of ocelli with the fulvous crescents.

This species is so variable, not only in colour and markings, but even in the form of the wings, that the older entomologists described several forms as new species, which are now considered to be merely varieties of P. icarus; and others they mistook for different Continental species which do not occur in England. Thus, Stephens mistook a viriety of $P$. icarus for $P$. tithoms (Hübner $=P$. eros, Ochsenheimer), a pale blue species with broad brown borders, found in the Swiss Alps, and almost impossible to be found in Britain. Specimens of $P$. icarus are sometimes met with, in which the colouring of both sexes are combined, the wings on one side exhibiting the colours of the male, and on the other those of the female. These are called gynandromorphous individuals. Variable as this species is, it can yet be easily distinguished, in most cases, from any of the allied British species.

The larva is green, pubescent, with a darker dorsal stripe, and with lighter stripes on the sides; the pupa is also green. The larva feeds on a variety of low plants. 



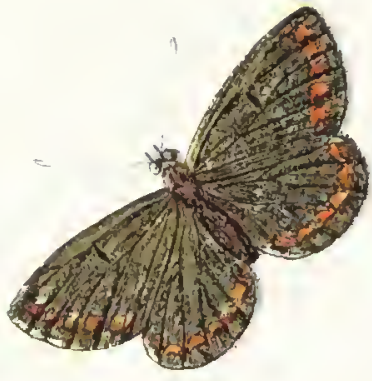

J.

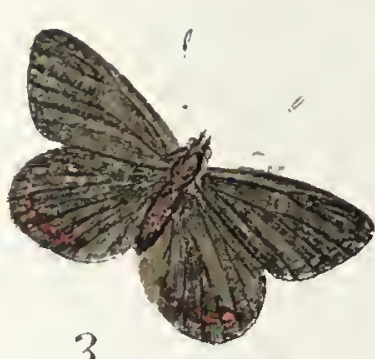

.3
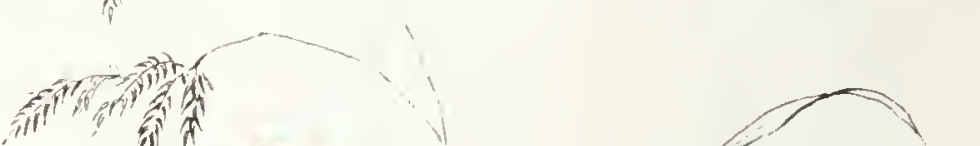

4.

7.

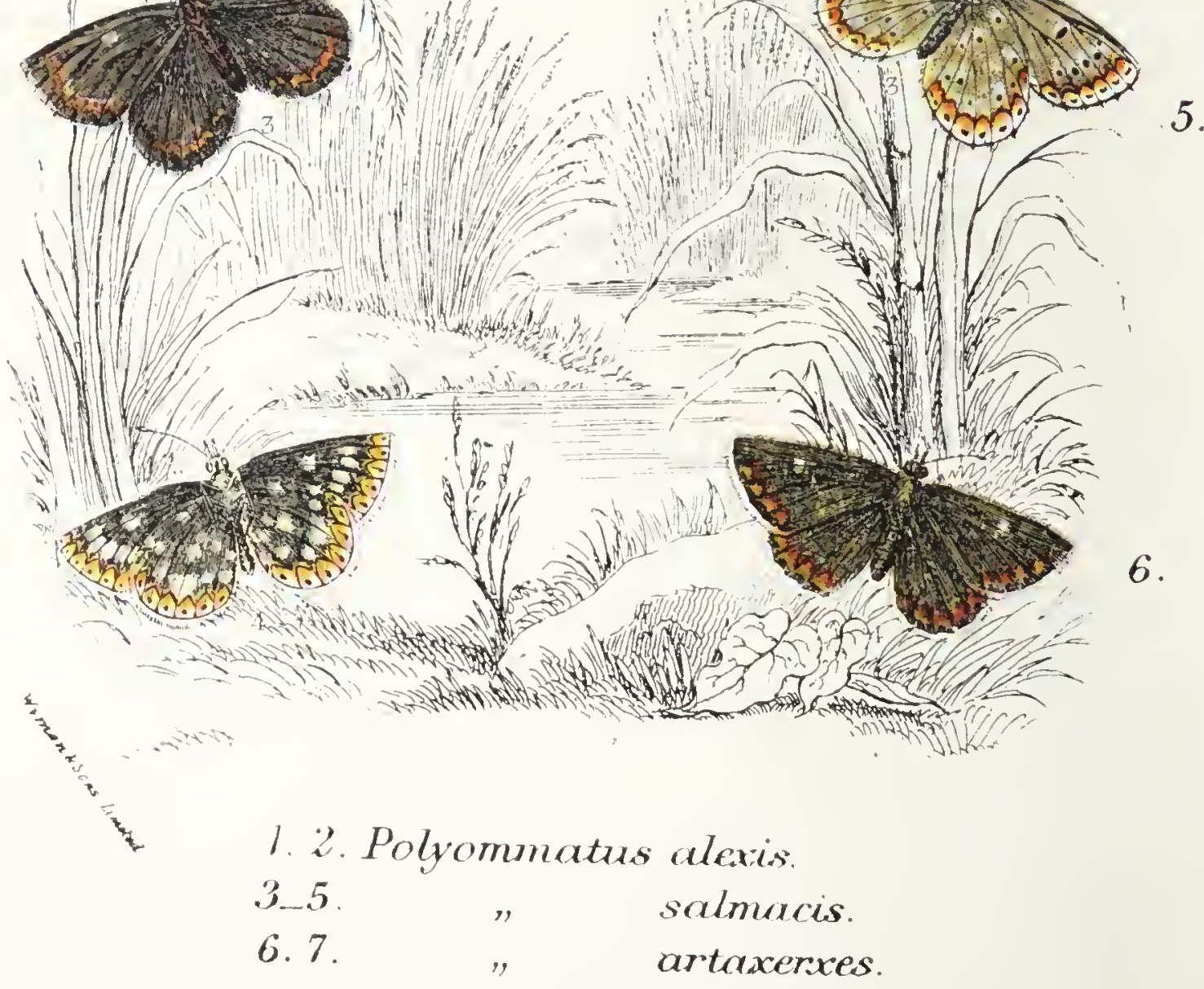


IV. THE BROWN ARGUS. POLYOMMATUS ALEXIS.

(Plate XLVIII. Figs. I, 2.)

Papilio alexis, Scopoli, Ent. Carn. p. I 79 (1763); Von Rottemburg, Naturforscher, vi. p. 22, no. 9 (1776). Papilio medon, Hufnagel, Berl. Mag. ii. p. 7S, no. 4I (I786); Von Rottemburg, l.c. no. Io (1776); Esper, Sc'mett. i. (I) p. 330, pl. 32, fig. I (r779); i. (2) p. 29, pl. 55, fig. 7 ( 780$)$.

Lycana medon, Newman, Brit. Butterflies, p. I 2 I (I88 I). Fapilio ageslis, Denis \& Schiffermüller, Syst. Verz. Schmett. IVien, p. I 84, no. 1 3 ( 1776 ); Hübner, Eur. Schmett. i. figs. 303-306 (1803?).

Polyommatus agestis, Godart, Enc. Méth. ix. p. 689, no. 220 (1823); Stephens, Ill. Brit. Ent. Haust. i. p. 94 (1827) ; Barrett, I epid. Brit. Isl. i. p. 73, pl. 10, figs. 3, 3a, b (1892); Buckler, Larva of Brit. Lepid. i. p. I r 6, pl, I6, fig. I ( I 886).

Papilio astrarche, Bergsträsser, Nomenclator, iii. p. 4, pl. 49, figs. 7, 8 ( і 779 ).

Polyommatus astrarche, Kirby, Eur. Butterflies and Moths, p. 50, pl. I4, fig. 9 (I879).

Lycana asıarche, Lang, Butternies Eur. p. I I 4, pl. 24, fig. 9 ( I 882).

Var. Lyccena astrurike, v. cestiva, Staud. Cat. 1.cpid. Eur. ed. 2 , p. I I, no. I 556 ( 187 I ).

Var. I'apilio allius, Hübner, l. c. figs. 988-992 (I84 I ?).

The Brown Argus is common throughout the greater part of Europe, the Mediterranean Region, and Northern and Western Asia. The largest and brightest-coloured specimens come from the Mediterranean Region, where the two broods present constant differences in many localities. It is a local insect in the south of England, where it is double-brooded, 
occurring in May and Nugust, like the allied "Blues," and it is fond of chalky districts, though less exclusively confined to them than are $P$. corydon and $P$. thetis. The Northern and Scotch forms are noticed under separate headings. The variety $P$. allows was figured from a specimen in which the usual red sub-marginal spots were wanting.

The Brown Argus measures an inch or a little more across the fore-wings, which are dark brown on the upper side in both sexes, with a fine silky gloss, and white fringes. There is a sub-marginal row of deep red spots on all the wings, and a black discoidal spot on the fore-wings. The under side is greyishbrown, with no bluish tinge towards the base, and no basal spots on the fore-wings, but three are present on the hind-wings. There are discoidal spots, a central row of spots beyond (all conspicuously ringed with white), and the sub-marginal reddish spots connected into a band, edged within by a black line of crescents. Beyond this the wing is white, with a row of black dots outside the reddish band, and a black line at the base of the fringes; a white dash runs from the middle of the hindwings to the reddish band.

The larva is green, with white hairs, a dark dorsal line, and a pink line over the spiracles. It feeds on Helianthemum vulgare and Ero.7ium cicutarium. The green pink-striped pupa is generally found on the ground amongst leaves.

V. THE DURHAM ARGUS. POLYOMMATUS SALMACIS.

$$
\text { (Plate XLVIII. Fig. } 3 \delta^{\pi}, 4,5 \text { \%.) }
$$

Polyommatus salmacis, Stephens, Ill. Brit. Ent. Haust. iii. p. 235, note (I $83 \mathrm{r}$ ); Westwood \& Humphreys, Brit. Butterflies, p. I I 5 , pl. 37 , figs. I-3 (I $\left.S_{4} \mathrm{I}\right)$.

Polyommatus agestis, var. salmacis, Barrett, Lepid. of Brit. Isl. i. p. 74, pl. ro, figs. $3 s^{\circ}-3^{\circ}(1892)$.

This is the usual form of Polyommatus alexis found in the 
north of England, where it was first met "ith at Castle Eden Dene, and subsequently in considerable numbers, on the magnesian limestone district near Newcastle, in July; it has also been found in Yorkshire and Cumberland.

This insect differs from the typical $P$. alexis in the orange spots of the upper side being more or less obsolete, especially in the male, and in the black discoidal spot being edged with white. The black spors on the under side are smaller than in $P$. alexis. Stephens' original description is as follows :-

"Alis fusco-nigris, subtus fuscescentibus maculis subocellatis, anticis supra in masculis puncto discoiclali atro, in fominis albo, posticis utrinque fasciâ submarginali rubrâ. (Exp. alar. o I unc. I lin.; $q$ I unc. 2 lin.)"

Duncan's more detailed description may also be quoted :"Silky brown above, with a macular posterior band of orange-red on all the wings, somewhat obsolete in the male, and a white spot on the disk of the primary wings, which, however, is occasionally wanting in both sexes, but especially in the female. The fringe is white, slightly variegated with brown at the base. The colour of the under side is greyish-brown, the anterior wings with a discoidal white spot; beyond this is a curved band of similar spots, with a minute dusky pupil, succeeded by a band of orange spots, bounded on both sides by a dusky crescent, surmounted with white, the outer margin defined by a dusky line; the hinder wings have a similar marginal band, several scattered white spots towards the base, a larger one near the centre, and a very irregular row behind the middle, with a broad white central patch connecting it with the yellow band. Most of these spots have a minute dusky pupil in the male, but greatly more conspicuous in the female."

'This and the following form appear to be only singlebrooded. A complete series of transitions has now been 
traced from $P$. alexis through $P$. salmacis to $P$. arlaxerxes; and there are no constant differences of larvæ and food-plants which were at one time expected to separate the extreme forms.

VI. THE AR'TAXERXES BUTTERFLY. POLYOMMATUS ARTAXERXES.

$$
\text { (Plate XLVIII. Figrs. 6, 7.) }
$$

Ilesperia arlaxerxes, Fabricius, Entomologia Systematica, iii. (I) p. 297 , no. т 29 ( $\left.178_{3}\right)$; Hübner, Eur. Schmett. i. figs. 95 I-954 (I 84 I ?).

Polyommatus ariaxerxes, Godart, Enc. Méth. ix. p. 68s, no. 2 I 9 (I823); Stephens, Ill. Brit. Ent. Haust. i. p. 95 ( 1827 ).

Polyommatus agestis, var. artaxerxes, Barrett, Lepid. Brit. Isl. i. p. 74, pl. iо, figs. 3c-3f (1892); Buckler, Larvæ of Brit. Lepid. i. p. I 2 I, pl. 16, fig. I (I886).

Lycent astrarche, var. artaxerxes, Lang, Butterflies Eur. p. I I $5, \mathrm{pl} .24, \mathrm{fig}$. Io ( I 882$)$.

The present insect was always considered to be a perfectly distinct species till recently, when its identity with $P$. alexis and $P$. salmacis has been fully established by careful and repeated breeding experiments. The true $P$. ariaxerues is locally abundant in many parts of Scotland, and is singlebrooded, occurring in July and August. For many years, Arthur's Seat, at Edinburgh, was the only known locality, and some entomologists even undertook a journey to Edinburgh (a most formidable undertaking a century ago) in order to obtain specimens, while others had a drawing made of the insect, and placed it in a corner of their cabinets, to do duty for the original. In fact, the description of the Butterfly was taken by Fabricius, as in the case of su many other species, from the collection of drawings made by Jones of Chelsea. 
As in the other forms of the insect, $P$. artaxerxes is a brown Butterfly with white fringes, and a sub-marginal band of red spots, more or less obsolete in the male. There is a conspicuous white discoidal spot on the fore-wings. On the under side, which is light brownish-grey, the discoidal spots, the outer band of spots, and the basal spots on the hind-wings, are all conspicuously white, without any black centres; the sub-marginal band being more orange, paler, and ec'ged outside with a row of black dots; beyond, the wings are whitish, with a brown line at the base of the fringes.

'There are one or two Alpine Butterflies with large white spots on the underside of the wings-Agriades orbitulus (De Prunner) and $A$. atys (Hubner)-but they are allied to, if not congeneric with, Nomiades semiargus (Von Rottemburg).

GENUS CYANIRIS.

Cyaniris, Dalman. K. Vet. Acad. Handl. Stockholm, xxxiii. pp. 63, 94 (I \& 16) ; Scudder, Syst. Rev. Amer. Butterflies, p. 34 (1872); Moore, Lepid. Ceylon, i. p. 74 (I88 I).

Species of this genus are found in almost all parts of the world, except South America and Australia. Many are very closely allied, and the greater number are of a rather pale blue in both sexes, with broad dark borders in the female. The under surface is usually bluish-white with numerous black spots, and rarely with any traces of a sub-marginal orange band. The type is

THE AZURE BLUE. CYANIRIS ARGIOLUS.

(Plate YLIL. Figrs. I, 3 ơ Fig. 2 q.)

Papilio argiolus, Linn. Syst. Nat. (ed. x.) i. p. $48_{3}$, no. I 53 (1758) ; id. Faun. Suec. p. 284 ( 1761 ) ; Herbst, Naturs. Schmett. xi. pl. 3io, figs. 4-6 (I 804 ).

Papitio cleobis, Sulzer, Gesch. Ins. pl. I 8 , figs. r 3, I 4 (I776); Esper, Schmett. i. (I) p. 360, pl. 40, fig. 3 (г778 ?) ; i. (2) D. 27, pl. 54 , figs. $4 a, 6$ (I 780 ). 
Pafpilio acis, Fabricius, Mantissa Ins. ii. p. 73, no. 687 (1787); Hübner, Eur. Schmett. i. figs. 272-27+ (1803).

Polyommatus argiolus, Godart, Enc. Méth. ix. p. 678, no. 190 (I823); Stephens, Ill. Brit. Ent. Haust. i. p. 85 (I827); Kirby, Eur. Butterflies and Moths, p. 46, pl. I 4 , figs. $4 a, b$ (1879); Barrett, Lepid. of Brit. Isl. i. p. 88, pl. I3, figs. 2, 2a-e (1892); Buckler, Larvæ of Brit. Lepid. i. pp. 94, I 88 , pl. I 4, fig. I (i 886 ).

Lycana argiolus, Newman, Brit. Butterflies, p. I35 (I88I); Lang, Butterflies Eur. p. I27, pl. 31, fig. I (I882).

The Azure Blue Butterfly is common in many parts of England and Ireland, frequenting woods and thickets, where its food-plants grow, in early spring, and again in summer and autumn. It is also common throughout Europe, North Africa, and Northern and $W^{\top}$ estern Asia, as far as the frontiers of India; and closely-allied species are found in North America. It varies coniderably in size, expanding from rather less than an inch to nearly an inch and a half across the wings. It is the earliest to appear of all the Blues, sometimes being seen in April ; and it is still met with in various localities quite close to London.

The fore-wings are of a light blue, somewhat inclining to lilac above, with white fringes, slightly interrupted by the black ner vures, and a black border, narrow in the male, but broad in the female on the fore-wings; on the hind-wings it is narrow. The under side is of a pale blue, with black discoidal lunules, and an outcr row of black spots, not ocellated; towards the base of the hind-wings are several more spots. There are no distinct sub-marginal spots.

The larva, which feeds on the flowers of holly, buck-thorn, and ivy, is pubescent, of a greenish-yellow colour, deepest on the back; the head and legs are black; the pupa is yellowishbrown. 


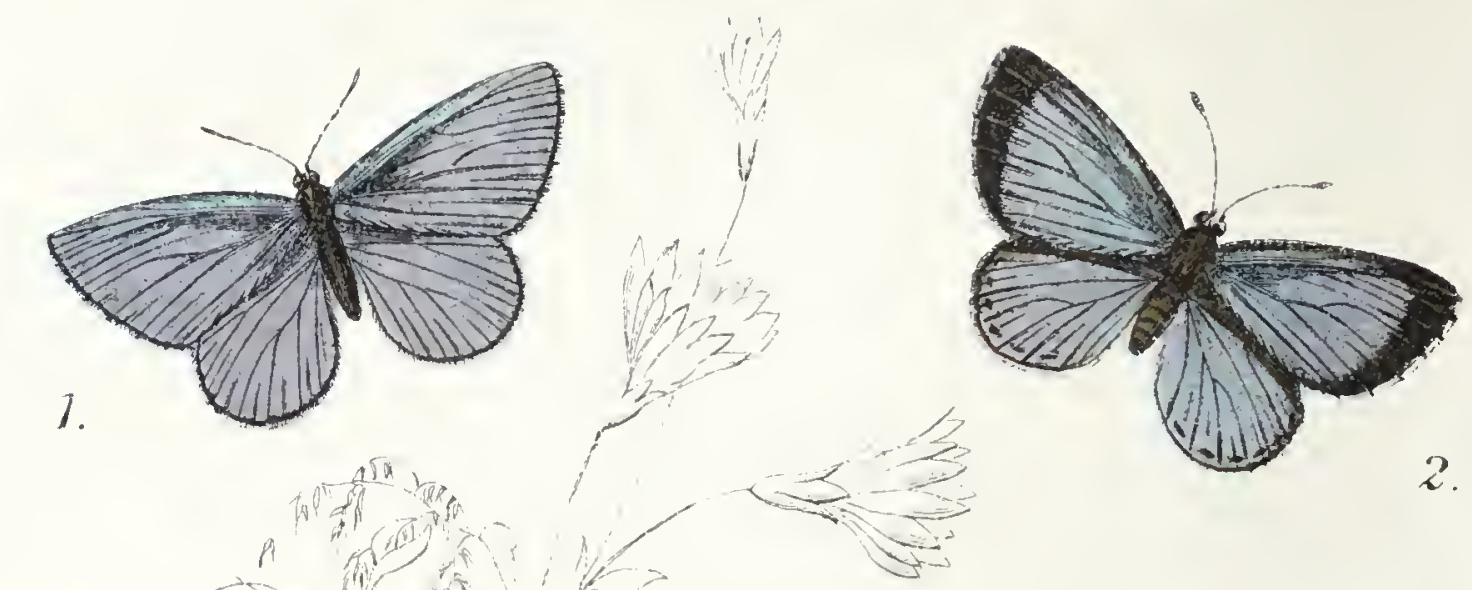

5.

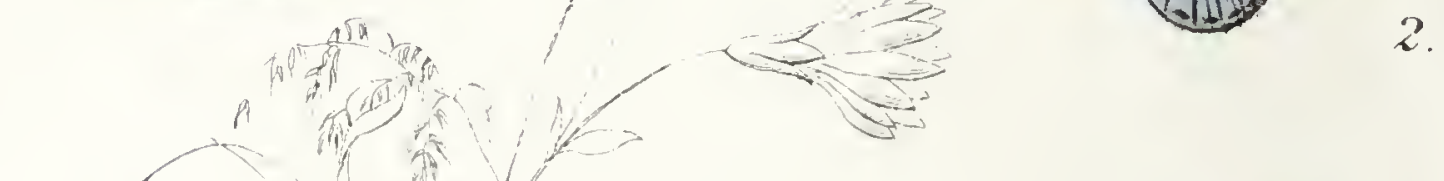

3.

5.

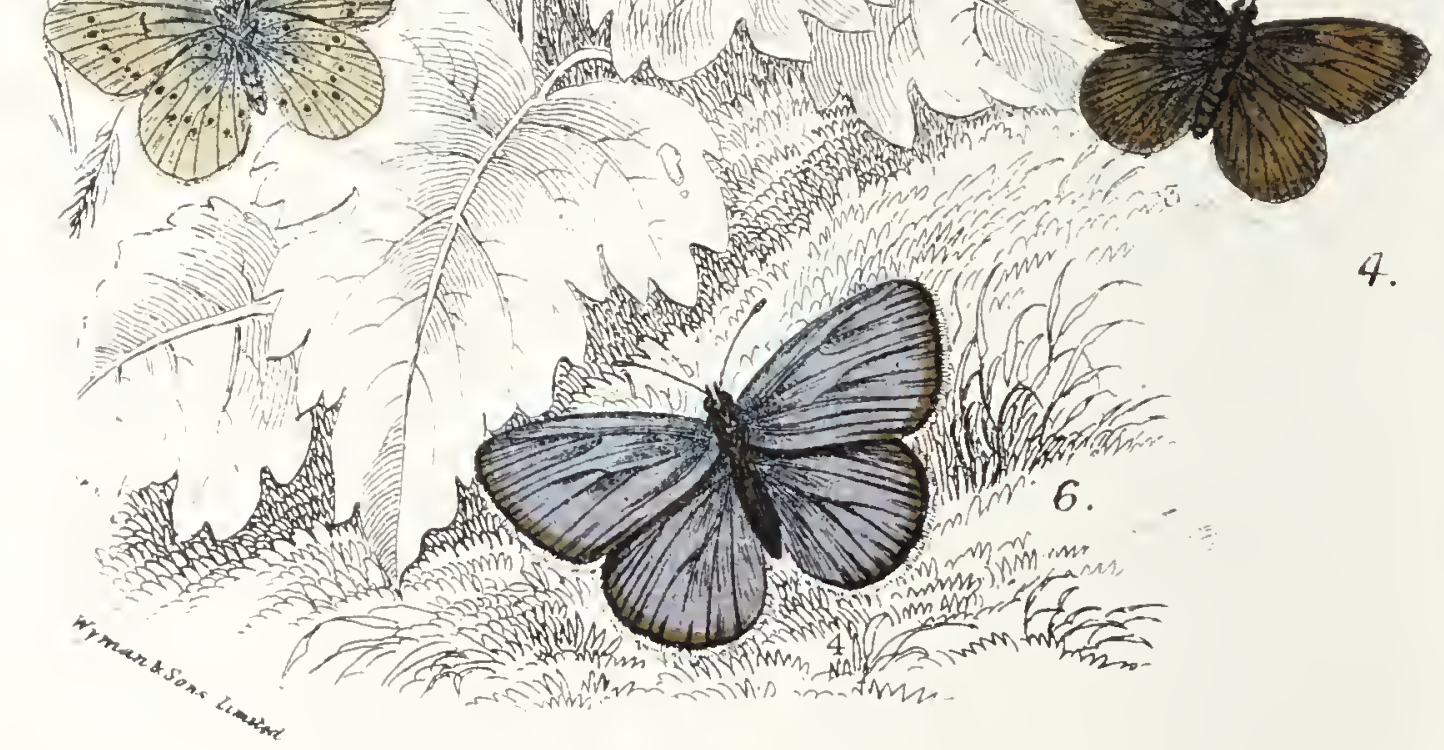

1.3. Cyaniris argiolus.

4. 5. Zizera minima.

6. 7. Nomiades semiargus. 
GENUS ZIZERA.

Zizera, Moore, Lepid. Ceylon, i. p. 78 (ISSI).

This genus includes very small Butterflies, with no submarginal markings beneath, and no basal spots on the fore wings.

I. THE BEDFORD BLUE. ZIZERA MINIMA.

$$
\text { (Plate XLIX. Figrs. 4, 5.) }
$$

Papilio minima, Fuessly, Verz. Schweitz. Ins. p. 3 ז, no. 599 ( 775 ) ; Esper, Schmett. i. (x) p. 338, pl. 34, fig. 3 ( 1778 ?).

Papilio alsus, Denis \& Schiff. Syst. Verz. Schmett. Wien, p. I 84 , no. $9($ I 776$)$; Hübner, Eur. Schmett. i. figs. 278,279 ( 1803 ?).

Cupido puer, q Schrank, Fauna Boica, ii. (1) p. 2I5, no. 1374 ( I SO I).

Polyommatus alsus, Godart, Enc. Méth. ix. p. 704, no. 246 $(\mathrm{I} \delta 23)$; Steph. Ill. Brit. Ent. Haust. i. p. $\delta 6$ (I $\delta 2 \delta)$; Barrett, Lepid. of Brit. Isl. i. p. 92, pl. I 4, figs. I $a-\mathrm{I} c$ (I $S_{92}$ ).

Polyommatus mir.m r, Kirby, Eur. Butterflies and Moths, p. 46, pl. I 4, fig. 3 (is79).

Lycrena alsus, Newm. Brit. Butterflies, p. I34 (i88r). Lycana minima, Lang, Butterflies Eur. p. I28 (is82).

The Bedford Blue is the smallest of our British Blues, expanding from two-thirds of an inch to an inch across the wings, which ale brown above, with white fringes, and have a faint bluish tint in the male. On the under surface they are pearly-grey, slightly bluish or greenish at the base, with discoidal spots, and a row of black eyes in white rings beyond; on the hind-wings there are several additional spots towards the base. It is double-brooded, and is met with from May to August. 
'The larva is green, with orange and yellow lines, and feeds on Antlyllis vulneraria, and other vetches. The pupa is pale grey, with black dots and dashes; it is found on the ground, unattached, according to some writers, but others say that it is attached by a belt to a stalk of the food-plant.

The Butterfly is common throughout Europe and Northern and Western Asia, but is very local in Britain, preferring a chalk or limestone soil. 'In Switzerland it is frequently found in company with Cupido argiades, which led Schrank to regard it as the true female of that species.

\section{GENUS NOMIADES.}

Nomiades, Hübner, Verz. bek. Schmett. p. 67 (I8I6).

This name may be provisionally applied to a number of species of moderate or large size, which are generally blue above in the males, and brown in the females. The under surface of the wings is marked with discoidal spots, at least on the fore-wings, and at least one row of spots beyond, generally largest on the fore-wings. There are no marginal markings, or at least no red or orange ones, and not always discoidal lunules, or basal spots on the hind-wings. Dr. Scudder has indicated the type as $N$. semiargus; but this species and its allies will probably be separated ultimately from the group represented by $N$. arion. The British species of this group are on the verge of extinction in England.

TIIE MAZARINE BLUE. NOMIADES SENIARGUS.

$$
\text { (Plate XLIX. Figs 6, 7.) }
$$

Papilio semiargus, Von Rottemburg, Naturforscher, vi. p. 20, fig. 6 (I775); Herbst, Naturs. Schmett. xi. p. I 77 (I804). Papilio argiolus, Esper, Schmett. i. (I) p. 277 , pl. 2 I, figs. I, $a, b($ I $77 S)$; Hübner, Eur. Schmett. i. figs. 269-27 I ( $\left.1 \mathrm{SO}_{3}\right)$. 
Pafilio acis, Denis \& Schiffermüller, Syst. Verz. Schmett. Wien, p. I 82 , no. 5 (1776); Herbst, l. c. pl. 310, figs. $\mathrm{I} a-c\left(\mathrm{I} \mathrm{SO}_{4}\right)$.

Polyommatus acis, Godxrt, Enc. Méth. ix. p. 703, no. 245 (1823); Steph. Ill. Brit. Ent. Haust. i. p. 86 (1828); Barrett, Lepid. Brit. Isl. i. p. 94, pl. I4, figs. 2, $2 a, b$ (IS8I).

Polyommatus semiargus. Kirby, Eur. Butterflies and Moths, p. 46 ( 1 8 ; 9 ).

Lycrena semiurgus, Lang, Butterflies Eur. p. I 29, pl. 31, fig. 5 (I 882 ).

Lycena acis, Newm. Brit. Butterflies, p. I33 (I881).

The Mazarine Blue Butterfly is common throughout the greater part of Europe and Northern Asia, but has always been a scarce and local insect in England Sixty or seventy years ago, however, it used to be taken in most of the counties of England and Wales, though only occasionally common in very restricted localities. Since that time it has gradually disappeared from its former haunts, and for many years past only single specimens have been taken casually at long intervals. Latterly even such captures have become very rare, and the insect is supposed to be now almost, if not quite, extinct as a British species. It frequents dry meadows in June and July, being single-brooded, and used to show a certain preference for chalky localities, though by no means confined to them. I have taken it in Germany among Polyominatus icarus, but seldom commonly; and I could hardly tell the insects apart, except in the net, or from a view of the under side. I am therefore of opinion that collectors who would take the trouble to net any blues they may notice, especially in out-ofthe-way parts of the country, may possibly meet with an occasional specimen of this species. This advice has, I know, been given before, and, doubtless, largely acted on without 
success; but still I do not regard it as by any means hope. less.

The Mazarine Blue expands about an inch and a quarter across the wings. The male is dark purplish-blue, with a moderately broad blackish border, and white fringes; the female is brown. The under side is of a dull ash-colour, greenish at the base, with discoidal lunules (very narrow on the hind-wings), and a single row of rather small black cyes in white rings beyond.

The larva is covered with fine yellowish-green hair; the dorsal and lateral streaks darker. The head, feet, and stigmata are dark brown. It feeds on Anthyllis vulneraria from July to September.

$N$. cyllarus (Von Rottemburg) is an extremely pretty species allied to $N$. semiargus, and it is not uncommon on the Continent, but is absent in the North-west. The male is of a bright blue above; and on the under side the eyes on the fore-wings are much larger than those on the hind-wings, and the under side of the hind-wings is of a beautiful green, from the base to beyond the middle.

\section{THE LARGE BLUE. NOMIADES ARION.}

\section{(Plate XLVII. Figs. I, 2.)}

I'apilio arion, Limn. Syst. Nat. (ed. x.) p. 483, no. I $_{5}$ I (1758), id. Faun. Suec. p. 283 (I761); Esper, Schmett. i. p. 266, pl. 20, fig. 2 (I 777); i. (2) p. 53, pl. 59, fig. 2 (I 7 So); Hübner, Eur. Schmett. i. figs. 254-256 (r So3 ?).

Polyommatus arion, Godart, Enc. Méth. ix. p. 69\$, no. 235 (1823) ; Stephens, 11l. Brit. Ent. Haust. i. p. S7 (1 $82 S$ ); Kirby, Eur. Butterflies and Moths, p. 45 (is79); Barrett, Lepid. Brit. Isl. i. p. 96, pl. s 4, figs. 3, $3^{a-c}$ (rSga); Bucliter, Larva of Brit. Lepid. i. pp. 185, ISS ( I SS6). 
Lycrena arion, Newman, Brit. Butterflies, p. I 36 ( ISS I) ; Lang, Butterflies Eur. p. I 33, pl. 32, fig. 5 (isS2).

Var. Polyommatus alcon, Stephens, l.c. p. 88 (1828).

The Large Blue is common throughout a great part of Europe and Northern and Western Asit, and on the Continent is frequently found in company with three or four other closely-allied species which do not occur in England. One of these, $N$. arcas (Von Rottemburg), is a very dark-coloured species. Like $N$. semiargus, it was always very local in England and Wales, the principal locality for many years having been Barnwell Wold in Northamptonshire, where it is said to have been finally exterminated by a dealer. As, however, it is fond of waste ground, the advance of cultivation has been its real enemy; for it appears to have been taken occasionally in most counties in the southern half of England. But for many years it has been rapidly disappearing, and is apparently on the verge of extinction as a British species, though it still lingers on in certain restricted localities in Devonshire and Cornwall.

The Large Blue measures an inch and a half, or rather more, across the wings, which are of a purplish-blue, with rather broad black hind-margins, and the costa of the hind-wings black. The fore-wings have a black discoidal lunule, beyond which is a row of rather large black spots. The fringes are white above, but spotted with brown on the nervures beneath. The hind-wings have a sub-marginal row of black spots, and in some varieties of the female are spotted almost as in the fore-wings. The under side is greyish-brown, greenish towards the base, with discoidal lunules, and a central row of black eyes beyond, ringed with white, one or two more or less distinct rows of sub-marginal spots, and some additional eyes towards the base of the hindwings. The Butterfly appears in July, and is fond of settling on the blossoms of wild thyme, on which the larva, which is imperfectly known, feeds. 
The Butterlly called Polyommatus alcon by stephens is considered to be cnly a variety of $N$ arion, and not the Continental species described below. The specimen, which is stated to have been taken in Buckinghamshire, is said to have been nearly iminaculate above, and to have measured an inch and a half across the wings. "Beneath brownish-ash, the anterior [wings] with ocellated black dots as in the preceding, and a series towards the hinder-margin, which has not the lunulated spots as in $P$. arion; the posterior wings also bear ocelli, as in the lastnamed insect, and a series behind, but the hinder margin is nearly immaculate. The female is nearly all brown above, with some obsolete dots, but resembles the male beneath."

THE ALCON RLUE. NOMIADES ALCON.

(Plate XIVII. Figs. 3, 4.)

Papilio alcon, Denis \& Schiffermüller, Syst. Verz. Schmett. Wien, p. I 82 , no. $4\left(\mathbf{I}_{776}\right)$; Fabr. Mant. Ins. ii. p. 72 , no. $68_{3}$ ( 1787$)$; Hübner, Europ. Schmett. i. figs. $26_{3}-$ 265 ( 1 803 ?).

Papilio arcas, Esper (nec. Von Rottemburg), Schmett. i. (I) p. 338 , pl. 34, figs. 4, 5 ( 778 ?).

Polyommatus alcon, Godart, Enc. Méth. ix. p. 699, no. 236 (1823); Duncan, Brit. Butterflies, p. 234, pl. 32, fig. 2 (1835); Kirby, Eur. Butterflies and Moths, p. 45 (i879). Lycena alcon, Lang, Eur. Butterflies, p. I32, pl. 32, fig. 3 (1882).

As we have mentioned above, the present species was included in the British lists on the strength of a specimen which was suspected, even at the time it was described as $N$. alcon, to be only a variety of $N$. arion. It is a rather scarce and local species on the Continent, and I have occasionally taken it on heaths in Northern Germany, where no other species of the group of $N$. arion were to be met with. 
$N$. alcon masircs rather less than an inch and a half in expanse. The male is purplish-blue, with a moderately broad black borler on the hind-margins, and a discoidal spot on the fore-ivings. The female is blue, with the costa and hind-margin of all the wings very broadly brown; the fore-wings have a discoidal lunule, and an obscure curved row of black spots. The under side is brownish-ashy, with discoidal spots, an outer row of eyes, and some basal spots on the hind-wings. There is also a sub-marginal row of eyes; all the eyes being rather small, and uniform in size. The hind-wings are slightly bluish towards the base. The transformations are unknown.

Having now completed the survey of the British "Blues," I will add a short notice of some of the more important European and exotic genera which are still frequently grouped with them under the magazine genus Polyommatus, or Lycana.

\section{GENUS SCOLITANTIDES.}

Scolitantides, Hübner, Verz. bek. Schmett. p. 68 (r\& i6).

This little group is considered by 1)r. Scudder to be congeneric with Plebeius; but the wings are rather longer and less acute, and there are no metallic spots in the sub-marginal markings of the hind-wings beneath. It includes a few European and East Indian species.

SCOLITANTIDES ORION.

Papilio orion, Pallas, Reise, i. p. 47 I (I 77 I).

Papilio telephii, Esper, Schmett. i. (I) p. 363, pl. 4I, fig. 2 (1 778 ?) ; i. (2) p. 6, pl. 94, fig. (1790).

Papilio bathis, Hübner, Eur. Schmett. i. figs. 328-330 (1803 ?); figs. 801,802 (I 827 ?).

Polyommatus orion, Kirby, Eur. Butterflies and Moths, p. 5 I ( I 879$)$. 
Lycona orion, Lang, Butterflies Eur. p. ioS, pl. 24, fig. i ( ( $\$ S 2$ ). l'olyommatus telephii, Godart, Enc. Méth. ix. p. 6S6, no. 2 I 5 ( 1823$)$.

This is a widely distributed, but local species, inhabiting many parts of Europe and Northern and Western Asia, and frequenting rocky places in May and June. It is dark brown above, with the fringes spotted with white, and the base of the wings purplish-blue in the male, most broadly on the forewings. There is a large black discoidal lunule on the forewings. The hind-margins of the fore-wings are marked with rows of more or less distinct bluish-white spots, and the hindwings are marked with indistinct black spots in bluish-white rings. The under side is bluish-white, with large and conspicuous black spots, consisting of basal spots on both fore-and hind-wings, discoidal lunules, a row of spots bzyond, and a double row of sub-marginal spots, separated on the hind-wings by a broad orange band.

The larva is sea-green, with a violet dorsal line, and feeds on Telephium.

\section{GENUS CASTALIUS.}

Castalius, Hübner, Verz. bek. Schmett. p. 70 (ISI6); Moore, Lepid. Ceylon, i. p. 82 (ISSI) ; Distant, Rhop. Malayana, p. $2 \mathrm{I}_{4}\left(\mathrm{ISS}_{4}\right)$.

This genus includes a number of rather small East Indian and African Butterflies of a white colour, slightly tinted with blue, and with blackish borders, and black spots and bands on the under side. The hind-wings are provided with a short and slender tail. The type is

\section{CASTALIUS ROSIMON.}

Papitio rosimon, Fabricius, Syst. Ent. p. 523, no. 34I (I775). Papilio clyton, Cramer, Pap. Exot. i. pl. 67, figs. F-G (I 775 ). 
Papilio coridon, Cramer, l. c. iv. pl. 340, figs. C-F ( $\left.\mathrm{I}_{7} S_{\mathrm{I}}\right)$. Polyommatus rosimon, Godart, Enc. Méth. ix. p. 658 , no. I4I (1823).

Castalius rosimon, Moore, Lepid. Ceylon, i. p. 83 , pl. 36, fig. 2 (IS8I); Distant, Rhop. Malayana, p. 215, pl. 22, fig. $20(\mathrm{I} S 84)$.

This Butterfly is common in India and the adjacent islands; it measures about an inch and a half across the wings, which are white, tinged with pale blue at the base, and with blackish borders, broader in the female than in the male, which are spotted with white on the hind-wings. There are large black lunules at the end of the cell, and some large black spots and markings, partly connected with the border. The under side is white with some heavy black stripes and spots towards the base, and three rows of black sub-marginal spots. It flies near the ground, and frequently settles among grass and low plants.

The genera Pepliphorus and Thysonotis, Hübner, include a number of beautiful and closely-allied species, found throughout the Austro-Malayan Region; they are extremely numerous in New Guinea and the adjacent islands. These species measure about an inch and a half across the wings, which are of a light blue in the males, and brown in the females, usually with a white band, broadest at the inner margin of the hind-wings, and diminishing towards the costa of the fore-wings; on the under surface the borders of the wings are broadly black. In the species of Pepliphorus, the type of which is Papilio cyanea, Cramer, there is a marginal row of eyes on the under side of the hind-wings. In Thysonotis (type, Papilio danis, Cramer), the black borders of the under side are transversed by broad stripes of metallic green or blue. 
GENUS PITHECOPS.

Pithecops, Horsfield, Cat Lepid. Mus. E. I. C. p. 66 (1828); Schatz \& Röber, Exot. Schmett. ii. p. 272 (1 892 ).

The type of this genus, P. hylax (Fabricius), is a small Butterfly from Java, with moderately long, rounded wings, hardly expanding more than three-quarters of an inch. It is dark brown above, and whitish below, with no basal or discoidal markings, but with a large blackish spot just before the extremity of the costa. There are some small sub-marginal black dashes, and within them, on the hind-wings, is a yellowish line. The first sub-costal nervule anastomoses with the costal nervure, which distinguishes this genus from the very similar Neopithecops (the types of which are found in Ceylon and Singapore), in wh:ch the sub-costal and costal nervures are distinctly separated.

\section{GENUS LYCANESTHES.}

Lycanesthes, Moore, Proc. Zool. Soc. Lond. I 865, p. 773 ; id. Lepid. Ceylon, i. p. 87 (ISSI) ; Distant, Rhop. Malay. p. 232 (1884); Hewitson, Trans. Ent. Soc. Lond. I 874, p. 343 ; Schatz \& Röber, Exot. Schmett. ii. p. 274 (I892).

The type of this genus is L. bengalensis, Moore, a Butterfly which is common throughout India and the Indo-Malayan region. It measures about an inch and a half across the wings, which are dark purplish-blue above in the male, and purplish-brown, with a bluish patch at the base, in the female; towards the anal angle is a small black spot. The under side is pale greyish-brown, with irregular white lines partly enclosing darker spaces, and a small orange spot with a black pupil towards the anal angle of the hind-wings.

A great number of East Indian and African Butterflies, resembling small species of Thecla, Plebeius, \&c., have been, rightly or wrongly, referred to this genus. Most of them are 
. 


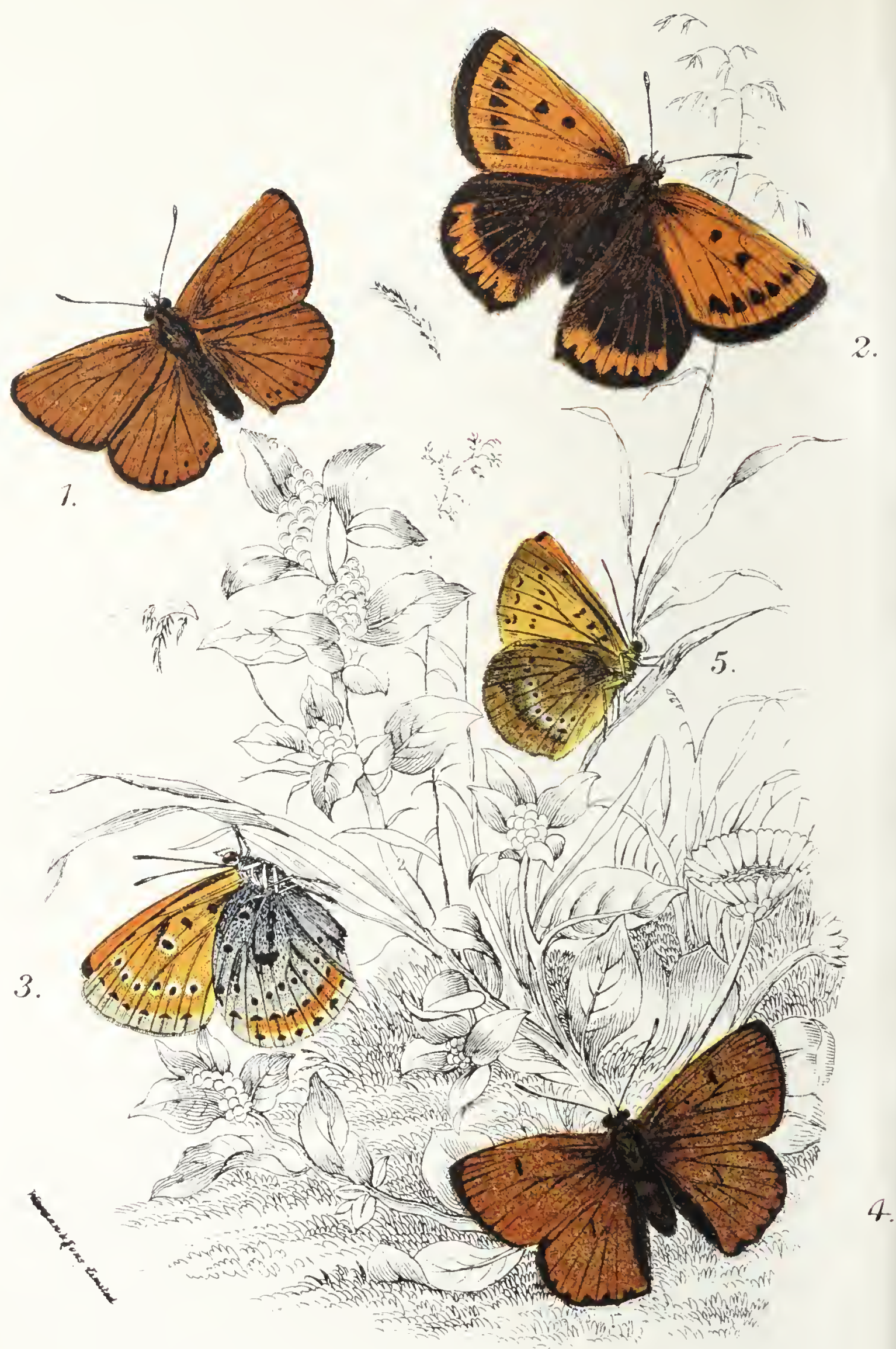

1.3. Lycana dispar.

4. 5. " virgaurea. 
remat'xable for possessing two, or more often three, small projecting tufts of scales on the hind-margin of the hind-wings.

\section{GENUS LYCAENA.}

Lyccia, Fabricius in Illiger, Mag. Insekt. vi. p. 2S5 (1807); Leach, Edinb. Encycl. ix. p. I 29 (IS I 5); Curtis, Brit. Lnt. i. pl. I 2 (1824) ; Stephens, Ill. Brit. Ent. Haust. i. p. 79 (IS28).

Polyommatus, pt. Latreille, Hist. Nat. Crust. Ins. xiv. p. i I 6 (1805).

Chrysophanus, Hübner, Verz. bek. Schmett. p. 72 (18I6); Westwood, Gin. Diurn. Lepid. p. $497\left(18_{52}\right)$; Schatz \& Röber, Exot. Schmett. ii. p. 274 ( ( 892 ).

I have already, in my remarks on the genus Folyommatus, explained my reasons for regarding $L$. phlceas as the type of Lycana.

The present genus differs from those which we have already noticed, in which the sub-costal nervure is four-branched, by the absence of the upper disco-cellular nervule on the fore-wings, and by the brilliant coppery-red colour of most of the species. They are widely distributed in Europe and Asia, and in addition to their bright coppery colour, many are flushed with purple. Others are slightly tailed; but these peculiarities are but slightly indicated in any of our British species, all of which, with one exception, are now excessively rare, if not actually extinct in Britain.

I. THE SCARCE COPPER. IYYCENA VIRGAUREE.

(Plate L. Figs. 4, 5.)

Papilio virgaurece, Linnæus, Syst. Nat. (ed. x.) i. p. 484, no. I 8 I (I 758); id. Faun. Suec. p. $2 S_{5}$ (I766); Esper, Schmett. i. (I) p. 2s7, pl. 22, figs. 2a, b (1 777 ) ; Hübner, Europ. Schmett. i. figs. 359-36 I (i $\mathrm{So}_{3}$ ?), figs. $\mathrm{SS}_{4}-\mathrm{SS}_{7}$ $(1827$ ?). 
Polyommatus virgauree, Godart, Enc. Méth. ix. p. 6Gy, no. r66 (I823); Lang, Butterflies Eur. p. 86, pl. I9, fig. I (I88I).

Lycana virgaurea, Stephens, Ill. Brit. Ent. Haust. i. p. 83, pl. 9 (1 828 ); Kirby, Eur. Butterflies and Moths, p. 56, pl. I 5 , figs. I $a-c(1879)$.

Chrysophanus virgaurea, Barrett, Lepid. Brit. Isl. i. p. 55 (1892).

The present species is common in many parts of Europe and Western Asia, and was stated by Stephens, on the authority of older writers, to be found in marshes in Cambridgeshire and Huntingdonshire, frequenting the flowers of the Golden Rod in August. These localities have long been destroyed, and the insect, if it ever existed there, has probably been exterminated, with so many others; but it must have always been a great rarity in this country. One or two British specimens have been recorded in more recent times, but Mr. Barrett thinks that they were probably accidentally introduced with plants, or otherwise. The last recorded specimen was taken at Cromer, not a very unlikely locality. On the Continent it frequents flowery slopes, open places in woods, \&c., where its brilliant colour renders it very conspicuous. It may easily be distinguished from all other European species by the white markings on the under side.

The Scarce Copper measures about an inch and a quarter across the wings, which are in the male of a brilliant copper above, slightly inclining to yellow, with a narrow black border; towards the border of the hind-wings are some small black dots. The female is dull copper, with discoidal lunules, a spot in the cell on the fore-wings, and two rows of large black spots on the fore-wings, and three rows on the hind ones, the innermost incomplete. On the under side the fore-wings are coppery, with two small black spots in the cell within the discoidal lunule, and a row of small black spots beyond; the 
hind-wings are light brown, often greenish or yellowish, with an orange stripe at the anal angle. Across the wings runs an irregular white band, generally broken into two large spots, and nearer the base are several small black spots.

The larva is pubescent, and of a dull green, with a yellow dorsal line and pale green streaks on the sides. It feeds on Golden Rod, Rumex, \&c., in June and September, the Butterfly being double-brooded (on the Continent), and appearing there from May to August.

II. THE LARGE COPPER. LYCÆNA DISPAR.

$$
\text { (Plate L. Figs. I ₹ ; 2, 3․) }
$$

Papilio hippothoe (nec Linn.), Lewin, Ins. Brit. i. pl. 40 ( ( 795);

Donovan, Nat. Hist. Brit. Ins. vii. p. 3, pl. 217 (1798);

Hübner, Europ. Schmett. i. figs. 966-968 (r8+1 ?).

Papilio dispar, Haworth, Lepid. Brit. p. 40, no. 5 I (1803).

Lyccena dispar, Curtis, Biit. Ent. i. pl. I2 (I824); Stephens,

Ill. Brit. Ent. Haust. i. p. Sr (1828); Kirby, Eur. Butter-

flies and Moths, p. 55 (1879).

Polyommatus dispar, Boisd. Icones, i. pl. го, figs. I-3 (г 833 );

Lang, Butterflies Eur. p. 90, pl. 19, fig. 4 (r88r).

Polyommatus hippothoe, Newman, Brit. Butterflies, p. II4 (r88r).

Chrysophamus dispar, Barrett, Lepid. Brit. Isl. i. p. 56, pl. 9, figs. I, $\mathrm{r} a, b$ ( 1892 ).

Some difference of opinion exists as to whether the Large Copper is a distinct species, or only a local insular form of the following. It was probably known to English entomologists for some time before the end of the last century, but Wilkes does not mention it, writing in $\mathrm{r} 745$; and the first notice by an English writer is by Lewin, in 1795 , who says that his specimens were taken "on a moorish piece of ground 
near Cambridge." Haworth, in 1803 , who first described the British insect as a distinct species, says that it was taken by his friends, Mr. W. and Dr. F. Scrimshire, in reedy places in Cambridgeshire; and formerly in Wales, by the celebrated botanist Hudson. (Apropos of this last, and unconfirmed, statement, I may say that I have been told that Butterflies somewhat resembling this species have been seen by persons riding through the country on the borders of Wales. Without attaching any importance to casual reports of this kind, I think it my duty to record them, in case of their giving a clue which may possibly be worth following up.) Donovan recorded the insect from Scotland, which Haworth says is an error. Curtis sta'es, in 1824 , that it was first discovered in Wales by Hudson, and was subsequently captured in considerable abundance by Messrs. Standish, who went to Whittlesea Mere, Huntingdonshire, in expectation of finding it. They informed him that the end of July was undoubtedly the right season for this insect, although they met with it at the beginning of August, flying among reeds; it was very active, and in windy weather concealed itself amongst the highest reeds, where they found the Butterfly just emerged from the chrysalis, drying its wings.

At that time the Butterfly was probably generally distributed over the fens of Cambridgeshire and Huntingdonshire, but Whittlesea Mere and Yaxley Fen (about two miles apart, though standing on opposite sides of the boundary between the counties just mentioned) continued to be the two chief localities for the Butterfly, until they were drained. It was also recorded from Holme Fen in the same neighbourhood, as well as from Bardolph Fen in Norfolk, and Benacre in Suffolk, but strange to say, never seems to have been very common in the two latter counties. It was already noted by Westwood, in $\mathrm{r} \delta_{4} \mathrm{r}$, as getting scarce, owing 
to the immense numbers taken by former collectors, and the drainage of the fens having nearly, if not quite, exterminated the species. Its disappearance has also been attributed to a great flood (probably due to the draining operations) which drowned all the broods. But whatever the cause, it is said to have become practically extinct in Cambridgeshire after 1845 , and in Huntingdonshire after 1847 or I 848. In Miller and Skertchley's interesting book on "The Fenland," we read (p. 594): "Nearly eighty years ago, Mr. J. C. Dale recorded taking a specimen at Bardolph Fen, but the whole district has altogether changed since then. In I 85 I, the year Whittlesea Mere was drained, Mr. Wagstaff took a solitary specimen at Bottisham Fen." How greatly the district has been changed, not only for zoology but for botany, may be seen in the fact that a plant once so abundant everywhere in the fens as the Bog-Myrtle, is now all but extinct in Cambridgeshire, the only locality known for it in the county at present being near March. Mr. Barrett records the occurrence of casual specimens subsequently to ${ }^{8} 8_{5}$ in Staffordshire (?), Somersctshire, and Suffolk. The last authenticated specimen is said to have been picked up dead among sedges, at Slapton Lee in Devonshire, in I865. In the year I 859 the insect was stated, on unreliable authority, to have reappeared in the fens at Ranworth, in Norfolk. The Butterfly is now looked upon as hopelessly extinct; but I have been told by a gentleman who knows the fens well, that he is aware of one locality where it may possibly still linger. Its re-discovery as a British species, though highly improbable, cannot be looked upon as absolutely impossible. Abroad, it has been stated to occur in the Pontine Marshes, near Rome; near Moscow; and in Egypt or Nubia. The last record certainly requires confirmation; in the other cases, highly-coloured specimens of L. rutila may have Leen mistaken for it. The 
Corean form of the insect (var. L. aurata, Leech) apiears to be quite as near to true $L$. dispar (though somewhat smaller) as to L. rutila.

The Large Copper measures an inch and three-quarters, or two inches across the wings. The male is of a brilliant coppery-red, with a narrow black border, and well-marked long discoidal spots, within which is a black spot in the cell on the fore-wings. The female is of a more orange colour above, with one, and often two, black spots in the cell of the forewings, within the discoidal spot; beyond the cell is a row of large black spots. The hind-wings are blackish, with the nervures more or less orange, and a broad coppery submarginal band, indented by black spots resting upon the border. On the under side the fore-wings are of a paler copper, with the hind-margin greyish, intersected by a black line, and preceded by a row of black spots between the nervures. All the other spots on the wings are ringed with white; there are two in the cell, and a third at its extremity, and a curved row of large spots beyond. The hind-wings are blue, with four or five basal eyes, an ocellated discoidal streak, a row of large spots beyond, and a broad orange submarginal band, bordered on both sides with a row of black spots, not ocellated. The whitish hind-margin, which is intersected by a black line at the base of the fringes, is narrower than on the fore-wings.

"The caterpillar is somewhat hairy, bright green, with innumerable white dots; it feeds upon a kind of dock. [Rumex hydrolapathum, the great water-dock, and $R$. aquaticus (Stainton).] The chrysalis is at first green, then pale ashcoloured, with a dark dorsal line, and two abbreviated white ones on each side; and lastly, sometimes deep brown" (Stephens).

When I used to visit the late Mr. Henry Doubleday, at 
Epping, he showed me the dock-plant still growing, on which he used to rear Lyccena dispar. It was the nearest connecting link with the living insect which ever came in my way. A detailed account of the life-history of this insect is given by Newman, but is too long to quote here. It is much to be regretted that the breed of this interesting Butterfly was not kept up, like that of the Gipsy Moth, Porthetria dispar(Linn.), but the entomologists of the time seem to have been quite taken by surprise, and wholly unprepared for its sudden and utter extinction, though this was foreshadowed as early as I 84 I in Humphrey and Westwood's "British Butterflies."

III. THE DARK-UNDERWING COPPER. LYCENA RUTILA.

(Plate L1. Figs. 3, 4.)

Papilio hippothoe, Denis \& Schiffermüller (nec. Linn.), Syst.

Verz. Schmett. Wien. p. I 8 I, no. 2 (I 775); Esper, Schmett.

i. (r) p. 350 , pl. 38 , figs. r $a, b$ ( 778 ); Hübner, Europ. Schmett. i. figs. $35^{2-354}$ (1803?).

Polyommatus hippothoe, Godart, Enc. Méth. ix. p. 668, no. I 65 (1823).

Lycana hippothoe, Stephens, Ill. Brit. Ent. Haust. i. p. 82 (1 $82 S$ ).

Papilio rutilics, Werneburg, Beitr. Schmett. i. p. 39 I ( 1864 ). Lycana dispar, var. rutilus, Kirby, Eur. Butterflies and Moths, p. 55, pl. 14, fig. I 2 (1879).

Polyommatus dispar, var. rutilus, Lang, Butterfies Eur. p. 91, pl. 20, fig. I (1 $88 \mathrm{r})$.

The Dark-Underwing Copper was introduced into the British lists by Stephens on the strength of a specimen from Beckwith's collection (locality unrecorded), and another, from an old collection called the Kentish Cabinet, from iț consisting 
almost entirely of silecimens from that county. Curiously enough, no confirmation of the insect being British was forthcoming till a year or two ago, when Mr. Bethune-Baker exhibited a series of Lycana dispar and $L$. rutila which had been captured togethor, many years ago, by his late father; but the locality was not recorded. Stephens expressly asserts that no specimens agreeng with this species had been met with among hundreds taken at Whittlesea Mere; and Mr. Bethune-Baker's specimens possibly came from some locality which was destroyed still earlier than the Mere.

This insect is common through Central and Eastern Europe, and Northern and Western Asia in July and August. In Western Europe, however, it becomes very local, though it is less exclusively confined to marsh-lands than $L$. dispar.

The Dark-Underwing Copper is so similar to the Large Copper that many entomologists do not consider it to be truly distinct. It is of a smaller average size, of a less reddish colour in the male, and the spots are all much smaller and less numerous, there being gencrally only one basal spot within the discoidal lunule on the fore-wings above. The under surface is generally greyish-ashy, sometimes more or less tinged with blue at the base, and the hind-wings are black in the female, with a sub-marginal orange band, but rarely orange along the nervures. The orange sub-marginal band beneath is likewise much narrower in both sexes than in $L$. dispar.

Larva green, with a paler lateral stripe. It feeds on various species of Rumex and on Polygonum bistortum (Lang).

IV. THE PURPLE-EDGED COPPER. LYCENA HIPPOTHOE.

$$
\text { (Plate LI. Figs. I, 2.) }
$$

Papilio hippothoe, Linn. Faun. Suec. p. 274 (1760); Esper, Schmett. i. (I) p. 292, pl. 22, fig. 3 (I777); p. 342, pl. 35 , fig. 5 ( 1778$)$. 
Papilio chryseis, Denis \& Schiffermüller, Syst. Verz. Schmett. Wien. p. I 8 I, no. 3 (I776); Hübner, Eur. Schmett. i. figs. $337,338,355$ (I803?); Haworth, Lepid. Brit. p. 4I, no. 53 ( 1803 ).

Pathilio euridice, Von Rottemburg, Naturforscher, vi. p. 28, no. I7 (I775); Esper, Schmett. i. (I) P. 329, pl. 3 I, fig. $3(1778)$.

Lycena hippothoe, Kirby, Eur. Butterflies and Moths, p. 55, pl. I4, fig. I 2 ( I 879 ).

Polyommatus hippothoe, Lang, Butterflies Eur. p. 92, pl. 20, fig. 4 (I88 r).

Polyommatus chryseis, Godart, Enc. Méth. ix. p. 667, no. 163 (1823).

Chrysophanus chryseis, Barrett, Lepid. Brit. Isl. i. p. 60 (I892). Ly'cena chryseis, Stephens, Ill. Brit. Ent. Haust. i. p. So ( 1828 ).

Var. Papilio eurybia, Ochsenheimer, Schmett. Eur. i. (2) p. 8I (i 808 ).

Polyommatus eurybia, Freyer, Neuere Beitr. ii. pl. I63, fig. 4 $(\mathrm{I} 836)$.

Papilio euridice, Hübner, Eur. Schmett. i. figs. 339-342 (1803?) ; Esper, Schmett. i. (2) p. г 20, pl. г 16, figs. 6, 7 (1806?).

Polyommatus euridice, Godart, Enc. Méth. ix. p. 668, no. i64 (I 823 ).

Polyommatus hippothoe, var. eurybia, Lang, Butterflies Eur. p. 92, pl. 20 , fig. 5 (I88I).

The Purple-edged Copper Butterfy was recorded by all the older writers on entomology as British. It is common in many parts of Europe and Northern and Western Asia, frequenting flowery meadows near woods and grassy slopes from June to August. It appears to have formerly inhabited the south of England, but is probably now extinct. Epping Forest, and 
Ashdown Forest in Sussex, are mentioned as its localities in Britain. The former is very doubtful, and the latter, though said to have produced many varieties in former times, has been little visited lately by entomologists. I have also seen a parr in the collection of the late Mr. T. Marshall, of Leicester, who trld me that he picked them out of a quantity of L. dispar received from Cambridgeshire at a time when the latter insect was selling for threepence a specimen, and I therefore see no reason to doubt the British origin of the specimens of L. hippothoe also. Mr. C. W. Dale has lately called attention to an old record of the occurrence of this species near London. As regards Ashdown Forest, I may take the present opportunity of mentioning that repeated reports have reached the Brighton entomologists of the occurrence of "Large Coppers" in out-of-the-way parts of Sussex. I leard of such reports about 1859 , and again in 1892 . If there is any truth in them, I expect they will be found to relate to the present species rather than to $L$. dispar.

The Purple-Edged Copper measures about an inch and a quarter across the wings, which are of a bright copper-red in the male, with slender discoidal lunules, and rather broad borders, glossed with purple. On the hind-wings is a narrow sub-marginal coppery band. The female varies on the forewings from brown shot with copper, to rather dull copper, and is marked with one or two irregular rows of black spots. The hind-wings are brown, with a sub-marginal orange or copper streak enclosing black spots. On the centre, which is sometimes tinged with copper, is generally a row of still darker spots.

The fore-wings are orange beneath, with the hind-margin ashygrey. There are two eyes in the cell before the discoidal one, and two rows of eyes beyond, the outer one slightly obsolete. The hind-wings are bluish at the base, and marked with 


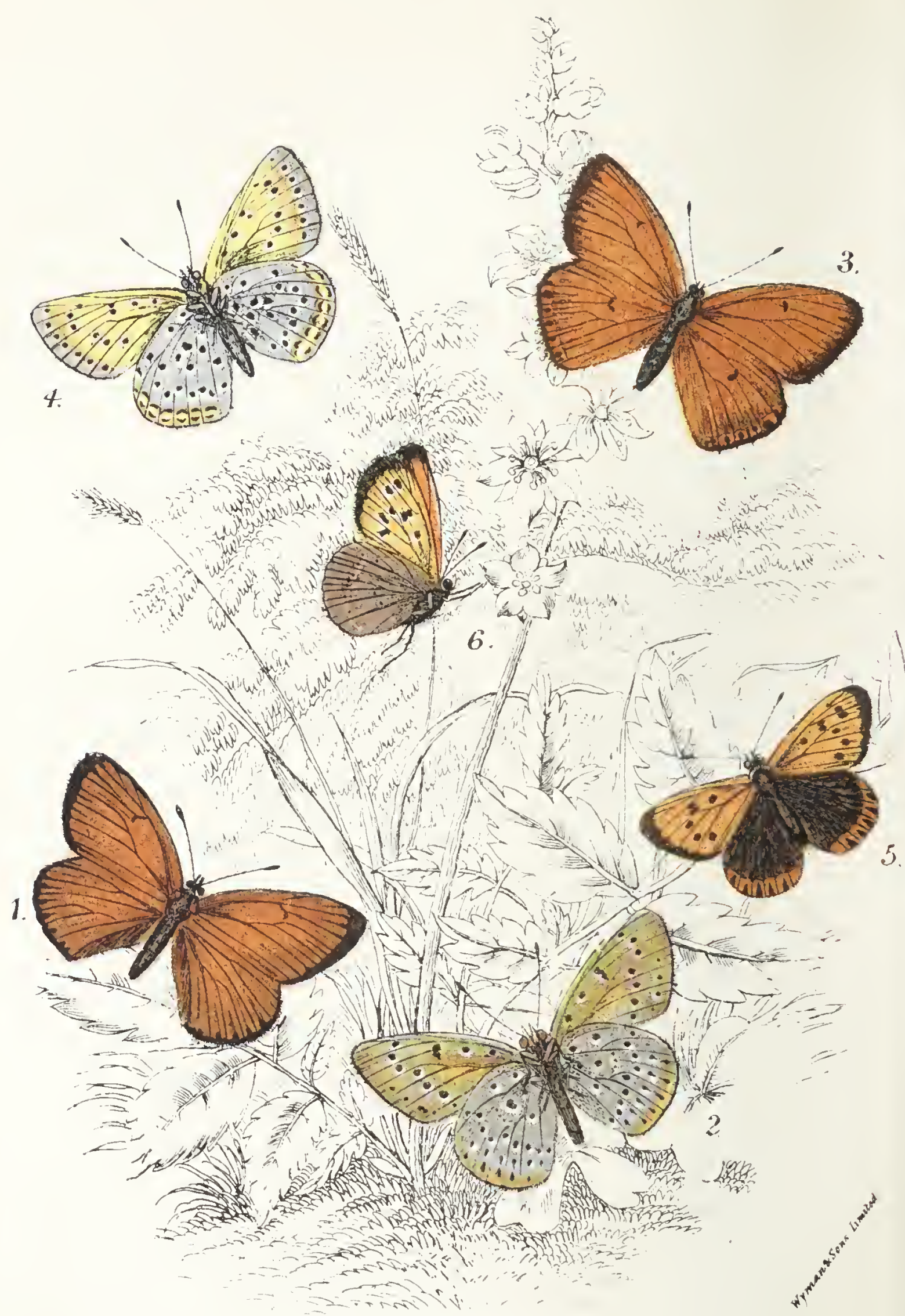

1. 2. Lycoena hippothoe

3. 4 . rutila.

5.6. "phloeas. 
numerous ocellated spots; there is also a sub-marginal orange band. The 1ringes are white, with the base brown.

In the Alpine variety L. eurybia, the male is of a paler copper, with a much narrower black border, not shot with violet, and the female is darker, both above and below, than in typical L. hippothoe.

The larva is green, with a darker dorsal stripe, and two paler lateral lines. It feeds on Rumex acetosa and R. obtusa in June.

V. THE SMALL COPPER. LYCENA PHLÆAS.

(Plate LI. Figs. 5, 6.)

Papilio phlaas, Linnæus, Fauna Suecica, p. $28_{5}$ ( I76I) ; Esper, Schmett. i. (I) p. 287 , pl. 22, fig. I (I 777 ); Hübner, Europ. Schmett. i. figs. 362, 363 (1803 ?).

Polyommatus phlaas, Godart, Enc. Méth. ix. p. 670 , no. I67 (1823); Newman, Brit. Butterflies, p. I I 5 (I88 I); Lang, Butterflies Eur. p. 95, pl. 2 I, fig. 4 (I88 I).

Lycana phlaas, Stephens, Ill. Brit. Ent. Haust. i. p. 79 (1828); Kirby, Eur. Butterflies and Moths, p. 56, pl. I 5, figs. $2 a, b$ ( I 879).

Chrysophanus phlaas, Barrett, Lepid. Brit. Isl. p. 62, pl. 9, figs. 2, $2 a-j$ (1892); Buckler, Larvæ of Brit. Lepid. i. p. 9I, pl. I3, fig. 4 (i 886 ).

Var. Polyommatus schmidtii, Gerhard, Mon. Lyc. pl. io, figs. $3^{a}, b$ ( 1853$)$.

Papilio phlaas, Esper, Schmett. i. (2) p. 58, pl.6o, fig. 5 ( I 780 );

Hübner, Europ. Schmett. i. figs. 636, 637 (i 8 is ?).

Polyommatus phlaas, var. schmidtï, Lang, Butterflies Eur. p. 96, pl. 22, fig. I ( I $88 \mathrm{I}$ ).

Var. Papilio timeus, Cramer, Pap. Exot. i. pl. is6, E, F ( 1777 ).

Hesperia eleus, Fabricius, Ent. Syst. Suppl. p. 430 ( $79 \$$ ). 
Polyommatus eleus, Gerhard, Mon. Lyc. pl. 5, fig. I (1S53). Polyommatus turcicus, Guérin, l.c. figs. 5a-c ( 1853 ).

This is the only species of the genus which was ever generally common in England. It is abundant throughout the British islands from April to October (there being a succession of broods), as well as throughout Europe, Asia as far as the Himalayas, and again in North America. It is found in meadows, heaths, gardens, \&c., often in company with Polyommatus icarus.

The Small Copper is one of the smaller species of the genus, generally measuring about an inch across the wings, which are similarly coloured in both sexes. The fore-wings are bright copper-red, with broad dark brown borders, a black spot at the end of the cell, and another nearer the base, and a row of black spots beyond. The hind-wings are black, with a submarginal copper band, spotted with black on the outside. On the under side the fore-wings are paler coppery, with greyish hind-margins, preceded by a more or less developed row of black spots; the spots as above, but slightly ocellated, and with two spots in the cell within the discoidal spot. The hindwings are brownish-grey, with several more or less distinct black dots, and an orange sub-marginal band.

The larva is green, with more or less distinct dorsal and lateral lines; the head is reddish or yellowish. It feeds on Rumex acetosa, and on other species of sorrel. The pupa is whitish, speckled with black or brown, "suspended by the tail and a silken girth to the stem or leaf of its foodplant" (Barrett).

This is a very variable species, the spots of the upper side being sometimes almost absent, and at other times agglomerated together into large blotches. Very frequently the copper submarginal band on the hind-wings is preceded by a row of blue spots. 
The variety $L$. schmidtii is an albino form, in which the copper colour of the wings is replaced with white; L. timens (Cramer) is a large dark Southern form with short tails.

On the Continent, this species is frequently accompanied by another species of similar size and habits, but much duller in colour-Lycana dorilis (Hofnagel) or L. circe (Hübner). It is said to have been once taken at Ilfracombe, but cannot be supposed to be indigenous in England. The male is brown above, spotted with black, and with traces of a copper band towards the anal angle of the hind-wings. The female has the centre of the fore-wings filled up with rather pale copper, spotted with black, and there is a sub-marginal copper band on all the wings, enclosing black spots on the hind-wings. The under side is greenish yellow, spotted with black, and there is a pale sub-marginal orange band on the hind-wings.

\section{GENUS TOMARES.}

Tomares, Rambur, Faune Ent. Andalusie, ii. p. 26I (1839). Thomares, Rambur, Cat. Lépid. Andal. i. p. 33 ( I 85 ). Thestor, Hübner, Verz. bek. Schmett. p. 73 (I8I6); Lederer, Wien. Ent. Mon. i. p. 26 (1857); Schatz \& Röber, Exot. Schmett. ii. p. 274 (1892).

This genus is generally called Thestor, but Dr. Scudder has shown that Papilio protımmus, Linn., a South African species, is the true type of the genus Thestor.

Tomares includes a number of small brown Butterflies with orange rather than coppery markings, which inhabit the Mediterranean Region and Central Asia. They are remarkable for their stout femora, and short stout tibix, with a strong spine at the extremity, which led Schatz and Röber to consider them 
somewhat intermediate between the Lycanidae and Lemoniida. In Lycana, \&c., the legs are slender, and no such spine is present. The type of this genus is T. ballus (Fabricius), which inhabits Southern France and Spain in very early spring. The male is brown, with traces of a sub-marginal orange band at the anal angle of the hind-wings. The female has orange forewings, with brown borders, and brown hind-wings with a broad orange sub-marginal band. The under side of the fore-wings is like the upper side of the female, but the base is green, and the orange markings are more coppery, and marked with three rows of black spots. The hind-wings are green, with a broad border of pale brown. The larva is yellowish-white, with a row of reddish dorsal spots bordered with brownish-red, and bisected by a blue line. It feeds on Lotus hispidus in May.

\section{GENUS FENISECA.}

Feniseca, Grote, Trans. Amer. Ent. Soc. ii. p. 308 (I 869), Scudder, Butterflies East. United States, pp. I009-IOI 4 (I8S9); Schatz \& Röber, Exot. Schmett. ii. p. 275 (I 892$)$.

The type of this genus is a small black-and-tawny North American Butterfly, with long slender pointed palpi, comparatively short and stout antennæ, a slightly concave hindmargin to the fore-wings, and rounded hind-wings. It is mentioned here on account of the peculiar habits of the larva.

The type is,

THE WANDERER. FENISECA TARQUINIUS.

Hesperia tarquinius, Fabricius, Ent. Syst. iii. ( I) p. 3 I9, no. 207 ( I 793).

Papilio tarquinius, Donovan, Insects of India, pl. 44, fig. I ( I 800 ).

Erycina tarquinius, Godart, Enc. Méth. ix. p. 556, no. 580 $(1823)$. 
Polyommatus tarquinius, Doubleday \& Hewitson, Gen. Diurn. Lepid. pl. 77, fig. 8 (I 852 ).

Feniseca tarquinius, Scudder, Butterflies Eastern United States, pp. го09-1026 (1889).

Polyommatus cratcesi, Boisduval \& Leconte, Lépid. Amér. Sept.

p. 228 , pl. 37 , figs. I-5 (I 833 ).

Polyommatus porsenna, Scudder, Proc. Essex Institute, iii.p. I63, no. I 2 ( I 862 ).

Feniseca tarquinius is widely distributed over North America, from Canada to Florida. It measures rather less than an inch and a half across the wings. The male is dark brown, with an irregular longitudinal tawny band on the fore-wings, marked with a dark line interrupted towards the base. There is a broad tawny patch in the middle of the hind-margin of the hind-wings, marked with a sub-marginal row of black dots. The fore-wings of the female are tawny, irregularly bordered with brown, and crossed by two interrupted longitudinal black bands. The hind-wings are bordered with tawny, and marked with a double row of black dots. The under side of the forewings is similar to the upper side, but paler; the hind-wings are reddish-yellow, with darker spots, slightly surrounded with white.

The larva is green, with white longitudinal lines; it is exclusively carnivorous, and feeds on aphides. Ants, which are in the habit of milking the larvæ of other Lyccenide, attack and destroy these. The pupa is greyish, the back darker and tuberculated, the hinder extremity pointed and slightly curved. "The chrysalis is an odd-looking object, and the anterior half with its bizarre markings bears, when viewed laterally, head downward, a curious resemblance to a monkey's face, as pointed out by Miss Morton. It is far more irregular in surface and form than any other of our Chrysophanides, the abdomen being basally hunched, and laterally expanded, and the seg- 
ments provided with transverse series of low tubercules; besides which the last segment, with the preceding, form a separately curved, transverse sub-spatulate pad for the cremastral hooks" (Scudder).

A similar strange resemblance to a monkey's face has also been pointed out by Dr. Hollanu in the sase of the pupa of an African Lycænid.

GENUS AMBLYPODIA.

Amblypodia, Horsield, Cat. Lepid. Mus. E. Ind. Co. p. 98 (1829); Westwood, Gen. Diurn. Lepid. p. 477 (1852); Schatz \& Röber, Exot. Schmett. ii. p. 274 (r892).

This genus and its allies (among which the most important is Arhopalu, Boisduval), include a great number of handsome species found throughout the Indo-Malayan and AustroMalayan Regions, from India to New Guinea. They are of considerable size, usually expanding from an inch and a half to considerably over two inches, and are generally of some shade of blue above, most frequently inclining to deep purple or violet, with black borders, broadest in the females, and the hind-wings have usually a strong short tail before the anal angle. The under surface is of a darker or lighter brown, with light bands enclosing darker spaces, often more or less chain-like, and usually forming distinctly ocellated spots towards the base, and in the cell of the fore-wings. On the under side of the hind-wings there are usually some greenish or bluish markings about the base of the tail. The type is Amblypodia apidanus (Cramer), a violet-blue species found in Java, with the base of the costa marked with red. It is useless to give a detailed description of a single species of a group containing so many closely-allied forms.

GENUS OGYRIS.

Ooyris, Westwood, Gen. Diurn. Lepid. p. 472 ( $\left.{ }^{8} 8_{52}\right)$; Schatz \& Röber, Exot. Schmett. ii. p. 275 (זS92). 
$\Lambda$ genus peculiar to Australia, including a feiv species of large and handsome Butterflies, generally measuring nearly two inches in expanse, and blue or green above, with broad black borders (sometimes wholly brown or black in the females), and with the hind-wings shorter than the fore-wings, and not tailed, but strongly dentated. The sub-costal region of the forewings is transversely banded beneath with white, blue, brown, or black, and occasionally with red, and the hind-wings are generally irregularly banded or spotted with brown, on a bluishgrey ground. The type is Osyris abrota (Doubled. \& Hew.), a very deep purple species, expanding rather more than an inch and a half across the wings. It is bordered with black, and the fore-wings are distinctly dentated as well as the hind-wings. The wings are nearly black beneath, with only some slight transverse bluish-white markings in the cell of the fore-wings. The female has black fore-wings, with a large round yellow spot in the middle; the base of the fore-wings, and the hind-wings are light brown.

\section{GENUS CURETIS.}

Curetis, Hübner, Verz. bek. Schmett. p. Io2 (ISI6); Schatz \& Röber, Exot. Schmett. ii. p. 276 (1892).

Anops, Boisduval, Spec. Gén. Lépid. i. pl. 23, fig. I ( $\left.8_{3} 6\right)$; Westwood, Gen. Diurn. Lepid. p. 473 (1 852 ).

A curious little genus, including a number of closely-allied forms, found throughout the Indo- and Austro-Malayan Regions. They expand rather less than two inches across the broad subtriangular fore-wings, which are more or less pointed at the tip ; the hind-wings are rounded, or else with a rectangular projection in the middle of the hind-margin. The type is an Indian species, Curetis thetys (Drury), the male of which is coppery-red above, with a rather narrow black border; the female is brown, with a large white blotch on each wing. The 
hind-wings are almost white beneath. In this species, the margins of the wings are regularly curved. The other species of the genus differ chiefly in the outline of the wings, and the width of the dark border, the females being sometimes marked with orange-yellow instead of white; but in all cases, the under surface is white or yellowish-white, with very slight transverse darker markings, if any are present.

\section{GENUS GERYDUS.}

Gery'dus, Boisduval, Spec. Gén. Lépid. i. pl. 23, fig. $2\left(\mathrm{IS}_{3} 6\right)$; Distant, Rhop. Malay. p. 205 (1884).

Miletus, pt. Hübner, Verz. bek. Schmett. p. 7 I (1816); Westwood, Gen. Diurn. Lepid. p. 502 (1852); Schatz \& Röber, Exot. Schmett. ii. p. 276 (1892).

This genus and several of its allies are dull-coloured brown and white species, with slender bodies and rather long wings. Most of them are found in the East Indies. In the type of Gerydus, the first joint of all the tarsi is unusually long, compressed, and spatulate. The type is,

\section{GERYDUS SYMETHUS.}

Papilio symethus, Cramer, Pap. Exot. ii. pl. I49, figs. B, C (I 777 ); Stoll. Suppl. Cramer, pl. 37, figs. 3, 3c (I 790 ). Polyommatus symethus, Godart, Enc. Méth. ix. p. 675, no. I8o (I 823 ).

Gerydus symethus, Boisduval, Spec. Gén. Lépid. i. pl. 23, fig. 2 $(1836)$; Distant, Rhop. Malay. p. 205, pl. 20, fig. 2, pl. 22 , fig. I4 (I884).

The present species, which is a native of Java and Malacca, has rather long greyish-white fore-wings, with the base, and the basal half of the costal area bluish-grey, and all the borders of the wings broadly black. The hind-wings are bluish-grey 
with an oblique whitish streak in the centre, and the costa blackish. The female has longer hind-wings, and the central whitish area of the wings more extended. 'The fore-wings beneath are pale brownish, varied with white towards the extremity of the inner-margin; the hind-w.ngs are greyish or yellowish-grey, with light brown fascix bordered with whitish.

'This species has been erroneously stated to inhabit ants' nests. I imagine the error to have arisen from the fact that the larvre of many Lyccenide, and possibly of this species too, exude a substance which is attractive to ants.

\section{GENUS LUCIA.}

Lucia, Swainson, Zool. Ill. ii. p. I35 (I 833$)$; IVestwood, Ill. Diurn. Lepid. p. 50 I ( 1852 ).

The type of this species is Lucia lucanus (Fabricius), a small Australian Butterfly with rounded wings, which are yellow above, with broad black borders, and a black spot in the middle of the fore-wings. The latter are yellowish beneath, with square brown spots, and the hind-margin brown. The hind-wings are red beneath, irrorated with yellow, and marked with some square brown spots.

Schatz and Röber erroneously give Lachnocnema bibulus, (Fabricius), a small brown South African Butterfly, as the type of this genus.

\section{SUB-FAMILY II. LIPTENINAE.}

Under this heading, Schatz and Röber propose to include a number of African genera which agree in having the sub-costal nervure always five-branched. With them they enumerate the abnormal Eastern genus Liphyra. Until recently, very few of these aberrant African Lycenide were known, but within the last twelve years a great number have been described and 
figured in Grose Smith and Kirby's "Rhopalocera Exotica," and several additional species have appeared in the works of other authors. In most cases, the wings are rounded and entire, or but slightly scalloped.

Many of these species are tawny, with broad black borders, and have much resemblance to species of Acreina, which they evidently mimic. Thus, the species of Mimacrea, Butler, expand considerably over two inches across the wings, which are yellowish or reddish beneath, with radiating black and yellowish streaks on the outer half of the wings, and with numerous black spots towards the base of the hind-wings.

The typical species of the genus Liptena, Westwood, are smaller than Mimacrea, not attaining two inches in expanse of wing. They are red or tawny, with broad black borders, and a transverse white or yellow transverse fascia towards the tip of the fore-wings, while the border of the hind-wings is spotted with white beneath, both above and below. On the under side, they are reddish or yellowish, with transverse black and white markings towards the costa of all the wings. These Butterflies appear to mimic the common African Moths belonging to the genus Aletis, Westwood.

Other genera with black and red, or black and tawny markings, but containing smaller species, are Psenderesia, Butler, Alena, Boisduval (long included in the Acreince, notwithstanding its very different appearance), and Durbania, Trimen.

There are three genera of blue Butterflies of this group, replacing in Africa the species of Thecla, \&c., which are so numerous in other parts of the world. They vary in size from an inch and a half to over two inches in expanse. These genera are Phytala and Epitola, IVestwood, and Hezitsonia, Kirby. Epitola contains a considerable number of rather discordant species, and will ultimately require sub-dividing. The 
larger species have the fore-wings long and sub-falcate, with yellowish or whitish radiating markings on the hind-wings ; but in the majority of the smaller species, the fore-wings are rather short and broad, with the under side of the wings brown or grey, and obscurely marked.

The genus Vanessula, Dewitz, is rather aberrant. The single species, $V$. milca (Hewitson), has long and slightly angulated fore-wings. It expands rather more than an inch and a half, and is a native of West Africa. The wings are black, crossed by a broad continuous band of pale red, which is narrowed and angulated towards the costa of the fore-wings.

The species of Tingra, Boisduval, are of moderate size, and of a white or yellow colour, with broad black borders above, and numerous black spots above and below. Those of Pentila, Boisduval, are similarly coloured, but with fewer spots, and the under side of the hind-wings is marked with transverse lines.

The species of Teriomima and Citrinophila, Kirby, are small white and yellow Butterflies, with broad black borders, and are deceptively similar to some of the Pieride which inhabit the same countries; indeed, some of them have actually been described as Pierida. Many dark-coloured species have also been included in Teriomina.

Larinopoda, Butler, was originally described as a genus of Pieride; it includes a number of milky-white Butterflies, with black borders, easily recognised by two very conspicuous characters, viz., the possession of one or more large round black spots on at least the under side of the hind-wings, and the tufted tawny legs.

Deloneura immaculata, Trimen, from the Bashee River, South Africa, is a pale ochreous-yellow Butterfly, wholly without markings, and measuring rather more than an inch and a half across the wings. 
Aslaugra, Kirby, is a genus including only two species from West Africa, A. vininga (Hewitson) and A. marginalis, Kirby. The wings are long, thick, somewhat obtuse, and in the first species, produced at the tip of the fore-wings, with a very convex hind-margin, while the hind-margin of the hind-wings is rounded and convex in the middle, and triangularly toothed below, before the anal angle. A. vininga is dark blue above, and dark grey below; $A$. marginalis, which some authors regard as the female of the former, has regularly rounded oval wings, and is tawny-yellow, with broad black borders.

The only Asiatic species of this group is a very remarkable Butterfly.

\section{GENUS LIPIYRA.}

Liplyyra, Westwood, Proc. Ent. Soc. London, i864, p. 31 ; Distant, Rhop. Malay. p. 204 (i884); Schatz \& Röber, Exot. Schmett. ii. p. 282 (1 892 ).

Sterosis, Felder, Reise Novara, Lepid. ii. p. 2 rg (1865).

The single species of this genus has a wide range from India to Halmahéra. It is a very large stout brown and tawny Butterfly, nearly three inches across the wings, much more resembling a species of the South American genus Brassolis (whence its name), or some large species of Hesperiidae than any other known Lycenida.

\section{LIPHYRA DRASSOLIS.}

Liphyra brassolis, Westwood, Proc. Ent. Soc. I.ondon, I 864 , p. 3 I ; Distant, Rhop. Malay. p. 204, pl. 22, fig. IS (i 884 ); Staudinger, Exot. Schmett. i. p. 269, pl. 94 (1886).

Sterosis robusta, Felder, Reise Novara, Lepid. ii. p. 21 9, pl. 27 , figs. io, i i (I 865 ).

This is a Butterfly with a very stout body, short thick 
antennæ, and broad densely-scaled wings of a dull ochreyellow colour, with broad brown borders, large black connected spots on the fore-wings, and several small brown spots in the middle of the hind-wings. The fore-wings are considerably longer than the hind-wings. The under side is dull ochreousyellow, rather darker towards the hind-margins, especially on the fore-wings, and with some dark spots in the middle of the latter, less connected than on the upper side. The female lias brown fore-wings, with the hind-margin forming a rectangle, and a large ochreous-tawny longitudinal irregular band running from the base parallel to the inner margin, and a tawny spot at the end of the cell. The hind-wings are tawny, with brown borders, and black blotches. The under side is brown, lighter on the fore-wings except in the centre, and on the costal area of the hind-wings.

\section{FAMILY V. PIERIDA.}

Egg.- "Very tall and slender, tapering toward a much smaller rounded summit, either squarely truncated at the base, or appearing as much or nearly as much so at the summit, so as to render the egg sub-fusiform, provided with a variable number of distinct longitudinal ribs, and crossed by frequent transverse finer raised lines" (Scudder).

Larva.-Smooth or downy, cylindrical, slightly tapering at the ends, not spiny, nor furnished with retractile tentacles.

Pupa.-Angulated, slender, the head more or less pointed; attached by the tail, and a girth round the body; sometimes boat-shaped.

Imago.-Of moderate size, rarely much less than two inches in expanse, and still more rarely exceeding three inches; wings rounded, very rarely pointed, sub-dentate or sub-caudate. 
Prevailing colours white and yellow, sometimes black, varied with red or yellow, rarely red or blue, over the greater part of the wings, often with the apex orange or yellow, never with any approach to ocellated spots, except towards the end of the cells on the under surface of some of the yellow species. Structure moderately robust; flight rapid, except in some of the smaller species, but rarely high. Wings with closed cells, sub-median nervure un-branched, sometimes bifid at the base. Fore-wings with no internal nervure, but the hind-wings always with one, and, in many cases, with streaks resembling nervures between the nervures on the under-side of the wings, thus giving the appearance of three sub-median nervures. Innermargin of the hind-wings usually forming a gutter to receive the abdomen.

Six perfect legs in both sexes, without spurs, claws bifid.

Range.-The greater number of genera and species of this family inhabit the Tropics of the Old World; but the Alpine and Arctic genus Eurymus extends as far to the north and south as any Butterflies exist. The smail white and yellow Butterflies belonging to Terias and its allies, and the larger ones belonging to Catopsilia, \&c., inhabit the tropics of both Hemispheres. Several remarkable genera are peculiar to Tropical America; some of these have longer wings than usual, and mimic various species of Ithomiince. "Orangetips" are peculiarly characteristic of Africa, though similarlymarked species are found in Europe, Asia, North America, and Chili.

Habits. - The Pieride inhabit woods and meadows. Their flight is often rapid, but not generally very lofty. 'The more delicate species, which have a weak flight, are often very local.

Classification.-Fourteen genera of Pieridce were admitted by Boisduval in $1 \delta_{3} 6$; and sixteen by Doubleday in the 
"Genera of Diurnal Lepidoptera," in 1847 . In 1870 Dr. A. G. Butler published a revision of the family in the "Cistula Entomologica," in which he enumerated forty-eight genera, primarily classified according to the number of branches of the sub-costal nervure; and in I 886 Schatz again revised the Family, not admitting all Butler's genera, but including Pseudopontia, Plötz, which is certainly a Moth. Schatz divides the Pierida into four families, which appear on the whole to be natural, and which will therefore in the main be adopted in the present work.

Schatz, however, places his four groups in the following order: Dismorphide, Pieride, Dryade, and Charide. I have re-arranged these divisions as Sub-families, in what appears to me to be a more natural sequence: Pierinc, Dismorphine, Anthochorince, and Callidryine.

\section{SUB-FAMILY I. PIERINAE.}

Antennæe generally with a well-marked club. Palpi generally extending beyond the head, and clothed with long stift hairs in front. Terminal joint pointed, as long as or longer than the middle joint, rarely smaller. Pre-costal nervure always distinctly present. Sub-costal nervure generally with three or four branches.

This is the typical group of the Pieride. The species are generally of a white colour, and the hind-wings are rounded, more or less dentated only in one or two genera allied to Pereute. The sections of the old genus Pieris are mostly treated as sub-genera by Schatz, but the more important of these will be here enumerated as separate genera.

GENUS APORIA.

Aporia, Hübner, Verz. bek. Schmett. p. 90 (1816); Schatz, Exot. Schmett. ii. p. 60 (1886). 
Pieris, pt. Schrank, Fauna Boica, ii. (I) pp. 152, I60 (1801); Steph. Ill. Brit. Ent. Haust. i. p. 25 (I 827 ); Curtis, Brit. Ent. viii. pl. 360 (1831).

Pontia, pt. Fabricius, Illiger, Mag. Insekt. vi. p. 283 (I 807 ); Butler, Cist. Ent. i. p. 50 (1870).

Leuconea, Donzel, Ann. Soc. Ent. France, vi. p. 80 (1837).

Antennæ with an abrupt, obconic, slightly compressed club; palpi short, the basal joint long, recurved, cylindrical ; second about half the length of the first, the terminal one slender, short, linear, as long as the second. Wings thinly clothed with scales, especially in the female, which is almost sub. diaphanous; cells broad, of about equal length on the foreand hind-wings; sub-costal nervure four-branched; the third and fourth branches forming a rather wide fork; upper discoidal nervure emitted about half-way between the cell and the base of this fork; fringes almost absent ; larvæ gregarious, feeding under a web when young.

I consider that there is but one species of this genus, for the Asiatic species which have been associated with it by various authors are much more densely scaled, and have well-developed fringes, and appear to me to be much more closely allied to the genus Metaporia.

THE BLACK-VEINED WHITE. APORLI CRATAGI.

$$
\text { (Plate LXII., Fig. 2.) }
$$

Patpilio cratagi, Linnæus, Syst. Nat. i. p. 467 , no. 57 (1758); id. Faun. Suec. p. 269 (176r) ; Esper, Schmett, i. p. 47, pl. 2, fig. 3 (1 777 ) ; Hübner, Europ. Schmett. i. figs. 399 400 ( I 803 ?).

Pieris cratagi, Godart, Enc. Méth. ix. p. 154, no. I27 (1819); Boisduval, Spec. Gén. Lépid. i. p. 445 (1836); Steph. Ill. Brit. Ent. Haust. i. p. 27 (I\$27); Curtis, Brit. Ent. viii. pl. $360(183 \mathrm{r})$. 


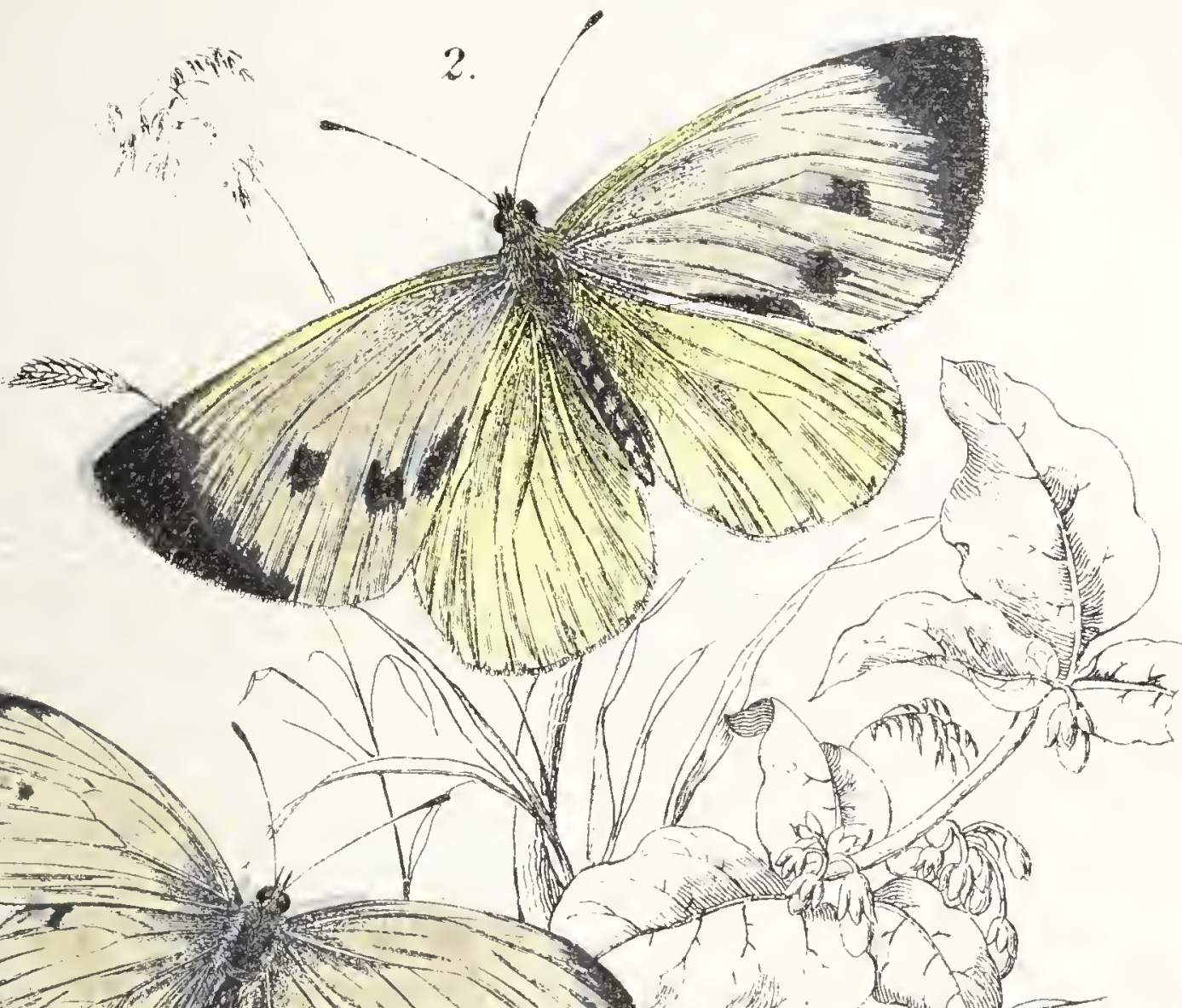

3.
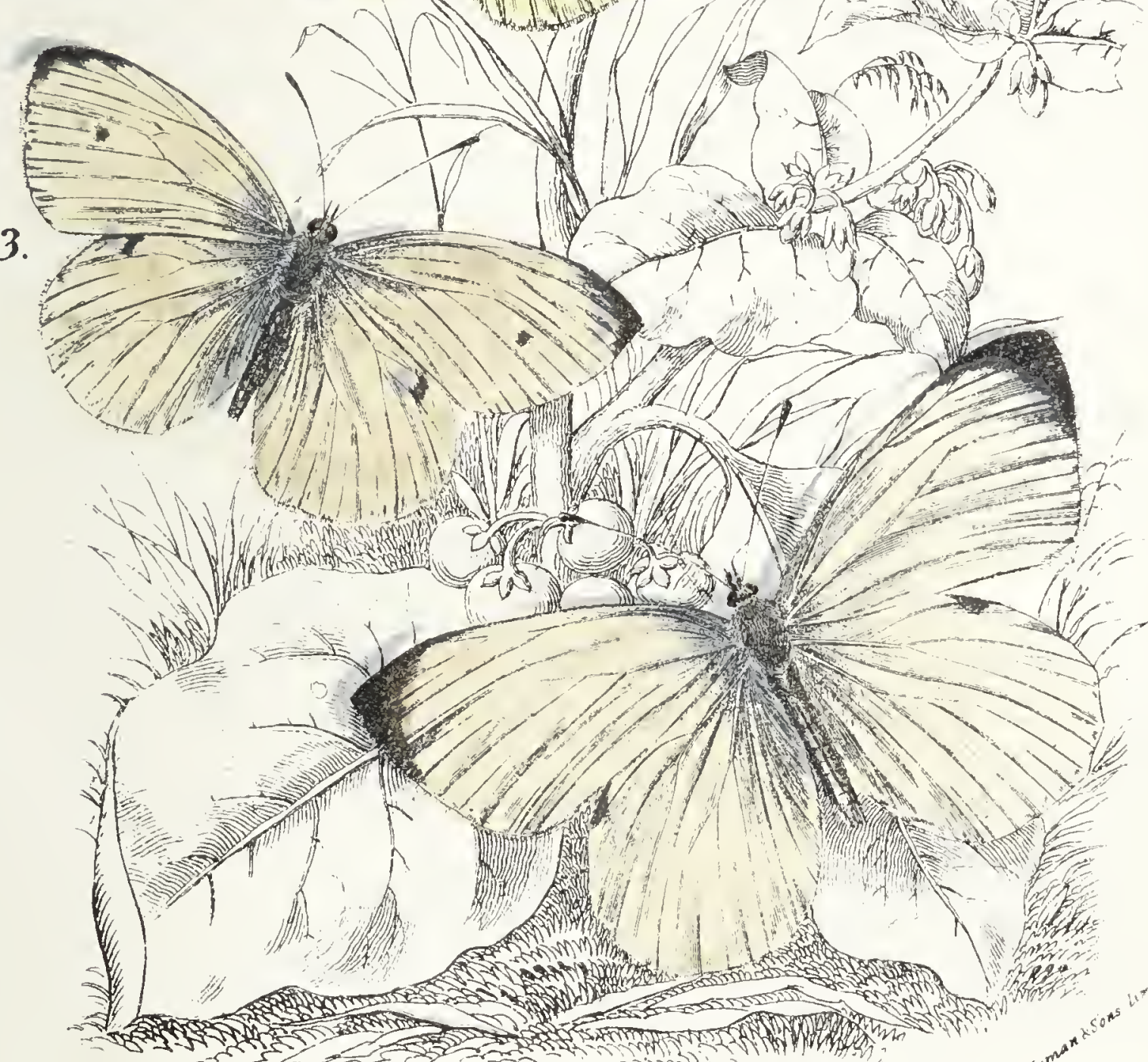

is

(n)

1 en

\section{2. Hieris brassica.



Aporia cratcegi, Newman, Brit. Butterfies, p. I67 (188r); Kirby, Eur. Butterflies and Moths, p. 8, pl. 4, figs. $2 a-c$ (1878); Lang, Butterflies Eur. p. 27, pl. 6, fig. I ; pl. I5, fig. I (transf.: I88г); Barrett., Lepid. Brit. Isl. i. p. I8, pl. I, figs. 2, 2a-c (1892); Buckler, Larvæ of Brit. Lepid. i. pl. 2, fig. I (1886); Rye, Handb. Brit. Macro. Lepid. p. 9, pl. 2, fig. 2 (I892):

This Butterfly is a very common species throughout Europe and Northern and Western Asia, but is always more or less uncertain in appearance. On the Continent it ranks among destructive insects; and Pallas mentions his having seen it in such abundance in Siberia, that it looked like flakes of snow. It frequents meadows in the neighbourhood of woods, gardens, \&c., and has a strong flight. It is very common on the lower slopes in Switzerland, where it flies with Parnassius apollo, which it much resembles on the wing, at a little distance, when the red spots of the latter are inconspicuous. It was always considered a local insect in the south of England and Wales (it is unknown in Scotland and Ireland), but less than a century ago, was common in many localities as near London as Chelsea and Muswell Hill. Until recently, it was still abundant in the New Forest, and in various parts of Kent, \&c.; but within the last quarter of a century, it has disappeared almost suddenly from all its old haunts, and is now thought to be on the very verge of extinction as a British species. There is only one brood, which appears on the wing in early summer, and does not last very long. It is supposed that the disappearance of this Butterfly is due to the multiplication of insect-eating birds, in consequence of the Wild Birds' Protection Act. It feeds on common trees, and admirably illustrates the well-known fact that the range of insects is by no means co-extensive with that of the plants on which they feed. A f sw years more will probably decide whether the Butterfly will actually disappear from England, or recover itself, and again become comparatively common with us. 
The Black-veined White Butterfly measures about two inches and a half across the wings, which are of a uniform white, thinly scaled, and semi-diaphanous in the female, with the nervures and the terminal nervures of the wing narrowly black, but not incrassated, though the nervules frequently terminate in dusky triangles on the hind-margin. The cilia are so short as to be almost obsolete.

The larva (vol. i. pl. 3, fig. 3) feeds on hawthorn, sloe, and various fruit-trees. The female lays her eggs on the ends of the branches, with a coating of varnish so effectually weatherproof, that they remain in security (sometimes, it is said, for several years) till circumstances favour the exclusion of the larvæ. (If this is correct, it goes far to account for the periodicity of the insect.) The larvæ are black when young, and live gregariously under a common white web. Subsequently, they become clothed with short hair, and striped with reddish-brown on the sides. The pupa (vol. i. pl. 3, fig. 4) is yellow or white, streaked and spotted with black.

\section{GENUS PIERIS.}

Pieris, Schrank, Fauna Boica, ii. (I) pp. I 52, I64 (I80I); Latreille, Hist. Nat. Crust. Ins. xiv. p. I I I (I805); id. Enc. Méth. ix. pp. I I, I I9 (I8 I9); Boisduval, Spec. Gén. Lépid. i. p. 434 (I836); Doubleday, Gen. Diurn. Lepid. p. 42 (1847) ; Schatz, Exot. Schmett. ii. pp. 6o, 6I (I886). Pontia, pt. Fabricius, Illiger, Mag. Insekt. vi. p. 283 (I807);

Steph. Ill. Brit. Ent. Haust. i. p. I4 (I 827 ).

Mancipium, Hübner, Tentamen, p. I (18 го ?).

Catophaga, Hübner, Verz. bek. Schmett. p. 93 (I \& I6). Ginnoris, Dalman, Vetensk. Acad. Handl. Stockh. xxxvii. pp 6 I, 86 ( I 8 I6).

B:t for the mythological associations of the name Danaus, 
I should have accepted Pieris brassica (Linn.) as the type of that genus (cf. vol. i. pp. 18, 19). It is, however, the type of Mancipium, Ganoris, and, I think, Catophaga. I cannot follow Dr. Scudder in making the East Indian Appias paulina (Cramer) the type of Catophaga, as the name too obviously relates to the destructive habits of our common European Cabbage Whites. I think, however, that Dr. Scudder has shown that the types of Pieris and Pontia are P. rapa (Linn.) and $P$. daplidice (Linn.) respectively, and as I do not propose to separate P.brassice and $P$. rape generically in the present work, I retain Pieris as the name of the genus in which I place them. At the same time I am glad to have the opportunity of figuring Pieris chariclea, $P$. metra, and $P$. sabellica (Stephens), and I have therefore given them separate places, though I see no reason to regard them as anything more than the early broods of the common species.

Characters. - Antennæ nearly as in Aporia; palpi short, nearly cylindrical, with the terminal joint longer than the second; wings opaque, the apex of the anterior wings obtusely angulated; cells of the fore-wings longer than those of the hindwings, sub-costal nervure four-branched, the third and fourth forming a very sharp fork; upper discoidal nervule emitted much nearer the cell than the base of this fork; fringes well developed. Larvæ often gregarious, but not living under a web. Pupa pointed above.

This genus includes our common White Cabbage Butterfies, and is fairly well represented in the Northern Hemisphere, attaining its maximum of variety and development in Northern and Central Asia. The species of this genus are very abundant, and are often very destructive in gardens to cabbages, Indian Cress (generally, but improperly, called Nasturtium), and other cruciferous plants. Occasionally these Butterflies cross the Channel in vast flights. 
THE LARGE WHITE CABBAGE BUTTERFLY. PIERIS BRASSICF. (Plate LII. Figs. I o, 2 f.)

Pieris brassice, Linn. Syst. Nat. i. p. 467 , no. $5^{8}$ ( $175^{8}$ ); Esper, Schmett. i. (I) p. 52. pl. 3, fig. I ( I 777 ); Hübner, Eur. Schmett. i. figs. $40 \mathrm{I}-403$ ( 1803$)$.

Pieris brassice, Godart, Enc. Méth. ix. p. I58, no. I38 (18 I9);

Boisd. Spec. Gén. Lépid. i. p. 52 I, no. I 2 I $(1836)$;

Newman, Brit. Butterflies, p. I65 (г88г); Kirby, Eur.

Butterflies and Moths, p. 8, pl. 4, figs. $3 a, b$ (1878);

Lang, Butterflies Eur. p. 28, pl. 6, fig. 2, pl. 15, fig. 2 (transf. I88I) ; Barrett, Lepid. of Brit. Isl. i. p. 2 I, pl. I, figs. I, $1 a-c$ (1892); Buckler, Larvæ of Brit. Lepid. i. p. I48, pl. 2, fig. 2 (1 886); Rye, Handb, Brit. Mาcro. Lepid. p. I I, pl. 2, figs. 3, 4 (I895).

Pontia brassica, Stephens, Ill. Brit. Ent. Haust. i. p. I 5 (1827).

It is hardly necessary to say more of this insect than that it is generally common throughout the Palæarctic Region, frequenting fields and gardens, and that there is a succession of broods throughout the year. There is a permanent form in the Canary Islands, $P$. cheiranthi (Hübner), with larger and confluent black spots on the wings; and forms intermediate between this and the ordinary type occur in the Himalayas (P. nepalensis, Gray) and in Madeira ( $P$. wollastoni, Butler). It is an insect of fairly strong flight.

This Butterfly generally measures from two and a half to two and three-quarter inches acrosi the wings, which are white above, with a black triangular patch, somewhat indented on the inner edge, at the tip of the fore-wings. There is also a rather large spot on the costa of the hind-wings towards the tip, and in the female there are two large spots on the disc of the fore-wings, and a black streak about the middle of the inner-margin. On the under side both sexes are nearly alike; the colour inclines to yellow, especially on the hind-wings, 


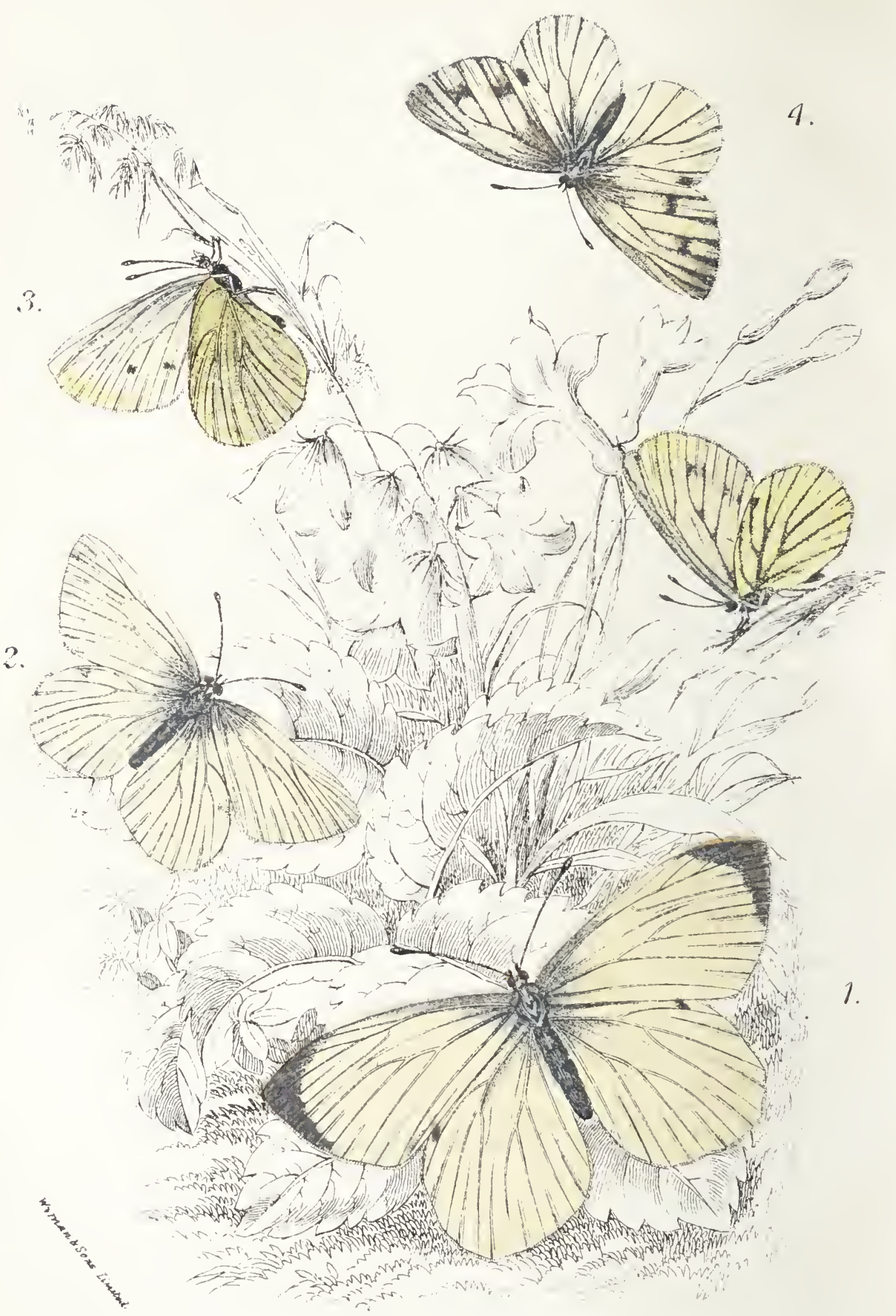

5.

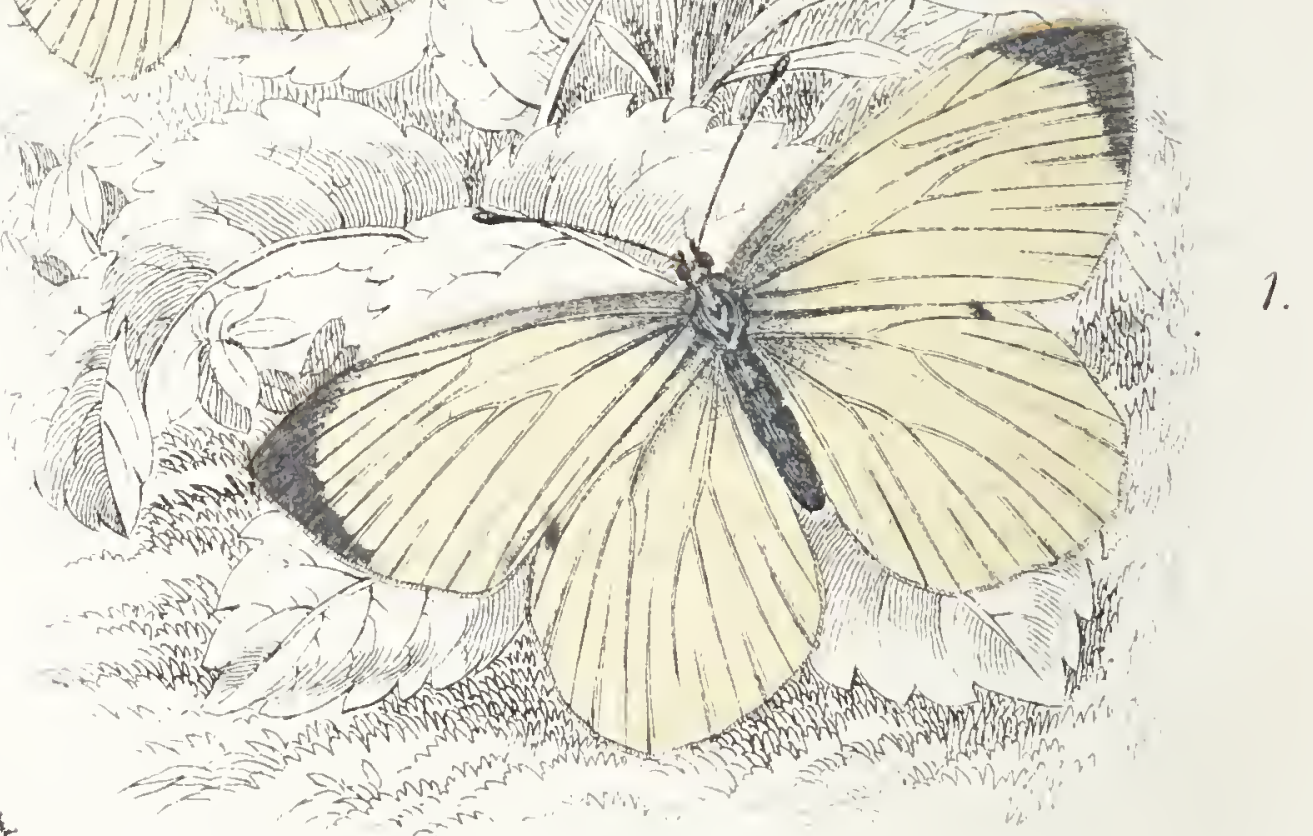

\section{Pieris charidea.}

2.3. " metra

4.5. " sabellica 
which are also sprinkled with black scales. The two discal spots on the fore-wings reappear below in both sexes; the other dark markings are obsolete; the fringes are yellowish, slightly waved with black. The body and antennæ are white beneath and black above; the thorax is clothed with hoary pubescence above.

The larva is green, with yellow lines on the back and sides; it is thickly covered with black tubercular points, each with a hair in the centre. It feeds on cabbages, Tropcolum, mignonette, and many other plants, and is very liable to the attacks of small Ichneumons, or rather Braconide. The yellow cocoons of one of the most destructive of these parasites (Apanteles glomeratus) may often be seen clustered round a dead larva. The pupa is greenish, with yellow streaks, and numerous black dots. The egg is figured (vol. i. pl. I, fig. 4).

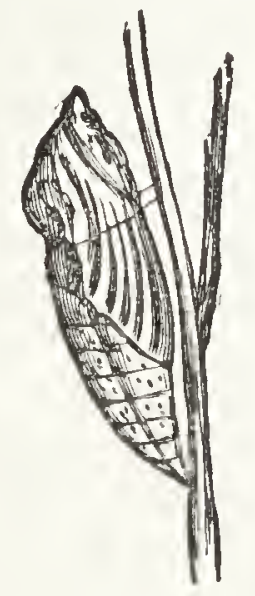

Pupa of P. brassice.

THE EARLY WHITE CABBAGE BUTTERFLy. PIERIS CHARICLEA. (Plate LIII. Fig. I.)

Pontia chariclea, Stephens, Ill. Brit. Ent. Haust. i. p. I7, pi. 3, figs. I, 2.

This Butterfly, which occurs in May and June, is considered to be only the spring brood of $P$. brassice, and although the 
larve have been said to differ, that of $P$. brassice is known to be variable, and therefore too much importance cannot be attached to this statement, even if correct. The perfect insect is generally rather smaller than typical $P$. brassice, measuring from 2 to $2 \frac{1}{2}$ inches across the wings; it is similarly marked, but the apical patch on the fore-wings is of a light brown, approaching to ash-colour, especially in the female, and the inner edge of the patch is not indented, but regularly concave; the fringe is yellowish-white. On the under side the tips of the fore-wings are clear yellow, and the hind-wings are deep yellow, very thickly dusted with black.

THE SMALl White CABbage BUtTERfly. PIERIS RAPÆ. (Plate LIII. Fig. 3.)

Papilio rapa, Linn. Syst. Nat. (ed. x.) i. p. 488, no. 59 ( ( 758 ); id. Faun. Suec. p. 270 (I76I); Esper, Schmett. i. (I) p. 55, pl. 3, fig. 2 (г777): Hübner, Eur. Schmett. i. figs. 404, 405 ( 1803 ?)

Pieris rape, Godart, Enc. Méth. ix. p. x61, no. I44 (1819); Boisd. Spec. Gén. Lépid. i. p. 520, no. I 20 (1836); Newman, Brit. Butterflies, p. I6r (I88I); Kirby, Eur. Butterflies and Moths, p. 8, pl. 4, figs. 4a, 6 (1878); Lang, Butterflies Eur. p. 30, pl. 6, fig. 4, pl. 15, fig. 3 (ISSI); Barrett, Lepid. Brit. Isl. i. p. 22, pl. 2, 2a-e (IS92); Buckler, Larvæ of Brit. Lepid. i. pp. 19, 152, pi. 2, fig. 3 (г886); Rye, Brit. Macro-Lepid. i. p. Iz, pl ii. figs. 5-6 (I 895$)$.

Pontia rapa, Stephens, Ill. Brit. Ent. Haust. i. p. I8 (1827).

This species, like P. brassice, is found throughout the Palæarctic Region, and is frequently very destructive, although the eggs are laid singly and not gregariously. It is probably the most abundant of all our Butterflies, and frequents fields and gardens. In Southern Europe, and in Northern and Western 
Asia, many closely-allied races are met with, some of which are probably simply local forms of this Butterfly, while others are to be ranked as distinct species. Rather more than thirty years ago, this Butterfly was introduced into North America (where, however, several closely-allied species are truly indigenous), and has since spread over the country, and become very destructive. It has also developed a yellow variety ( $P$. novanglia, Scudder), which is very rarely observed in any other part of its range.

The Small White Butterfly measures from $\mathrm{I} 3 / 4$ to nearly $2 \mathrm{~T} / 2$ inches across the wings, which are coloured nearly as in $P$. brassice. The wings are rather more yellowish than in the last-

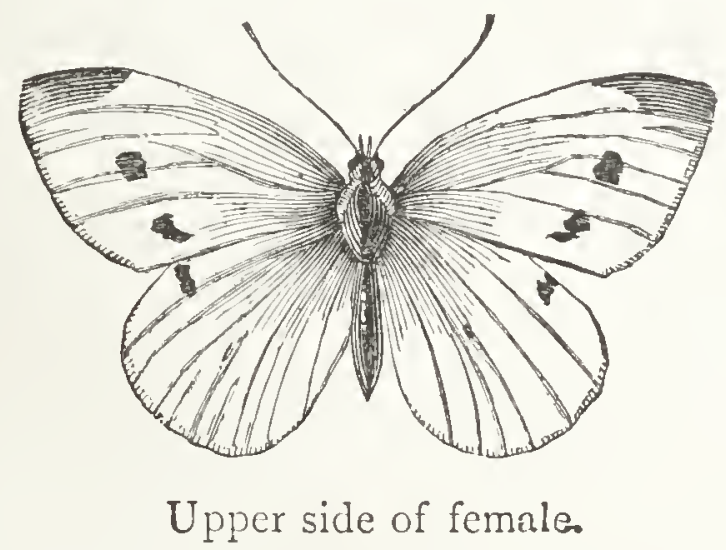

named species, the fore-wings having an ash-coloured blotch at the tip, much smaller and paler than in $P$. brassicre. The male has a black spot on the disc (often wanting), and the female has two; the patch on the inner-margin is less distinct. On the hind-wings there is a black spot on the costa towards the tip. On the under side, the fore-wings have two black spots, the tip is yellow, and the base dusted with blackish. The hind-wings are rather bright yellow, dusted with black, and there is a narrow orange streak at the base of the costa.

The larva is pale green, with yellow dots on the sides. It feeds on cabbage, mignonette, \&c. ; and there is probably a 
succession of broods throughout the year. The pupa is greenish, spotted with black.

HOWARD'S WHITE BUTTERFLY. PIERIS METRA.

(Plate LIII. Figrs. 2, 3.)

Pontia metra, Stephens, Ill. Brit. Ent. Haust. i. p. I9 (I827). Pieris metra, Westwood, Brit. Butterflies, p. 26, pl. 5, figs. 5, 6 (I $84 \mathrm{I}$ ).

This insect is found in April and June, and is considered to be undoubtedly a mere var ety of $P$.rape, as the pupa does not differ.

The wings are white or cream-colour, the fore-wings being much pointed at the tip, with the base black, and the tip more or less clouded with dusky. The male has one black spot on the fore-wings above, and the female two; but these are frequently more or less obsolete. The hind-wings are white, with the base black, and a dusky spot towards the end of the costa. On the under side the tip of the fore-wings is yellow; the base is blackish, and there are two obsolete spots on the disc; the hind-wings are rather bright yellow, thickly dusted with blackish, and there is a pale orange strcak at the base of the costa; the fringes are white.

THE GREEN-VEINED WHITE BUTTERFLy. PIERIS N.API.

(Plate LIV. Figs. I, 2.)

Papilio napi, Linm. Syst. Nat. (ed. x.) i. p. 468, no. 60 ( 75 S) ;

id. Faun. Suec. p. 27 I ( т б I) ; Esper, Schmett. i. (I) p.

57, pl. 3, fig, 3 (1777); Hübner, Eur. Schmett. i. figs. 406, 407 ( $1 \mathrm{So} 3$ ?).

Pieris napi, Godart, Enc. Méth. ix. p. I6r, no. I45 (ISI9);

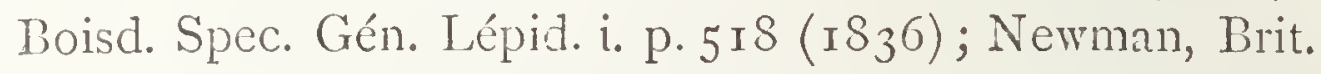
Butterflies, p. I60 (ISSI) ; Kirby, Eur. Butterflies and Moths, p. 7, pl. 4. fig. 5 ( 878 ); Lang, Butterflies Eur. p. 3I, pl. 7, fig. I, pl. I 5, fig. 3 (r88 I); Barrett, Lepid. Brit. Isl. i. p. 24 , pl. 3 (I892); Buckler, Larvæ of Brit. 
Lepid. i. pp. 20, 156, pl. ii. fig. 4 (IS86); Rye, Brit.

Macro-Lepid. i. p. I3, pl. iii. figs. I-5 (I895).

Pontia napi, Stephens, Ill. Brit. Ent. Haust. i. p. 20 (1827).

Var. P. bryonice.

Var. Papilio bryonice, Ochsenheimer, Schmett. Eur. i. (2) p. I5 I (1808).

Pieris bryonia, Godart, Enc. Méth. ix. p. I62, no. I46 (г819). Papilio napi, var. Esper, Schmett. i. (2) p. 87, pl. 64, figs. 3-5

( 783 ) ; Hübner, Eur. Schmett. i. fig. 407* (I 803 ?).

Pieris napi, var. bryonice, Lang, Butterflies Eur. p. 32, pl. 7, fig. 2 (I88I).

\section{Var. P. napiea.}

Var. Papilio napree, Esper, Schmett. i. (2) p. i I9, pl. i i6, fig.

5 (1800?); Hübner, Eur. Schmett. i. fig. 664, 665 (18 I8?). Pontia napae, Stephens, Ill. Brit. Ent. Haust. i. p. 2 I (I827).

The Green-veined White is as widely distributed as the other species of Pieris, but is not quite so abundant, and is perhaps rather more fond of lanes and clearings in woods. It is also very variable, and like the other species, is found throughout the summer, being at least double-brooded.

It is about the size of $P$. rapa, expanding from an inch and a half to nearly two inches. The wings are white, with the base blackish, and the tip of the fore-wings and a spot towards the end of the costa on the hind-wings brown or blackish. The male has a black spot on the disc of the forewings, and the female has two. On the under side the tips of the fore-wings, and the hind-wings are sulphur-yellow, with the nervures more or less strongly incrassated with dusky-green. In the female the two black spots on the disc are reproduced.

This is an extremely variable insect, and one of its forms ( $P$. sabellice, Stephens) will be considered separately. Another form, P. napace (Esper), is larger than the typical form, the 
markings are blacker than usual, and on the under side of the hind-wings, which are rather pale, only the three first nervures are dilated and greenish, the rest being short and blackish. P. bryonia, (Ochsenheimer) is of a deep smoky-yellow, much irrorated with black, and with the nervures and spots dilated. It is an Alpine race, of the female, common in the Swiss Alps;

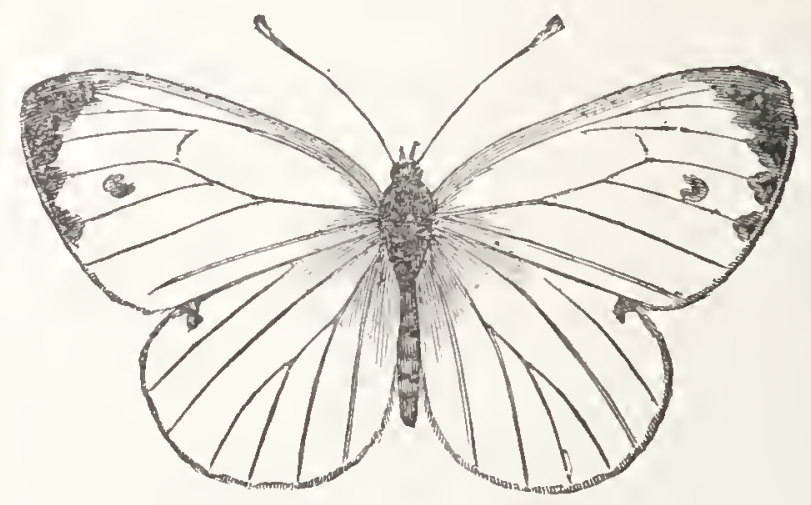

Upper side of male.

but specimens approaching it are sometimes met with in the North of Scotland and in some parts of Ireland.

The larva is dull green, paler on the sides, and with yellowish stigmata. It is covered with white warts, tipped with black, and tufted with short hairs. It feeds on various Cruciferce, and especially on watercress. The pupa is greenish-yellow, with prominent angles.

THE DUSKy-VEINED WHITE EUTTERfLy. TIERIS SAREI,LIC. (Plate LIII. Figs. 4, 5.)

Pontia sabeldice, Stephens, Ill. Brit. Ent. Haust. i. p. 2 I, pl. 3 , figs. 3, 4 (I $\$ 27)$.

This is a form of $P$. napi which occurs in Jume, and is not uncommon, but is no longer supposed to be a distinct species. It expands about an inch and three-quarters. The wings are shorter and more rounded than in typica! $P$. napi, the forewings approaching those of Euchloe cardamines in shape. "It 
has the upper surface of all the wings of a yellowish-white, with broad dusky irrorated nervures, broadest towards the hinder margin. The male has the base of the anterior wings and a single irregular spot in the fourth marginal cell dusky. The female has the base and tips of the same wings, a spot in the fourth and sixth marginal cells, and the inner edge of the wings of the same colour. Both sexes have a similarly-coloured spot on the upper margin of the posterior wings above. Beneath, all the wings are adorned with very broad dusky nervures, varying in different specimens, and the dilated nervure on the upper edge of the discoidal cell is destitute of the insulated yellow spot which every specimen of $P$. napi that has passed under my examination possesses" (Stephens).

\section{GENUS PONTIA.}

Pontia, Fabricius, in Illi ̧er, Mag. Insekt. vi. p. $2 S_{3}$ (1807); Curtis, Brit. Ent. i. pl. 48 (I 824 ). Synchloe, pt. Hübner, Verz. bek. Schmett. p. 94 (18 16) ; Kirby, List Brit. Rhop. p. т $\left(\mathrm{I}_{5} \mathrm{~S}\right)$; Butler, Cist. Ent. i. pp. 38 , 5 I (1870); Schatz, Exot. Schmett. ii. p.6 I (1886). Mancipium, pt. Stephens, Ill. Brit. Ent. Haust. i. p. 22 (IS27); Duncan, Brit. Butterflies, p. I 24 ( $S_{35}$ ).

Antennæ with a well-marked club; sub-costal nervure with only three branches; lower disco-cellular nervules much straighter than in Pieris; wings white, the hind-wings marbled with green beneath.

A small genus, almost confined to Europe and Northern and IVestern Asia. One species, P. callidice (Esper), is a thoroughly mountain form, reaching the height of 8,000 feet in the Alps, and 16,000 in the Himalayas. It may be known by the dull green colour of the hind-wings beneath, with white sagittate spots. 
THE BATH WHITE. PONTIA DAPLIDICE.

$$
\text { (Plate LIV. Figs. } 3 \text { đ, 4, 5?.) }
$$

Papilio daplidice, Linn. Syst. Nat. (ed. x.) p. 468, no. 62 ( $75^{8}$ ) ; Esper, Schmett. i. (I) p. 62, pl. 3, fig. 5 ( ( 777 ) Hübner, Eur. Schmett. i. figs. 4I4, 4I5 (1803?); figs. 777,778 (1825).

Pieris daplidice, Godart, Enc. Méth. ix. p. I28, no. 29 (1829); Boisduval, Spec. Gén. Lépid. i. p. 544, no. I 54 (1836); Newman, Brit. Butterflies, p. I58 (I88 I) : Kirby, Eur. Butterflies and Moths, p. 7, pl. 4, fig. 6 (1878); Lang, Butterflies Eur. p. 33, pl. 7, fig. 4 (188I) ; Barrett, Lepid. Brit. Isl. i. p. 26 , pl. 4, figs. I, I $a-d$ (I892); Buckler, Larvæ of Brit. Lepid. i. p. 21, pl. 3, fig. I (1886); Rye, Brit. Macro-Lepid. i. p. I 4, pl. iii. figs. 6, 7 (1895).

Pontia daplialice, Curtis, Brit. Ent. i. pl. 48 (1824); Stephens, Ill. Brit. Ent. Haust. i. p. 22 ( $\mathrm{I}_{27}$ ). Papilio edusa, Fabricius, Gen. Ins. p. 255 (1777). Var. Papilio bellidice, Brahm, in Illiger, Mag. Insekt. iv. p. 362 (1805); Ochsenheimer, Schmett. Eur. i. (2) p. 354 (r So8). Papilio belenida, Hübner, Eur. Schmett.i. figs.93 I, 934 (I 84 I ?). Pieris daplidice, var. bellidice, Lang, Butterflies Eur. p. 34, pl. 8, fig. I ( ISS I).

The Bath White is common in many parts of Europe, the Mediterranean Region generally, and Northern and Western Asia, but it is commonest in the South. Although it has long been known as an occasional inhabitant of most of the southern counties of England, it has always been of extreme rarity with us. It is found in May and August, but the spring brood is much less frequently met with in Central Europe than the autumn brood. It has a heavier flight than the species of Pieris, and is fond of resting on low flowers on waste ground, or in stubble fields. It derives its name fron a young lady having once executed a piece of needlework on which she 


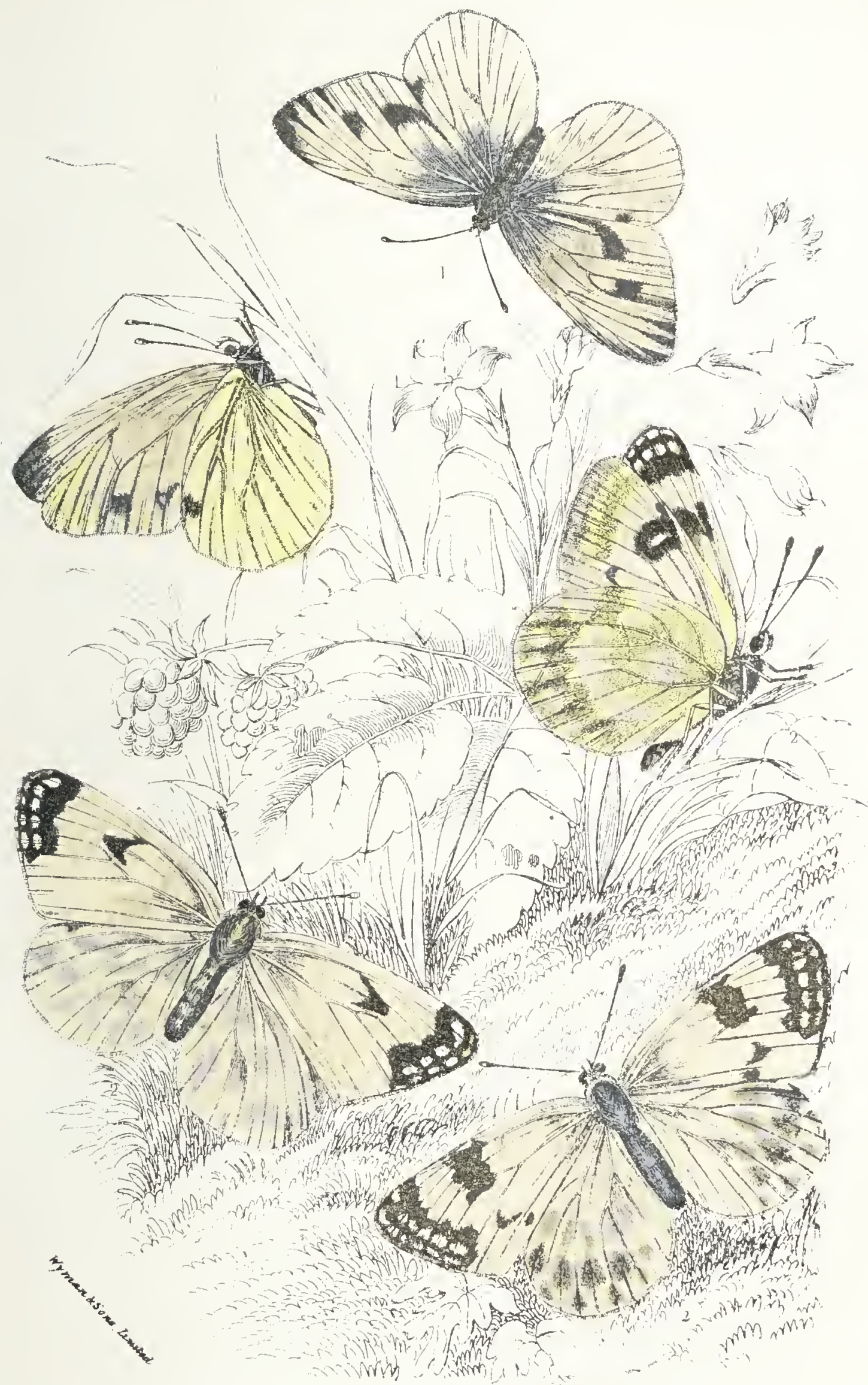

1.2. Pieris napi

3.5. Pontia daplidice 

represented a specimen of the Butterfly which had been taken at Bath. In recent times more specimens appear to have been captured about Dover than anywhere else in England, which lends colour to the surmise that most of the so-called "British" specimens were blown over, or otherwise introduced, from the Continent.

This Butterfly measures about an inch and three-quarters across the wings, which are white above, with a marginal black band on the fore-wings, spotted with white, running from the apex to below the middle of the hind-margin. Near the hinder angle is usually a detached black spot, largest in the female, and a broad black band, divided by a white line, runs from
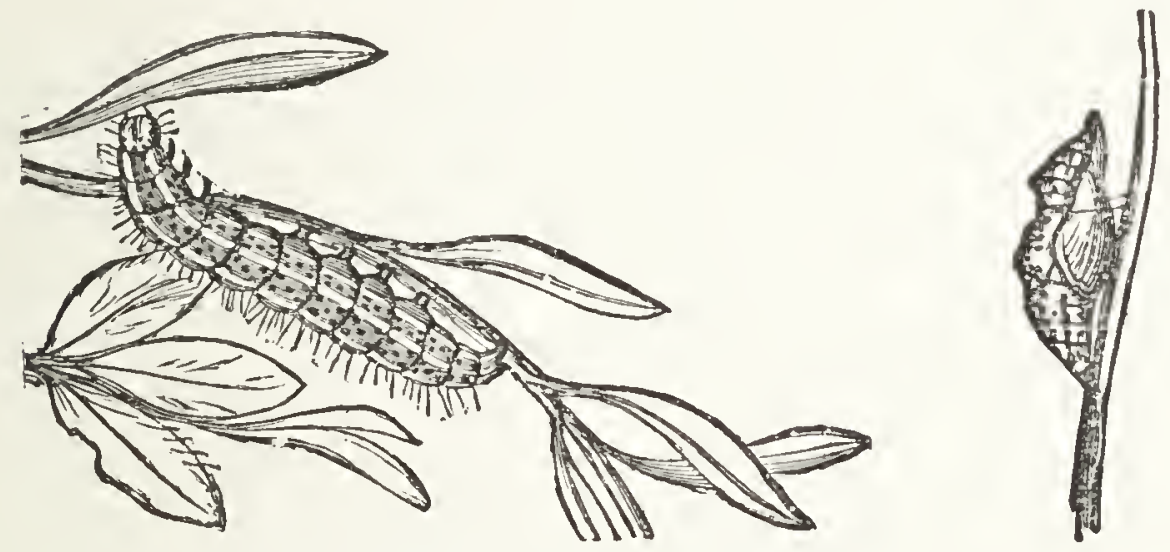

Larva and pupa of $P$. daplidice.

the costa just beyond the end of the cell. The hind-wings are unspotted in the male, except for the markings of the under side showing indistinctly through, but are usually more or less heavily bordered with black in the female, with a row of white spots between the broad dusky nervures. The fore-wings beneath are coloured as above, except that the dark markings are greenish. The hind-wings are green beneath, varied with yellowish, and dusted with black, with a row of large white spots on the hind-margin, an irregular transverse white band, and three white basal spots. The spring brood, $P$. bellidice, has the dark sub-marginal band narrower, and more interrupted 
with whitish. The spot towards the hinder angle of the forewings is absent, and the hind-wings are less varied with yellow beneath, and consequently greener.

The larva is dull blue, yellowish on the sides, and dotted with black. The head is green, spotted with yellow. It feeds on wild mignonette (Reseda lutea) and allied flants. The pupa is at first greenish, but afterwards grey.

\section{GENUS MESAPIA.}

Mesapia, Gray, List I.epid. Ins. Brit. Mus. i. p. 92 (1856); Schatz, Exot. Schmett. ii. p. 59 (1886); Kirby, Entomologist, xxvii. p. IоI (1894).

Here I propose to insert some very aberrant mountain genera from the Himalayas and Central Asia, about which but little is known at present. Mesapia was for some time supposed to be one of the Equitida allied to Parnassius; but Schatz referred it provisionally to the Pieride; and an examination of the essential characters proves it to possess bifid claws, and an internal nervure on the hind-wings. Mesapia resembles the genera Aporia and Metaporia in neuration, but the density of the scaling, and the hairy fringes of the wings will distinguish it from the former; and the long hairs at the base of the wings, the very long club of the antennæe, and the peculiarities of neuration will amply separate it from both. I reprint here my description of the genus and species in full. "Palpi long, rather pointed; antennæ long, moderately stout, with a large but gradually formed pyriform club. Body and base of wings clothed with very long slender hairs; fringes with shorter hairs; claws of front tarsi distinctly bifid; wings short, rounded, densely scaled, the fore-wings very broad, subtriangular; costal nervure about two-thirds of the length of the wing; sub-costal nervure four-branched, the first branch emitted 
at about three-fourths of the length of the cell, and running obliquely to the costa, the second emitted at or a little before the end of the cell, and slightly arched, the third emitted a little beyond the cell, and running to the costa just before the apex, the fourth emitted about half-way between the end of the cell and the apex, and running to the hind-margin just below the latter. Disco-cellular nervules oblique, the discoidal and median nervules nearly straight. Hind-wings with the upper sub-costal nervule eritted at half the distance between the base and the upper disco.cellular nervules, the nervules running to the hind margin straight, and at nearly equal distances apart; a well-marked basal cell ; two sub-median nervures."

\section{MESAPIA PELORIA.}

Pieris peloma, Hewitson, Exot. Butterflies, i. pl. 2, figs. I5, I6 ( 1853 ).

Mesapia peloria, Kirby, Entomologist, xxvii. p. Ior (I 894). Aporia lama, Alpheraky, in Romanoff's Mém. Lépid. ii. p. 404 (1887).

Greenish-white, with the nervures broadly margined with grey, and grey spots on the nervures on the hind-margin of the hind-wings. Under side of hind-wings yellowish-white, tinged with orange, with all the nervures strongly bordered with brown, as is also a fold so strongly marked as to look like an additional sub-median nervure below the median; costal area and basal cell orange.

The Butterfly measures an inch and a half across the wings. It is found at a great elevation in the mountains of Chinese Tartary and N.E. 'Thibet.

This is the only known species of the genus. Mesafia share $\ddot{i}$, Bates, from Yarkand, is also a true Pierid, but it is the 
type of the genus Baltia, Moore, which differs from all the genera allied to Pieris and Aporia by the very large club of the antennæ, and the short, broad, hind-wing cells, which are almost truncated at the end, and scarcely angulated. Mr. Moore has described a second species of Baltia from Lahore, under the name of Synchloe butleri. The references to these species are as follows :-

\section{BALTIA SHAWII.}

Mesapia shazeii, Bates, in Henderson and Hume, Lahore to Yarkand, p. 305 (1873).

Baltia shazeii, Moore, and Yarkand Exped. Lepid. p. 3, pl. I, fig. 5 (1879); Kirby, Entomologist, xxvii. p. 100 (I894).

Pieris shaweii, Groam-Grshimailo in Romanoff's Mém. Lépid. iv. p. 222 , pl. Io, figs. $2 a, b$ (1890).

\section{BALTIA BUTLERI.}

Synchloe butleri, Moore, P. Z. S. I882, p. 256, pl. i I, figs. $6,6 a$.

These specics are white, with blackish apical markings, and have much more superficial resemblance to Pontia than to Mesapia.

\section{GENUS DAVIDINA.}

Davidina, Oberthür, Études d'Ent. iv. pp. I9, 108 (I878); Schatz, Exot. Schmett. ii. p. 59 (I 886); Leech, Butterflies of China, p. 474 (1893).

The type of this genus is a very remarkable Butterfly, found at a great elevation in the mountains of Central China. The genus is imperfectly known, and I will therefore only characterise it here as far as the figures enable me to do so.

Palpi long; antennæ about one-third as long as the costa of 
the fore-wings, apparently with a long gradually formed fusiform club; wings moderately broad, oval, rounded at the tips, with long cells of nearly equal length; hind-wings nearly as long as the fore-wings. Costal nervure about two-thirds of the length of the costa; sub-costal nervure five-branched, the first branch emitted just before the end of the cell, the second a little beyond, nearly parallel to it, the third emitted a little beyond it, and slightly diverging from it, the fourth and fifth forming a rather large fork at the extremity of the wing. The discoidal nervules both rise from the end of the cell, and from the base of the median nervure rises a well-marked nervure in the cell, which forks in the middle, the upper branch reaching the end of the cell between the discoidal nervures, while the lower one is continuous with the upper median nervule. Hind-wings with a similar forked nervure in the cell, and ap. parently with three sub-median nervures, the two lowest confluent for a short distance from the base.

It is not quite clear whether the forked cellular nervure and the third sub median nervure are true or false. If perfect, the structure is very remarkable; if false, we meet with a wellmarked false third sub-median nervure in most of the allied genera of Pierida, and sometimes with obsolete traces of neuration in the cell. In certain families of Moths (Zeuzerida, \&c.) the cell is still divided by nervures; but, with the possible exception of Davidina, this character has become almost obsolete in Butterflies.

\section{DAVIDINA ARMANDI.}

Davidina armand, Oberthür, Études d'Ent. iv. pp. I9, ro8, pl. 2. fig. I (I879); Leech, Butterflies of China, p. 474 , pl. 33, fig. 9 (1893).

The Butterfly measures about two and a quarter inches across the wings, which are yellowish-white, suffused with blackish 
along the llack nervures and along the hind-margin; the fringes are also black. On the under side the wings are yellowish-grey, with black nervures.

This genus, like Mesapia and Baltia, was originally placed in the Equitide. D. armandi flies among the rocks after the manner of Parnassius, to which these three genera have been thought to be allied.

\section{GENUS METAPORIA.}

Metaporia, Butler, Cist. Ent. i.pp. 38, 5 I ( IS70).

Front-wings sub-pyriform, second sub-costal nervule not so near end of cell as in Apuria; upper disco-cellular oblique, nearly as long as lower, which is perpendicular and feebly arched; second and third median branches rather near together. Hind-wings sub-pyriform, the cell broader and less pointed, disco-cellulars of equal length, the upper oblique, the lower less so. Body moderately hairy; palpi slender, hairy beneath ; antennæ with distinct flattened club (Butter).

This genus contains a number of Indian Butterflies, more or less pale in the cells of the wings, and broadly dark along all the nervures. The type is $M$. agathon (Gray), from North India, a Butterfly of about three inches in expanse, which might either be described as white, with black spots widely separated by the nervures and a transverse black band beyond the cell; or black, with the cells and intermediate spaces beneath white, and a double series of long spots beyond.

\section{GENUS PERRHIBRIS.}

Perrhybris, Hübner, Verz. bek. Schmett. p. 9г (I8I6) ; Herr.Schäff. Corresp. Blatt. Regensb. xxi. pp. I04, I 27 (IS67); Schatz, Exot. Schmett. ii. p. 6i (i 886). Pieris, pt. Butler, Cist. Ent. i. pp. 37, 49 (1870). 
A Tropical American genus, with moderately long wings, and the sub-costal nervure three-branched (or, rarely, four-branched). Sexes dissimilar, the males white above, with black borders, and the females resembling species of Heliconius, Lycorea, \&c., as do also the males to some extent, on the under surface of the hind-wings. The type is

\section{PERRHYBRIS PYRRIA.}

\section{(Plate LV. Figs. $40 \hat{\delta}, 5 \%$.}

Fapilio pyrrha, Fabricius, Syst. Ent. p. 464, no. 95 (1775);

Cramer, Pap. Exot. i. pl. 63, figs. A, B (I 775).

Papilio iphigenia, Schulzens, Naturforscher, ix. p. 1о8, pl. 2

( 1776 ); Fabricius, Gen. Ins. p. 256 (I777); Donovan,

Nat. Rep. iii. pl. 8 I (1825).

Pieris pyrrha, Godart, Enc. Méth. ix. p. I56, no. I29 (I819);

Boisd. Spec. Gén. Lépid, i. p. 440 (1836).

Pieris iphigenia, Godart, Enc. Méth. ix. p. I56, no. I29 (I819). Perrhybris eieidias, Hübner, Samml. Exot. Schmett. ii. (I824), Perrhybris pyrrha, Staudinger, Exot. Schmett. i. p. 36, pl. 20 (1884).

\section{Fenale.}

Papilio pamela, Cramer, Pap. Exot. iv. pl. 319, fig. A (1780). Pieris pamela, Godart, Enc. Méth. ix. p. 156, no. rзr (I8r9).

This is a common Tropical American species, measuring about two inches and a half in expanse. In the male the wings are white above, with the tip of the fore-wings triangularly black to below the middle of the hind-margin, above which it is deeply indented by the white ground-colour. The hind-wings have a rather narrow black band on their lower half. The fore-wings are coloured beneath as above; the hind-wings are white, tinted with pale yellowish towards the base, and with three black bands running from the base and inner-margin far 
into the wings; the first costal narrow, the second and third broader, parallel, the second running from the base of the innermargin, and the third parallel to it below, and separated from it by a red band; the fourth broader than above, and covering the lower half of the hind-margin to the anal angle; the nervures above it are also expanded into blackish triangular spots on the margin. The female is black, tawny, and yellow. On the fore-wings the lower part of the cell is tawny, separated from the costa by a black band, expanding at the end, and from the tawny lower part of the wing by a black band running from the base, and curving round as far as the outer half of the innermargin; this again is separated from the black apex by a broad irregular yellow band, running somewhat obliquely-from the costa. The hind-wings are tawny, with the costa narrowly, and the hind-margin broadly, black; between them is a short black streak. The fore-wings are coloured beneath nearly as above, but are paler, and the black markings are less extensive; the hind-wings are coloured nearly as in the male, but the pale portion of the wing is more strongly tinged with yellow, and the hind-margin is broadly bordered with black, as on the upper side of the female.

\section{GENUS MYLOTHRIS.}

Mylothris, Hübner, Verz. bek. Schmett. p. 90 (1816); Butler, Cist. Ent. i. pp 34, 42 (I870); Schatz, Exot. Schmett. ii. p. 6I (I886); Trimen, S. Afr. Butterflies, iii. p. 28 (is89).

Antennx moderately long, with flattened club; palpi long, slender, hairy beneath; sub-costal nervure three-branched, the first two branches emitted before the end of the cell. Wings ample, delicate, of a silky white or yellow (often more or less orange at the base) with round black spots at the ends of the 
nervures, generally coalescing into a band at the tip of the fc:e-wings. Larva clothed with short hairs.

Pupa.- "Head with frontal process large and curved upwards; a dorsal series of prominent tubercles (larger on thorax) along middle line of back, and two laterally-projecting claw-shaped processes on each side of the basal half of abdomen" (Trimen).

The type of this genus is the West African M. rhodope (Fabricius), in which the male has yellow fore-wings and white hind-wings; and the female is white, with a reddish spot at the base of the fore-wings. The hind-margins are spotted with black on the nervures, and the tip of the fore-wing is narrowly bordered with black.

\section{GENUS BELENOIS.}

Belenois, Hübner, Verz. bek. Schmett. p. 92 (ISI6); Butler, Cist. Ent. i. p. 50 (I870); Schatz, Exot. Schmett. ii. p. 6 I (I886).

Antennæ with an oval flattened club; wings shorter, broader, more scalloped, and more densely scaled than in the last genus; costa straight, and very slightly serrated. Sub-costal nervure of the fore-wings four-branched, the fourth branch well marked; disco-cellular nervules oblique, the lower one shorter on all the wings than the middle one.

The type is $B$. calypso, Drury, a common West African Butterfly. It measures from 2 to $21 / 2$ inches across the wings, which are white, with a broad black border, spotted with white on the under side of the fore-wings, and a black bar running from the base of the costa of the fore-wings, which is produced into a transverse bar at the end of the ceil. The hind-wings are tinged with ycllow beneath, and are bordered with a row of connected yellow spots, edged on each 
side by a row of black ones. There is also a round black spot at the end of the cell, which is sometimes visible above. In the male, the black marginal bands of the upper surface are incomplete and macular.

\section{GENUS SCIIATZIA.}

Eucheira (nec Dejean), Westwood, Trans. Ent. Soc. Lond. i. p. 44 (I 834); Butler, Cist. Ent. i. pp. 34, 42 (I870); Schatz, Exot. Schmett. ii. p. 62 (I 886 ).

Head and body very hairy, antennæ with a gradually-formed club; wings with very long cells; fore-wings triangular, rounded off at the angles; hind-wings oval, likewise much rounded; fore-wings with the sub-costal nervure four-branched, the two first branches emitted before the end of the cell, the third and fourth forming a long fork; upper disco-cellular nervule (rarely present in the Pieride) distinct, but short, so that the first discoidal nervure rises from the cell, and not beyond it.

The type is a Mexican species, remarkable for the gregarious nest-building habits of the larva; a habit which is somewhat uncommon in Butterflies, though more frequent in Moths.

It is necessary to change the name of the genus, on account of the Coleopterous genus Eucheirus, Dejean, and I have there fore been glad to name it after the late eminent Lepidopterist, Dr. Schatz, whose work on the families and genera of Butterflies is one of the most valuable contributions to systematic entomology that has ever appeared.

SCHATZIA SOCIALIS.

(Plate LV. Fig. 2.)

Euchira socialis, Westwood, Trans. Ent. Soc. London, i. p. 44, pl. 6 (I 835$)$; Staudinger, Exot. Schmett. i. p. 26 (4884). 



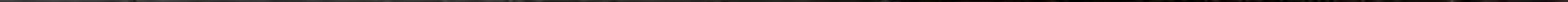


This Butterfly expands about two inches across the wings, which are blackish above, with a transverse row of greyishwhite spots running across the wings, and a row of smaller ones between these and the hind-margin ; there is also a large white spot at the end of the cell of the fore-wings. On the under side the wings are of a more brownish-black, with the white spots on the fore-wings much extended and confluent; on the hind-wings they are nearly obsolete.

The larvæ and pupæ live gregariously in a large bag-like nest of very strong silk, which is suspended to the branches of trees, and from which the caterpillars must make excursions in scarch of food, as in the case of Moths with similar habits. These cases appear more to resemble the nests formed by the gregarious larve of the African genus Anaphe, Walker (one of the Bombjces) than any others which have been described.

\section{GENUS ARCIIONIAS.}

Archonias, Hübner, Zutr. Ex. Schmett. iii. p. 19 (1825); Schatz, Exot. Schmett. ii. p. 63 (1 886). Euterpe, Swainson, Zool. Ill. Ins. ii. p. 74 (I 831 ); Boisduval, Spec. Gén. Lépid. i. p. 404 ( 1836$)$; Doubleday, Gen Diurn. Lepid. p. 33 (I847); Butler, Cist. Ent. i. pp. 34, $42(1870)$.

Body hairy; palpi and antennæ slender, the latter terminating in a flattened club; wings moderately broad and long, sub-costal nervure four-branched, the second branch emitted beyond the cell; cells long, rather narrow; disco-cellular nervules nearly straight.

The species of this genus are not very numerous. They inhabit tropical America, and mimic the genus of Equitidce called Priamides, by Hübner, which inhabits the same countries. The type is Archonias tereas (Godart). The species, 
which are very similar to each other, are black, with a white blotch on the fore-wings, and a broad scarlet band, more or less broken into spots, on the hind-wings, the under surface of which is paler, and marked with red spots at the base, and greenish-yellow spots on the hind-margin. The red band is present, but paler.

The allied genus Catasticla, Butler, differs little in structure, but has the second branch of the sub-costal nervure emitted from the end of the cell. The fore-wings are more pointed than in Archonias, the hind-margin being often slightly concave instead of curved, and the wings are more distinctly dentated. The Butterflies differ very much in appearance, however, being black, banded and spotted with white, yellow, buff, or some other pale colour.

\section{GENUS PEREUTE.}

Pereute, Herrich-Schäffer, Corresp. Blatt. Regensb. xxi. pp. I05, I3S (1867); Butler, Cist. Ent. i. pp. 34, 40 (I870); Schatz, Exot. Schmett. i.p. 63 (1886).

Antennæe long, terminating in a flattened club; wings ample, rounded, with the sub-costal nervure only three-branched, the lower disco-cellular nervule angulated.

The species are black, varied with bluish-grey, and spotted with red or yellow. They inhabit various parts of South America, and I have figured a species from New Granada, which is closely allied to the type of the genus.

PEREUTE LEUCODROSIME.

(Plate LV. Fig. I.)

Euterpe leucodrosime, Kollar, Denkschr. Akad. Wiss. Wien. Math. Nat. C1. i. p. 358, pl. 44, figs. 3, 4 (1850). Euterpe casarea, Lucas, Rev. Zool. I854, p. I94. 
This Butterfly measures rather more than two inches and a half across the wings, which are black above, with a broad red band, slightly cut by the nervures on the fore-wings, running from the costa obliquely across the outer part of the cell and the disc to the inner-margin, above the hinder angle. The basal area of the wings is bluish-grey towards the inner-margin of the fore-wings, and over the whole of the hind-wings to beyond the middle. There are some red spots at the base of the wings beneath.

$P$. callinice (Felder), from New Granada and Venezuela, which is the type of the genus Pereute, differs from P.leucodrosime in having only the hind-wings grey at the base above, and in wanting the red spots on the under side.

$P$. charops (Boisduval), from Mexico, has red markings only in the female; the male has diffused bluish markings on the fore-wings above; and beneath a yellow band running from the costa of the fore-wings, and then curving broadly across the wing to the hind-margin; and a yellow costal stripe on the hind-wings.

\section{GENUS DELIAS.}

Delias, Hübner, Verz. bek. Schmett. v. pp. 9I, 92 (1816); Butler, Cist. Ent. i. pp. 34, 40 (1870); Schatz, Exot. Schmett. ii. p. 63 (i 886 ).

Thyca, Wallengren, Oefv. Vet. Akad. Förh. Stockh. I858, p. 76 ; Wallace, Trars. Ent. Soc. Lond. (3) iv. p. 344 (1867).

General structure as in Pereute; wings generally longer ; subcostal nervure three-branched, the first branch emitted before the end of the cell; the cells long and narrow, the lower discocellular nervule on both pairs of wings straight and oblique; pre-costal nervule of the hind-wings curved outwards instead of inwards, as is the case in Pereute.

The larvæ are clothed with long detached hairs, and the 
pupæare armed with a row of strong spines on the ventral surface.

This is one of the most extensive and characteristic genera among those inhabiting the Indo- and Austro-Malayan Regions, to which it is exclusively confined. Notwithstanding its close structural affinity to Pereute, there is little outward resemblance between the genera; for Delias, notwithstanding the many forms which it assumes, has always the unmistakable appearance of a true Pierid. Most of the species are black above, varied with bluish-grey, and often marked with red or yellow at the base or on the hind-wings beneath; or they are white, more or less bordered with black, and with the hind-wings bordered beneath with a row of red, orange, or yellow spots, or banded with red. They have a weaker flight than would be supposed from their appearance, and are easily captured.

I will first discuss the species which I have figured to illustrate the genus, and will then proceed to notice some of the more interesting forms which are not figured in the present work.

\section{DELIAS BELISAMA.}

\section{(Plate LVIT. Fig. I.)}

Papiliobelisama, Cramer, Pap. Exot. iii. pl. 258, figs. A-D (1 779 ). Pieris belisama, Godart, Enc. Méth. ix. p. I47, no. Io4 (I \&I9); Boisduval, Spec. Gén. Lépid. i. p. 464 (1836).

This species, which is common in Java and Sumatra, measures about two inches and a half across the wings. The male is yellowish-white above, with the costa and apex of the fore-wings, and the hind-margin of the hind-wings rather broadly black. The female is ochreous-yellow, with very broad black borders. The under side of the fore-wings is black, with a whitish streak at the end of the cell, and a row of four or fve white or yellow spots towards the tip. The hind-wings are orange-yellow beneath, with a red streak, bifid at the end, at 
the base, and a black border, serrated on the inner side, and containing a row of rounded spots of the same shade as the ground-colour. The body is whitish or yellowish; antenna black. The larva, which feeds on a species of Discorea during the rainy season in Java, from December to February, is green and yellow, with very long separate hairs; pupa brown, with a row of black hooks on the ventral surfare.

DELIAS EUCHARIS.

(Plate LVI. Figs. I, 2.)

Papilio eucharis, Drury, Ill. Exot. Ent. ii. pl. Io, figs. 5, 6 (1 773 ); Cramer, Pap. Exot. iii. pls. 20 I, figs. B C; p. 202, fig. C ( I 782 ).

Papilio hyparete, Fabricius, Syst. Ent. p. 474, no. I 36 (I 775 ). Pieris epicharis, Godart, Enc. Méth. ix. p. I53, no. I22 (I 8 I9); Boisduval, Spec. Gén. Lépid. i. p. $45^{6}$ ( $183^{6}$ ).

Mancipium vorax Hyparete, Hübner, Samml. Exot. Schmett. i. pl. 136 ( 1824 ?).

This species, which must be well known to everyone who has seen a case of Butterflies from India, measures about three inches across the wings. The latter are of a slightly bluishwhite tint in the male, and yellowish-white in the female, with the nervures broadly black, except on the upper side of the hind-wings in the male. The marginal area is marked off by a transverse black line, outside which is a series of large oval spots, separated by the nervures. On the fore-wings these are of the ground-colour in the male, but tinged with yellow towards the tip in the female; on the hind-wings they are pink. The under side of the fore-wings is similar to the upper, except that the sub-marginal spots are more decidedly yellow, especially in the female; the hind-wings are yellow beneath, nearly to the sub-marginal line; and the sub-marginal spots are of a brighter red than above, and bordered with whitish. The body is white. 
The larva is reddish-brown, with long black detached hair (but shorter than in D. belisama), and a white collar, behind which is a black blotch dotted with white. The pupa is yellowish-green, with black markings on the dorsal surface, and strong black teeth on the ventral surface. The larva feeds on lime (citrus) and guava.

\section{DELIAS CæNEUS.* \\ (Plate LVI. Fig. 3.)}

Papilio ceneus, Iinn. Mus. Lud. Ulr. p. 27 I (I 764 ).

Papilio hyparete, var. (?), Linn. l. c. p. 247 (1764); Clerck, Icones, pl. $3^{8}$, fig. 3 ( 1764 ); Cramer, Pap. Exot. iii. pl. 2r6, figs. A, B (1779); iv. pl. 339, figs. E, F ( $178 \mathrm{r}$ ). Papilio plevaris, Donovan, Ins. New Holl. pl. i8, fig." 2 (I805). Pieris plexaris, Godart, Enc. Méth. ix. p. I49, no. п1о (1819). Pieris philyra, Godart, l.c. p. I50, no. I13 (I819); Boisduval, Spec. Gén. Lépid. p. 462 (1836).

This Butterfly, which measures rather more than two inches and a half across the wings, is common in Australia, Papua, Amboina, and Ceram. It is the type of Hübner's genus, Cathamia, which he regarded as distinct from true Delias.

The male is bluish-white above, with a black border, broadest at the tip of the fore-wings, which are crossed by a curved row of oval white spots. The female is nearly black above, but dull white towards the base, and with a series of white apical spots on the fore-wings, as in the male. The under side is black, with the base broadly yellow, dusted with black. On the fore-wings there is a white spot at the end of the cell, and a sub-marginal row of large yellow spots, largest towards the tip. The hind-wings have seven long reddish-brown spots beyond the middle, becoming lighter on the outer side. These are sometimes so extensive as to make the hinder part of the 


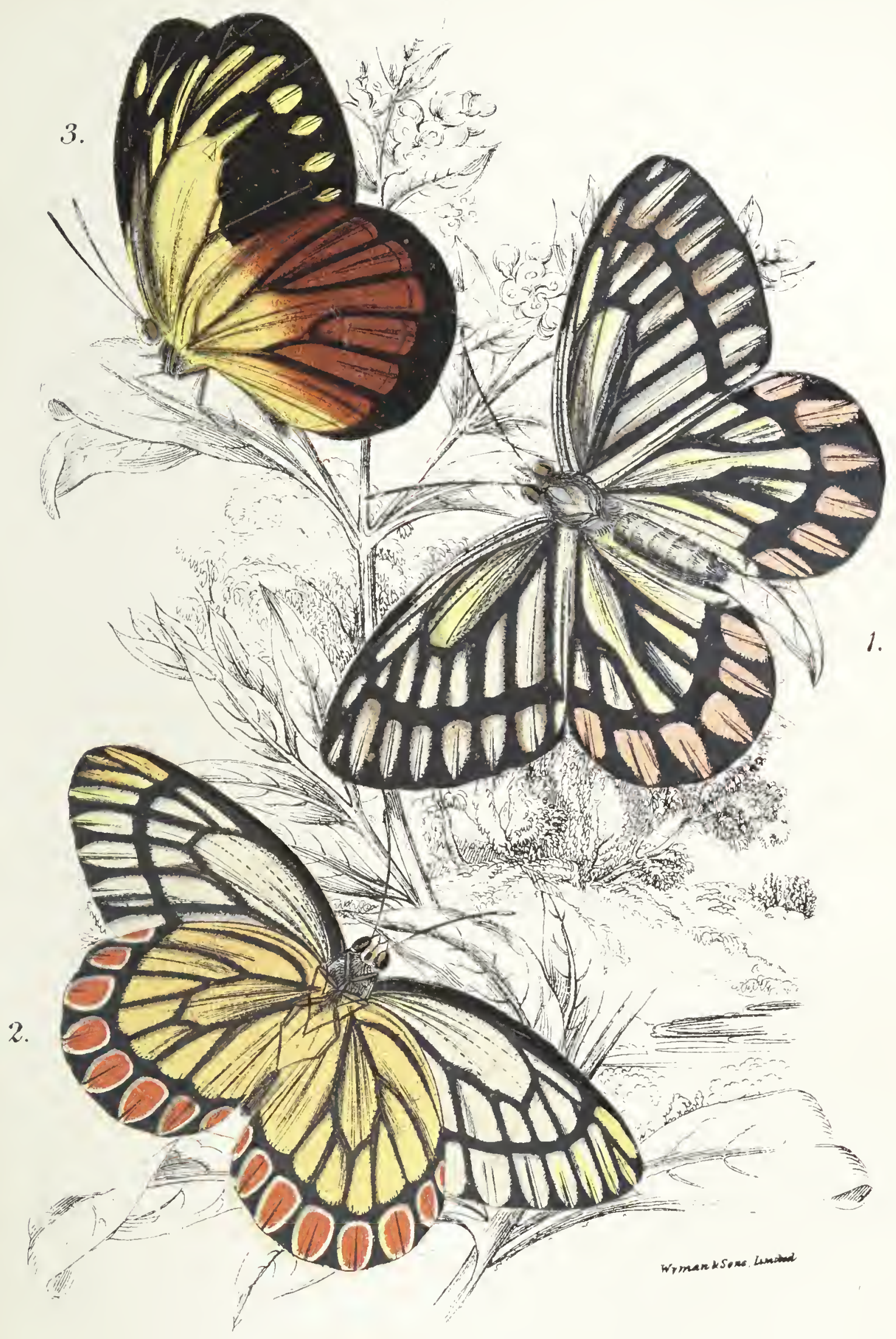

1.2. Delias eucharis.

3. "philyra. 

wing from the middle of the discoidal cell appear almost entirely reddish-brown, with broad black nervures, and a black border.

The type of the genus Delias is

\section{DELIAS EGIALEA.}

Papilio egialea, Cramer, Pap. Exot. ii. pl. I8y, figs. J), IE (I777); iii. pl. 256, figs. E, F (I 779 )

Pieris egialea, Boisduval, Spec. Gén. Lépid. p. 4jّo (1836).

Delias egialea, Staudinger, Exot. Schmett. i. p. 34, pl. 20 ( $188_{5}$ ).

This Butterfly, which is common in Java and Sumatra, measures two inches and a half across the wings, or a little more. The male is bluish-white, dusted with blackish at the base; the costa and apical half of the fore-wings (narrowing to the hinder angle), and a broad border to the hind-wings, are black; the inner-margin of the hind-wings is tinged with yellow, especially towards the anal angle. On the under side, the fore-wings are brown, with a white band, narrower and whiter than above; the hind-wings are red at the base, beyond which they are yellow, partly divided into spots by broad black incrassated nervures, and bordered with black. The female has black fore-wings, with a broad orange central band above and below; the hind-wings are white above, shading into yellow on the basal half, and black beyond; on the under side they resemble the male, except that the yellow portion is replaced by orange.

\section{Austro-Malayan Species (if I)elias.}

Some of these species are remarkably handsome. One of the most beautiful is $D$. aruna (Boisduval), which inhabits Papua and the Moluccass. It has broad wings, measuring up- 
wards of three inches in expanse. The male is of a rich orange above, with the hind-margins, the costa, and apical region of the fore-wings black; the under side is black, the forewings with a yellow sub-costal line from the base, a grey spot at the end of the cell, and a whitish dash on the inner-margin; the hind-wings have a broad red band near the base, interrupted along the sub-costal nervure. The female is black above, pale yellow towards the base, with the outer half of the cell of the fore-wings filled up with white both above and below. The forewings are coloured beneath as in the male, but are marked with a sub-apical row of white spots, represented by one or two detached spots on the hind-wings, which otherwise differ from the colour of the upper surface chiefly by possessing a red patch near the base of the costa.

Two very pretty, but rather smaller, species with black under sides, inhabit Australia. One of these is D. nigrina (Fabricius), which measures about $2 \mathrm{I} / 3$ inches across the wings. The male is white, with the tip of the fore-wings black, crossed by a row of white spots; the female has black fore-wings, with a row of grey sub-apical spots, and bluish towards the base on the innermarginal area; the hind-wings are bluish, with a broad black border. The under side is black; the fore-wings with a subapical macular yellow band, and the hind-wings with a red streak near the base of the costa, and a narrow curved red stripe running across the middle of the wing.

Delias aganippe (Donovan) is a larger insect; white, with broad black borders, marked with large greyish-white blotches; on the fore-wings of the female are two large black spots. The under side is black and white, with blotches of orange and crimson. The larva is brown, with white spots and hairs, and feeds on the native cherry (Exocarpus).

Delias dorimene (Cramer) represents a different section of the genus. It is found in Ceram and Amboina, and measures 
about two inches across the wings. The fore-wings are blackish, with some sub-apical white spots, most distinctly seen beneath, where they are tinged with yellow, and the hind-wings are white above, with a black border, and yellow below, with a narrow and incomplete black border, spotted with yellow.

\section{GENUS PRIONERIS.}

Prioneris, Wallace, Trans. Ent. Soc. Lond. (3) iv. p. $38_{3}$ ( $\mathrm{IS}_{7}$ ); Butler, Cist. Ent. i. pp. 33, 39 (1870) ; Schatz, Exot. Schmett. ii. p. 64 (1886).

The Butterflies of this genus resemble Delias, but the subcostal nervure is four-branched, with the two first nervules emitted before the end of the cell. The wings are generally more pointed than in Delias, and the costa is strongly serrated in the males. Apart from other differences, Prioneris may be distinguished from Appias by the absence of an anal tuft.

The species are large and conspicuous, though not numerous, and are confined to India and the Indo-Malayan Islands. The type is,

\section{PRIONERIS THESTYLIS.}

Pieris thestylis, Doubleday, in Gray, Zool. Misc. p. 76 (1842); id. Gen. Diurn. Lepid. pl. 6, fig. 2 ( $\mathrm{I}_{47} 7$ ).

Prioneris thestylis, Wallace, Trans. Ent. Soc. Lond. (3) iv. p. I94, no. I (1867); Staudinger, Exot. Schmett. i. p. 35, pl. 20 ( 1884$)$.

\section{Fenale.}

Pieris seta, Moore, Cat. Lepid. Ins. Mus. E. I. Co. i. p. $7 S$ (1857) ; id. Proc. Zool. Soc. Lond. I 857 , p. Io2, pl. 44, fig. 3 .

A large and handsome Butterfly, with rather pointed wings, expanding from three to four inches; it inhabits North India. 
The male is white above, with the costa, apical third, and hindmargin of the fore-wings black, marked with long white spots and streaks between the nervures. The hind-wings are white, with a narrower black border, containing round white spots, very narrowly separated from the ground-colour. On the under side of the fore-wings, the white portion is broken up into spots by the strongly incrassated black nervures, and the spots towards the apex are tinged with yellow. The hind-wings are black, with the inner-margin and the base of the costa broadly yellow, the cell filled up with yellow, and two rows of yellow spots beyond, one discal, and the other marginal.

We quote Mr. Moore's original description of the female, as it has been confounded with some of the allied species:

"Upper side blackish-brown; fore-wings with two rows of narrowish white marks; two lengthened marks between median and sub-median veinlets, and four small spots within discoidal cell ; hind-wings with a marginal row of whitish spots ; another row from anterior margin widening towards the anal angle; abdominal margin broadly whitish, the latter tinged with yellow; also white linear mark in discoidal cell. Under side as in the upper side, but with all the markings on the hind-wings yellow."

\section{GENUS APPIAS.}

Appicus, Hübner,Verz. bek. Schmett. p. 9 I (ris 6 ); Butler, Cist. Ent. i. pp. 37, 49 (I870); Distant, Rhop. Malay. p. 3 Iо (I 885 ).

Tachyris, Wallace, Trans. Ent. Soc. Lond. (3) iv. p. 36 I (I867); Schatz, Exot. Schmett. ii. p. 64 (rSS6).

This genus includes a considerable number of Indo-Malayan and Austro-Malayan species, distinguished by having the anal valves of the male elongated and provided with a tuft of long and stiff hairs at each side of the base beneath. "The species 
are of moderate size, and are, generally speaking, of uniform colours. The fore-wings are sub-triangular and rather pointed, with the sub-costal nervure four-branched; the hind-wings are oval, and rather produced towards the anal angle; larva hairy, and with four or six longitudinal rows of spines; pupa with two lateral spines" (Wallace).

This large genus includes several sections, which many writers are inclined to treat as of generic rank. The following species is the true type of the genus,

\section{APPIAS ZELMIRA.}

Papilio zelmira, Cramer, Pap. Exot. iv. pl. 320 , figs. C-D ( I 780 ).

This is an Indian Butterfly, measuring about two inches across the wings. The male is white, with the nervures, especially the branches of the sub-costal nervure, broadly black towards the hind-margin, or expanding into black triangular spots; on the under side of the hind-wings nearly all the nervures are black. The costa of the fore-wings is dusted with bluish-grey, especially beneath, and the base of the costa of the hind-wings is yellow beneath. The female is brown, with sub-marginal white spots, and two large white spaces on the fore-wings, and one on the hind-wings. On the under side, the nervures are not black as in the male. 'The fore-wings are greenish in the cell and towards the tips, with a black streak from the end of the cell meeting a black oblique sub-apical streak. On the hind-wings, the base of the costa is stained with orange, the hind-margin is yellowish-green, and a yellowishgreen band runs from the sub-median nervure near the base to the border, a little below the tip.

The type of the genus Tachyris, Wallace, is T. nero (Fabricius), from the Malay Peninsula and the adjacent islands. It measures about three inches across the wings, which are 
rather pointed, and are of a bright red, varying in tint above in different specimens of the male sex. On the under side they are more of an orangered, inclining to greenish-yellow on the costa of the fore-wings, and along the inner-margin and nervures of the hind-wings. The female is of a darker red above, with narrow irregular black borders, and an oblique black streak running outwards from the middle of the costa of the fore-wings; there are also some irregular blackish marks opposite the hindmargin on the fore-wings. Beneath, the fore-wings are tawny, with the costa greenish-yellow, and the apical region black, crossed by a whitish band; there are also some blackish markings towards the hinder angle; the hind-wings are reddish-grey, with an irregular dusky band.

There are several allied species, in which the upper side is red, blue, or brown, at least in the males. The female of $T$. zarinda (Boisduval), a Celebesian species, is dark brown, with a row of yellowish-white sub-marginal spots, and a broad white band within, crossing the lower part of the fore-wings and the upper part of the hind-wings. The male of these species is red, like that of $T$. nero, but the wings are still more acute.

In most species, the fore-wings are less pointed than in $T$. nero and its allies. They are frequently white, with black borders, and often with the hind-wings yellow beneath. These average about two inches in expanse. In some species, with pointed wings, the sub-costal nervure is only three-branched, either in both sexes, or in the female, the male being fourbranched, as in true Appias. These form the genus Salctara, Distant, the type of which is S. nathatia (Felder), from Malacca, Sumatra, Celebes, \&c. Other species, in which the fore-wings are less acute, and the hind-wings are varied, at least beneath, with yellow, orange, or green markings, form the genus Huphina, Moore. 


\section{GENUS MELETE.}

Melete, Swainson, Zool. Ill. Ins. ii. pl. 79 (I 833 ).

Daptonura, Butler, Cat. Fabr. Diurn. Lepid. p. 209 (1869); id. Cist. Ent. i. pp. 37, 50 (I870); Schatz, Exot. Schmett. ii. p. 64 (1886).

Palpi and antennæ long and slender, the latter with a gradually formed club; abdomen not tufted, but with a pair of strong anal hooks in the male; wings broad, the fore-wings somewhat produced at the tip, but not longer than the hindwings; hind-margin slightly concave; hind-wings somewhat oval. Sub-costal nervure four-branched, the two first branches emitted before the end of the cell; disco-cellulars of nearly equal length, the upper ones oblique, the lower straight.

This is a Tropical American genus much resembling some of the smaller species of Appias in size and shape, but with a peculiar facies which renders it easily recognisable. The Butterflies measure about two inches or a little more across the wings, which are of a white or yellow colour, with the hindmargins narrowly black. The costa is also narrowly black to the middle, and sends off a black bar across the end of the cell, at least on the under surface. There are several closelyallied species; in the type, M. fippantha (Fabricius), which is a Brazilian Butterfly, the fore-wings are white, and the hindwings are yellow.

\section{GENUS ELODINA.}

Elodina, Felder, Reise d. Novara, ii. p. 2 I 5 (I865); Butler, Cist. Ent. i. pp. 34, 40 (I 870 ) ; Schatz, Exot. Schmett. ii. p. 65 (1886).

Antennæ short, with a flattened club; fore-wings short, rather pointed; sub-costal nervure three-branched, the first branch emitted before the end of the cell; only the lowest 
disco-cellular nervule present on the fore-wings, the second discoidal nervule rising from the end of the cell; hind-wings rounded.

This genus is confined to Australia and the Indo-Australian Region generally, and includes a few silky-white species, more or less bordered with black (often only at the tips of the forewings), and measuring about an inch and a half across the wings. The type is E. egnatia (Godart), from Australia and the Moluccas.

\section{GENUS LEPTOSIA.}

Leptosia, Hübner, Verz. bek. Schmett. p. 95 (I8I6); Distant, Rhop. Malay. p. 287 (i 885 ).

Pontia, Boisduval (nec Fabricius), Spec. Gén. Lépid. i. p. 430 $\left({ }_{1} 8_{3} 6\right)$; Doubleday, Gen. Diurn. Lepid. p. 40 ( 1847$)$; Schatz, Exot. Schmett. ii. p. 65 (I 886). Nychitona, Butler, Cist. Ent. i. pp. 34, 4I (IS70).

Antennæ long, with a compressed spindle-shaped club; palpi very short; wings rounded at the tips; sub-costal nervure three-branched, with two branches emitted before the end of the cell, the second discoidal nervule rising from or close to the end of the cell.

A small but very well-marked genus, confined to the tropics of the Old World. The species measure about an inch and a half across the wings, which are white, with the tip of the fore-wings black, and generally a round black spot on the disc, opposite the middle of the inner-margin. The under surface of the hind-wings is more or less mottled with green. The insects have a very weak flight, and resemble Ieptidia sinapis in their habits. They have a superficial likeness to the litter species, except for the broader wings, and as in the Wood White, too, spotless forms of the species of Leptosia are sometimes met 


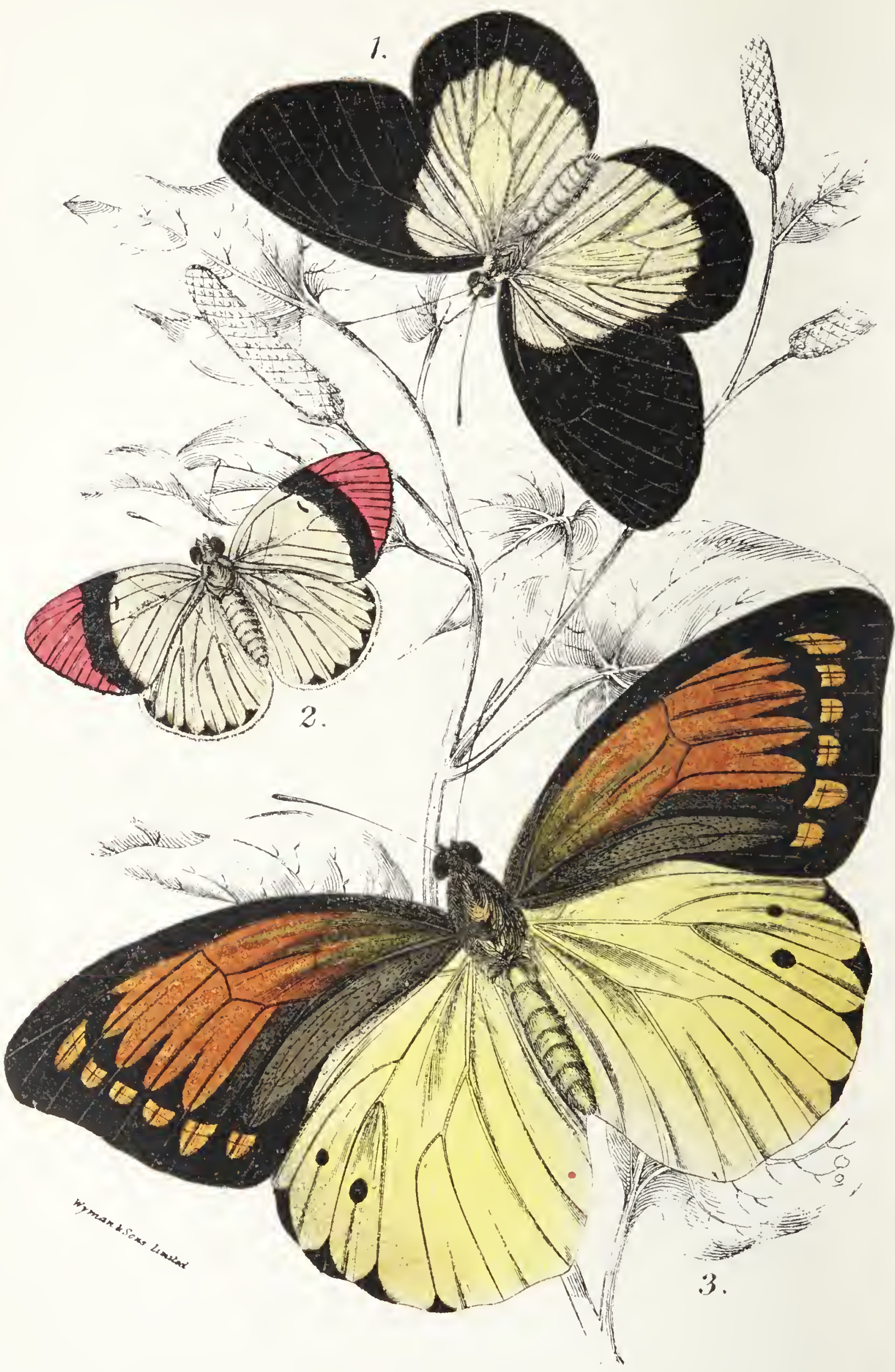

1. Delics belisama.

2. Callostune danià.

3. Hebomoir leucippe: 
with. The type is L. xiphia (Fabricius), a common East Indian species.

\section{GENUS LEUCIDIA.}

Leucialia, Doubleday, Gen. Diurn. Lepid. p. 77 (I 847 ); Butler, Cist. Ent. i. pp. 35, 43 (1870); Schatz, Exot. Schmett. ii. p. 66 (I886).

Antennæ with the club gradually formed; palpi very short, scaly, and bristly; wings rounded; sub-costal nervure fourbranched, the first joint emitted much before the end of the cell, the second a little beyond; sub-costal nervures of the hind-wings stalked.

This genus contains a few South American species. They are the smallest of the Pieride, scarcely measuring an inch across the wings. 'They are small white Butterflies, the type, L. elvina (Godart), being white or yellow, with the fore-wings narrowly bordered with black; another species, L. brephos (Hübner), is almost pure white.

On account of the resemblance presented by Leptidia to Dismorphia on the one hand, and to Euchloe on the other, we place here Schatz's Sub-family Dismorphince.

\section{SUB-FAMILY II. DISMORPHINAE.}

Antennx slender, with a gradually-thickened, spindle-shaped, or a suddenly-formed, distinct club. Palpi short, not reaching beyond the head, with short scales above and on the sides, and hairy in front. The middle and terminal joints are very small. The sub-costal nervure five-branched, the branches very short, and placed at equal distances. A pre-costal nervure present.

The species of this group are delicate Butterflies, with long wings. Most of the South American forms mimic species of Ithomiince. 


\section{GENUS LEPTIDIA.}

Leptidia, Billberg, Enum. Ins. p. 76 (r820).

Leptosia, pt. Hübner, Verz. bek. Schmett. p. 95 (1816); West wood, Butterflies of Great Britain, p. 28 (1855); Butler

Cist. Ent. i. pp. 39, 54 (1870).

Leucophasia, Stephens, Ill. Brit. Ent. Haust. i. p. 24 ( ${ }_{1} S_{27} 7$ ); Boisduval, Spec. Gén. Lépid. i. p. 428 ( 1836 ); Doubleday, Gen. Diurn. Lepid. p. 38 (1847); Schatz, Exot. Schmett. ii. p. 57 (IS86).

Leptoria, Westwood, Brit. Butterflies, p. 4I (184I).

Cells of the wings very short; sub-costal nervure fivebranched, all the branches emitted beyond the end of the cell ; first discoidal nervule emitted from the end of the cell ; antennæ short, slender, with a well-marked flattened club.

Wings narrow, elongate-oval, thickly clothed with scales.

This genus only includes a few species, much resembling each other, and is confined to Europe and Northern and Western Asia. It has a slight superficial resemblance to the African and Indian genus to which Dr. Scudder correctly restricts the name Leptosia, but this has much broader, shorter, and rounder wings.

THE WOOD WHITE. LEPTIDIA SINAPIS.

(Plate LVIII. Fig. 5.)

Papilio sinapis, Iinn. Syst. Nat. i. p. 468, no. 61 (1758); id. Faun. Suec. p. 27 I (I76I); Esper, Schmett. i. (I) p. 59, pl. 3, fig. 4 (I 777 ); Hübner, Eur. Schmett. i. figs. 4104 II (I 803 ?).

Papilio candidus, Retzius, Gen. Spec. Ins. p. 30, no. 4 ( 1789 ).

Pieris sinapis, Godart, Enc. Méth. ix. p. I55, no. I48 (18 8 9) 
Leucophasia sinapis, Stephens, Ill. Brit. Ent. Haust. i. p. 24 (1827) ; Boisd. Spec. Gén. Lépid. p. 429 (1836) ; Ne:wman, Brit. Butterflies, p. I54 (г88I); Kirby, Eur. Butterflies and Moths, p. 5, pl. 4, figs. $1 a-c\left(\mathrm{I}_{7} 8\right)$; Lang, Butterflies Eur. p. 45, pl. Io, fig. 4 ; pl. I 6 , fig. I (transf. ISS I) ; Barrett, Lep:d. of Brit. Isl. i. p. 30, pl. 5, figs. r, $\mathrm{I} a-c(\mathrm{IS} 92)$; Buckler, Larve of Brit. Lepid. i. p. 25, pl. 3 , fig. 3 (1886).

Leptoria candida, Westw. Brit. Butterflies, p. 32, pl. 6, figs. I I-I 3 (I 84 I).

Var. Papilis lathyri, Hübner, Eur. Schmett. i. figs. 797, $79^{8}$ ( I 8 I 8 ?).

Var. Leucophasia sinapis, var. diniensis, Boisduval, Gen. Ind. Méth. p. 6, no. 33 (1840); Lang, ut suprà, p. 46, pl. io, fig. 5 (I SS I).

Var. Pupilio erysimi, Borkhausen, Eur. Schmett. i. p. I32 ( I 788 ).

The Wood IVhite Butterfly is common throughout a great part of Northern and Western Asia, and is in many localities very abundant; but in North-western Europe, including England, Wales, and Ireland, it is extremely local, and has disappeared from many localities where it was formerly found ; in Scotland it is unknown. It has a low weak flight about bushes and open places in woods, but rarely strays far from the shelter of the trees. It is double-brooded, appearing from May to August.

It measures about an inch and a half across its long and narrow wings, which, together with its slender body, have been thought to give it somewhat the appearance of a Dragon-fly. The wings are of a milky-white above, with an ash-coloured blotch at the tip of the fore-wings ; on the under surface, the tip of the fore-wings and the under side of the hind-wings are greenish, mixed with scattered black scales. The whitest specimens are 
called $L$. diniensis, the greenest $L$. lathyri, and those in which the dark apical blotch is wanting, are called L. erysimi.

The larva is green, with a deep yellow lateral line. It feeds on Lotus coiniculatus, Lathyrus pratensis, Sc. The pupa is
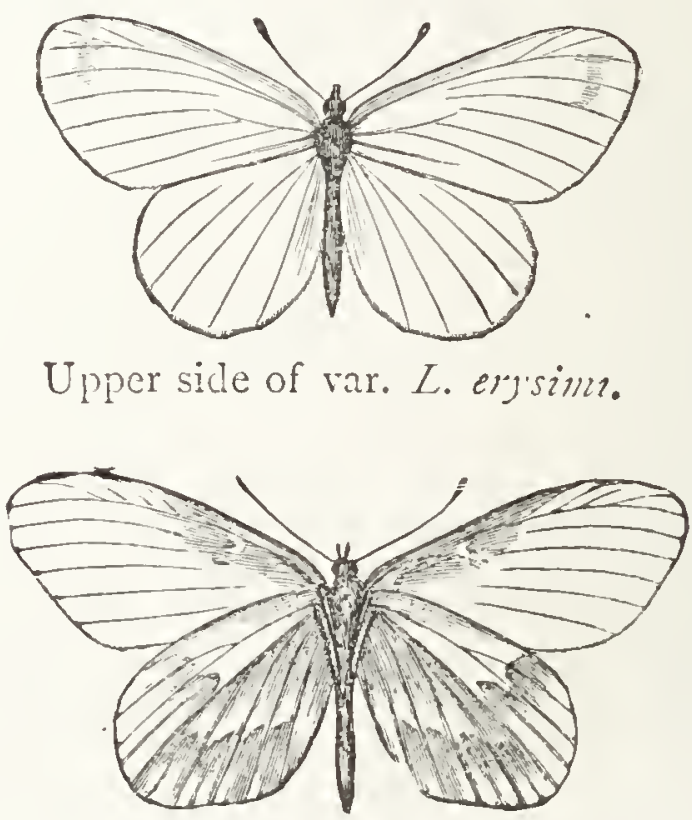

Under side of $L$. sinapis.

fusiform, of a greenish colour, with a ycllow strcak on the sides, and with white spots on the stigmata.

\section{GENUS DISMORPHIA.}

Dismorphia, Hübner, Verz. bek. Schmett. p. Io (r816); Butlcr, Cist. Ent. i. pp. 39, 54 (1870); Schatz, Exot. Schmett. ii. p. 57 (1886).

Leptalis, Dalman, Anal. Ent. p. 40 ( I $23_{3}$ ); Boisduval, Spec. Gén. Lépid. i. p. 4 1 $2\left(\mathrm{I}_{3} 6\right)$; Doubleday, Gen. Diurn. Lepid. p. 35 ( $1 S_{47}$ ).

Palpi very short; antennæ long and slender, very gradually thickening into a spindle-shaped club. Fore-wings generally long, rather narrow, and sometimes pointed; hind-wings long, sometimes very largely developed in the male, being not only 
much broader, but longer than the fore-wings. Cells long; sub-costal nervure five-branched; the first sub-costal nervure emitted before, at, or beyond the end of the cell, the others always beyond; the first discoidal nervure emitted from the cnd of the cell. Many of the species resemble various species of Ithomiince, or of the genus Actinote in the Acrcinc; but they vary much in form, and may easily be divided into several genera. Under the generic name Moschoneura, Dr. Butler has scparated some small species with oval wings, in which all the sub-costal nervules are emitted beyond the end of the cell, and the first discoidal nervule is emitted much beyond the end of the cell.

The type of Moschoneura is M. methy'mna (Godart), a Brazilian species, measuring nearly two inches across the wings, which are long, narrow, and rounded. They are yellow, with very broad, smoky black borders; on the inner side of the dark apical area is a broad oblique greyish band, whiter beneath. On the under side of the hind-wings the dark border bears an inner tawny and an outer stone-coloured marginal stripe.

More recently, Messrs. Godman and Salvin have given the following table of the genera into which they divide the Central American species :-

1. First sub-costal branch of the primaries united avith the costal.

a. First sub-costal branch of the primaries emitted beyond the end of the cell.

A. Sub-costal branch of the secondaries in the $0^{*}$ emitted far beycnd the end of the cell. (Type, Papilio amplioune, Cramer.) 
I. Sub-costal branch of the secondaries in the $\delta$ emitted at the end of the cell. (Type, Picris nomesis, Latr.)

Acmetopteron.

6. First sulb-costal branch of the primaries emitted at the end of the cell. (Type Papilio melite, L.)

ENANTIA.

D. First sub-costal branch of the brimaries frce. (Type, Pieris nehema, Boisd.)

Pseunopieris.

The type of Dismorphic is D. lais (Cramer), a rather scarce Butterfly from Surinam, which measures about two and onethird inches across the wings. The fore-wings are black, with a red bar from the base running along the upper part of the cell, and curving downwards at its extremity. There is another red band on the inner-margin, and a large red spot towards the hinder angle; there is also a yellow sub-apical band. On the hind-wings, the costal area is white, the middle of the wing red, and the marginal area black.

D. amphione (Cramer), which many authors regard as the type of Dismorphia, is very like the last species, and also occurs in Surinam; but the fore-wings are broadly streaked with red at the base, and they have a yellow band at the end of the cell, and some yellow sub-apical spots.

L. astynome, Dalman, the type of the genus Leptalis, resembles $D$. amphione, but has much longer and narrower wings, expanding from $2 \mathrm{I} / 2$ to $23 / 4$ inches. The fore-wings are black with a short sub-costal fulvous stripe, and a longer broad fulvous band towards the inner-margin; beyond is an oblique yellow band, and two yellow spots at the tip. The hind-wings are yellow in the middle, shading into fulvous, bordered with black 
above, below, and on the hind-margin; the costa is pale ycllow, and the lower border rusty-brown. It is a native of Brazil.

We have figured the following species of this genus :-

\section{DISMORPHIA EGAENA.**}

\section{(Plate LV. Fig. 3.)}

Leptalis egaena, Bates, Journ. Ent. i. p. 230 , no. 2 (1861); id. Trans. Linn. Soc. Lond. xxiii. p. 566, pl. 57, fig. 7 (i 862 ).

This specics was brought by the late Mr. Bates from Ega, on the river Ega or Teffe, a tributary of the Upper Amazon. It is remarkable for the close resemblance of the female to Mechanitis egaensis, Bates, a Butterfly found in the same locality. D. egaena measures from 2 to $21 / 2$ inches across the wings, which are long and narrow, except the hind-wings in the male. The fore-wings are black, with red longitudinal streaks towards the base, a large black discoidal spot, bordered within with red, and outwardly by the first of two oblique bands of yellow spots; the hind-wings are dull black, streaked with red on both sides of the median nervure and its branches in the female, but in the male only below it. In the male, the wing is light brown above the median nervure, and markcd with a very large white space, extending to the costa, but not to the hind-margin.

The type of Acmetopteron, Godman and Salvin, is $A$. nemesis (Latreille), a common species from Mexico to Bolivia and Venezuela, which measures from 2 to $2 \mathrm{I} / 2$ inches across the wings. The fore-wings are longer than the hind-wings, and are drawn out into a sharp point; the hind-wings are nearly rectangular in the female. In the male, the forewings are black, with the nervures yellowish at the base, and two oblique rows of greenish-yellow spots on the disc. The

- D. esraensis on plate. 
hind-wings have the costal area and cell silvery-grey, and the lower part of the wing yellow, edged above with black towards the base. In the female, the fore-wings are black on the costal area, and over the cell and beneath it creamy-yellow; an ob lique creamy-ycllow band crosses the wing beyond the cell, and there are two small yellow spots near the top; the hindwings are yellow, narrowly bordered with black.

The type of Enantia, Hübner, is E. licinia (Cramer), which is found in Surinam and on the Upper Amazon. The wings expand about two inches, and are somewhat oval. They are white, with narrow black borders in the male, and broad black borders in the female, and the hind-wings are yellow beneath, with two longitudinal dusky stripes. In the male the fore-wings are narrow, but in the female they are as broad as the hind-wings.

E. melite (Linn.), which Messrs. Godman and Salvin have taken as the type of Enantia, has rather narrow fore-wings, especially in the female; it measures two inches in expanse. In the male the fore-wings are orange, with a black band running from the base through the middle of the wing to the lower end of the black apical border; there are two yellow spots near the tip, and a black bar at the end of the cell. The hind-wings have a pale costa, and a black border. The female is yellow, with black borders to the fore-wings and sometimes to the hind-wings, and a black bar at the end of the cell on the fore-wings. 'The under side of the hind-wings is yellow, with two dusky stripes. It is common in South America.

The type of Pseudopieris, Godm. \& Salv. is P. nehemia (Boisduval), a common species in Mexico and South America. It measures about an inch and a half across the wings, and much resembles an immaculate Picris rafer, bo:h in size, shape, and colour, being of a greenish-white, very narrowly bordered with brown at the tips of the fore-wings. On the under side, the hind-wings and tip of the fore-wings are buff. 

1.
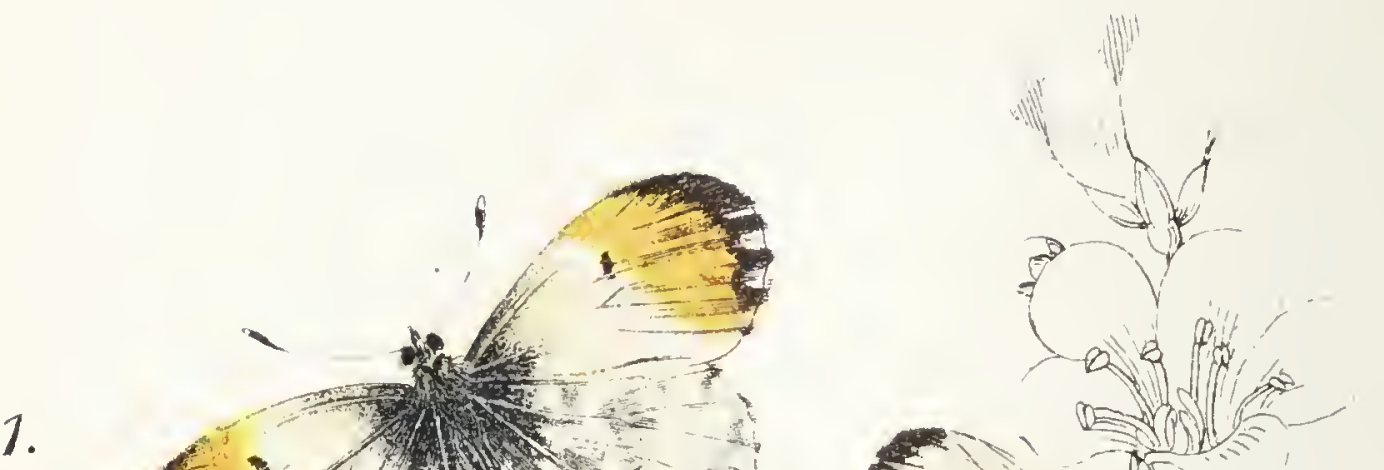

5.
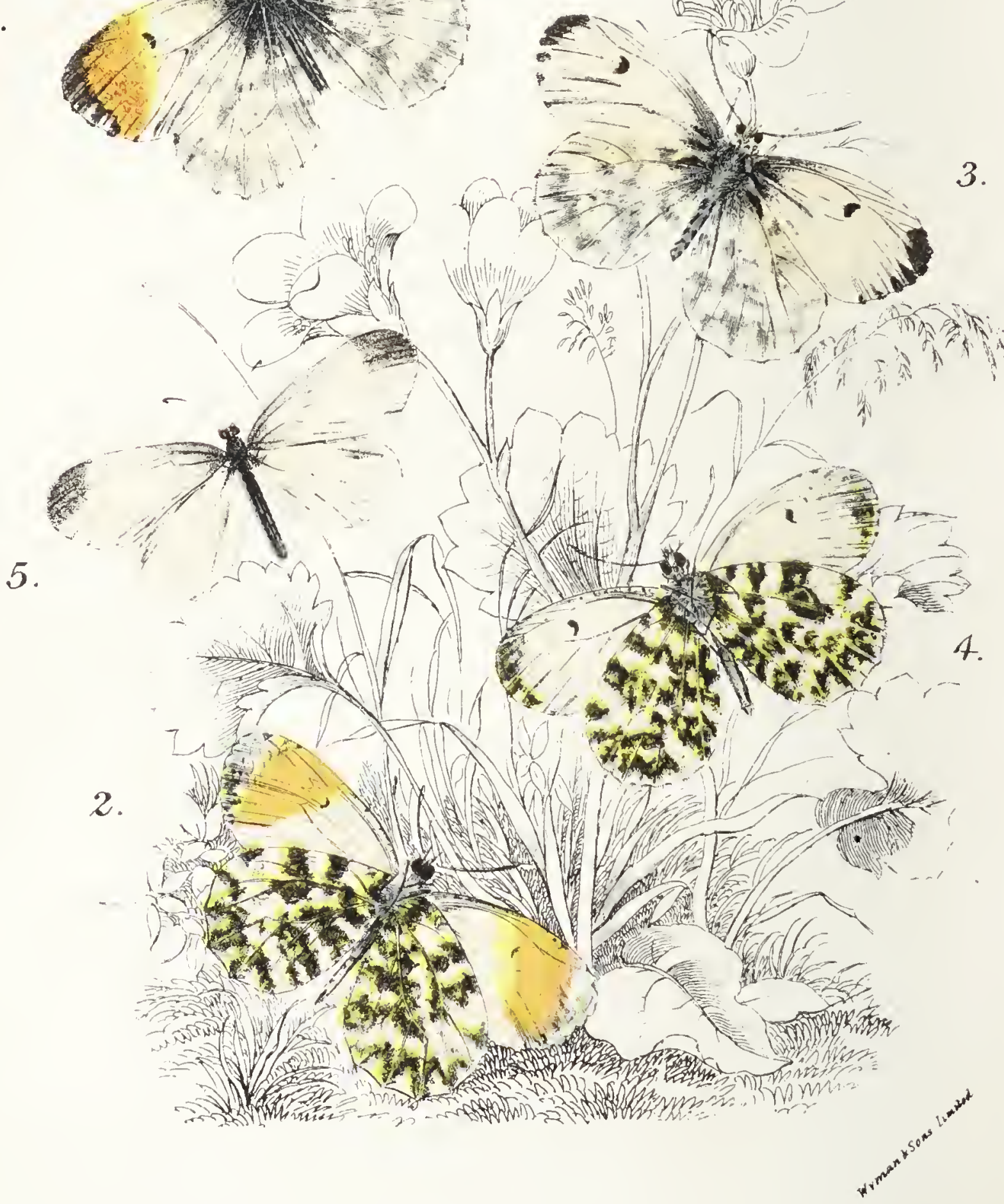

1. 2. Euchloe cardamines o

3. $4 . "$

5. Leptidia sinapis. 


\section{SUB-FAMILY III. ANTHOCHARINA.}

Antenne with a distinct club, rarely with a gradually-formed one. Palpi projecting beyond the head, with long, stiff hairs in front, but rarely scaly. Terminal joint pointed, generally shorter than the middle joint; in a few cases rounded. Subcostal nervure four- or five-branched. Pre-costal nervure always present.

Schatz calls this gro'lp "Chariden," but this is doubtless only an abbreviation of Anthocharis, and is the more objectionable because there is a genus Charis in the Lemoniida.

This Sub-family is less numerous in species than the typical Pierince, and the species are of moderate size, rarely large, and are mostly of a white or yellow colour, with a band at the tip of the fore-wings of an orange, yellow, red, blue, or white colour, more or less edged with black outside, and sometimes inside. It is represented in England by one of our prettiest and most familiar spring Butterflies, the Orange-Tip.

\section{GENUS EUCHLOE.}

Euchloe, Hübner, Verz. bek. Schmett. p. 94 (1866); Westwood, Brit. Butterflies, p. $30\left(\mathrm{I} \delta_{41}\right)$; Butler, Cist. Ent. i. pp. 39, 53 (1870).

Anthocharis, pt. Boisduval, Spec. Gén. Lépid. i. p. 555 (1 S36);

Doubl. Gen. Diurn. Lepid. p. $55\left(\mathrm{IS}_{47}\right)$; Schatz, Exot. Schmett. ii. p. 70 (1886).

Antennæ short, with a distinct club. Wings white or yellow, tipped with orange in the male. Sub-costal nervure five branched, the two first branches emitted before the end of the cell, the upper radial thrown off a little beyond the cell, the middle disco-cellular nervule well marked.

Larva pubescent, green, cylindrical, tapering at the ends; pupa boat-shaped. 
This genus is confined to the Palearctic Region. Most of the species are more or less similar to our own, but in some of the Central Asian species the orange colour of the male extends over nearly the whole of the fore-wings.

TIIE ORANGE-TIP BUtTERfly. EUCHLOE CARDAMINES.

(Flate LVIII. Figs. I, 2 ơ, 3, 4 ?.)

Papilio cardamines, Linn. Syst. Nat. (ed. x.) p. 468, no. 63 ( 1758 ) ; ed. Faun. Suec. p. 27 I ( 77 1) ; Esper, Schmett. i. (1) p. 64, pl. 4, fig. I (1777); p. 318, pl. 27 , fig. 2 $(1778)$; Hübner, Eur. Schmett. i. figs. 4I9, 420, 424, 425 (I803?); figs. 791, 792 (I824?).

Pieris cardamines, Godart, Enc. Méth. ix. p. I25, no. 22 ( 18 I 9 ).

Puntia cardamines, Steph. Ill. Brit. Ent. Haust. i. p. 23 (г\&27). Anthocharis cardamines, Boisduval, Spec. Gén. Lépid. i. p. 564 (I836); Newman, Brit. Butterfies, p. I56 (is8 I); Barrett, Lepid. of Brit. Isl. i. p. $2 S$, pl. 4, figs. 2, $2 a-b$ (r892); Buckler, Larvæ of Brit. Butterflies and Moths, i. p. I59; pl. 3, fig. 2 (1886).

Euchloe cardamines, Kirby, Eur. Butterflies and Moths, p. 6, no. 4, pl. 4, figs. $7 a, b\left({ }_{1} 878\right)$; Lang, Butterflies Eur. p. 39, pl. 20, fig. I, pl. I 5, fig. 5 (transf.) (I $88 \mathrm{I})$; Rye, Handb. Brit. Macro-Lepid. p. I6, pl. iv. (1895).

The Orange-Tip Butterfly is common throughout Europe and Northern and Western Asia. It appears in April, May, and June, and is said to be occasionally double-brooded. It has a fluttering but sustained flight, though not very strong or lofty, and is found most abundantly in meadows, especially if somewhat damp, but may also be seen in lanes, open places ir. woods, and gardens. It is fond of perching on flowering umbelliferous plants, with the wings raised, when the orange patch is drawn down under the hind-wings, and only the 
extreme mottled green tip of the fore-wings is left visible beyond the mottled green hind-wings; thus the Butterly is lost to view among the similarly-coloured leaves and flowers of the plant. This habit was first recorded about thirty years ago by the late Mr. T. IV. Wood. Accidental varieties are not uncommon; the ground-colour of the wings is sometimes white, and sometimes more or less tinged with yellow. Gynandromorphous specimens have also been met with, exhibiting the male colouring with the orange spot on one side of the wings, and the ordinary plainer colour of the

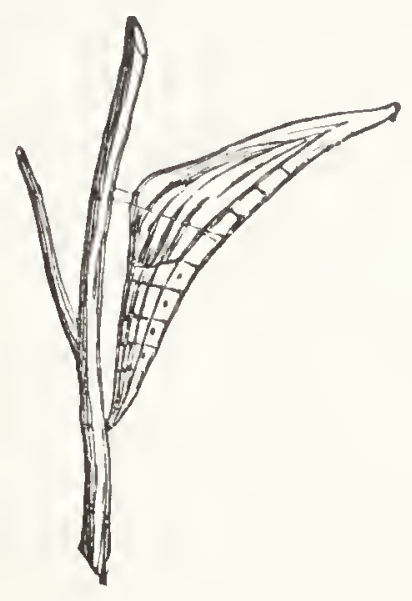

Tupa of Euchloe cardamines.

female, without the spot, on the other. Specimens are met with in some localities and during certain seasons, which are much smaller than the usual individuals; and according to my own experience I am inclined to think that the female varies in size more than the male.

The Orange-Tip measures from one and a quarter to nearly two inches across the wings. The wings are white above, sometimes slightly tinged with yellow. The fore-wings are blackish at the base, and brown, spotted with white on the margin, at the apex; there is a black spot at the end of the discoidal cell, and the male has a bright orange patch over the outer half of the fore- 
wing. $\Lambda$ ccording to the late Mr. Jenner Weir, the orange spot extends to the hinder angle in Continental, but not in British, specimens. On the hind-wings the markings of the under surface show indistinctly through. On the under surface the orange spot of the male is smaller, and the tip of the fore-wings, and the whole of the hind-wings are of a bright green, dusted with yellow and mottled with white. The antennæ are white, ringed with dusky.

The larva is green, slightly pubescent, very finely dusted with black, and with a white lateral stripe. It feeds on Cardamine impatiens and various other cruciferous plants in July. The pupa is greenish-yellow, and is remarkable for its curious boat-shaped form, thick in the middle, and pointed at both ends.

I append full particulars of one or two forms generally regarded as mere varieties of E. cardamines, but which some authors consider to be distinct species.

EUCHLOE TURRITIS.

Pontia turritis, Ochsenheimer, Schmett. Eur. iv. p. ${ }_{56}^{6}$ $(18$ I 6$)$.

Euchloe turritis, Kirby, Eur. Butterflies and Moths, p. 6, no. 5 (1878); Newnham, Ent. Record, v. pp. 97, 146 (1894). Euchloe cardamines, var. turritis, Lang, Butterflies Eur. p. 89 (IS82).

Ochsenheimer remarks, respecting this insect: "A very small aberration, from Italy, is distinguished by having the central spot on the edge of the orange-coloured spot, whereas in $P$. cardamines it is placed within it. I have seen both sexes under the name $P$. turritis in the collection of the Abbé Mazzola."

In the first edition of my "European Butterflies and Moths" I treated this insect as a distinct species, on the strength of in. 
formation received from the late Mr. J. Watson, that it had a different plumule. But after Mr. Watson's death, his intimate friend, Mr. B. B. Labrey, told me that he believed that Mr. Watson had wrongly identified the Butterfly which he called E. turritis, and I therefore withdrew the insect as a species from later editions of my work. Within the last year or two, however, the question has been revived, and is still sub judice.

\section{EUCHLOE HESPERIDIS.}

Euchloe hesperidis, Newnham, Ent. Record, v. pp. 97, 219 (rS94); cf. tom. cit. pp. I46, I 72.

Mr. Barrett, writing of E. cardammes, says (Lepid. of Brit. Isl. i. p. 29): "There is also a recurrent small variety, a quarter of an inch less in expanse in both sexes; and in Surrey this variety occurred year after year, a day or two earlier in the spring than the ordinary form, with great regularity. It is not certain, however, that this is the rule."

Mr. Newnham has lately proposed the name $E$. hesperidis for this small form, considering it as a distinct species; and there has been some correspondence respecting this and other forms allied to $E$. cardamines, in the Journal quoted above. I abstract Mr. Newnham's observations on the subject.

"E. hesperidis varies in expanse from $1 \frac{3}{16}$ inches to $1 \frac{5}{16}$ inches, whereas $E$. cardamines varies from $\frac{7}{16}$ to $1 \frac{13}{16}$. It differs from $E$. cardamines in having the discoidal spot of the fore-wings at the junction of the white and orange spaces instead of well within the orange space. It differs from the true $E$. turritis by its smaller size, and by having the costa dotted with black. The females resemble small females of $E$. cardamines, and expand from $\mathrm{I} \frac{5}{16}$ to $\mathrm{I}_{\frac{6}{15}}$. Both sexes appear much more slender than $E$. cardamines, even allowing for difference of size. Under a powerful microscope the plumules 
of $E$. hesperidis are narrower and proportionately much longer than those of E. cardamines, while the whole appearance of the wing is much more cven, and not nearly so rough as is the case in the latter species."

This form occurs in Surrey; Sussex; Church Stretton, Salop (where Mr. Newnham finds it much rarer than E. cardamines and apparently restricted to a small area), Llandago (common and generally distributed: A. Nesbitt), Glamorganshire, Haslemere, Pembroke, \&c.

Further observations are much needed to determine whether this insect has any real claim to be regarded as distinct from $E$. cardamines or not. One point must not be overlooked. That $E$. cardamines sometimes appears in a diwarf form in some localities is certain; and yet it is quite possible that $E$. hesperidis may be a distinct species, normally smaller than E.cardamines. It would therefore be necessary, before attempting to decide the point, to make sure that our specimens are really what are called $E$. hesperidis, and not simply dwarfed E.cardamines.

Dr. Scudder proposes to restrict the name Anthocharis, Boisduval, to the small American and Japanese group impropcr'y called Midea by Herrich-Schäffer. The two principal species are $A$. genutia (Fabricius), from North America (the type), and $A$. scoly'mus, Butler, from Japan. 'They are white species, with an orange sub-apical spot on the fore-wings of the male above, and the hind-wings marbled with green and white beneath; b it they differ from Euchloe in the longer fore-wings, which are strongly po:nted at the tips.

\section{GENUS PHYLLOCIIARIS.}

Phyllocharis, Schatz, Exot. Schmett. ii. p. 7 I (ISS6).

This genus is intended to include some European species which have hitherto been included in Euchloe, but which differ 
from that genus in various structural characters, as well as in the want of any "orange-tip" to the forc-wings; consequently both sexes resemble females of Euchloe. They are white above, with similar markings, and on the under surface they are green, sometimes varied with yellow, and with silvery-white markings. The sub-costal nervure of the fore-wings is five-branched, only the first branch being thrown off before the end of the cell, and the second at or beyond the end of the latter. The first radial nervule only separates from the sub-costal at about one-third of its length, and the middle disco-cellular nervule is either very short or wanting, whereas it is well marked in Euchloe. On the hindwings the lower radial is almost straight. The type is Phyllocharis tagis (Hübner), a small species, not measuring more than about an inch and a quarter across the wings. It is white above, with the tip of the fore-wings black, spotted with white, and a black streak at the end of the cell, narrower than in the allied specics, in which it more resembles Pontia daplidice. The under side is green, or greenish-yellow, with white, rarely silvery, spots.

The larva is green, pubescent, with a white lateral band, bordered above with a red one. The pupa is pale flesh-colour, darker at the hinder end. The ends are pointed, but it is more slender than the pupa of Euchloe.

The Butterfly is found in Southern France, Spain, and Portugal, Corsica, and Sardinia, and in each country it exhibits slight local variations.

There is a small genus, Zegris, Rambur, confined to the extreme South of Europe, and Western Asia, in which the orange in the apical area is reduced to a long oval patch, surrounded with black, and with the tip of the wing pale greenish. The 
hind-wings are yellowish beneath, more or less varied with white, and crossed by a broad green band curving from the base towards the hind-margin across the middle of the wing; there are also green patches branching from or more or less connected with it.

Ano:her "Orange-Tip" which deserves a passing notice is Erocssa chilensis (Guérin). It is the only true Orange-Tip in South America, and it is a Chilian species of great rarity, being remarkable for its resemblance to the African genus Callosune. It measures nearly two inches across the fore-wings, which are white, with the apical half of the fore-wings black, closed by a broad orange band, and the hind-wings are spotted with black at the ends of the nervures. On the under side the hind-m.urgin of the fore-wings is spotted with white, and the hind-wings are of a greenish or yellowish-white, with irregular transverse black markings. Structurally it is distinguished from Callosune by the five-branched sub-costal nervure of the fore-wings.

\section{GENUS TERACOLUS.}

Teracolus, Swainson, Zool. Ill. ii. pl. I I 5 (1823); Butler, Cist. Ent.i. pp.36, 47 (1870); Trimen, South African Butterflies, iii. p. So (1889) ; Schatz, Exot. Schmett. ii. p. 72 (1S92). Ptychopteryx, Wallengren, Lepid. Rhop. Caffr. p. I 7 (I 857 );

Butler, Lepid. Exot. i. p. 45 (I870); id. Cist. Ent. i. pp. 36, 47 (1870).

Thespia, Wallengren, Efv. Vet. Acad. Förh. Stockh. I 858, p. 77.

This and the following genera, Callosune, Abcis, and Colotis, form a little group peculiar to Africa and South-western Asia as far as India, where they represent the Palæarctic g nus Euchloe. They are very numerous in species, which, though differing very much in outward appearance, present few tangible characters by which they can be satisfactorily separated 
into genera; and hence they have been united into a single genus by Dr. Butler, in which he has been followed by Mr. Trimen, who formerly treated Idmais as distinct. Schatz, however, though admitting the absence of well-marked generic characters, keeps the three genera provisionally separate, because most of the species belonging to each can readily be separated at a glance by their colour and pattern; and he thinks it probable that these differences may be correlated in their earlier stages. Mr. Trimen, while including all the species under the single genus Teracolus, divides them into nineteen sections; and although it is not likely that all these will ultimately be raised to generic rank, yet the mass of species which they include will certainly be sub-divided sooner or later, and therefore I prefer to treat the three best known genera separately, giving the generic characters, which mostly apply to all three, under the genus Callosune. The characters of Mr. Trimen's first division, in which he includes only the type of Teracolus, are given by him as follows:-

"General structure robust; wings thick. Antennæ rather short and thick, with broad blunt club. Fore-wings acute in both sexes; hind-wings with a fringe of hairs on costa near base.* First and second sub-costal nervules of fore-wings closely approximate; hind-wings with discoidal cell rather more than half their length; costa and costal nervure strongly arched; second sub-costal nervule originating some distance before extremity of discoidal cell."

Teracolus subfasciatus, Swainson (Ptychopteryx bohemani, Wallengren), though widely distributed in Southern Africa,

* Mr. Trimen remarks in a note: "This fringe of hairs (which occurs in both sexes) is quite peculiar to $T$. subfasciatus, no other species in the same genus possessing it. This character occurs, however, in Eronia leda." Ought it not to be considered generic, is Wallengren, who first discovered it, thought it to be? 
where it flies very swiftly in March and April, appears to be a local insect, and is generally scarce in European collections.

It measures from 2 to $2 \mathrm{I} / 2$ inches across the fore-wings, which are of a sulphur-yellow colour above in the male, the tip of the fore-wings being narrowly black, between which and the end of the cell, which is marked by a small black dot, is a short black band running from the costa; the under side of the wings is greenish-white. The female varies from pale yellow to nearly white, and the apical spot of the fore wings is orange.

\section{GENUS CALLOSUNE.}

Anthocharis, sect. 3, Callosune, Duubleday, Gen. Dium. Lepid. p. $57(1847)$.

Callosune, Schatz, Exot. Schmett. ii. p. 72 (1886). Anthopsyche, Wallengren, Lep. Rhop. Caffr. p. Io (1857).

Antennæ with an oval flattened club; palpi rather short, bristly beneath; fore-wings triangular, with the tip slightly rounded off; hind-wings rounded; fore-wings with the subcostal nervure four-branched, the two first branches emitted near together before the end of the cell, the upper discoidal nervule rising from the end of the cell, the upper disco-cellular nervule being thus rendered obsolete, as is also the case on the hind-wings.

Pupa less boat-shaped than in Euchloe, and with prominent wing-covers.

This genus is met with throughout Africa, the Mediterranean district excepted,* but in Asia Minor it is not found, though it extends through Arabia to India and Ceylon, where, however, the species are far less numerous than throughout Africa south of the Sahara.

* The single Algerian species of the group belongs rather to Abais. 
In Callosune, the wings are broader and shorter than in Euchloe, the hind-wings are frequently bordered or spotted with black on the hind-margin above, but are not tesselated with green beneath, being generally uniformly coloured, with but little pattern. They are white or yellow, sometimes merely with an orange apical spot on the fore-wings, narrowly bordered outside with black, but more frequently, the apical region is black, with more or less of its centre filled up or spotted with red, orange, violet, blue, or (in the females sometimes) white. Some species are more or less heavily marked with black at the junction of the wings, and are also barred with black on the hind-wings, and one or two of the females have extensive dusky markings, leaving very little of the white ground-colour visible. Thus C. achine (Cramer), the type of Wallengren's genus Anthopsyche, is one of these orange-tipped species, with dark markings towards the junction of the wings, and a black bar on the hind-wings in both sexes, broadest in the female. The under side is white, with an orange streak on the hindwings. It is common and widely distributed throughout a large part of Eastern and Southern Africa. A dwarf form, sometimes measuring as little as $I / 4$ inches across the wings, has been taken by Mr. Trimen in the Knysna district, and it is interesting to note that the females, which otherwise vary in this species more than the males, are likewise most variable in size. According to Mr. Trimen's measurements, he has met with females both smaller and larger than any males, though the average size seems to be about the same. These observations may be compared with our remarks on Euchloe cardamines (antea, p. I87).

The Indian species are far less numerous and varied than the African ones, and have all red or orange tips. One of

* This group is closely allied to, if not identical with, Abais 
these was selected by Dr. Scudder as the type of the genus Callosune.

\section{CALlosune DANAE.}

(Plate LVII. Fig. 2.)

Papilio danae, Fabricius, Syst. Ent. p. 476, no. I44 (x 775);

Donovan, Ins. Ind. pl. 26, fig. 2 (isoo).

Papilio eborea, Cramer, Pap. Exot. iv. pl. 352, figs C-F ( I $\left.7 S_{I}\right)$.

Picris danae, Godart, Enc. Méth. ix. p. 124, no. 20 (1Sig). Anthocharis danae, Boisduval, Spec. Gén. Lépid. p. 570 $\left(\mathrm{I} S_{3} 6\right)$.

Callosune danae, Moore, Lepid. Ceylon, i. p. I 29 (ISSo).

This species, which is not uncommon in India and Ceylon, measures about $\mathrm{I} / 2$ inches across the wings, which are white above, with the apical half of the fore-wings of a deep red, bordered with black, narrowly outside, but broadly inside. The black colouring extends to the hinder angle; and there is also a row of more or less connected black marginal spots on the hind-wings. On the under side an irregular row of black spots crosses the disc of all the wings, which is more or less visible on the upper side in the female.

This species was formerly confounded with its African representative (C. anna (Wallengren); C. cinerascens (Butler)) ; but this is a larger insect, much more shaded with grey at the base of the wings, especially in the female, which is very dark. This insect furnishes an instance of a fact that is very noticeable in looking through the localities given by Mr. Trimen for South African Butterflies, namely, that the South African Fauna is a continuation of that of the East Coast, and not of the West Coast. Thus in the present instance, $C$. annee is not recorded from any locality on the West Coast further north than Damara Land; but on the East Coast it has heen met with as far north as Zanzibar 
Its range, therefore, coincides with that of many birds which mark the South African Region as defined by Dr. Bowdler Sharpe.

\section{GENUS ABEIS.}

Abceis, Hübner, Verz. bek. Schmett. p. 97 (ISI6).

The type of this genus (with which Anthopsyche, Vallengren, referred to under Callosine, is probably synonymous) is a female Butterfly figured by Cramer, from Sierra Leone. It may be a variety of a common West African Orange-Tip figured by Drury as Papilo arethusa (Drury, Ill. Exot. Ent. ii. pl. r9, figs. 5, 6), but does not quite agree with any specimen at present in the British Museum.

\section{ABÆIS CERRENE.}

Anthocharis cebrene, Boisduval, Spec. Gén. Lépid. i. p. $5^{s_{3}}$ $\left(\mathrm{I} \mathrm{S}_{3} 6\right)$.

Papilio arethusa (nec Drury), Cramer, Pap. Exot. iii. pl. 210, figs. E, F ( I 779 ).

This Butterfly measures $\mathrm{I} / 2$ inches across the wings, which are dull white, stained with ferruginous towards the base. The forewings have a rather broad umber-brown border, a small black discoidal spot, and some large black spots on the inner-margin, which are continued on the hind-wings in an irregular row on the disc. The border of the hind-wings is composed of rather large contiguous spots. The under side of the fore-wings is orange at the base, and rufous towards the hind-margin; the intermediate white space is marked with a black spot towards the inner-margin. The hind-wings are brown, slightly tinged with pink, paler in the middle, and reddish on the costa. The discoidal spot is black and red, a short black line runs perpendicularly from the costa, while below the middle of the wing is a straight black transverse bar. The male will be white, 
with a black discoidal spot, and a bright red tip on the forewings, bordered with black on both sides; the hind-wings probably with a marginal row of black spots.

\section{GENUS COLOTIS.}

Colotis, Hübner, Verz. bek. Schmett. p. 97 (1816).

\section{GENUS IDMAIS.}

Idmais, Boisduval, Spec. Gén. Lépid. i. p. $5 \$_{4}\left(\mathrm{I} \$_{3} 6\right)$; Doubleday, Gen. Diurn. Lepid. p. 59 (I847); Schatz, Exot. Schmett. ii. p. 73 (1886).

Under these names are included a number of African, Arabian, and Indian Butterflies, which present no very salient characters to distinguish them from Callosune, except their general colour and markings. Instead of "Orange Tips," we have here moderate sized or rather small Butterflies, with more delicate and rounded wings than in Eurymus, and of a paler orange or yellow colour, generally with much slighter dark borders. Several of Mr. Trimen's sections of Teracolus will fall under this genus, which is used to include various discordant groups of species, differing almost as much from each other as they do from Callosune. Those which most nearly approach the latter genus are Pontic eris, Klug, and its allies. This is a white species found in Africa and Arabia, with broad black bands covering the junction of the wings, and coalescing with the lower end of the black sub-marginal band, which is spotted with pinkish-white towards the tips; the female is yellower, and the dark markings are much less extended.

The type of Colotis is C. amata (Fabricius), a common Indian Butterfly, measuring about an inch and a half across the wings. This Butterfly is not unlike a small Eurymus above, being of a brick-red colour in the male, and yellow in the female, with 
broad black borders, bearing a double row of pale spots of the ground-colour.

The type of Idmais, Boisduval, is an Arabian Butterfly ( $I$. chrysonome (Klug), which measures about an inch and a half across the wings. It is orange, rather lighter on the hind-wings than on the fore-wings, and dusted with bluish-grey at the base in the male. The fore-wings have the costa and nervures distinctly black, a black spot at the end of the cell, and a row of connected black spots beyond. The hind-wings are unspotted in the middle. There is a black border, better defined on the fore-wings than on the hind-wings, and marked between the nervures with semi-detached orange or yellow spots. The under side of the fore-wings is orange, with the costa and hindmargin greenish-yellow; the hind-wings are greenish-yellow, with three transverse rows of rather indistinct reddish spots. It is allied to one of the most beautiful species of this group, and the only one which extends to the Palæarctic Region, $I$. fausta (Olivier), which is common in Western Asia, including Asia Minor and Northern India. It measures about an inch and three-quarters across the wings, which are of a peculiar reddish-orange colour, hardly like that of any other Butterfly; the under surface is much paler. The fore-wings have a black discoidal spot, and an incomplete double row of marginal spots, sometimes forming a border; there are also traces of marginal spots on the hind-wings.

\section{GENUS IXIAS.}

Ixias, Hübner, Verz. bek. Schmett. p. 95 (I816); Butler, Cist. Ent. i. pp. 37, 48 (1870); Distant, Rhop. Malay. p. 309 (1885); Schatz, Exot. Schmett. ii. p. 73 (I886).

Thestias, Boisduval, Spec. Gén. Lépid. i. p. 590 (1836); Doubleday, Gen. Diurn. Lepid. p. 60 ( 1847$)$. 
This is wenus of "Orange-Tips" which, with Hebomoia, practically replaces Callosune in the Indo-Malayan Region, and extends to some of the Austro-Malayan Islands, though in India and Ceylon the ranges of these three genera overlap. There are no African species, though Wallengren erroneously referred Callosune annee to this genus.

The body and palpi are rather hairy, the antennæ slender, with a pear-shaped club. The wings are broad, more robust than in Callosune, yellow or white, with the apical half of the fore-wings black, filled up with a large orange or yellow band (sometimes white in the females), and the hind-wings are bordered with black. Beneath, the wings are generally yellow, more or less flushed with brown, and frequently with traces of rust-coloured eyes with silvery pupils. They are "generally larger insects than Callosune, averaging about two inches in expanse. The sub-costal nervure of the fore-wings is fourbranched, with two branches emitted before the end of the cell, and the third and fourth forming a larger fork than in Callosune; but the most important character is that the first discoidal nervule is thrown off from the sub-costal nervure distinctly beyond the cell, instead of rising from the cell, as in the last-named genus.

The type is Ixias pyrene (Linn.), one of the largest yellow species, which is common in India and South China.

\section{GENUS HEBOMOIA.}

Hetromoia, Hübner, Verz. bek. Schmett. pp. 95, 96 (I8I6); Doubleday, Gen. Diurn. Lepid. p. 62 (1847) ; Butler, Cist. Ent. ii. pp. 37, 48 (I 870 ); Schatz, Exot. Schmett. ii. p. 73 (1 886 ).

This genus not only includes the largest " Orange-Tips," but also the largest species of the Pieride. They average about 
four inches across the wings, which are white or yellow, and more or less reddish or orange towards the tip of the fore-wings, the orange tip, however, being absent in the females of some of the species. They are not very numerous; the type, $I I$. glaucippe, Linn., a white "Orange-Tipped" species, being found throughout India, Malacca, South China, Java, \&c. The hind-wings are white above, and the under side is yellowish-grey, with dusky mottlings, giving it somewhat of the appearance of a dead leaf when at rest. It is an insect of very rapid flight. 'The female is yellower, with a row of marginal and sub-marginal black spots on the hind-wings. Other species inhabit the Indo-Malayan and several of the Austro-Malayan Islands, as far as the Moluccas and Bouru.

The body is stout, hairy, and rather short; the palpi are short, scaly, clothed with long and stiff hairs beneath, and the terminal joint is very small. The antennæ are long, not clubbed, as in all the other genera of this group, but only very gradually thickened towards the end. The sub-costal nervure of the forewings is four-branched, the two first branches being thrown off close together before the cell, while the first almost touches the costal nervure; the third and fourth form a fork towards the tip of the wing. The cell of the fore-wings is rather broad, and the upper discoidal nervule is thrown off from the cell, the upper disco cellular nervule being distinctly present; the cell of the hind-wings is narrower and more pointed.

The larva of $H$. glaucippe is stout, tapering at both ends. It is green, with a pale red-dotted stripe on the sides, and is shagreened on the upper surface. It feeds on a species of Capparis in Java and Ceylon. The pupa, which is likewise green, is boat-shaped, like that of Euchloe; it is much arched, and is produced into a long point at both ends.

I have figured one of the handsomest species of this genus, which is found in Amboina and Ceram. 


\section{HEBOMOIA LEUCIPPE.}

$$
\text { (Plate LVII. Fis. 3.) }
$$

Papilio leucippe, Cramer, Pap. Exot. i. pl. 36, figs. A-C (r 775). Pieris lewcippe, Godart, Enc. Méth. ix. p. г18, no. г (r8 I9). Ithias laucippe, Boisduval, Spec. Gén. Lépid. i. p. 596 (1836); I)oub?eday \& Hewitson, Gen. Diurn. Lepid. pl. 8, fig. 2 $(\mathrm{i} S 47)$.

Hebomoia leucippe, Doubleday \& Hewitson, 1. c. p. 63 ( 1847 ).

This is a rather larger Butterfly than $H$. glaucippe, measuring more than four inches across the wings. The fore-wings are of a deep red colour, clouded with greenish-yellow at the base, and with the nervures and margins black; the female has a detached row of red sub-marginal spots. The hind-wings are citron-yellow, with a dentated or macular black border in the female, usually preceded by a curved row of black spots; but in the male, the hind-wings are only marked with one or two sub-margiral spots towards the costa. The under side is deep fulvous in both sexes, sprinkled with tlack points, and marked with short transverse dusky lines, most numerous in the female. The head and thorax are brown, the abdomen yellow. The antennæ are black, tipped with reddish.

Although this Butterfly has been well known to entomologists for more than a century, it is still rather sca ce in collections.

\section{GENUS ERONIA.}

Eronia, Hübner, Samml. Exot. Schmett. ii. pl. I27 (I 824 ?); Boisduval, Spec. Gén. Lépid. i. p. 604 ( 1836$)$; Doubleday, Gen. Diurn. Lepid. p. 64 (1847); Butler, Cist. Ent. i. pp. 38, 72 (1870); Schatz, Exot. Schmett. ii. p. 74 (I886); Trimen, S. African Butterflies, iii. p. r69 (г889). The genus Eronia is typical of a group of Butterflies of 
moderate extent, which is confined to the tropics of the Old World. The African species are extremely dissimilar, and evidently belong to several genera, while the Eastern group is more compact. The costa of the fore-wings is arched, and the subcostal nervure is five-branched, the two first branches rising near together before the end of the cell, and the others separating towards the tip of the wing. Three of the African groups have received names: Eronia (type E. cleodora, Hübner); Dryas. Boisduval (pre-occupied), proposed for Eronia leda, Doubleday, which Butler and Trimen both include in Eronia; and Nepheronia, Butler, intended to include the remaining African and Eastern species. Mr. Trimen has lately proposed to include the African species in Eronia, and to leave the name Nepheronia to the Eastern species, but this is impossible, for Dr. Butler expressly indicated $N$. idotea, Boisduval, as the type of his genus. I therefore propose to employ these two genera in the sense in which they were used by Dr. Butler, quoting the characters, which he gives for them, and noticing the types and some of the principal forms which they include.

Dr. Butler characterises Eronia as follows, specifying $E$. cleodora, Hübner, as the type, but including $E$. leda, Doubleday, in the genus :

"Front wings broad, sub-triangular, with strongly arched costa; first and second sub-costals emitted near together at some distance before end of cell, the third at a great distance beyond end of cell, the fourth and fifth forming a short fork to the apex; upper [the second, the first being obsolete] discocellular about one-third the length of lower, both arched, and forming a nearly perpendicular line; median branches at nearly equal distances apart.

"Hind-wings: Upper disco-cellular about one-quarter the length of lower, oblique; the lower disco-cellular also oblique, 
strongly angulated and curved; second and third median branchcs rather near togethcr.

"Body robust; metathorax clothed with long silky hairs; palpi short, densely hairy; antennæ moderatcly long, rather thick, with gradually formed club."

The type of this genus, Eronia cleodora, Hübner, is a widelydistributed species in Southern and Eastern Africa. It is a Butterfly expanding from two to nearly three inches across the wings, which are short, broad, and slightly dentated, the tip of the fore-wings being slightly pointed. The wings are white or yellowish-white, with a rather broad black border, broadest in the female, somewhat irregular on the inner edge, and widened at the tip of the fore-wings, where it is marked with one or two small white spots. On the under side the borders are silvery-grey, more or less bordered with black, especially on the inncr edge, and sometimes dusted with ferruginous; the forewings are white, and there is a yellow spot on the border towards the tip ; the hind-wings are bright yellow, with variable scattered brown and silvery-grey markings, the largest and most constant being on the costa.

Mr. Trimen mentions that Mrs. Barber and Mr. Mansel Weale have found the larva on Capparis zey'heri. It resembles that of a Callosine, and is difficult to find, the reddish-yellow lateral stripe matching in tint the edge of the leaves.

The other species, Dryas leda, included by Dr. Butler in typical Eronia, is a very different-looking Butterfly, inhabiting East Africa, and the warm districts of South Africa. The wings arc rather more regularly rounded, and less denticulated than in $E$. cleodora, and the tip of the fore-wings is less pointed. The wings are sulphur-yellow, with a large "orange-tip" on the fore-wings, slightly edged with black on the outside. On the under side the fore-wings are white, with the tip and hind-wings of a deeper yellow than above, flecked with brown and fcrry- 
ginous, the larger spots sometimes having silvery centres. The female is pıler, with the "orange-tıp" much smaller, or obsolete.

As Mr. Trimen remarks, this Butterfly much resembles another form inhabiting portions of South Africa, a true "Orange-Tıp," Callosune auxo, Lucas, but this is generally an inch smaller, and may be distinguished at once by the subcostal nervure being only four-branched.

The Eronia group seems largely to take the place of the Butterflies of the East Indian and South American Callidryas group, which has only one or two representatives in Africa, just as Callosune replaces the genus Euchloe of the Palæarctic Region.

\section{GENUS NEPIIERONIA.}

Nepheronia, Butler, Cist. Ent. i. pp. 38, 53 (1870); Distant, Rhop. Malay. p. 3 I9 (I $88_{5}$ ).

Dr. Butler proposed this genus to include the African $N$. idotrea (Boisduval), which he indicated as the type, $N$. thalassina (Boisduval), $N$. argia (Fabricius), $N$. buquetii (Boisduval), $N$. pharis (Boisduval), and $N$.chione (Doubleday), and the Asiatic $N$. hippia (Fabricius), N. iobaa (Boisduval), N. babera (Eschscholtz), and allies. 'The characters given for Nepheronia are as follows :

"Front wings occasionally sub-pyriform ( $N$. pharis and $N$. chione); upper disco-cellular strongly excavated, more than half the length of lower, which is oblique and slightly angulated.

"Hind-wings: Upper disco-cellular more than half the length of the lower, very oblique; lower disco-cellular rather less oblique and waved; second and third median branches wide apart.

"Body moderately robust, slightly hairy; palpi and antennæ 
short, the latter slender with gradually formed compressed club, sometimes flattened."

The genus Nepheronia, as thus constituted, includes at least three well-marked groups of almost generic value.

In the typical group the species are of considerable size, measuring about three inches across the wings, which are broad and only slightly denticulated, with the hind-margin of the fore-wings slightly concave, and therefore the tip somewhat prominent. The colour is white, greenish-white, or yellow, with more or less extensive black borders. The type is $N$. argia (Fabricius), in which the male is greenish-white, with a moderately broad black border at the tip of the fore-wings, gradually diminishing, and not extending to the hinder angle. The females are white or yellow, with broad black borders, greatly indented on the inner side, and on the hind-wings almost macular. The yellow form of the female is $N$. idotaa (Boisduval); the type of Nepheronia. $N$. argia is a common West African species, but there are several allied species found in various parts of Africa.

The next group is represented by $N$. pharis, Boisduval, and $N$. chione, Doubleday. These are much smaller Butterflies, only measuring about two inches across the wings, which are of a pure white, very slightly bordered with black towards the tips of the fore-wings. The wings are entire, broad, and rounded, and the Butterflies are delicately formed, and resemble those of the genus Leptosia. The outer half of the hind-wings is mottled with greenish beneath. These Butterflies are found in West Africa, and are rather scarce in collections.

In the Eastern species of Nepheronic we again meet with larger Butterflies, measuring two and a half or three inches and more in expanse. The wings are longer than in the African species, and in the fore-wings the costa is less arched, and the 
hind-margin more oblique; the hind-wings, too, are distinctly narrower. These Butterflies are green, with black borders and black nervures. The females are greenish-white, with the nervures so broadly black as to break up the ground-colour into long rays, thus mimicking the Danaince of the genus Tirumala and its allies, which inhabit the same countries.

\section{SUB-FAMILY IV. CALLIDRYINAE.}

Antenne short, gradually thickened towards the extremity, rarely with a distinct club. Palpi not extending much beyond the head, and clothed with large depressed scales; the middle and terminal joints short, the last joint thickencd, or slightly pointed. Sub-costal nervure with three- or four-branched. Precostal nervure absent, or else but slightly developed. Body generally rather short and stout, and clothed with hair.

This group includes the Brimstones and Clouded Yellows, which are characteristic of the Northern Hemisphere, though one species of the latter is found in South Africa, and others have reached the extreme south of South America, apparently along the chain of the Andes. Two other groups, represented respectively by Eurema and Catopsilia of Hübner, abound in most tropical countries, while the remaining genera are confined to limited areas, chiefly in the tropics.

\section{GENUS NATHALIS.}

Nathalis, Boisduval, Spec. Gén. Lépid. i. p. $589(1836)$; Doubleday, Gen. Diurn. Lepid. p. 54 (1847); Butler, Cist. Ent. i. pp. 34, 4I (1870); Schatz, Exot. Schmett. ii. p. 69 (I886).

This is a small and very isolated little genus peculiar to North America and the northern parts of South America. 
The antennze are short, with a well-marked club (an unusual character in this Family), and the palpi are long, pointed, and hairy rather than scaly. The claws of the tarsi are without appendages, as in Eurymus.

The fore-wings are rather long and somewhat narrow; the hind-wings are somewhat rounded. The sub-costal nervure of the fore-wings is three-branched (not four-branched, as Dr. Butler states), the sccond branch being emitted close to the end of the cell ; the upper discoidal nervule separating from the sub-costal some distance beyond the cell. The lower discocellular nervule is strongly angulated outwards in both the foreand hind-wings, the upper median nervule being strongly arched. The pre-costal nervure of the hind-wings is rudimentary.

The type, Nathalis iole, Boisduval, which inhabits the Southern United States, is a small Butterfly, expanding about an inch across the wings. It is of a sulphur-yellow colour above, with the fore-wings black at the tip, and with a black spot towards the hinder-angle; the hind-wings are also sometimes marked with black marginal spots. The under side is greenish, dusted with black. 'The larva is at present undescribed.

\section{GENUS EURYMUS.}

Eurymus, Swainson; Horsfield, Cat. Lepid. E. Ind. Mus. pp. I 29, I 34 (I829); Swainson, Zool. Ill. (2) ii. pl. 60 (183r?); Scudder, Butterflies of East. U. S. p. 1096 (rS89).

Colias, pt. Fabricius, in Illiger, Mag. Insekt. vi. p. 284 (rSo 7 ); Latreille, Enc. Méth. ix. pp. ro, S9 (ISI9); Boisduval, Spec. Gén. Méth. i. p. $634(1836)$; Doubleday, Gen. Diurn. Lepid. p. 72 ( 1847 ); Butler, Cist. Ent. i. pp. 35 , 43 (1870); Schatz, Exot. Schmett. ii. p. 68 (I 866). 


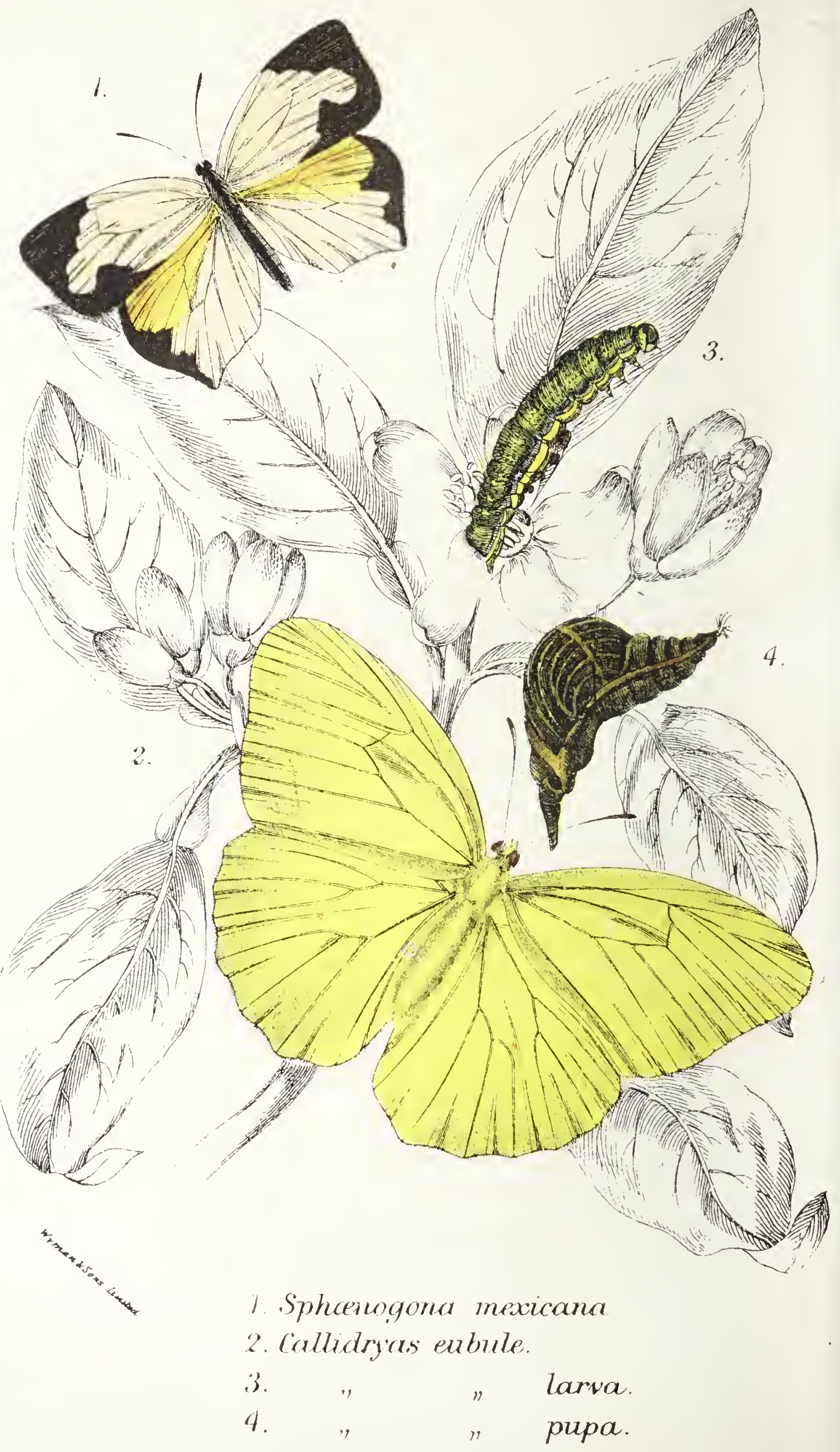


Eriocolias, Watson, Entomologist, xxviii. p. I67 (I 995 ).

Antennæ short, red, with a large but gradually-formed club. Palpi long, compressed, scaly, and somewhat bristly, the terminal joint short. Tarsi without appendages. Wings rather short and broad; the hind-wings rounded, the fore-wings with the cell rather short and broad, the hind-wings with the cell rather long and narrow. Fore-wings with the apex slightly rounded off, the sub-costal nervure four-branched, the first branch emitted before the end of the cell, the second emitted at or beyond the end of the cell, the third and fourth forming a small fork at the tip of the wing. The upper radial is thrown off from the sub-costal considerably beyond the cell. Middle disco-cellular short, straight; lower one long, slightly curved on the fore-wings, oblique, and somewhat angulated.

The Clouded Yellows form a very distinct group, and are very numerous in species, especially in Central Asia. The males are generally of a yellow colour, varying from light sulphur-yellow to deep orange, the latter being sometimes flushed with purple, so deep, in one or two instances, as to appear almost black. Some species are of a dull green. Some of the females are coloured like the males, and others are white; and in many cases the same species exbibits two constant forms of the female, one yellow and one white. There is always a black central spot on the fore-wings, and generally a large reddish spot on the hind-wings; on the under side these are replaced by a rusty ring with a silver pupil, or by two similar contiguous markings, one smaller than the other. The wings are almost always more or less bordered with black, the border being often veined or spotted with the groundcolour, or with some paler colour; it is often veined in the male and spotted in the female.

The larvæ are green, smooth, pubescent, and feed on Leguminose. The pupa is pointed in front. 
Mr. Watson's new genus, Eriocolias, is intended to include the group of E. hyale, in which the border is often streaked, but never spotted in the male. The principal character is that the males have, on the upper side of the hind-ivings, "between the costal and sub-costal nervures, a patch of modified scales of a smaller size, and much more numerous than the surrounding ones, usually of the same ground-colour." In the old genus Colias (our Enrymus), Mr. Watson proposes to retain the orange species in which these scales are wanting ( $E$. chrysothme [Esper], \&c.,) and the sub-groups represented by Emymus phicomone, Esper (improperly indicated as the type, as it is not even one of the species mentioned in Illiger's Magazine); C. Firbyi, Lewis, and C. palceno, Linn.

Pending a critical examination of the numerous species of this genus, which might probably reveal other characters of greater importance among them, we content ourselves here with calling attention to Mr. Watson's new genus, without adopting at present a sub-division which would separate species so much resembling each other as E. hiy'ale and E. chrysotheme, solely on a secondary sexual character, however well-marked or constant.

The Clouded Yellows are found throughout the Northern IIemisphere, as far as the IHimalayas. Isolated species are found in the Nighiris; South Africa, and in the mountains or in the southern part of South America; but they appear to be entirely absent from the insular portion of the Indo-Malayan Region, and from the whole of the Austro-Malayan Region, the reputed occurrence of a specics of Eurymus in the Sandwich Islands being now reginded as an crror.

Dr. Butler's genus Scalidonama, which includes some small species found in the Andes of South America, is chiefly characterised by the shortness of the upper radial nervule on the fore-wings, which only separates from the sub-costal nervure near its extremity. 


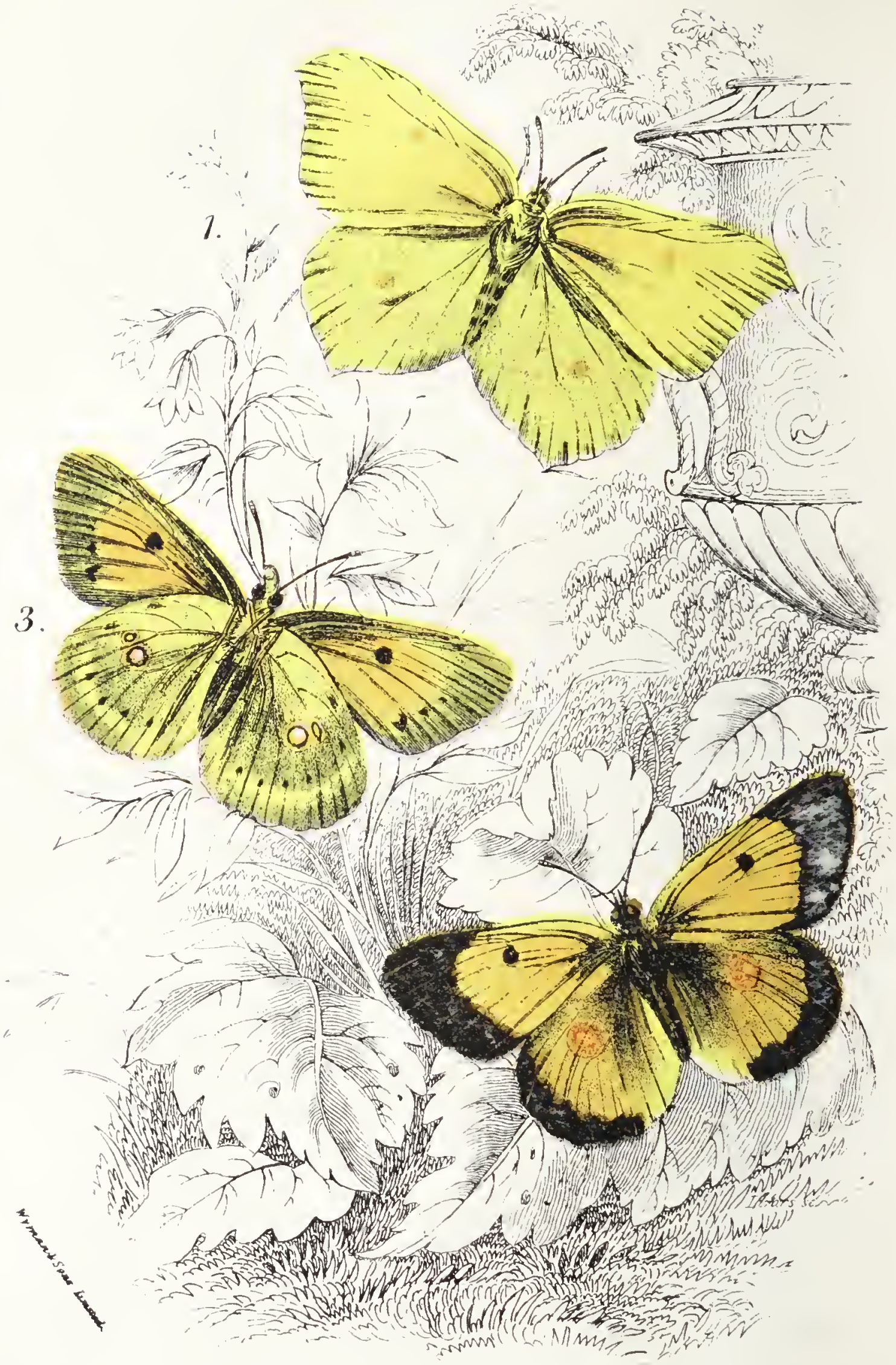

2 .

\section{Colias rhamni.}


These Butterfies have strong wings, and though they do not rise to a great distance from the ground, the flight of $E$. liyale is stronger, more rapid, and more sustained than that of any other British Butterfly. Alpheraky has recorded that one of his Cossacks galloped two miles after E. auroria, Esper, one of the largest of the orange Siberian species, measuring over two inches across the wings, before he could capture it. The largest and handsomest species of this genus inhabit Centrail and Western Asia.

TIE CLOUDED YELLOW. EURYMUS HYALE.

(Plate LXY. Figs. 2, 3.)

Papilio hy'ale, Linnæus, Syst. Nat. (ed. x.) i. p. 469 (I75S); id. Faun. Suec. (ed. ii.) p. 272 (1764); Scopoli, Ent. Carn. p. I73 (I763) ; I)enis \& Schiffermuiller, Syst. Verz. Schmett. Wien. p. I65, no. 3 (1776); Esper, Schmett. i. p. 7I, pl. 4, fig. 3; p. 3I7, pl. 26, fig. 3 (г777); Hübner, Eur. Schmett. i. figs. 329-33 I (IS०3 ?). Pippilio croceus, Fourcroy, Ent. Paris, ii. p. 250 ( 1785 ). Pupilio edusa, Fabricius, Mant. Ins. ii. p. 23, no. 240 ( 1787 );

Ochsenheimer, Schmett. Eur. i. (2) p. I 73 (I80S). Fapilio electra, Lewin (nec Linn.), Ins. Brit. i. pl. 3I ( I795). Colias edusa, Godart, Enc. Méth. ix. p. гог, no. 38 (ISI9); Boisduval, Spec. Gén. Lépid. i. p. 638 (I $\$_{3} 6$ ) ; Stephens, Ill. Brit. Ent. Haust. i. p. I 2 ( 1827 ) ; Kirby, Eur. Butterflies and Moths, p. Io, pl. 3, figs. 4a-d (1878); Newman, Brit. Butterflies, p. I43 (I88r); Lang, Butterflies Eur. p. 6I, pl. I4, fig. I ; pl. r6, fig. 2 (larva) (I88I); Barrett, Butterflies of Brit. Isl. i. p. 35, pl. 6 (IS92); Buckler Larvæ of Brit. Lepid. p. 9, pl. I, fig. 3 (I886). Colicas croceus, Kirby, Cat. Diurn. Lepid. p. 490, no. I (187 I). Colias hyale, Kirby, Cat. Diurn. Lepid. Suppl. p. 799, no. I (1877). 


\section{Var. Eury'mus helice.}

Var. Pafilio helice, Hübner, Eur. Schmett. i. figs. 440, 44 ! ( $\mathrm{SO}_{3}$ ?); Haworth, Lepid. Brit. p. I 2, no. I I (I $\mathrm{So} 3$ ). Colias edusa, var. helice, Stephens, Ill. Brit. Ent. Haust. i. p. I 3, pl. $2^{*}$, fig. 3 (1827); Lang, Butterflies Eur. p. 62, pl. I 4 , fig. 2 (I $88 \mathrm{I})$.

Var. Colias chrysotheme, Stephens (nsc E-per), l.c.p. I I, pl. 2*, figs. I, 2 (I827).

Var. Colias my'midone, Westwood and Humphreys (nec Esper), Brit. Butterflies, p. 139, pl. 42, figs. I-3 (I 84 I).

The Clouded Yellow Butterfly measures from $\mathrm{I}^{2} / 3$ to upwards of 2 inches across the wings, which are of a rich chrome-yellow above, sometimes nearly orange, and occasionally with a slight purple flush. There is a broad black border (brondest at the tip of the fore-wings), which is veined in the male and spotted in the female with sulphur-yellow; at the end of the cell is a round black spot. The hind-wings are sometimes more or less dusky, especially in the female; there is a large reddish-yellow spot at the end of the cell, and in the female, the black border, which har extends to the anal angle, is more or less spotted on the inner side with yellow. The fringes of the wings, as well as the antennx, are rose-colour. On the under side, the fore-wings are paler, with the black spot reproduced, and a more or less distinct row of black spots on the disc; the tip is greenish. The hind-wings are green, with a central silvery spot, surrounded with rusty red, and a smaller one adjoining; there is also a row of rose-coloured dots on the disc.

This insect is extremely variable, and some of its numerous varieties have been mistaken for the East European species, E. chrysotheme and E. myrmidone (Esper), which could not reasonably be expected to be found in England at all. There is a pale greenish-white form of the female, which is sometimes 
taken in England, but is much commoner in Southern Europe; it is known as var. $E$. helice.

The larva is deep green, with a white line on the sides, spotted with yellow. The pupa is greenish, striped with yellow. The larva feeds on clover in summer. The Butterfly is
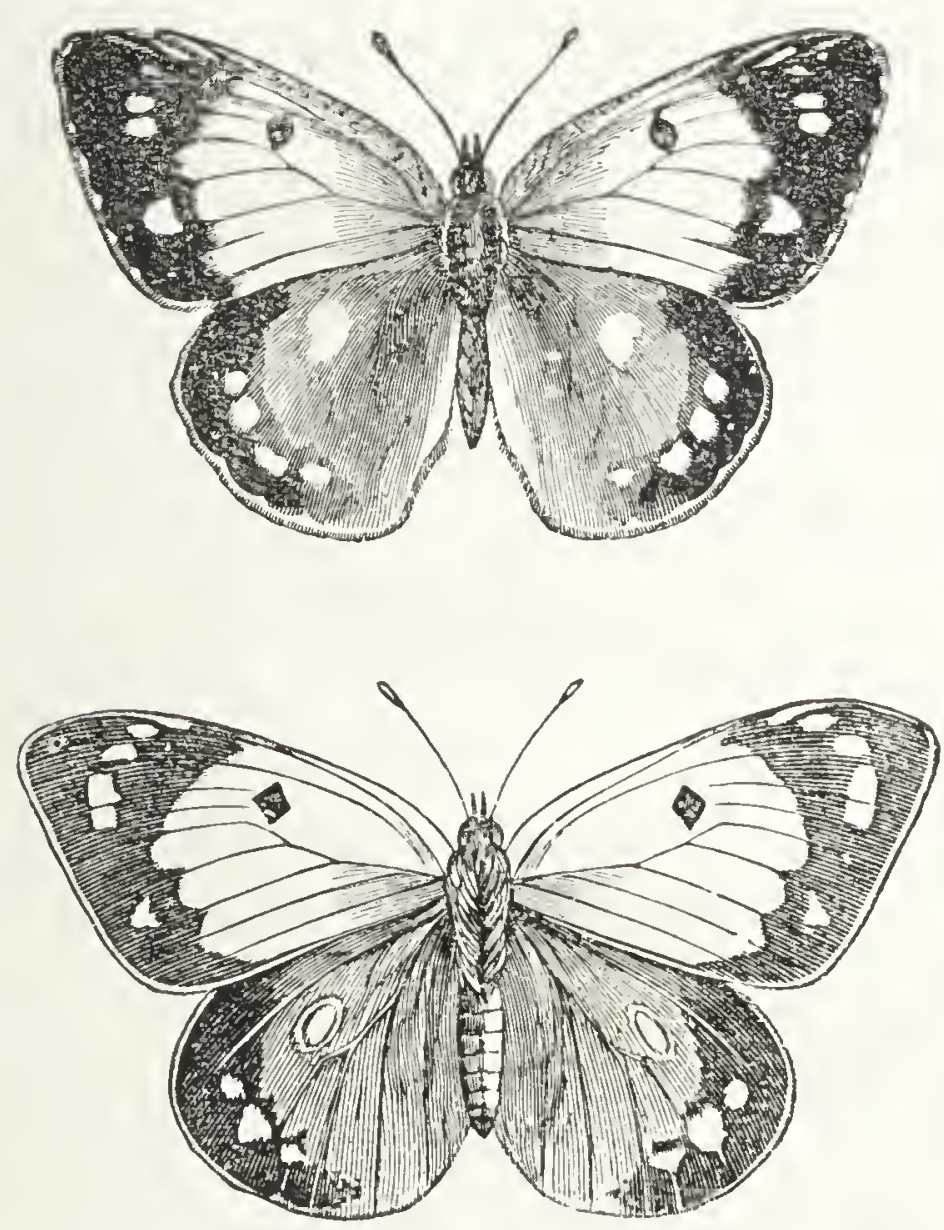

E. Ry'ale q, and var. E. helice.

double-broorled on the Continent, but is rarely seen in England except in autumn. It is a very common species throughout Europe, Northern Africa, and a great part of Asia ; in Southem and Eastern Africa it is replaced by a closely-allied species, E. electra (Linn.); and it is not impossible that the two spccies 
may occur together at the limits of their respective ranges, in East Central Africa. E. electra is a more reddish insect than E. hlale, with a strong pink lustre in certain lights; and $M r$. Trimen states that the larva is more listinctly striped with dark and light grcen, and has no orange spots on the white lateral line.

E. hyale is chicfly found in clover ficlds and along railway banks; and we have already spoken of its extremely rapid night.

'I'he confusion in the names of our two well-known species of Clouded Yellow is much to be regretted. When Fabricius discriminatcd between these and E. palcno (Linnæus), he applied the Linnean name hyale to the wrong spccies, using cdusa (a discarded synonym of his own for Pontia daplidice) in its place. But even if the Clouded Yellow were not the true E. hyale (Linn.), Fourcroy's name of crocezs would have to be adopted instead of the later edusa, Fabr. The original Linnean description of $C$. hyale runs as follows:

"P.D. alis integcrimis rotundatis flavis; posticis macula fulva, subtus punclo sesquialiero argenteo" ("Hab. in Europa, Africa ").

It is clear from the last locality, that Limneus confoundcd E. clectra with it, though he aftcrwards separated the latter as a distinct species, calling it "fulvous," not yellow, which the much (lecper colour of E. clectra will readily account for. E. electra is, however, so like our Clouded Yellow, that some authors have been inclined to regard it as the same species as $E$. hyale.

Both our Clouded Yellows are very rare in. Scandinavia, where E. palceno, Linnæus, a sulphur-yellow or greenish-yellow Butterfly with moderately broad black borders, and other species of the genus occur; but Linnæus includes E. hyale in his "Fauma Succica," and describes it as follows:

"Sinilimus Palanoni, sed Alæ magis flava. Alæe primores 



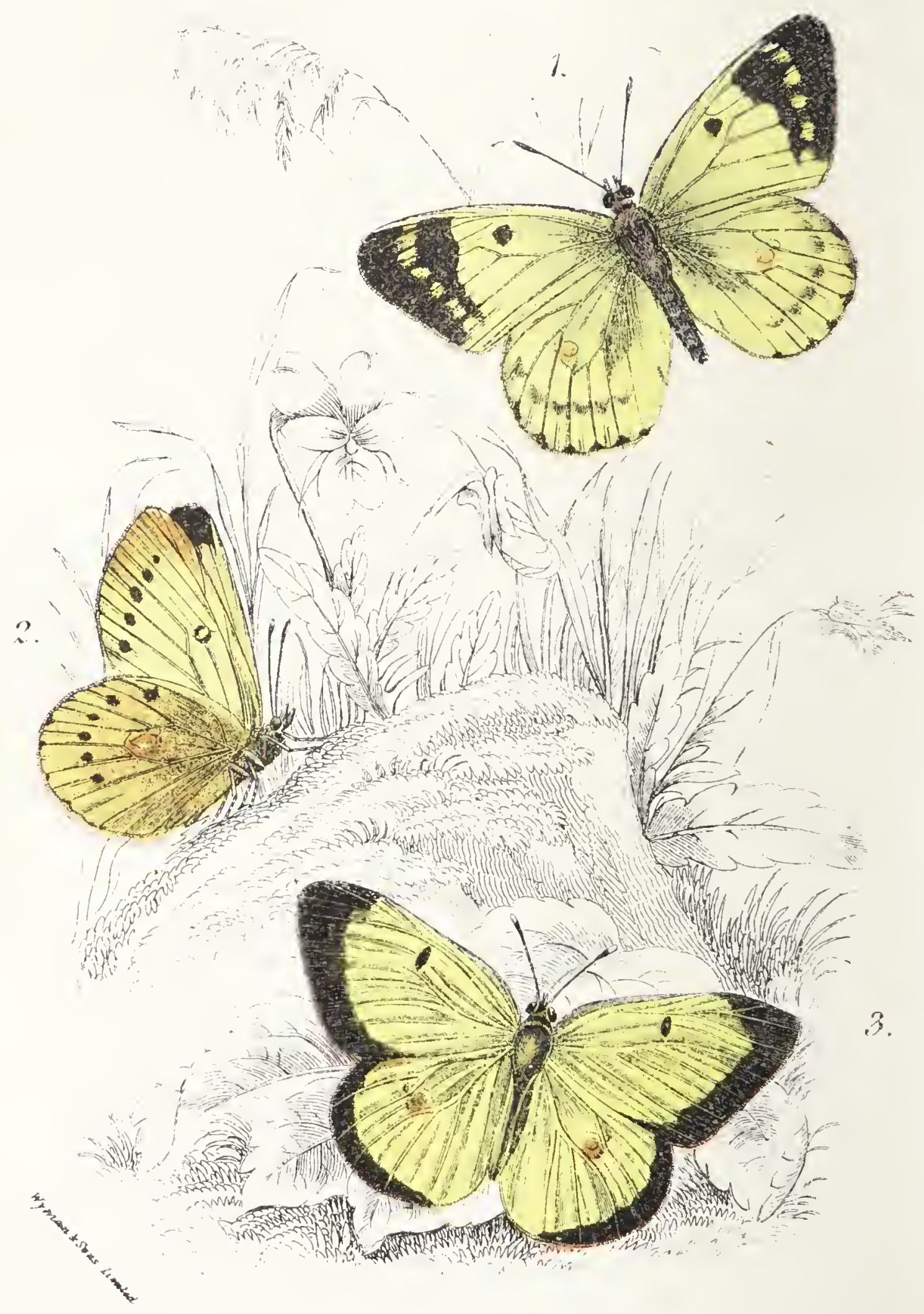

7. 2. Eurvmus hirbyi. 
flare, apice nigra, nigredine fascia quasi lutca in duas partes dissecta. Secundarix supra in medio puncto s. macula ferruginea, cui subtus opposita puncta duo argentea approximata, annulo ferrugineo cincta; altero puncto valde parvo. Antennæe et margo ciliaris alarum rubra ut in sequente" (Palreno).

I regard this description as undoubtedly referable to the femsle of our Clouder Yellow, in which the spotting of the border is often divided into two patches, and which is much yellower han either E. pationo or the Pale Clouded Yellow. All the figures originally quoted by Limnaus (Petiver's and Rocsel's) represent the female of the Clouded Yellow, to which I have ventured to restore the original name of hyale; and it was recognised as that species by most of Linnæus' contemporaries, though Geoffroy and Scopoli confounded the Pale Clouded Yellow with it as a variety, or as the female, while others mistook it for E. patceno (Linn.).

THE P.ILE CLOUDED YELLOW. EURYMUS KIRBYI.

$$
\text { (Plate LAT. Fiss. I, 2.) }
$$

Papilio luyale +, Scopoli, Ent. Carn. p. I73, no. 455 (1763);

Fabricius, Mant. Ins. ii. p. I3, no. 243 ( 1787 ); Ochsenheimer, Schmett. Eur. i. (2) p. I\& I (1 S0\$).

Papilio palano, Denis \& Schiffermüller (nec Linn.), Syst. Veř. Schnett. Wien. p. i 65, no. 2 ( т 776 ); Esper, Schmett. i. (I) p. 6S, pl. 4, fig. 2 ( 1777 ); Iiibner, Eur. Schmett. i. firs. $43^{3}, 439$ ( 4 So 3 ?).

Colias hy'ale, Godart, Enc. Méth. ix. p. 99, no. 33 ( I S I 9) ; Boisduval, Spec. Gén. Lépid. i. p. 650 ( ${ }_{3} 6$ ) ; Stephens, Ill. Brit. Ent. Haust. i. p. I 3 ( $S_{27}$ ); Curtis, Brit. Ent. vi. p. 642 (rS29); Kirby, Eur. Butterflics and Moths, p. 9, pl. 5, figs. 3a, b ( $\left.S_{7} S\right)$; Newman, Brit. Butteiflies, p. I 4 I ( I $S S_{\text {I }}$; Lang, Butterflies Eur. p.53, pl. I 2, fig. 3 ; pl. I6, fig. 2 (larva) (ISSI) ; Barrett, Lepid of Brit. Isl. i. p. 32, pl. 5, figs. 2, za-e (1S92); Buckler, Tarwe of Brit. Lepid. i. p. I6 (I886). 
Colias sareptensis, var. Kirbyi, Lewis, Discussion on the I.ain of Priority, p. 34 (1872).

The Pale Clouded Yellow is a Butterfly of rather smaller average size than the last species. 'The wings are of a sufficicinty bright yellow on the upper side, but with no tendency towards orange, and the females are often whitish. There is a lroad black border on the fore-wings, irregularly spotted with yellow, which is incomplete at the hinder angle; on the hind-wings it is narrow, often incomplete, and there is frequently a second narrow macular line within it. The fore-wings are marked with a black discoidal spot, and the hind-wings with a large orange one. The under side is of a deeper yellow than the upper, especially on the hind-wings; there is a sub-marginal raw of rustybrown spots, a black discoidal spot on the fore-wings, and two contiguous silvery spots surrounded with ferruginous on the hind-wings. The antennæe and fringes are reddish.

The larva (vol. i. pl. 3, fig. 2) is velvety-green, with two yellow lateral lines, and black dots on each segment. It feeds on clover, trefoil, \&c. The pupa is also green, with a yellow line on the sides. 'The Butterfly is double-brooded in many places, but is rarely seen in England till the autumn.

The Pale Clouded Yellow is found throughout a large part of the Palrarctic Region, but not beyond it, unless its reported, but doubtful, occurrence in South Africa should be confirmed. It is a rather scarce insect with us, and is found chiefly in clover and lucerne fields in the south of England, and is uncertain in appearance, though commoner than formerly. In many parts of Germany it is a much commoner insect than $E$. hyale, and much more regular in appearance; and in ordinary years it is one of the commonest autumn Butterfies, not much less common, sometimes, than the White Cabbage Butterflies. My own experience is that its flight is much less rapid than that of $E$. hy'ale, though in England it is said to fly with equal or greatcr 
rapidity, perhaps because, being a much rarer insect, it is more hotly pursued.

In Eastern Europe, and throughout Northern and Central Asia as far as the Himalayas and Japan, there are a cluster of species or varieties closely allied to this, which some authors associate with it, and others regard as distinct. Among these is $E$. erate, Esper, in which the black border of the fore-wings is continued to the hinder angle; another is the form known as E. sureptensis, Staudinger, which is thus described: "Alis anticis margine postico lato nigro ; 0 saturatius flavus."

It is much to be regretted that this species has always been confounded either with E. hjale or E. palcno, two Linnean species about the identification of which there never ought to have been any doubt. There is consequently no old name that belongs to it at all, and I have therefore no alternative but either to adopt for it the name of $E$. sareptensis (as I once proposed to do), or of some other allied Eastern form with which it may not after all be truly identical; or to adopt the name of E. Kirbyi, given to it in jest by the late Mr. Arnold Lewis.

THE SCARCE CLOUDED YELLOW. EURYMUS PHILODICE. (Plate LXJ. Fig. 3.)

Pafilio palano, Cramer (nec Linn.), Pap. Exot. i. pl. I4, figs. $\mathrm{F}, \mathrm{G}$ ( I 775 ).

Colias dorippe, Godart, Enc. Méth. ix. p. ror, no. 36 (rsro). Zerene anthyale, Hübner, Zutr. Exot. Schmett. ii. p. 2 r, figs 307,308 ( 1 823 ).

Colias europome, Stephens, Ill. Brit. Ent. Haust. i. p. Io, pl. I ( 1827 ).

Eurymus philndice, Swainson, Zool. Ill. ii. (2) pl. 6o (183 I ?). Colias philodice, Godart, Enc. Méth. ix. p. roo, no. 55 (rSrg):

Boisduval \& Leconte, Lépid. Amér. Sept. p. 64, pl. 2 r, figs. I-3 (r833); Boisduval, Spec. Gén. Lépid. i. p. 647 $\left({ }_{3}{ }_{3} 6\right)$; Scudder, Butterflies East. U.S. p. r r r r (r $\left.\$ 89\right)$. 
The present species, which is very common in North America, measures two inches and upwards across the wings. As regards our two British Clouded Yellows it may be regarded as somewhat intermediate between them, being of a sulphuryellow colour, like the male of $E$. Firby $i$, but with a continuous black border, lined with yellow in the male, and spotted with yellow in the female, like that of E. hyale. There is a black discoidal spot on the fore-wings, and a rather broal rust. coloured spot on the hind-wings ; the antennze and fringes are reddish. Beneath, the discoidal spots are all pupilied with silvery, that on the hind-wings being double, and there is a row of ferruginous spots on the disc.

This Butterfly has the habit of congregating in great numbers on damp mire. I have not heard of our European species of Eurymus acting thus.

The larva is green, more or less varied with rosy, and feeds on a variety of leguminous plants. The pupa is green, irrorated with yellowish-white.

This Bulterfly was confounded by many of the older entomologists, both in England and on the Continent, with the European E. palcno (timn.) ; but this insect is of a greener yellow in the male, and whiter in the female. The American species was originally introduced into our British lists on the strength of specimens in the cabinets of Francillon and Swainson, both of whom were in close correspondence with Abbot, the famous Georgian entomologist, from whom their specimens were almost certainly received.

Hübner figured $E$. palcno under the name of europime, which Haworth adopted, and gave an unsatisfactory description, taken, as Haworth admits, from a German specimen.

Stephens' figures, derived from specimens obtained from the collections of Francillon and Marsham, undoubtedly represent the American insect; and between $S_{20}$ and $S_{40}$ various 
accounts were published of its having been taken in company with E. hyale and E. Kirbyi between Brighton and Lewes; near York; near Ipswich; and in the West of England, near the confluence of the Avon and the Severn, in August and September. Dr. Scudder thinks that the Butterfly might have been introduced into England, maintained itself for a few years, and then died out again; but it is more probable that the first reputed British specimens were American, and that when attention was called to the subject, specimens of one or other of our British species were mistaken for it. Similar errors constantly occur even at the present day, (an instance is mentioned in the "Entomologist's Monthly Magazine" for July, I 895 , of a specimen of Pontia daplidice being found in an old Staffordshire collection labelled "sinapis,") and such errors must have been far more common fifty or sixty years ago when there were hardly any books on Natural History, even on British Butterflies, than now, when they are plentiful. It is not likely that a Butterfly, said fifty or sixty years ago to have been taken in all parts of the country, should have disappeared so utterly that not a single specimen has been heard of since. Besides, it is positively asserted by the Rev. W. 'T. Bree, in "Loudon's Magazine of Natural History" for May, I $S_{32}$ (vol. v. p. 333, note), that the so-called specimens of E. curupome, said to have been taken between Brighton and Lewes, were only L. kirbyi.

\section{GENUS MEGANOSTOMA.}

Meganostoma, Reakirt, Proc. Ent. Soc. Philadelphia, ii. p. 356 (IS63); Butler, Cist. Ent. i. pp. 36, 46 (is7o); Schatz, Exot. Schmett. ii. p. 69 (1886).

Antenna short, with the club gradually formed; palpi moderately iong. Fore-wings pointed, the cell rather short; 
sub-costal nervure four-branched, the second branch rising at or a little before the end of the cell, the fourth running to the tip or to the costa just before it, the upper radial nervule separating from the sub-costal a little less than half way between the cell and the tip. On the hind-wings, which are rounded, the cell is longer and very pointed; and the pre-costal nervule is rudimentary. The claws are without appendages, but the middle and hind tarsi in the females are said to possess two delicate membranous three-jointed structures, which Reakirt terms "Eupronychia." They are very delicate and casily lost, and are therefore difficult to find except in very fresh specimens.

This is a purely American genus, and differs considerably from Eurymus both in shape and pattern. The commonest species is M. cesonia (Stoll) which inhabits the Southern United States. It is a yellow species, shading more or less into orange, but on the fore-wings the base is black, and the hind-margin likewise, the centre of the wing being crossed by a broad yellow band, on which the black discoidal spot is pliced. The inner side of the border is very irregular; on the costa it extends narrowly to the black at the base, and on the inner-margin inwards for half its length; but between, it forms a series of rectangles, the yellow colouring extending squarely into it in the middle half way to the hind-margin. Another species, $\boldsymbol{A}$. eurydice, Boisduval, which is found in California, resemble; this, but is more of an orange-yellow; the fore-wings are beautifully flushed with purple, and the hind-wings have no black border. The female much resembles that of Colias rhammi, except in shape. Other species are found in Venezuela, Bolivia \&c.

\section{GENUS COLIAS.}

Colias, Fabricius, in Illiger, Mag. f. Insekt. vi. p. $2 S_{4}$ (ISo7); Latreille, Consid. Générales, p. 440 (1S10); id. Enc. Méth. ix. pp. Io, S9 (ISI9). 
Goneptoryx, Lcach, Edinb. Encycl. ix. p. izs (IS15); Doubl. Gen. Diurn. Lepid. p. 69 (г 847 ); Butler, Cist. Ent. i. pp. 35, 45 (I870); Schatz, Exot. Schmett. ii. p. 68 (I886). Rhodocera, Boisduval \& Leconte, Lépid. Amér. Sept. p. 70 (1833) ; Boisd. Spec. Gén. Lépid. i. p. 597 (1836).

Body stout, hairy ; palpi and antennæ short, the latter thick, with the club gradually formed. Fore-wings with the costa strongly arched, and ending in a projecting point; hind-wings with a short projection at the end of the second median nervule; the lower disco cellular nervule much curved on all the wings. Fore-wings with the sub costal nervure four-branched, the second branch emitted some distance before the end of the cell; the upper radial a little beyond. The fourth sub-costal nervule runs to the costa just above the projecting tip. The pulvillus between the claws of the tarsi is long and narrow.

This genus is common throughout the Palrearctic Region, but does not extend beyond it. It attains its maximum of development in the south-west in C. cleopatra (Linn.), with a fiery-orange centre to the fore-wings of the male; and in the more subdued, but more generally diffused rich orange of the Canarian C. c.ébule (Hübner).

THE RRIMSTONE BUTTERFLY. COLIAS RHAMNI.

$$
\text { (I'late LX. Fis. I.) }
$$

Tapilio rhamni, Linn. Syst. Nat. (ed. x.) i. p. 470, no. 73 (1758); id. Faun. Suec. (ed. ii.) p. 272 (1764) ; Esper, Schmett i. (I) p. 73, pl. 4, fig. 4 (I777); Hübner, Eur. Schme:t. i. figs. $44^{2-444}$ (I 803 ?).

Colias rhamni, Godart, Enc. Méth. ix. p. 89, no. z (I8I9). Gonepterya rhamni, Stephens, Ith. Brit. Ent. Haust. i. p. S (1827); Curtis, Brit. Ent. iv. pl. I73 (1827); Kirby, Eur. Butterlies and Moths, p. i I, pl. 4, tig. 9 ( 187 S); Lang, 
Butterflies Eur. p. 65, pl. I 4, fig. 4, pl. 16, fig. 4 (transf.) (188I) ; Barrett, Lcpid. of Brit. Isl. i. p. 40, pl. 7, figs. I, $1<$-d (1892); Buckler, Larve of Brit. Lep.j. i. p. I45, pl. 1 , fig 2 (isS6).

Khodocera rhammi, Boisduval, Spec. Gén. Iépid. i. p. 602, pl. 6, fig. 7 (is $\left.S_{3} 6\right)$; Newman, Brit. Butterflies, p. I 47 (ISSI).

The Brimstone Butterfly, which measures two and a quarter or two and a half inches across the wings, may at once be recognised by its arched and pointed fore-wings and its slightly tailed hind-wings. They are of a bright sulphur-ycllow in the male, and grecnish-yellow in the female, with a small orange spot at the end of the cell in all the wings, and with small ferruginous spots at the ends of the nervules. The under side is of a somewhat glaucous-greenish. The antennæe are red, and the thorax is clothed with long white silky hairs. (A side view of the bifid claws will be found in vol. i. pl. I, fig. I3).

The following account of its transformations is given by Stephens. "The caterpillar is green, with a paler line on each side of the belly, and very small scalc-like black dots on the hack, which give that part a bluish aspect; the fore part of the body is thick and rounded, the hind part compressed. It feeds upon the Rhammus catharticus (or buck-thorn) and the $R h$. frangulus (berry-bearing alder); and is said to occupy three or four days in changing to the pupa state; the pupa or chrysalis is very gibbous in the middle, acuminated before, and green with a clearer line on each side, and a reddish or fulvous spot in the middle; it is vertically suspended on a perpendicular branch, with a loose silken streak round its middle. The perfect insect is produced in about fifteen days."

The Brimstone miy be considered as the typical Butterfly for excollence, for it must have been this species rather than the 
succies of Emrmus, as Dr. Scudder suggests, * which gave rise. to the idea of "the butter-coloured fly." Common everywhere throughout the greater part of the Palrarctic Rcgion, in open woods and lancs, almost all the ycar round, it could hardly have failed to attract generai attention. It is not, however, an inhabitant of the extreme north of Europe, and in the British Islands it scarcely reaches Scotland. In Ircland it is found at Killarney, and has been reputed to occur in Wicklow. It raries little in size and colour, though, very rarely, individuals cxhibit a slight trace of orange-red on the fore-wings which is perhaps the reason that some authors still persist in regarding the splendid Meditcrancan C. cleopatra (Lian.), to which we have already alluded, as a varicty. It is duuble-brooded, and owing to the strong texture and thick scaling of its wings, it is comparatively rare to meet with rubbed or bïoken specimens.

\section{Exotic senera allicd to Colias.}

The first of these which we hare to mention, is Amjnthia, Swainson, which greatly resembles Colias, which it replaces in Tropical America (including the Trest Inlies), but is very much larger, the species measuring from three to four inches across the wings. The type, $A$. morula (Fabricius), is almost the counterpart of Colias rhamin, except that the discoidal spot on the fore-wings is black, and that on the hind-wings pale orange, speckled with biack. Another species, A. clorinda (Godart), is grecnish-white, with a sulphur-yelluw blotch cxtending from the costa over the outer half of the cell in the male; at the end of the cell is an orange spot. On the forc-wings, the second branch of the sub-costal nervure is emitted before the cud of the ccll, and on the hind-wings, the short tooth on the hind-

* In former times, C. rhamni would have been more abundant than at present; but when there were no clover-ficlds, Enymus would have been much scarcer. 
margin is placed at the upper, instead of the middle, median nervule, and the space between this and the anal angle is slightly dentated.

Recent authors have proposed to restrict the use of Boisduval's name Rhoducera to one of the largest of the Pieride, $R$. menippe (Hübner), which is not an uncommon species in South America. It expands about $3 \frac{1}{2}$ inches across the wings, which are of a yelluwish-green, with a black spot at the end of the cell on the fore-wings, and an orange spot on the hindwings. The fore-wings have a conspicuous orange-"tip," the inner edge of which extends obliquely beyond the cell; it is narrowly bordered with black at the apex, along the upper half of the hind-margin, and as far as it extends. The fore-wings are strongly arched, and are slightly pointed, not from the extreme apex being acute, but from the hind wargin being somewhat concave below the tip ; the hind-wings are regularly rounded, and scalloped, but with no short tail. The antennæe are red, as in most of the allied genera.

Kricogonia, Reakirt, is another small genus of the group found in the Southern States of America, Mexico, and the West Indies. The antennæ are distinctly clubbed, the palpi are rather long, and the fourth branch of the sub-costal nervure runs to the tip of the fore-wings, which are nearly rectangular at the tip, while the hind-wings are rounded. The type, $K$. lyside (Godart), measures about two inches across the wings, which are white above, with the base and, more faintly, the tip of the fore-wings tinged with sulphur-yeliow. On the under side the hind-wings are greenish-white.

Dercas, Doubleday, is a small genus characteristic of the Indian Region. The wings are unusually short and broad, as are also the wing-cells; the fore-wings have a short, but prominent hook at the tip, and the hind-wings, which are almost square, have a projecting tooth at the end of the upper 
median nervule, as in Amyuthia. The type, D. vermulli, Van der Hoeven, which inhabis North India and South China, measures about $2 \mathrm{r} / 2$ inches across the wings, which are sulphuryellow above, with the tip and hind-margin of the fore-wings rather narrowly blackish; a short ferruginous stripe on the disco cellular nervules of the fore-wings, and a slightly oblique yellowish line, most distinct below, running from the apical blotch on the fore-wings to beyond the middle of the hindwings.

\section{GENUS CATOPSILIA.}

Catopsitia, Hübner, Verz. bek. Schmett. p. $9^{S}$ ( I $S_{\text {I } 6)}$; Butler, Lepid. Exot. p. I 54 (I873) ; Distant, Rhop. Malay. p. 295 (1885); Schatz, Exot. Schmett. ii. p. 67 (1886).

Antennæ moderately stout, longer than in Colius and its allies, but shorter and thicker than in typical Pieris, \&c. ; gradually thickened into a club, truncated at the tip. Wings moderately long and broad, the fore-wings with the costa arched, and the apex more or less distinctly rectangular, the hindmargin slightly oblique; hind-wings rounded. Sub-costal nervure four-branched, the first branch emitted about the middle of the cell, the second near the end of the cell, the third and fourth forming a rather large fork; the fourth running to the hind-margin a little below the tip, the upper radial nervule separating at about one-third of the distance beyond the cell. Hind-wings with the pre-costal nervure obsolete. The males have a tuft of silky hairs near the base of the inner-margin of the fore-wings, and a patch of raised scales above the subcostal nervure of the hind-wings.

The larvæ are slender, cylindrical, and granulated. They are green or grey, with black spots, and feed on Cassia. The pupa is moderately stout, pointed at both ends, but not curved, and with a conical hump on the back.

These Butterflies are confined to the tropics of the Old 
World, where they are extremely abundant. They are grejarious, sometimes assembling in large numbers on damp sand (if. vol. i. p. lxiv.). They have a very rapid and powerful flight, and frequently migrate in large flocks. The Butterflies are of a white or yellow colour, and some of them very closely resemble American species of allied genera. They are probably not all strictly speaking, congeneric; thus the Malayan and Australian C. seylla (Limn.), a conspicuous Butterfly with white fore-wings narrowly bordered with black, and orange hind-wings, has a much stouter larva, and a stouter and more regularly-formed pupa, with the thoracic hump rounded off.

The type of the genus is C. crocale (Cramer), another very abundant Indo-Malayan and Australian species, which measures a) out $23 / 4$ or 3 inches across the wings. The male is greenishwhite, with the greater part of the costa and hind-margin narrowly bordered with black; the base of all the wings is broadly sulphur-yellow, the outer limits of this colour being very irregular, and narrowly produced for some distance below the black edging of the costa of the fore-wings, and along the inner-margin of the hind-wings. 'The female is of a more creamy white, tinged with ochreous towards the base, and with the costa of the fore-wings and the hind-margins of all the wings more broadly edged with black. From the costa of the forewings an irregular black mark descends over the disco-cellular nervules, and towards the tip the black markings are broader, forming the commencement of a spotted band.

\section{GENUS CALLIDRYAS.}

Callidry'cs, Boisduval \& Leconte, Lépid. Amér. Sept. p. 73 (1833); Boisduvai, Spec. Gén. Lépid. i. p. 605 (1836); Doubleday, Gen. Diurn. Lepid. 1) $66\left(1 \$_{47}\right)$; Butler, Cist. Ent. i. pp. 36, $46(1870)$; id. Lepricl. Exut. pp. 2 2, $15.5\left(1870-1 S_{73}\right)$. 
This grenus nearly resembles Catopsitia, but there is no brush of hairs on the wings of the male, though there is a patch of raised scales towards the base of the hind-wings, and the upper radial nervure !ises at only one-fourth of the distance beyond the cell. The species inhabil Tropieal America, one or two extending as far north as the Southern United States. They are all of a yellow, orange, or red colour, some of them, such as C. solstitia, Butler, from Chili, and C. avellaneda, HerrichSchäffer, from Cuba, being blotehed with red and ycllow in such an extraordinary manner as to look more like clumsilyexecuted daubs than natural Butterfics. 'The type of the genus is

\section{CALLIURYAS EUBULE.}

(Plate Llit. Figss. 2 (imago), 3 (larva), 4 (pupa).)

Papilio eubule, Linn. Syst. Nat. (ed. xii.) i. (2) p. 743, no. Io2 (1767); Abbot \& Smith, Lepid. Georgin, i. pl. 5 ( I 797 ).

Calidry'rs eubule, Boisduval \& Leconte, Lépid. Amér. Sept. p. 74, pl. 24 ( IS33) ; Boisduval, Spec. Gén. Lépid. i. p. 6 I 2 , pl. 6, fig. $6\left(\operatorname{IS}_{3} 6\right)$; Butler, Lepid. Exot. i. p. 5 , pl. 2 , figs. 7-IO (I $87 \mathrm{I})$.

This is a eommon Butterfly in the United States. It measures about three inches across the wings, which are of a fine sulphuryellow above, unspotted, or with a linear brown border to part of the costa and hind-margin of the fore-wings, and brown dots on the ends of the nervures on the hind-wings. Beneath, there is a brown spot centred with silvery at the end of the eell of the fore-wings, and two larger contiguous silvery spots, in ferruginous rings, on the hind-wings; there are also some irregular brown or ferruginous lines or dots seattered over the under side of the wings. The fenale is of a somcwhat deeper yellow both above and below, with the dark edging of the fore-wings rather broader, 
and a rather large black spot at the end of the cell; on the under side a ferruginous line runs round all the wings, and there are two silvery discoidal spots in ferruginous rings on the fore-wings as well as on the hind-wings. The body is yellow, with greenish hairs on the thorax, the antennæe and terminal joint of the palpi are rose-colour, varied with brown.

The larva is green, with a yellow line on each side, surmounted by a blue one. It is covered with small black granules, and feeds on different species of Cassia. The pupa is also green, changing to brown before the emergence of the Butterfly. As will be seen by the figure, the anterior projection is very conspicuous, and the ventral surface is much rounded, but the upper surface of the body is slightly concave, without the hump on the thorax, which is so conspicuous in the pupa of Calopsilia.

The remaining genera of this group all belong to Tropical America. Aphrissa, Butler, differs from Callidry'as chiefly by its longer palpi, especially in the female. The type, A. statira (Cramer), a South American species, is rather smaller, and of a paler yellow than Callidry as eubule; towards the hind-margins, which are narrowly bordered with black, the colour shades into whitish; the under side is marked only with a silvery discal spot on the hind-wings, ringed with brown. In the female, the border is rather broader, and there is a black discoidal spot on the fore-wings above, and a corresponding spot beneath, centred with silvery; there is also a series of slight disconnected brown sagittate spots on the disc, following a short zig-zag line running from the inner edge of the brown apex of the forewings.

The next genus, Phabis, Hübner, has a tuft of silky hairs in 
the male above the sub-costal nervure, near the base of the hindreings, instead of on the inner-margin of the fore-wings, as in Catopsitia; the wings are rounded, and the fore-w ings are rather longer than the hind-wings, with the apex generally rounded off, and the hind-margin regularly curved and slightly oblique; the type is $P$. hersilia (Cramer), which is common in South and Central America. In this genus the males of most of the species are of an orange-yellow above, and the females are slightly bordered or spotted towards the margins with brown, and are marked with a black or brown discoidal spot on the fore-wings. On the under surface both sexes present the characteristic silvery discoidal spots, bordered with ferruginous, and are more or less varied with incomplete ferruginous zig-zag lines and mottlings.

Another small genus, allied to Phabis, is Rhabdodryas, Godman \& Salvin, which differs from Pheebis in having an additional patch of closely-packed scales between the costal and sub-costal nervures of the hind-wings. The type is $R$. statira (Cramer), a yellow species, easily distinguished from any other Butterfly of this group by having a straight black line running across all the wings beneath. It is found in South America.

The last genus of this group has been called Metura by Dr. Butler, but this name had been previously used by Walker for a genus of Moths belonging to the family Psjchide, and I therefore prefer to substitute the name Parura, at Dr. Butler's suggestion, for the present genus. 'The type will be P. cipris (Fabricius). The males have a tuft of hair above the sub-costal nervure of the hind-wings near the base, as in Phabis, but the fore-wings are shorter and broader in proportion, the costa being much more strongly arched, and the hind-margin much straighter and scarcely oblique; the hind-wings are produced into a short broad pointed tail at the anal angle. The Butterflies are of considerable size, frequently exceeding three inches 
in expanse, and are yellow or orange, with very large discoidal jpots on the fore-wings, at least in the females, in which sex the hind-wings are sometimes bordered with red. The type, I. apris (Fabricius), is sulphur-yellow in both scxes. They are all Troncal American species.

\section{GENUS SPILTENOGONA.}

Sthonggona, Butler, Cist. Tint. i. pp. 35, 44 (iS70).

The present genus, which is confuned to the warmer parts of America, chiefly differs from the succeeding ones in having the hind wings produced into an angle or short tail about the middle median nervule. The sub-costal branch on the hind-wings is cmitted beyond the cell.

Dr. Butler (l.c. p. 44) indicated S. ectriec as the type of the genus, in which 1)r. Scudder has followed him; but previously (..c. p. 35) he had stated simply, that the genus "includes S. ectriua, bosotana, and allics." 'The truc type would appear not to be S. ectriata, but S. bogotana, Felder; for not only was S. ectriva, in 1870, only a manuscript name of Doubleday's; but when Dr. Butler described the species shortly afterwards, he only did so by briefly comparing it with S. salome, Felder, also an unfigured specics at that time (which Felder, when describing it, compared with his own S.bogotana), and this, again, I)r. Butler had already compared with S. Fogrtina, Felder. The species of Sphanogona are generally yellow or white, with broad black borders, deeply indented on the forcwings with the ground-colour. As a representative of this genus we have figured

SPHENOGONA MEXICANA.

(rlate LLI. Figr. I.)

Terias mericana, Boisduval, Spec. Cén. T،épid. i. p. 655, no. 3; pl. 19, fig. I (1 $\left.S_{3} 6\right)$; Godman \& Salru, Biol. Centr.-Amer. Lepid. Rhop. ii. p. 157 ( $\mathrm{ISS}_{9}$ ). 
Abcis mexiana, Geyer; Hübner, Zutr. Exot. Schmett. v. p. 29, figs. 9i 7,9 I $S$ (I 837$)$.

This species, which inhabits Mexico, as its name denotes, measures about $\mathrm{I} 3 / 4$ inches across the wings, which are white, with a broad black border; the latter is very irregular, and is decply indented by the ground-colour in the middle on the fore-wings. In the male the hind-wings are broadly yellow along the costal area. This species is closely allied to S. bogotanu, Felder, the type of the genus; but in S. bogotana the deep white indentation on the middle of the band of the forewings is much narrower, and the costa of the hind-wings is not yellow in the male.

As the male of his S. mericann, Boisduval described a yellow species, which has since been named S. boisduvaliana by Reakirt.

\section{American gencrir allied to Sphonogona.}

In Pyrisitia, Butler, the fore-wings are slightly pointed, and the hind-wings are sub-quadrate, the hind-wings showing a slight tendency to form a rectangle on the hind margin, but with no projecting tooth. The type is P.proterpia (Cramer), a South American species, remarkable for its bright orange colour and for the broad black costal area of the fore-wings.

Another genus, Xanthidir, Boisduval, differs from all the other American genera by the male possessing a patch of felted scales on the under side of the hind-wings between the median and sub-median nervures. It includes several rather large yellow and orange species, with broad black borders and broad rounded wings. The type is $X$. nicippe (Cramer), which is common in many parts of North America. It measures about two inches across the wings, which are of a bright orange colour, with broad black regular borders, and a black streak at the end of the cell of the fore-wings. The female is of a much paler 
yellow, and the border is much narrower and more incomplete. The larva is green, with a darker dorsal stripe and a white band on the sides, marked with five yellow dots. It feeds on Ononis and Trifolum. The pupa is green, sightly arched, and sprinkled with ferruginous points.

Eurema, Huibner, is another American genus, including smaller species, rarely attaining the expanse of an inch and a half. They are yellow or white, with rather narrow fore-wings and broad rounded hind-wings. In several species the fore-wings are yellow and the hind-wings white. They are more or less bordered with black, and the males have always a black stripe towards the inner-margin of the fore-wings, which band is not unfrequently edged with a narrower orange stripe. The type is E. delia (Cramer), a North American species. It is yellow, marked as described, but there is a large black triangular marginal blotch towards the tip of the hind-wings above instead of a border; on the under side the hind-wings and the tip of the fore-wings are of a dull greyish-red. The larva is green, with a white lateral stripe, and feeds on Trifolium, \&c. 'The pupa is also green.

\section{GENUS TERIAS.}

Terias, Swainson, Zool. Ill. i. pl. 2 I (I 222 ); Horsfield, Cat. Lepid. E. I. Co. p. I3+ (IS29); Boisduval, Spec. Gén. Lépid. i. p. 65 I (1836); Doubleday, Gen. Diurn. Lepid. p. 76 (I 847 ); Butler, Cist. Ent. i. pp. 35, 44 (I 870 ); Distant, Rhop. Malay. p. 302 (I 886 ).

Body slender, rather hairy; palpi short, compressed; antennæ short, slender, with a gradually formed club. Wings rather short and broad, cells broad, lower disco-cellular nervules arched; fore-wings rounded, or more or less pointed at the tips ; hindwings rounded. Fore-wings with the sub-costal nervure fourbranched, the first branch emitted at about a quarter of an inç 
before the end of the cell, the second near the end of the cell, the third and fourth forming a rather long fork; upper discoidal nervule thrown off at about one-third of the distance between the cell and the tip of the wings. Hind-wings with the pre-costal nervule more or less obsolete; sub-costal nervure bifurcating about the end of the cell.

The larva is moderately slender, cylindrical, and pubescent; the pupa is straight, pointed at the ends, and very convex on the back.

This genus includes an immense number of small white and yellow Butterflies, which inhabit the warmer parts of Asia and Africa. There are several well-marked groups among them, which must ultimately be divided into genera like their American allies. Many species have a wide distribution, and are very variable. They are all of a white or yellow colour, sometimes with only the tip of the fore-wings black, at other times with black borders varying in shape and width. On the under side they are generally more or less flecked with brown or ferruginous. The type, Terias hecabe (Limneus), is a widelydistributed East Indian Butterfly, with broad black borders, which are broader towards the tip of the fore-wings, but below the middle of the border it is deeply and squarely indented by the yellow ground-colour in the manner of Sphanogona mexicana (.f. plate lix. fig. I). The border of the hind-wings is narrower and regular. This is a very variable species. On the under side it is distinctly spotted, but in the closely-allicd $T$. sari, Horsfield, and in some allied species, there is a large square reddish-brown blotch at the tip of the fore-wings beneath. The larva of $T$. hecabe is green, with a pale yellow lateral stripe. It feeds on various species of Aischynomene, especially $A$. sesban.

In another species, representing a different group, T. candida (Cramer), the wings are yellow above and below in the male, 
and white above in the female, with a broad regular black border, not indented, which is continued narrowly along the costa of the fore-wings, and is represented by a brown shade along the inner-margin of the lind-wings. Other species have a black band, varying in width, on the inner-margin of the fore-wings, resemblung what we find in the genera Nathalis and Earrema.

\section{FAMILY VI. EQUITIDA.}

Egg,-Dome-shaped, flattened at the base, slightly rugose, more ovate in the Parmassime, and reticulate.

Larva.-Cylindrical, with a Y-shaped retractile tentacle behind the head; smooth or granulated, sometimes humped towards the head, not hairy or bristly, but occasionally furnished with rows of fleshy tubercles.

Pupa.-Attached by the tail, generally in an upright position, and secured by a girth round the middle of the body.

Imago.--Of large or moderate size ; wings strong, often tailed; pattern generally simple and uniform, not variegated, and very rarely with well-marked ocellated spots; sub-costal nervure of fore-wings four-branched (rarely five-branched); lower radial nervure appearing like a fourth branch of the median; median and sub-median nervures connected by a short cross-nervule near the base; sub-median nervure throwing off a short fork near the base to the inner-margin; hind-wings with but one sub-median nervure, the lower sub-median, or internal nervure, so conspicuous in the Pieride, being always absent. Six perfect legs in both sexes, the tibia furnished with a leaflike projection; the claws always simple, except in Leptocircus, in which they are sometimes bifid.

* This is technically called an osmaterium, and always emits a strong odour. 
range. - The species formerly included in the genus Papilio and its immediate allies are sparingly represented all over the world, but attain their maximum of size, beauty, and variety in the Indo- and Austro-Malayan Regions. 'The genera which most nearly resemble the Picride, on the other hand, are mountain insects, and, with the exception of Pamassius, which cxtends to the Rocky Mountains, are almost cntircly confmed to Europe and Northern and Western Asia.

Habits.-Most of the larger and more typical specics of this family feed on trees, and others on Umbelliferc. 'They frequent woods and gardens, and have a lofty, sailing flight, but as they frequently rest on tall flowers or flowering shrubs, they are less difficult to capture than might be supposed. As already mentioned, the white species which rescmble Picride frequent mountain slopes, and their larve feed on saxifrages and other low plants.

I believe that Dr. Scudder is right in regarding the Camberwell Beauty, Vanessa antiopa of our first volume (p. 92), as the true type of the genus Papilio, Linn., for Schrank assigned that name to the $N_{y} m p h$ halide before Latreille restricted it to the Linncan Equites. But the genus necd not carry the Family name with it, and the Nymplatide may retain that title. The present Family may be called Equitide, which course I have decided to adopt in the present volume, pending the final subdivision of the great genus Pafilio, Latreille (nec Schrank), into natural genera.

The Equitide form several very distinct groups, which may be treated as Sub-families. Schatz defines threc, but they are more readily separable by their general appearance than by the cliaracters which he assigns to them. 


\section{SUB-FAMILY PARNASSIINÆ.}

Palpi moderately long, not extending beyond the head; wings rounded, white or yellow, often with red spots; forewings with the sub-costal nervure four or five-branched, with no transverse nervule connecting the median and sub-median nervures at the base; hind-wings with no transverse nervule connecting the costal and sub-costal nervures. These Butterflies frequent mountains and steppes; the pubescent larvæ feed on saxifrages and similar plants, and the pupa is enclosed in a rough cocoon on the surface of the ground, or is subterranean. Several authors have remarked on the Moth-like characteristics of this group of Butterflies.

\section{GENUS PARNASSIUS.}

Parnassius, Iatreille, Hist. Nat. Crust. Ins. xiv. p. I Iо (1805); id. Enc. Méth. ix. pp. 9, 79 (I8I9); Boisduval, Spec. Gén. Lépid. i. p. 394 (1836); Doubl. Gen. Diurn. Lepid. i. p. 26 (I847); Elwes, P. Z. S. I886, pp. 6-53, pls. i.-iv. ; Schatz, Exot. Schmett. ii. p. 48 (isS6).

Body hairy; antennæ short ; club variable in form ; wings rounded, often semi-transparent towards the tips, from the presence of hair-like scales; fore-wings with the sub-costal nervure four-branched, the upper radial nervule rising considerably beyond the cell; hind-wings with the inner-margin considerably concave. Female with a horny pouch at the extremity of the abdomen.

THE APOLLO BUTtERFLy. PARNASSIUS APOLLO.

$$
\text { (Plate LXIT. Fig. I.) }
$$

Papilio apollo, Linnæus, Syst. Nat. (ed. x.) i. p. 46r, no. 4I $\left(175^{S}\right)$; id. Faun. Suec. p. 268 (1761); Esper, Schmett. i. (I) p. 4I, pl. 2, fig. I (I 777); Hübner, Eur. Schmett.

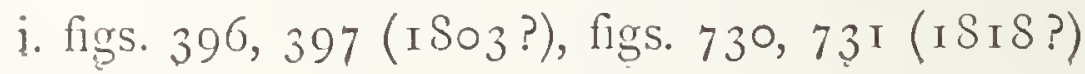


120

$+3$
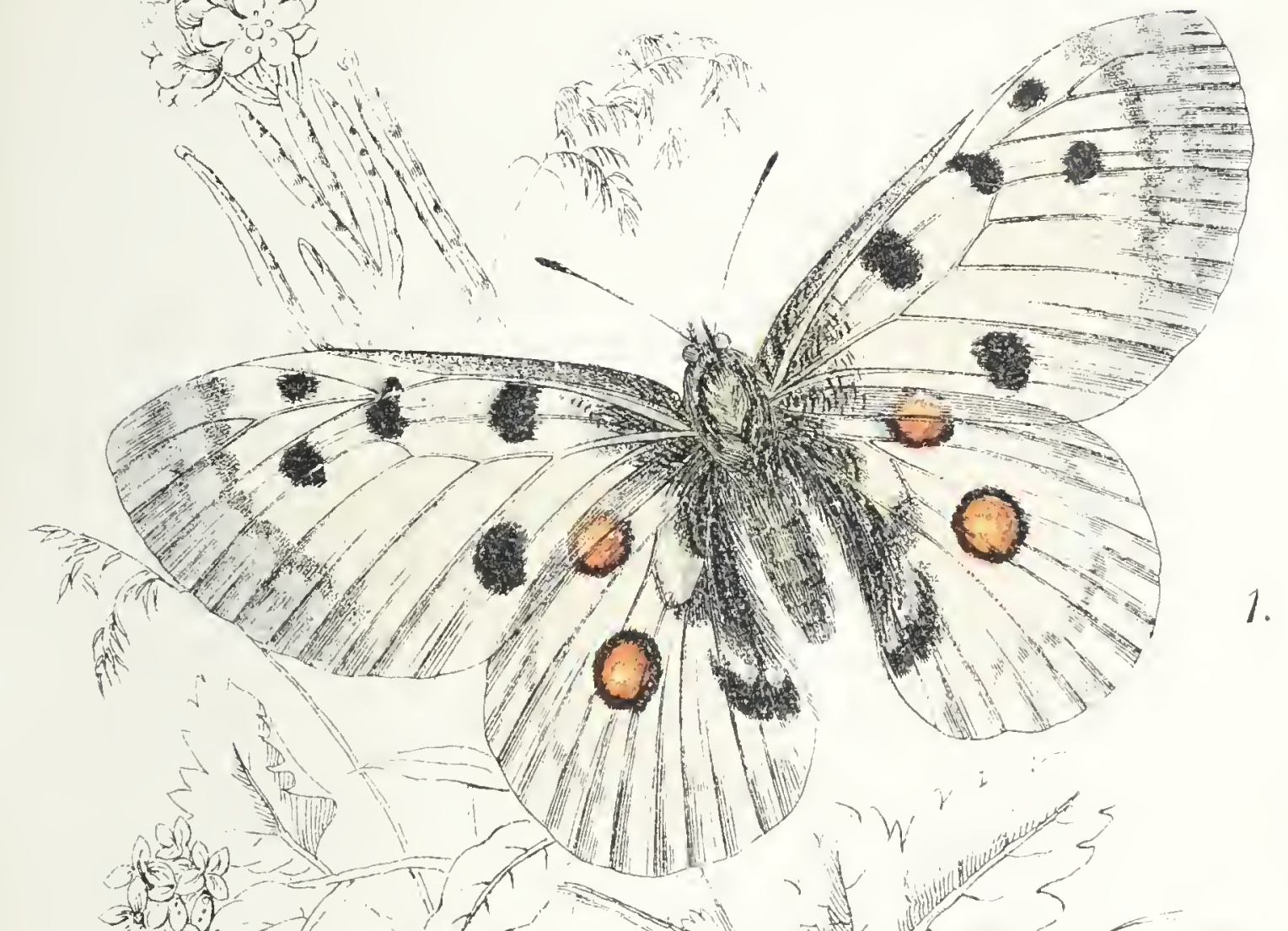

3.

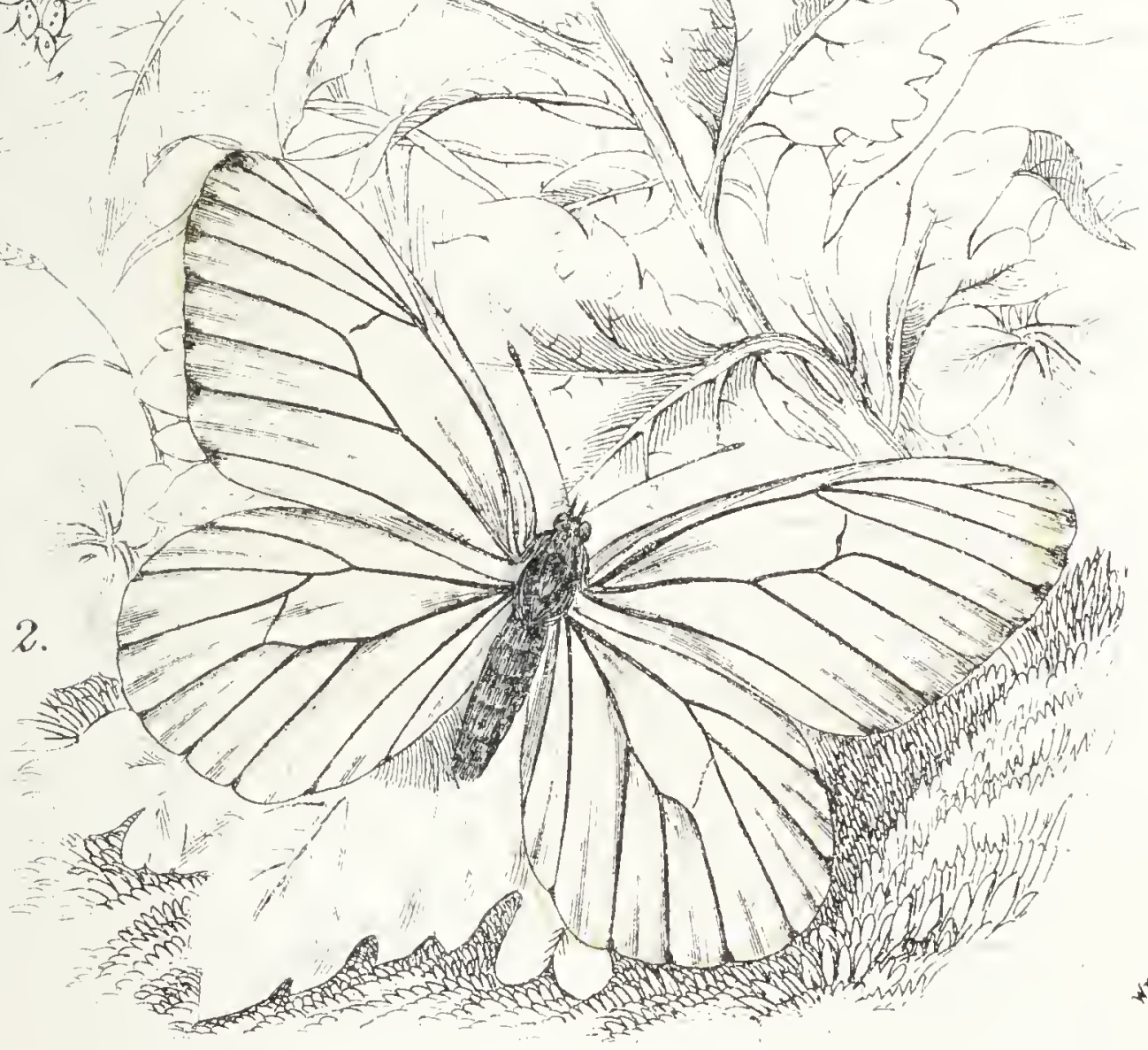

1. Parnassius apollo.

2. Aporia cratagi. 

Purnassius apollo, Godart, Enc. Méth. ix. p. 79, no. I (1819); Boisduval, Spec. Gén. Lépid. i. p. 395 (1 836$)$; Newman, Brit. Butterflies, pp. I 75, I 76 (ISSI); Kirby, Eur. Butterflies and Moths, p. 4, pl. 3, figs. 1 $a-d$ (1878); Lang, Butterflies Eur. p. I6, pl. 2, fig. I, pl. 4, fig. I (pouch); pl. 5, fig. 6 (transf.) ( $188_{1}$ ); Austaut, Les Parnassiens, pp. 86, I93 (is89).

Ordinary European specimens of this well-known Butterfy measure from $2 \frac{1}{2}$ to $3 \frac{T}{4}$ inches across the wings, which are white, slightly tinged with yellow. The fore-wings are marked with five black spots, one in the cell, one at its extremity, two or three beyond, and a larger one just beyond the middle of the inner-margin. The base is thickly dusted with black; the hind-margin is semi-transparent, as if varnished, being covered with fine hair-like scales; within this is a moderately broad dusky line, more or less distinct. The hind-wings are white, with the inner-margin thickly dusted with black, and clothed with long white hair, and there are two dusky zig-zag sub-marginal stripes. There are also two very conspicuous large red spots in black rings, and generally with whitish centres: one below the costa, towards the base, and one beyond the cell; towards the latter, a black bar, sometimes marked with red, at least on the under side, runs from the inner-margin. On the under side there is an additional row of red spots, bordered with black externally, at the base. The body is black with white hairs above, and yellowish beneath; the antennæe are black, ringed with white, with a black ovoid club.

The larva is velvety-black, with two rows of deep orange spots on each side; the incisions are glossed with blue, and the whole body is clothed with short black hair. It feeds'on the Orpine (Sedum telephium) and on various other species of saxifrages, \&rc. 
The pupa is spun up betwecn leaves, thus being placed in a slight cocoon.

'This Butterfly is found throughout the greater part of Europe and Northern and Central Asia, in summer and autumn, in mountainous regions. In Scandinavia it occurs in the plains, but in the Alps it is one of the commoner Butterflies on the lower slopes, from about $\mathrm{r}, 000$ to 5,000 feet above sea-level. In Spain it is found at a great elevation in the Sierra Nevada, in Andalusia; and the spots of these individuals are of a yellowish-white instead of red colour. In West Central Europe it becomes rare; in the Vosges it is very scarce and local, if it occurs at all. It is absent from North Germany, and in Western Germany it is only met with in a few localities near Coblenz, between the Mosel ànd the Ahr. Many reports have been published of its having been taken in England and Scotland, but it could hardly occur in some of them (such as Dover) except by direct importation with plants or otherwise, and several of the principal Scotch reports are now known to have been erroneous. At present there is no justification for including it in the British lists. The largest European specimens have been said to come from Silesia, where, however, it is now almost, if not quite, extinct. 'The great Siberian Pamassius hesebolus, Nordmann, which is generally considered to be a variety of $P$. apollo, sometimes expands nearly four inches.

The other two European species are much more local in the Alps. P. delius (Esper) is smaller on an arcrage than P. apollo, and flies in damper places at a higher elevation; it may be distinguished by having the sub-costal spots beyond the cell marked with red. P. mnemosyne (Linnaus) is also a local Butterlly, and in P'russia Proper it is found on the plains, though elsewhere in Central burope it is a mountain liutterlly. It has no red spots, but only two black oncs, in and at the end of the cell of the fore- 
wings, and some blackish markings towards the inner margin of the hind-wings. The club of the antenne is very long, and gradually formed, and this species and its allics will certainly be separated as a distinct genus by future entomologists.

The foreign species of Pamassius are usually very similar to the rel-spotted European ones; and, as already mentioned, one or two are found in the Rocky Mountains and California. At the other end of their range they do not cross the Mediterranean though they are found in Spain, Italy, Greece, and Armenia; but in Central Asia they are very numerous. Some species, such as $P$. stubbendorfí, Ménétriés, which is found in the Altai, are almost entirely white, without red, and even without black spots; others, such as $P$. eversmummi, Ménétriés, from East Siberia and Alaska, are yellow, at least in the male; for the white $P$. zosnesenstii, Ménétriés, is believed to be the female. Most of the species, however, resemble $P$. afollo and $P$. delius so much, that one description, unless detailed, would fit them all; some, however, such as $P$. apollonius, Eversmann, which frequents salt-marshes in Central Asia, have a row of three or more red or yellow spots on each wing. 'T'wo of the Indian species may be noticed: $P$. charltonims, Gray, a scarce species, as large as $P$. apollo, found at a great elevation, which has a row of sub-marginal black spots, with blue pupils, on the hind-wings beyond the two large red eyes: and $P$. hardzeickit, Gray, a much smaller and commoner species, hardly reaching two inches in expanse, which is similarly marked, but the red spots are smaller in proportion, and there are, moreover, red spots on the forc-wings as well.

There are two other small gencra of this Sub-family besides Parnassins. Doritis, Fabricius, is distinguished by the fivebranched sub-costal nervure of the fore-wings. D. apolline (Herbst) measures about two inches across the wings, which are semi-transparent yellowish-grey (whiter on the fore-wings in 
the male), with two very large biack spots on the fore-wings, one in, and one at the end of the cell, and the hind wings have a sub-marginal row of black eyes with blue pupils, marked within by a row of red spots. The larva feeds on Aristolochia, and the pupa is found under moss and stones. 'The Butterfly appears from January to March in Asia Minor and Syria. It has also been reported to occur in European Turkey and in some of the Greek Islands.

Hypermnistra, Heydenreich, has the sub-costal nervure of the fore-wings four-branched, as in Parnassius, but the upper disco cellular nervule is well marked, the upper radial nervule rising from the discoidal cell, and not from the sub-costal, as in the preceding genera. The type, $I$. helios (Nickerl) is common on the steppes of Turkestan and North Persia, and the pupa is said to bury itself deep in the ground. The Butterfly measures about one and a half inches across the wings, which are of a yellowish-white, with black spots arranged nearly as in Parnassius, the two beyond the cell on the fore-wings marked with red; the hind-wings are marbled with green beneath, which gives the insect somewhat the appearance of a Pontia.

These two genera have no horny pouch in the female, as in Parnassius; but we may notice two outlying genera which possess it, though Schatz includes them in the Equitina, because they have a cross-nervule near the base on the fore-wings between the median and sub-median nervures, and one on the hind-wings between the costal and sub-costal nervures. The sub-costal nervure of the fore-wings is five-branched in both genera.

Eurycus, Boiscluval, is a small genus, including one or two species from Australia and New Guinea. The type, E. cressida (Fabricius), is common in Australia, and is remarkable for the dissimilarity of the sexes. It averages about three inches in expanse, the female being rather smaller than the male. This 
is exceptional in Butterflies, though it is the case in Drurya antimachus (Drury), and in some other Butterflies. The male has longer and narrower wings than the female. The forewings are smoky-hyaline, broadly black at the base, and more narrowly round the margins, with two very large roundish black spots, one in, and one at the end of, the cell. The hind-wings are slightly dentated, and are black, with a transverse white band, divided by the nerrures across the middle; about its centre is a black spot, of moderate size, at the end of the cell. On the black space beyond the white band is a row of submarginal red spots, and there is a row of marginal yellowishwhite spots. The female is really very similar in markings, but has a very different appearance, being of a yellowish smokyhyaline, more strongly yellowish towards the base, where it is black in the male. On the fore-wings the apex is broadly dusky, and the black spots in and at the end of the cell are very small. On the hind-wings the white band is hardly differentiated from the general colouring of the wing, and the sub-marginal spots are yellow instead of red. The female has some resemblance to the common Australian Acrea andromacha (Fabricius), which it is thought to mimic.

The genus Euryades, Felder, which is confined to the Argentine Republic and the neighbouring countries of South America, is intermediate between Eurycus and some of the more typical groups of South American Equitina, but it may be distinguished by its peculiar neuration, the upper disco-cellular nervule of the fore-wings being, instead of all the disco-cellulars, very short, and the fourth sub-costal nervule rising from the third beyond the cell, and the fourth and fifth forming a rather short fork. The horny pouch of the female, too, is peculiar. The fore-wings are triangular, and the hind-wings are dentated, and, in some of the species, tailed. The type is $E$. corethrus (Boisduval). 


\section{SUB-FAMILY THAIDINAE.}

Palpi long, projecting beyond the head; antennæe short; wings dentated or tailed; sub-costal nervure of the fore-wings fire-branched; median and sub-median nervures of the forewings not connected by a short cross-nervure near the base, cxcept in Tcinopalpus, but the hind-wings with the costal and sub-costal nervures thus connected.

A very small, but interesting group, confined to the Mediterranean Region, Bhutan, China, and Japan. They are so well marked that it is hardly necessary to distinguish them here by more than their outward characters.

\section{GENUS THAIS.}

Thais, Fabricius in Illiger's Mag. Insekt. vi. p. $2 S_{3}\left(1 S_{07}\right)$; Latreille, Enc. Méth. ix. p. 9 ( ISrg) ; Boisduval, Spec. Gén. Lépid. i. p. $382\left(18_{3} 6\right)$; Doubleday, Gen. Diurn. Lepid. p. 30 (18.47); Schatz, Exot. Schmett. ii. p. 50 ( 1886.$)$

Moderate-sized Butterflies, expanding about two inches across the wings, which are broad, and not very long. They vary from yellowish-white to ochreous, and are ornamented with festooncd markings on the hind-margins, somewhat like those on the under surface of the genus Cethosia in the Nymphalide (cf. vol. i. p. 4\$). The fore-wings are banded or spotted with black, chiefly towards the costa, and are often more or less spotted with red; the hind-wings are more or less clouded or spotted with black, chiefly towards the base and inner-margin, and have always a sub-marginal row of red spots. The hind-wings are always dentated, and sometimes subcaudate.

The larve are cylindrical, rather short, and covered with fleshy spines and short hairs. They feed on different species 


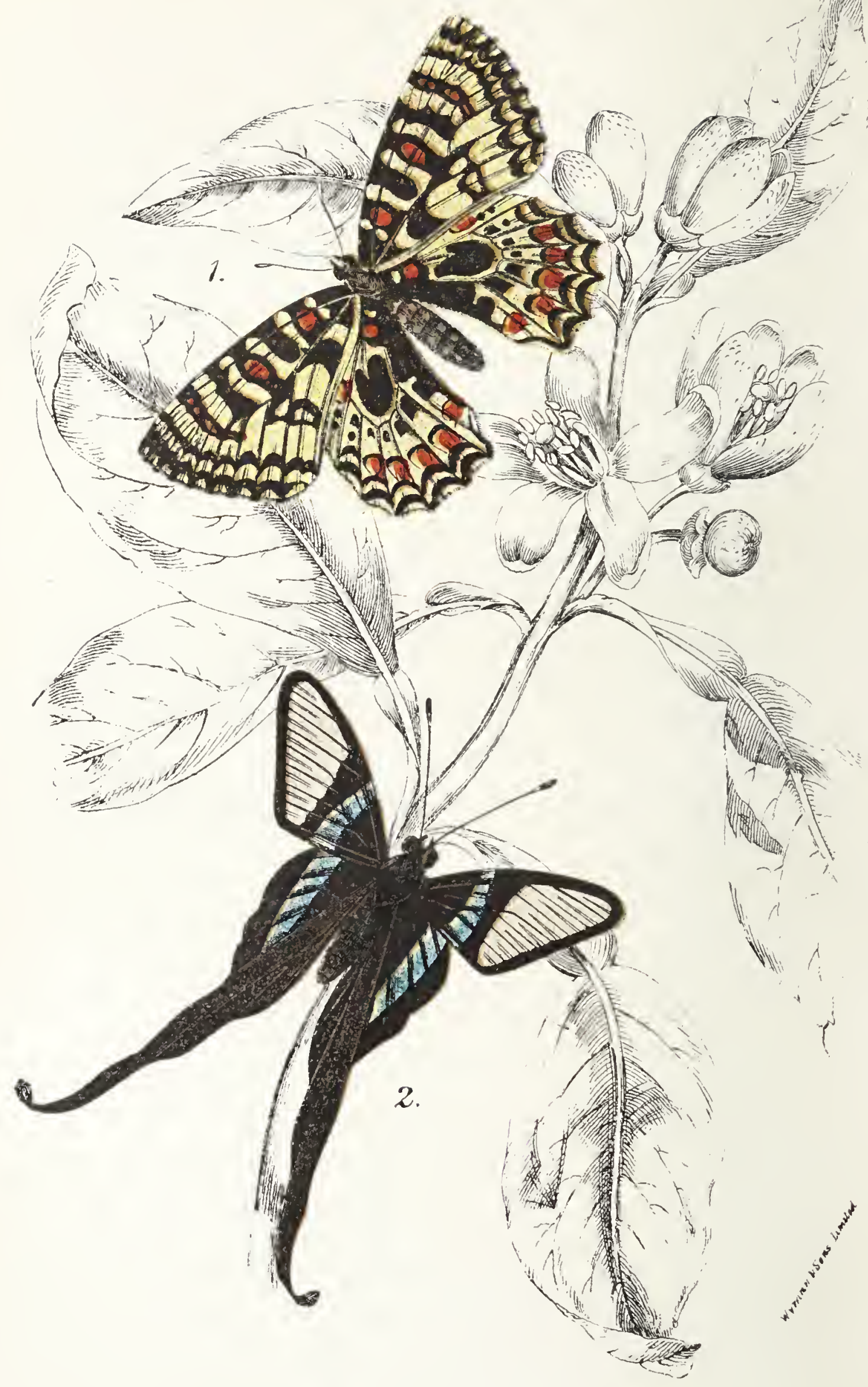

1. Thats medesicaste.

2. Leptocircus meges. 
of Aristolochia, either singly, or in small companies. The pupa is cylindrico-conical, somewhat angular in front.

The species are all found in spring and carly summer in the Mediterranean Region. The type is $T$. polyxena (Denis and Schiffermuiller), which is found in South France, Italy, Austria, and South-eastern Europe and Western Asia generally. It is a longer-winged insect than the species figured, and has only one red spot (if any) on the costa of the fore-wings. The larva is yellowish, with a brown dorsal band, six rows of reddish-yellow spines tipped with black, and black dots on the sides. It feeds on Aristolochia clematidis in August, and the Buttcrfly appears in early spring.

\section{THAIS MEDESICASTE. \\ (Plate LXIII. Fig. 1.)}

Papilio medesicaste, Fabricius in Illiger's Mag. Insckt. ii. p. I 81 (1803); Hübner, Eur. Schmett. i. fig. 632 (1818).

Thais medesicaste, Godart, Enc. Méth. ix. p. 84 (1819); Boisduval, Spec. Gén. Lépid. i. p. 388 (1836); Kirby, Eur.

Butterflies and Moths, p. 3 ( I 878 ).

Papiliv rumina, Hübner, Eur. Schmett. i. figs. 394, 395 ( 1803 ?).

Papilio rumina Eurofice austraics, Esper, Schmett. i. (2) p. $1 \times 5$, pl. 72 , fig. 4 ( 1782 ?).

Thais rumina, var. medesicaste, Lang, Butterflies Eur. p. 24, pl. 3, fig. 4 (I 88 I).

\section{Var. Thais honnoratii.}

Var. Thais honnoratii, Boisduval, Icones, p. I 8, pl. 3, figs. 3-5, (I 832 ).

Thais medesicaste, var. honnoratii, Boisduval, Spec. Gén. Lépid.

i. p. 389 , pl. 5 , fig. $4(1836)$. 
Thais rumina, var. honnoratii, Lang, Butterflies Eur. p. 24, pl. 3 , fig. 5 ( $188 \mathrm{I})$.

This species, which is common in Southern France in May, is the smallest of the genus, expanding an inch and a half or an inch and three-quarters. It is of a yellowish-white or pale ochreous-yellow; the fore-wings with a series of five broad black bands running from the costa, the first, third, and fifth marked xith red; the base is also more or less black. The second and fifth bands are narrower, and converge with the first, to the inner-niargin, the outermost of these bands being again marked with red. Towards the hind-margin are two continuous festooned black bands, the ends of the outermost touching the margin. The hind-wings are more or lcss black at the base, close to which a red spot is generally visible, and there are some small black spots on the disc. Beyond is a row of red spots, bordered within with black, and there are two sub-marginal lines which form crescents, but not the abrupt festoons of those on the fore-wings. Towards the tip of the fore-wings is a transparent spot. The under side is similar, but paler, and the light portions of the hind-wings have a peculiar white glazed appearance. The body is black, with yellow spots on the abdomen.

The larva, which feeds on various species of Aristolochia, is variable in colour, being reddish-yellow, brown, or dull reddishgreen, with rows of interrupted black lines. It has six rows of fleshy orange-yellow spines, tufted with black at the end.

This Butterfly is frequently considered to be a local form of the Spanish Thais rumina (Linn.), which differs by its larger size and deep ochreous colour. The Rev. Douglas C. Timins, who observed $T$. medesicaste in South France, writes:- "It is less sluggish than some of the other species of the genus, but seldom flies after two or three o'clock, and prefers localities where the beautiful rose-coloured cistus 
grows." He adds: "There is a variety of this species figured under the name of Thais homoratii, by Boisduval, which appears to be only found in the neighbourhood of Digne; it is smaller than the type; the crimson spots are much enlarged upon the lower wings, and upon the upper wings are much more numerous and also larger than in the type; the second and third costal bands are very small. This variety is exceedingly rare, and specimens fetch about $\mathcal{E}_{\mathrm{I}}$ each in the Paris dealers' shops. I have been told, however, by an old French entomologist, that they have been known to fabricate this variety by selecting small individuals of $T$. medesicaste and dexterously colouring them by means of crimson scales borrowed from other specimens; the biack scales of the second and third costal bands being neatly removed, and their place supplied by yellow scales. I have followed most authors in giving $T$. honnoratii as a variety of $T$. medesicaste; if, however, this is the case, it is rather curious that it should only have appeared in one locality out of several in which $T$. medesicaste abounds. The statement, moreover, that it has been reared from a larva identical with that of $T$. medesicaste must be received with caution. I knew a French collector who had at one time two thousand larvæ of $T$. medesicaste, and not one produced T. honnoratii." (Proc. Ent. Soc. London, r 867 , p. ro3.)

Digne, although one of the most famous localities for Lepidoptera in France, appears, for some reason or other, to be but little visited by English entomologists.

The remaining genera of this Sub-family are rare in collections, being mostly confined to localities more or less difficult of access, and may be dealt with briefly. 
Inchdorfia, Crüger, may be structurally distinguished from Tha is by the presence of a short upper disco-cellular nervule (which is absent in Thais) on the fore-wings, and the much shorter middle disco-cellular. The species are confined to North China, including the Amur district and Japan, and are larger than Thais, usually expanding more than two inches across the wings. The fore-wings are more triangular, and the hindwings sub-caudate. The species are of an ochreous-yellow, with alternating longer or shorter bands running from the costa of the fore-wings, some of the longer ones extending to the costal region of the hind-wings. The latter have a row of red spots towards the hind-margins beneath, though on the upper surface there is sometimes only a large red blotch towards the anal angle. Outside this is a black band, marked with a row of biue spots, beyond which is a sub-marginal row of ochreous spots, sometimes tinged with reddish, the incisions being also marked with ochreous. At the end of the upper median nervule is a short tail. The larva is black, with yellow spots and incisions, and the pupa more resembles that of Achious machaon in form than that of Thais.

The genus Sericinus, Westwood, inhabits the same localities as Luchdorfic, but its range is less extensive, as it is unknown in Japan. There are a cluster of closely-allied forms, which some writers consider to be distinct, while others consider them all to be varieties of $S$. telamon (Donovan). They are white or yellowish-white Butterflies, measuring from two to two and a half inches across the wings. The latter are more or less banded, and spotted with black, and are sometimes; marked with one or more small red spots. Towards the anal angle of the hind-wings is a red band, narrowly edged inside with black, and outside broadly with black, spotted with blue. In the female the black bands often expand and anastomose to such an extent as to cover a laige portion of the wings, 
and the red and black, blue-spotted band towards the anal angle is extended sub-marginally nearly to the costa of the hind-wings; nearer the base is a red spot on the costa in the female. The hind-wings are very slightly dentated, but are produced into a single long tail at the end of the upper median nervule. The larva, which feeds on Aristolochia, is black, with hair-bcaring warts, and resembles that of a Thais. There are two hairy projections on the sides of the neck, besides the retractile fork which we find on the back of the neck of the larve of all this Family. The pupa has a row of spines down the back; the head is bifid, and the opposite extremity is obtuse.

Armandia thaidina, Blunchard, is a large Butterfly, with long and rather narrow wings, found in Western China. It was first brought from Mou-pin by the French missionary, Abbé David, who was the first to make known the natural history treasures of the far interior of China. It measures rather more than three inches across the wings, which are black, crossed by slightly undulated thread-like white transverse lines. The hind-wings are black towards the anal angle, with a broad red bar, some bluc flecks beyond it, and a few deep orange submargmal dashes outside. The hind-wings are dentated, and the median nervules terminate in three long tails, that at the end of the upper median nervule being the longest (half as lon as the length of the rest of the wing), and spatulate.

Bhutanitis lidderdalii, Atkinson, much resembles Armandio thaidina, and is placed by some authors in the same genus The structural characters appear to be slight, and the colour is much the same, but $A$. lidderdalii is a considerably larger Butterfly, measuring ncarer four inches than three across the wings, which are much broader, and of a much dceper black with whiter striae. On the hind-wings the orange-ochreous submarginal dashes are replaced by large spots of the same colour. 
the long tail is not spatulate, but linear, and is preceded by two short tails at the ends of the lower sub costal and the discoidal nervules, making five tails in all. In $A$. thaidina they are merely indicated by notches. $B$. lidderdalii was first taken by the celebrated hunter and naturalist, Lidderdale, in Bhutan, at a height of 5,000 feet above the sea. It has since been taken by others, but is still very scarce in collections. Nothing seems to be yet recorded concerning the early stages of these two remarkable Butterflies.

To this Sub-family I add another very beautiful species from North India and South China, which Schatz places in the next Sub-family. It seems to me, however (pending a thorough revision of the Equitide, which cannot be much longer delayed), to have considerable affinity to Armaindia and Bhutanitis, and hence I place it near them. It is true that the fore-wings are broad, sub-triangular, and rather pointed, instead of forming a long rounded oval; but the hind-wings are very similar in shape, and, what is of more consequence, the short upper disco-cellular nervule on the fore-wings, and the very long incurved middle orie are almost precisely of the same form.

The sexes of Teinopalpus imperalis, Hope, differ very considerably. The species measures from three and a quarter to four and a half inches across the wings. In the male the wings are of a silky green, with some darker, rather ill-defined strupes on the fore-wings; the hind-wings have a large orange band, bordered with black, running from the costa for half the length of the wing; on the outside the black colour extends nearly to the tip; it is bordered externally by a suffused lilac-white stripe, which, beyond the orange band, runs obliquely to the inner-margin, being edged internally with black. On the under side the wings are green towards the base, but the outer two-thirds of the fore-wings are suffused with a rich orange; the orange band of the hind-wings is more extended, and 
the lower and outer part of the wing is varied with lilacwhite. At the end of the upper median nervule is a long, slender tail, and a shorter one at the end of the lowest. The female is much larger than the male, and is broadly banded with green and lilac; and the orange band on the hind-wings is wanting. There are three long tails on the hind-wings, the shortest in the middle, and the longest nearest to the anal angle.

'This splendid Butterfly is found in the forests at Sikkim, at a height of from 6,000 to 10,000 feet, and has also been met with in Central China. The male flies, in the morning, about high trees, but may be attracted by ordure, or may descend to water, like Apatura iris. The female is very rarely taken, as is the case with many other Butterflies, of which the habits of the males are well known. The pupa has been found attached to the leaves of Daphne nipalensis, on which the larva no doubt feeds. It is a shrub resembling the mezereon, which grows at a height of from 7,000 to 9,000 feet in the mnuntain forests, and is used for paper making.

\section{SUB-FAMILY III. EQUITIN.E.}

Palpi short; antennæe generally long and slender, with the club more or less gradually formed. Fore-wings with the costal nervure nearly always five-branched, and with the upper disco cellular nervule well developed. Median nervure with a short cross-nervule near the base, which rarely extends as far as the sub-median; hind-wings, with the pre-costal nervure bifid (as is also the case in the genera Sericinus, Westwood, and Teinopalpus, Hope, but not in any other genera placed in the preceding Sub-families; and with a cross-nervule connecting the costal and sub-costal nervures near the base) Hind-wings often dentated and tailed. 
This Sub-family, as above restricted, corresponds exactly to the genus Papilio, as understood by Felder.

Three genera are now recognised by most Continental and English writers, but the real number is much larger.

GENUS DRURYA.

Drurya, Aurivillius, Entomol. Tidskrift, ii. p. 44 (r88r); Schatz, Exot. Schmett ii. p. 40 (т886); Rippon, Icones Ornith. p. iv.* ( 1892$)$.

Club of the antenne gradually formed; collar well developed; fore-wings very long, the hind-margin gradually concave; subcostal nervure five-branched, the third rising just before the cell; hind-wings short, rounded, slightly dentated, the inner-margin straight, not concave or folded; abdomen extending beyond the hind-wings.

The type of this genus is the famous Papilio antimachus, Drury, a specimen of which was brought to Europe by Smeathman from Sierra Leone, and figured by Drury in I 782 , and subsequently by Donovan in his "Naturalist's Repository." 'This specimen is now in the Sydney Museum, and no other was brought to Europe till i 864 , though it is now known to occur, though always sparingly, over a large portion of Tropical West Africa, even as far inland as Stanley Falls on the Congo. The wings are very long and narrow (less so in the female, which is smaller than the male), expanding from seven to nine inches. The fore-wings are black, with large tawny spots and markings towards the base, and the hind-wings are tawny, with a row of black sub-marginal spots. It has been supposed to mimic some unknown, and probably extinct species of the Sub-family Acreince. Its nearest ally is a West African Butterfly, which has been described as Pafilio ridleyanus, White, and which both in size, shape, and colour, much resembles Gnesia zetes (Linn.).** 


\section{GENUS TROIDES.}

Troides, Hübner, Verz. bek. Schmett. p. $8 S$ (ISIG). Ornithoptera, Rippon, Icones Ornithopterorum, p. I (I 89I).

With this genus we commence the series of Butterflies usually included in Boisduval's genus Ormithoptera, or Bird-winged Butterflies, which Mr. Rippon is now engaged in illustrating in his "Icones Ornithopterorum." They include many of the largest and most beautiful Butterfies in the world, and their range extends from China and India to North Australia. But only the gencra Ornithoptera, Boisduval, and Trogonoptera, Rippon, are found in the Indo-Malayan Region; the others belong cxclusively to the Austro-Malayan Region. I have published a paper on this group in Nature for January ro, is $S_{94}$, from which the accompanying figures have been taken, with the kind permission of the editor. I have not attempted here to reproduce all the information contained in that paper, though I have added some new matter which did not appear in it.

Here I may emphasise the fact that in dividing the Iinnean Erifuites into genera, Hïbner usually employed classical patronymics. In my determination of the types of these genera I have taken into consideration two points to which previous authors seem to have paid but little attention. Firstly, the applicability (if any) of the rame itself, which cannot be ignored in cases where there is a direct connection between the names of genera and species; and sccondly (though this is of much less consequence), the species figured under these names by Hübner himself. If, therefore, I ignore the types which some previous authors have affixed to Hübner's genera, it is usually on these grounds.

So far as is known, most of the species of this group agree in the large anal claspers of the males, the large collar, the long and rather pointed fore-wings, and the generally rounded and scalloped hind-wings, the tuberculate larve, Scc, 
The genus Troides may be briefly defined as follows. Antennie with a large, but gradually-formed club; fore-wings black, with green, blue, or orange bands in the male, and the hind-wings greenish, blue, or orange. Female black, more or less marked with large white or yellowish-white spots. On the fore-wings of the male is a large patch of raised scales. The third sub-costal nervule of the fore-wings rises considerably before the cell in both sexes, and the fourth and fifth sub-costals rise from a very short stalk just beyond the cell. Sides of the thorax red, abdomen yellow in male, yellowish-white in female.

TROIDES PRIAMUS.

(Plate LXIV. Fig. I.)

Papilio priamus, Linn. Syst. Nat. (ed. x.) i. p: 453, no. I ( $775^{8}$ ) ; id. Mus. Ulr. p. I 82 (I764); Clerck, Icones, pl. I 7, fig. I (I 764); Cram. Pap. Exot. i. pl. 23, figs. A, B (I775); Godart, Enc. Méth. ix. p. 25, no. I (IS19).

Troides priamas, Hübner, Samml. Exot. Schmett. ii. taf. I16, II 7 (I824).

Ornithoptera priamus, Boisduval, Spec. Gén. Lépid. i. p. 173 (1836); Rippon, Icones Ornith. p. 4, pl. r $a$, Ib (r89 I). o Papilio panthous, Limn. Syst. Nat. (ed. x.) i. p. $46 \mathrm{r}$, no. r6 (1758); Clerck, Icones, pl. In (I764); Cramer, Pap. Exot. ii. pl. I23, fig. A; pl. r24, fig. A (r777); Godart, Enc. Méth. ix. p. 25, no. 2 (1819).

This species, which appears to be confined to the islands of Amboina and Ccram, is not only one of the largest of the present group, but one of the largest Butterflies known. It measures from cight to ten inches across the wings. The male has velvety black fore-wings, with a bright green or bluish-green sub-costal band running from the base ncarly to the tip. A narrower grcen band, just above the innermargin, runs from the base, and curves round opposite the 



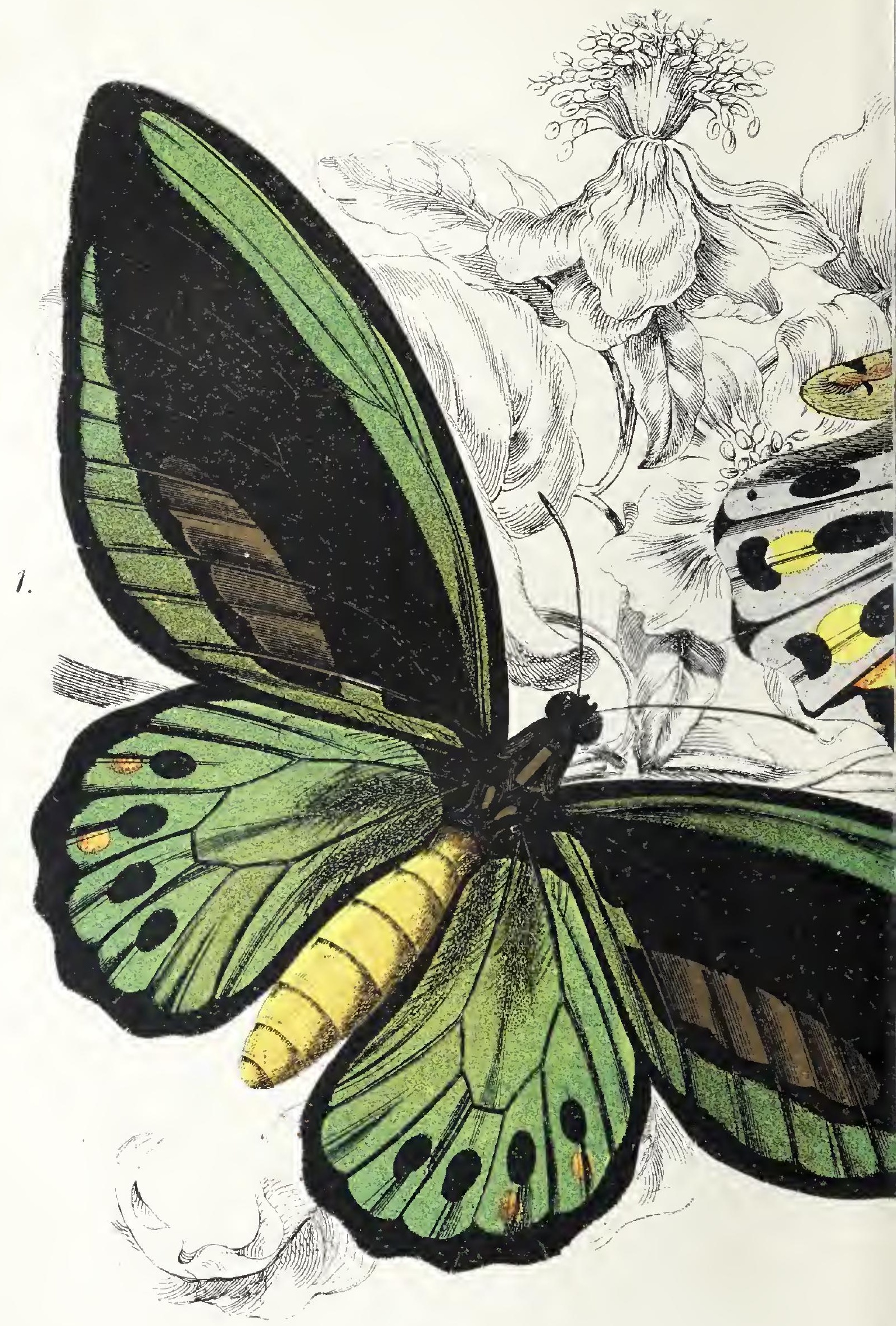




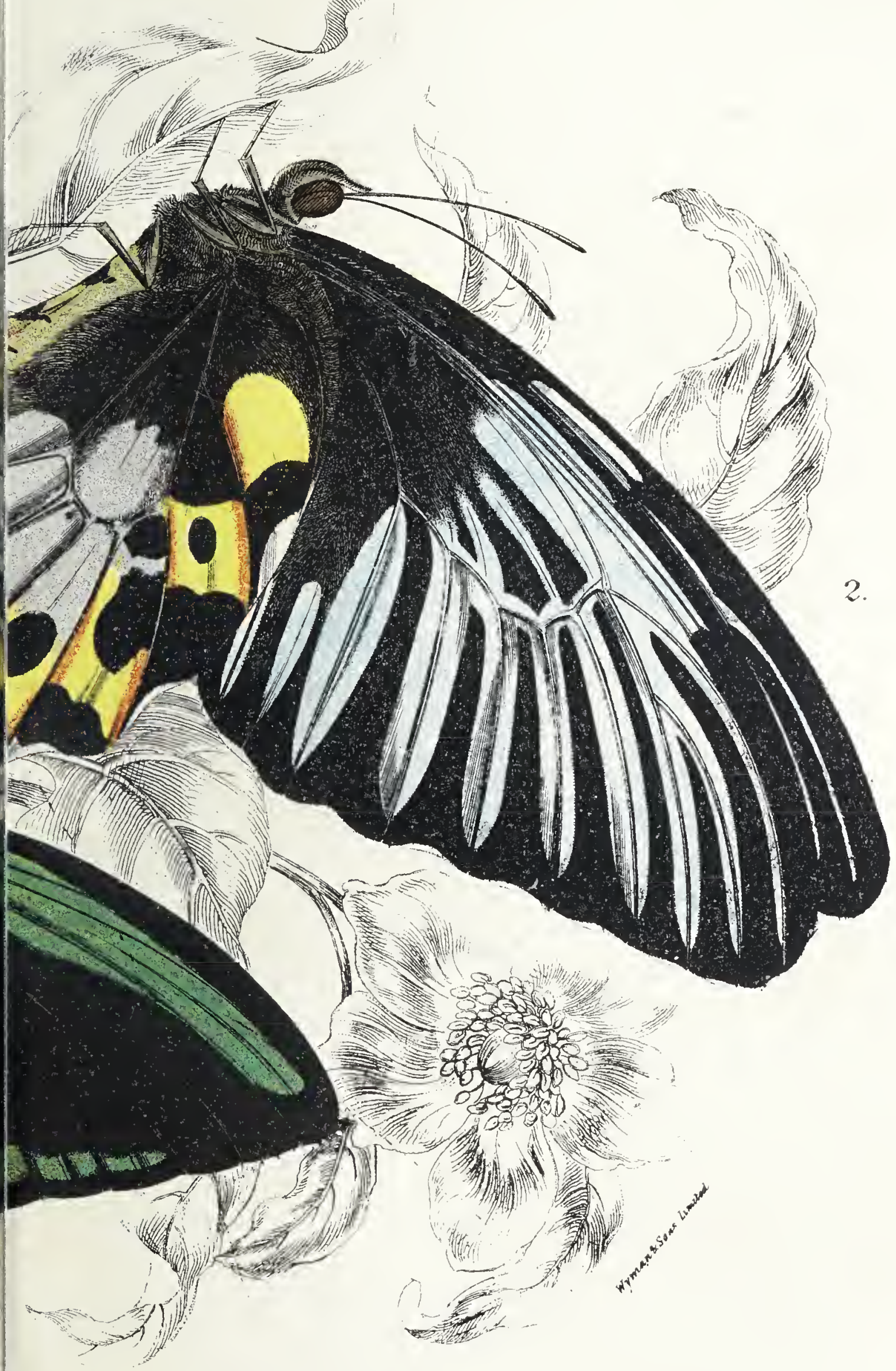



hind-margin for about two-thirds of its length. Above this ss a large patch of raised scales opposite the inner-margin. The hind-wings are green, with a narrow black border, waved on the inner side, and a row of large round black dots on the disc, near which are sometimes some small orange ones. On the under side the fore-wings have the end

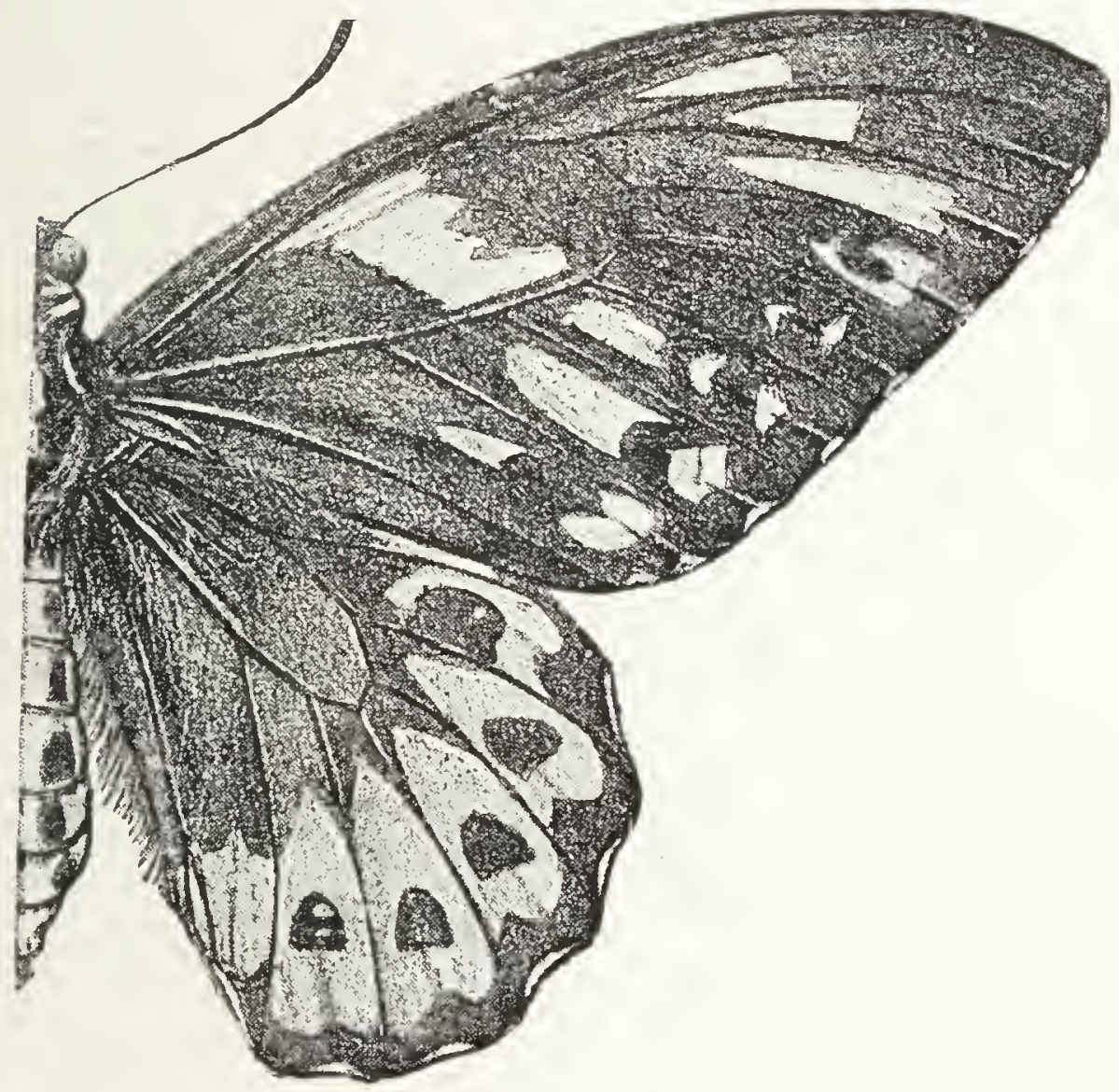

Troides richmondia, .

of the cell, and a great part of the disc between the broad black nervures, green, crossed on the outer side by a broad black bar. On the hind-wings the marginal black band is broader, and the inner-margin is black; the sub-marginal spots curve round to the costa, and within them is a large orange spot above the cell. The head and thorax are black, the latter spotted with red beluw the winss, and with a green lungitudinal 
line above; the abdomen is yellow, with small black dots on the sides. The female is dark brown, with a row of long white spots on the disc; on the fore-wings many of these are interrupted, and on the hind-wings they are divided by a row of black spots, beyond which the white of the inner portion of these long spots is replaced by buff. Head and body as in the male, but the stripe on the thorax above is of a much paler

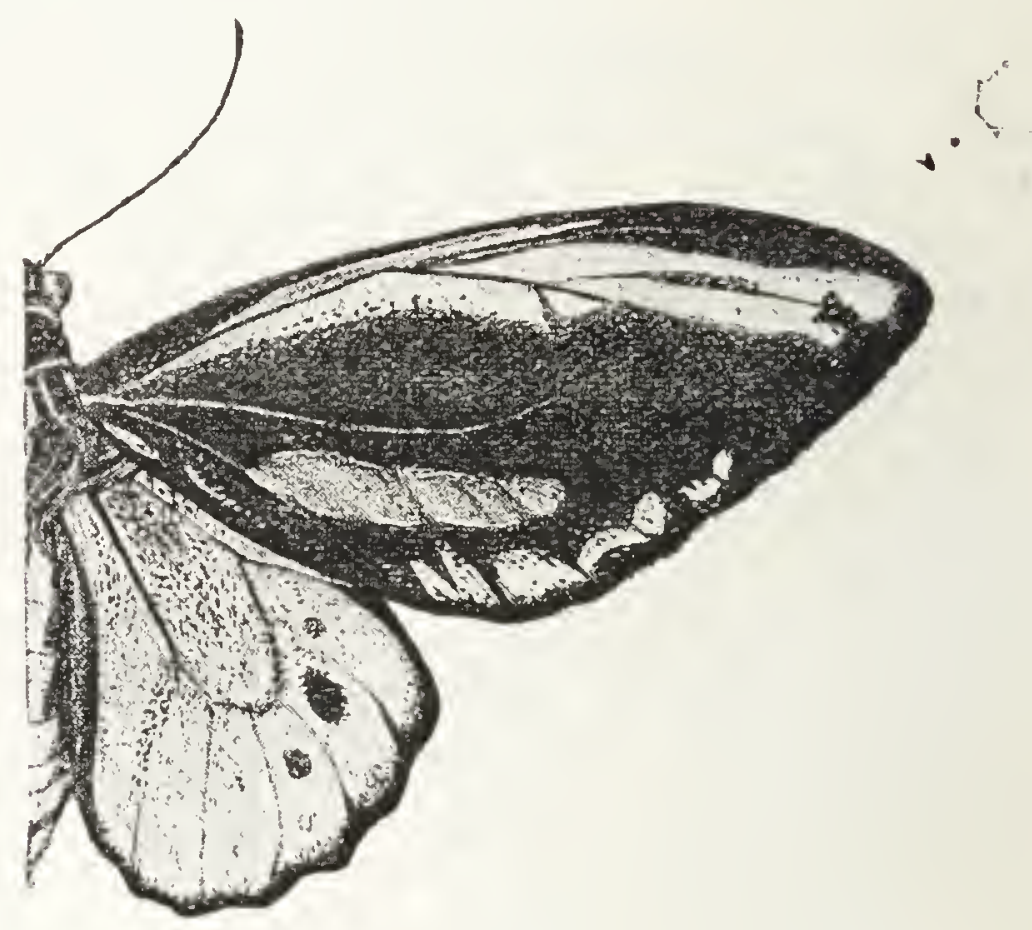

Troides richnondia, o" Var.

green, and the abdomen is of a much paler yellow, often shaded into grey above.

The larva of $T$. friamus has not been described; but as the Butterfly has been seen flying about Mangifera indian, it has been thought likely that it may feed on that tree.

There are a great number of species closely allied to this, but locally constant, chiefly differing in size, and in the different arrangement of the green bands in the male, and of the white spois in the female. 'The smallest species is $T$. richmondia, 
(Gray), which is common in Queensland and New South Wales.

From the green species (in some of which the green subcostal band is shot with coppery-red in certain lights) we pass on to $T$. urvilliamus (Boisduval), in which the green is rep'aced by rich deep blue, showing a green or coppery iridescence on the band in certain lights. It has lately been found in New Guinea, New Ireland, Duke of York Island, and the Solomon Islands. The larva, which feeds on Aristolockia, the favourite

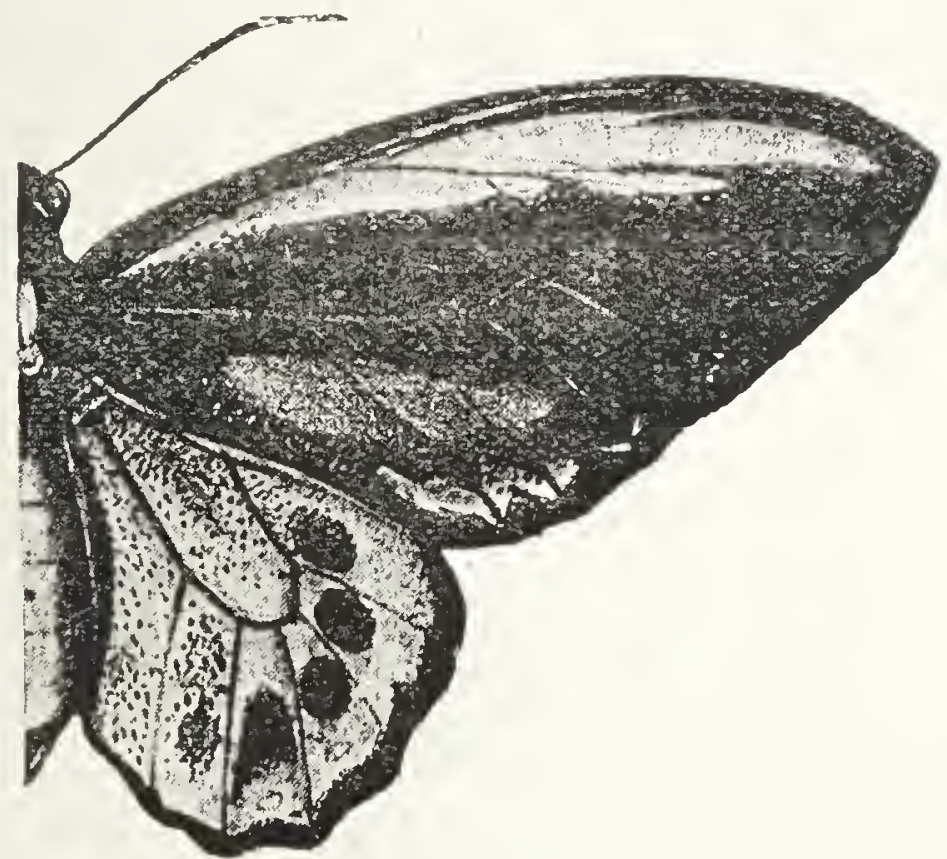

Troides richmondia, ô.

food of so many tropical and sub-tropical Butterfies, is black, with carmine tentacles, and fleshy spines, the latter tipped with black.

Another remarkable species is $T$. crasus (Wallace), from the island of Batchian, one of the Northern Moluccas. Here the green or blue of the species we have already mentioned is replaced by a brilliant golden orange, shading into green in certain lights. Mr. Rippon proposes the name Priamoptera 
for T. urvilliumes and $T$. crosus. T. lydius (Felder), which inhabits Gilolo or Halmahéra, an island not far from Batchian, has the sub-costal band of the ma!e of a very deep copperyred, but both in this species and in $T$. crasus, the only other mark on the fore-wings, except a short dash at the base of the inner-margin, is the very large oval blotch of scales. The hindwings are paler than the band of the fore-wings, and varied with yellow. The female of $T$. crasus does not differ much from the ordinary females of this genus; but that of $T$. lydius is black, with the cell and two complete rows of long spots, concave at the extremity, and the inner row very large, between the nervures beyond the cell. The hind-wings are yellowishbrown, with the base, nervures, a sub-marginal band of nearly connected spots, and another on the hind-margin, black.

\section{GENUS ETHEOPTERA.}

Etheoptera, Rippon, Icones Ornith. p. 4 (1891).

Fore-wings of the male very long, narrow, and pointed. Hind-wings very long in both sexes; in the male, with the fold of the inner-margin enclosing scent-scales. Fore-wings with the third sub-costal nervule rising from the end of the cell in both sexes; the fourth and fifth sub-costals separating at about one-third of the distance from the cell to their extremity in the male, and at a quarter of the distance in the female.

E. victorice (Gray), the type of this genus, is found in Guadalcanar, one of the Solomon Islands. The male measures six inches across the fore-wings, which are black, with the basal third of the wings green and yellow, except on the costa ; and another blotch of the same colour near the costa before the apex, divided by the nervures. The hind-wings are green, bordered nutside by a yellow band, on which stand three orange spots (also visible below, where they have black spots 



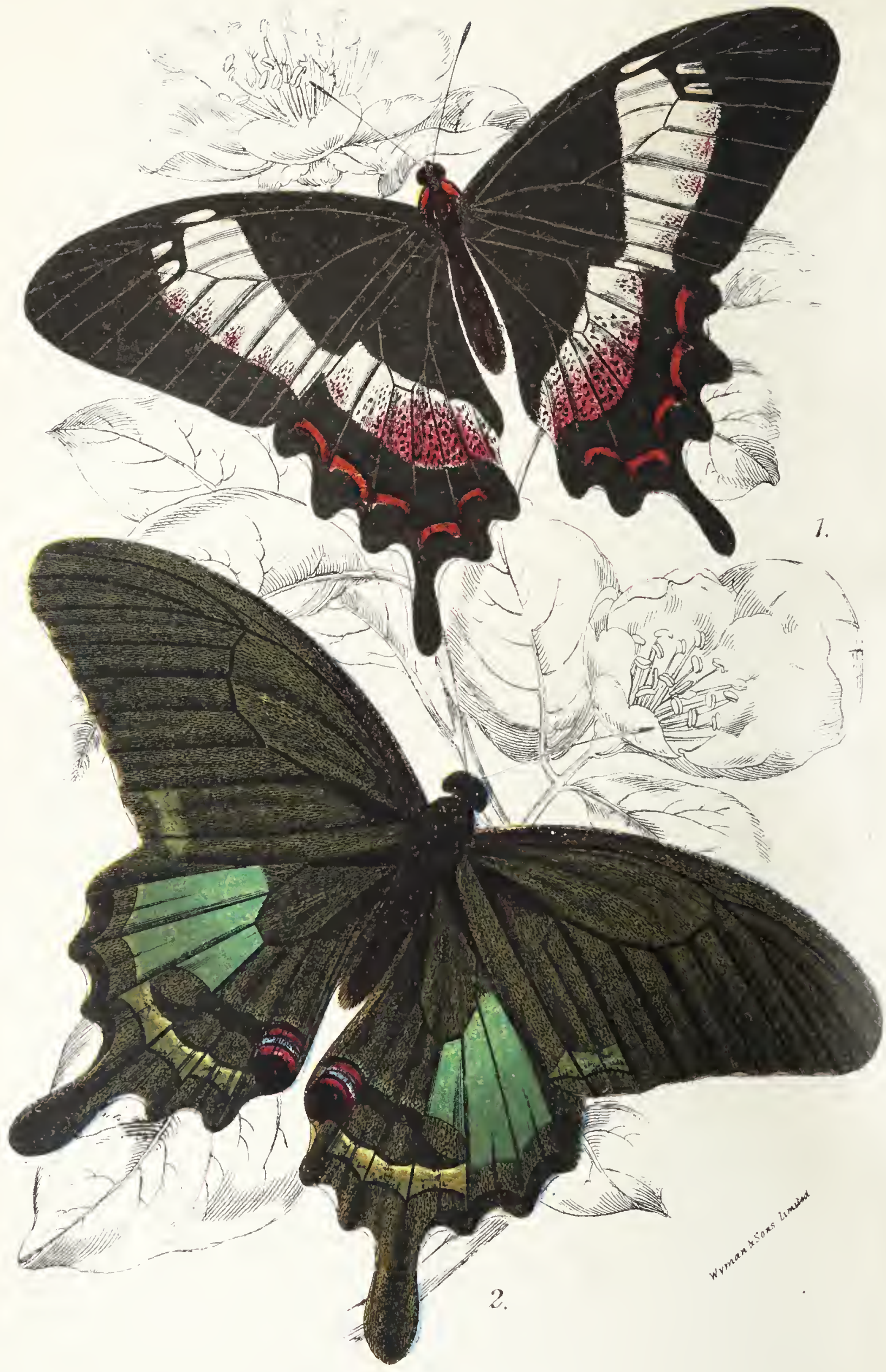

1. Hectorides ascanius.

$\therefore$ Achillides paris. 
beneath and beyond them); and beyond these is a narrow black border. The female is black, with much broader wings; it measures seven inches in expanse.

There is a row of large white central spots, and another of sub-marginal spots on all the wings; on the fore-wings a yellow band, white at the extremity, runs along the cell, and another along the inner-margin; on the costa of the hind-wings is a ycllow band. The larva is dark brown, with long carmine fleshy spines; the retractile fork is yellow.

The closely-allied $E$ regince (Salvin), which is found in the neighbouring island of Malayta is larger; the male has more black on the hind-wings, and the gellow band is replaced by three orange spots surrounded with green in the dark part of the wing.

These Butterfies, as well as Troides urvilliamus, are found flying about the sweet-smelling white flowers of Cerbera odollam, a plant which is allied to the oleander, and is common in the East Indies.

\section{GENUS SCHCENBERGIA.}

Schankergia, Pagenstecher, Jahrb. Nassau. Ver. xlvi. p. 35 (1893).

The fore-wings of the male of this very curious genus resemble those of the last as regards neuration, but are broader, and the hinder angle, which is completely rounded off in Eitheoptera, is more distinct. The hind wings, however, have a very short costa, and very long hind- and inner-margins. They are almost rectangular at the apex, and thence fall almost straight to the base of a very long and slender tail. The cell reaches almost to the hind-margin, the nervures beyond being so short as almost to suggest the idea that the wings have been trimmed with a pair of scissors. The females are not specially remarkable. 
The only known species is Schanbergia paradisca, Staudinger, which is found in the Finisterre Mountains of New Guinea

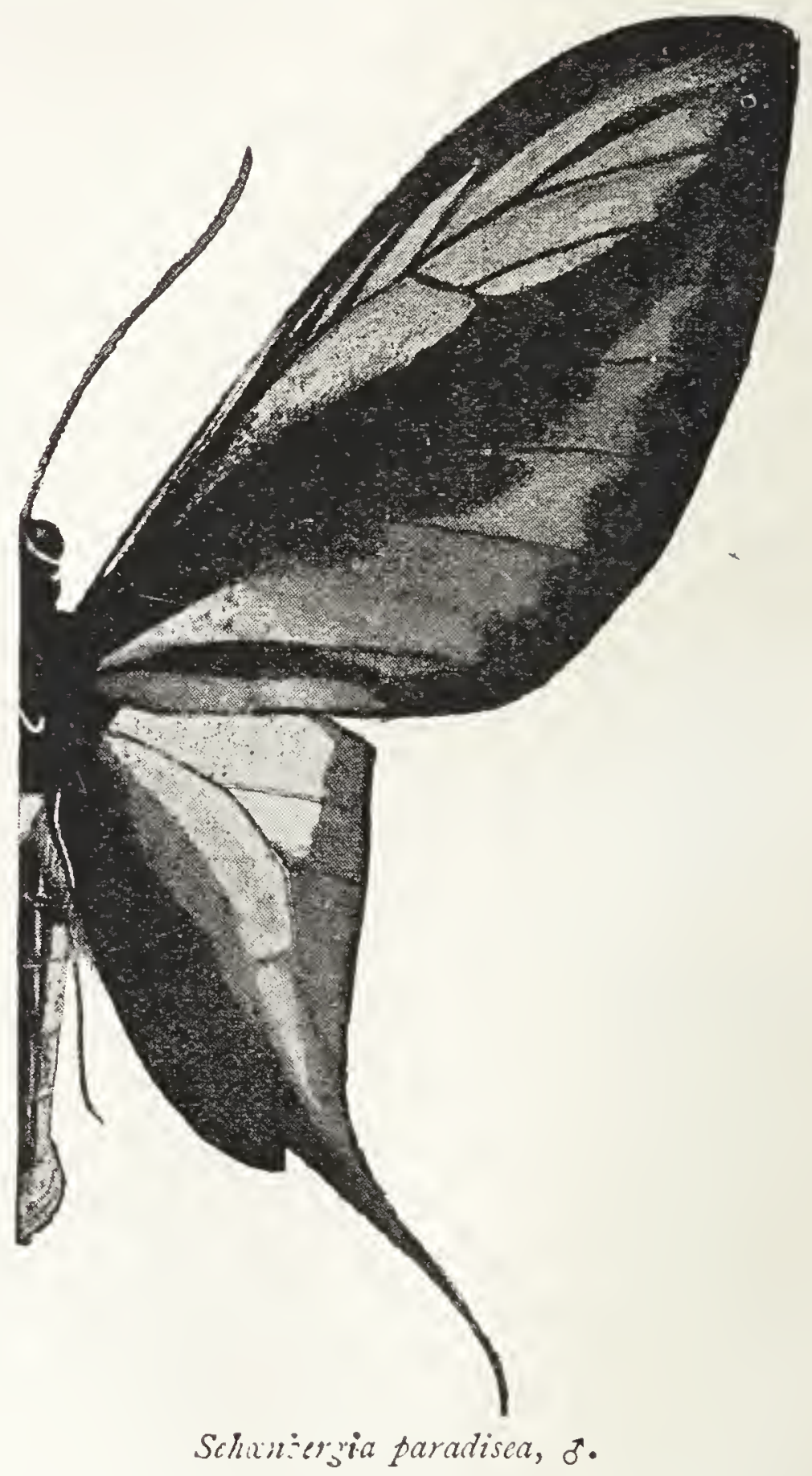

at a height of about 1,500 feet. The male, which measures five inches in expanse, has black fore-wings, with two broad 
green bands glossed with golden-yellow, one below the costa, and the other between the cell and the sub-median nervure, curving upwards opposite the hind-margin. There is also a short green band on the inner-margin The hind-wings are green, more suffused with orange-yellow than the fore-wings, and narrowly bordered outside with black, the base and innermargin being very broadly bordered with black.

The females are larger, and are black, with two rows of white spots on the fore-wings, decreasing in size, and converging towards the hinder angle. Hind-wings with a pale submarginal band, extending across the lower half of the wing, but much incurved towards the costa; the outer part is yellow, shading within to bluish-grey and whitish; across it runs a row of black spots.

\section{GENUS TROGONOPTERA.}

Trogonoptera, Rippon, Icones Ornith. part ii. (I S9o).

Fore-wings longer and narrower than in Schanbergia, the apex rounded off, the hinder angle well-marked; cell very long and narrow; third sub-costal thrown off in both sexes at the end of the cell ; fourth and fifth forking at about one-fifth of the distance from the cell to their extremities. Hind-wings slightly oval, dentated, and in the male slightly projecting at the anal angle. No patch of raised scales on the fore-wings of the male, but the abdominal fold on the hind-wings is very large, enclosing scent-scales.

TROGONOPTERA BROOKEANA.

Ornithoptera brookiana, Wallace, Proc. Ent. Soc. Lond. (2) iii. p. 104 (1855); Staudinger, Exot. Schmett. i. p. 42, pl. 2, (ISS6).

Ornithoptera brookeana, Hewitson, Exot. Butterlies, i. pl. I, fig. I (1855); Distant, Rhop. Malay. p. 3.30, pl. 27 A, fig. 4, pl. 27 a, fig. I (I 885 ). 
Papilio trogon, Snellen Van Vollenhoven, Tidschr. v. Ent. iii. p. 69 , pl. 6 (i 860$)$.

Ornithoptera (Trogonoptera) brookeana, Rippon, Icones Ornith. part ii. (1890).

This splendid Butterfly is not only the single green species of the group found on the continent of Asia, but the only known green Indo-Malayan species, except $T$. trojana. It was first

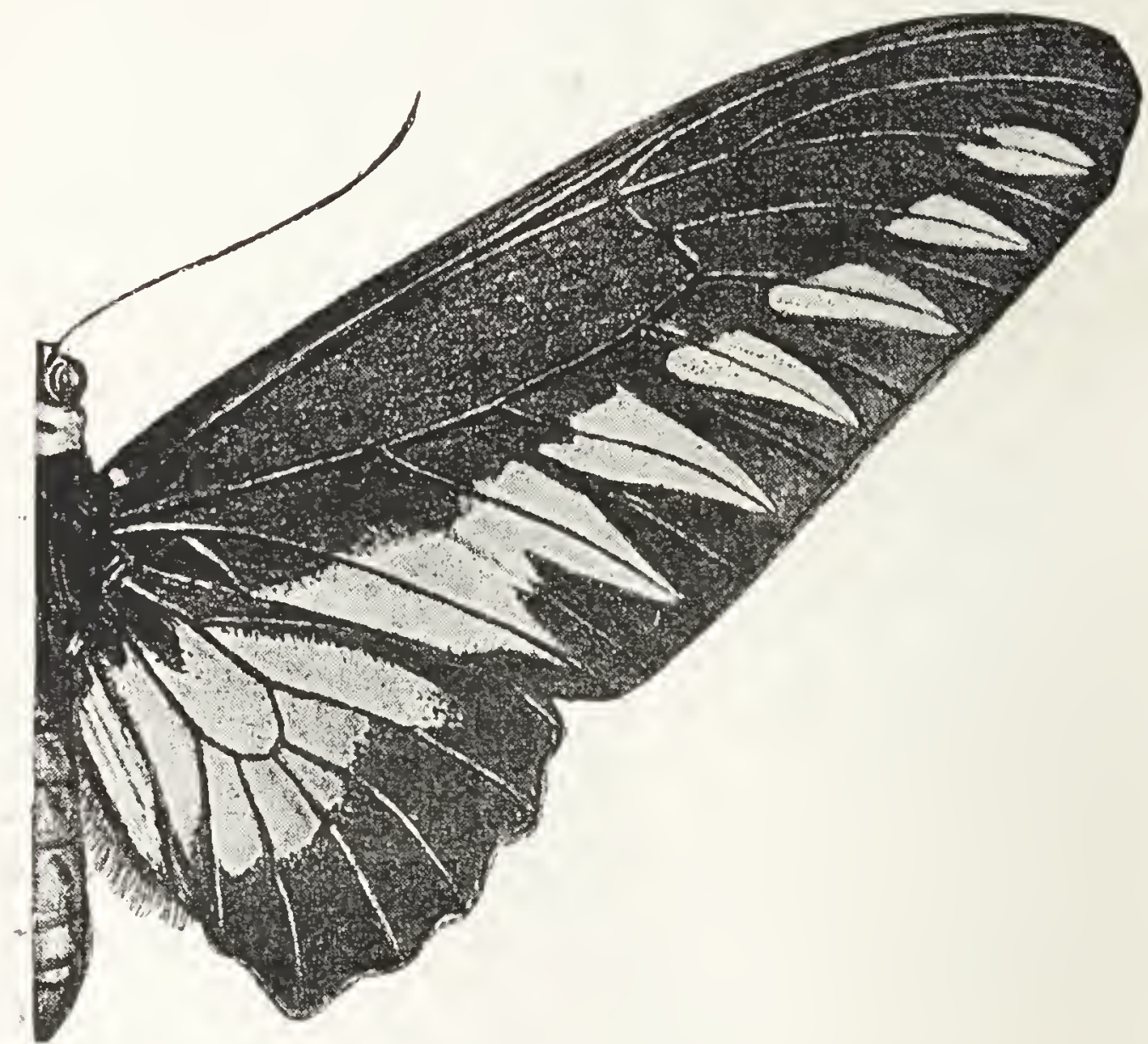

Trogonopiera orookena, o̊.

discovered by Dr. A. R. Wallace, near the coal-mines of Simunjon, in Sarawak, and named by him after Rajah Brooke. It has since been met with in Sumatra as well as in Borneo, and in Perak and Malacca in the Malay Peninsula. It measures from six to eight inches across the fore-wings, which are black, with a 
row of large green sub-marginal triangles, each intersected by a nervure; on the hind-wings the whole centre is green. In the female, which is very rare indeed in comparison to the male, the green is much more glossed with brassy, and is bordered within with blue, which is seldom the case in the male, and the green markings which disappear towards the costa in the male, are, in the female, replaced by long bifid grey streaks between the nervures. The body is black, with a broad crimson collar, and with crimson spots on the sides of the thorax below the wings. The names given to this species by Van Vollenhoven, and to the genus by Mr. Rippon, were suggested by the resemblance in colour to the beautiful black and green tropical American birds called Trogons.

The only other species of this genus, T. trojana, Staudinger, has shorter and squarer green spots. It is found in the Island of Palawan, and is at present very rare in collections.

Nothing appears to be known of thecarly stages of $T$. brookeana. Various interesting notes on its habits may be found in the works of my friends Messrs. Distant and Rippon, which I do not draw upon, as Sir Hugh Low has very kindly favoured me with the following account of its habits as observed by himself in Perak, \&c. :-

"I first met with Ormithoptera brookeana on the Island of Labuan, about the time that it was first collected by Wallace, but I only saw one specimen of it. It was in an open space in a magnificent forest, and I was not able to capture it, though I saw it in the same place on two different days. The fine jungle which at that time covered the island has since been utterly destroyed, so that I imagine the insect is no longer to be found there. I never met with it in the neighbouring islands of Kuraman or on Pulo Daat, where I collected many other fine species. I saw one specimen fly rapidly past me on the mainland in the neighbourhood of Kina Balu, in an open 
country, and as those are the only occasions on which I came upon it during my long residence in Borneo, and as my numerous native collectors never brought me specimens of it, I imagine it must be a rare insect in the country in which Wallace first discovered and captured it.

"In $x 878$, on visiting 'Gopeng,' a village of miners in the 'Kinta' district of the State of Perak, in the Malay Peninsula, I was very much delighted, as I descended from my elephant, to see a fine specimen of this Butterfly settle in the most leisurely and confident manner on a patch of black mud in the middle of the village street, and quite close to me On the following morning, as I walked through the valley in which the open pits of the tin miners were excavated, the beautiful creatures were flying about in all directions, as many as six or seven being visible at a time. Their flight was straight, rather slow, and heavy, very different from that I had seen on Kina Balu. It flew generally about ten feet above the ground, to which it frequently descended, resting on damp spots. It was easily caught, and at my request my people secured a great many specimens for the museum at Singapore, by knocking them over with their cotton jackets and waist-cloths taken off for the purpose. At one place I noticed a great number of the wings of the Ornithoptera lying round a saturated piece of plank close to a little rill of water near a Chinese gardener's hut, and, passing the spot shortly afterwards, I saw a cat of the 'knotted tailed ' race peculiar to Malaya watching for the Butterflies as they settled on the end of the plank nearest to the water, and catching them most deftly with its paws. It ate the body of the one I saw it catch, leaving the beautiful wings to be strewn by the wind on the surface of the ground around its breakfast table. I ascertained that the plank was used by the Chinese occupants of the hut for cutting up and cleaning their fish and pork, and as it was saturated with moisture and the iuices of 
the chopped food, its attraction for the Butterflies was accounted for. I again visited Gopeng five years ago, but the baautiful Butterfy was no longer to be seen in the valley, which had been entirely altered in character by the extension of the works of the miners.

"The only other place in which I met with the insect in Perak was at another mining centre called 'Chandariang,' in the Betang Padang district, about ten miles from Gopeng. There were a good many specimens flying, like those at Gopeng, about ten feet or less from the surface of the ground in the neighbourhood of a pool of water; all the specimens observed in both places were males, with one exception. The female was resting on the flowers of a beautiful Taxonia, on the edge of the jungle, about fifteen feet from the ground.

"Mr. Leonard Wray, who is the curator of the excellent Museum of the State of Perak, and a most zealous and scientific naturalist, lately sent me two specimens from Perak, but did not mention the district in which they had been collected. Mr. Künstler was in charge of the Singapore Museum when I took the specimens from Perak to it, and he subsequently visitcd the State and revelled in collecting and scnding home large quantities of insects for sale, and he was also a very successful botanical collector for Dr. King, the director of the Royal Butanical Gardens at Calcutta."

\section{GENUS ORNITHOPTERA.}

Ornithoptera, Boisduval, Voy. Astrolabe, Lépid. p. 33 (1832); id. Spec. Gén. Lépid. i. p. I73 (I836); Doubleday, Gen. Diurn. Lepid. p. 3 (I 846$)$; Schatz, Exot. Schmett. ii.p. 40 ( I 886 ).

Fore-wings long, sub-triangular, the apex rather pointed; hind-wings rounded and dentated. Fore-wings with the third branch of the sub-costal nervure generally rising at the cell. 
rarely before or after it, the third and fourth nervures rising beyond the cell from a longer or shorter stalk. There is no patch of raised scales on the fore-wings of the males, but scentproducing scales are concealed in the fluffy abdominal fold; colours black and yellow.

The species of this group are characteristic of the IndoMalayan Region, though some of them extend to the Moluccas, \&c. The type is O. helena (Linn.), which inhabits the Moluccas and the Papuan Islands. It is a large species, with black forewings in the male, and yellow hind-wings, very broadly black at the base, and on the hind-margin. The female is of a

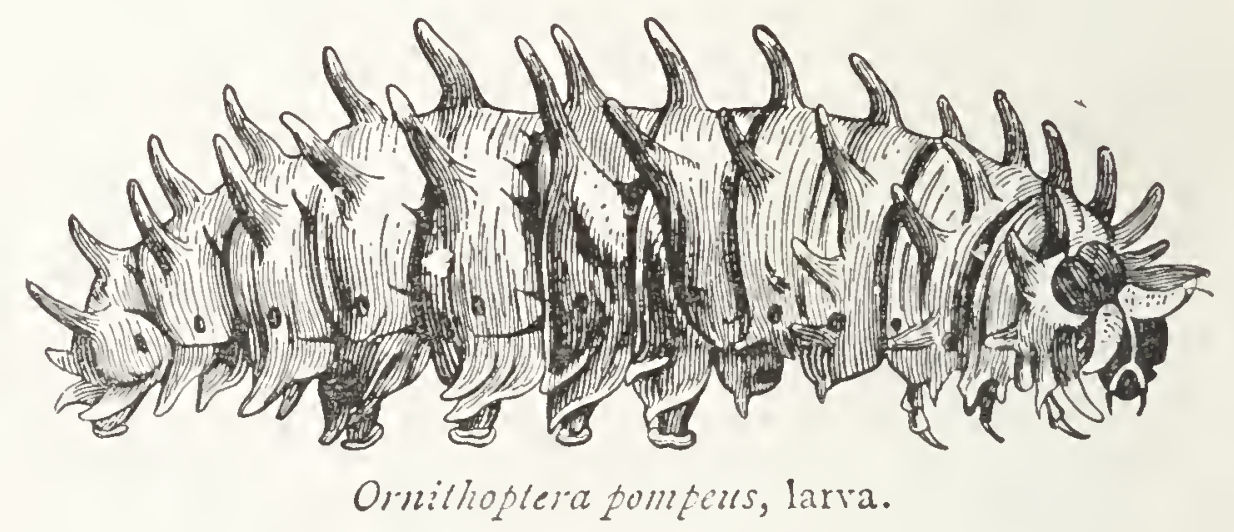

lighter brown, with a large buff or yellowish spot, divided by the nervures, in the middle of the hind-wings.

Many species have black or brown fore-wings, more or less rayed with grey along the nervures, especially in the females; and golden-yellow hind-wings, with a narrow black border, festooned on the inner side; and, in the females, there is a row of large black spots, sometimes touching the incurves of the border, and sometimes perfectly distinct. Among these is $\boldsymbol{O}$. pompeus (Cramer), found in Java and Borneo. We have figured the larva and pupa; the former feeds on Aristolcchica, and is yellowish, with a broad whitish dorsal stripe, dilated to a band on the sixth segment, and with eight rows of fleshy spines; the 
pupa is yellowish. Another and very similar species of this group is O. rhadamanthus, Boisduval, which is found all over India, South China, and Indo-China. For this species and its allies, the name Pachlioptera, Reakirt, may be retained, if they are generically distinct from Ornithoptera, the type of which is O. helena (Linn.). Other yellow species, such as O. ruficollis, Butler, from the Malay Peninsula, have a red collar; others, like $O$. amplorysus (Cramer), have the fore-wings more or less

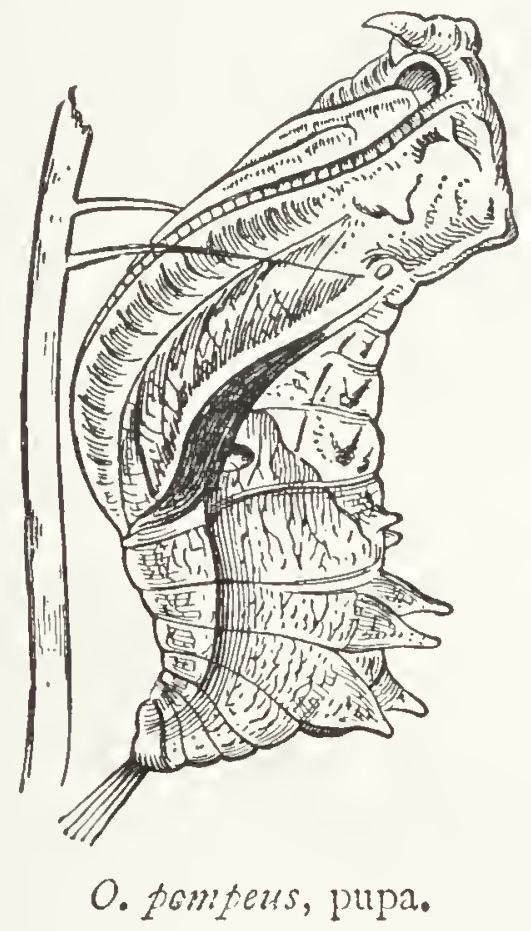

rayed with yellow in the males; and the male of one species, O. magellanus, Felder, from the Philippines, exhibits a wonderful iridescence of the most delicate pale silvery blue or green over the golden-yellow hind-wings. This is quite unique in the group, though something resembling it is seen in some South American Butterflies belonging to the genus Priamides in the Equitina, and to the genus Euselasia in the Lemoniida. Even Morptro sulkozessyi will not compare with Ornithoptera magellanus for metallic beauty. 
We have figured one of the largest and finest species of Ornithoptera, which differs somewhat from the other species of the genus. It is a native of the Moluccas, and was first brought from the island of Amboina, which has always been famous for its splendid Butterfies, and from which nearly all the Moluccan Butterflies known to the entomologists of the last century were obtained.

\section{ORNITHOPTERA HIPPOLYTUS.**}

\section{(Plate LXIV. Fig. 2.)}

Papilio panthous, o, Clerck (nec Limn.), Icones, pl. i 8 ( I 764 ). Papilio hippolytus, Cramer, Pap. Exot. i. pl. iо, figs. A, B ; pl. I I, figs. A, B ( I 775 ).

Papitio remus, Fabricius, Gen. Ins. p. 250 (I 777 ); Cramer, l. c. ii. pl. I 35 , fig. A ; pl. I36, fig. A (1777); iv. pl. 386 , figs. A, B ( I 782); Godart, Enc. Méth. ix. p. 26, no. 3 (IS I 9). Ornithoptcra remus, Boisduval, Spec. Gén. Lépid. p. I 76, no. 3 $\left(\mathrm{I}_{3} 6\right)$.

Ormithoptera (Pompeoptera) hippolytus, Rippon, Icones Ornith. part i. (i 890$)$.

This is one of the largest species of the group, sometimes measuring nearly eight inches across the wings in the female. The fore-wings are black, with a slight greenish reflection, and with greyish-white rays bordering the nervures on each side (brst marked in the females), and extending in to the outer part of the cell. In the male, the hind-wings are black, dusted with grey, and bordered with a row of large yellow spots, running from the base of the costa round to the anal angle. On the under side the hind-wings are white, except the marginal black and yellow markings. In the female, the yellow spots are enlarged and lengthened so as to form a band, separated into spots by the nervures, and extending from just beyond the cell

* O. remus on plate. 
to the narrow, irregular, and partly macular border; the incisions are pale yellow. This yellow band is marked with a row of large black spots between the nervures; and, nearest the anal angle, the pale spots are longest, and are mostly white within the black spots. On the under side, which we have figured, the white is more extended, and invades the outer part of the cell.

This fine Butterfly has been met with in Amboina, Ccram, Ternate, Celebes, the Sula Islands, Morty Island, and Halmahéra.

There is one African Butterfly which is now considered to belong to Ormithoptera, or to an allied genus. This is Papilio zalmoxis, Hewitson, which measures about seven inches across the wings, which are broader and more rounded than in the typical Eastern Butterflies of this group. The male is of a rather pale blue, with black borders, slightly spotted with blue on the hind-wings, and with black lines between the nervures towards the margins, and a black costa on the fore-wings. The male is now fairly common in collections from West Africa, but the female, which is of a yellowish-grey instead of blue, is still very rare in our Museums.

\section{THE GENUS PAPilio, Latreille.}

We have already mentioned that Linnæus originally included all the Lepidoptera, and afterwards all the Butterflies under the genus Papilio, , dividing it into various sub-genera, \&c., among which were Eques and Nymplialis. In I 80 I Schrank restricted Papilio to Ny'mphalis; but in $\mathbf{1} 805$, Latreille, who set aside

* Cf. vol. i. p. 3 , et seq. 
Schrank's work in the most capricious manner, even while quoting it, arbitrarily transferred the name Papilio to Eques; and in this sense Papilio (the real type of which Dr. Scudder, with apparent reason, argues to be Vaness a antiopa), * has since been used for the bulk of the Linnean Equites. Boisduval shrank from sub-dividing this vast mass of species into genera, and contented himself with dividing it into groups; and in this he has been followed by Felder, Oberthür, Distant, Godman and Salvin, Schatz, and other writers. Hübner, however, divided the few species known to him into genera, and among recent authors, Moore and Scudder have done the same for Indian and North American species; and in this they have been followed by some few writers who have dealt with the Lepidoptera of those countries. Under these circumstances, I think it will be most useful to enumerate the principal groups of Latreille's genus Papilio under the names which have been assigned to any of them, with a brief sketch of their most obvious characteristics. It must be noted that although Boisduval did not indicate any characters for his groups of Papilio, definite characters were assigned by Felder to the various sections into which he divided the genus, and his essay still remains the most comprehensive summary of the whole series of species. $\dagger$

We commence by giving the most important references to Papilio as used by Latreille and his followers.

* See Scudder's "Historical Sketch of the Names Proposed for Butterflies," pp. 238-240. It is true that in his "Butterflies of the Eastern United States" he has accepted Papilio in the usual sense, and has proposed the new genus Euvanessa for Papilio antiopa, Linn.; but he does so under protest, and apparently in ignorance of Barbut's genus, Achivus.

+ Since the above remarks were written, the Hon. W. Rothschild has published "A Revision of the Papilios of the Eastern IIemisphere, exclusive of Africa " ("Novitates Zoologicre," ii. pp. I67-463). Ifere he divides the genus into groups, but does not give generic names. Although convinced that the various sections recogniced in the present volume, in addition to many others not specified, should have generic titles, I have refrained from naming the new genera, as Mr. Rothschild is working out the group. 
GENUS PAPII.IO, Latreille (nec Schrank).

Papilio, pt. Linnæus, Syst. Nat. (ed. x.) i. p. 458 (I 858 ); Latreille, Hist. Nat. Crust. Ins. iii. p. 387 (1803); xiv. p. 108 (1805); id. Enc. Méth. ix. pp. 9, 25 (1819); Boisduval, Spec. Gén. Lépid. i. p. 9 (r836); I)oubleday, Gen. Diurn. Lepid. p. 5 ( 1846$)$; Felder, Verz. Zool. Bot. Ges. Wien. xiv. p. 289 ( ( 864 ); Kirby, Cat. Diurn. Lepid. pp. $5 \times 7,637,809,860(x 87 x-1877)$; Oberthür, Études d'Ent. iv. (r879): Schatz, Exot. Schmett. ii. p. 42 ( 1886 ) ; Rothschild, Nov. Zool. ii. pp. r67-463 (1895).

The multifarious species included in the old genus Papilio have short palpi, and long antennæ, with a gradually-formed club. On the fore-wings the third branch of the sub-costal nervure rises from the end of the cell, and the fourth and fifth form a long fork, generally separating further beyond the cell than in the preceding genera. The upper disco-cellular nervule is rather shorter than the others. The fore-wings are generally triangular or produced towards the tip; the hindwings are often dentated or tailed.

It would be useless to go much into detail; the shape of the wings and the structure of the larva differ very much in the different sections.

In the following sketch I have followed Felder's grouping, with his numbers, referring to later authors for species discovered since, and supplying generic names, so far as they exist. I have not, however, attempted to include the whole of Felder's seventy-five sections, and some of them, among which are the three first, include Ornithoptera, \&c., which I have already discussed. This will explain the omission of several numbers in the series. All the named genera are, however, included.

[Iv.] Ascanides, Geyer. The type, A. triopas (Godart) is a small black Butterfly, from Guiana and the lower Amazons, not expanding much more than two inches across the long and 
narrow fore-wings; the hind-wings are short, oval, and dentated, with white incisions. 'There are two yellowish-white patches, more or less divided into spots by the nervures, one towards the tip, and one about the middle of the fore-wings; and the centre of the hind-wings is pale yellow. The collar and pectus are dotted with red.

[v.] Endopogon, Boisduval (apud Felder). Includes a large number of Tropical American Butterflies, with triangular forewings, with the hind-margin more or less oblique, and the hindwings somewhat produced, and strongly dentated, with white incisions. They are black, and the males generally have a dull green mark, sometimes enclosing a white spot; and the hindwings have a large red spot or band in the middle, often showing a beautiful violet iridescence. In the female, there is generally a white spot on the fore-wings, and the red spot of the hind-wings is paler; sometimes the hind-wings are spotted with red at the base beneath. The type is indicated by I)r. Scudder as $E$. sesostris (Cramer), a species nearly four inches in expanse, with a large green spot on the fore-wings of the male, but no red spot on the hind-wings. It is common in South America.

[vi.] Hictorides, Hübner. A handsome group of Tropical American Butterflies, with rather long, but not pointed, forewings, and shorter hind-wings, produced towards the anal angle; strongly dentated, and with a rather long tail; they are black with red and white markings.

We have figured the type

\section{HECTORIDES ASCANIUS.}

\section{(Plaie LXV. Figr. I.)}

Papilio ascanius, Cramer, Pap. Exot. i. pl. I $4 a$ (1775); Drury, Ill. Exot. Ent. iii. pl. 9, fig. I ( 1782 ); Godart, Enc. Méth. ix. p. 73, no. I37 (1819); Boisduval, Spec. Gén. Lépid. i. p. $306(1836)$. 
, 
PIATE LXVI.

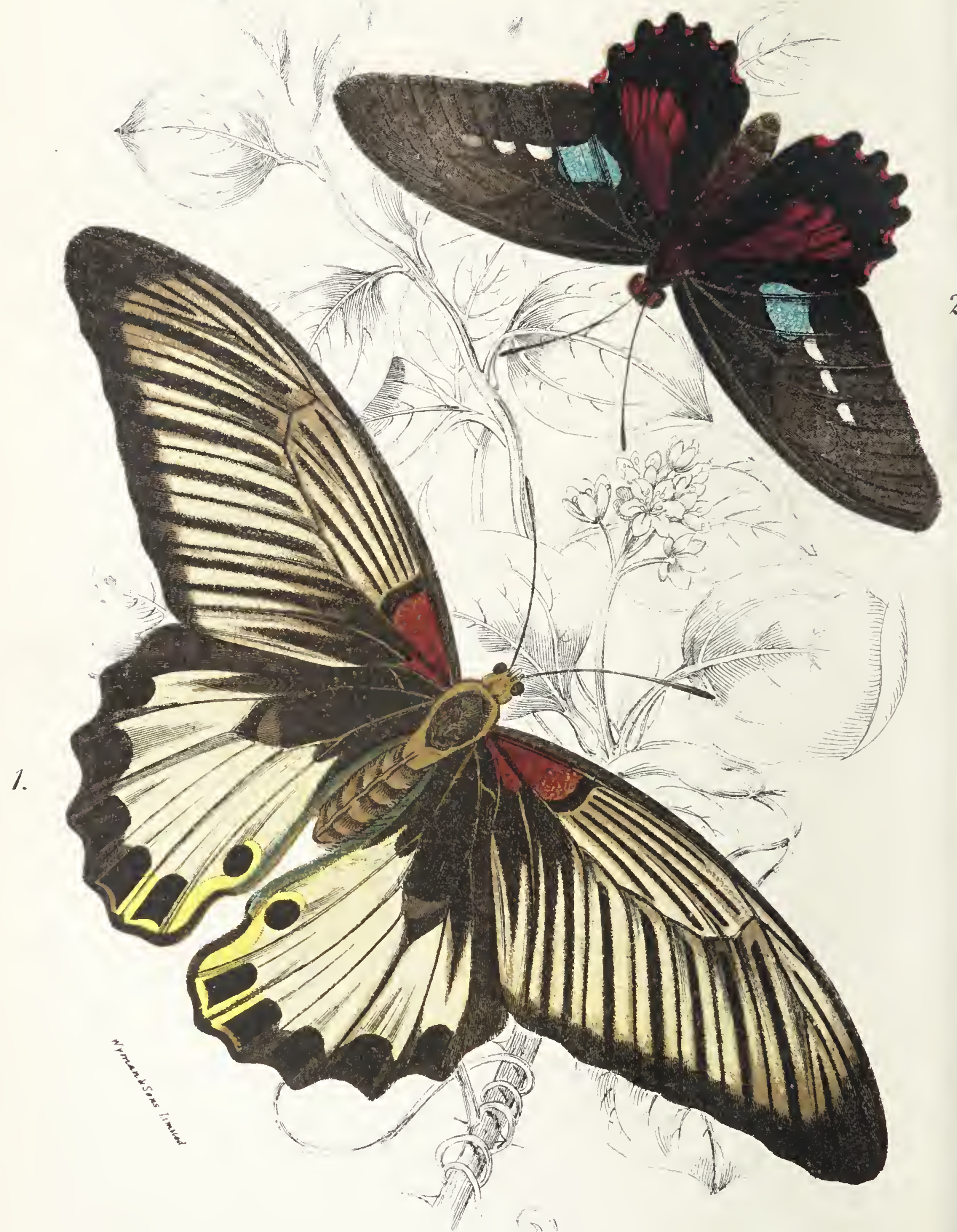

1. Lliades agenor.

2. Parides aneas. 
Hectorides ascanius, Hübner, Samml. Exot. Schmett. ii. pi. 105 ( 1824 ).

This is a Brazilian Butterfly, measuring four inches across the wings, which are black, crossed by a broad white band, shading into red on the outside on the hind-wings, which are also marked with a row of sub-marginal red lunules; the incisions are white. The pectus, and under side of the abdomen are spotted with red.

[vir.] Parides, Hübner. A tropical American group, much resembling Endopogois (q.v.), but with pink instead of white incisions.

We have figured a representative species.

PARIDES ÆNEAS.

(Plate LXVI. Fig 2.)

Pafilio aneas, Linn. Syst. Nat. (ed. x.) i. p. $46 \mathrm{I}$, no. I5 (1758); id. Mus. Ulr. p. 197 (1754); Cramer, Pap Exot. iii. pl. 279, figrs. C, D ( 780 ); Godart, Enc. Méth. ix. p. 33, no. 24 ( I 8 I9); Boisduval, Spec. Gén. Lépid. i. p. $286(1836)$.

Papilio aneides, o, Esper, Ausländ. Schmett. pl. I5, fig. 4 ( I 785 ?).

\& Princeps dominans marcius, Hübner, Samml. Exot. Schmett.

i. pl. I22 (1816?).

Papilio marcius, Boisduval, l. c. p. 286 ( $\mathrm{I}_{3} 6$ ).

This Butterfly is common in Guiana and on the Lower Amazons, and measures over three inches across the wings. The fore-wings are rather pointed, with the hind-margin very oblique; and the hind-wings are rounded and dentated. The colour is black, with a nearly square green spot on the innermargin of the fore-wings, and with three white spots obliquely above and beyond it. The hind-wings are red from the base to beyond the middle, and the incisions are also red. On the under-side, the hind-wings are marked with five red spots, and 
the pectus is spotted with red. The female is black, with a large white spot, divided by the nervures, in the middle of the fore-wings, and a row of bright crimson sub-marginal spots on the hind-wings.

[viIr.] Ithobalus, Hübner. This is another genus peculiar to America, but very unlike the foregoing. The species much resemble each other; the type is $I$.polydamas (Linn.), which is common throughout the warmer parts of America. The fore-wings are broad with the costa arched, the tip produced, but rounded off, and the hind margin very oblique. The hindwings are ample, rounded, and strongly dentated, but not tailed. The colour is a greenish-black, with pale yellow incisions; and a row of greenish-yellow spots, smallest towards the tip of the fore-wings, runs parallel with the hind-margin of the fore-wings, and curves across the disc of the hind wings. On the under-side there are some larger yellow sub-marginal spots on the lower half of the fore-wings, and a row of submarginal red lunules on the hind-wings; the pectus and abdomen are also marked with red. The larva is stout, slug. shaped, of a dirty yellow, with long, pointed, fleshy spines of a pale pink; it feeds on Aristolochio. The pupa is green, with a long, conical protuberance on the back of the thorax.

[xiv.] Eurytides, Hübner. The type of this genus, E. dolicaon (Cramer), is a fine South American Butterfly, nearly four inches in expanse. The fore-wings are creamy-white, with broad black borders, with an oblique row of creamy spots towards the apex of the fore-wings, and a double submarginal row of spots on the hind-wings. The fore-wings are broad, with the hind-margin concave below the tip, and a broad black band at the base of the costa, and then curving across the middle of the cell; the hind-wings are furnished with a long slender tail on the upper median nervule.

[XIX. B.] Cosmodesmus, Haase. We may, perhaps, restrict 
this name, used by Haase with a very wide extension, to the following species and its allies.

\section{COSMODESMUS PROTESILAUS.* \\ (Plate LXVIII. Fig. I (Frontistiece).)}

Pafilio protesilaus, Linnæus, Syst. Nat. (ed. x.) i. p. 463, no. 29 (1758); id. Mus. Ludov. Ulr. p. 209 (1764); Clerck, Icones, pl. 27 , fig. 2 (I 764 ); Cramer, Pap. Exot. iii. pl. 202, figs. A, B (r779); Godart, Enc. Méth, ix. p. 5॰, no. 73 (r8I9); Boisduval, Spec. Gén. Lépid. i. p. $262\left(\mathrm{I} S_{3} 6\right)$.

This species, and those related to it, are fine swallow-tailed Butterflies of Tropical America, measuring four inches across the wings. The fore-wings are broad, but not very long, and the hind-margin is not very oblique. They are white, shading into grecnish at the base, and on the costa of the forc-wings there are a number of black bars, some short and some long; running from the costa of the fore-wings; the hind-margin is black, and a stripe, bifid above, runs obliquely to meet it at the hinder angle. The hind-wings are imperfectly bordered with incomplete black bands and lines; at the anal angle is a long spot, black below and red above, and beyond it the lower part of the wing projects in a lobe, throwing off a very long tail from the upper median nervule. There are several closelyallied species (or varieties of the same) in South America. The larva of $C$. protesilaus is said much to resemble that of Iphiclides podalirius, and to feed on a tree like a Magnolia.

[xx.] Pazaia, Moore. The type of this genus is the North Indian $P$. glycerion (Gray). It measures about $2 \mathrm{I} / 2$ inches across the wings, which are white, with ten narrow black stripes, partly coalescing, running from the costa of the forewings; stripes $3^{-6}$ crossing the cell, the rest longer, reaching, or nearly reaching the inner-margin. The hind-wings have

* Iothiclides protesilaus on plate. 
two or three sub-marginal black lines, meeting in a broad black space at the base of the long slender tail. On this space are two or three blue lunules, and on its imner side, close to the anal angle, is a yellow lunule, surmounting a smaller black one.

[xxi.] Pathysa, Reakirt. The type of this genus is $T$. antiphates (Cramer). It is a common and variable species throughout the Indo-Malayan Region. It is a creamy-white Butterfly, rather less than three inches in expanse, with black bars across the cell of the fore-wings, which are greenish towards the base; and a black border, separated from two broad black bands from the costa by greenish streaks. The hind-wings have a festooned black marginal line, and a long slender black tail, edged with yellow; at the end of the inner margin is a black spot, marked with blue on the under side. On the latter the hind-wings are green towards the base, streaked and spotted with black, and yellow beyond; the tail is strcaked with white. The larva, which feeds (in Javil) on a species of Uvaria, is cylindrical with a bifid tail; yellow, with reddish-brown transverse stripes,and reticulated with brown; it has two separated lateral stripes, the upper greenish, and the lower reddish. The pupa is dull green, with brown and ycllowish markings.

[xxıI.-xxv.] Iflidides, Hübner. Under this genus we may provisionally place several of Felder's sections, in which the fore-wings are broad, rather pointed, with the hind-margin more or less oblique, while the hind-wings are strongly dentated towards the anal angle, but not so distinctly lobate as in Cosmodesmus, and terminating in a long s!ender tail. $\mathbb{T}^{\top} \mathrm{C}$ have figured two species, the second of which is the type of the genus.

IPIIICLIDES CEIADON.

(Plate 1.AVIII. Fig. 2 (Frontisficic).)

Pafilio simon, Cramer (nec Fabricius), Pap. Exot. iii. pl 3 I figs. Ii, li (17:0). 



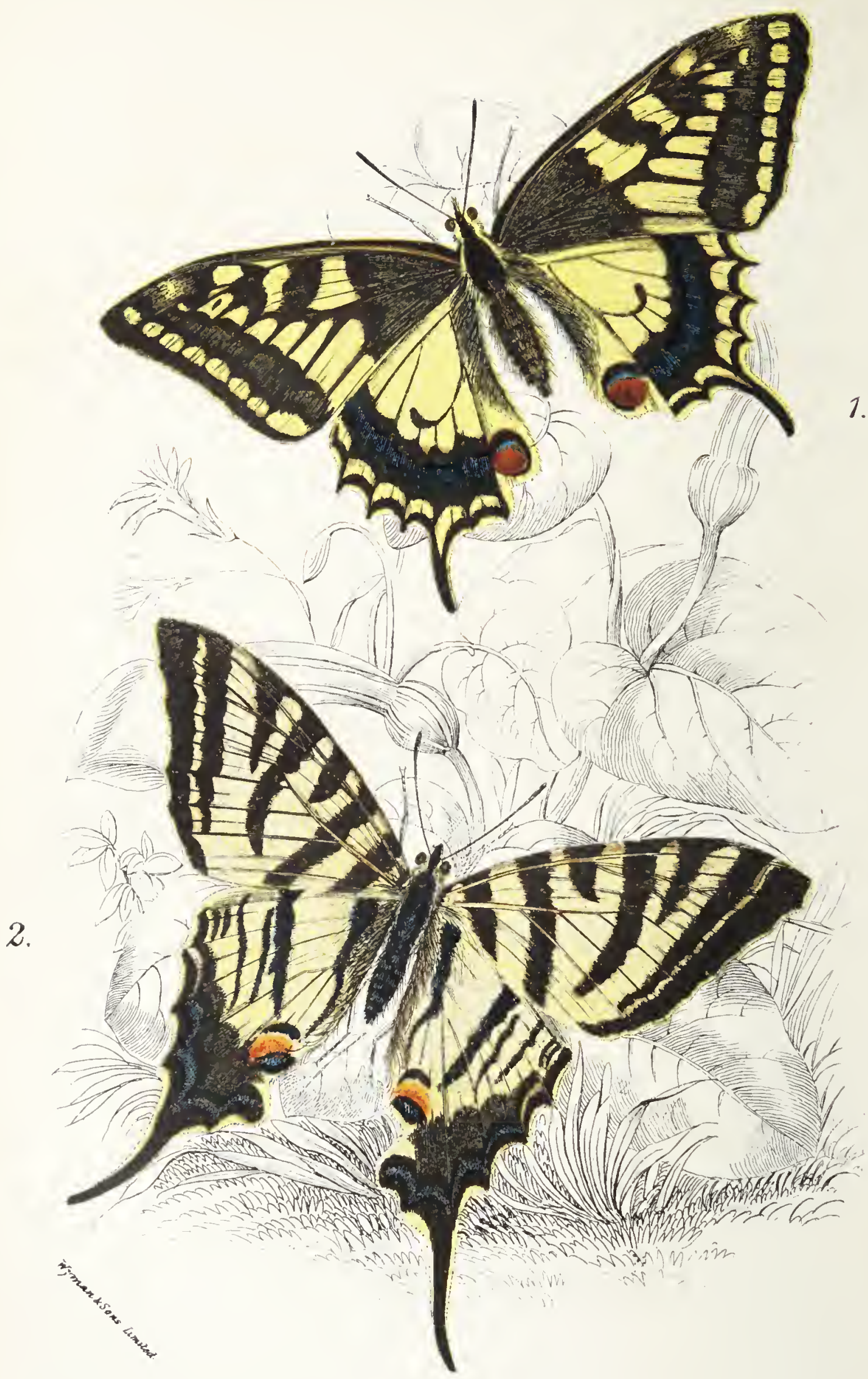

1. Achivus machaon.

2. Iphiclides podalirius 


\section{Papilio celadon, Lucas, Rev. Zool. I852, p. I3o.}

This Butterfly, which inhabits Jamaica and Cuba, measures a little more than thrce inches across the wings. It is black, with a row of green sub-marginal spots running round all the wings, and five green bands running from the costa of the fore-wings; the first thrce extend to the hind-wings ; the first is narrow and basal; the sccond is also narrow; the third is very broad, and bifid above; and beyond are two short bands, one just before, and the other just after, the cnd of the cell. There is a conspicuous red spot on the middle of the inncr-margin of the hind-wings; on the under side the second green stripe is bordered outside with rcd.

There are several black and green species, much rcsembling this, both in America and Africa. The breadth of the third green band will distinguish $I$. celadon from any of the others.

TIIE SCARCE SIVALLOW-TAIL. IPHICLIDES PODALIRIUS.

$$
\text { (Plate LYVII. Fig. 2.) }
$$

Papilio podalirius, Linn. Syst. Nat. (ed. x.) i. p. 463, no. 29 $\left(175^{8}\right)$; id. Mus. Ludov. Ulr. p. 208 (1764); Esper, Schmett. i. (r) p. 36, pl. I, fig. 2 (I 777); Hübner, Exot. Schmctt. i. figs. 388, 389 ( 1803 ?) ; Godart, Enc. Méth. ix. p. 50, no. 74 (ISI9); Buisduval, Spec. Gén. Lépid. i. p. 245 (I 836$)$; Steph. Ill. Brit. Ent. Haust. i. p. 6 (IS27); Curtis, B1it. Ent. xiii. pl. 578 (I836); Newman, Brit. Butterfles, p. 3 (г 88 I); Kirby, Eur. Butterflies and Moths, p. 2, pl. 2, figs. i, $1 a-d$ (1878); Lang, Butterflics Eur. p. I, pl. I, fig. I, pl. 5, fig. I (transf.) (1881); Barrett, Lcpid. of Brit. Isl. i. p. 16 (1892). Papilio podalivins, Cramer, Pap. Exot. ii. pl. 1 52 , fig. B ( ( 777 ). Var. Papilio feisthamelii, Duponchel, Lépid. France, Suppl. i. p. 7, pl.r, fig. I; pl. 2, fig. I ( $\left.13_{32}\right)$; Hcrrich-Schäffer Schnett. Eur. i. Nachtrag, p. 34, figs. 4r4-4I6 (IS4S). 
This Butterfly measures from $21 / 2$ to $3 / 4$ inches across the wings. It is yellowish-white, with seven black streaks running from the costa of the fore-wings, the first basal divided by a pale line, the third and fifth short, the rest crossing the wing, or nearly so, the two last being close together, and the last marginal. The hind-wings are dentated and tailed, the innermargin is dusky, and there is a black streak from the costa to the eye-spot, which is situated on the inner-margin towards the anal angle, and is black, with a large blue pupil, and is surmounted by an orange stripe, bordered above with yellow. There is a festooned black marginal line, enclosing blue lunules, and the space between this and the eye-spot is also blackish, except a patch of yellow below the eye; the incisions, and tip of the slender tail, are also yellow. On the under side, the hind-wings are lighter, and the principal black streak is double, and intersected by a yellowish line.

The larva is thickest just before the middle, tapering most behind. It is smooth and green, dotted with red, with yellowish-white lines and intermediate oblique streaks. It feeds on almond, sloe, plum, apple, pear, and oak in June and September, but seems to prefer the sloc. The pupa is pale yellow.

The Butterfly is double-brooded, being found from May to August. It is far less widely distributed than Achivus machaon, inhabiting Central and Southern Europe, North Africa, and Western Asia as far as Persia and the Altai. Spanish specimens are whiter, with broader dark markings, and are called $I$. feisthamelii. In France it is known as "Le Flambé," from the flame-like shape of its markings, and in Germany as the "Segrelfalter" or Sail-Butterfly, either from its sail-like wings, or from its sailing flight. In Holland, North-IVestern Germany, and on the north coast of Germany it is either absent or extremely rare; and although it is traditionally a British insect, it seems to have disappeared about the time that entomology began to 
be studied in England. It is most often found in woods and bushy places in hilly districts, but does not extend very high up the mountains, and it shuns the neighbourhood of towns, being easily exterminated or driven away by clearing and cultivation.

[xxvir. B.] Dalchina, Moore. The type of this genus is D. sarpedon (Linn.), a common Indian species, widely distributed in the Indo-Malayan and Austro-Malayan Regions. There are also a number of closely-allied forms, which may or may not be distinct species. It measures about three inches across the wings; the fore-wings are considerably produced, the hind-margin being very oblique; and the hind-wings are also considerably produced towards the anal angle, but not tailed. The wings are black, with a broad glaucous green band running obliquely from near the tip of the fore-wings, where it is macular, to below the middle of the hind-wings, where it tapers downwards; there is a sub-marginal row of five green spots on the hind-wings. On the under side the green is mixed with whitish, and there are several red spots marked with black on the hind-wings.

The larva is smooth, rather short and stout; dark green, with paler incisions. The pupa is strongly ridged; grassgreen, striped with yellow. The larva feeds on cinnamon and soursop.

This is a Butterfly of lofty and rapid flight, not always easy to catch, as it flies about the tops of the trees.

[xxvil. c.] Zetides, Hübner. The type of this genus is $Z$. eurypylus (Linn.). This species and its allies are black, with the hind-wings less produced than in Dalchina, and tail-les. These Butterflies, which are found throughout the IndoMalayan and Austro-Malayan Regions, expand about three inches across the wings, and are black, with a common green band, more or less macular on the hind-wings, a row of submarginal green spots, and green transverse streaks in the cell 
of the fore wings. Itere, too, the hind-wings are spotted with red beneath as in Dalchina.

[Xxvil. D.] Another East Indian genus allied to the last, but which has not yet received a generic name, is represented by Papilio asramemnon, Linn., in which the wings are black, thickly spotted with green, the green band being entirely broken up into spots, and the hind-wings are sub-caudate.

[xxvir. f.] Iddaides, Hübner. The type of this genus, $I$. codrus (Cramer), is a large Butterfly measuring about five inches in expanse, which is found in Amboina and Ceram. The fore wings are rather pointed, the hind-margin being oblique, and the hind-wings are regularly scalloped, with a moderately long broad tail. It is blackish, with the hind-wings broadly grey towards the base, and with a curved row of round green spots running from the tip to the middle of the innermargin of the fore-wings.

[xxix. A.] The type of Dabasa. Moore, is D. gyas, Westwood, a rare North Indian Butterfly. It is very dark brown, with indistinct, sub-marginal, ferruginous lunules, rather pointed fore-wings, and a moderately long tail on the hind-wings. The female has a broad white band from the end of the cell of the fore-wings to the inner-margin of the hind-wings, and a row of sub-marginal yellow spots. The white band is edged above with yellow spots, and there are also some on the costa of the fore-wings above it.

[xxix. 13.] Acandrusa, Moore, is another peculiar IndoMalayan genus, the type of which is $M$. evan, Doubleday. It is a large tawny Butterfly, five inches in expanse, with broad black borders spotted with tawny; the fore-wings are extremely falcate, and the hind-wings have a long tail. The under side is of a dirty yellow.

[xxx.] (Unnamed.) Includes some white African species, with brond black white-spotted borders, and dentated hind 
wings, on the under side of the wings are some red spots. 'This genus is represented by Papilio pylades, Fabricius, and its allies.

[xxxi. A.] Includes another African Butterfly, Papilio lenilias, Fabricius, with less strongly dentated hind-wings. The wings are black, with large green spots on the fore-wings, and the middle of the hind-ivings green, followed by one or two rows of sub-marginal spots. It has some resemblance to the genus Tirmmala among the Danaina.

[xxxi. 5. And xxxir.] These include Papilio rilleyamus, White, and Drurya antimachus (Drury), of which we have already spoken (anteì, p. 250).

[xxxur.] Includes Papilio idaoiles, Gray, a rare Philippine Butterfly, measuring nearly six inches in expanse. It has greyish-white rounded wings, with black marginal and submarginal spots, and larger spots towards the base. It is very similar to Hestia idea (Linn.) among the Danaine.

[xxxvi.] Paranticopsis, Wood-Mason and De Nicéville. The type of this genus is $P$. macareus, Godart, a Butterfly about three inches in expanse, with black wings, shightly dentated, but not tailed, and with longitudinal greenish-white stripes. It is found in North India, Java, and Borneo, and much resembles some of the green Danaina, which inhabit the same countries.

[xxxvir.] Chilasa, Moore. The type of this genus is C.panope (Linneus), an Indian Butterfly, measuring nearly four inches across the wings, which are brown, with sub-marginal rows of white spots, which are rather long towards the tip of the fore-wings. The hind-margin of the hind-wings is dull yellowish beneath. Nearly all the Equiline which minic Damaina have more or less dentated hind-wings; but much casicr and more certain tests to distinguish them are the apparently fourbranched median nervure on all the wings, and the fully 
developed front legs in the Equitida. An allied species is $C$. dissimilis (Linn.), which is covered with pale buff spots and markings on a blackish ground.

[xxxvir. Pt.] Euplaropsis, De Nicéville (Isamiopsis, Moore). This genus includes a number of Indo-Malayan Butterflies, generally very rare in collections, which mimic the brown, blue-flushed Danaince allied to Euplo'a. The type is the North Indian P. telearchus (Hewitson), one of the largest species, expanding $4 \frac{1}{2}$ inches. The fore-wings are of a rich purple, triangular, and pointed at the tip, with a blue spot in the cell, a row of long blue spots beyond, and a sub-marginal row of white ones; the hind-wings are brown.

[xxxvir. Pт.] Menamopsis, De Nicéville. This genus, like the last, includes a few North Indian species resembling Danaine of the Euplaca group. The type is $M$. tavoyanus (Butler), from Tenasserim, which measures $33 / 4$ inches across the fore-wings, which are much longer than the hind-wings, and rounded. It is brown, with blue streaks on the fore-wings in and beyond the cell, and between the nervures on the disc. The hind wings have an inner sub-marginal row of white streaks, and an outer row of yellow ones, the largest at the anal angle surmounted by a black crescent.

[xxxvini.] Cadugoïdes, Moore. This is another Indo-Malayan genus, resembling species of the Danaince. The type, C. agestor (Gray), which is found in Sumatra, and also in the SouthWestern Himalayas, measures $31 / 2$ inches across the wings. It is grey, with black nervures, and black borders dotted with grey; the hind-wings are more or less reddish.

[xxxix.] Orpheides, Hübner. The two principal species of this genus, O. demolcus (Linn.) and O. erithonius (Cram.) inhabit $A$ frica and India respectively, and are among the most abundant Butterflies of their respective countries. O. demolens, found throughout Africa, except in the north (for its alleged 
occurrence in Egypt probably means Upper Egypt or Nubia) measures from 3 to $4 \mathrm{x} / 2$ inches across the wings, which are black, with the fore-wings rather short and broad, and the hindmargin slightly oblique; the hind-wings are rather long, and strongly dentated, but not tailed. There is a row of pale yellow sub-marginal spots on all the wings; the incisions are yellow, and a row of rather large yellow spots runs obliquely across the fore-wings, coalescing into a band on the hindwings, where it reaches the middle of the inner-margin. On the fore-wings there are two large spots towards the end of the cell, and also two short oblique rows of small spots between the cell and the sub-marginal spots, the main band rising below the interspace; the base is dusted with yellow towards the base. On the hind-wings there is a large black eye-spot beyond the band, on the costa, enclosing red and blue lunules; beyond the band on the inner-margin a blue crescent surmounts a black space bordered below with reddish. On the under-side the yellow markings are larger, and more extended, the base being streaked with yellow, and there are several blue and black lunules on the hind-wings bordering the dark space between the two large eye-spots.

Mr. Trimen describes the larva as dark-coloured when young, and clothed with short spines; when larger, it is pale yellowish-green, with purplish markings, and a white line on the sides. There are two small tubercles on each side of the retractile fork, which is crimson, and emits a very strong odour; and two similar tubercles on the anal segment; it fceds on Umbelliferce, as well as on a great variety of trees. 'The pupa is rather long, with the head bifid; there are four rows of tubercles on the abdomen, and many tubercles elsewhere. The colour of the pupa assimilates itself to its surroundings.*

* For detailed particulars, cf. Trimen, "South African Butterflies," iii. pp. $225,226$. 
The East Indian species, O. erithonius (Cramer), has the central band much broader and more irregular, especially on the hind-wings, where the eye-spot on the costa is very slightly marked, and that on the inner-margin has become a large red spot.

[XLI.] This genus has not yet received a name. It includes some handsome West Indian tailed Butterflies, among which is I'apilio homems, Fabricius, a very local Butterly in Jamaica, and one of the largest of all the American Equitide, expanding 5 I $/ 2$ or 6 inches. It is black, with a very broad yellow band on all the wings, bifid towards the costa of the fore-wings. The fore-wings have two or three yellow spots towards the tip; and beyond the yellow band on the hind-wings is an outer row of blue dusting, and some orange-red sub-marginal lunules.

[xuII.] Heraclides, Hübner. This is another genus peculiar to America. It includes large and handsome Butterflies, measuring from four to six inches across the wings. The type is H. thoas (Linn.). The fore-wings are rather long and pointed, the hind-margin being slightly concave, as well as oblique, and the hind-wings are strongly dentated, with a broad spatulate tail. The wings are black, with a broad yellow band, more or less macular, at least on the fore-wings, where it often bifurcates towards the costa, and broadest on the inner-margin of the hind-wings. The hind-wings have a curved row of yellow lunules on the disc, followed by a more or less distinct black, blue, and red eyc-spot towards the inner-margin; the tail is often streaked with yellow. On the under side the yellow markings are more extended, and the principal black band on the hind-wings is marked with blue and reddish crescents. The larva of II. cresphontes (Cramer), the common North American specics, in which the yellow band is narrower and more broken into spots than in the Southern species of the genus, feels on orange, like so many of the American Equitide. 
It is brown, with large white blotches on the back, irregularly marked with brown. The pupa is light brown, dottcd with blackish.

[xLIII.] Troilides, Huibner. The type of this genus is T. torquatus (Cramer), a common South American Butterfly. measuring from two and a half to three inches in expanse. In the male the fore-wings are much shorter and broader than in the last genus, and much less pointed, the hind-margin being only slightly oblique. The hind-wings are much more strongly dentated, the tail is shorter and more distinctly spatulate, and the two projections between this and the anal angle are longer than in Heraclides, more like two short tails. There is a very broad pale yellow band running obliquely from the upper median nervule of the fore-wings ; on the hind-wings it extends nearly to the base. There is also a broad oblique sub-apical pale yellow band on the fore-wings, and a row of sub-marginal yellow lunules on the hind-wings; the incisions are also yellow. On the under side of the hind-wings there are rows of blue lunules and red spots within the yellow lunules. The female is brown, with a large white spot covering the basal half of the lower median nervule. The hind-wings are strongly dentated and tailed, with pink incisions, and a red band on the disc, divided into spots by the nervures.

[xurv. B.] Calaides, Hübner. The type is $C$. androgeus (Cramer), a fine Butterfly common in Tropical America, which measures over five inches in expanse. The for wings are long, but rounded off at the tip, and the hind-margin is ublique and concave. The hind-wings are strongly dentated, and have a moderately long tail, pointed (not spatulate) at the end of the upper median nervule; and the other nervures on each side of the tail exhibit well-marked, but shorter, projections. A broad yellow band, commencing beyond the cell of the forewings, runs obliquely across the wings, and on the hind-wings 
extends nearly to the base. The hind-wings have a double row of yellow crescents, and towards the anal angle is an orange lunule. The female is bluish-black, with or without an oblique yellow transverse band on the fore-wings, and with a double row of greenish sub-marginal lunules on the hind-wings. The middle tail is hardly longer than the others. The larva is brown, with pinkish-white markings, and feeds on a species of Malva. The pupa is brown and grey.

[xLv.] Priamides, Hübner. This is another South American genus, much resembling Parides in appearance, but much larger and more robust; the type is $P$. pompeins (Fabricius). The wings expand from three to five and a half inches; the fore-wings are produced at the tip, with the hind-margin more or less concave, and the hind-wings are strongly dentated, but not tailed. The wings are black, the fore-wings often with one or two large whitish spots toward the inner-margins; the hindwings with a rather broad sub-marginal band, more or less divided into spots, at least towards the anal angle. Sometimes the outer part of the fore-wings is paler. The larva is brown, with white longitudinal dashes, and short fleshy spines; head and legs yellow. The pupa is brown, with a bifid head. The larva feeds on the lime tree (Citrus).

[Xlvi.] This genus has not yet received a name. It includes Papilio zagreus, Doubleday, and one or two other rare South American species, measuring about four inches in expanse. They have broad rounded wings, the hind-wings being very slightly scalloped, and are black, with tawny markings arranged in the same way as in the genus Lycorea, Doubleday, in the Danaine (see vol. i. p. 29).

[xlix.] Euphaades, Hübner. The type of this genus is the fine North American species, E. glaucus (Linn.), a yellow Swallow-tail, three or four inches in expanse, with black borders 
crossed by a row of yellow spots on the fore-wings, and yellow lunules on the hind-wings, the black space within the latter dusted with blue. Four black bands run from the costa of the fore-wings, the two outermost short, the basal one and the next long, uniting above the black border of the hindwings; between this and the border is an orange mark on the inner-margin. The hind-wings are strongly dentated, and the tail is rather long and slender. This typical form is often called Papilio turmus, Linn. The true E. glaucus is a large dimorphic and melanic form of the female, most frequently found along with the type in the Southern United States. The larva, which feeds on Prumus, has the thoracic segments much thickened. It is green above, and whitish below, with seven oblique greenish stripes on the sides, and an interrupted red lateral line. Between the fourth and fifth segments is a transverse band, yellow before, and black behind; on the third segment is a lateral yellow eye-spot, pupilled with blue. The head is flesh-colour, with a yellow collar. The pupa is varied with brown.

[LI. A.] Jasoniades, Hübner. The type of this genus is J. xuthus (Linn.), a Butterfly found in Siberia and Northern Asia generally, which has been erroneously reputed European. It measures three or four inches across the wings, and resembles a large pale Achimus mackaon, but all the nervures are broadly black, leaving only long or triangular creamcoloured spots between, and there is a row of sub-marginal lunules of the same colour. There is a small orange eye-spot at the anal angle of the hind-wings, yellow beneath, and enclosing a black pupil. The spring brood is smaller and paler. The larva, which feeds on Umbellifere, is green, with broken black transverse bands, ending in hooks or spots below. The retractile fork is yellow. 


\section{[I,I. B., C.] GENUS ACIIIVUS.}

Achizus, Barbut, Gencra Inscetorum, p. I 69 ( I $7 S_{1}$ ). Princeps, Hübner, Tentamen, p. I ( I S I O ?). Amaryssus, I)alman, Ef. K. Vet. Akad. Handl. Stockh. xxxvii.

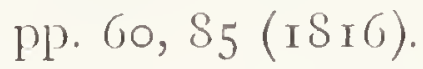

The type of this genus is regarded by most authors as the type of Papilio, limneus. It is a well-known European and Mediterranean insect, and is represented by various closelyallied forms as far as the Himalayas, and throughout Central and Northern Asia, to Alaska and California. A closely-allicd species, but darker, and with shorter tails (A. hospiton, Géné) is confined to Corsica and Sardinia. The largest and handsomest of this cluster of imperfectly segregated species is the Japanese $A$. hifpocrates (Felder).

\section{TIIE SWALLOW-TAIL. ACHIVUS MACHAON.}

(Plate LXVII. Fig. I.)

Papilio machaon, Linn. Syst. Nat. (ed. x.) i. p. 462, no. 27 (1758) ; id. Faun. Suec. p. 267 (I761) ; Esper, Schmett. i. (I) p. 3I, pl. I, fig. I (I 777 ); Hübner, Eur. Schmett. i. figs. 390, 39 I (ISo3?); Godart, Enc. Méth. ix. p. 57 , no. S9 (r8r9); Boisduval, Spec. Gén. Lépid. i. p. 328 ( $\left.1 S_{3} 6\right)$; Stephens, Ill. Brit. Ent. Ilaust. i. p. 6 (rS27); Newnan, Brit. Butterflies, p. I50 (ISSr); Kirby, Eur. Butterflics and Moths, p. 2, pl. 2, figs. 3, 3a-d ( $\delta_{7} 8$ ); Iang, Butterllies Eur. p. 7, pl. I, fig. 4; pl. 5, fig. 3 (transf. ISSI); Barrett, Butterflies of Brit. Isl. p. i I, pl. I, I $a-c($ IS92); Buckler, Larvæ of Brit. Lcpid. i. p. I, pl. I, fig. I ( I SS6).

The Swallow-tail Butterfly, our only undoubted British representative of the great Family of the Equitide, measures from three to fre inches in expanse, and is our largest Butterfly, if 
we exeept the Purple Emperor, which sometimes cquals small specimens of $A$. machaon in size. The wings areyellow and black, dusted with yellow; the fore-wings are strongly arched, rather pointed at the tip, with the hind-margin oblique, and the hindwings are not very strongly dentated, but have a long pointed tail at the end of the upper median nervule. On the fore-wings, the base and hind-margin are broadly black, dusted with ycllow, the latter divided by a row of long yellow spots. The nervures are broadly black, especially towards the costa, and there are transverse black streaks in and at the end of the eell. The hindwings are black along the inner-margin for the sreater part of its length, and have a black curve at the end of the cell; the border is broadly black with the incisions yellow, and a sub-marginal row of yellow lunules, within which is a row of ill-defined spots of blue dusting. At the anal angle is a large round red spot, with a blue crescent above, and a triangular blue spot below, and enclosed by a black ring ineomplete below.

The full-grown larva (vol. i. pl. 3, fig. I) has the front segments somewhat thickened; it is of a yellowish-green, with black ineisions and a black band, spotted with orange, on each scgment; the sides are also streaked and spotted with black, and the spinacles are yellow; the head is ycllow, with black markings, and the retractile fork on the neek is red. The early stages are extremely interesting, as they much resemble those of the adult larva in Ornithoptera, \&c. The newly-hatched larra is black, with the ineisions dark green, and the seventh and eighth segments creamy-white. It has two rows of pale pink tubercles on each side, which afterwards turn black. After the first monit, the tubereles on the white patch become tipped with black, and after the second moult the orange spots begin to appear; but the fleshy tubcrcles are not lost till after the fourth moult. The pupa is green, with a streak of yellow along each side, and an irregular row of yellow spots on the 
back. It is straight, with somewhat projecting wing-cases, and a pointed projection on the thorax.*

The larva feeds on a varicty of umbelliferous plants, and is often found in gardens on the Continent, feeding on the common carrot, but its favourite food in England is Pencedamum palustre. The Butterfly is found from May to August, and the insect may be met with in all stages during the summer months.

Fifty or a hundred years ago this Butterfly appears to have becn fairly common in many parts of the South of England, though it is doubtful if it cxtended further north than Yorkshire. But drainage and cultivat on have driven it away almost

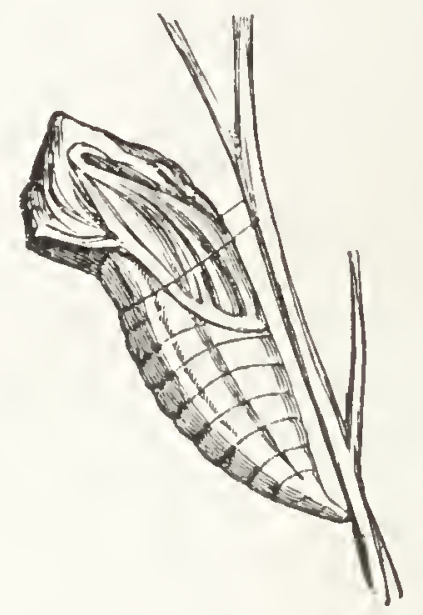

Achious machaon, pupa.

everywhere, and it is now practically confined to the undrained fens of the Eastern counties, being most abundant and gencrally distributed in Norfolk, though it is also found in some parts of the adjoining counties. In the fen district proper it is now very local. It is found in meadows and on the edges of woods, and though not a mountain Butterfly, is fond of careering about hill-sides. 'The tails are very fragile, and a large proportion of netted specimens have them damaged, though the Butterflies themselves may be otherwise uninjured.

* $C f$. the long and interesting account of the transformations of this insect given by buckler. 
[u11.] Plomirus, Scopoli. Dr. Seudder fomerly seleeted Papilio troilus, Linn, as the type of this "magazine" genus; but he afterwards withdrew it, and suggested $P$. troilus as the type of Enphaxades, in which we do not follow him. P. troilus may be taken as typical of a small group of North American Butterflies, measuring about four inehes aeross the wings. 'The fore-wings are narrower and more produeed than in Achious, the hind-margin being much more oblique; and the hind-wings are more rounded, with a broader, but not spatulate tail. The wings are blaek, often more or less suffused with blue, and are frequently marked with rows of yellow spots, or narrow yellow bands, and there is a red eye-spot at the anal angle. On the under side the outer half of the hind-wings is marked with red and blue spots and streaks. The typical P. truilus (Linn.) measures $33 / 4$ inehes across the wings, which are black, with small greenish-yellow sub-marginal lunules; the hind-wings are dusted with bluish-grey on the disc, and there is a small orange eye-spot at the anal angle. The under side of the fore-wings has a yellow spot at the end of the cell and two rows of yellow sub-marginal spots; the hind-wings are brown, with two rows of orange-red spots (the innermost row large and nearly round), the spaee between the bands being dusted with bluish-grey. It inhabits the Southern United States. A closely allied, and mueh more widely diffused species is P. ilioneus, Smith and Abbot, in whieh the spots are yellower, and the blue dusting more extended, sometimes as far as the lower half of the fore-wings; towards the tip of the costa of the hind-wings is a large orange spot above. The larva is green above and reddish below, the eolours being separated by a yellow lateral line; there is a blaek collar, and on the third segment two pink spots eontaining black spots marked with a blue ring; and on the fourth segment are two smaller pink spots pupilled with white. The hinder segments are 
marked with transverse rows of black spots (about four on each). The larvæ feed on sassafras, and are called "mellow worms "from their peculiar odour.

[LIv.] Eques, Linnæus. I propose to restrict this nanre to Eques uircus (Linn.); the representative of a very distinct African group, and almost the only species originally placed in Eques by Linnaus which has not yet been made the type of a genus. In these Butterflies the fore-wings are moderately broad, with the costa arched, and the hind-margin oblique, and the hind-wings are contracted in a series of obtuse projections to the anal angle, which is lobate or sub-caudate. The wings are black, with a green or bluish-green band, varying in width, running obliquely from beyond the middle of the costa of the fore-wings to above the anal angle of the hindwings. There are also frequently some green spots towards the tip of the fore-wings, and the inner-margin of the hindwings. The under surface is sometimes obscurely marked, while in other species there is a narrow white or yellowishwhite band or row of spots towards the hind-margin of the hind-wings; the body is dotted with white. The larva of the South African E. lycus (Doubleday), as described and figured by Mr. Trimen, is green, with the thoracic segments very much enlarged, and the "widest portion of the back on the third thoracic and first abdominal segment is occupied by a sub-ovate patch or shield of pale bluish-green, crossed mesially by a thin whitish line, closely irrorated generally with white dots, and bearing near its posterior edge a transverse row of four small pinkish-lilac spots." The projections on the first thoracic segment are short; but there are two rather long yellow projections on the anal segment. It feeds on orange as well as on various native trees. The pupa is green, with two projections on the head, and the wing-cases are very prominent. 
[LV. \& LVI. C.] This unnamed genus includes the remarkable group of Papilio merope, Cramer. They are large Butterflies, measuring from $3^{\mathrm{T} / 2}$ to nearly 5 inches across the wings, and are confined to Africa and Madagascar. In the males the upper side is pale sulphur-yellow, the fore-wings with the costa narrowly and the hind-margin more broadly black, with a pale yellow spot near the tip; on the hind-wings there are some black spots towards the hind-margin, and three large black spots, one near the end of the costa, one above the anal angle, and one beyond the cell; sometimes these are united into a continuous border. The under side of the hind-wings is of a rather shining yellowish-grey. The fore-wings are rather short and broad, the costa being strongly arched, and the hind. margin not very oblique, and slightly concave; the hind-wings are almost rectangular at the outer angle, where there is a long, slightly spatulate tail. The females, however, have rounded and scalloped hind-wings, without a tail, and are black, with white, buff, red, or orange markings, corresponding with those of various species of Danaina of the genera Limnas and Amauris, which abound in the same localities. This is one of the most interesting cases known of the phenomenon called "mimicry," more especially as the Madagascar representative of the group (Papilio meriones, Felder), which is distinguished by having a broad black band on the costa, and also one or two East African forms, have black and pale yellow tailed females almost identical with the males in shape, colour, and pattern.

Respecting the habits of the West African Papilio merope, Surgeon-Captain Clements writes ("On a Collection of Sierra Leone Lepidoptera," by W. Schaus, F.Z.S., and W. G. Clements, Surgeon-Captain A.M.S., p. 6): "Of the females of $P$. merope I obtained but one variety. This is indistinguishable on the wing from Amauris niavius; the male keeps within the shady parts of the forest, and has a bold, lofty, and sailing 
flight. Selecting an open glade it will fly rapidly up and down for a space of some 300 yards, coming fearlessly near to one's net, which it generally manares to evade by a quick double, and finally approaching a tuft of grass, or the projecting branch of a tree, disappears. It almost invariably selects a broad-bladed grass, striped with brown and yellow, and hanging pendent from its extremity with the wings folded, the upper ones being covered over and concealed by the lower, it cannot be seen until it is again startled into flight."

The larva of the South African Fapilio cenea, Stoll, is slugshaped, bluish-green, with short tubercles (white, and longer in the young larva) on the second and anal segments; the retractile fork crimson-lake, tipped with greenish-white. The pupa is also green, slender in front, with the two usual procisses contiguous, and meeting in a point; it is wide in the middle and pointed again at the hinder end. The larva feeds on Vepris lanceolata.

Although the females of these Butterflies resemble highlyprotected insects, yet they themselves are well protected otherwise, the green pupa resembling a leaf, and the under side of the Butterfly resembling in colour the shrubs among which it perches.

[Lix.] Araminta, Moore. The type of this genus is $A$. demolion (Cramer), which is met with throughout the greater part of the Indo-Malayan Region. It measures nearly five inches across the wings. The fore-wings are considerably produced, the hind-margin being very oblique, and the hindwings are rounded and scalloped, with a long and somewhat spatulate tail. A pale green band runs obliquely from near the base of the inner-margin of the hind-wings nearly to the tip of the fore-wings, where it grows much narrower, and becomes broken into spots. On the hind-wings are some submarginal gresn lunules, and at the anal angle is a round black 
spot in a red ring. The presence of this red and black eye. spot at the anal angle on the upper side sufficiently distinguishes this group from any other black and green East Indian Butterflies. The larva is green, with the thoracic segments somewhat thickened behind, and two short whitish horns on the first and last segments; segment seven has a whitish transverse band, dotted with reddish, and surmounted by two small white horns; the fourth, fifth, and ninth have similar transverse bands; the belly is white, varied with red. The pupa is grey, much arched, with a bifid head, a long spine on the pectus, and the lateral ridges of the abdomen strongly serrated beneath. The larva feeds on a species of Fagara called "Sampang" in Java.

[Lx. A.] This genus includes a number of East Indian Butterflies of moderate size, to which some authors have improperly proposed to restrict the generic name Laërtias, Hübner. One of the commonest species is Papilio polytes, Limn. The sexes are very dissimilar. The male, which Linnzus called Papilio fammon, has broad and rather short fore-wings, the hind-margin being oblique to the level of the hind-wings, which are ample, dentated, and furnished with a spatulate tail. The wings are black, the fore-wings with a row of white marginal spots, and the hind-wings with a t!ansverse and slightly curved white band, divided into spots by the nervures; sometimes the anal angle is marked with orange above, but always on the under side, where there is also a submarginal row of orange lunules. The female (the true $P$. poly'tes, Linn.), instead of the white band on the hind-wings, has a large white spot in the middle of the latter, below which is a red spot at the anal angle and a row of rather large red sub-marginal spots. The nervures of the fore-wings are bordered with white on the disc. There is a second form of the female (Papilio romulus, Cramer), with extensive red markings on the 
hind-wings instead of the large white spot. Many forms closely allied to $P$. polytes, differing chicfly in the extent of the markings, are found in the East. Some are tailed, and others tailless; they measure rather more than three inches across the wings.

The larva of $P$. polytes is green above, with cream-coloured bands and markings on several segments; the anterior segments are inflated. Beneath, it is cream-coloured. It feeds on different species of Citrus. The pupa is green or brown.

[LX. B.] Charus, Moore. This genus, the type of which is C. helenus (Linn.), much resembles the last in shape, and is also tailed, but the species are considerably larger, often measuring four or five inches across the wings, and are differently coloured. They inhabit various parts of the Indo- and Austro-Malayan Regions, and are black above, with a very large creamy-white spot on the hind-wings, which is narrow above, and extends from the costa over the upper and outer half of the wings, but without reaching the hind-margin. On the under side there are one or two black spots, more or less completely bordered with red towards the anal angle, with some blue lunules between these and the white patch ; these markings are sometimes partially reproduced above, while in other species they are very much reduced. Sometimes the red markings are replaced by yellow. The larva of $C$. helenus is dark green above, and flesh-coloured below; the hinder part of the thoracic segments is much thickened. In front of the inflation is a flesh-coloured spot, with two black pupils on each side of the upper surface; and behind the inflation is a flesh-coloured band. Beyond the middle is a broad oblique pinkish-white band, and another transverse band of the same colour between this and the end of the body. The food-plant is probably Citrus, but has not been recorded. The pupa is brown, much curved, with a bifid head. 
[Lx. c.] Tamera, Moore. The type of this genus, $T$. castor (Westwood), is a North Indian species remarkable for the dissimilarity of the sexes. It measures about $3 \frac{1}{2} / 2$ inches across the wings, which are black, with the incisions spotted with white. The hind-wings are dentated, but not tailed, and in the male, are ornamented with a large quadrifid creamy-white spot towards the tip. The female is brown, with sub-marginal white spots. The fore-wings have a rather large white spot at the end of the cell, and are dusted with grey on the lower half of the disc. The hind-wings are strongly dusted with greenishgrey in the cell, and between the nervures, except towards the hind-margin.

[Lx. E.] Nestorides, Hübner. This genus includes a number of very large and handsome species which are confined to the Austro-Malayan Region. The type, $N$. gambrisius (Cram。), is found in Amboina and Ceram. It is a fine Butterfly, measuring six inches in expanse. The male is black, with yellow incisions, and three or four yellow spots towards the tip of the fore-wings; beyond these, the wing is dusted with yellow. The hind-wings are strongly dentated, with a broad yellow band over the end of the cell, and coppery dusting beyond. The female is black; on the fore-wings, the end of the cell, and the spaces between the nervures on the disc are white, shading into buff; the hind-wings have a rather narrow tawny band across the end of the cell, and are dusted with blue beyond.

The only species of this genus which is really common in collections is $N$. agelts (Donovan), from Australia. It measures upwards of four inches across the wings, which are broad, but the fore-wings are not produced, the hind-margin being only slightly oblique; the hind-wings are ample, strongly dentated, but not tailed. The male is black, with an oblique row of spots across the tip of the fore-wings, and the hind 
wings have a curved creamy-white band running from the costa nearly to the anal angle, which is marked with a red spot. On the under side, the white band of the hind-wings has disappeared, but there is a row of large red sub-marginal spots, followed within by a row of bhe lunules. In the female, the outer part of the fore-wings is grey (whiter bencath), with a dark blotch at the end of the cell, and shading into brown on the margins; the hind-wings are coloured on both sides nearly as on the under side of the male; but the whole centre of the wing is filled up with a large irregular sub-triangular space, extending both to the costa and to the inner-margin. "When young, the larvæ are brown, with patches of white, and covered with spines; but when full-fed, they are dull green, with blotches of brown, edged with white on both sides, and the spines much reduced in size. The fourth and fifth segments are considerably thickened, and the caterpillar is soft and falsby to the touch. The chrysalis is green, speckled with black, and is attached to the food-plant " (Anderson and Spry, "Victorian Butterflies," p. I6). The larvæ feed on orange, and are sometimes very destructive, and the long rosecoloured retracile tentacles enit a disagreeable odour of putrid oranges.

[Lxir.] Laërtias, Hübner. WVe now come to one of the most splendid gencra of Austro-Malayan Equitida, represented by L. ulysses (Limn.), from Amboina. They measure four inches and upwards across the wings; the fore-wings are not very long, but rather pointed, the hind margin being regularly oblique; the hind-wings are long towards the lower part, and strongly dentated, with a long spatulate tail. The wings are black, with a rich cobalt-blue jatch covering at least the basal half of the wings; in the female, the blue is much duller, and less extended.

[rxm.] Marimala, Moore. With this genus, we commence 
the beautiful group of Equitide in which the wings are powdered with metallic green. Harimala is represented both in the Indo-Malayan and Austro-Malayan Regions, but the type, H. crino (Fabricius), is found in India, Ceylon, and Cochin China. It is a comparatively small species, not measuring more than about $3 / / 4$ inches across the wings, which are slightly falcate, the hind-margin being concave as well as oblique; the hind-wings are dentated and tailed. The wings are black, dusted with golden-green, and are crossed by a blue band, running from the costa of the fore-wings beyond the cell, where it is narrowest, and curving round to the inner-margin on the hind-wings; below it there is a black spot in a red ring, and a row of green lunules between it and the spatulate tail. On the under side the wings are brown, with sub-marginal rows of red, bluish, and grey lunules. The larva is slugshaped, with the anterior segments convexly scutellated, and a pair of short fleshy tubercles on the anterior and anal segments. The pupa is curved, and the head is broad in front. The larva feeds on the satin-wood tree.

\section{[LXIV. $\Lambda$, PT.] GENUS $\Lambda$ CIIILIIDES.}

Achillides, Hübner, Verz. bek. Schmett. p. $85(1816)$.

\section{ACIIILLIDES PARIS.}

(Plate LIY T. Fig. 2.)

Papilio paris, Linn. Syst. Nat. i. p. 459, no. 3 (1758); id. Mus. Ludov. Ulr. p. I $8_{4}$ ( $\left.\mathrm{I}_{7} 64\right)$; Clerck, Icones, pl. I 3 , fig. I ( 764 ); Drury, Ill. Ex. Ent. i. pl. I 2 , figs. I, 2 (г773) ; Cramer, Pap. Exot. ii. pl. го3, figs. A, B (г777); Godart, Enc. Méth. ix. p. 67, no. i 6 (1819); Boisduval, Spec. Gén. Lépid. i. p. 208 ( $\left.{ }_{3}{ }_{3} 6\right)$.

The genus Aclillides is remarkably like Charus in the dis- 
tribution of colours, though the colours themselves are very different; and unlike Charus, the species are restricted to the Indo-Malayan Region, being particularly numerous in India and Java. The commonest and most anciently known species is A. paris (Linn.), which is found in India and China, and measures about four inches across the wings, which are shaped nearly as in Harimala, but the fore-wings are longer, with the costa more strongly arched, the tips more produced, and the hind-margin more oblique; the hind-wings are more narrowed behind than in Harimala, but strongly dentated, and furnished with a long spatulate tail. The wings are black, dusted with golden-green, coalescing to form traces of a sub-marginal band towards the inner-margin of the fore-wings; the hind-wings have a large bluish-green patch on the costa, extending over the upper half of the wing, but not reaching to the hind-margin, opposite to which they exhibit several concavities; on its lower and inner edge it is connected with the inner-margin by a golden-green stripe, below which is a round black eye-spot in a red ring, surmounted by a blue crescent. The under side is black, with a broad whitish suffused sub-marginal band, intersected by the black nervures on the fore-wings. On the hind-wings, there is a sub-marginal row of red lunules, bordered with blue ones; the incisions are white. In the Javanese $A$. arjuna (Horsf.), the patch on the hind-wings is of a more greenish-blue, and extends in a point towards the anal angle. The larva of $A$. arjuna is green, with slender oblique and transverse white lines, and the thoracic segment but slightly raised; the pupa is yellowish-green. The larva feeds on a species of Citrus.

[Lxiv. A., PT.] Sarbaria, Moore. The type of this genus, which forms part of the same sub-section as the last in Felder's arrangement, and which most authors would not consider generically distinct, is S. polyctor (Boisduval), a well-known North Indian species, measuring $3 \frac{1}{2}$ inches across the wings. 
It is bronzy-green, with a broad sub-marginal band of green streaks on the fore-wings; the hind-wings have a large blue patch, dentated on the outer side, before the tip, and two large red sub-marginal crescents on each side of the base of the tail.

[LXv. A-C.] Iliades, Hübner. This genus includes a number of large and handsome Butterflies, most of which measure five inches in expanse of wing. They are extremely characteristic of the Indo- and Austro-Malayan Regions. I have figured the female of one of the commonest species.

\section{ILIADES AGENOR. \\ (Plate LXV. Fig. 2.)}

Papilio agenor, Linn. Syst. Nat. (ed. x.) p. 460, no. I3 (1758); id. Mus. Ludov. Ulr. p. I 94 ( 1764 ); Clerck, Icones, pl. I 5 (r764); Cramer, Pap. Exot. i. pl. 32, figs. A, B (г775); Godart, Enc. Méth. ix. p. 28, no. 9 (r819); Distant, Rhop. Malay. p. 339, pl. 29, fig. I (1885).

This species belongs to a small group of closely-allied forms in which the males are almost all alike, and the females differ greatly. Boisduval united them all under one species, to which he applied the name of Papilio memnon; but Dr. Wallace ("Trans. Linn. Soc. Lond." xxv. pp. 46, 47) recognised two species, with polymorphic females. More recent authors (Messrs. Butler and Distant, for example) are inclined to recognise a larger number of species, thinking that it will be found possible ultimately to separate the males into species as well as the females. It is a parallel case to that of Papilio merope, Cramer, which we have already noticed (anteda, p. 29r). The present species belongs to the group of forms which are peculiar to continental India, and to which Dr. Wallace applied the name of Papilio androgeos, Cramer. They differ from the forms found in Java, Sumatra, Borneo, and Lombock, in 
having red markings towards the anal angle of the hind-wings beneath.

The fore-wings are much produced and rather narrow, the hind-margin being very oblique, and slightly concave; the hind-wings are ample, rounded, and scalloped. There are always large red (or more rarely, yellow) spots at the base of the wings bencath, and in the females, at the base of the forewings above.

The male is black, thickly dusted with blue on the nervures towards the hind-margins; on the under side of the hindwings there is a sub-marginal row of large round black spots bordered inside with red lunules, and a large red blotch enclosing two or three black spots towards the anal angle. The female has brown fore-wings, with the nervures broadly bordered with grey, and a large red spot in the cell at the base; the hind-wings are black at the base, to the end of the cell, with the disc white; there is a row of sub-marginal black spots, outside which, and towards the anal angle, the white is strongly stained with yellow. The underside of the wings is marked with large red spots at the base, as in the male, and the anal angle is stained with yellow instead of red.

The cluster of forms which Dr. Wallace places together under the name of Papilio memnon have no red spots at the anal angle, though Wallice figures a female from Jara hardly differing from typical I. agenor. The females generally have the greater part of the hind-wings white on the upper side, and some of the forms are furnished in addition with long spatulate tails. I. memnon (Cramer) is the type of the genus, but when its true female has been accurately determined, it will have to take its name (most of these doubtful forms having been figured under different names by Cramer and others); for the description and locality assigned by Limmeus to his Pafilio memnon, as well as Petiver's figure, which he 
quotes, show that it is a species pzculiar to the Philippine Islands, being generally known by the name of $I$. emaltion, Hübner. 'The male differs from $I$. agenor and its allies in having the black sub-marginal spots on the hind-wings broadly surrounded with red; the female is black, veined with grey, with a transverse red band, varied with white, towards the base of the wings.

'The larva of $I$. memnon (Cramer) is daik green and smooth, with the thoracic segments dilated. There is a green or buff band (the first marked with a black spot on each side) before and behind the inflation; an oblique white band just beyond the middle, and a transverse one between this and the extremity of the body. The pupa is green, with three yellow lines on the abdomen; the head is produced and bifid.

'The foodplant is not recorded.

[Lxv. D., PT.] Samia, Moore. 'This is another smail genus, which is almost confined to India, China, and Japan. The type is S. protenor (Cramer), one of the commonest and most widely-distributed species; it expands from four to six inches across the wings. 'The fore-wings are shaped as in lliakes, but the hind-wings are longer, not tailed, and the hind-margin regularly waved. The wings are blue-black, the fore-wings ve ned with black, and the hind-wings have a black spot towards the anal angle, surrounded with reddish. The female, which is much larger than the male, has browner fore-wings, and the hind-wings have a large red patch at the anal angle, enclosing a black spot; and a second red ring below it. In the male, these markings appear on the under side only.

[Lxv. D., PT.] Panosmiopsis, Wood-Mason and De Nicéville. $P$. rhetcnor (IVestwood), the type of this genus, much resembles Samia protenor (Cramer). It measures four inches across the wings, which are of a dark brown, the fore-wings striated with 
black nervures, and the hind-wings dusted with blue. In the male, the costa of the hind-wings has a short greenish-yellow stripe at the base, and a black spot in a red or peach-coloured rim at the anal angle; in the female there is a cluster of similar spots at the anal angle.

[Lxv. D., pr.] Pangeranopsis, Wood-Mason and De Nicéville, is a generic name that has been proposed for another North Indian species, P. elephenor (Doubleday), which much resembles Panosmiopsis protenor, but the fore-wings are longer, greenish-black rather than blue-black, and the blue-black hindwings are narrower and more produced, with a red and black eye-spot at the anal angle. Beneath, the hind-wings have two very large red patches towards the anal angle, and some large red sub-marginal lunules on the hind-margin.

[Lxvi., pt.] Pangerana, Moore. The type of this genus is $P$. varuna (White), which is found in North India and also at Penang. This Butterfly measures from four to five inches across the wings, the female being larger and paler than the male, and with broader wings. The hind-wings are, however, narrower than in the preceding genera, and less strongly scalloped. They are blue-black, with grey rays between the nervures towards the hinder angle of the fore-wings, especially on the under side. In the female the fore-wings are greyer, with the nervures and black lines on the interspace showing more distinctly than in the male. The collar, a tuft between the eyes, the pleura, and the abdomen beneath, are scarlet, and the abdomen is spotted with black.

[LXvi., PT.] Atrophaneura, Reakirt. The type of this genus is A. semperi (Felder), a curious Butterfly, confined to the Philippine Islands, which measures a bout four inches across the wings. The body is red, and the wings are black; the fore-wings are long and narrow, and considerably produced at the tips, the hind-margin being very oblique; the hind-wings are much ex- 
panded below, and are dentated and sub-caudate, or furnished with a strong tooth at the outer angle; the inner half of the wing is brown at the base, and dirty white beyond. On the under side of the hind-wings is a large red blotch at the outer angle, with some black spots in the middle and on the hind-margin; and there are several more red spots towards the margins above the large patch. In the female, the white inner marginal space is absent, and the red markings of the under surface are at least faintly visible above, but frequently there are two rows of sub-marginal pink spots. This very curious Butterfly is still scarce in collections.

[Lxvir.] The type of this still un-named genus is Papilio nox, Swainson. This, and the few allied species, are peculiar to the Malay peninsula and the adjacent islands of Borneo and Sumatra, and are remarkable for their dark colour, very long forewings, rounded at the tips, and long narrow rounded hindwings.

[Lxix., pt.] Panasmia, Moore. We now come to two peculiarly-shaped genera which are restricted to North India. Penasmia dasarada (Moore) is the type of one genus. It ex. pands $5 \frac{1}{2}$ inches across the wings; the fore-wings are long, narrow, and rounded at the tips, and the hind-wings are very long and narrow, forming three large lobes on the hind-margin, and then expanding into a very broad tail, slightly constricted at the base; within this are two more lobes, one at the innermargin, and one between this and the tail. The fore-wings are dark grey, with the nervures, intermediate lines, and a series of longitudinal lines in the cell, black; there are several large square white spots on the hind-wings, which are scarcely marked with red on the upper side; but on the under side the three on the hind-margin are white, that on the tail is red, and the three at the anal angle and on each side of it are red, more or less marked with white on the inner side. 
[Lxix., Pr.] Bjasa, Moore. B. philoxemus (Gray), the type of this genus, much resembles Penasmia dasarada, but the wings are broader and shorter, expanding only $43 / 4$ inches. The body is red; the fore-wings are eoloured as in Penasmia dasarada; and on the hind-wings, the tail is short, almost round, and much constricted at the base. 'Towards the tip is a large white spot, divided in two by a line at its lower end; there is a red spot on the tail, one on the inner lobe, one at the anal angle, and one on the inner-margin, one on the hind-margin between the white spot and the outer lobe at the base of the tail, and one between the curve beyond this and the spot at the anal angle.

The larva of $B$. philovenus is pale purplish-brown, with several short tubercles on each segment, and a short, broad, white oblique band on the side of the serenth and eighth. The pupa is broad, reddish-ochreous in colour, with the head bifid in front, the thorax curved above and beneath, the wingeases expanded laterally; and the dorsal segments with foliaecous lateral appendages. The larva has been found feeding on a creeping piteher-plant, at an elevation of about 6,200 feet; and the pupa is said to squeak when touched, an unusual habit in Butterflies, though well known in Manamia atropos, and several other Sphingide. The pupa has not been described.

[Lxxin.] Menelaides, Hübner. This genus ineludes a number of Indo-Malayan and Austro-Malayan Butterflies, most of whieh are smaller and less peeuliarly shaped than those which we have just been eonsidering; several of them mueh resemble the female of Papilio polytes, Linn The type is $M$. polydorus (Linn.), whieh is found in the Moluccas and Australia. It has broad, black wings, three or four inches in expanse, and the fore-wings are rayed with greyish-white, the rays towards the hinder angle eoaleseing into a large blotch. 'The hind- 
wings have a broad white patch crossing the end of the cell, and a row of large red sub-marginal spots. The hind-wings are long, with the hind-margin much waved, and sub-caudate. The larva feeds on Aristolochia, and much resembles that of a Thais. It is dark red, with several rows of short carmine fleshy spines; about the middle is a transverse white band slightly tinted with rose-colour. The pupa resembles that of Tros hector.

[Lxxiv.] Tros, Barbut. The type of this genus is $T$. hector (Limn.), a handsome and rather isolated Butterfly, which is common in India and Ceylon. It measures about four inches across the wings, which are rather long and narrow; the tip of the fore-wings is rather pointed, and the hind-margin oblique. The hind-wings are long, dentated, and with a moderately long and rather broad, but hardly spatulate, tail. The wings are black, the fore-wings with two rows of long and mostly bifid white spots, one near the tip, and the other running from before the middle of the costa to the hinder angle; the hindwings have two row of large round red sub-marginal spots, the innermost turning inwards at a right angle to the inner margin at the end of the fold. The head, the body beneath, and the greater part of the abdomen are red.

The larva is smooth and green, with the hinder thoracic segments slightly thickened. The lower part of the body is brown in front and white behind. On the upper surface there is a narrow greyish band on the third segment, a transverse brown band on the fourth, and an oblique white band, varied with brown, on the seventh, which rises to the eighth; the extrenity of the ninth segment is also whitish. The pupa is pale grey, reticulated with brownish, with a bifid head, a projection on the pectus, and the ventral surface of the abdomen serrated. The larva feeds on the lime, and also on another species of Citrus, called "Jurok" in Java. 
[uxxv.] Pharmacophagus, Haase. I propose to restrict this generic name, used by Haase in a very wide sense, to $P$. antenor (Drury), the largest and handsomest Butterfly found in Madagascar. It measures six or seven inches across the wings; the fore-wings are long, with the costa not much arched, the tip rounded off, and the hind-margin very oblique, and slightly concave. The hind-wings are half as long again as broad, and very strongly scalloped, with a long, broad, slightly spatulate tail. The antennæ have a stout but gradually-formed club. The thorax and antennæ are black above, the head and most of the under surface of the body red; the abdomen red and white. The wings are black, the fore-wings with three large pure white spots in the cell, and two rows of large white spots on the disc. On the hind wings there are two large white spots in the cell, two small ones above, and a curved row of small ones below; there is also a row of large red submarginal lunules running from the tip to the anal angle; and on the inner-margin, opposite the end of the abdomen, which only extends two-thirds of the length of the hind-wings, is a red spot, marked above and below with white.

Among the recently discovered specics, which were unknown to Felder, Papilio laglaizii, Depuiset, from New Guinea and the Aru Islands, deserves special mention from its curious resemblance to Alcidis metanus (Hopffer), a Moth belonging to the $N_{y}$ ctalcmoniide. It measures about $3 \frac{\mathrm{T}}{2}$ inches across the wings, which are greenish-black, with a pale bluish-green band on all the wings, much wider on the hindwings than on the fore-wings. The fore-wings have a short subapical band of the same colour, and on the hind-wings, the incisions and the short tail are white. 


\section{GENUS BARONIA.}

Baronia, Salvin, Trans. Ent. Soc. London; 1893, p. 33 r.

Under the name of Baronia brevicomis, Mr. Salvin has described a new form of Butterfly from Western Mexico (Sierra Madre del Sur, near Chilpancingo, at an altitude of about 4,500 feet), which is remarkable for its very short antennx, with a long club, and the long hair-like frontal scales, which are drawn down between the eyes. The sub-costal nervure of the fore-wings is three-branched, "the first branch arising at a distance from the end of the cell about equal to its width, and the second the same distance beyond; the usual third branch from the end of the cell is wanting, as well as either the first or second before the end of the cell; the upper disco-cellular nervule is short, and the middle disco-cellular about twice as long as the lower." The wings are brown, the fore-wings with rows of ochreous spots, those towards the tip whitish in the female, and the hind-wings with the upper part of the cell and the space above nearly to the costa yellowish-ochreous, and with several additional spots of the same colour.

\section{SUB-FAMILY IV. LEPTOCIRCINA.}

I have ventured to separate the anomalous genus, Leptocircus, Swainson, as a distinct Sub-family. The head and body are very thick, the abdomen short, the eyes large and prominent, the palpi very short and thick, with long stiff hairs in front, and the antennæ thickening into a club, which is slightly curved upwards. In one species only, L. curius (Fabricius), the claws of the tarsi are bifid, as in the Pieride; in the others they are simple. The fore-wings are short, sub-triangular, with the tip rather pointed, and the hind-margin oblique; the outer part is hyaline, except at the edges. The hind-wings are long, folded, and produced into a very long tail. On the fore-wings 
thesub-costal nervure is five-branched, with two branches thrown off near together before the end of the cell; the third and fourth fork half way between the rather pointed cell and the tip, while the fifth forks just beyond the cell. The upper discocellular nervule is present, the first discoidal nervule being cmitted from the cell. There is a short internal nervure and an oblique cross-nervule connecting the median and submedian nervures near the base. On the hind-wings the precostal nervule is present, and curved, and there is a crossnervure connecting the costal and sub-costal nervures at the base; the second sub-costal nervule is absent; the cell is very small, and all the remaining nervures are very long, the upper median nervule running down to the extremity of the tail.

\section{GENUS LEPTOCIRCUS.}

Leptocircus, Swainson, Zool. Ill. Ins. ii. p. Io6 ( $S_{32}$ ?); Boisduval, Spec. Gén. Lépid. i. p. 3 So $\left({ }_{1} S_{3} 6\right)$; Doubleday, Gen. Diurn. Isepid. p. 22 ( $\mathrm{IS}_{47}$ ); Schatz, Exot. Schmett. ii. p. 47 (I 8S6).

This genus includes only a few species, very similar to each other, which have a wide range over the Indo-Malayan Region, but do not appear to extend beyond it, except to Celebes. I have figured the type, which is also one of the commonest species; it is found in India, Malacca, Java, \&c. The species of Leptocircus are said to hover over water in company with Dragonflies, which some observers say they resemble on the wing.

\section{LEITOCIRCUS REGES. \\ (Ilate LXIII. Fig. 2.)}

Erycina aurius, Godart (nec Fabricius), Enc. Méth. ix. p. S27 ( 1823 ).

Papilio meges, Zinken-Sommer, Nova Acta Acad. Nat. Cur xv. p. ír, pl. I 5 , fig. $S\left(1 S_{3} r\right)$. 
Lamproptera curius, Gray, in Griffith's Animal Kingdom, xv. pl. 102, fig. 4 ( 1832 ).

Leptocircus curius, Swainson, Zool. Ill. Ins. ii. pl. Io6 (I833); Boisduval, Spec. Gén. Lépid. i. p. $3 S_{\text {I }}$ pl. 7 , fig. I ; pl. I 7, fig. I ( I 836).

Leptocircus meges, Doubleday, Zoologist, i. pp. i ro, i I r, cum. fig. (I843) ; Distant, Rhop. Malay. p. 385 , pl. 32, fig. 3 (I 886). Leptocircus virescens, Butler, Cat. Lep. Fabr. p. 259 (1870).

This species measures rather less than two inches across the wings, which are black. The fore-wings are hyaline on the outer half, traversed by the black nervures, and a green band runs straight from the costa of the fore-wings, at about onethird of their length, to the middle of the hind-wings.

The earliest known species of the genus, L. curius (Fabr.) is smaller, with shorter tails, and a white transverse band instead of a green one; it inhabits Java and Siam.

With this genus we conclude our second volume, and our account of the more typical Butterflies. Our next volume will commence with the Hesperiide, or Skippers, which may be regarded as intermediate between Butterflies and Moths; followed by an account of those families of Moths which appear to be most nearly allied to the Butterflies. 



\section{ALPHABETICAL INDEX.}

Abxis. I92, 194, I95, 197.

celorene. I97.

mexicana. $23 \mathrm{I}$.

Abisara. IO, I 4, I 5 . gerontes. I 5 .

abrota, Ogyris. I 3 I.

achieus, Anteros. 36.

Papilio. 36.

Polyommatus. 36 .

Achillides. 297.

arjuna. 298.

paris. $297,298$.

achine, Anthopsyche. 195.

Callosune. 195.

Achivus. 268, 289.

hippocrates. 286.

hospiton. 296.

machaon. $276,285,286,287,2 \&$ g.

acis, Helicopis. 20, 2 I

Lycrena. 107.

Papilio, 20, 104, I07.

Polyommatus. I07.

Acmetopteron. I82, I83.

nemesis. I 82,183 .

Acrea andromachit. 24I.

Acræinæe. I34, I8I, 250.

Actinote. I8I.

Adelpha. 48.

adonis, Lycena. 94.

Papilio. 94.

Polyornmatus. 92, 93, 94, 95 .

xgeus, Nestorides. 295.

ægon, Lyєæna. 88.

Papilio. 88.

Polyommatus. 88. rlianus, Lampides. $\quad$ S5. æneas, Papilio, 27 I.

rneides, Papilio. 27 I.

xstiva, Lycina. 99.

Etheoptera. 256, 257.

victorix. 256.

agamemnon, Papilio. 273.

aganippe, Delias. I 70.

agathon, Metaporia. I $5^{\mathrm{S}}$

agrenor, Iliades. 299, 300, $30 \mathrm{I}$.

Papilio. 299.

agestis, Papilio. 99.

Polyommatus. 99, IOI, IO2.

agestor, Cadugoides. $2 S \mathrm{O}$.

Agriades atys. 103.

orbitulus. I03.

agyrtus, Erycina. 43.

Isapis. 43.

Papilio. 43.

Alena. I34.

albicans, Lycrena. 91, 92.

albipunctata, Zemeros. I $\hat{3}$.

alcides, Myrina. 76.

Papilio. 76.

Alcidis metaurus. 306.

Alcon Blue. I Io.

alcon, Lycrena. I Io.

Nomiades. I IO.

Papilio, I Io.

Polyommatus. Iog, I IO.

Aletis. 134.

alexis, Lycana. 96.

Papilio. 96, 99, 105.

Polyommatus. 94, 96, 99, 100 IOI, IO2. 
allous, Papilio. 99.

Polyommatus, IOD.

Alocides. 77, 79.

Aloeides picrus. 79.

alphra, Lemonias maculata. $3^{3}$.

alsus, Cupido. 85.

Lycrna. I05.

I'olyommatus. I0j.

Amaryssus. 286.

amata, Colotis. I90.

Amauris, 29 I.

Amauris niavius. 29I.

Amblypodia. 48, I 20.

apidanus. I 30.

erylus. 62.

amphione, Dismorphia. ISI, IS2.

- Papilio. ISI.

amphrysus, Ornithoptera. 265.

amyntas, Papilio. $\$ 6$. Polyommatus. 86.

Amynthia. 223, 225 .

clorinda. 223 .

mæerula. 223.

Anaphe. I63.

Ancyluris. $30,31,3 \%$.

iphinoe. 29.

melibceus. $3 \mathrm{I}$.

androgeos, Papilio. 299.

androgeus, Calaides. $2 S_{3}$.

andromacha, Acrea. $24 \mathrm{I}$.

annæ, Callosune. I96, 200.

Anops. I 3I.

antenor, Pharmacophagus. 305.

Anteros. 35 .

achrus. 36.

formosus. 35 .

Anthocharine. I 39, I S5.

Anthocharis. I $\$ 5$, I 90, I9.

cardamines. I 86 .

cebrene. 197.

danae. 196.

genutia. I90.

scolymus. I90.

Anthopsyche. 194, 195, 197.

achine. 195.

anthyale, Zerene. 2 I 7.

antimachus, Drurya. 240, 2.4 I, $250,279$.

Papilio. 250. antiopa, Papilio. 235, 265. Vanessa. 235, 268.

antiphates, Pathysa. 274.

Apatura iris. 249.

Aphnæus. I 3, 79.

orcas, 80.

Aphnaria. 47,48 .

Aphrissa. 228. statira. $22 \mathrm{~S}$.

apidanus, Amblypodia. I30. apollina, Doritis. 239

A pollo Butterfly. 236.

apollo, Papilio, 236.

Parnassius. I4I, 236, 237, 238, 239.

apollonius, Parnassius. 239. Aporia. I 39, I 43, I 54, I 56. cratiegi. I40, I4I.

lama. I 55 .

Aprias. I7I, I72, I74, '175.

paulina. I 43 .

zelmira. 173.

Araminta. 292. demolion. 292.

Arcas. 58. imperialis. 58.

arcas, Nomiades. Ion.

Papilio. I Io.

Archonias. 163, I64.

tereas. 163.

arcthusa, Papilio. 197.

argia, Nepheronia. 205, 206.

argiades, Cupido. $8_{5}$, 106.

Lycrena. 86, 87.

Papilio. 85 .

Polyommatus. 86 . argiolus, Cyaniris. 103.

Lycrena. IO4.

Papilio. 103, I06.

Polyommatus. IO.

Argus, Brown. 99, 100.

Durham. I0o.

argus, Lycrena. SS.

Papilio. SS.

Plebeius. $47,87,88,89$.

Polyommatus. 88,89 .

Arhopala. I 30 .

alion, Lycena. 109.

Nomiades. тоб, IoS, Iro. 
arion, Papilio. Io8.

Polyommatus. IoS, I Io.

arjuna, Achillides. 298.

armandi, Davidina. I $57,{ }_{5} 8$.

Armanclia. $247,248$.

thaidina. $247,248$.

Artaxerxes Butterfly. IO2.

artaxerxes, IIesperia. I02.

Lycrena. IO2.

Polyommatus. I02, $\mathrm{IO}_{3}$.

aruna, Delias. I69.

Ascanides. 269.

triopas. 269.

ascanius, Hectorides. 270, $27 \mathrm{I}$. Papilio. 270.

Aslauga. I36.

marginalis. 136 .

vininga. 136 .

astarte, Catagramma. 42.

astrarche, Ly'cena. 99, I02.

Papilio. 99.

Polyommatus. 99.

astynome, Leptalis. I 82.

Atrophaneura. 302.

semperi. 302.

atropos, Manduca. 304.

atymnus, Loxura. 77.

atys, Agriades. I03.

aurata, Lycrena. I 20.

aurora, Eriocolias. 2 II.

Aurotis. 65 .

auxo, Callosune. 205.

avellaneda, Catopsilia. $22 \%$

Axiocerses. 63, 78 . perion. 64.

Azure Blue. I03, IO4.

bachmanii, Hypatus. 4.

Libythea. 4.

netica, Lampides. 84 .

Lycæena. 83.

bxticus, Lampides. 82,85 .

Papilio. 82.

Polyommatus. 83,90 .

ballus, Thestor. $12 \mathrm{~S}$.

Tomares. I 28.

Baltia. I 59,158 .

butleri. I 56 .

shawii. I 56 .
Barbicornis. 34. basalis. 34 .

Baronia. 307. brevicornis. 307.

basalis, Barbicornis. 3 .

Bath White. I 52.

Bedford Blue. I05.

belemida, Papilio. I52.

Belenois. I6I. calypso. I6r.

belenus, Heliophorus. 69 . belisama, Delias. I66, I6S. Papilio. I66.

Pieris. 166.

bellargus, Lycæna. 94.

I'apilio. 93.

Polyommatus. 93 .

belliclice, Papilio. 152.

Pieris. I 52.

Pontia. I 53.

bengalensis, Lycrnesthes. II 4 .

betulie, Papilio. 66.

Polyommatus. 66.

Thecla. 48,66 .

Zephyrus. 66.

Bhutanitis. 247, 248.

lidderdalii. 247,248 .

bibulus, Lachnocnema. I 33 .

Biduanda. 74 .

lifasciata, Mesosemia. 24.

Black Hair-streak. 53

Black-veined White. I40, 142.

Ilue, Alcon. I Io.

Azure. I03, I04.

Bedford. I05.

Challi-hill. 9I.

Common. 96, 97 .

Large. IOS, IOO.

Large Tailed. 82.

Mazarine. I06, I07, IOS.

Silver-studded. 88.

Small Tailed. 85 .

bobera, Nepheronia. 205.

bohemani, Ptychopteryx. I93.

boisduvaliana, Sphænogona. $23 \mathrm{I}$.

Bombyces. I7, 32, I63.

bogota, Zeonia. 27.

bogotana, Sphænogona, 230, 23 I.

brassịcæe, Papilio. I 44. 
brassica, Pieris. I43, I44, I45, I 46, I 47.

Pontia. I 44 .

Brassolis. I 36 .

brassolis, Liphyra. 136.

brephos, Leucidia. I 77.

brevicornis, Baronia. 397.

Brimstone Butterfly. 22I, 222.

brookeana, Ornithoptera. 259,260, $26 \mathrm{I}$.

Trogonoptera. 259, 260, 261 .

Brown Argus. 90, I00.

Hair-streak. 65.

bryonix, Papilio. I 49.

Pieris. 149, 150.

buquetii, Nepheronia. 205.

butleri, Baltia. 156 .

Synchloe. 156.

Byasa. 304.

philoxenus. 304.

Cablbage Butterflies. I43.

Cadugoides. $2 S \mathrm{So}$.

agestor. 2 So.

creneus, Delias. I6S.

cresarea, Euterpe. I6 4 .

Calaides. 283.

androgeus. 283 .

callidice, Pontia. 151 .

Callidryas. 205, 226, $22 \mathrm{~S}$. eubule. $207,228$.

Callidryinæe, I39, 207.

callinice, Pereute. 165.

Callophrys. 54.

dumetorum. 55 .

rubi. 54, 69.

Callosune. I92, 194, 196, 200, 204, 205.

achine. I95.

annæ. 196, 200.

allxo. 205.

cinerascens. 195.

calphurnia, Euerycina. 33 .

calypso, Belenois. I6I.

Camberwell Beauty. 235.

candida, Leptoria. I79.

Terias. 233.

candidus, Papilio. 178.

cardamines, Anthocharis. IS6. cardamines, Euchloc. I50, IS6, I87, I88, I89, I90, 195 .

Papilio. 186.

Pieris, I86.

Pontia. 186.

caricæ, Erycina. 41.

Limnas subtilis. 40.

Nymphidium. 40, $4 \mathrm{I}$.

Papilio. 40.

carinenta, Papilio. 3.

Libythea. 5 .

carolina, Eurybia. 25.

Cartea. 32.

Castalaria. $47,48$.

Castalius. 48 , I 12.1

rosimon. II 2 II 3 .

castor, Tamera. 294.

Catagramma astarte. 42. sinamara. 42.

Catagrammina. 42. hewitsoni, 43. tapaja. 42.

Catasticta. I64.

Catochrysops. 48.

Catophaga. 142, 143, $22 \mathrm{~S}$.

Catopsilial. I39, 207, 225, 227. 229.

avellaneda. 227.

crocale. 226.

scylla. 226.

solstitia. 227.

cebrene, Abris. 197.

Anthocharis. 197.

celadon, Iphiclides. $274,275$.

Papilio. 275.

celtis, Libythea. $2,4,6$.

Papilio. 2, 4.

cenea, Papilio. 292.

ceneus, Papilio. I68.

ceronus, Lycæena. 9.4.

Papilio. 94, 95.

Polyommatus. 95 .

cesonia, Meganostoma. 220.

Cethosia. 242.

Chalk-hill Blue. 9r.

Chamælimnas, 33.

Charidae. 139.

Charis.

$37,195,294,297$, 
chariclea, Pieris. I 43 , I 45 . Pontia. I45.

charitonius, Parnassius. 239. charops, Pereute. I65.

Charus helenus. 294. cheiranthi, Pieris. I44. Cheritra. 74.

Chilasa, 279. dissimilis. 280 . panope. 279.

chilensis, Eroessa. 192.

chione, Nepheronia, 205, 205. chitra, Sithon, 75. Thecla. 75 .

chorineus, Papilio, 28. Zeonia. 28. chryseis, Chrysophanus. 123. Lycæna. I 23.

Papilio. I 23.

Polyommatus. I 23.

chrysonome, Idmais. I99.

Chrysophanidi. I29.

Chrysophanus. I I 5 .

chryseis. I 23.

dispar. II 7 .

phlæas. I 25 .

virgaurere. I I6.

Chrysorychii. 63.

chrysotheme, Colias. 212.

Eurymus. 210, 212.

Cigaritis. $77,79$. zohra. 79.

:inerascens, Callosune, I0J. cinnus, Papilio. 94, 95.

Polyommatus. 95.

cipris, Parura. 229, 230.

circe, Lycrena. I 27.

Citrinophila. I 35 .

cleobis, Papilio. 103.

cleobule, Colias. $22 \mathrm{I}$.

cleodura, Eronia. 203, 204.

cleopatra, Colias. 221, 223.

Clifden Blue Butterny. 93, 95.

clorinda, Amynthia. 223.

Clouded Yellows. 207, 209, 210 ,

2II, 2I 2, 2I 4, 2I 5, 2I 7,2 IS

clyton, Papilio. I I 2. codrus, Idaides. 278 .

Colins. 208, 210, 220, 223, 225.
Colias chrysotheme. 2 I 2.

cleopatra. 221, 223.

croceus. 2 II, 2 I 4 .

dorippe. 217.

edusa. 2 I I 2 I 2.

europome. $2 \mathrm{I} 7,2 \mathrm{IS}$.

helice. 2 I2.

hyale. 2II, 2I5.

kirbyi. $210,216$.

myrmidone. $2 \mathrm{I} 2$.

palino. 2 IO.

philodice. $2 \mathrm{I} 7$.

rhamni. 220, 22 I, 223 .

sareptensis. $2 \mathrm{I} 6$.

Colotis. 192, 198. amata, I98.

Common Blue. 96, 97.

Compsoteria. 26.

Copper, Dark-underwing. I 2 I, I 22

Large. I I 7, I 20, I 22, 124.

Purple-edged, I22, I23, I24.

Scarce. I I 5, I I 6.

Small. I25, I 26.

coretas, Papilio. 86.

corethrus, Euryades. 241.

coridon, Papilio. II 3 .

corydon, Lyciena. 9I.

Papilio. 91.

Polyommatus. $\quad 82,91,92,91$.

95, 100.

Cosmodesmus. 272, 274 .

protesilaus. 273.

cratregi, Aporia. I4O, I4I.

Papilio. I40.

Pieris. I 40.

Polyommatus. I 29 .

cresphontes, Heraclicles. 232.

cressida, Eurycus. 240.

crino, Harimala. 297.

crispus, Papilio. 39.

crocale, Catopsilia. 226.

croceus, Colias. 211, 214.

Eurymus. 214.

Papilio. 2 I I.

crœesus, Papilio. 35.

Troides. 255, 256 .

Cupido. 8I, 85 .

alsus. 85 :

argiades. 85, IO6. 
Cupido puer. 85, 105.

cupido, Helicopis. 20, 21 . Papilio. $2 \mathrm{I}$.

Curetaria. 47, 48 .

Curetis. 48 , I 3 I. thetys. I 3 I.

curius, Erycina. $30 S$. Lamproptera. 309.

Leptocircus. 307, 309 .

cyanea, Papilio. I I 3 .

Iepliphorus. II3.

Cyaniris. 82, $\mathrm{IO}_{3}$. argiolus. IO3.

Cyllopoda. 33 .

cyllarus, Nomiades. 103

Dabasa. 278. gyas. 278 .

Dalchina. 277,278 . sarpedon. 277. danae, Anthocharis, 196. Callosune. 196.

Pieris. I 96.

Danainæ. 207, 279, 2So, 2S4, $29 \mathrm{I}$. danis, Papilio. II $3,196$.

Thysonotis. II3.

daplidice, Pontia. I43, 152, 153 , I9I, 2I4, 2I9.

Daptonura. I75.

Dark-underwing Copper. I2I, I 22.

dasarada, Penasmia. 303, 30.7.

Davidina. I $56,157$. armandi. I 57, I 5 S.

decorata, Dicallancura. I 4 .

delia, Eurema. 232.

Delias. I65, I68, I69, I 7 I.

aganippe. I70.

aruna. 169.

belisama. I66, I6S.

cæneus. I6S.

dorimene. 170.

eucharis. I67.

egialea. I69.

nigrina. I 70.

philyra, I68.

delius, Parnassius. 238, 239.

Deloneura immaculata. I 35 . demoleus, Orpheides. 2 So. demolion, Araminta. 292.

Jercas. 224.

verhuellj. 225 .

Deudorix. 48, 7 I, 73 .

cpijarbas. 71,72 .

isocrates. 72.

Dicallaneura. I 3 .

decorata. I 4 . pulchra. I 3 .

diniensis, Leptidia. ISo. Leucophasia. I79, I80.

Dioptidx. 45.

Dioptis. 26.

Diorhina. 29, 30. laonome. 29. periander. 29.

Dipsas. 65. epijarbas. $7 \mathrm{I}$.

Dismorphia. I77, I80, I31, ISz. amphione. ISI, IS2. egaena. I 83 .

lais, I82.

Dismorphidæ. I 39 .

dispar, Chrysophanus. II7.

Lycæna. II7, I 20, I 2 I, I 22 , I24.

Papilio. II7.

Polyommatus. II 7 .

Porthetria. I2I.

dissimilis, Chilasa. 2 So.

Dodona. I3.

dolicaon, Eurytides. 272 .

dolus, Polyommatus, 93.

donna, Eurybia. 26.

dorilis, Lycæena. I 27.

dorimene, Delias. I70.

dorippe, Colias. 2 I 7 .

Doritis. 239. apollina. 239.

dorylas, Polyommatus. 94, 95 .

Drurya. 250. antimachus. 240, 241, 250, 279.

Dryadre. I39.

Dryas. 203. leda. 203, 204.

dumetorum, Callophrys. 55 .

Durbania. I 34 .

Durham Argus. Ioo, 
Dusky-reined White Butterly. epijarbas, Deudorix. 71, 72. I 50 .

Early White Cabbage Butterfly. 145 .

cborea, Papilio. 196.

ectriva, Sphrenogona. 230.

edusa, Colias. $211,212$.

Eurymus, 214 .

Papilio. 152, 2 I 1.

clima, Eurygona. I7.

Euselasia. I7.

egaena, Dismorphia. $1 S_{j}$.

Leptalis. 183.

egaensis, Dismorphia. IS3.

Mechanitis. $\mathbf{I}_{3}$.

egialen, Delias. 169.

Papilio. 169.

Pieris. I69.

egnatia, Elodina. 176.

ehrenbergii, Morpheis. I9.

eieiclias, Perrhybris. 159.

electra, Eurymus. 213, 214. Papilio, 2 II.

elephenor, Pangeranopsis. 302.

eleus, Hesperia. I25. Polyommatus. I 26.

Elodina. 175. egnatia. 176.

elvina, Leucidia. 177.

emalthion, Thades. 301.

emesioides, Zemerus. ${ }_{13}$.

Emesis. 36, 37 .

emylius, Erycina. 39.

Lemonias. 39.

Papilio. 39.

Enantia. I82, I84.

licinia. I $S_{4}$.

melite. IS2, ISt.

Endopogon, 270, 27 I. sesostris. 270.

endymion, Helicojis. 20. Papilio. 20, 57, 90. Polyommatus. 57.

epicharis, Pieris. $\quad 167$.

epicles, IIeliophorus. 69.

Ilerda. 69, $7 \mathrm{I}$.

I'olyommatus. 69.

Thecla. 69.

Dipsas. 7 r.

Epinephele janiı. 66.

Epitola. I 34.

epalus, Lemonias maculata. $3 S$.

Lques. 267, 2SS, 290.

lyreus. 290.

nireus. 290.

Eruites. 235, 25I, 268.

Equitid.e. 17, 27, 154, 158, 163,

$23 t, 235,240,241,242,24 S$,

279, 2SO, 2S2, 2S5, 296,

297.

Equitinx. 265.

crate, Eurymus. 217.

Eriocolias. 209, 210.

hyale. 210.

eris, l'ontia Ig8.

erithonius, Orpheides. $2 S 0,2 S 2$.

Eroessa chilensis. 192.

Eronia. 202, 203, 205.

cleodora. 203, 204.

leda. 203.

eros, Polyommatus. 97, 98 .

Erycina. S, 27, 30.

agyrtus. 43 .

carice. $4 \mathrm{I}$.

curius. 308 .

emylius. 39.

gelon. 17.

iphinoe. 29.

melibous. $3 \mathrm{I}$.

octavius. $2 S$.

philocles. 24.

tarquinius. $\quad 128$.

Erycinide. 8, 14, I5.

erylus, Amblypodia. 62 .

Hypolyciena. 62, 63.

Myrina. 62.

crysimi, Leptidia. ISo.

Leucophasia. ISS.

Papilio. 179.

ethelinda, Nymphidium. 4I.

cubule, Calliclryas. $227,223$.

Papilio. 227.

eucharis, Delias. 167.

Papilio. 167.

Eucheira. I62.

socialis. $\mathbf{I} 62$. 
Euchloe. I77, IS5, 190, 191, 194, 195, 201, 205 . cardamincs. I50, IS6, IS7, ISS, I $89,190,195$. hesperidis. I89. I90. turritis. ISS, IS9.

Fudymion regalis. 57 .

Euerycina. 34. calphurnia. 33.

Eumæus. 46, 48, I60, minyas. 60.

Eumenia. 46,60. toxea. 60.

Euphœades, $2 S_{4}$. glaucus. $28_{3}, 2 S_{4}$.

Euplœa. 280.

Euplocopsis. 2So, 2So. glaucus. $2 S_{4}, 285$. telearchus. 280.

Euptychia. 16, 18, 23.

Eurcma. 207, 232, 23 \% delia. 232.

euridice, Papilio. I23. Polyommatus. I23.

eurisus, Iolaus. 73 . Papilio. 73.

europome, Colias. 217, 218. Eurymus. 218, 219.

Euryades. $24 \mathrm{I}$. corcthrus. $24 \mathrm{I}$.

Eurylia. 22, 25.

carolina. 25.

donna. 26.

nicreus. 26.

salome. 26.

eurybia, Papilio. 123, 125.

Polyommatus. 123.

Eurycus. 240, $24 \mathrm{I}$. cressida. 240.

eurydice, Meganostoma. 220.

Lurygona. i 6. effima. 17.

Eurygonine. 8.

Eurymus. I3S, 19S, 208, 210,2 IS, 220,233 .

aurora, 2 II

chrysothcme. $210,212$.

croceus. $2 \mathrm{~J} 4$

edusa. $2 \mathrm{I} 4$.
Eurymus elcctra. 2I3, 2 I4. erate. 217.

europome. 218, 219.

helice. $212,213$.

hyale. 2IO, 2II, 2I4, 2I 6,217 , $218,219$.

kirbyi. 2II, 2I5, 2IS, 2 I9.

myrmidone. $2 \mathrm{I} 2$.

palæno. 2I4, 2I5, 217.

phicomone. 2 Io.

philodice. 217.

sarcptensis. 217 .

euryonc, Euselasia. 18.

eurypylus, Zetides. 277.

Eurytides. 272.

dolicaon. 272.

Euselasia. I6, 23, 265 .

effima. 17.

curyone. Is.

gelon. 17.

opalescens. I7.

phædica. 18.

præclara. 17.

Euselasiinæ. 8, I5, 1 9.

Euterpe. $\quad 163$.

cæsarea. I64.

leucodrosime. 164.

Euvanessa. 268 notc.

evagoras, Ialmenus. 70.

Myrina. 70.

Papilio. 70.

evan, Meandrusa. 279.

Evenus. 57. regalis. 57.

Everes. 85.

eversmanni, Parnassius. 239.

faunus, Papilio. 27. Zeonia. 27, 28.

fausta, Idmais. I99.

feisthamelii, Iphiclicles. 276. Papilio. 275.

Feniseca. I2S.

tarquinius. I2S, 129.

ficedula, Myrina. 76.

flegyas, Zemeros. I3.

flippantha, Melete. 175 .

formosus, Anteros. 35 .

Papilio. 35 . 
gambrisius, Nestoricles. 205.

Ganoris. I42, 143 .

gelon, Erycina. I7.

Euselasia. I7.

Papilio. 17.

genutia, Anthocharis. 190.

gerontes, Abisara. 15.

Gerydus. 4S, I 32 .

symethus. I 32 .

Gipsy Moth. I 2 I.

glalicippe, Hebomoia. 201, 202.

glaucus, Euphœades. $2 S_{4}, 2 S_{5}$.

glycerion, Pazala. 273.

Gnesia zetes. 250.

gnidus, Papilio. 20.

Golden-Spot Butterfly. $\approx 0$.

Gonepteryx. $22 \mathrm{I}$. rhamni. $22 \mathrm{I}$.

Green IIair-streak. 54.

Green-veined White Lutterny. I4S, I 49.

gyas, Dabasa. 278.

Hades noctula. I 8 , I9.

IIair-streaks. 48,49 .

Black. 53 .

Brown. 65.

Green. 54 .

Pale Brown. 49.

Purple. 67, 68.

White-letter. 50, $5 \mathrm{r}$.

Hamearis lucina. II.

hardwickii, Parnassius. 239.

IIarimala. 296, 297, 29 . crino. 297.

Ilebomoia. 200. glaucippe. 201, 202. leucippe. 202.

hecabe, Terias. 233.

hector, Thais. 305. Tros. 305.

Hectorides. 270. ascanius. $270,27 \mathrm{I}$.

helena, Ornithoptera. $2 \sigma_{4}, 2 \sigma_{5}$.

helenus, Charus. 294.

helice, Colias. 2 I 2.

Eurymus, 2I2, 2I3.

Papilio. 2I2:

heliconides, Zeonia. $2 S$.
IHeliconius. I 59 .

Helicopis. I4, I9, 35 .

acis. $20,2 \mathrm{I}$.

cupido. 20, $2 \mathrm{I}$.

endymion. 20.

Heliophorus. 6S, 70.

belenus. 69.

epicles. 69.

helios, Hypermnestra. 26,O.

helius, Iolaus. 73.

Papilio. 73.

Polyommatus. 73 .

hera, Isapis. 44.

Heraclides. 282, $\mathbf{S} 3$.

cresphontes. 282.

thoas. 282.

hersilia, Phoebis. 229.

hesebolus, Parnassius. $23 \mathrm{~S}$.

IIesperia artaxerxes. I02.

eleus. 125 .

pindarus. So.

tarquinius. I 28

hesperidis, Euchloe. I $\$ 9$, I 90.

Hesperiidix. $33,82,136,309$.

Hestia idea, 279.

hewitsoni, Catagrammina. 43.

Ifewitsonia. I34.

Hipparchia hyperanthus. 67.

hippia, Nepheronia. 205.

hippocrates, Achivus. 286.

hippolytus, Ornithoptera 266. Pompeoptera. 266.

hippothoe, Lyciena. I 2 I-I 25. Papilio. II7, I2I, I22, 266. Polyommatus. I1 7, I21, 123 , I 24.

homerus, Papilio. 282.

honnoralii, Thais. $243,244,245$.

hospiton, Achivus. 286.

Iloward's White Bulterfly. I4S.

Iluphina. I 74 .

hyacinthus, Papilio. 94.

hyale, Colias, 2II, 215.

Eriocolias. 210.

Eurymus. 210, 21I, 213, 2I 4 , 2 I6.

Papilio. 2II, 215.

hylax, Pithecops. II 4 .

hyparete, Mancipium. IC 7 . 
hyparete, Papilio. I67, I68.

Hypatus. 3, 5 . bachmanii. 4 .

hyperanthus, Ilipparehia. 67.

Hypermnestra. 240.

helios. 240.

IIypochrysops. SI.

Hypolycena. $48,6 \mathrm{r}$. erylus. 62,63 .

lara. 6r.

Ialmenus. 70. evagoras. 70.

icarinus, l'apiiio. 96.

icarus, Lycrena. 96, 97.

Papilio. 96, 98.

Polyommatus, $87,94,96,97$, 98, 107, 126.

idreoides, Papilio. 279.

Idaicles. 278. codrus. 278.

idea, Hestia. 279.

Idmais. I93, I9S, I99.

chrysonome. I 99.

fausta. I99.

idotze, Nepheronia. 203, 205, 206.

Ilerda. 68.

epicles. 69.

Iliades. 299, 301 .

agenor. 299, 300, 301.

memnon. 300, 301 .

ilicis, Thecla. 54, 68.

ilioneus, P'terurus. 289.

immaculata, Deloneura. I 35 .

imperialis, Arcas. 58 .

I'apilio. 58.

Teinopalpus. 248.

Thecla. 58.

iober, Nepheronia. 203.

Iolaus. 73 .

eurisus. 73 .

helius. 73 .

silas. 73 .

iole, Nathalis. 20 S.

Iphias leucippe. 202.

Iphiclides. 274.

celadon. 274,275 .

feisthamelii. 276.

podalirius, 273,275 .
Iphiclides protesilaus. 273 .

iphigenia, Papilio. 159.

Pieris. I 59.

iphinoe, Ancyluris. 29.

Erycina. 29.

iris, Apatura. 249.

Isamiopsis. 2 So.

Isapis. 22,43 . agyrtus. 43 .

hera. 44.

isocrates, Deudorix. 72.

Ithobalus. 272. polydamas. 272.

Ithoneis. 33 .

Ithomia. 26.

Ithomiinx. $33,44,13 S, 177, \mathrm{IS}$.

Ithomiopsis. 33 .

Ixias. 199 .

pyrene. 200.

janira, Epinephele. 66.

Jasoniades. 285 .

xuthus. 285 .

kirbyi, Colias. 2 Iо, 216.

Eurymus. 215, 217, 2IS, 210.

Kricogonia. 224.

lysicle. 224 .

labienus, Polyommatus. 97.

Lachnocnema bibulus. 133.

lacon, Polyommatus. 97.

Leosopis roboris. 69.

Laertias. 293, 295. ulysses. 296.

laglaizii, Papilio. 305.

lais, Dismorphia. IS2.

lama, Aporia. I 55.

Lampides. 4 S, S2, $S_{5}$. xlianus. 85 .

breticus. $82,84,85$.

Lamproptera curius. 309.

laonome, Diorhina. 29.

lara, Hypolycena. $6 \mathrm{I}$.

Large Blue. IoS, I09.

Large Copper. I I7, I2O, I22, I24.

Large Tailed Blue. S2.

Large White. I4t.

Larinopoda. 135 . 
lathyri, Leptidia. ISO. Leucophasia. ISO. Papilio. 179.

leda, Dryas. 203, 20.4. Eronia. 2n3.

Lemonias. $38,39,40$. alphra. 38. emylius. 39. epulus. 38 . luciana. 38 .

Lemoniidre. $6,8,12,14,23,33$, $34,44,128, I 85,265$.

Lemoniinæe. $2 \mathrm{I}$. leonidas, Papilio. 279.

Leptalis. I80, I 82 . astynome. I $\delta 2$. egaena. I 83 .

Leptidia. I77, I7S. diniensis. $\mathrm{I} 80$. erysimi. I8o. lathyri. I 80. sinapis. I78, 219.

Leptocircus. $27,234,307,30$. meges. 308, 309 . virescens. 309.

Leptoria. I78. candida. I79.

Leptosia. I76, I78, 205. xiphia. 177.

Leucidia. 177. brephos. 177. elvina. 177 .

'eucippe, Hebomoia. 202. Iphias. 202.

I'apilio. 202.

Pieris. 202.

leucodrosime, Euterpe. I6: Pereute, I64, I65.

Leuconea. I40.

Leucophasia. I78. diniensis. I79, I80. erysimi. I 80 . lathyri. I80. sinapis. 179 .

Lethe. I4.

Libythea. 2, 3, 6, 73 . bachmanii. 4 . carinenta. 5 . celtis. $2,4,5,6$.
Libythea motya. 5 .

Libytheidle. I.

licinia, Enantia. IS4.

lidderdalii, Bhutanitis. 247,248 .

Limnas. 291. caricie. 40.

Liphyra. I33, r 36. brassolis. I 36 .

Liptena. 134.

Lipteninæe. $46,47,48,133$.

Lithosiidx. 32.

Loxura. $48,74,77$. atymnus. 77 .

lucanus, Lucia. I33.

Lucia. I33. lucanus. $\quad$ I33.

luciana, Lemonias. ${ }_{3} \mathrm{~S}$. lucina, IIamearis. II.

Nemeobius. I I. Papilio. Ir .

Luehdorfia. 246. lyæus, Eques. 290.

Lycieides. 87.

Lycæena. 46, 78, 81, 82, 90, II5, I $28,159,284$.

acis. 107.

adonis. 94.

xgon. 88.

restiva. 99.

albicans. 91, 92.

alcon. I ro.

alexis. 96.

alsus. I05.

argiades. $86,87,104$.

argus. 88.

arion. IO9.

artaxerxes. IO2.

astrarche. 99, I02.

aurata. I 20.

bretica. 83 .

bellargus. 94 .

ceronus. 94 .

chryseis. I 23.

circe. 127.

corydon. 9I.

dispar. II 7, I 20, I 21,122, I 24

hippothoe. I21, I23, I24, I25.

icarinus. 97.

icarus. 96,97 . 
Lycrena medon. 99.

minima. I05.

orion. II 2 .

phlacas. $78,79,90$, I I 5 , I2 5 .

rutila. I I9, I 20, I2 I, I 22.

semiargus. 107.

schmidtii. I27.

timeus. I 27.

virgaurex. I I 5, I I 6.

Lycrenesthes. 4S, I I 4 .

bengalensis. II A.

Lycæenidæ. 45, I $2 S$.

lydius, Troides. 256.

Lymnas. 35.

lynceus, Papilio. 50.

Lyropteryx, 32.

lyside, Kricogonia. 224.

macareus, Paranticopsis. 279.

machaon, Achivus. $246,276,286$.

Papilio. 286.

mærula, Amynthia. 223.

magellanus, Ornithoptera. I7, 265.

Mancipium. I42, I43, I 5 I.

vorax hyparete, 167.

Manduca atropos. 304.

marcins, Papilio. $27 \mathrm{I}$.

marginalis, Aslauga. I 36 .

marsyas, Papilio. 56.

Polyommatus. 56 .

Pseudolycxena. 56, 5S.

Thecla. 56.

maturna, Melitia. $3 \mathrm{~S}$.

Mazarine Blue. I06, I07, IoS.

Meandrusa. 278 .

evan. 278 .

Mechanitis egrensis. I $S_{3}$. medesicaste, Papilio. 243.

Thais. $243,244,245$.

medon, Lycxna. 99.

Iapilio. 99.

meeda, Mesosemia. 25.

Meganostoma. 219.

cesonia. 220.

eurydice. 220.

meges, Leptocircus. 30S, 309. Papilio. $30 S$.

Melete. I75.

flippantha. I 75 . melibœus, Ancyluris. 3I. Erycina. $3 \mathrm{I}$.

Papilio. $3 I$.

Melitra. IO, I 2, 79. maturna. $3 S$.

melite, Enantia. I $\delta_{2}, \mathrm{I} S_{4}$. Papilio. IS2.

memnon, Iliades. 300, 301 . Papilio. 299, j00, 301.

Menamopsis, 280. tavoyanus. 280.

Menelaides. 304 . polydorus. 304.

menippe, Rhodocera. 224.

meriones, Papilio. 291.

merope, Papilio. 29I, 299.

Mesapia. I 54, I 56, I 58. peloria. $\quad$ I 55 .

shawii. I $55,156$.

Mesene. 37.

Mesosemia. IS, 22, 23. bifasciata, 24 .

meeda. 25 .

philocles. 24.

Metaporia. I40, I 54, I5S. agrathon. I 58.

metaurus, Alcidis. 306.

Methonella. I9.

methymna, Moschoneura. IEI. metra, Pieris. I4 $3, I_{4} S$. Pontia. I4S.

Metura. 229.

mexicana, Alrois. 23I.

Sphrenogona. 230, 235, 233.

Terias. 230.

Micandra. 59. platyptera. 59.

Mider. I90.

milca, Vanessula. $13 j$.

Miletus. I 32 . polycletus. SI.

Mimacræa. I 34 .

ninima, Lycæna. I05.

Papilio. I05.

Polyommatus. I05.

Zizera. 86, 87, 94, 105.

minyas, Eumæus. 60.

mnemosyne, Parnassius. 238.

Morpheis ehrenbergii. I9. 
Norpho sulkowskyi. I7, 265.

Moschoneura. ISi. methymna. ISI.

motya, Liloythea. 5 .

Mylothris. I60. rhodope. I6I.

Myrina. 74,75 . alcides. 76 . erylus. 62. evagoras. 70. ficedula. 76 . silenus. 76 . thecloides. 62. myrmidone, Colias. 2 I2. Eurynus. 2I 2.

naprex, Papilio. 149. Pieris. I 49.

Pontia. I 4.9.

napi, Papilio. I48, I49.

Pieris. I48, I 5 I.

Pontia. I49.

nathalia, Saletara. I 7 \%

Nathalis. 207, 234. iole. 208.

Necyria. 3 I. tapaja. $42,43$.

nedymond, Papilio. 74. Thecla. 75 .

nedymonda, Sithon. 74, 75.

nehemia, Picris. I82.

Pseudopieris, I82, I 84 .

Nemeoliinæ. 8, 9, I2, 15, 22.

Nemeobius. I0, I2, 44. lucina. I I .

nemesis, Acmetopteron. IS2, IS3. Pieris. IS2.

Neopithecops. 48, II4. nepalensis, Pieris. I 44 .

Nepheronia. 203, 205, 206.

argia. 205, 206.

boebera. 205.

buquetii. 205 .

chione. $205,206$.

hippia. 205.

idotæa. 203, 205, 206.

iobrea. 205.

pharis. $205,206$.

thalassina. 205. neriene, Zeritis. 79.

nero, Tachyris. I73, I74.

Nestorides. 295.

xgeus. 295.

gambrisius. 295.

Nettle-tree Butterfly. 4. niaivius, Amauris. 29 I. niceus, Eurybia. 26.

Papilio. 26.

nicippe, Xanthidia. $23 \mathrm{I}$.

nigrina, Delias. I 70.

nireus, Eques. 290.

noctula, Hades. IS, I9.

Nomiades. Io6.

alcon. IIO, I II.

arcas. I09.

arion. I06, Io8, i Io.

cyllarus. ios.

semiargus. I03, I06, I0\$, I09.

novangliee, Pieris. I 47.

nox, Papilio. 303.

Nychitona. I76.

Nyctalemoniidæe, 306.

Nymphalidæ. I, 7, 9, I2, 235 , 242.

Nymphalinze. I9, 33, 40.

Nymphalis. 267.

nymphidia, Stiboges. I2.

Nymphidium, 37, 40.

Nymphidium carice. 4O, 4I. ethelinda. 4 I.

octavius, Erycina. $2 S$.

Papilio. 27, 28 .

Zeonia. 28.

Ogyris. 48, I 30.

abrota. I 3 I.

opalescens, Euselasia. I7.

Orange-Tip Butterfly. I 85, I86, IS 7, 192, 200, 20I, 205.

orbitulus, Agriades. I03.

orcas, Aphnieus. So.

Papilio. 80.

I'olyommatus. 80.

Orestias. 32.

orion, Lyciena. I I 2.

Papilio. III.

Polyommatus. I I I.

Scolitantides. I I I 
Ornithoptera. 251, 265, 267, 269, Papilio alcon. I 10. 287.

amphrysus. 265 .

brookeana. 259, 260, $26 \mathrm{I}$.

helena. 264, 265 .

hippolytus, 266.

magellanus. I 7,265 .

pompeus. 264,265 .

priamus. 252.

remus. 266.

rhadamanthus. 265 .

ruficollis. 265.

Orpheides. 2 So.

demoleus. $2 \mathrm{So}$.

erithonius $2 \mathrm{SO}, 2 \hat{3}$.

Pachlioptera. 265.

Pienasmia, 303.

dasarada. 303, 30..

palæno, Colias. 2 ro.

Furymus. 214, 215, 217.

Papilio. 215, 217, 21S.

Pale Brown Hair-streak. 49.

Pale Clouded Yellow. 215, 216.

pamela, Pieris. 159.

pammon, Papilio. 293.

Pandemus pasiphaë. 37.

Pangerana. 302.

varuna. 302 .

Pangeranopsis. 302.

elephenor. 302.

panope, Chilasa. 279.

Panosmiopsis. 301 .

rhetenor. 301.

panthous, Papilio. 252, 266.

Papilio. 235, 250, 267, 268, 269 , $2 S 6$.

achieus. 36 .

acis. 20, 104, 107.

adonis. 94.

rgon. SS.

rneas. 271.

aneides. 271.

agamemnon. $2>S$.

agenor. 299.

agestis. 99.

agyrtus. 43.

alcides. 76 .

alexis. 96, 99.

allous. 99.

alsus. 105 .

amphione. ISI.

amyntas. 86.

androgeos. 299.

antimachus. $25^{\circ}$.

antiopa. 235, 26.

apollo. 236 .

arcas. IIO.

arethusa. 197.

argiades. 85 .

argiolus. I03, IOG.

argus. 88.

arion. Io8.

ascanius. 270.

astrarche. 99.

bæticus. 82.

bathis. III.

belemida. I 52 .

belisama. I 66 .

bellargus. 93.

bellidice. I 52 .

bet ulx. 65 .

brassice. I44.

bryonix. I 49.

candidus. I78.

cardamines. ISG.

carice. 40.

carinenta. 3 .

celadon. 275 .

celtis. 2,4 .

cenea. 292.

ceneus, I 68 .

ceronus. 94, 95 .

chorineus. $2 S$.

chryseis. I23.

cinnus. 94,95 .

cleobis. I03.

clyton. I I 2.

coretas. 86.

coridon. II3.

corydon. 91.

cratægi. 140.

crispus. 39.

croceus. $21 \mathrm{I}$.

croesus. 35 .

cupido. $2 \mathrm{I}$. 
Papilis cyanea. II 3 . danae. 196.

danais. II 3 .

daplidice. I 52.

dispar. I I 7 .

eborea. J96.

edusa. I 52, 2 I I.

egialea. 169.

electra. 2 I I .

emylius. 39.

endymion. 20, 57, 90

erysimi. $\quad \mathrm{I} 79$.

eubule. 227.

eucharis. I67.

euridice. 123.

eurisus. 73 .

eurybia. I23, I25.

evagoras. 70.

faunus. 27.

feisthamelii. 275 .

formosus. 35 .

gelon. I7.

gnidus. 20.

helice. 2 I2.

helius. 73 .

hippothoe. II 7, I2I, I22.

homerus. 282.

hyacinthus. 94 .

hyale. 2II, 2 I 5.

hyparete. I67, ICS.

icarus. 96,98 .

idreoides. 279.

imperialis. $5 \mathrm{~s}$.

iphigenia. I59.

laglaizii. 306.

lathyri. I 79 .

leoniclas. 279.

ieucippe. 202.

lucina. I I.

lynceus. 50.

marcius, $27 \mathrm{I}$.

marsyas. $5^{6}$.

medesicaste. 243 .

medon. 99.

meges. 308.

melibocus. 3 I.

inclite. I82.

memnon. 299, 300, 301.

meriones. $29 \mathrm{I}$.
Papilio merope. 291, 299.

minima. 105.

napre. I 49.

napi. I48, I 49.

nedymond. 74 .

nicreus. 26.

nox. 303 .

octavius. 27,28 .

orcas. So.

orion. I I .

paleno. 2I 5, 2I 7, 2IS.

pamela. I 59 .

pammon. 293.

panthous. 252, 260 .

paris. 297.

periander. 29.

perion. 64.

philocles. 24.

phlicas. I25.

pindarus. 80.

plexaris. I68.

podalirus. 275 .

polyphemus. 96.

polysperchon. 85 .

polytes. $293,294,304$.

priamus. 252.

protesilaus. 273 .

protumnus. 127 .

pruni. 50, 53 .

pylades: 279 .

pyretus. 3I.

pyrrha. I 59.

quercus. $49,67$.

rape. 146.

regalis. 57.

remus. 266.

rhamni. $22 \mathrm{I}$.

ridleyanus. 240,279 .

romulus. 295 .

rosimon. I I 2 .

rubi. 54 .

rumina. 243.

rutilus. I2I.

salome. 26.

scmiargus. Io5.

silenus. 76 .

sinapis. I 75 .

sinon. 274.

spini. $48,49$. 
Papilio symethus. 132.

tarquinius. I 28.

telephii. I I I.

thetis. 93,96 .

timeus. I25.

tiphys. 9I.

tiresias. 85 .

trogon. 260.

troilus. 289.

turnus. 285 .

valens. 36 .

venus. 58 .

virgaurea. I I 5 .

w-album. 50.

zagreus. 284 .

zalmoxis. 267.

zelmira. I73.

paradisea, Schœnbergia. 253.

Paranticopsis. 279.

macareus. 279.

Parides. 27 I, 284.

paris, Achillides. 297, 298.

Papilio. 297.

Parnassiinze. $234,236$.

Parnassius. I 54, I 58, 236, 239, 240.

apollo. I4I, 236, 237, 238, 239.

apollonius. 239.

charltonius. 239.

delius. 238, 239 .

eversmanni. 239.

hardwickii. 239.

hesebolus. $23 \mathrm{~S}$.

mnemosyne. 23 S.

stubbendorfi. 239.

wosnesenskii. 232.

Parura. 229.

cipris. 229, 230.

pasiphaë, Pandemus. 37 .

Pathysa. 274.

antiphates. 274.

paulina, Appias. I 43 .

Pazala. 273.

glycerion. 273.

peloria, Mesapia. I 55 .

Pieris, I 55.

Pentila. I 35 .

Pepliphorus. II3.
Pepliphorus cyanea. I 3 .

Pereute. I39, I64, I65, I66. callinice. I 65.

charops. I65.

leucodrosime. I64, I65.

periander, Diorhina. 29.

Papilio. 29.

perion, Axiocerses. 64.

Papilio. 64.

Perophthalma tenera. IS.

Perrhybris. I 58 .

eieidias. I59.

pyrrha. I 59.

phædica, Euselasia. I 8 .

pharis, Nepheronia. 205, 206.

Pharmacophagus. 306. antenor. 306.

Phasis. $77,78$.

thero. 78 .

phicomone, Eurymus. 210.

philocles, Erycina. 24.

Mesosc nia. 24.

Papilio. 24.

philodice, Colias. 2 I 7 .

Eurymus. 217.

philoxenus, Byasa. 304.

philyra, Delias. I6S.

Pieris. I68.

phlæas, Chrysophanus. I25.

Lycrena. $78,79,90$, I I 5, I 25.

Papilio. I25.

Polyommatus. I25.

phlegia, Stalactis. 45 .

Phœbis. 228.

hersilia. 229.

Phyllocharis. I90.

tagis. I9I.

Phytala. I34.

Pieride. I 35, I 37, I3S, I 39, I 54,

I 57, I 62, I 77, I $85,200,224$, $234,235,307$.

Pierina, I 39

Pieris. I 39, I40, I42, I43, I 5 I, I $56,158,225$.

belisama. I66.

bellidice. I 52 .

brassicre. I $43, \mathrm{I} 4 \mathrm{f}, \mathrm{I} 45, \mathrm{I} 4 \mathrm{6}$, 147. 
Pieris bryonix. I49, 150. cardamines. I 86 . chariclea. 145. cheiranthi. I44. cratægi. I 40. danae. 196. daplidice. I52. egialea. 169. epicharis. 167. iphigenia. I59. leucippe. 202. metra. I43, I4S. naprer. I 49. napi. I4S, I49, I50, I 5 I. nehemia. IS2. nemesis. I I 2 . nepalensis. I44. novanglize. 147 . pamela. I 59. peloria. I 55 . philyra. 168. plexaris. 168. pyrrha. I 59. rapre. I43, I46, I4S, I49, I84.

sabellica. I43, I49, I50. shawii. 156 . sinapis. 178 . thestylis. I7 I. wollastoni. 144.

pierus, Aloeides. 79. pindarus, Hesperia. So. Papilio. So.

Pithecops. I I4. hylax. II 4 . platyptera, Micandra. 50. Pseudolycæna. 59.

Plebeius. $\quad 8 \mathrm{I}, 87$, II I, II 4 . argus. $47,87,88,89$. argyrognomon. $\delta S$. plexaris, Papilio. $\quad$ I68. Pieris. I68. podlalirius, Iphiclides. $273,274$. Papilio. 275.

Polyciena. 9, IO, I 2. polycletus, Miletus. 8 I. polyctor, Sarbaria. 298. polydamas, Ithobalus. 272. polydorus, Menelaides. 304.
Polyommatus. $46,47,82,90$, I I I , I 5 . achrus. 36. acis. 107. adonis. 92, 93, 94, 95 . rgon. 88. agestis. 99, I00, IO2. alcon. I09, IIO. alexis. 94, 96, 99, I00, IOI, IO2.

allous. IOO. amyntas. $\$ 6$. argiades. 86. argiolus. IO4. argus. $88,89$. arion. IOS, I IO. artaxerxes, 102, 103. astrarche. 99. betica. 82 . breticus. $8_{3}, 90$. bellargus. 93 . betulie. 66. ceronus. 95 . chryseis. I23. cinnus. 95 . corydon. $82,35,91,92,94,95$, IOO.

cratrgi. I29.

dispar. I I 7, I2I.

dolus. 93.

dorylas. 94,95 .

eleus. I26.

endymion. 57.

epicles. 69. eros. 97,98 . euridice. 123. eurybia. I 23. helius. 73 . hippothoe. II7, I2I, I23, I24. icarus. $87,94,96,97,98,107$, I 26.

labienus. 97 .

lacon. 97.

marsyas. 56.

minima. 105.

orcas. So.

orion. I I .

phlæas. I25.

porsenna. I 29. 
Polyommatus pruni. 5.3.

quercus. 67.

rosimon. II 3 .

rubi. 55 .

rutilus. I 2 I.

salmacis. I00, 102.

schmidtii. I 25 .

semiargus, 107.

spini. 49.

symethus. I 32 .

tarquinius. I 29.

telephii. I1 2 .

thestylis. 97 .

thetis. 93, 94, 95, 100.

tithonus. 98 .

turcicus. I 26.

valens. 36 .

venus. 58 .

virgaurea. II6.

w-album. 50.

polyphemus, Papilio. 96.

polysperchon, Papilio. $8_{5}, S_{7}$.

polytes, Papilio. 293, 294, 304.

polyxena, Thais. 243.

pompeius, Priamides. $2 S_{4}$

Pompeoptera hippolytus. 266.

pompeus, Ornithoptera. 264,265 . Pontia. I40, 142, 143, I 5 I, 156, I 76,240 .

bellidice. I 53 .

brassicre. $14 \%$.

callidice. I $5 \mathrm{I}$.

cardamines. I $\$ 0$.

chariclea. I 45.

daplidice. I 43, I 52, I 53, IgI, 214.

eris. $19 S$.

metra. 148.

naprex. I 49.

napi. 149.

rapx. 146 .

sabellicæ. I 50.

turritis. I $S S$.

Poritia. I 5, Is.

porsenna, Polyommatus. I 29.

Porthetria dispar. I2I.

preclara, Euselasia. 17.

Priamides. $16_{3}, 265,28_{7}$.

pompeius. 284 . priamus, Ornithoptera. $\quad=52$. Papilio. 252.

Troides. 252, 254.

Priamoptera. 255.

Princeps. 286.

Prioneris. I7 I.

Prioneris thestylis. I7I.

protenor, Saunia. 301, 302.

proterpia, Pyrisitia. 23 I.

protesilaus, Cosmodesmis.

Iphiclides. 273.

Papilio. 273.

protumnus, Papilio. 127.

Thestor. 127.

pruni, Papilio. 50, 53 .

Polyommatus, 53 .

Thecla. 50, 53, 54 .

Pseuderesia. I 34 .

Pseudolycæna. 56.

marsyas, 56, 58 .

platyptera. 56 .

Pseudopieris, I82, IS4. nehemia. I82, I84.

Pselidopontia. I 39.

Psychidæ. 229.

Pterurus. 289.

ilioneus. 289 .

troilus. 289 .

Ptychopteryx. 192.

bohemani. 193.

puer, Cupido. $85,105$.

pulchra, Dicallaneura. I3.

Purple-edged Copper. I22, I23.

l'urple Emperor. 287.

I'urple IIair-streak, 67, 63.

pylades, Papilio. 279.

pyrene, Ixias. 200.

pyretus, Papilio. 3 I.

Pyrisitia. 23I.

proterpia. $23 \mathrm{I}$.

pyrrha, Papilio. I 59.

Perrhybris. I 59.

Pieris, I 59.

quercus, Papilio. 49,67.

Polyommatus. 67.

Thecla. 48.

Zephiyrus. $65,67,98$. 
rape, Papilio. I 46.

Pieris. I43, I46, I I 3, I49, I $S_{4}$.

regalis, Endymion. 57 .

Evenus. 57.

Papilio. 57.

Thecla. 57.

reginæe, Etheoptera. 257.

remus, Ornithoptera. 266.

l'apilio. 266.

Rhiabdodryas. 229.

statira. 229.

rhadamanthus, Ornithoptera. 265 .

rhamni, Colias. 220, 22 I, 223.

Gonepteryx. $22 \mathrm{I}$.

Papilio. 221.

Rhodocera. 222.

rhetenor, Panosmiopsis. 30I.

Rhodocera. 221, 224.

menippe. 224.

rhamni. 223.

rhodope, Mylothris. I6I.

richmondia, Troides. $253,25 \%$.

ridleyanus, Papilio. $250,279$.

roboris, Lxosopis. 68.

robusta, Sterosis. I 36 .

romulus, Papilio. 293.

rosimon, Castalius. I I 2, I I 3 .

Papilio. I I 2.

Polyommatus. II 3 .

rubi, Callophrys, 54, 68 .

Papilio. 54.

Polyommatus. 55 .

Thecla. 55.

ruficollis, Ornithoptera. 265 .

rumina, Papilio. 243.

Thais. 243, 244 .

Ruralis, 64,65 .

Rusticus, 87.

rutila, Lycæena. II9, I 20,121 , 122.

rutilus, Lycæna. I $2 \mathrm{I}$.

Papilio. I2I.

Polyommatus. I2I.

sabellic:e, Pieris. I43, I49, I 50.

Pontia. I 50.

Saletara. I74.
Saletara nathalia. I74.

salmacis, Polyommatus. 100, 102.

salome, Eurybia. 26.

Papilio. 26.

Sarbaria. 298.

polyctor. 298 .

sareptensis, Colias. 216.

Furymus. $2 \mathrm{I} 7$.

Saribia tepahi. I4.

sarpedon, Dalchina. 277.

Satyridie. 9, I6.

Saunia protenor. 301, 302.

Scalidoneura. 2 Io.

Scarce Clouded Vellow. 2 i7.

Scarce Copper, Ir 5, I 6.

Scarce Swallow-Tail. 275.

Schatzia. I62. socialis. I62.

Schoenbergia. 257,259 .

paradisea. 258 .

schmidtii, Lycena. I27.

Polyommatus. I 25 .

Scolitantides. II I.

orion. II I .

scolymus, Anthocharis. I90.

scylla, Catopsilia. 226.

semiargus, Lycæena. 107.

Nomiades. I03, I06, IoS. IOO.

Papilio. I06.

I'olyommatus. 107.

semperi, Atrophaneura. 302.

Sericinus. $246,249$.

telamon. 246.

sesostris, Endopogon. 270.

seta, Pieris. I I I.

shawii, Baltia. I 56 .

Mesapia. I $55,156$.

Pieris. 156.

silas, Iolaus. 73 .

silenus, Myrina. 76 .

Papilio. 76.

Silver-spot Butterfly. 20.

Silver-studded Blue. 88.

Simiskina. 9, I0, I5.

sinaınara, Catagramma, 42.

sinapis, Leptidia. I76, I7S, 219

Leucophasia. 179.

Papilio. I78. 
sinapis, Pieris. I 7 S. sinon, Papilio. 274. Sithon. $48,74,76$. chitra. 75 . nedymonda. 74,75 .

Skippers. 309.

Small Copper. I25, I26.

Small Tailed Blue. 85.

Small White Cabbage Butterfly. 146.

Snout Butterfly. 4.

socialis, Schatzia. I62.

solstitia, Catopsilia. 227.

Sphænogona. 204, 230, 321 . bogotana. 230, $23 \mathrm{I}$. boisduvaliana. $23 \mathrm{I}$. ectriva. 230.

mexicana. 230, 23I, 233.

Spindasis. 80.

spini, Papilio. 48, 49.

Polyommatus. 49 .

Thecla. 48, 49 .

Stalachtine, 44 .

Stalachtis. 22, 33, 44 . phlegia. 45 .

statira, Aphrissa. $22 S$.

Rhabdodryas. 229.

Sterosis. I 36.

robusta. I 36 .

Stiboges nymphidia. I 2.

stubbendorfi, Parnassius. 230.

subfasciatus, Teracolus. I93.

sulkowskyi, Morpho. I 7, $2 \cup$ j.

symethus, Gerydus. I 32.

Papilio. I 32.

Polyommatus. I32.

Symmachia. 37.

Synchloe. I5 I.

butleri. I56.

Syrmatia. 32, 34.

Tachyris. I72, 173 .

nero. I73, I74.

zarinda. I 74 .

Tamera. 295 .

castor. 295.

tapaja, Catagrammina. 42, 43.

Necyria. 42, 43. tarquinius, Erycina. I28. tarquinius, Feniseca. I28, I 29 Hesperia. I 28.

Papilio. I 28.

Polyommatus. I 29.

Taxila. I4.

tavoyanus, Menamopsis. $2 S 0$.

Teinopalpus. 242, 248, 249 . imperialis. 243 .

telamon, Sericinus. 246 .

telearchus, Euplœopsis. 2 So.

telephii, Papilio. II I.

Polyommatus. II 2 .

tenera, Perophthalma. I8.

tepahi, Saribia. I4.

Teracolus. I92, I93, I9S.

subfasciatus. I93.

tereas, Archonias. ${ }^{6} 63$.

Terias. I 38, 232.

candida. 233 .

hecabe. 233.

mexicana, 230.

sari. 233.

Teriomima. I 35 .

Thaidinx. 242.

thaidina, Armandia. 247, $24 \mathrm{~S}$

Thais. 242, 246, 247,305.

hector. 305 .

honnoratil. $243,244,245$.

medesicaste. $243,244,245$.

polyxena. 243 .

rumina. 243, 244.

Thecla. \&, I7, 23, 37, 4I, 46, 47 $48,55,59,65,61,64,65,68$,

7 I 75,8 I, 82, I I 4, I 34 .

betulie. 48,66 .

epicles. 69.

ilicis. 54,68 .

imperialis. 58.

marsyas. 56 .

nedymond. 75 .

pruni. 50, 53, 54 .

quercus. 48.

regalis. 57.

rubi. 55 .

spini. 49.

w-album. 50, 5I, 54.

thecloides, Myrina. 62.

Theope. 37.

thero, Phasis. 78. 
Thespia. 192.

Thestias. I 99.

Thestor. 127. protumnus. 127.

thestylis, Pieris. I7 I. Polyommatus. 97. Prioneris. I7 I. thetis, Papilio. 93, 96. Polyommatus. 93, 95, I00. thetys, Curetis. I3I. thoas, Heraclides. $2 \mathrm{~S} \mathbf{2}$. Thomares. 127.

Thyca. 165.

Thysonotis. II3. danis. II 3 .

Timetes. 33.

timeus, Lycrena. 127 . Papilio. 125.

Tingra. 135 .

tiphys, Papilio. 91.

tiresias, Papilio. 85 .

Tirumala. 207, 279 .

tithonus, Polyommatus. 93.

Tomares. 127. ballus. 128 .

torquatus, Troilides. 283.

toxea, Eumenia. 60.

turcicus, Polyommatus. I26.

turnus, Papilio. 285.

turritis, Euchloe. I $88,189$. Pontia. I 88 .

Trichonis. 48.

triopas, Ascanides. 269.

trogon, Papilio. 260.

Trogonoptera. 25I, 259.

brookeana. $259,260,26 \mathbf{I}$. trojana. $260,26 \mathrm{I}$.

Troides. 251, 252. crœsus. $255,256$.

lydius. 256 .

priamus. 252,254 .

richmondia. $253,254,255$.

urvillianus. $255,256,257$.

Troilides. 283.

torquatus. 283.

troilus, Papilio. 289.

Pterurus. 289.

trojana, Trogonoptera. 260, $26 \mathrm{r}$.

Tros. 305.
Tros hector. 305.

ulysses, Laertias. 296.

urvillianus, Troides. 255, 256, 257.

valens, Papilio. 36. Polyommatus. 36 .

Vancssa. 4. antiopa. $235,268$.

Vanessula. I 35 .

milca. 135 .

varuna, Pangerana. 302.

venus, Papilio. 58.

Polyommatus. 58.

verhuelli, Dercas. 225.

victorix, Atheoptera. 256.

vininga, Aslauga. 136.

virescens, Leptocircus. 300.

virgaureæ, Chrysophanus. I 16.

Lycæena. I I5, II 6.

Papilio. II 5 .

Polyommatus. II 6 .

w-allum, Papilio. 50.

Polyommatus, 50.

Thecla. 50, 5I, 54 .

Wanderer. I2S.

White Cabbage Butterflics. I43.

White-letter Hair-streak. 50, 5I.

wollastoni, Pieris. I 44 .

Wood-White. I78, I79.

wosnesenskii, Parnassius. 239.

Xanthidia. 23I. nicippe. $23 \mathrm{I}$.

xiphia, Leptosia. 177.

xuthus, Jasoniades. 285 .

zagreus, Papilio. 284.

zalmoxis, Papilio. 267.

zarinda, Tachyris. I 74 .

Zegris. I9I.

zelmira, Appias. 173.

Papilio. 173.

Zemeros: I3.

albipunctata. 13.

emesioides. I3.

flegyas. I 3 . 
Zeonia. 27, 29.

bogota. 27.

chorineus. 28 .

faunus. $27,2 S$.

heliconides. 28. oclavius. $2 S$.

Zephyrus. $48,64,68,69,71$ belulie. 65,66 . quercus. $65,67,68$. Zerene anthyale. 217.
Zeritis. $77,78,79$.

neriene. 79.

zetes, Gnesia. 25.

Zetides. 277.

eurypylus. 277.

Zeuzeridx. I 57 .

Zizera. 105.

minima. $85,87,94,105$. zohra, Cigaritis. 79.

zygia, Lemonias maculata. 33. 


